


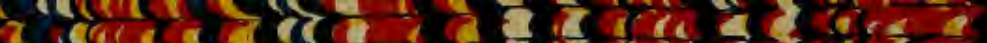

$\alpha=1$

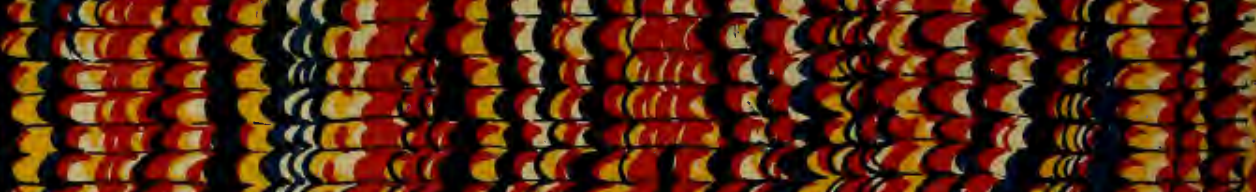
ce. icl ary

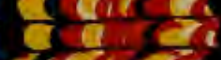

$\Rightarrow$ alc

$i_{1}$

$\cos \frac{\pi}{6}$

(1)

$\rightarrow \frac{1}{2} \frac{1}{6}$

$\rightarrow$

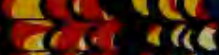

QI)

ace rice

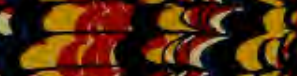

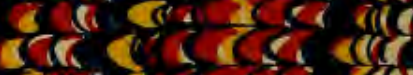
$\cos \theta$

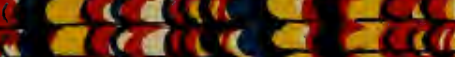

C दि काष

icr cein idis

CII

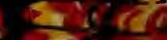

1

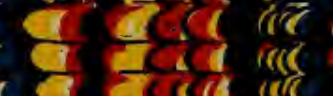

$11 \%$

(l)

$\operatorname{lig}_{12}$

14

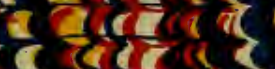

( $\mathrm{Cl}$

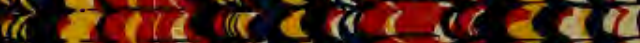

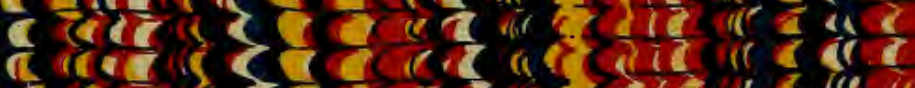

a

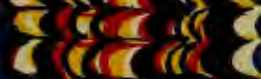

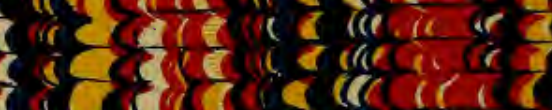

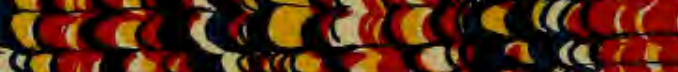

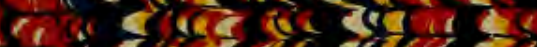

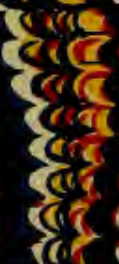

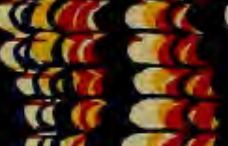

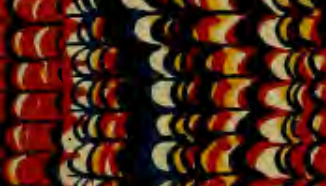

ciris

(1)

cictiotia

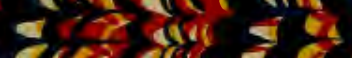

21,0

$\lim _{<\rightarrow \infty}$

$\Rightarrow d r$ r (ci)

4

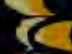

$\rightarrow$ C

deri give

$\cos \cos$

Q ere $\cos 1$

$\cos 2 \mathrm{~s}$

$\pi, \frac{a}{2}$

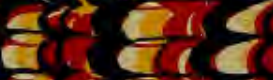

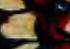

Qर 1

ate

ciat

$\left.\operatorname{cit}^{+}\right)$

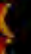

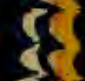

$\sin$

$\operatorname{cis}$

$\sin$

4

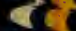

$\sin (-1)$

i $(r)$

aris

Q?

$1 \mathrm{C}$

19

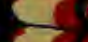

if

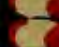

2

C 1

$7 r$

ac

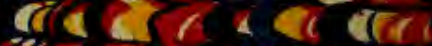

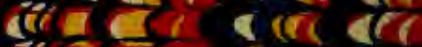

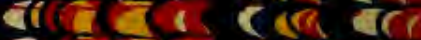

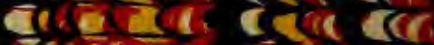

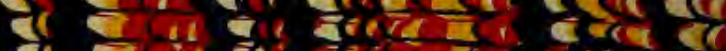

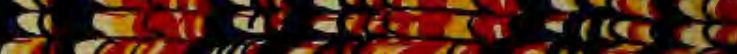

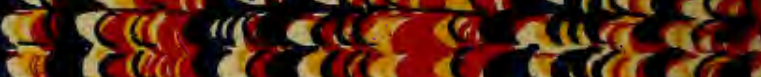

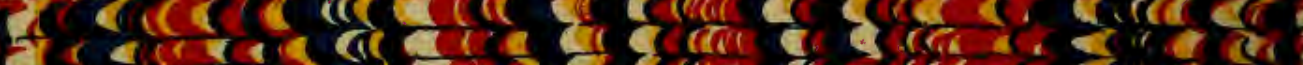

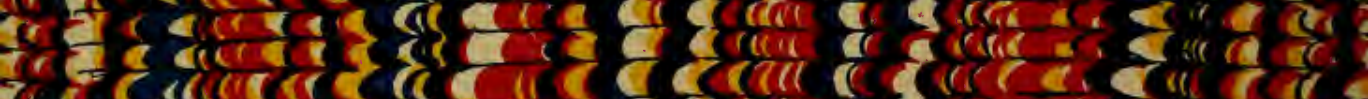
a

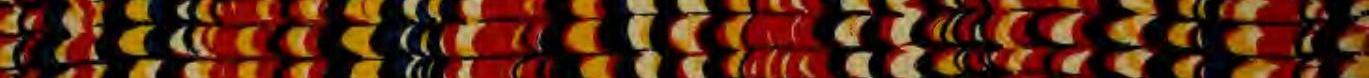

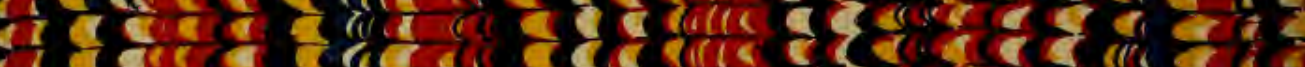

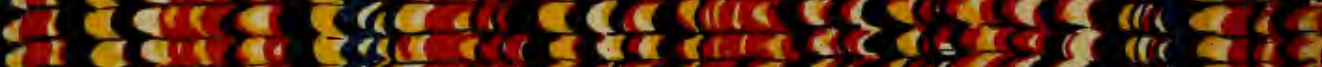

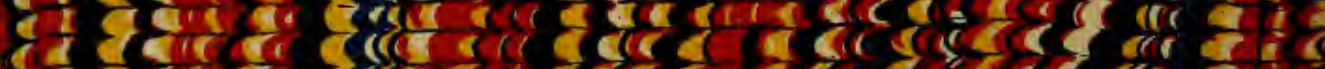
CI

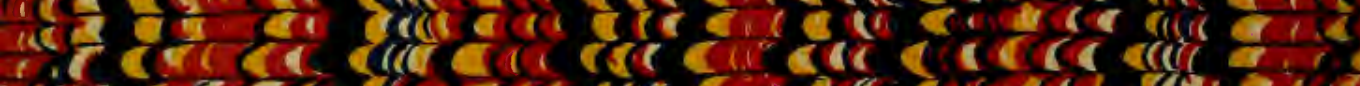
(a) 0

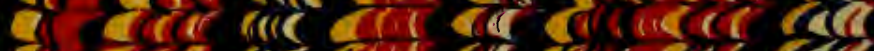

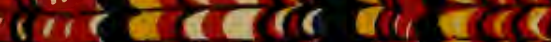

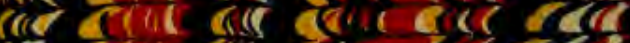
4

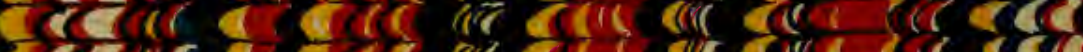




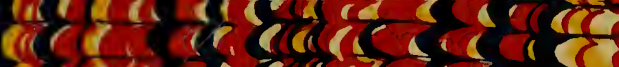

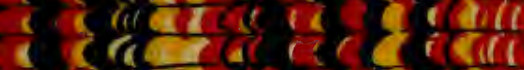

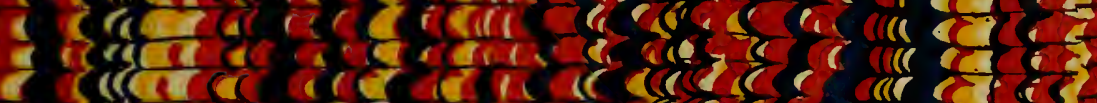

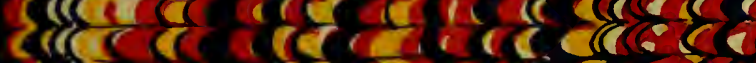

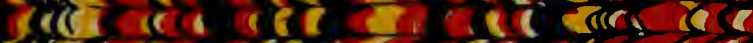

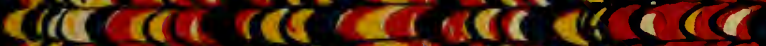
are

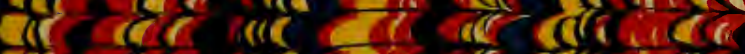

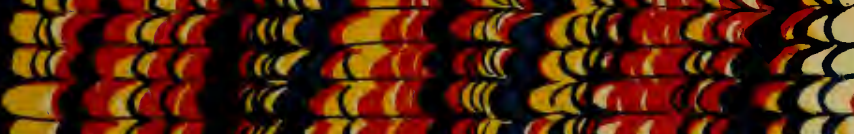

तe है

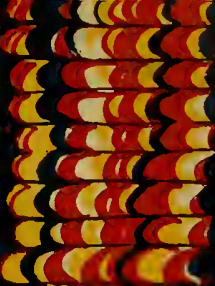

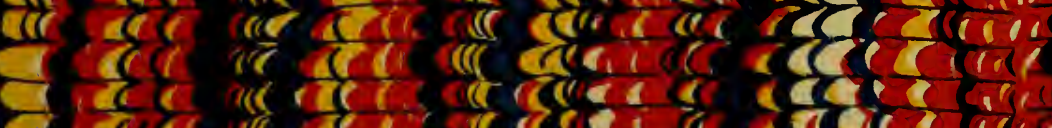

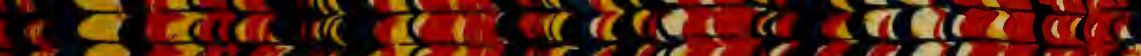

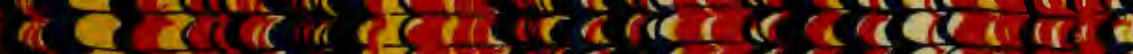

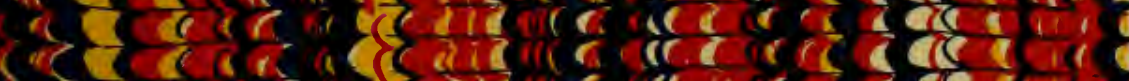

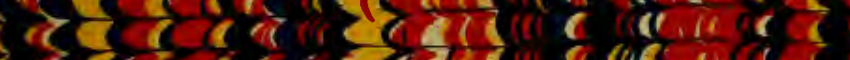

is $4 \pi, 4$ a $\cos _{0}$

a $\operatorname{loc}\left(\frac{1}{6}\right.$

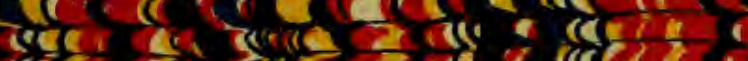

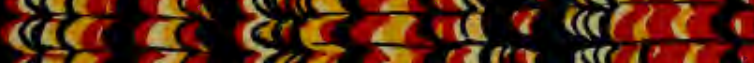

(a)

dive tal sera

(c)

\&e

iç

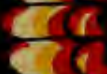

cars

खis.

(i)

(ci)

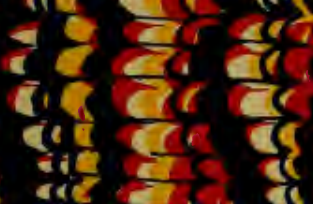

I $(2)=$

(C)

ac $\cos$

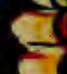

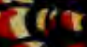

sc(

icie $\frac{\pi}{2}$

Ii ade a

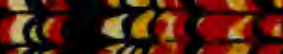

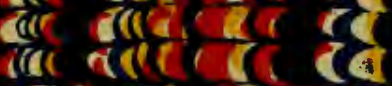

$\rightarrow$

gal rarar

de

ic

ifficti

act

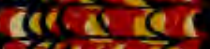

बaritar

$\operatorname{los}^{2}$

$\operatorname{coc}_{\rightarrow}$

$\rightarrow$

ara $=0$

ex $\frac{a r}{4}$ ed

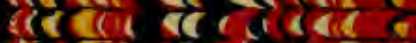

edir deisirar

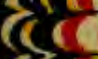

$48 \mathrm{C}$

51

1

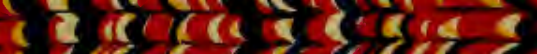

4.

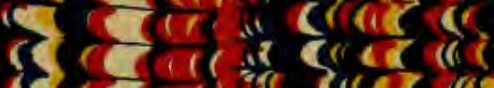

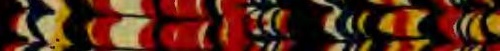
cor c.

id dei, है

परा स्व है

त्रि

$\operatorname{lic} \mathrm{c}$

$\frac{\cos (\mathrm{C})}{\mathrm{Cl}}$

ide cesitis

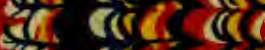

$46 \operatorname{cic}$ (1)

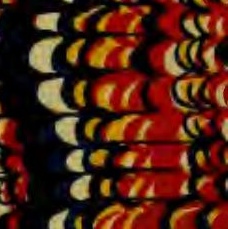

7 "is, of

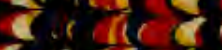

$\operatorname{coc} t i c$

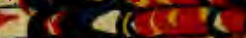

is a $\operatorname{coc}(\mathbf{T )}$

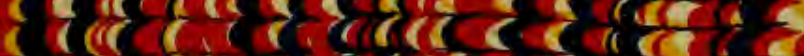

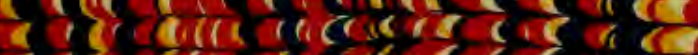

C.

tost al a

ser ar ar $\operatorname{coc}(\mathrm{C})$ a

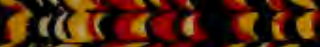

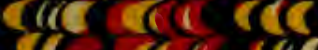

a 9 is al al, are

(U)

(6.) C.

$\operatorname{cis} 8$

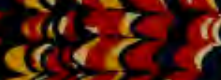

(C)

${ }_{2}$

th

I $\cos 49$

\& I

$\cos )^{2}$

$\rightarrow$ G

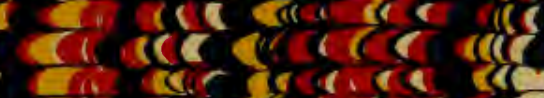

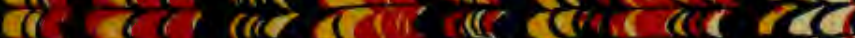

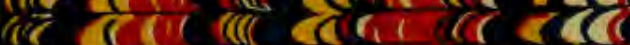







\section{PALAONTOGRAPHICAL SOCIETY.}

INSTITUTED MDCCCXLVII.

LONDON:

MDCCCLXXVIII-MDCCCLXXXVI. 


\section{THE LIAS AMMONITES.}

\section{DIRECTIONS TO THE BINDER.}

The Monograph on the Lias Ammonites will be found in the Volumes of the Palæontographical Society for the years $1878,1879,1880,1881,1882,1883,1884$, and 1885 .

Cancel the Title-pages to the Parts issued in the Palæontographical Volumes for the years 1878,1879 , $1880,1881,1882,1883$, and 1884; substitute the accompanying Title-page; and place the sheets and plates in the order indicated below.

ORDER OF BINDING AND DATES OF PUBLICATION.

\begin{tabular}{|c|c|c|c|}
\hline Pages & PIATES & $\begin{array}{l}\text { I8SUED IN VOL. } \\
\text { FOR YEAR }\end{array}$ & PUDLISHED \\
\hline Title-page. & - & 1885 & January, 1886 \\
\hline $1-48$ & I-VIII & 1878 & March, 1878 \\
\hline $49-164$ & IX-XVIII & 1879 & May, 1879 \\
\hline \multirow[t]{3}{*}{$165-264$} & XIX-XXII & 1880 & May, 1880 \\
\hline & $\mathrm{XXII}_{A}-\mathrm{XXIIв}$ & 1881 & May, 1881 \\
\hline & XXIII-XL & 1880 & May, 1880 \\
\hline $265-328$ & XLI-XLVIII & 1881 & May, 1881 \\
\hline $329-400$ & $\begin{array}{c}\text { XLIX-LII, LIIA, } \\
\text { LIII_LXIX }\end{array}$ & 1882 & June, 1882 \\
\hline $401-440$ & LXX-LXXVII & 1883 & October, 1883 \\
\hline$\therefore \quad 441-480$ & LXXVIII-LXXXVII & 1884 & December, I 884 \\
\hline $4.81-503$ & LXXXVIII & 1885 & January, 1886 \\
\hline
\end{tabular}



*** This Monograph on the Lias Ammonites (a memorial of the ability of its painstaking Author, and representing the desire of a life) possesses a melancholy interest. Commenced in 1878, and continued year by year until only a few pages remained unprinted, its further progress was, in 1884, stayed by the hand of death. Sufficient notes, however, were in existence to complete the work, and with these it is offered in its present form.

THOS. WILTSHIRE.

2nd January, 1886. 


\section{PALAONTOGRAPHICAL SOCIETY.}

INSTITUTED MDCCCXLVII.

VOLUME FOR 1878.

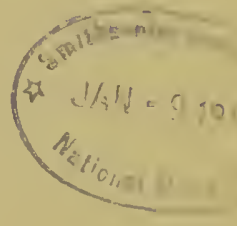

LON DON :

MDccelXxiII. 



\section{MONOGRAPH}

ON TEE

\section{LIAS}

\section{AMMONITES}

OF

\section{THE BRITISH ISLANDS.}

$\mathrm{BI}$

\section{THOMAS WRIGHT, M.D., F.R.S. EDIN., F.G.S.,}

VICE-PRESIDENT OF THE PALEONTOGRAPHICAL SOCIETY; CORRESPONDING MEMBER OF THE ROYAL SOCIETY OF SCIENCES OF LIÈGE; THE SOCIETY OF NATURAL SCIENCES OF NEUCHÂTEL; VICE-PRESIDENT OF THE COTTESWOLD NATURALISTS' FIELD CLUB; CONSULTING SURGEON TO THE CHELTENHAM HOSPITAL; AND MEDICAL OFFICEK OF HEALTH TO THE UTBAN SANITARY DISTRICTS OF CHELTENHAN, CHARLTON KINGS, AND LECKHAMPTON.

PART FIRST.-THE LIAS FORMATION.

Pages 1-48; Píates I-VIII.

LONDON :

PRINTED FOR THE PALAONTOGRAPHICAL SOCIETY. 
PRINTED BY

J. F. ADLARI, BARTHOLOMEW CLUSE. 


\section{THE LIAS AMMONITES \\ OF THE}

\section{BRITISH ISLANDS.}

Before describing the Ammonitidæ of the Lias I purpose giving a short account of the several zones of life into which this great formation is divided, with the view of defining their statigraphical distribution in time and space. More ample details on the subject will be found in the various works cited in the synonyms prefixed to the description of the different zones.

English geologists divide this formation into Upper Lias, Marlstone, and Lower Lias, but these subdivisions require additions and modifications in order to place the liassic beds of the British Isles in strict correlation with those of France, Switzerland, and Germany. For on the Upper Lias clays, in certain localities, are superimposed extensive arenaceous deposits, which, previous to the publication of my memoir on the Upper Lias Sands, ${ }^{1}$ were grouped with the Inferior Oolite, and in the Lower Lias are included several beds of clays and marls which, with the Marlstone of English anthors, form the Middle Lias of Continental geologists.

Taking the Lias beds so well exposed in their natural order of superposition in the north and south of England in the magnificent sections on the Yorkshire and Dorsetshire coasts, and naming each group of berls by the most charactcristic Ammonite form contained therein, we find the following zones of life, taken in descending order:

The Upper Lias.-The sands ${ }^{2}$ forming the upper portion of this zone, are characterised for the most part by Anmonites belonging to the groups Harpoceras and Lytoceras, as Harpoceras opalinum, Rein., H. radians, Schloth., H. Thouarsense, d'Orb.,

1 "Palæootographical and Stratigraphical Relations of the so-called 'Sauds of the Inferior Oolite," 'Quart. Journ. of the Geological Society,' vol. xii, p. 292, 1856.

2 Midford Sands, so named by the late Professor Phillips in his 'Geology of Oxford and the Thames Valley,' p. 118, 1871. 
H. insigne, Schübl., with Lytoceras jurense, Ziet., L. lircinum, Schlüb. The clays forming the lower part of the zone are everywhere distinguished by Harpoceras bifrons, Brug., H. serpentinum, Schloth., and numbers of the group Stephanoceras, as Steph. commune, Sow., S. anguinum, Rein., and S. fibulatum, Sow.

The Middle Lias.-This is divisible into five zones, each characterised in descending order by-1. Amaltheus spinatus, Brug. 2. A. margaritatus, Mont. 3. Aegoceras Henleyi, Sow. 4. Amaltheus Ibex, Quenst. 5. Aegoceras Jamesoni, Sow.

The Lower Lias is divisible into seven zones. These are-1. Zone of Arietites raricostatus, Ziet. 2. Amaltheus oxynotus, Quenst. 3. Arietites obtusus, Sow. 4. A. Turneri, Sow. 5. A. Bucklandi, Sow. 6. Aegoceras angulatum, Schloth. 7. Aegoceras planorbis, Sow., reposing comformably on the Avicula contorta series.

Complicated as these subdivisions may at first sight appear to those who have been accustomed to regard the Lias formation as a great clay deposit, with a uniform fauna throughout, still their accuracy may be clearly demonstrated in the extensive section on the Dorsetshire coast, extending from near Bridport Harbour on the east to Pinhay Bay on the west. For within these limits the entire series of beds rise beneath each other on the shore, and are exposed in the cliffs, so that this coast section may be said to be complete from the great arenaceous deposit of Upper Lias Sand, containing Harpoceras opalinum, with each succeeding zone of the Upper, Middle, and Lower Lias, down to Aegoceras planorbis, and its Ostrea series, resting on the Avicula contorta beds of the Trias formation.

In the following table I have placed the different zones of the English Lias in correlation with those of Germany, so well described by Professors Quenstedt, Oppel, Fraas, and others ; those of France by the late M. A. d'Orbigny, and those of England by Sir R. Murchison, Sir H. De la Beche, and the Rev. W. D. Conybeare.

This table likewise shows how completely the whole Lias formation is represented in England, and how nearly it corresponds bed for bed with the Würtemberg series. I shall now describe the different zones in ascending order, commencing with the zone of Avicula contorta.

As much difference of opinion formerly prevailed regarding the true position of the Contorta zone, I have deemed it best to give a short account of the beds in question for the purpose of showing how distinct their lithological and palæontological characters are from those of the true Lias formation which rests upon them, and how necessary it is to clear away all doubts as to the true affinities of these beds before entering upon the study of the Lias formation which forms the subject of this introductory part of our Monograph. 


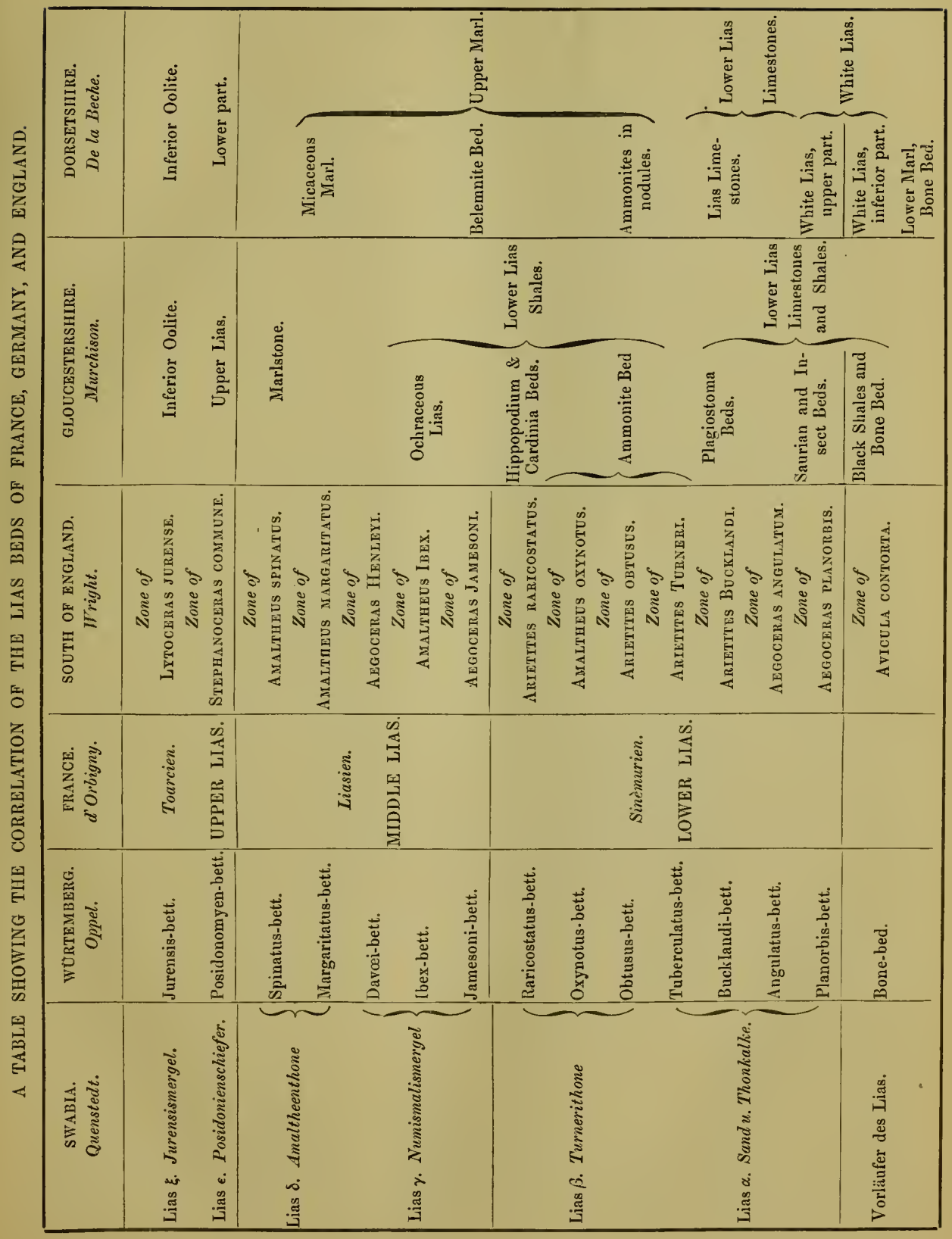




\section{The Zone of Avicula contorta.}

Synonyms.--Von Buch, "Schicht mit Gervillien auf der Gruber Alp am Setzberge in den bayr. Alpen," Denksch. Akad. Wissensch. Berlin, Jahrg. p. 82, 1828. Alberti, "Versteinerungsreicher Sandstein von Täbingen," 1834. Strickland, "Calcareous Sandstone with Pectens, and White Micaceous Sandstone with Bivalve Shells." Proceedings of the Geological Society, vol. iii, p. 586, 1842. Portlock, "Shale" with Avicula contorta and "loose gritty marl" containing Pecten Valoniensis, Report on Geology of Londonderry, pp. 126, 127, 1843. Brodie, "Pecten-bed," Fossil Insects of the Secondary Rocks, p. 58, 1845. Quenstedt, "Gelbe Sandsteine," Flözgebirge Württembergs, 1846. Emmerich, "Gervillien-Schichten," Neues Jahrbuch, p. 437, 1849. Schafhäutl, "Schiefergebilde der Wetzsteinformation mit Gervillien," Geognost. Untersuch. südbayrischen Alpengebirges, 1851. Von Haner, "Kössener-Schichten," Jahrbuch der k. k. geologischen Reichsanstalt, p. 733, 1853. Escher, "Oberes St.Cassian.," Geologische Bemerkungen über Voralberg, 1853. Gümbel, Gervillien(Kössener-)Schichten in der Grünten," Geognostische Skizze, 1856. Oppel and Suess, "Kössener-Schichten," Sitzungsber. Akadem. Wissenschaft. Wien, vol. xxi, p. 525, 1856. Oppel, "Kössener-Schichten," Jura, p. 290, 1856. Wiukler, "Die Schichten der Avicula contorta inner- und ausserhalb der Alpen," 1859. Oppel, "Die Zone der Avicula contorta," Württemberg. natur. Jahreshefte, p. 315, 1859. Lyell, "Infra-liassic Strata of Austrian Alps," Supplement to the Manual of Geology, 5th ed., 1857. Suess, "Kössener-Schichten," Ueber die Brachiopoden, \&c., 1854. Jules Martin, "Infra-Lias" (pars), Paléontologie stratigraphique de l'Infra-Lias du Département de la Côte-d'Or, Mém. Soc. Géol. France, 2 série, vol. vii, 1860. Stoppani, Essai sur les conditions générales des couches à Avicula contorta, 1861, supplement à l'essai 1863 . Alphons v. Dittmar, Die Contorta-Zone ihre Verbreitung und ihre organischen Einschlüsse, 1864. Renevier, Notices géologiques et paléontologiques sur les Alpes Vaudoises, p. 1, 1864. Dumortier, "Infra-Lias, zone à Avicula contorta," Etudes Paléont. sur les Dépots Jurass. du Bassin du Rhône, tom. i, p. 6, 1864. Boyd Dawkins, " Rhætic Beds," Journ. Geol. Soc., vol. xx, p. 396, 1864. Das Rhät in der Umgegend v. Göttingen, L. Pflücker y Rico, Berlin, 1868. Brauns, Die untere Grenze des Jura und die ihr zunächst liegenden Triasschichten, p. 22, 1871. Tate and Blake, Yorkshire Lias, "The Rhætic Series and the relations of the Lias with the Keuper," p. 30, 1876.

The Avicula contorta beds, as proved by the above list of synonyms, have for forty years engaged the attention of geologists, who, after much discussion as to their true place in the series, are still divided in opinion as to whether they ought to be considered the upper portion of the Keuper or the basement-beds of the Lias. It is now generally admitted that the facies of the fauna of the Avicula contorta zone has more affinities with the Kössener-Schichten of the Tyrol and the Upper St.-Cassian beds of Germany than with the true Lias, and it can be demonstrated that most of the species of Radiata, Mollusca, and Fishes, found in the Avicula contorta beds, are special to them, and do not pass into the Lias. 
The question where does the Lias formation commence is easier asked than answered, for between the uppermost beds of the grey marls of the Keuper and the lowest true beds of the Lias is a remarkable assemblage of strata, which I long ago described as the "Avicula contorta BEDs," from that shell forming their leading fossil. Typical sections of the Contorta series are exposed at Garden cliff, Aust cliff, Penarth, and Watchet on the Severn shores; at Weston, Keynsham, Willsbridge, and Salford, near Bath, and at Puriton, Uphill, and Wells in Somersetshire, as well as in many other localities. In the upper part of the series are dark-grey sliales interstratified witl bands of limestone containing Avicula contorta, Cardium Rhaticum, Pecten Valoniensis, and Schizodus elongatus; and in the lower part the Bone-bed, consisting of hard dark siliceous grit, charged with bones, spines, teeth, and scales of Fishes belonging to the genera Nemacanthus, Acrodus, Sargodon, Hybodus, and Ceratodus, with bones of Reptilia belonging to the genera Ichthyosaurns and Plesiosaurus, and the teeth of a small Mammal, Microlestes antiquus, Plieninger.

As no sketch of the Lias formation can be said to be complete without its relation to the Trias below and the Jurassic rocks above being clearly defined, I shall briefly describe some type sections of the Avicula contorta beds in which the relation of these to the base of the Lias is very well shown.

\section{Garden Cliff, near Westbury-on-Severn.}

I made a detailed section of the Avicula contorta beds of Garden Cliff, near Westbury-on-Severn, many years ago, ${ }^{1}$ as it affords one of the most typical profiles of the zone known to me, and that best situated for study, and I recommend its careful examination to all who wish to know this series, as each stratum emerges in succession by the river bank, and can be measured and searched for its fossils, as it rises in the cliff at a low angle. The Rev. W. D. Conybeare ${ }^{q}$ gave a section of this, which he called "Westbury Cliff, on the west bank of the Severn," for the purpose of illustrating the lower beds of the Lias formation, which reads as follows :-

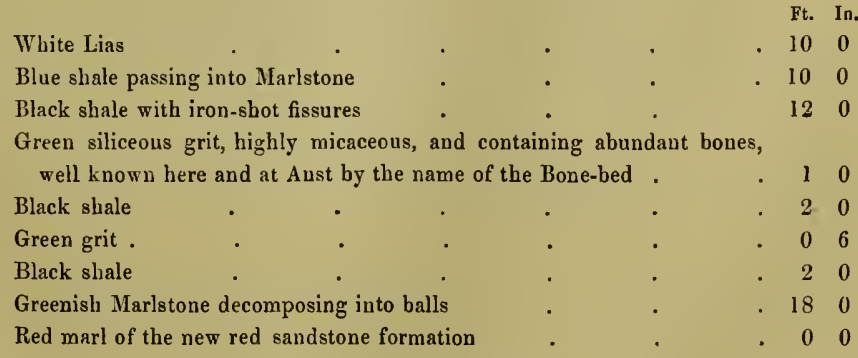

\footnotetext{
1 'Quart. Jour. Geol. Soc.,' vol. xvi, p. 378, 1860.

2 'Geology of England and Wales,' p. 263, 1822.
} 
The outline of the above agrees in some respects with my section, but the naming of the beds and the absence of their fauna, renders it valueless for the purpose of correlation with the many other exposures of strata of the same age throughout Europe.

The cliff should be reached about ebb-tide, as this will afford ample time for examining all the beds as they rise from the shore line. The Estheria-bed ${ }^{1}$ must be $^{2}$ diligently searched for its special Crustacea. The Contorta shales and Cardium shales contain an immense number of small shells, much compressed; and it will be necessary for the student to carry with him a thin solution of gum arabic and a hair pencil, so as to give the fossiliferous slabs he extracts a coating of the solution whilst the shells are in situi, and allow them to dry in the sunshine, otherwise he will fail to preserve the treasures he gathers from these brittle paper-like strata.

Detailed Section of Garden Cliff.

\begin{tabular}{|c|c|c|c|}
\hline No. & LIтнодоgy. & $\begin{array}{l}\text { THICK- } \\
\text { NESS. }\end{array}$ & PaLAFONTOLOGY. \\
\hline 1 & Brown or grey hard limestone with & & Modiola minima, Ostrea liassica, Protocardium, \\
\hline 2 & 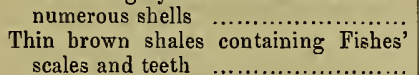 & $\begin{array}{ll}0 & 4 \\
2 & 0\end{array}$ & $\begin{array}{l}\text { Pleuromya. } \\
\text { Fish remains, scales, and teeth ; genera indeter- } \\
\text { minable. }\end{array}$ \\
\hline 3 & $\begin{array}{l}\text { Cream-coloured fissile argillaceous lime- } \\
\text { stone, the Mronotis-bed }\end{array}$ & & $\begin{array}{l}\text { Monotis decussata, Anatina pracursor, Myacites } \\
\text { musculoides, Gervillia pracursor. }\end{array}$ \\
\hline 4 & 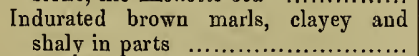 & & $\begin{array}{l}\text { Fishes' teeth and scales are seen on the split } \\
\text { laminæ. }\end{array}$ \\
\hline 5 & $\begin{array}{c}\text { Grey fissile marls, with thin pyritic } \\
\text { limestone bands } \ldots \ldots \ldots \ldots \ldots \ldots \ldots \ldots \ldots\end{array}$ & & $\begin{array}{l}\text { Fossils in the limestone bands, but indeter- } \\
\text { minable as to species. }\end{array}$ \\
\hline 6 & 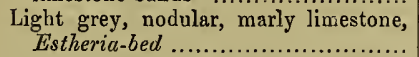 & & $\begin{array}{l}\text { Estheria minuta, var. Brodieana, Jones, found in } \\
\text { nests in the hard limestone. }\end{array}$ \\
\hline 7 & $\begin{array}{l}\text { Chocolate-coloured shales, laminated } \\
\text { and friable, containing many seams of } \\
\text { compressed shells, which must be } \\
\text { examined when exposed }\end{array}$ & & $\begin{array}{l}\text { Avicula contorta, Pecten Valoniensis, Cardium } \\
\text { Rhaticum, Axinus cloacina, Lima precursor, } \\
\text { Neoschizodus posterus, Pleurophorus, Mya- } \\
\text { cites, Modiola, and Gasteropods indeterminable. }\end{array}$ \\
\hline 8 & $\begin{array}{l}\text { Dark shaly clay with many seams of } \\
\text { compressed shells, and two indurated } \\
\text { bands containing Pectens } \ldots \ldots \ldots \ldots . .\end{array}$ & & $\begin{array}{l}\text { Pecten Valoniensis forms an upper Pecten-bed. } \\
\text { Pullastra arenicola, Axinus, Cardium Rhati- } \\
\text { cum, and Pecten Val. Lower Pecten-bed. }\end{array}$ \\
\hline 9 & 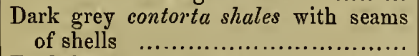 & 26 & $\begin{array}{l}\text { Avicula contorta compressed with Axinus, Car- } \\
\text { dium, Pecten, \&c. }\end{array}$ \\
\hline 10 & $\begin{array}{l}\text { Dark browu paper-like Cardium-shales } \\
\text { with many seams of shells ............ }\end{array}$ & & $\begin{array}{l}\text { Cardium Rhaticum in great numbers, Pecten } \\
\text { Valoniensis, Axinus, Ophiolepis Damesii. }\end{array}$ \\
\hline 11 & $\begin{array}{l}\text { Bone-bed calcareo-siliceous pyritic band } \\
\text { forming an osseous breccia in parts } \\
\text { with a clay bed between .............. }\end{array}$ & $\begin{array}{ll}1 & 0 \\
0 & 6 \\
0 & 1\end{array}$ & $\begin{array}{l}\text { Acrodus minimus, Nemacanthus flifer, Hybodus } \\
\text { minor, Gyrolepis tenuistriatus, Saurichthys } \\
\text { apicalis, Sargodon tomicus, Avicula, Axinus, } \\
\text { Pullastra. }\end{array}$ \\
\hline 12 & Black shales .............................. & 1 & Non-fossiliferous. \\
\hline 13 & 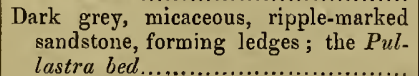 & & $\begin{array}{l}\text { Lvicula contorta, Cardium Rhaticum, Pullastra } \\
\text { arenicola, Modiola minima. Fishes' teeth. }\end{array}$ \\
\hline 14 & Dark shales ............................ & 110 & Non-fossiliferous. \\
\hline 15 & 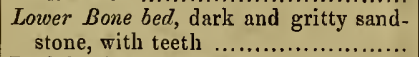 & & $\begin{array}{l}\text { Acrodus, Sargodon, Gyrolepis, dvicula contorta, } \\
\text { Pullastra arenicola. }\end{array}$ \\
\hline 16 & Dark laminated shales .. ................... & & Teeth, scales, coprolites, \&c., at base. \\
\hline 17 & Grey marls of Keuper & & Unfossilifcrous. \\
\hline
\end{tabular}

1 Rupert Jones' 'Monogr. Foss. Estheriæ,' Pal. Soc. vol. for year 1860, p. 70, Sc. 


\section{Fig. 1.-A Vertical Profile of Garden Cliff.}

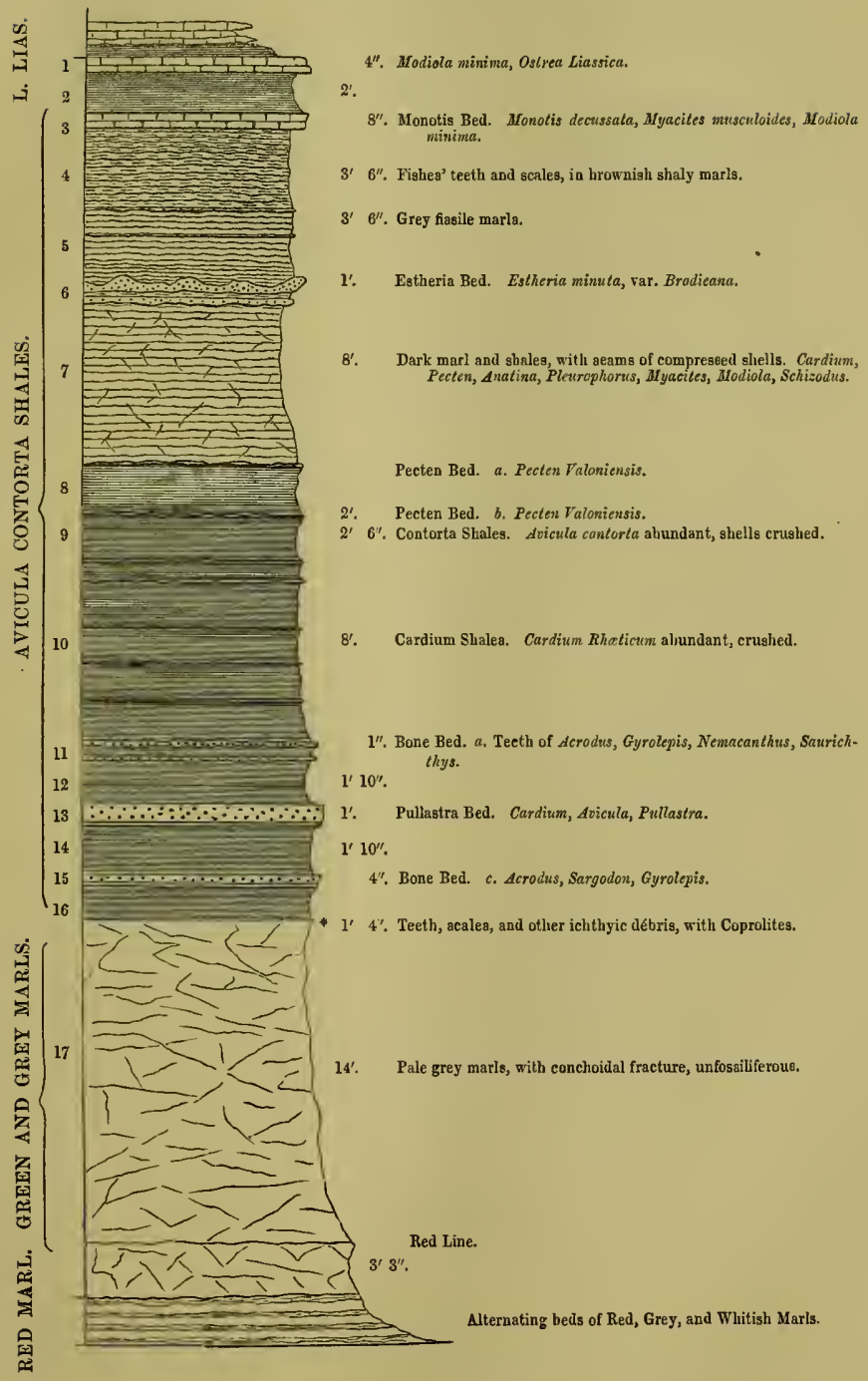


THE LIAS AMMONITES.

Fig. 2.-A Vertical Profile of Aust Cliff.

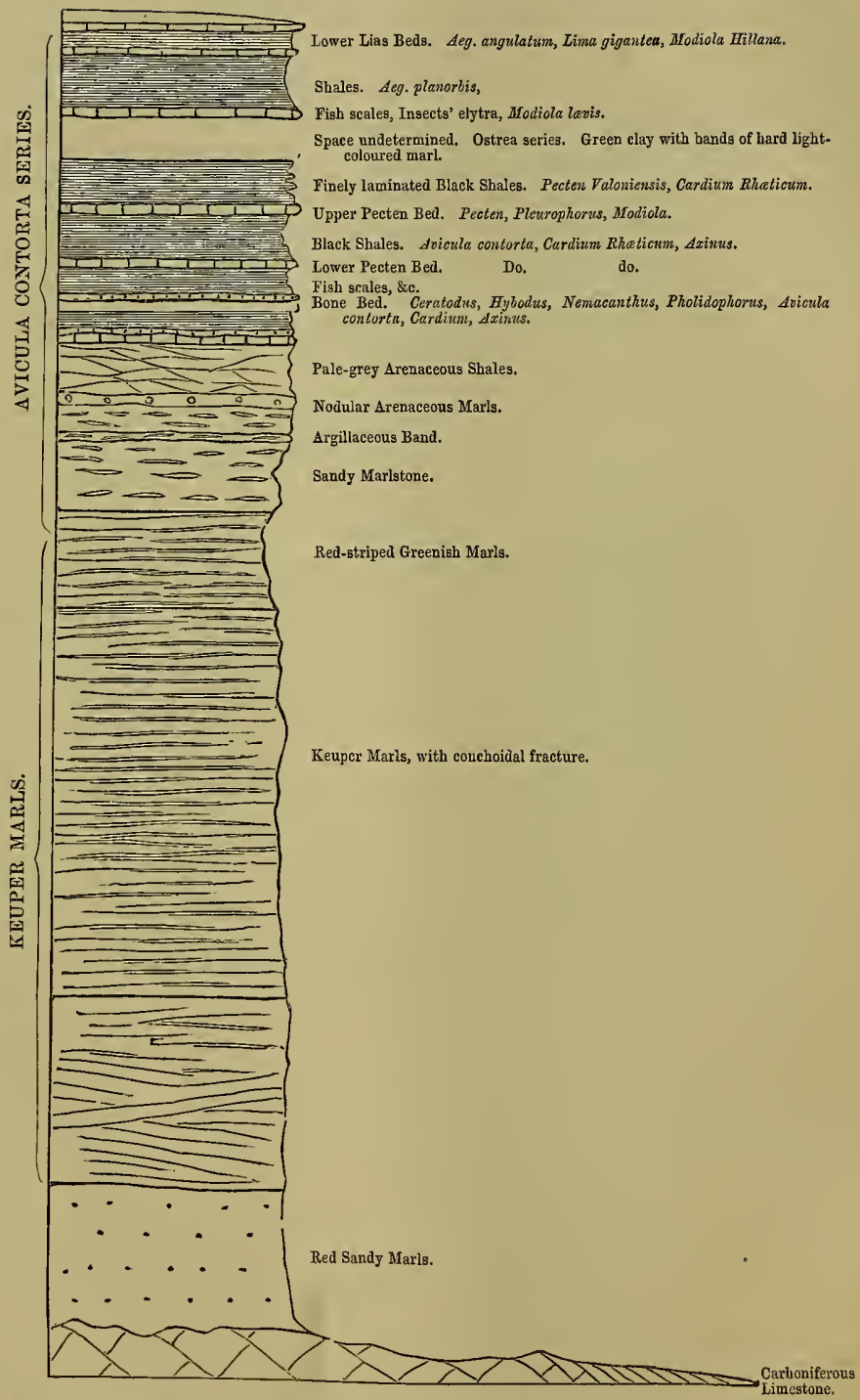

Figs, 1 and 2 were drawn by my friend Robert Etheridge, Esq., F.R.S., to illustrate papers published in the 'Trans. of the Cotteswold Naturalists' Field Club;' be has kindly allowed me to use them here ; and my friend Dr. Paine, F.C.P., Hon. Secretary to the Society, has given me the use of the woodcuts. To both old friends I return my best thanks. 


\section{Aust Ciliff.}

If we proceed from Garden Cliff down the Severn, the mext section of the Avicula contorta beds is met with at Aust Cliff, so long famons for its Bone-bed and the large number of Ceralodus teeth which from time to time have been collected therefrom.

My old friend, the late Mr. William Sanders, F.R.S, of Bristol, many years ago carefully measmred this section, a matter of much difficulty from the mural character of the escarpment, and the result of his labours was published by Sir Henry De la Beche, in his valuable memoir on the geology of the South-west of England, ${ }^{1}$ Buckland and Conybeare having previonsly published a section of the cliff in their memoir on the south-western coal-district of England.?

In the upper part of the section are found about threc fect of grey argillaccons Lias Limestone, containing Aegoceras angulalum, Schloth., Lima gigantea, Sow., Lima antiquata, Sow., and Modtiola Ilillana, Sow., representing the lower beds of the Lima-series. Below these are nine beds consisting of grey marls and argillaceous limestone representing the zone of degoceras planortis. The lowest limestone bed of the series contains scales of Fishes, elytra of Insects, with Modiola minima and Terebratulce; this rests upon cight feet of grey, light-coloured marls, with nodular limestone, the equivalent of the Ostrea-beds and White Lias series, of the strata numbered two to six inclusive in the detailed section of Garden Cliff (p. 6). 'The Cotham Marble caps the marly beds, and this well-known singular band forms the base of the Ostrea-series. The gap in the section is intended to represent a space of thirteen feet which conld not be satisfactorily examined. Below this space five feet of thinly laminated black shales are exposed, and beneath is a five-inch band of hard grey limestone, containing scales of Fish, Pecten Valoniensis, Plucunopsis alpina, Pleurophorus clongatus, representing the upper Pecten bed of the Garden Cliff section, \&c.; this band rests upon another bed of black shales, eight feet in thickness, containing seams of shells. Here are found Avicula contorta, Cardium Rhaticum, Pullastra arenicola, Axinus, Anomia, \&c. The fossils are very numerous, but much conpressed, and determined with difficulty. The Contorta-shales rest upon a second or lower Pecten-bed, consisting of a hard grey silelly limestone, eight inches thick, containing Aviculu contorta, Cardium Rhaticum, Pullastra, Axinus, Anomia, \&c., in fact all the same slells that are found in the black shales above. Beneath the limestone band is another bed of black sliales, four feet thick, intersected by thin, inconstant, indurated bands, containing Fishes' scales, \&c. The shales rest upon the true Bone-bed, which is here a most remarkable band of dark-grey, crystalline, calcareo-siliceous rock, containing nodnles of marl, nasses of dark coprolitic matter, bones of Saurians, tecth of Ceratodus and other Fishes, in fine preservation. Its thickness varies from two to eight inches, and it rests upon a thin band of dark shales, to which succeeds a yard of grey sandy marls, containing hard concretionary nodules; beneath are bands of hard sandy marl, resting upon eight feet of pale-grey arenaceous marls,

1 'Memoirs of the Geological Survey of Great Britain,' vol. i, p. 253, 1846.

2 'Geological Transactions,' 2nd series, vol. i, pl. 37, 1824. 
having at their base a nodular band of similar marls, passing into a thick bed of sandy marlstone, six feet six inches thick, and forming the base of the Avicula contorta series, which rests on nodular greenish marls, thick-bedded and red-striped, fourteen feet thick, and next a thick mass of marls fifty-two feet thick, liaving a conchoidal fracture; then follow the gypsiferous series, containing fibrous gypsum, in string-like lines, for twentyfive feet six inches, having at the base twenty feet of red sandy marls, the whole resting upon highly inclined strata of the lower portion of the Carboniferous Limestone, which here forms the bed of the Severn.

\section{Penarth Cuiff.}

At Penarth Head, near Cardiff, a magnificent section is exposed, showing the Lower Lias and Avicula contorta beds resting on the variously coloured marls of the Keuper. The lowest half of the cliff is a roll of the same beds which occur at Garden Cliff, fortyfour miles higher up the Severn. The upper part of the Head is composed of alternate beds of shale and limestone with Arietites Turneri, Cardina ovalis, Gryphaa arcuata, and Pentacrinus tuberculatus, fifteen feet thick, which overlie the Zone of Arietites Bucklandi, consisting of alternate beds of limestone and shale, which attain from fifty to sixty feet in thickness; and contain Lima antiqua, Sow., Lima gigantea, Sow., Lima punctata, Sow., Lima pectinoides, Sow., Cardinia liybrida, Stuch., Unicardium cardioides, Phil., with fragments of Arietites Bucklandi. Beneath the Lima-series are beds of laminated clay containing Aegoceras planorbis, Sow., with alteruate strata of clay and limestone, and a profusion of Ostrea liassica on the surface of the slabs. They attain a thickness of ten feet, and are underlain by a bed of stiff clay containing Ostrea liassica and Modiola minima.

The Avicula-contorta-beds form an important feature in the cliff, consisting as they do of blackish shales interposed between the light-coloured marls of the Keuper below, and the light-coloured shales and limestone of the Planorbis-beds above; beneath are dark marly clays with impressions of teeth, scales, and shells that lie compressed in seams of clay, resting on a calcareous rocky band containing Pecten Valoniensis, Defr., closely pressed together, and badly preserved. Beneath this Upper Pecten-bed are several feet of dark shales, resting on a second stony band with Pecten Valoniensis, and this lower Pecten-band is underlain by shales and layers of ripple-marked micaceous sandstone, containing Avicula contorta and Pullastra arenicola, Strick. The Bone-bed occurs in the section, but is feebly represented, and often with difficulty discovered, as its contents are sparse, and often much comminuted. Two feet of Black Sliales separate the sandstone from the Keuper.

In the county of Somerset there are several exposures of the Contorta-beds laid open either by railway-cuttings or by the action of the sea along the coast; to the former belong the Uphill Cutting near Weston-super-Mare. As I watched this exposure during its entire progress, and have stndied it several times since, I give the details, for it is very typical of the others. ${ }^{1}$ 


\section{Uphill Railway-cutting, Bristol and Exeter Line.}

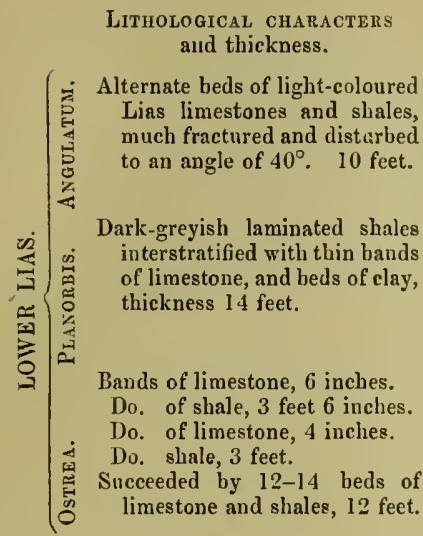

A thin band of dark grit, $1 \frac{1}{2}$ inches, resting upon dark-grey shaly marl, 4 feet 6 inclies.

Dingy-coloured pyritic limestone, many shells, 2 inches.

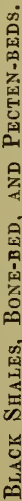

Grey marl, 2 inches, resting on a band of limestone with shells and gypsum, 2 inches, and dark marl, 4 feet.

Dark shelly pyritic limestone, 6 inches.

Dark marls, 3 feet.

Laminated Shale, 3 inclies.

Dark marl, 1 foot 9 inches.

Stony band of impure limestone, 3 inches.

Dark pyritic conglomerate ; coprolites' teeth, and scales of Fishes, 2 inclies thick.

Dark shaly marl, 3 feet 6 inches. Dark stony band, 8 inches. Dark indurated marl, 2 feet. Band of limestone, 6 inches.

Dark indurated marl, resting on a pebbly conglomerate, 3 feet 6 inches.
BEDS.

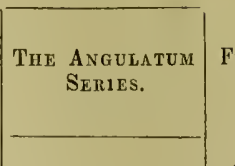

Planorbis

Series.

Ostrea

Series.

Dark Grit.

Black Shales.

UPPER

Pecten-bed.

Grey MarL with

GYPSUM.

LOWER

Pecten-Bed.

Lower DarK

Marls and

Shales.

Black Shales.
Organic Remains.

Fragments of Aegoceras angulatum and Aeg. liassicum.

Aegoceras planorbis, much compressed between the shaly laminæ, the white outer layer of the shells is well preserved.

\section{Modiola minima, Ostrea liassica,} Pleuromya Crowcombeia, Astarte obsoleta.

These fossils were found sparingly on the surface of the slabs.

Teeth and Scales of Fishes.

Fossils rare.

Pecten Valoniensis.

Cardium Rhaticum.

Avicula contorta. Cardium Rhaticum. Axinus cloacinus.

Pecten Faloniensis.

Avicula contorta.

Isodonta pracursor.

Many small shells in compressed seams lie within the laminæ of the shales, is Pullastra, Axinus, and Avicula contorta.

Teeth and scales of Fishes.

BoNE-BED, Saurichthys, Iyybodus, Gyrolepis.

These black sluales are not fossiliferous. 
The Lower Black Shales rest upon beds of pale green and grey marls, interstratified with bands of limestone which are here interposed between the Contorta-series and the Red Marls of the Kenper.

In this cutting, when first made, the uppermost portion of the grey marls was overlain by a thin bed of conglomerate formed of small round quartz pebbles, and on this rested the basement layer of the Black Shales. The Bone-bed was uniformly thin and found with difficulty in situi, although fragments of it were discovered on the spoil-banks. I have collected from these many good specimens of teeth and scales of the Fishes in the list.

The Lower Pecten-bed is a slate-coloured, pyritic, semi-indnrated shale, containing many compressed bivalved shells in tolerable preservation, and the dark shales between the two Pecten-beds have a few fossils closely compressed between the laminæ.

The Upper Pecten-berl was very rich in Conchifera, which were enclosed in a hard, argillaceous limestone with iron; so the fossils were too pyritic to be preserved, otherwise a larger list might have been added.

At Puriton is another railway-cutting in which the Contorta-series is well exposed; and the Bone-bed was found to be richly fossiliferous. In this cutting the Ostrea- and Planorbis-beds of the Lower Lias were likewise well laid open.

The railway-cutting near Shepton Mallet affords another instructive section of the Contorta-series overlain by the Ostrea-, and Planorbis-, and Angulatum-beds of the Lower Lias; and similar sections are exposed likewise near Wells, and Whitchurch, and at Saltford and Weston, near Bath. The latter show the relation of the Contorta-series to the Lias extremely well, as will be seen in the sequel.

A very fine coast-section of the Contorta-series, ranging from the tea-green and grey Marls through the Black Shales and Limestones of the Lower Lias, is admirably exposed at St. Audrey's Slip, two miles east of Watchet. At the base are seen the red marls of the Keuper having in succession the tea-green marls, and above alternating beds of pale-grey, hard, and soft marls, resting on beds with strontian and gypsum. The pale grey marls are overlain by black shales, which collectively are here about forty feet thick, and almost unfossiliferous. The black shales are overlain by a band of nodular limestone containing Cardium Rhaticum, Axinus depressus; above this band comes in dark grey, sandy shales with the Bone-bed, consisting of a grey calcareo-siliceous rock, enclosing the teeth of Saurichthys apicalis, Acrodus minimus, and Hybodus. 'The Bone-bed is overlain by dark shales, and inconstunt bands of limestone, containing Avicula contorta, Pecten Valoniensis, Anatina Suessii, Myophoria postera, and other Conchifera. The dark-grey shales, some of which are indurated and ripple-marked, are sixteen feet thick, and are overlain by the Cotham Marble-bed, on which rests eight feet of the White Lias series, containing the Sun-bed; on this reposes a series of laminated shales five feet thick, some of the beds containing immense numbers of Pullastra, similar to the condition of the same beds at Pinhay Bay, on the Dorset coast. These shales separate the White Lias from the Ostrea-series, fifteen feet thick, which succeeds in the section. 
The Contorta-beds have likewise been found in Warwickshire, Staffordshire, and Leicestershire, also at Colin Glen, near Belfast, and in other localities in Ireland. ${ }^{1}$ The sections discovered in these comnties and Ireland closely resemble those alrealy described. The following list contains the fauna special to the Avicula-contorta-zone:

\section{ECHINODERMATA.}

Ophiolepis Damesii, Wright. Garden Cliff; Leicestershire; Warwickshire; Hildesheim, N. Germany.

\section{LaMeLiIBRANCHIATA.}

Avicula contorta, Portlock.

- solitaria, Moore.

Lima precursor, Quenst.

Modiola minima, Goldf.

Placunopsis alpina, Moore.

Plicatula intusstriata, Emmerich.

Gervillia præcursor, Quenst.

Pecten Valoniensis, Defrance.

- Rhæticus, Merian.

Plenromya Crowcombeia, MToore.

Myophoria inflata, Emmerich.
Pleurophorus elougatus, Moore.

- $\quad$ angulatus, Moore.

Anatina præcursor, Quenst.

- Suessii, Oppel.

- elongata.

Schizodus depressus, Moore.

- elongatus, Gümbel.

- concentricus, Moore.

Cardium Rbæticum, Merian.

Cypricardia Suevica, Oppel.

Pullastra arenicola, Strickland.

\section{Gasteropoda.}

Cylindrites elongatus, DLoore.

- fragilis, Dunker.

Cypris? liassica, Brodie.

Estheria minuta, var. Brodieana, Jones.
Chemnitzia alpina, Dittmar.

- granum, Dittmar,

\section{Crustacea.}

Pollicipes Rlıticus, Moore.

Tropifer lævis, Gould.

\section{Pisces.}

Acrodus minimus, Agass.

Saurichthys apicalis, Agass.

- acuminatus, Agass.

Sargodon tomicus, Plieninger.

Nemacanthus monilifer, Agass.

filifer, Agass.

Gyrolepis tenuistriatus, Agass.

- Alberti, Agass.

Hybodus pyramidalis, Agass.

\section{Reptilia.}

Plesiosaurus.

Ichthyosaurus.

1 Portlock, 'Geol. Report, Londonderry,' pp. 126-127, 1843; Tate, 'Quart. Journ. Geol Soc.,' vol. xx, pp. 105-107, 1864. 


\section{Mammalia.} Somerset.

Microlestes antiquus, Plieninger, in the Bone-bed of Würtemberg, and in the Rhætic Breccia of

M. (Hypsiprymnopsis) Rhæticus, Dawkins, Rhætic Beds, Watchet.

Foreign Correlations. - The Zone of Avicula contorta has a wide geographical range on the Continent of Europe, where the beds are found with lithological and palæontological characters very similar to those already described in the English counties, thus-

In South-west Germany they are developed in Württemberg near Tübingen, near Balingen, in the neighbourhood of Stnttgart, and uear Nürtingen and Esslingen. In the Langenbrücker Jura at Malsch and Osvingen, in Baden; in Bavaria, at Bamberg and Baireuth ; in Coburg, at Gotha in North-west Germany, near Brunswick, near Hildesheim, near Hanover, and in the vicinity of Göttingen.

In Switzerland, near Basel, and in the Canton of Argau, and in the Vaudois Alps, and in the Eastern, Western, and Italian Alps.

In France, in the departments of the Haute Saone, in the Franche Comté, in the Meurthe, Moselle, and Côte d'Or, Aveyron, Herault, Var, Mont d'Or, near Lyons, and Saint-Sorlin Saône-et-Loire, and in Luxembourg and Belgium.

In Lombardy they have a wide extent and great thickness, and are found in the north-west of Hungary at many points in the Carpathians. They are found likewise in Sweden as saudstone, shales, and coal, with plant remains, and attain a considerable thickness.

A careful review of the fauna shows-

1. That the zone of Avicula contorta contains a special assemblage of species, few of which are limited to any one bed.

2. That the vertebrata represented by Fishes are all more closely connected with the well-known forms of the Trias, and are claimed by Ichtlyologists as such.

3. That the Molluscan fauna contains two or three species that ascend into the Lias, but are never found in the Trias beds, whilst the greatest number are special to the zone, and have many organic affinities in relation with Triassic species. For these reasons it is contended that the Contorta-beds are truly Triassic.

\section{THE LOWER LIAS.}

\section{The Zone of Aegoceras planorbis.}

Synonyms.—“White Lias," William Smith, 'Memoir to the Map,' p. 47, 1815. “White Lias (pars)," De la Beche, 'Geol. Trans.,' 2nd series, vol. ii, p. 26, 1826. "Saurian Beds," Murchison's 'Geology of Cheltenham,' 2nd ed. by Buckman and Strickland, p. 49, 1845. "Psilonotenbank," Quenstedt, 'Der Jura,' Table, p. 293, 1857. “Die Schichten des Ammonites planorbis," Oppel, Juraformation,' p. 24, 1856, "Zone of 
Ammonites planorbis,” Wright, ‘Quart. Journ. Geol. Soc.,' vol. xvi, p. 389, 1864. “Zone de l'Ammonites planorbis," Dumortier, 'Etudes Paléont.,' t. i, p. 15, 1864. “Die Psilonotonschichten," Brauns, 'Die untere Jura,' p. 55, 1871. “Zone of Anmonites planorbis," Tate and Blake, Yorkshire Lias, p. 38, 1876.

This division of the Lower Lias is well developed in the South of England.' In general it consists of a series of thin, greyish, or bluish, argillaceous limestones, with alternating beds of laminated shale; or it forms sometimes the upper part of the thickbedder, argillaceous, crean-coloured limestone, called "White Lias" by William Smith. In the upper half of this group Aegoceras planorbis (Sow.), in some localities, is found in considerable numbers, compressed in the shales, with the outer layer of its white shell more or less preserved; in the lower portion of the series Ostrea liassica, Strick., appears in great numbers; and beneath these strata are three or four beds of hard limestones (or "firestones"), in which the finest skeletons of Enaliosauria have been discovered. As this distinction, by means of LE. planorbis, Ostrea liassica, and Saurians, is a practical and useful one in the investigation of this zone of life, I shall adhere to it on the present occasion,--premising, however, that Ammonites are very rare in the lower beds, and numerons in the upper; and that Ostrece are abundant below, and rare above, whilst Saurian remains are found throughout the entire series.

The best sections of the planorbis-zone are those afforded by the extensive quarries at Street and the coast-sections at Watchet, and St. Audrey's Slip, in Somerset; ${ }^{3}$ at Binton and Wilmcote, in Warwickshire; and at Pinhay Bay and Up-Lyme, in Dorset. I purpose giving a detailed description of the most typical sections in each county.

Somersetshire.-At Street the strata are nearly horizontal and undisturbed, and therefore admit of accurate measurement. The following section of Mr. Cree's quarry I have compared with like sections afforded by the quarries of Messrs. Seymour, Underwood, and Talbot in the same parish; and find that the variation is so inconsiderable that any one may be said to represent the others, both as regards the sequence of the beds and the fossils they contain.

1 The substance of the following observations on the Lower Lias is contained in my memoir on the 'Zone of Aricula contorta, and the Lower Lias of the South of England," "Quart. Jour. of the Geological Society,' vol. rvi, p. 374, 1864 .

2 Ostrea liassica, Strickland, is a very characteristic shell of the lowest Lias beds. It resembles Ostrea irregularis, Münster (Goldfuss, 'Petr. Germ.,' pl. vii-ix, fig. 5), and Ostrea rugata, Quenstedt ('Jura,' pl. iii, fig. 17). Dunker, in the 'Palæontographica' (pl. vi, fig. 27), has figured a small Oyster from the Lias of Halberstadt (Ostrea sublamellosa, Dunker), which appears to be identical with our species. These small, thin, rugose Oysters are found in great abundance in the lowest beds of the Lower Lias in England and Germany. They are probably only varieties of one species, which had a wide geographical distribution in the seas which deposited the basement-beds of the Lias.

3 R. Etheridge, F.G.S., "Physical Structure of the Watchet Area," 'Proc. Cotteswold Nat. Field Club,' 1871 , p. 40 , and section No. 6 . 
Section of the Zone of Aegoceras planorbis, at Street, Somerset.

\begin{tabular}{|c|c|c|c|}
\hline No. & Lithology and Local Names of Beds. & $\begin{array}{l}\text { Tuxck- } \\
\text { NEss. }\end{array}$ & Organic Remains. \\
\hline & & ft. in. & Planorbis Series. \\
\hline 1 & Ligbt-coloured marly clay. "Top Bed" & 30 & Saurian bones and Aegoceras planorlis. \\
\hline 2 & Light-coloured Lias limestone ........... & & Aegocieras planorbis in moulds. \\
\hline 3 & 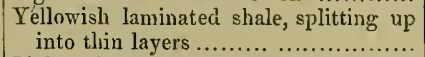 & 30 & $\begin{array}{l}\text { Ichthyosaurus intermedius, Aegoceras planorbis, } \\
\text { Lima punctata, and Isastrce Murchisoni. }\end{array}$ \\
\hline 4 & Light-coloured sbaly limestone................ & 04 & Aegoceras planorbis, compressed. \\
\hline 5 & Hard grey linestone. "Building-stóne" & 7 & $\begin{array}{l}\text { Aegoceras planorbis, on the top of the bed, Lima } \\
\text { punctata and Lima gigantea. }\end{array}$ \\
\hline 6 & Dark-grey shale.. & 0 & $\begin{array}{l}\text { Aegoceras planorbis and muricated spines of } \\
\text { Cidaris Edwardsi. }\end{array}$ \\
\hline 7 & $\begin{array}{l}\text { Dark-grey limestone. "Corn-sized build- } \\
\text { ing-stone "............................ }\end{array}$ & 06 & $\begin{array}{l}\text { Spines of Cidaris and bones of Ichthyosanrus } \\
\text { tenuirostris. }\end{array}$ \\
\hline 8 & $\begin{array}{l}\text { Ostrea Series. } \\
\text { Dark laminated shale } \ldots \ldots \ldots \ldots \ldots \ldots \ldots \ldots \ldots \ldots\end{array}$ & & $\begin{array}{l}\text { Ostrea Serres. } \\
\text { Ostrea liassica. }\end{array}$ \\
\hline 9 & $\begin{array}{l}\text { Dark-grey limestonc. "Five-inch build- } \\
\text { ing-stone" }\end{array}$ & & Ostrea liassica. \\
\hline 10 & 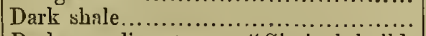 & 03 & Ostrea liassica. \\
\hline 11 & $\begin{array}{l}\text { Dark-grey limestone. "Six-inch build- } \\
\text { ing stone" }\end{array}$ & & $\begin{array}{l}\text { Cardinia erassiuscula, Lima punctata, and Ostrea } \\
\text { liassica. }\end{array}$ \\
\hline 12 & 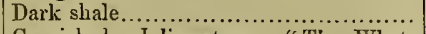 & & - \\
\hline 13 & $\begin{array}{l}\text { Greyish hard limestone. "The Whet- } \\
\text { stones." Best paving-bed. Consisting } \\
\text { of two 4-inch beds .................... }\end{array}$ & & Fossils rare: Ostrea liassica and Modiola minima. \\
\hline 14 & Hard dark marl. "Saurian bed" "....... & 09 & $\begin{array}{l}\text { Many Saurians have been obtained from this bed. } \\
\text { Ichthyosaums intermedius and Plesiosaurus } \\
\text { Hawkinsii (British Museum). Many jaws of } \\
\text { Saurians and Fishes. }\end{array}$ \\
\hline 15 & 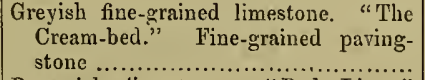 & & \\
\hline 16 & 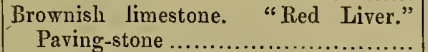 & & . \\
\hline 17 & 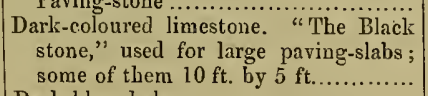 & 0 & $\begin{array}{l}\text { Few fossils. } \\
\text { Modiola minima, Ostrea liassica, Pleuromya, and } \\
\text { Rhynchonella variabilis. }\end{array}$ \\
\hline 18 & Dark-blue shale.......................... & & Ostrea liassica and Modiola minima. \\
\hline 19 & 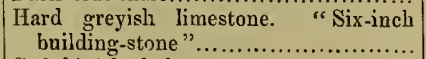 & 0 & Ceromya, sp., Modiala minima, and Ostrea liassica. \\
\hline 20 & Soft bluish shale .............................. & 0 & - \\
\hline 21 & 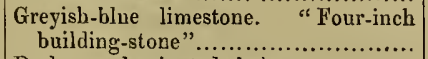 & 0 & Fossils as in No. 19. \\
\hline 22 & 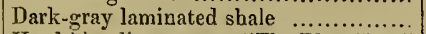 & 0 & Ichthyosaurus intermedius and $I$. tenuirostris. \\
\hline 23 & $\begin{array}{l}\text { Hard blue limestone. "The Blue Clog," } \\
\text { or "One-foot building-stone," used } \\
\text { for steps ............................ }\end{array}$ & & Ceromya, sp., Ostrea, Modiola, and Rhynchonella. \\
\hline 24 & Grey laminated shale & 13 & $\begin{array}{l}\text { Saurians abundant: Ichthyosaurus intermedius } \\
\text { and I. tenuirostris, Pholidophorns leptocephalus, } \\
\text { Agass. }\end{array}$ \\
\hline 25 & $\begin{array}{l}\text { Greyish limestone. "Grey Clog." A } \\
\text { valuable building-stone, used for steps, } \\
\text { troughs, \&c. ......................... }\end{array}$ & & \\
\hline 26 & 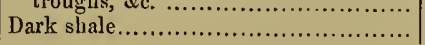 & $\begin{array}{ll}1 & 0 \\
0 & 2\end{array}$ & Modiola minma. \\
\hline
\end{tabular}




\begin{tabular}{|c|c|c|c|}
\hline No. & Lithology and Local Names of Beds. & $\begin{array}{l}\text { THICK- } \\
\text { NESS. }\end{array}$ & Oroanic Remains. \\
\hline 27 & 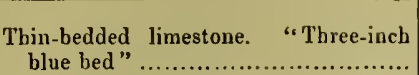 & $\begin{array}{l}\text { ft. in. } \\
0 \quad 3\end{array}$ & $\begin{array}{l}\text { Fish remains, Modiola minima and Otopteris acu- } \\
\text { minata L. \& H. }\end{array}$ \\
\hline 28 & Thick blue limestone..................... & & - \\
\hline 29 & $\begin{array}{l}\text { Hard fine-grained limestone. "Fire- } \\
\text { stone" }\end{array}$ & & \\
\hline 30 & Hard, grey, fine-grained limestone ....... & $0 \cdot 4$ & $\begin{array}{l}\text { Plesiosaurus Etheridgii. (In Jermyn Street Mu- } \\
\text { seum; and another in Street are from this bed.) }\end{array}$ \\
\hline $3 I$ & 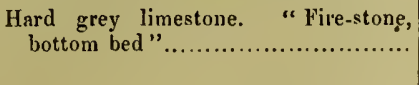 & 10 & $\begin{array}{l}\text { Plesiosaurus Hawkinsii. [The large Ples. mega- } \\
\text { cephalus, Stutch., now in the Bristol Institution, } \\
\text { was obtained from this bed near Street.] }\end{array}$ \\
\hline
\end{tabular}

The Saurian beds near Langport have likewise yielded Reptilian remains. I obtained two fine specimens of Ichtlyosaurus intermedius and an imperfect specimen of $I$. tenuirostris from this locality; the former is now in the Collection of the Earl of Ducie. In connection with the Saurian beds of Somerset, it is important to note that the oldest Enaliosauria of the Lias are Plesiosaurus Hawkinsii, Owen, and Pl. Etheridgii, Huxley, which were both exhumed from the 4-inch firestone, forming the bottom bed of the Ostrea-series; the remarkable Plesiosaurus megacephalus, Stutch., now in the Bristol Museum, was likewise found in the firestones of a quarry near Street Foss ; and it will be shown in my section of the correlative beds of this zone at Wilmcote, in Warwickshire, that the fine skeleton of Plesiosaurus megaceplaalus contained in the Warwick Museum was also exhumed from the "firestones" of that locality-beds which are the true equivalents of the "firestones" of Street.

The small number of Lamellibrancliata hitherto found in these beds is very remarkable. Ostrea liassica, Strickl., O. irregularis, Quenst., Modiola minima, Goldf., M. psilonoti, Quenst., Gervillia Hagenovii, Dunk., Anomya striatula, Opp., Pleuromya Crowcombeia, Mor., Macrodon Hettangiensis, Terq., and Protocardia Phillippiana, Dunk., are the only species I have as yet collected from the firestone-beds.

This section likewise settles a question which has been often discussed, namely, what is the age of the Saurian beds of Somersetshire? It has been supposed that they appertain to the same horizon as the lower Saurian beds at Lyme Regis, Dorsetshire; this, however, is a mistake, inasmuch as the Saurian beds at Street belong to the zone of Aegoceras planorbis, whilst the Saurian remains at Lyme Regis, on the contrary, are for the most part found in and above the zone of Arietites Bucklandi.

Worcestershire and Gloucestershire.--The Planorbis-, Ostrea-, and Saurian-beds so well developed at Street, are likewise found in different parts of Worcestershire and Gloucestershire, where they present the same stratigraphical relations, and yield the same organic remains.

The neighbourhood of Tewkesbury affords several good exposures of these infraammonite beds. I have obtained Ichthyosaurus tenuirostris, Conyb., and Ichthyosaurus 
intermedius, Conyb., from a bed of light-coloured Lias at Haselgrove, near the "Folly ;" and the late Mr. Dudfield collected several very fine skeletons of Ichthyosaurus tenuirostris, Conyb., I. intermedius, Conyb., and I. communis (?), Conyb., with bones of Plesiosaurus Hawkinsii, at Brockeridge Common, and from similar beds in other localities near Tewkesbury; and I possess several vertebræ of Plesiosaurus rugosus, Owen, which were obtained from a bed of Lower Lias at Woolridge, near Hartpury.

The junction of the Lower Lias with the red marls of the Keuper in the Vale of Gloucester is, in general, indicated by a low escarpment, facing the west. At Brockeridge and Defford Commons this natural boundary is exceedingly well marked, and between these two localities are several quarries which expose to a greater or less extent the beds now under consideration. The presence of Aegoceras planorbis in the upper strata of these sections has enabled me to correlate the beds beneath with the corresponding strata at Street, in Somerset, and at Binton, Grafton, and Wilmcote, in Warwickshire.

Section of the Planorbis-, Ostrea-, and Saurian-beds at Brockeridge and Defford Commons.

\begin{tabular}{|c|c|c|c|}
\hline Zones. & Strata and Organic Remains. & Brockeridge. & Strensham, \\
\hline 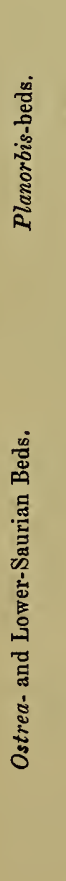 & 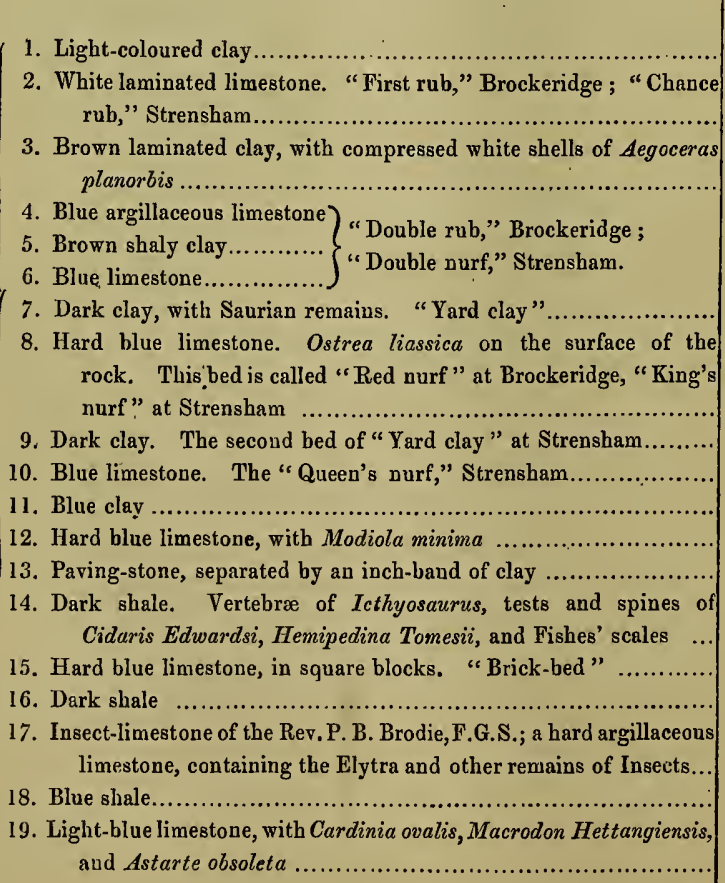 & $\begin{array}{ll}1 & 0 \\
1 & 6 \\
0 & 3 \\
0 & 0 \\
0 & 0 \\
0 & 0 \\
& \\
0 & 0 \\
0 & 0 \\
0 & 0 \\
0 & 0 \\
0 & 0 \\
0 & 0\end{array}$ & $\begin{array}{ll}0 & 3 \\
3 & 0 \\
0 & 3 \\
0 & 3 \\
0 & 6 \\
0 & 4 \\
0 & 6 \\
0 & 5 \\
0 & 3 \\
0 & 6 \\
1 & 3 \\
0 & 4\end{array}$ \\
\hline
\end{tabular}


I have placed the sections together for the purpose of comparison : they were first made by my friend, the Rev. P. B. Brodie, F.G.S., and have been often examined since with similar results. These sections show the uniformity which prevails in the Lower Saurian beds of Gloucestershire and Worcestershire, and how much they resemble their correlative strata at Street.

The late Mr. Dudfield, of Tewkesbury, obtained from the Ostrea-beds at Brockeridge Common, enumerated in the preceding sections, and from other strata occupying the same horizon in the vicinity of that town, a very fine series of Saurian remains, which were all sold and dispersed in June, 1843. From my notes of that collection I find there was a specimen of Ichthyosaurus intermedius, about 8 feet in length; the two forepaddles and a portion of the scapular arch were tolerably complete; and there were upwards of 100 vertebræ, and many ribs nearly all in place. I. tenuirostris; 4 feet in length; the skull, jaws, and teeth were well preserved, and the vertebral column was tolerably complete; likewise one fore-paddle. I. communis; very fine paddles. $I$. platyodon; large skull, with orbital plates in position. Plesiosaurus Hawkinsii; the vertebral column, ribs, and humeri; and fifty vertebræ in position.

The Ostrea- and Saurian-beds at Binton, Brockeridge, and Street are overlain by clays and laminated shales, containing Aegoceras planorbis. As these beds form a most important horizon in the Lias formation, and have a wide geographical distribution in England, France, and Germany, they require to be defined with accuracy, especially as some authors are of opinion that the true Lias commences with this zone of life.

The relation of the Planorbis-shales to the Saurian beds below is extremely well exposed in the Railway-cutting at Uphill and in the quarries at Street, Somerset; at Binton and Wilmcote, in Warwickshire; at Brockeridge Common, in Gloucestershire; at Strensham, Worcestershire; and to the Bucklandi-or Lima-beds above in the sections at Saltford, near Bristol; Penarth Head, near Cardiff; Pinhay Bay, near Lyme Regis ; and St. Audreys Slip, near Watchet, Somerset.

The following section of the beds at Binton was made by Mr. R. Tomes, F.Z.S., from a working now abandoned. A similar exposition, however, was seen in the quarry worked near the former, which I examined and measured with Messrs. Tomes and Kershaw.

Section of the Zones of Aegoceras planorbis and Avicula contorta, at Binton, Warwickshire.

\begin{tabular}{|c|c|c|c|}
\hline No. & Lithology and Local Names of Beds. & $\begin{array}{l}\text { Trick- } \\
\text { NESS. }\end{array}$ & Organic Remains. \\
\hline $\begin{array}{l}1 \\
2 \\
3\end{array}$ & 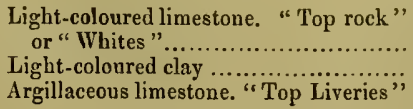 & $\begin{array}{cc}\text { ft. } & \text { in. } \\
0 & 6 \\
2 & 6 \\
0 & 3\end{array}$ & Ichthyosaurus; on the upper surface, Insects. \\
\hline
\end{tabular}




\begin{tabular}{|c|c|c|c|}
\hline No. & Lithology and Locar. Names of Beds. & $\begin{array}{l}\text { Thick- } \\
\text { Ness. }\end{array}$ & Organic Remains. \\
\hline & & ft. in. & \\
\hline 4 & Light-coloured clay ....................... & & - \\
\hline 5 & 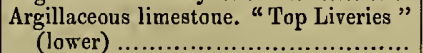 & 0 & Aegoceras Johnstoni, Sow. \\
\hline 6 & 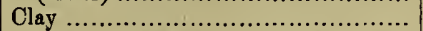 & 11 & \\
\hline 7 & $\begin{array}{c}\text { Greyish limestone. "Extra rock," } \\
\text { "Thick paving-bed " ............... }\end{array}$ & $0 \quad 6$ & No fossils. \\
\hline 8 & 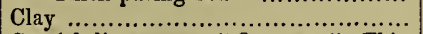 & $\begin{array}{ll}0 & 3 \frac{1}{2}\end{array}$ & 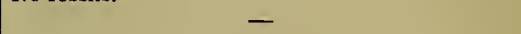 \\
\hline 9 & $\begin{array}{l}\text { Greyish limestone. "Quarters." Thin } \\
\text { and irregular when covered by the } \\
\text { preceding.................... } 2 \text { in, to }\end{array}$ & & - \\
\hline 10 & 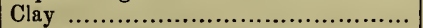 & $0 \quad 8 \frac{1}{2}$ & - \\
\hline 11 & $\begin{array}{l}\text { Greyish limestone. "Ribs." A con- } \\
\text { stant bed ............................ }\end{array}$ & & Insects. \\
\hline 12 & 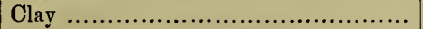 & $0 \quad 5 \frac{1}{2}$ & - \\
\hline 13 & Limestone. "Paving-stoue "............ & $0 \quad 3$ & A few Insects, and Pholidophorus Stricklandi, Ag. \\
\hline 14 & 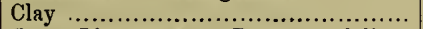 & $0 \quad 10 \frac{1}{2}$ & - \\
\hline 15 & Insect Limestone. "Bottom rock" ... & \begin{tabular}{ll|}
0 & $3 \frac{1}{4}$
\end{tabular} & $\begin{array}{l}\text { More Insects here than in all the other beds } \\
\text { collectively. }\end{array}$ \\
\hline 16 & 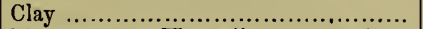 & 0 & $-1-$ \\
\hline 17 & Limestone. "Hoggs" ........ 3 in. to & & Tetragonolepis angulifer, Ag. (Warwick Mus.) \\
\hline 18 & Strong hard clay ........................ & $03 \frac{1}{2}$ & No fossils in this bed. \\
\hline 19 & Argillaceous limestone ; imperfect stone. & & - \\
\hline 20 & 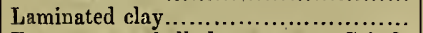 & 16 & - \\
\hline $2 \mathrm{I}$ & $\begin{array}{c}\text { Fragmentary shelly limest one. "Grizzle } \\
\text { hed" ................................. }\end{array}$ & & $\begin{array}{l}\text { Saurian bones, Fishes' teeth and scales, Aegoceras } \\
\text { planorbis, Lima punctata, Protocardia Phillip- } \\
\text { piana, and Ostrea liassica; spines of Cidaris } \\
\text { and other Echinida abundant. }\end{array}$ \\
\hline 22 & Stony shale. & 一 & - \\
\hline 23 & $\begin{array}{l}\text { Hard limestone. "Blue stone" or } \\
\text { "Blocks" } " . \ldots \ldots \ldots \ldots \ldots \ldots \ldots \ldots \ldots \ldots \ldots \ldots \ldots \ldots \ldots \ldots \ldots \ldots\end{array}$ & & Pleuromya Crowcombeia, and elytra of Coleoptera. \\
\hline 24 & 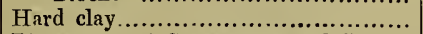 & 13 & \\
\hline 25 & Limestone. "Grave-stone rock" ....... & $0 \quad 3 \frac{\lambda}{2}$ & $\begin{array}{l}\text { Ichthyosaurus and Otopteris acuminata, Lin. \& } \\
\text { Hut. }\end{array}$ \\
\hline 26 & 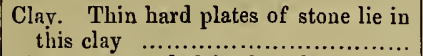 & $0 \mathrm{Il}$ & 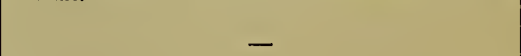 \\
\hline 27 & $\begin{array}{l}\text { Limestone, underlain by clay. (The } \\
\text { clay frequently wanting) } \ldots \ldots \ldots \ldots \ldots \ldots . . . . .\end{array}$ & & \\
\hline $\begin{array}{l}28 \\
29\end{array}$ & $\begin{array}{l}\text { Limestone; inconstant. "Gummerals" } \\
\text { Clay. }\end{array}$ & 06 & Ostrea liassica. \\
\hline 30 & Hard grey limestone. "Fire-stone beds" & & Saurian remains and Protocardia Phillippiana. \\
\hline 31 & 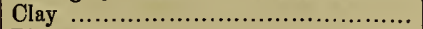 & & Modiola minima, $P$ l. Crowcombeia, and $O$. liassica. \\
\hline 32 & Limestone.......................... & & In these limestones and clays only one small \\
\hline 33 & Clay $\ldots . . . . . .$. & & Aegoceras planorbis has been found. \\
\hline 34 & Limestone ..... & 0 & \\
\hline 35 & Clay & 0 & \\
\hline 36 & $\begin{array}{c}\text { Hard dark limestone. "The Guinea- } \\
\text { bed." (This is the bottom bed of the } \\
\text { quarry) } \ldots \ldots \ldots \ldots \ldots \ldots \ldots \ldots \ldots \ldots \ldots \ldots \ldots \ldots \ldots \ldots \\
\text { in. to }\end{array}$ & 010 & $\begin{array}{l}\text { Saurian bones, Avicula longicostata, Stutch., } \\
\text { Monotis fallax, Lima punctata, Pleuromya } \\
\text { Crowcombeia, Ostrea liassica, Hemipedina } \\
\text { Tomesii, Wr., in numbers; Septastrca. }\end{array}$ \\
\hline
\end{tabular}

Avicula Contorta Beds.

Thick clay-beds ; yellowish blue ; breaking in angular fragments...............

Dark ferruginous clay, with conchoidal fracture, the Estheria-bed. 


\begin{tabular}{|c|c|c|c|}
\hline No. & Lithology. & $\begin{array}{l}\text { ThieK- } \\
\text { Ness. }\end{array}$ & Palatontology. \\
\hline $\begin{array}{l}39 \\
40 \\
41 \\
42 \\
43 \\
44 \\
45 \\
46 \\
47 \\
48\end{array}$ & 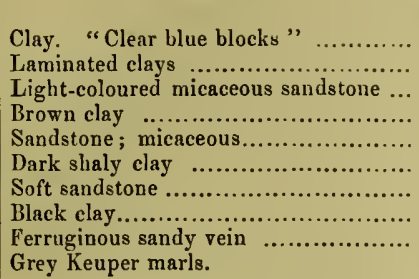 & $\begin{array}{ll}\mathrm{ft.} & \text { in. } \\
& ? \\
3 & 0 \\
0 & 1 \\
0 & 2 \\
0 & 2 \\
0 & 6 \\
0 & 1 \\
0 & 3\end{array}$ & $\begin{array}{l}-\overline{-} \\
\text { Pullastra arenicola, Strickl. } \\
\text { Pullastra arenicola, Strickl. } \\
= \\
=\end{array}$ \\
\hline
\end{tabular}

The beds from No. 37 to N. 48 were found in sitú in an escarpment at a short distance from the quarry at Binton. The "Guinea-bed" is the lowest stratum seen in sitú in the pit, and No. 37 occupies its natural position relatively to that bed, although not exposed in the Binton section.

Lithology.-The Planorbis-beds at Brockeridge (p. 18) consist of dark, laminated shales, with interstratified beds of marl and limestone. The shales split into very thin laminæ, between which innumerable shells of Aegoceras planorbis lie closely compressed; the white, calcareous, pulverulent material of the shells forming a strong contrast to the dark shales enclosing them. In Somersetshire, at Uphill, the rock consists of shales which greatly resemble those at Brockeridge; at Watchet, of dark clays which are more indurated and have the shell-structure better preserved: Aegoceras planorbis and Aeg. Jolnstoni are here found with the iridescent nacreous layer of their shells beautifully lustrous. At Street the rock is a light-yellowish clay, with bands of greyish limestone and marl beneath, and in Worcestershire at Strensham, and in Warwickshire at Binton, similar lithological conditions prevail.

The White Lias series of the section at Saltford (see p. 37) represents in part the Planorbis-beds : the relations of that zone to the Samian beds below, and to the Bucklandi-beds above, are here also well shown. In Dorsetshire the Planorbis-beds are represented by the upper portion of the White Lias so well exposed in the large quarries at Up-Lyme, where it is raised for caustic lime, and in the coast-sections at Charlton and Pinhay Bays; and consists of a fine-grained, cream-coloured limestone. The two principal quarries afford the necessary details. Mr. Webb's quarry shows-

In the uppermost portion, thin bands of grey limestone interstratified with shales; in these are found Aegoceras planorbis and A. Jolinstoni; in two thick beds of dark, shaly clay are numerous spines and plates of sea-urchins, as Cidaris Edwardsii, Wrt., Pseudodiadema lobatum, Wrt., Hemipedina Bechei, Brod., Hemipedina Bowerbankii, Wrt. These same shales are found at low-water mark at Pinhay Bay, and have yielded nearly all the Echinidæ said to be found in the Lower Lias at Lyme Regis. 
Beneath the lower bed of the Cidaris-shales are several thin beds of light-coloured limestone, locally called Whetstones, and separated by intermediate shales; then in descending order come the beds known as Grey Burr, Rotten Burr, Fire-stones, Cliffledge, Half-foot, One-foot, Red Size, and Anvil-ledge, all separated by thin bands of shale; on the surface of the limestones and in the shales are many fossils, among which Ostrea liassica forms the dominant shell. The shale above Anvil-ledge contains great numbers of Pullastra arenicola, Strickland, apparently indicating a change of condition in the series of beds which lie below this fossil band. The beds from the Whetstones to the Pullastra-shales represent the Ostrea-series, and from the circumstance of the exposed edges of the rock having weathered to a cream-colour, they form the upper portion of the White Lias. The lower portion of this formation differs both lithologically and palæontologically from the upper portion; it is a compact, earthy limestone, with conchoidal fracture, cream-coloured, and close-grained; and many of the beds are so fine that they might be used as lithographic stone. Beneath Anvil-ledge are three feet of light-coloured, rubbly beds, containing Modiola minima, Ostrea liassica, Pleuromya Crowcombeia, resting upon eighteen inches of White Lias; then follow a series of irregular beds, with thin partings, twelve feet in thickness, which overlie a bed, twenty-one inches thick, of fine, white limestone, resting on a like thickness of shale; beneath this is a bed of smooth, regular, fine, white limestone, six feet thick; then a bed of shale; and at the base of the series is a band of Cotham marble or Landscape-stone. The lower portion of the White Lias from the Pullastra-shales downwards represent, I believe, the upper beds of the Avicula-contorta-zone; there are many fossils in the limestones, which have not yet been determined. I have found casts of Cardium Rhaticum, Monotis decussata, Pullastra arenicola, and shells of Pecten Valoniensis. Unfortunately the fossils are mostly in the form of moulds, and for this reason we must wait until better specimens are obtained. The lower portion of the White Lias series is only seen in $\mathrm{Mr}$. Fowler's quarry at Up-Lyme.

The coast-section at Pinhay Bay is a complete repetition of the Up-Lyme quarries ; the Cidaris-shales are well exposed at low water during spring-tides, and from them are obtained all the Eclinida found in the section. I know of no Asteriada in these beds.

In Gloucestershire this zone is well exposed at Brockeridge Common, and at Wainlode, in a quarry on the right-hand side of the Gloucester Road, between Hartpury and Ashelworth, and at Elmore, in quarries near the Old Kennel.

In Glamorganshire it is seen in the fine coast-section at Penarth Head. In Somersetshire, in the cutting of the Great Western Railway at Saltford; in the Uphill Cutting on the Bristol and Exeter Railway; in the coast-section at St. Audreys Slip, near Watchet; and in all the quarries at Street.

In Worcestershire it is found at Strensham ; and in Warwickshire at Binton, Grafton and Wilmcote. 
It is likewise found at Robin Hood's Bay, on the coast of Yorkshire; the beds lie here below low-water mark, and large blocks, frequently washed up by the tide, are literally crowded with Aegoceras planorbis, known at Scarborongh and Whitby as Aeg. erugatum, Bean.

The Coral-bed at Lussay, Isle of Skye, ${ }^{1}$ probably represents this zone, as I found the same species of Anthozoa as the Hebridean Coral Isastrcea Murclisoni, Wrt., in the lightcoloured clays with Aeg. planorbis at Street.

This lower Ammonite-zone has, therefore, a wide geographical range throughout the Lower Lias of the northern, midland, and southern counties of England, and retains the same relative position in the Lower Lias of France, Germany, and Switzerland.

The detailed sections which I have given of the Planorbis-zone form some of the best known types of the basement-beds of the Lias in England, and enable us to understand their relations to the Contorta-series below, and the Angulatom-strata which succeed them.

Fossils of the Planorbis-beds.-The fauna of this zone is very limited; at present I know only the following species from the English beds :

Ichthyosaurus intermedius, Conyb.

$$
\text { - } \quad \text { tenuirostris, Conyb. }
$$

Plesiosaurus Hawkinsii, Conyb.

- Etheridgii, Huxl.

- rugosus, Owen.

- dolichodeirus, Conyb.

Dapedius, sp. ined.

- megacephalus, Stutch.

Pholidophorus leptocephalus, $\boldsymbol{A g}$.

Aegoceras planorbis, Sow.

$$
\text { Stricklandi, } \boldsymbol{A g} \text {. }
$$

- Johnstoni, Sow. .

Lima punctata, Sow.
Lima gigantea, Sow.

- pectinoides, Sow.

Cardinia crassiuscula, Sow.

Unicardium cardioides, Phil.

Ostrea liassica, Strick.

Protocardia Phillipsiana, Dukr.

Pleuromya Crowcombeia, Moore.

Rhynchonella variabilis, Schloth.

Cidaris Edwardsii, Wrt.

Pseudodiadema lobatum, $\boldsymbol{W r}$.

Hemipedina Bechei, Brod.

- Bowerbankii, $\boldsymbol{H}^{r}$ rt.

Hemipedina Tomesii, Wrt.

Isastræa Murchisoni, $W r t$.

Foreign Correlations.-In the North of Germany the Planorbis-beds are well developed, and in some parts contain a Flora in which are found many species that appeared for the first time in the ConToRTA-zone; the most important genera are Equisetum, Dictyophyllum, Clathropteris, Glossopteris, Taniopteris, Pterophyllum, Zamites, Nilssonia, and many others.

The Molluscan fauna contains many species which are common to this and the Angulatum beds; the following species were nearly all collected at Halberstadt, and 
many of them were figured and described by Dr. Dunker in the 'Palæontographica" some years ago.

\section{Cephalopoda.}

Aegoceras planorbis, Sow.

- Johnstoni, Sow.

- Hagenovii, Dukr.
Aegoceras angulatum, Schloth.

- laqueum Quenst.

Nautilus intermedius, Sow.

\section{Gasteropoda.}

Cylindrites fragilis, Dukr.

Patella Schmidtii, Dukr.

- subquadrata, Dukr.

- tenuis, $D u k r$.

Dentalium Etalense, Terq.

Pleurotomaria rotellæformis, $D u k r$.

Discohelix pygmæus, $D u k r$.

Euomphalus liasinus, Dukr.

Neritina liasina, $D u k r$.
Turritella Zenkéni, Dukr.

Hydrobia Krausseana, Dukr.

- solidula, Dukr.

Hydrobia subulata, $D u k r$.

Rissoa liasina, $D u k r$.

Littorina inornata, Terqm.

Cerithium gratum, Tergm.

- Etalense, Piette.

Purpurina angulata, $D u k r$.

\section{LAMELLIBRANCHIATA.}

Ostrea sublamellosa, $D u k r$.

- ungula, Minst.

Hinnites inæquistriatus, Goldf.

Pecten textorius, Schloth.

Lima pectinoides, Sow.

- succincta, Schloth.

- gigantea, Sow.

Nucula navis, Piette.',

Macrodon pullus, Terqm.

Inoceramus pinnæformis, $D u k r$.

Gervillia Hagenovii, Dukr.

Avicula Kurrii, Oppel.

Pinna Hartmanni, Ziet.

Modiola Hillana, Sow.

- nitidula, Dukr.

- scalprum, Sow.

Astarte obsoleta, Dukr.
Cardinia concinna, Sow.

- crassiuscula, Sow.

- Listeri, Sow.

Hippopodium ponderosum, Sow.

Unicardium cardioides, Phill.

Cardium Heberti, Terqm.

Protocardia Phillippiana, Dulr.

Isodonta elliptica, $D u k r$.

Tancredia securiformis, $D u k r$.

Cyrena Menkei, Duler.

- Germari, Dukr.

Tæniodon ellipticus, Dukr.

Pholadomya corrugata, Dukr.

Goniomya heteropleura, Agass.

Gresslya Galathea, Agass.

Pleuromya subrufosa, Dukr.

The Planorbis-beds are developed in Württemberg, and exposed near Stuttgart; at Rüdern smooth forms of Aegoceras planorbis lie in a dark crystalline limestone; and. at Nellingen, the smooth and plaited varieties of the same species are found together in a dark-grey limestone.

In Swabia they are likewise worked, and from them a fine series of Ammonites have been collected by Professor Quenstedt, which are contained in the Tübingen University 
Museum. The $A$. planorbis of the Lias $a$, near Tübingen, very much resembles the variety of this shell found clustered together in blocks washed out of the Scar at Robin Hood's Bay. One of the finest specimens of this locality, in the Leckenby Collection, Woodwardian Museum, Cambridge, I have figured as typical of the species.

In Baden the Planorbis-beds are found in the Langenbrücker Jura resting upon the Bone-bed Sandstone of the Contorta series, and containing shells and fishes' remains similar to those found in England. The lower Lias begins at Malsch and Oestringen with a 2-foot bed of black-blue Limestone containing Aegoceras planorbis. The AnguLATUM zone appears to be absent, for the Planorbis-bed is overlain by clay containing Gryplicea arcuata and Fucoids, upon which rests the Bucklandi-series.

In France this zone is well developed in the department of the Côte d'Or, as proved by the following list of fossils obtained from the Lumachelle de l'Auxois, ${ }^{1}$ and contained in the well-arranged Museum of Semur, all of which I had the advantage of studying under the polite guidance of MM. Collenot and Bréon, to whose scientific knowledge, judgment, and good taste, this fine local collection owes its well-merited reputation.

\section{Reptiles.}

Ichthyosaurus, $s p$, at Beauregard, Semur.

Fishes.

Saurichthys acuminatus, Agass.

Sargodon tomicus, Plien.

Cephalopoda.

Aegoceras planorbis, Sow.

- Johnstoni, Sow.

- tortile, d'Orb.

Chemnitzia Phidias, $d$ Orb.

Neritina cannabis, Terq.

Littorina clathrata, Desh.

Turritella Deshayesei, Terq.
Aegoceras Prometheus.

- laqueus, Quenst.

- Burgundiæ, Mart.

Gasteropoda.

Pleurotomaria, $s p$.

Cerithium, $s p$.

Orthostoma, $s p$.

Turbo, $s p$.

\section{LAMELLIBRANCHIATA.}

Pleuromya crassa, Agass.

- striatula, Agass.

Pholadomya prima, Quenst.

Goniomya Sinemuriensis, Opp.

Anatina Sinemuriensis, Mart.

Leda tenuistriata, Piett.

Astarte Geuxii, d'Orb.
Cypricardia compressa, T'er $\boldsymbol{~}$.

Cardita tetragona, Terq.

Cardinia Sinemuriensis, d'Orb.

- Deshayesei, Terq.

- quadrangularis, Mart.

- Moreana, Mart.

- crassiuscula, Sow.

- trapezium, Mart.

1 J. J. Collenot, 'Description Géologique de l'Auxois,' p. 209. 
Cardinia Hennoquii, Terq.

- Collenoti, Mart.

- subovalis, Mart.

- brevis, Mart.

- Breoni, Mart.

- concinna, Sow.

- contracta, Mart.

- trigona, Mart.

- Listeri; Sow.

- hybrida, Stutch.

- ovum, Mart.

Lucina arenacea, Terq.

Tancredia Sinemuriensis, Mart.

- Desbayesei, Terq.

Cucullæa similis, Terq.

Arca Collenoti, MIart.

- Hettangiensis, Mart,

Pinna semistriata, Terq.

Mytilus minutus, Goldf.

- Geuxii, d'Orb.

- rusticus, Terq.

Saxicava, $s p$.

Lima edula, d'Orb.

- Valoniensis, Defrance.

Spiriferina Walcotii, Sow.

Pentacrinus angulatus, $O p p$.

Ophioderma, $s p$.

Septastræa excavata, $D e$ From.

Isastræa basaltiformis, De From.

Astrocœnia sinemuriensis, De From.
Lima Hettangiensis, Terq.

- pectinoides, Sow.

- prælonga, Mart.

- tuberculata, Terq.

- duplicata, Quenst.

Avicula Deshayesei, Terq.

- infraliasina, Mart.

- Dunkeri, Terq.

- Sideloci, Mart.

- similis, Piet. et Terq.

Inoceramus, $s p$.

Pecten pollux, d'Orb.

- calvus, Goldf.

- dispar, Terq.

Gervillia acuminata, Terq.

Plicatula spinosa, Sow.

- Deslongchampsei, $\boldsymbol{P}_{i e t}$. et $\boldsymbol{I}_{\text {erq }}$.

- Hettangiensis, Terq.

- intustriata, Emmr.

- Baylii, Terq.

Hinnites liasinus, Terq.

Ostrea marcignyana, Mart.

- irregularis, Münst.

- læviuscula, MIUnst.

\section{BRACHIOPODA.}

1 Terebratula perforata, Piet.

\section{Echinodermata.}

Cidaris Martini, Cott.

Hemipedina Burgundiæ, Cott.

\section{AnthozoA.}

In addition to the above fossils there are upwards of forty species of Foraminifera from the zone of $A$. planorbis at l'Auxois (see the description of "Les Foraminiferes de l'Auxois " in the memoirs of M. Terquem).

The zone of $A$. planorbis was likewise found by Dr. Reynès in the Aveyron; and in the Ardêche at Mercuer, near Aubenas, by M. Ch. Laforêt, where he collected both the smooth and plaited varieties of $A$. planorbis in the same bed. 


\section{The Zone of Aegoceras Angulatum.}

Synonyms.—“Sandige Kalke und Sandsteine mit Am. angulatus, Quenst.," 'Flötzgeb., p. 541, 1S43. "Grès infraliasique" (pars), Dufrénoy et De Beaumont. "Exp. Carte Geol. France,' vol. ii, p. 157, 184S. "Grès liasique, grès de Hettange," Terquem, 'Paléont. du Dép. de la Moselle,' p. 11, 1555. "Die Schichten des Ammonites angulatus," Oppel, 'Juraformation,' p. 2S, 1856. “Zone à Ammonites Moreanus," Martin, "Pal. Stratigraph. de l'Infra-lias dn Départ. de la Côte-d’Or," “Mém. Soc. Géol. de France,' p. 38, 2nd série, 1S60. “Angulatenschicten," Seebach, "Der Haunoversche Jura," p. 17, 1S64. "Die Angulatenschichten die untere Jura," Brauns, p. 70, 1871. "Zone d'A. angulatus," Dumortier, 'Etudes de Bassin de Rhone,' Prem. Pt., p. 100, 1564. "Zone of Ammonites angulatus," Tate and Blake, 'Yorkshire Lias,' p. 46, 1876.

The Angulatum-zone, so far as it has been exposed, appears to be imperfectly developed in the Midland Counties, and from the difficulty experienced in separating its beds from the Bucllandi-series, they were grouped with the latter in my memoir. ${ }^{1}$ On the Continent, however, and especially in France, this zone forms a very important horizon, and contains a rich fauna. M. Jules Martin, ${ }^{2}$ in his valuable memoir on the Infra-Lias of the department of the Côte-d'Or, says, "this zone forms one of the best characterised palæontological horizons in the Côte-d'Or, and contains the richest and most varied fauna. Limited to two or three yards in thickness, this deposit appears to correspond to a period of animalisation of admirable fecundity. It is from these that we have collected the charming famma which we last year indicated, and which has such intimate relations with the Hettangian fanma described by M. T'erquem." From this zone M. Martin has collected and catalogned-1 Ichthiyosaurus, 1 Ichthyodorulite, $10 \mathrm{sp.}$ of Ceplualopoda, $63 \mathrm{sp}$. of Gasteropoda, $77 \mathrm{sp}$. of Conchifera, $5 \mathrm{sp}$. of Brachiopoda, $4 \mathrm{sp}$. of Eclinodermata, $10 \mathrm{sp}$. of Anthozoa, $3 \mathrm{sp}$. Annelida, and the débris of Crustacea. In the Department of the Moselle M. Terquem ${ }^{3}$ has enumerated 177 species from the same zone. Aegoceras angulatum, (Schloth.), is found between Charmouth and Lyme Regis, in dark shale, below the grey concretionary limestone, with a mammilated surface; and likewise in the same strata sonth-west of the Cob. From these beds I lave collected Aegoceras angulatum (Schloth.), Aeg. Moreanum (d'Orb.).

This zone was well exposed in the Harbury cutting of the Great Western Railway, near Warwick, although very few Mollusca besides Aegoceras anyzlatum were obtained therefrom; on the spoil-banks, even now, some good fragments are occasionally found. On the coast of Yorkshire it occurs near Redcar, where it has been studied with much care by Messrs. Tate and Blake, and they have given a detailed account of its beds in their excellent work on the 'Yorkshire Lias,' p. 48, whence the following section is derived :-

1 'Quart. Jouru. Geol. S.,' xvi, p. 398, 1860.

2 'Paléontologie stratigraphique d'Infra-Lias du département de la Côte-d'Or,' p. 39, 1860. 'Mém. Soc. Géol. de France,' 2nd série, tom. vii, Mém. No. 1.

3 'Paléontologie du département de la Moselle,' p. 12, 1855. 
Section of the Angulatum-beds at Redcar (Yorleshire).

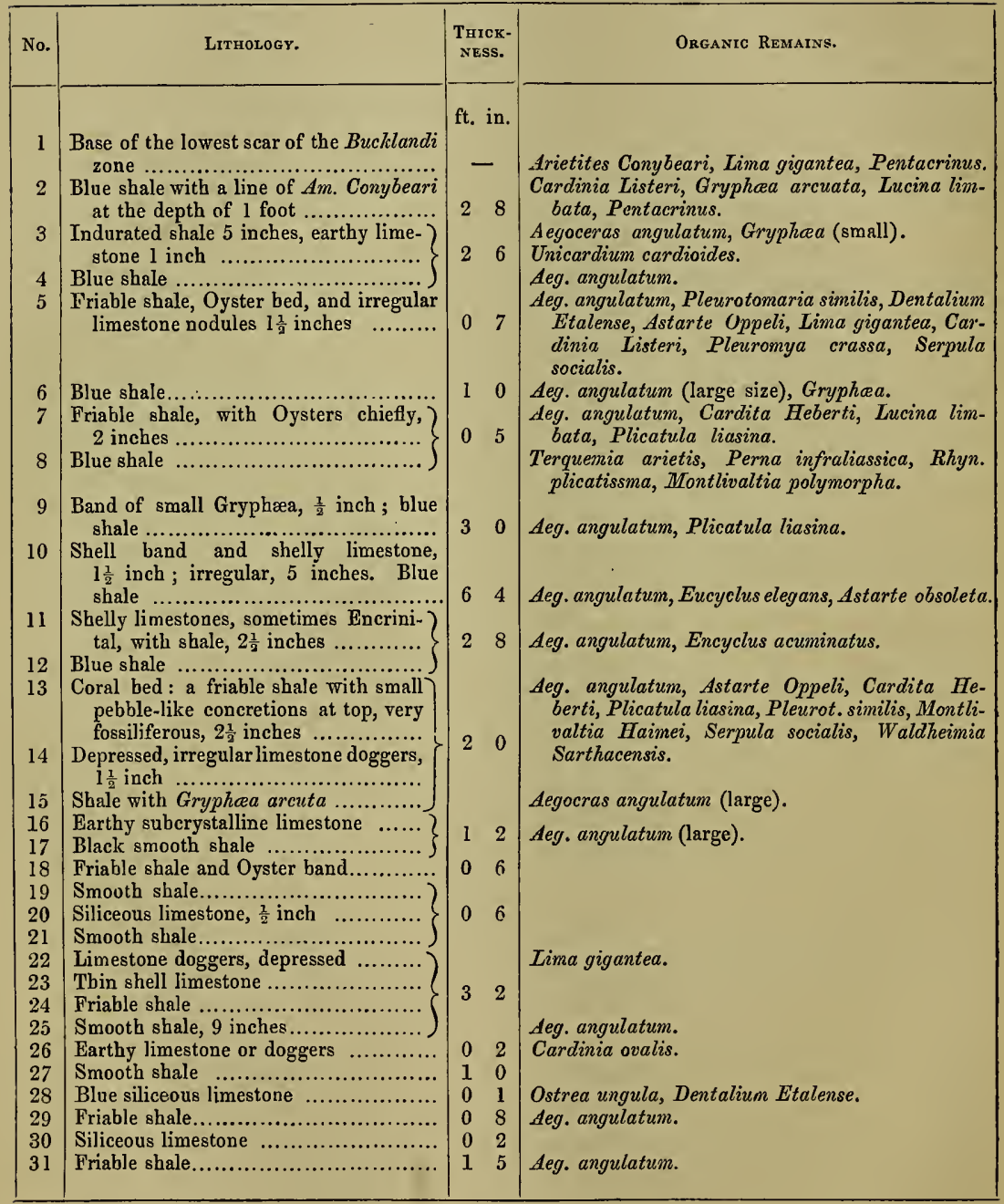

Palcontology.-The Angulatum-beds in the Department of Côte-d'Or have yielded a very rich fauna to the researches of M. Martin; many of these fossils were described and figured in the memoir already cited, and MM. Terquem and Piette have made like 
contributions to the history of the fauna of this zone in their valuable monograph, "Le Lias inférieur de l'Est de la France." The researches of MIM. Tate and Blake in the Yorkshire Lias have added much to our knowledge of the British fossils of the Angulatumbeds near Redcar, as the following list shows.

\section{Fossils from the Angulatum-Zone.}

\section{REPTILIA.}

Ichthyosaurus, vertebræ and teeth.

Hybodus minor, Agass.

Aegoceras angulatum, Schl.

- Johnstoni, Sow.

- Liasicum, d’Orbigny.

\section{Pisces.}

Plesiosaurus, vertebræ and teeth.

1 Acrodus minimus, Agass.

\section{Cephalopoda.}

Aegoceras nanum, Mart.

Nautilus striatus, Sow.

Belemnites infundibulum, Phillips.

\section{Gasteropoda.}

Discohelix striata, Piette.

- semiclausa, Tate.

Pleurotomaria obesula, Tate.

- similis, Sow.

- tectaria, Tate.

Pitonellus sordidus, Tate.

Cryptænia solarioides, Sow.

- rotellæformis, Dunker.

- nucleus, Terquem.

Cerithium gratum, Terquem.

- Semele, d'Orbigny.

- spiratum, Moore.

Dentalium Etalense, Terquem.

Dentalium limatulum, Tate.

Actæonina fragilis, Dunker.

Phasianella Morencyana, Piette.

Turbo solarium, Piette.

- philemon, d'Orbigny.

Littorina semiornata, Münst.

Eucyclus elegans, Mrünster.

- acuminatus, Chap. \& Dewal.

Turritella Dunkeri, Terquem.

Chemnitzia transversa, Blake.

- Berthandi, Dunker.

- unicingulata, Terquem.

- Etalensis, Piette.

\section{LAMELLIBRANCHIATA.}

Ostrea ungula, Münster.

- semiplicata, Münster.

Gryphæa arcuata, Lamarck.

Anomia alpina, Winkler.

- striatula, Oppel.

Plicatula liasina, Terquem.

Pecten calvus, Goldfuss.

- punctatissimus, Quenstedt.

- textilis, Münster.

- textorius, Schlotheim.

Limea Blakeana, Tate.

Avicula Pattersoni, Tate.

Perna infraliasica, Quenstedt.

Pinna Hartmanni, Zieten.

Macrodon pullus, Terquem.

- Hettangiensis, Terquem.

- navicula, Terquem.

Leda Galathea, d'Orbigny.

- Renevieri, Oppel.

- texturata, Terquem. 
Leda v-scripta, Tate.

Nucula nævis, Piette.

Astarte obsoleta, Dunker.

- cingulatr, Terquem.

- Oppeli, Andler.

Hippopodium ponderosum, Sow.

Cardita Heberti, Terquem.

Protocardia Phillipiana, Dunker.

Cardinia crassiuscula, Sow.

- ovalis, Stutchburg.

- Deshayesii, Terquem.

- Desoudini, Terquem.
Cardinia Listeri, Sow.

Lucina limbata, Terquem.

Modiola hillanoides, Chap. \& Dewalq.

- lævis, Sow.

- Hillana, Sow.

Saxicava arenicola, Terquem.

Myoconcha psilonoti, Quenstedt.

- inclusa, Terquem.

Unicardium cardioides, Phillips.

Pholadomya glabra, Agassiz.

Gresslya Galathea Agassiz.

Pleuromya crassa, Agassiz.

\section{BrachIOPODA.}

Waldheimia Sartbacensis, d'Orbigny. Spiriferiua rostrata, Schlotheim.

Rhynchonella plicatissima, Quenstedt.

\section{Crustacea.}

Bairdia liasica, Brodie.

- lacryma, Blake.

- Redcarensis, Blake.

- elongata, Blake.

Polycope cerasia, Tate.

| Cythere Blakei, Jones.

- circumscripta, Blake.

- paupercula, Blake.

- Redcarensis, Blalse.

- arcuformis, Blake.

ANNELIDA.

Ditrypa capitata, Phill.

- globiceps, Quenst.

Galeolaria socialis, Goldf.

Cidaris Edwardsii, Wright.

Hemipedina Tomesi, IV right.

$$
\mid \begin{gathered}
\text { Serpula limax, Goldf. } \\
-\quad \text { plicatilis, Goldf } \text {. } \\
-\quad \text { flaccida, Goldf. }
\end{gathered}
$$

Echinodermata.

Pentacrinus psilonoti, Quenst.

- basaltiformis, Miuller

AnthozoA.

Septastræa excavata, de From.

Montlivaltia Haimei, Chap. \& Dewalq.

Montlivaltia polymorpha, Terquem.

Foreign Correlations.-Professor F. A. Römer, in 1836, ${ }^{1}$ published an important work on the 'Jurassic Formations of North Germany,' which formed the starting-point of numerous observations made since that date by several accurate observers, as Dr. U. Schlönbach, "Ueber den Eisenstein des mittleren Lias in nordwestlichen Deutschland," as developed at Harzburg, Liebenburg near Goslar, Bodenstcin, Calefeld, and other places ;" also Professor von Seebach, "Der Hannoversche Jura;"3 and Emerson, "Der Liasmulde von Markoldendorf bei Einbeck."4 After a careful examination of the

1 'Die Versteinerungen des Nord-deutschen Oolithen-Gebirges,' 1836.

2 'Zeitschr. d. d. Geol. Ges.', Band xv, p. 465, Jahrg., 1863.

3 'Der Hannoversche Jura,' mit 10 Tafeln und 1 Karte, 1864.

4 'Zeitschr. d. d. Geol: Ges.,' Band xxii, p. 271, 1870. 
organic remains and an accurate determination of the species, each of these authors has placed the strata of the Lower and Middle Lias in their proper zones. Similar stludies had been well and carefully carried ont by previous observers with like results, as Bornemann, Strombeck, Ulrich, Ewald, Rolle, Wagener, \&c., and from the united Palæontological data thus obtained we have learned the correlation of the north-west German Lias beds, as shown in the following table-

\section{The Middle and Lower Lias of North Germany.}

\begin{tabular}{|c|c|c|}
\hline Von Seebach. & SCHLöNBach. & EMERson. \\
\hline & MIIDDLE LIAS. & \\
\hline \multirow{2}{*}{ Amaltheenthone. } & Zone of Am spinatus. & Beds with Am. spinatus. \\
\hline & Upper zone of $A m$. margaritatus. & Absent. \\
\hline $\begin{array}{l}\text { Beds with } \\
\text { Am. capricornus. }\end{array}$ & $\begin{array}{l}\text { Upper zone of Am. fimbriatus. } \\
\text { Lower zone of Am. margaritatus. }\end{array}$ & Absent. \\
\hline \multirow{3}{*}{$\begin{array}{l}\text { Beds with } \\
\text { Am. brevispina. }\end{array}$} & Lower zone of Im. fimbriatus. & Beds with Am. centaurus. \\
\hline & \multirow{2}{*}{ Zone of Am. Jamesoni. } & Beds with Am. brevispina. \\
\hline & & $\begin{array}{c}\text { Beds with Terebratula subovoides } \\
\text { and Am. armatus. }\end{array}$ \\
\hline & LOWER LIAS. & \\
\hline \multirow{2}{*}{ Beds with An. planicosta. } & \multirow{2}{*}{ Zone of Am. planicosta. } & Beds with Am. bifer. \\
\hline & & Beds with Am. planicosta. \\
\hline \multirow{2}{*}{ Arietenschichten. } & Zone of Ams. geometricus. & Beds with Am. geometricus. \\
\hline & Zone of Aim. Bucklandi. & Absent. \\
\hline Angulatenschichten. & Zone of Am. angulatus. & Beds with Am. angulatus. \\
\hline Psilonotenschichten. & Zone of Am. Johnstoni. & Psilonotenschichten. \\
\hline Rbætic. & Zone of Avicula contorta. & Avicula. \\
\hline
\end{tabular}


The Angulatum-zone, as shown in this table, is well developed in North Germany, as is proved by the valuable works of the late Professor U. Schlönbach and "Der untere Jura " of Dr. Brauns, from which it appears that many of the organic remains of the Planorbis. beds pass into the Angulatum-zone, and that it is difficult to draw a divisional line between them. The following list affords a correct idea of the Molluscan fauna of the North-German Angulatenschichten.

Cephalopoda.

Aegoceras angulatum, Schlotheim.

Nautilus intermedius, Sow.

Gasteropoda.

Hydrobia Krausseana, $D k r$.

Turritella Zenkeni, $D k r$.

Mesalia turritella, $D k r$.

Pleurotomaria Anglica, Sow.

Pleurotomaria rotellæformis, $D k r$.

Cylindrites fragilis, $D k r$.

Dentalium Etalense, Terq. et Piette.

Discohelix pygmæa, $D k r$.

Lamellibranchiata.

Ostrea sublamellosa, $D k r$.

Gryphæa arcuata, Lamk.

Pecten textorius, Schlth.

Lima pectinoides, Sow.

Leda Renevieri, Opp.

Macrodon pullus, Tqm.

Inoceramus pinnæformis, $D \mathrm{kr}$.

Gervillia Hagenovii, $D k r$.

Avicula inæquivalvis, Sow.

Pinna Hartmanni, Ziet.

Modiola Hillana, Sovv.

- nitidula, $D k r$.

- scalprum, Sow.

Astarte obsoleta, $D k r$.

Cardinia concinna, Sow.

- crassiuscula, Sow.

- Listeri, Sow.

Unicardium cardioides, Phill.

Cardium Heberti, Tqm.

Protocardia Phillippiana, $D k r$.

Isodonta elliptica, $D k r$.

Pholadomya corrugata, $D k r$.

Goniomya heteropleura, Agass.

- subrugosa, $D k r$.

- liasiua, Schübl.

Gresslya Galathea, Agass.

\section{Echinodermata.}

Pentacrinus, sp. Hypodiadema lobatum, Desor. C Cidaris, sp.

The Angulatum-beds are well developed in Württemberg; and the Stuttgart Museum contains a very fine series of the leading fossils, as Aegoceras angulatum, A. Moreanum, A. compressum, A. Liasicum, and many other Mollusca. Some of the Ammonites are upwards of one foot in diameter, and were collected from the Lias a near that town. I have one nearly as large sent me by my esteemed friend Prof. Fraas.

In France this zone is found in several Departments, as in the Côte-d'Or, and is remarkable for the very rich fauna it has yielded to the researches of M. Martin and MM. Collenot and Bréon. In this zone likewise are found, in the Commune of Thoste, and at the hamlet of Beauregard, the remarkable ferruginous beds which have yielded such an immense quantity of Cardinias. These shells are in admirable preservation, fossilized by iron, and present all the characters of their internal structure. The Ammonites. 
Aeg. Moreanum, d'Orb., and Aeg. catenatum, Sow., Aeg. Liasicum, d'Orb., Aeg. laqueum, Quenst., Aeg. angulatum, Schloth., Aeg. Charmassei, d'Orb.

The workmen call the bed "Foic de Vean," and M. Martin" has adopted the local name as equivalent to his Zone à Ammonites Moreanus, of which he has given an exhaustive account in the memoir. M. Collenot ${ }^{2}$ has likewise given a most able account of the zone, with very full details of the Mine at Beauregard, and has very carefully noted all the fossils that appertain to the "Foie de Veau," and placed them in separate cases in the Museum of Semur, where I had the opportunity of examining them, and has given the following list thereof in his exhaustive 'Description Géologique de l'Auxois.'

\section{REPTILES.}

Ichthyosaurus, sp.

\section{Cephalopoda.}

Aegoceras Liasicum, d'Orb.

$$
\begin{array}{ll}
\text { - } & \text { laqueum, Quenst. } \\
\text { - } & \text { angulatum, Schloth. } \\
\text { - } & \text { Moreanum, d'Orb. }
\end{array}
$$

Aegoceras Charmassei, $d^{\prime}$ Orb.

$$
\begin{aligned}
& \text { - Delmasi, Reynís. } \\
& \text { - Hettangieuse, Terqm. } \\
& \text { Nautilus striatus, Sow. }
\end{aligned}
$$

\section{Gasteropoda.}

Littorina clathrata, Desh.

Turritella Deshayesea, Terq.

- Humberti, Mart.

- Dunkeri, Terq.

Melania cyclostomn, Terq.

- crassilabrata, Terq.

Toruatella acuminata, Piet.

Orthostoma turgidum, Terq.

- frumentum, Terq.

- oryza, Terq.

- decoratum, Mart.

- exile, Mart.

- gracile, Mart.

Trochus sinistrorsus, Desh.

- nitidus, Terq.

- lineatus, Mart.

Turbo decoratus, Mart.

- cristatus, Mart.

- philemon, dOrb.

- Piettei, Mart.

- subcrenatus, Mart.

- nanus, MLart.

- selectus Chap. et Dewal.
'Turbo triplicatus, Mart.

- Andleri, Mart.

- intextus, Mart.

Solarium Ienticulare, Terq.

Straparolus Oppeli, Mart.

Pleurotomaria Terquemi, Mart.

$$
\begin{array}{ll}
\text { - } & \text { concava, Mart. } \\
\text { - } & \text { Martiniana, d'Orb. } \\
\text { - } & \text { rotelliformis, Dunk. }
\end{array}
$$

Purpurina tricarinata, Mart.

Trochotoma clypeus, Terq.

Cerithium verrucosum, Terq.

- Semele, d'Orb.

- subnudum, Mart.

- Martinianum, d'Orb.

- Sinemuriense, Mart.

- Arduennense, Piet.

- gratum, Terq.

- Henrici, Mart.

- acuticostatum, Terq.

- Deshayesei, Piet. et Terq.

- Collenoti, Mart.

- trinodulosum, Mart.

1 'Paléontologie stratigraphique de l'Iufra-Lias de Département de Côte d'Or,' p. 38, 1860.

2 'Description géologique de l'Auxois,' p. 219, 1873. 


\section{LameLLIBRANChIATA.}

Leda Aballoensis, Mart.

Cardita Heberti, Terq.

Astarte consobrina, Chap. et Dewal.

Cardinia Listeri, Sow.

- sublamellosa, d'Orb.

- acuminata, Mart.

- hybrida, Agass.

- exigua, Terq.

Lucina arenacea, Terq.

Cardium Terquemi, Mart.

Nucula Sinemuriensis, MIart.

Terebratula perforata, Piet.

- retusa, Mart.

Pentacrinus tuberculatus, Mill.

Montlivaltia Martini, de From.

- Sinemuriensis, d'Orb.

Thecosmilia Martini, de From.

Porosmilia Martini, de From.

Placopsilina Flouesti, Terq.
Arca pulla, Terq.

- Sinemuriensis, Mart.

Pinna Hartmanni, Ziet.

- semistriata, Terq.

A vicula Sinemuriensis, d'Orb.

Mytilus Guexii, $d$ 'Orb.

- rusticus, Terq.

Lima edulis, d'Orb.

- gigantea, Sow.

- Hettangiensis, Terq.

Ostrea irregularis, Münst.

\section{Brachiopoda.}

$\mid \begin{gathered}\text { Rhynchonella variabilis, } d^{\prime} \text { Orb. } \\ -\quad \text { plicatissima, Quenst. }\end{gathered}$

\section{Echinodermata.}

ANThozoA.

Astropecten, $s p$.

Isastræa Sinemuriensis, de From.

Stylastræa Martini, de From.

Astroconia Sinemuriensis, de From.

\section{Spongiaria.}

Amorphofungia Dumortieri, MIart.

\section{Foraminifera.}

Involutina petrea, Terq.

The Lower Lias is well developed in the Departments of the Meurthe and the Moselle, in the east of France, in the Grand Duchy of Luxembourg, Belgium, and in the Dep. Meuse. The fossils, from its different zones, have been collected with great care, and their species determined, beautifully figured, and well described by MM. O. Terquem and Ed. Piette in their valuable memoir." In the valley of the Moselle a great number of Mollusca have been discovered in the large quarries of the Angulatum-beds, "Le grès d'Hettange," which has become famous for its fossil riches. The authors enumerate 15 species of plants and 332 species of animals from the zone of Aeg. angulatum. Of this total 53 are found in the Planorbis-beds, 212, or two thirds, pass into the upper zones, and 120

1 "Le Lias inférieur de l'est de la France," 'Mém. de la Soc. Géol. de France,' 2e série, tome viii, 1865. 
species appear to be special to the zone of Aeg. angulatum, nearly all of which are represented in the "Grès d'Hettange."

In Luxembourg the Marne de Jamoigne represents the Angulatum-zone, and beds of the same age are found in the valleys of the Semois, the Chiers, and the Meuse. In Gloucestershire I have seen small specimens, which were found near Aust and Gloucester. This zone is likewise exposed in the north of Ireland, in the remarkable Lias district near Portrush.

\section{The Zone of Arietites Bucklandi.}

Synonyms._- Blue Lias," William Smith, 'Memoir to the Map,' 1815. " Blue Lias Limestone," De la Beche, 'Geol. Trans.,' 2nd series, vol, ii, 1829. "Gryphiten-Kalkstein," Alberti, "Die Gebirge des König. Württemberg,' p. 121, 1826. "Liaskalk," Mandelsloh, 'Geol. Profile der schwäbisch. Alpen," p. 28, 1834. "Calcaire à Gryphites" (pars), Dufrénoy et de Beaumont, 'Mém. Soc. Géol. de France,' p. 196, 1830. "Grès de Luxembourg " (pars. sup.), Omalius d'Halloy, 'F́lém. de Géologie,' p. 375, 1835. "Grès de Luxembourg," Dewalque, 'Descrip. du Lias de la Luxembourg,' p. 28, 1857. "Plagiostoma-beds, Lower Lias," Murchison, 'Geol. of Cheltenham,' 2nd ed., p. 49, 1845. "Arietenkalk," Quenstedt, 'Der Jura,' Table, p. 293, 1857. "Die Schichten des Ammonites Bucklandi," Oppel, 'Juraformation,' p. 35, 1856. " Zone of Ammonites Bucklandi," Wright, 'Quart. Jour. Geol. Soc.,' vol, xvi, p. 398, 1560. “Zone de l'Ammonites Bucklandi," Dumortier, 'Etudes Paléont. sur les Dépôts Jurassiques du Bassin du Rhone,' 2e part, p. 6, 1867. "Die Arietenschichten," Brauns, 'Der untere Jura,' p. 78, 1871. "Zone of Ammonites Bucklandi," Tate and Blake, 'Yorkshire Lias,' p. 54, 1876.

The Bucklandi-zone forms an important subdivision of the Lower Lias. This series attains a great development in the midland counties and in Glamorgan, Dorset, and Somerset. The rocks are characterised throughout by the prevalence of a number of large Ammonites belonging to the natural group Arietes (von Buch), and by many Lamellibranchiata of the genera Lima and Gryplaaa. In England it everywhere consists of beds of grey-bluish argillaceous limestone, interstratified with bands of marl, shale, and clay of a similar colour. In some parts of the counties of Warwick, Somerset, Dorset, and Glamorgan this series attains a thickness of 80 feet.

Gloucestershire and Somersetshire.-In Gloucestershire it was exposed in the deep cutting of the Dean Forest Railway at Highnam, and is seen in the Lias limestonequarries near Tewkesbury, and in the natural escarpments at Frethern and Purton-on-theSevern. In Somersetshire it was sectionised in making the Great Western Railway between Bristol and Bath, and probably at no point were the several beds of the Lima series better shown than in the cutting at Saltford, seven miles from Bristol. My late 
friend, Mr. William Sanders, F.R.S., made the following profile during the execution of the work, which, together with his notes on the fossils contained in the different strata, have been kindly communicated by my friend, Mr. Etheridge, F.R.S. This section is of great value, inasmuch as the beds are now partially concealed by débris and vegetation, and the characteristic fossils are no longer found in their respective beds.

Section of the Bucklandi-Beds at Saltford, near Bath, Great Western Railway. ${ }^{1}$

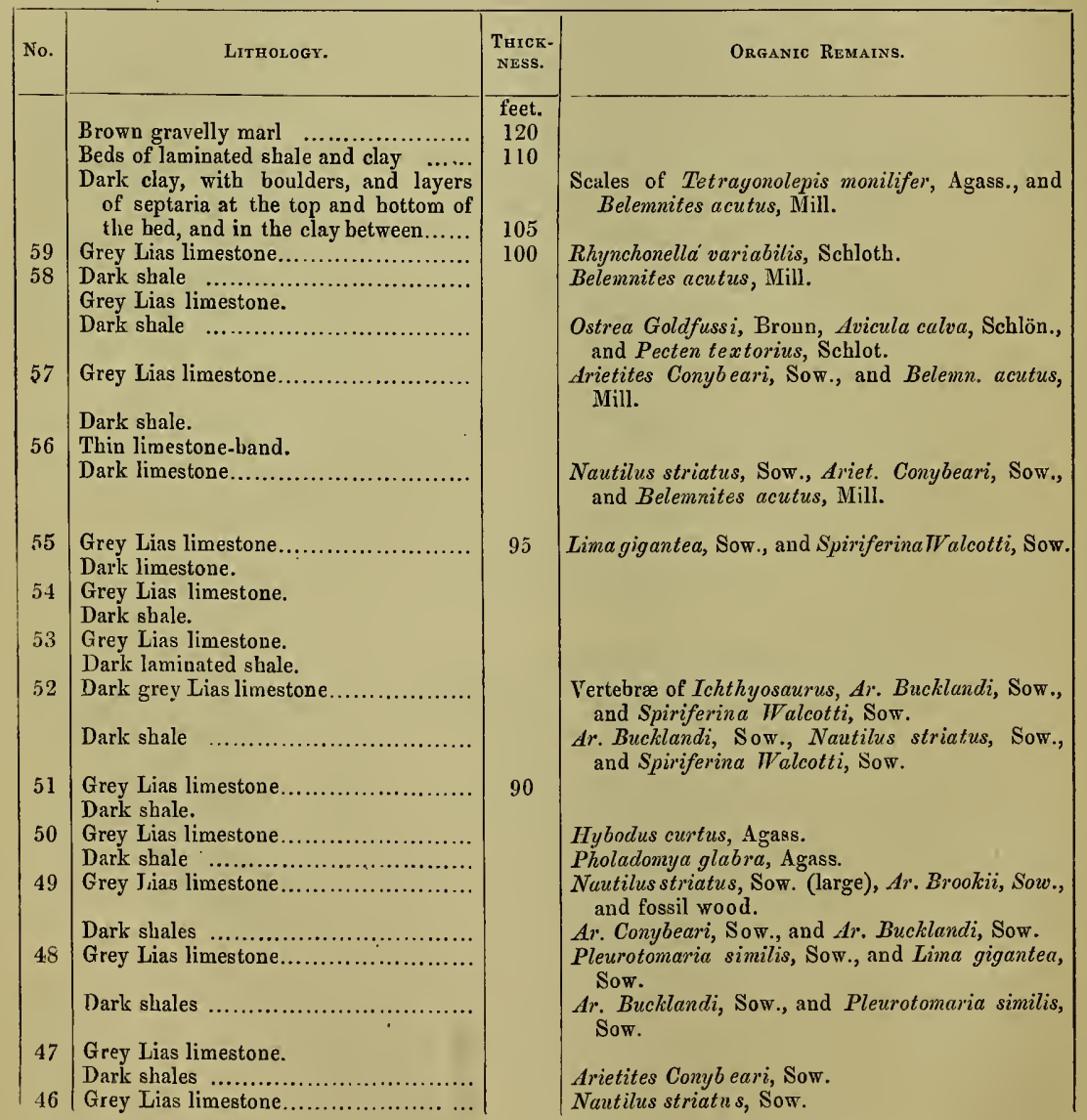

1 This section shows the relative position of the zones of Ar. Buclelandi, Aeg. planorbis, and Avicula contorta in this part of the county, and affords a good type for comparing these three stages in Somersetshire with the same groups in other parts of the south of England. 


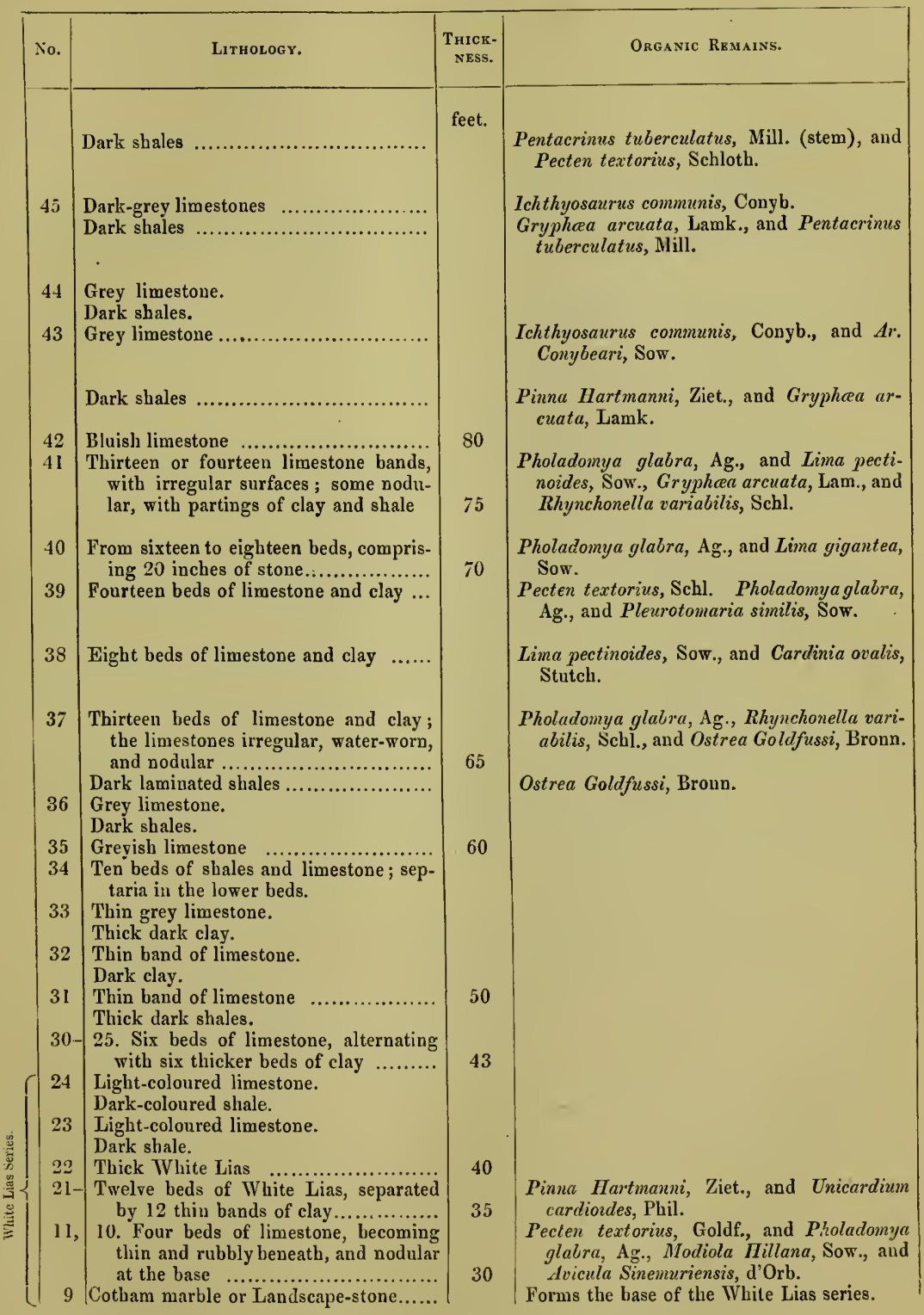




\begin{tabular}{|c|c|c|c|}
\hline No. & LITHOLOGY. & $\begin{array}{l}\text { ThICK- } \\
\text { NESS. }\end{array}$ & Organic Remains. \\
\hline $\begin{array}{l}6 \\
5 \\
4 \\
3 \\
2\end{array}$ & 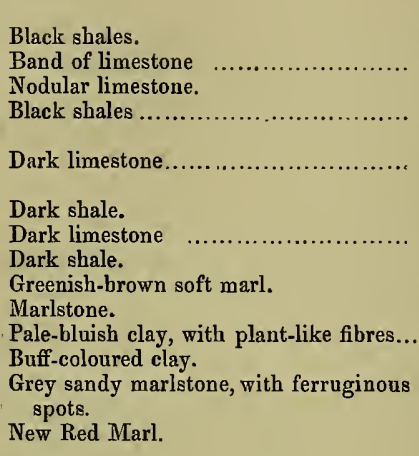 & $\begin{array}{l}\text { feet. } \\
20 \\
15 \\
10\end{array}$ & $\begin{array}{l}\text { Fishes' scales; layers of compressed Pul- } \\
\text { lastra arenicola, Strickl. } \\
\text { Pecten Valoniensis, Defr., and Avicula con- } \\
\text { torta, Portl. } \\
\text { Pullastra arenicola, Strickl. }\end{array}$ \\
\hline
\end{tabular}

Lyme Regis.-The Bucklandi-zone is admirably shown in the coast-section at Lyme Regis, Dorset, both in the Church Cliffs and at Pinhay Bay, where the beds consist of a series of grey limestones, from 2 to 10 inches in thickness, varying from earthy to compact, and alternating with marls and shaly beds-either in seams of a few inches, or in beds of many feet in thickness. The following section, from the lowest stratum on the shore to Broad Ledge, which may be considered the uppermost bed of the Bucklandi series, affords a correct view of the stratigraphical order of these strata at Lyme and of the fossils they contain. The profile must be read in a descending order through the Turneri and Bucklandi beds towards the Angulatum-zone on the shore.

Section of the Bucklandi-beds from Broad Ledge to the shore at Lyme Regis.

\begin{tabular}{|c|c|c|c|}
\hline No. & LiтноLоg. & $\begin{array}{l}\text { THICK- } \\
\text { NESS. }\end{array}$ & Organic Remains. \\
\hline 1 & $\begin{array}{l}\text { Dark-grey limestone. " Broad Ledge" } \\
\text { or "Table-bed" ....................... } \\
\text { Dark marls and shales, with bands of }\end{array}$ & ft. in. & $\begin{array}{l}\text { Ichthyosaurus communis, Conyb., I. platy- } \\
\text { odon, Conyb., Arietites semicostatus, Y. } \\
\text { \& B., and Rhynchonella variabilis, Schloth. }\end{array}$ \\
\hline & 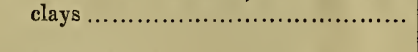 & 180 & Arietites Turneri, Sow., and Fishes. \\
\hline 3 & Grey limestorie...................... & & $\begin{array}{l}\text { drietites Turneri, Sow., and Ar. semicostatus, } \\
\text { Y. \& B. }\end{array}$ \\
\hline 4 & 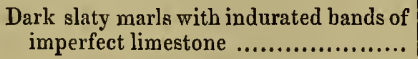 & 30 & Lima gigantea, Sow., L. antiquata, Sow. \\
\hline
\end{tabular}




\begin{tabular}{|c|c|c|c|}
\hline No. & Рathology. & $\begin{array}{l}\text { THICK- } \\
\text { NESS. }\end{array}$ & Organic Remains. \\
\hline 5 & Dark-grey limestone $\ldots$ & ft. in. & Lima gigantea, Sow., L. antiquata, Sow., \\
\hline 6 & Black shales, with partings of gypsum & 26 & $\begin{array}{l}\text { Ichthyosaurus communis, Conyb. (in the } \\
\text { "fire-stone beds" west of the Cobb). }\end{array}$ \\
\hline 7 & Dark-greyish limestone .. & 010 & $\begin{array}{l}\text { Lima gigantea, Sow., L. antiquata, Sow., } \\
\text { and Rhynchonella variabilis, Schloth. }\end{array}$ \\
\hline 8 & 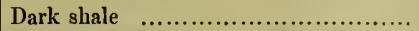 & 2 & Gryphaa arcuata, Lamk. \\
\hline 9 & Hard grey limestone. "Grey Luedge" & 13 & $\begin{array}{l}\text { Fin-spines of Hybodus, Rhynchonella varia- } \\
\text { bilis, Schloth, and Pentacrinus tubercu- } \\
\text { latus, Mill. }\end{array}$ \\
\hline 10 & Dark shaly marls...... & 20 & Icthyosaurus platyodon, Conyb. \\
\hline 11 & Grey limestone.......... & 06 & $\begin{array}{l}\text { Spines of Pseudo-diadema, and other Echi- } \\
\text { nida. }\end{array}$ \\
\hline 12 & Dark indurated shale & 3 & Ichthyosaurus platyodon, Conyb. \\
\hline 13 & Bluish limestone ............. & 10 & $\begin{array}{l}\text { Gryphoe arcuata, Lam., Rhynchonella vari- } \\
\text { abilis, Schloth, and Lima antiquata, Sow. }\end{array}$ \\
\hline 14 & 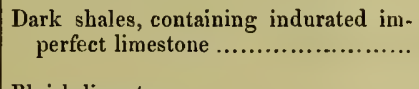 & 16 & $\begin{array}{l}\text { Ichthyosaurus communis, Conyb., I. platy- } \\
\text { odon, Conyb., Pentacrinus tuberculatus, } \\
\text { Mill., and Lima gigantea, Sow. }\end{array}$ \\
\hline 15 & Bluish limestone .... & 010 & \\
\hline 16 & Darls indurated clay... & 13 & $\begin{array}{l}\text { Gryphaa arcuata, Lam., and fragments of } \\
\text { Pentacrinus tuberculatus, Mill. }\end{array}$ \\
\hline 17 & 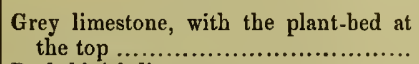 & 06 & $\begin{array}{l}\text { Otopteris obtusa, L. \& H., and Araucarites } \\
\text { peregrinus, Sternb., in the plant-bed. }\end{array}$ \\
\hline 18 & Dark-bluish limestone ...................... & 16 & $\begin{array}{l}\text { Arietites Conybeari, Sow., and Rhyncho- } \\
\text { nella variabilis, Schloth. }\end{array}$ \\
\hline 19 & Dark shale $\ldots . . . \ldots \ldots \ldots . . . .$. & & Gryphae arcuata, Lam. \\
\hline 20 & Dark-greyish limestone .. & 010 & $\begin{array}{l}\text { Arietites Bucklandi, Sow., and Ar. roti- } \\
\text { formis, Sow. }\end{array}$ \\
\hline $2 \mathrm{I}$ & Dark shale ...... & 0 & \\
\hline 22 & Grey limestone............................... & & \\
\hline 23 & Dark shale .................... & & Ichthyosaurus tenuirostris, Conyb. \\
\hline 24 & Dark greyish limestone .... & 1 & $\begin{array}{l}\text { Ichthyosaurus communis, Conyb., skulls and } \\
\text { bones of other species, with Rhynchonella } \\
\text { variabilis, Schloth. }\end{array}$ \\
\hline 25 & Hard shale, forming "Quick Ledge" & & $\begin{array}{l}\text { Ichthyosaurus communis, Conyb., and } I \text {. in- } \\
\text { termedius, Conyb. }\end{array}$ \\
\hline 26 & Blue limestone...... & & $\begin{array}{l}\text { drietites Bucklandi, Sow., and Lima } \\
\text { gigantea, Sow. }\end{array}$ \\
\hline 27 & Dark shale ... & 0 & $\begin{array}{l}\text { Gryphaa arcuata, Lam., and Rhynchonella } \\
\text { variabilis, Schloth. }\end{array}$ \\
\hline 28 & $\begin{array}{l}\text { Concretionary limestone (surface mam- } \\
\text { millated) }\end{array}$ & 0 & \\
\hline 29 & Dark-grey shale ........................ & 0 & Aegoceras angulatum, Schloth. \\
\hline 30 & Greyish limestone ...... & 0 & Lima gigantea, Sow., and $L$. antiquata, Sow. \\
\hline 31 & Dark indurated shale ... & 0 & $\begin{array}{l}\text { degoceras angulatum, Schloth. (large speci- } \\
\text { mens with small Gryphæea adherent). }\end{array}$ \\
\hline 32 & Hard grey limestone ................... & 0 & Lima gigantea, Sow., and $L$. antiquata, Sow. \\
\hline
\end{tabular}

The shingle of the shore covers the lower beds of the Angulatum series.

Coast of Glamorganshire.-In Glamorganshire there is an extensive exposure of the Bucklandi-beds for the distance of sixteen miles along the coast, from Penarth Head, 
by Barry Island, Aberthaw, and Dunraven Castle, to the mouth of the River Ogmore, where the Lower Lias rests on highly inclined beds of Carboniferous Limestone. The strata laid bare by the sea are chiefly those containing Lima gigantea and Grypliaa arcuata. At Cowbridge the same stratigraphical condition is observed, and the Lower Lias is here seen resting on Carboniferous Limestone. At Penarth Head, however, the relation of the Bucklandi to the Planorbis and Avicula contorta beds is much better seen than at any other part of the Glamorganshire coast.

The Rev. J. E. Cross, F.G.S., has described the Lias beds of North-west Lincolnshire, ${ }^{\mathrm{I}}$ which have recently been laid open by the extension of railways and searchings for Ironstone, and from his interesting and instructive paper I have dednced the following results.

A generalised profile of the Lias beds of North-west Lincolnshire.

Lincolnshire OOLitic LIMEstone.

\begin{tabular}{|c|c|c|}
\hline Hokizons. & Petrology. & Palzontologx. \\
\hline UPPER LIAS. & $\begin{array}{l}\text { Blue shale with moulds } \\
\text { of Ammonites of the } \\
\text { falcifer type, } 60 \text { feet } \\
\text { thick. }\end{array}$ & Harpoceras serpentinum, Lytoceras cornucopia. \\
\hline $\begin{array}{l}\text { MiddLe Lias } \\
\text { MaRLSTONE. }\end{array}$ & $\begin{array}{l}\text { Hard, light grey lime- } \\
\text { stone, weathering to } \\
\text { brown Ironstone with } \\
\text { Rhyuchonellæ, } 8 \text { feet } \\
\text { thick. }\end{array}$ & $\begin{array}{l}\text { Amaltheus spinatus, Avicula cygnipes, Terebratula punc- } \\
\text { tata, Rhynchonella tetraedra, Spiriferina rostrata. }\end{array}$ \\
\hline $\begin{array}{l}\text { MidDle Lias. } \\
\text { Maris. }\end{array}$ & $\begin{array}{l}\text { Blue clay with cement } \\
\text { nodules throughout, } \\
\text { containing Aegoceras } \\
\text { capricornus, } 66 \text { feet } \\
\text { thick. }\end{array}$ & $\begin{array}{l}\text { Aegoceras Henleyi= capricornum, Belemnites fraxillosus, } \\
\text { Plicatula spinosa, Avicula incquivalis, Nucula com- } \\
\text { planata, Lima acuticosta, Rhynchonella variabilis. }\end{array}$ \\
\hline $\begin{array}{l}\text { MIDDLE LIAS. } \\
\text { IRONSTONE. }\end{array}$ & $\begin{array}{l}\text { The Ironstone Pecten- } \\
\text { bed, crowded with } \\
\text { shells, } 4 \text { feet thick. }\end{array}$ & $\begin{array}{l}\text { Aeg. armatum, Aeg. striatum, Belemnites elongatus, Car- } \\
\text { dium multicostatum, C. hybrida, Ifyacites unionides, } \\
\text { Tancredia liassica, Pecten lavis, in great numbers and } \\
\text { of good size. }\end{array}$ \\
\hline $\begin{array}{l}\text { Oxynotus and } \\
\text { raricostatus zones. }\end{array}$ & $\begin{array}{l}\text { Blue Marls of the } \\
\text { Lower Lias, containing } \\
\text { different zones of life, } \\
90 \text { feet thick. }\end{array}$ & $\begin{array}{l}\text { Aegoceras Birchii, Amaltheus oxynotus, Arietites rari- } \\
\text { costatus, Aeg. Taylori, Aeg. Loscombi, Aeg. natrix, } \\
\text { Belemnites paxillosus, B. clavatus, Gryphaa IIaccul- } \\
\text { lochi, Terebratula mumismalis, Pinna folium, Phola- } \\
\text { domya ambigua. }\end{array}$ \\
\hline
\end{tabular}

I ‘Quart. Jour. Geol. Soc., vol. xxxvi, p. 115, 1875. 


\begin{tabular}{|c|c|c|}
\hline Iloxizons. & Petrology. & PaLAEontology. \\
\hline $\begin{array}{c}\text { Bucklandi-zone. } \\
\text { Semicostatus, and } \\
\text { Upper Bucklandi-beds. }\end{array}$ & $\begin{array}{l}\text { Scunthorpe Ironstone } \\
\text { beds, with } 27 \text { per } \\
\text { cent. ore, and having } \\
\text { a thickness of } 27 \text { feet. }\end{array}$ & $\begin{array}{l}\text { Arietites Bucklandi, A. Crossii, A. Conybeari, A. semi- } \\
\text { costatus, A. stellaris, Aegoceras Boucaultianum, Nan- } \\
\text { tilus striatus, Belemnites acutus, Pleurotomaria } \\
\text { Anglica, Cardinia gigantea, C. copides, C. crassissima, } \\
\text { Lima antiquata, L. gigantea, L. Iettangiensis, Pecten } \\
\text { texturatus, Gryphaea arcuata, Hippopodium ferri, } \\
\text { Cucullaa ovum. }\end{array}$ \\
\hline $\begin{array}{c}\text { Bucklandi-zone. } \\
\text { Lower Bucklandi-beds. }\end{array}$ & $\begin{array}{l}\text { Lower limestone ard } \\
\text { marl in Frodingham } \\
\text { Railway culting. }\end{array}$ & $\begin{array}{l}\text { A. Bucklandi, A. Conybeari, A. semicostatus, Nautilus } \\
\text { striatus, Belemnites acutus, Cardinia Listeri, C. con- } \\
\text { cinna, Pleurotomaria Anglica, Lima antiquata, Pecten } \\
\text { textorius, Gryphrea arcuata, Lima gigantea, Phola- } \\
\text { domya ambigua, Unicardium cardioides. }\end{array}$ \\
\hline \multirow[t]{2}{*}{$\begin{array}{l}\text { Angulatum } \\
\text { zone. }\end{array}$} & $\begin{array}{llr}\begin{array}{c}\text { Lowest } \\
\text { Valley, }\end{array} & \begin{array}{c}\text { Lias, } \\
1.0\end{array} & \begin{array}{r}\text { Trent } \\
\text { feet. }\end{array} \\
\text { Dark } & \text { shales } & \text { and } \\
\text { clays. } & & \end{array}$ & $\begin{array}{l}\text { Legoceras Liassicum, A. angulatum, Nautilus striatus, } \\
\text { Cardinia Listeri, C. concinna, Astarte obliqua, Pho- } \\
\text { ladomya prima, Cardita Heberti, MIodiola nitidula, } \\
\text { Unicardium cardioides, Lvicula decussata. }\end{array}$ \\
\hline & Planorbis-beds and & Avicula contorta series absent. \\
\hline Keuper. & Red Narls. & No fossils. \\
\hline
\end{tabular}

In Yorkshire the Bucklandi-beds are cxposed along the coast of Redcar and Robin Hood's Bay. In both localities they are, however, at high flood-tide covered by the sea, so that they are at all times studied with difficulty. Redcar affords the most complete section, and this has been well worked out by Messrs. Tate and Blake in their able and exhaustive work on the Yorkshire Lias. The sections I have given of these beds in the midland and southern counties of England show that they are there composed of thickbedded blue hydraulic-limestones interstratified with beds of clay, but in Yorkshire the whole forms a "great argillaceous series, consisting of shales with shelly tops and thin, earthy, and shelly limestones." The Redcar rocks consist of two sets of scars or ledges, separated by a broad expanse of a level pavement of shale. The scars succeed each other at pretty regular intervals, have the general direction of east by north and west by south, and are formed by the indurated tops of the shales. The inequality of the hardness of the scars and shales makes the shore appear like a deep ploughed field at lowtide. Their thickness is estimated at 150 feet, and they admit of a threefold division based on the Petrology and Palæontology of each series. Taking them in ascending order from the Angulatum-beds we have following series-

$$
1 \text { 'Yorkshire Lias,' p. } 54 .
$$




\begin{tabular}{|c|c|c|}
\hline Horizon. & Petrology. & PALAONTOLOGY. \\
\hline Lower Series. & $\begin{array}{l}\text { Black, crumbling } \\
\text { shales, covered by } \\
\text { thin, earthy, shelly } \\
\text { limestones, } 19 \text { feet } \\
\text { thick. }\end{array}$ & $\begin{array}{l}\text { Arietites Conybeari, Eucyclus elegans, Rissoa nana, } \\
\text { Turbo philemon, Discohelix Oppeli, D. striata, Tan- } \\
\text { credia ovata, Plicatula liasina, Rhyn. plicatissima, } \\
\text { Montlivaltia Haimei, Galeolaria socialis. }\end{array}$ \\
\hline Mindle Series. & $\begin{array}{l}\text { Soft blue shales, with } \\
\text { rows of small lime- } \\
\text { stone nodules in the } \\
\text { upper part, friable } \\
\text { shales, with shelly } \\
\text { bands, thickness } 93 \\
\text { feet. }\end{array}$ & $\begin{array}{l}\text { Arietites bisulcatus, degoceras Charmassei, Cryptania } \\
\text { solarioides, Turbo solarium, Cerithium gratum, Turri- } \\
\text { tella Dunkeri, Lima gigantea, Unicardium cardioides, } \\
\text { Cardinia crassiuscula, C. concinna, C. Listeri, Hippo- } \\
\text { podium ponderosum, Fryphaa arcuata, Lucina lim- } \\
\text { bata, Pecten textorius, Montlivaltia Guettardi. }\end{array}$ \\
\hline Upper Series. & $\begin{array}{l}\text { Earthy limestones, and } \\
\text { calcareous shales, } \\
\text { with agillaceous beds, } \\
\text { thickness about } 66 \\
\text { feet. }\end{array}$ & $\begin{array}{l}\text { Arietites Turneri, A. semicostatus, A. Sauzeanus, } \\
\text { Belemnites acutus, B. infundibulum, Cardinia Listeri, } \\
\text { Gryphea arcuata, Lima gigantea, Pecten Thiollieri, } \\
\text { Monotis incequivalvis, Spiriferina Walcotii, Acrodus } \\
\text { nobilis. }\end{array}$ \\
\hline
\end{tabular}

\section{Palceontology of the Buclalandi Zone.}

\section{Reptilia.}

Ichthyosaurus communis, Conybeare.

- intermedius, Conyb.
Ichthyosaurus platyodon, Conyb.

- tenuirostris, Conyb.

\section{Pisces.}

Ichthyodorulites of Hybodus reticulatus, Agass., and teeth of Acrodus nobilis, Agass.

\section{Cephalopoda.}

Arietites Bucklandi, Sow.

- bisulcatus, Brug.

- Conybeari, Sow.

- Sauzeanus, d'Orb.

- semicostatus, Young \& Bird.

- Brooki, Sow.

- Scipionianus, d'Orb.

- rotiformis, Sow.

Pleurotomaria similis, Sow.

$$
\begin{aligned}
& -\quad \text { Hennocqui, Terq } \\
& \text { - } \quad \text { concava, Mart. }
\end{aligned}
$$$$
\text { - tectaria, Tate. }
$$

Cryptænia solarioides, Sow.

$$
\text { - rotellæformis, Dunk. }
$$

Actæonina, fragilis, Dunk. sinemuriensis, MTart.

Turbo solarium, Piett.
Aegoceras Charmassei, d'Orb.

Amaltheus Greenoughi, Sow.

Nautilus striatus, Sow.

Belemnites acutus, Mill.

$$
\begin{array}{ll}
\text { - } & \text { pencillatus, Sow. } \\
\text { - } \quad \text { calcar, Phil. } \\
\text { - infundibulum, Phil. }
\end{array}
$$

\section{Gasteropoda.}

Turbo philemon, d'Orb.

- reticulatus, Moore.

- Wilsoni, Tate.

Rissoa nana Mart.

Phasianella Morencyana, Piette.

Pitonellus sordidus, Tate.

Eucyclus elegans, Münst.

- selectus, Chap. \& Dewalq.

Trochus Redcarensis, Tate. 
Chimnitzia Collenoti, Terq. \& Piet. unicingulata, Terq.

Cerithinm gratum, Terq. Semele, d'Orb.

Turritella Zenkeni, Dunk.

Ostrea semiplicata, Münst.

Pecten calvus, Goldf.

- textorius, Scholth.

- Thiollieri, MIart.

- punctatissimus, Quenst.

- lunularis, Roemer.

- Lohbergensis, Emmerich.

Lima Hettangiensis, Terq.

- gigantea, Sow.

- succincta, Schloth.

- pectivoides, Sow.

Limea Blakeana, Tate.

Monotis papyria, Quenst.

- inæquivalvis, Sow.

Gervillia Hagenovii, Dunk.

Perna infraliassica, Quenst.

Pinna Ilartmanni, Ziet.

Inoceramus pinnæformis, Dunk.

Macrodon pullus, Terq

- naviculus, Terq. \&. Piet.

- Hettangiensis, Terq.

Leda Galathea, d'Orb.

- Renevieri, $O p p$.

- texturata, Terq. \& Piet.

- subovalis, Goldf.

Spiriferina Walcotti, Sow.

Rhynchonella plicatissima, Quenst.

Ditrypa globiceps, Quenst.

- capitata, Phil.

- quinquesulcata, Münst.

Ophiura, $s p$.

Cidaris Edwardsii, Wright.

Himipedina Tomesii, $W r$.

Septastræa Murchisonæ, $W r$.

Montlivaltia Haimei, Chap.

Foreign Correlations.-Leopold von Buch ${ }^{2}$ long ago remarked that " the Ammonites

1 'Die Ammoniten,' Akademie der Wissenschaften, Phys. Abhandl., p. 142, 1830.

Turritella regularis, Terq. \&. Piet.

- Dunkeri, Terq.

Discohelix Oppeli, Mart.

- striata, Piette.

Natica purpuroidea, Tate.

\section{LAMELLIBRANCHIATA.}

Nucula navis, Piette.

Modiola Hillana, Sow.

- lævis, Sow.

- bifasciata, Tate.

Protocardia Philippiana, Dunk.

Cardita Heberti, Terq.

Cardinia crassiuscula, Sow.

- concinna, Sow.

- Listeri, Sow.

Astarte obsoleta, Dunk.

- cingulata, Terq.

Tancredia ovata, Chap. \&. Dewalq. apicistria, Rolle.

Lucina limbata, Terq. \& Piet.

Hippopodium ponderosum, Sow.

Myoconcha, psilonoti, Quenst.

Unicardium cardioides, Phil.

Gresslya Galathea, Agass.

Pleuromya liasina, Schliub.

- crassa, Agass.

- Dunkeri, Terq.

Pholadomya glabra, Agass.

Homomya veutricosa, dgass.

Goniomya heteropleura, Agass.

\section{BraChIOPODA.}

ANNELIDA.

Echinodermata.

Serpula limax, Goldf.

- deflexa, Phil.

Galeolaria socialis, Goldf.

Pentacrinus basaltiformis, Mill.

tuberculatus, Mill.

Holothuria spines?

AnthozoA.

Montlivaltia Guettardi, Blainv.

Montlivaltia Chuettardi, Blaino. 
of the Family Arietes are in general found together in great numbers; whole strata are sometimes composed of them, and they often grow to a very large size, from one to two feet in diameter. They are exclusively and only special to the Lias formation, and particularly in the lower beds thereof, where many different species are found. It is still remarkable that this group stands wholly isolated from all the others," and is well represented by Arietites Bucklandi, Conybeari, rotiformis, stellaris, semicostatus. In North Germany the Arietenschichten are well developed, and very rich in organic remains, as at Orsleben and near Harzburg, where the Bisulcatus-beds are worked for ironstone. At Sölenhai, near Liebenburg, and Falkenhagen, near Rischenau, the hydraulic limestone marls are found with Arietites bisulcatus and Gryplice arcuata in great numbers.

In South Germany, in Württemberg, the Bucklandi-beds are developed near Stuttgart, where they repose on the Angulatum-beds, which are worked at Vaihingen for hydraulic limestone; in these Pflastersteine are found large specimens of $A$. angulatum. For one of these fossils, thirteen inches in diameter, I am indebted to my friend Professor Fraas. The twenty feet of Angulaten-Schichten are overlain by a thin seam of yellow clay, on which rests hard, dark-coloured limestone containing Arietites Bucklandi, Conybeari, bisulcatus, obliquicostatus, Gryphaen arcuata, and numerous other Mollusca, so that the rock is completely composed, as in several specimens before me, of shelly organic remains. The Bucklandi-beds are only about three feet thick, but very fossiliferous, and the Museums of Stnttgart and Tübingen contain extensive suites of fossils from these beds. In Baden the Lower Lias is found at Malsch and Oestringen, in the Langenbrïck Jura, where the Planorbis-beds are overlain by the thick, hard, blue limestone of the Bucklan dibeds, the Angulatum series being here almost absent. Arietites Bucklandi, A. spiratissimus, A. Turneri, Gryphca arcuata, Lima Hermanni, L. gigantea, L. punctata, Pecten textorius, Pentacrinus tuberculatus, Mill., and Spirifer tumidus, are the leading fossils here.

In the Breisgau Jura the Lower Lias is represented by the Bucklandi-beds, where the same species are found as at Malsch.

In the Swabian Jura at Küssaburg the black bituminous limestone charged with pyrites are overlain by bluish-grey thick limestone, extremely rich in organic remains. Aegoceras angulatum, Arietites Bucklandi, Conybeari, Sauzeanus, Turneri, Kridion, raricostatus, Nautilus striatus, Plcurotomaria similis, Cardinia concinna, C. crassiuscula, Lima gigantea, L. Hermanni, Gryplıaa arcuata, Pecten textorius, Spiriferina Walcotii, Pentacrinus tuberculatus, Mill., are the fossils in these beds.

F. Ritter von Hauer, in his classical monograph "Ueber die Cephalopoden aus dem Lias der nordöstlichen Alpen," has given beautiful figures and most accurate descriptions of some of the most characteristic species of Ammonites from the Bucklandi-beds of the Eastern Alps, where these shells lie in a red-coloured limestone; we liere find $A r$. rotiformis, $A$. Conybeari, $A$. bisulcatus, $A$. spiratissimus, and $A$. tardicrescens, var. of Conybeari, A. Kridion, A. stellaris, A. liassicus, A. liungaricus, A. Nodotianus, $A$. multicostatus. All of these are well recognised forms of Bucklandi-zone.

${ }^{1}$ Denk. Kaiser, 'Akademie der Wissenschaft,' Wien, 1856. 
In Luxembourg the Lower Lias is well developed, and the Bucklandi-beds represented by the upper portion of the Grès de Luxembourg. This formation has received different names by different authors; it is the "Calcaire sableux" of Boblaye, the "grès de Luxembourg" of Omalius, the "Steininger" of Dumont, the "Calcaire sableux" of Sauvage and Buvignier, the "Lias $a$ " of Quenstedt, the "unterer lias Sandstein" of Roemer, the "Quadersandstein " (pars) of some German authors, and the "Grès liasique" of Terquem, with the Grès d'Hettange. In France, in Department of the Moselle, the Bisulcatus or Bucklandi-beds have been diligently studied by MM. Terquem and Piette, and the fruit of their labours is given in detail in their able work quoted already, in which the following species of Cephalopoda are catalogued from the Bisulcatus-beds: -Arietites bisulcatus, A. Kridion, A. Conybeari, A. obtusus, A. Birchii, A. lacunatus, 1. Boucaultianus, A. Laigneletii, A. centanrus, A. caprotinus, A. Hagenovi, A. raricostatus, A.lavigatus, A. sinemuriensis, Nantilus striatus, N. Schlumbergeri, Belemnites acutus. Besides these there are 60 species of Gasteropoda, 106 species of Lamelibranchiata, 11 species of Brachiopoda, 8 species of Annelida, 6 species of Polyzoa, 12 species of Echinodermata, 3 species of Crustacea, 15 species of Anthozoa, 20 species of ForamiNIFERA, and 3 species of Plants. Of this total 177 are found in lower zones, 57 are special to the Bisulcatus-beds, and 140 pass into the upper stages of life.

In the Côte d'Or M. Collenot, in his 'Description Géologique de l'Auxois,' has given a section of the Lower Lias, which slows the sequence of the beds near Semur.

The upper series represent the zone of $A$. Birchii.

The middle do. do. A. Bucklandi.

'The lower do. do. A. Scipionianus.

'The last rests upon the Angulatum-beds or the "Foie de Vean," and the following Palæontological list has been made with great care from the beds. I had the privilege, through the courtesy of MM. Collenot and Bréon, of examining all the species ohtained therefrom, and contained in the Semur Museum. ${ }^{1}$

List of the Fossils of the Bucklandi-beds in the Côte d'Or, France.

Cephalopoda.

Arietites Scipionianus, d'Orb.

- Hehli, Reynès.

- viticola, Dumort.

- Rouvillei, Reynès.

- Schlombachi, Reynès.

- Charmassei, d'Orb.

- Delmasi, Reynès.

- Scylla, Reynès.

- circumdatus, Mart.

- Collenoti, Reynès.

- rotiformis, Sow.

- rotator, Reynès.
Arietites coronarius, Quenst.

- obesus, Reynès.

- bisulcatus, Brug.

- Vercingetorix, Reynès.

- Bucklandi, Sow.

- Sinemurieusis, d'Orb.

- striarius, Quenst.

- mandubius, Reynès.

- Deffneri, Opp.

- d'all'Eræ, Reynès.

- Terquemi, Reynès.

- Petri, Reynès.

1 'Description Géologique de l'Auxois,' p. 226 ; ibid., p. 235, 1873. 
Arietites Conybeari, Serv.

- Conybearoides, Reynès.

- Aussoniensis, Reynès.

- Gmuendensis, $O p p$.

- compressarius, Quenst.

- Gaudryi, Reynès.

- Sauzeanus, $d^{\prime}$ Orb.

- subtaurus, Reynès.

- geometricus, Opp.

- falcarius, Quenst.

- ceratoides, Quenst.

- Birchii, Sow.

- obtusus, Sow.

- stellaris, Sow.

Littorina clathrata, Desh.

Bulla Flouesti, Deslong.

Turritella Dunkeri, Terq.

Phasianella Morencyana, Piet.

Turbo decoratus, Mart.

- philemon, d'Orb.

Cerithium verrucosum, Terq.

- Semele, d'Orb.
Arietites $\mathbb{E} d u e n s i s, d^{\prime} O r b$.

- Breoni, Reynìs.

- raricostatus, Ziet.

- rarisulcatus, Quenst.

Amaltheus oxynotus, Quenst.

- Lotharingus, Reynès.

Aegoceras Boucanltianum, d'Orb.

Amaltheus Guibalianus, $d^{\prime} \mathrm{Or} b$.

Arietites Nodotianus, d'Orb.

- debilitatus, Reynès.

- Bochardi, Reynès.

- Brookii, Sow.

- Landrioti, d'Orb., and others.

\section{Gasteropoda.}

Pleurotomaria Martiniana, d' Orb.

$\begin{array}{ll}\text { - } & \text { Hettangiensis, Terq. } \\ \text { - } & \text { Mosellana, Terq. } \\ \text { - } & \text { Vanderbachii, Terq. } \\ \text { - } & \text { Marcousana, d'Orb. } \\ \text { - } & \text { gigas, Deslong. }\end{array}$

Helcion, sp.

\section{LAMELLIBRANCHIATA.}

Pleuromya, sp.

Pholadomya Voltzii, Agass.

$$
\begin{array}{ll}
\text { - } & \text { ventricosa, d'Orb. } \\
\text { - } & \text { rhombifera, Agass. } \\
\text { - } \quad \text { Idea, d'Orb. }
\end{array}
$$

Goniomya Sinemuriensis, d'Orb.

Taucredia, 4 species.

Isodonta Engelhardi, Terq.

Panopæa striatula, $d^{\prime} O r b$.

Thracia, sp.

Lyonsa, sp.

Arcomya, sp.

Astarte, $2 \mathrm{sp}$.

Cardinia Listeri, Sow.

- hybrida, Stuchb.

- Eveni, Terq.

- angustata, Agass.

- lanceolata, Stuchl.

- copides, Terq.

- insignis, Mart.

Mactromya, sp.
Nucula, sp.

Psammobia, sp.

Pinna Hartmanni, Ziet.

- folium, Phil.

Avicula Sideloci, Mart.

- sinemuriensis, d'Orb.

Mytilus Guexii, $d^{\prime} O r \cdot b$.

Inoceramus, sp.

Lima antiquata, Sow.

- gigantea, Sow.

- Erosne, d' Orb.

- punctata, Sow.

- Hettangiensis, T'erq.

Pecten Helhii, d' Orb.

- dispar, Terq.

- textorius, Schloth.

Hinnites liasinus, T'erq.

Ostrea multicostata, Munst.

Gryphæa arcuata, Lamk.

- Maccullochii, Sow.

- obliquata, Sow. 
BrachIOPODA.

Spiriferina pinguis, Ziet.

- Walcotii, Sow.

Rhynchonella variabilis, $d$ ' Orb.

Terebratula perforata, $P$ iet.
Terebratula cor., Lamk.

- punctata, Sow.

- indentata, von Buch.

Echinodermata, Polyzoa, Anthozon.

Pentacrinus tuberculatus, Mill.

Neuropora mamillata, de From.
Cidaris, sp.

Montlivaltia Sinemuriensis, de From.

Foraminifera, 15 species.

\section{The Zone of Arietites Turneri.}

Synomyms. - "Hauptpentacrinitenbank des untern Lias," Qıenstedt, 'Flozgeb.' p. 152, 1843. "Lumachelle de Pentacrinites basaltiformis," Marcou, 'Jura salinois,' p. 47, 1846. "Die Schichten des Pentacrinus tuberculatus" Oppel, 'Juraformation,' p. 44, 1856. "'Tuberculatus-bed," Wright, 'Quart. Journ. Geol. Soc.,' vol xiv, p. 25, 1858. “Marne de Strassen," Dewalque et Chapuis, "Fossiles de Luxembourg,' 1853. " Zone of Ammonites Turneri,” Wright, 'Quart. Journ. Geol. Soc.,' vol. xvi, p. 403, 1860.

This subdivision of the Lower Lias forms a well-marked zone of life. The beds consist of light-coloured argillaceous limestone, of hard greyish limestone, or of deep-blue shelly, indurated shale, interstratified with beds of dark-coloured clay. Many of the slabs of limestone are covered with shells and portions of the stem and side arms of Pentacrinus tuberculatus, Mill. From one of these slabs, collected at Frethern or Purton, in Gloucestershire, Miller's original specimen of this Crinoid was obtained.

Gloucestershire and Warwickshire. - The Turneri zone was exposed at Bredon, in the deep cuttings of the Bristol and Birmingham Railway, from whence my type specimen (Pl. XII) was obtained. In the Vale of Gloucester portions of these beds are sometimes laid open in making drains, as at Badgeworth and Hardwick; and many fine slabs are occasionally procured from the Severn section at Purton. I know of no locality in Gloucestershire, where the entire series is shown. .My late friend, Dr. Oppel, ${ }^{1}$ referred the Saurian beds of Brockeridge Common to this zone. This I have shown, at p. 17, to be an error, as the Brockeridge Common-beds form a portion of the zone of Aegoceras planorbis, whereas the Fish and Saurian beds at Lyme Regis, with which he identified the Brockeridge-beds, certainly belong to the zone of Arietites Turneri, as the following section indicates. In Warwickshire the Turneri beds constitute the base of what is called in that county the "Cardinia-series;" in these are included all the strata of the Lower Lias between the Turneri and raricostatuin beds, characterised by different forms of the genus Cardinia. 
Dorsetshire.-At Lyme Regis the Bucklandi series is overlain by thick beds of clay and slaty marls containing many Enaliosaurian skeletons, with numerous Fishes, in fine preservation; these strata are known to local collectors as the Fish- and Saurian-beds. 'The magnificent specimen of Iclthyosaurus platyodon, Conyb., now in the British Museum, canie from this clay, as proved by the impressions of Arietites senicostatus seen on the matrix. This thick clay-bed is underlain by a thin band of greyish-limestone, in which Ar. Turneri is found. 'The following section at Lyme Regis shows the sequence of the Turneri beds at that locality in a descending order.

Section of the Zone of Arietites Turneri at Lyme Regis.

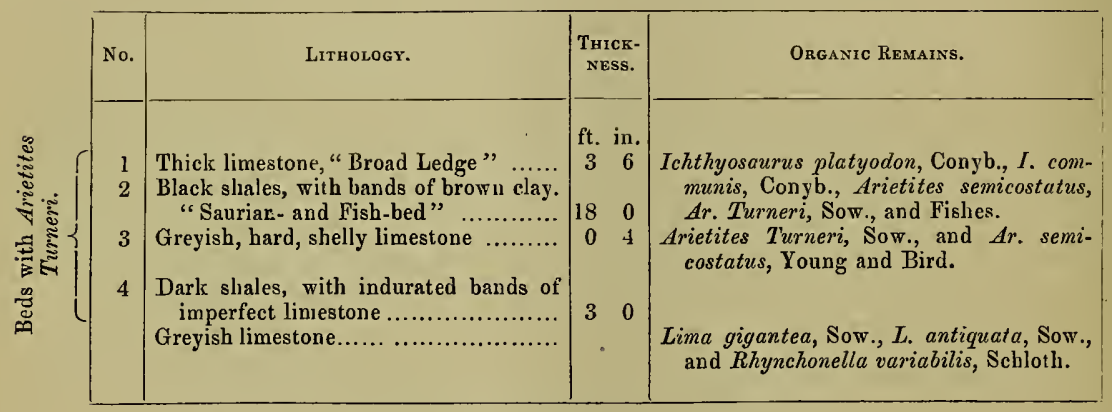

Beds with Arietites Bucklandi and Lima gigantea. (See p. 38.)

\section{Fossils of the Zone of Arietites Turneri.}

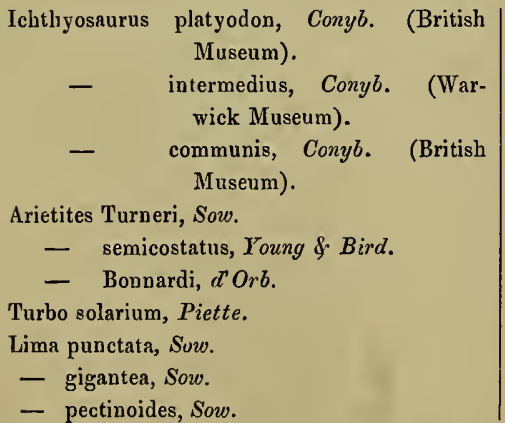

Cardinia ovalis, Stutch. Ostrea Goldfussii, Bronn.

Avicula inæequivalvis, Sow.

Pecten textorius, Schloth.

- glaber, Hehl.

Astarte obsoleta, Dunk.

Crenatula, nov. sp.

Plicatula spinosa, Sow.

Gervillia Hagenovii, Dunk.

Gryphæa arcuata, Lamk.

Cidaris Edwardsii, $W r$.

Pseudodiadema spines.

Pentacrinus tuberculatus, Miller.

I I have omitted the Lias Fishes found at Lyme Regis, as there is some doubt about the beds from: which the different species were collected; a large majority of them, however, I believe, were obtained from. this zone of life. 


\section{PALAONTOGRAPHICAL SOCIETY.}

INSTITUTED MDCCCXLVII.

VOLUME FOR 1879.

LONDON :

IIDCCOLXXIX. 



\section{MONOG RAPH}

ON THE

\section{LIAS AMMONITES \\ OF}

\section{THE BRITISH ISLANDS.}

BY

\section{THOMAS WRIGHT, M.D., F.R.S.EDIN., F.G.S.,}

VICE-PRESIDENT OP THE PALIENTOGRAPHICAL SOCIETY; CORRESPONDING MEMBEK OF THE ROYAL SOCIETY OF SCIENCES OF LIÈGE; THE SOCIETY OF NATURAL SCIENCES OF NEUCHÂTEL; VICE-PRESIDENT OF THE COTTESWOLD NATURALISTS' FIELD CLUB; CONSULTING SURGEON TO THE CHELTENHAM HOSPITAL; AND MEDICAL OFFICER OF HEALTH TO THE URBAN SANITARY DISTRICTS OF CHELTENHAM, CHARLTON KINGS, AND LECKHANPTON.

PART SECOND-THE LIAS FORMATION.

Pages 49-164; Plates IX-XVIII.

LONDON :

PRINTED FOR THE PALAONTOGRAPHICAL SOCIETY. 
3. E. ADLARD, BARTHOLOMEW CLOSE. 


\section{The Zon of Arietites obtusus.}

Synonyms.-“"Marston-Marble,” Sowerby, 'Min. Conch.,' Suppl. Index, vol. i, 1812. "Indurated marl and limestone-beds," De la Beche, "Section," \&c., 'Geol. Trans., 2nd ser., vol. ii, pl. iii, 1823. “'Turnerthone,” Quenstedt, 'Flözgeb. Württembergs,' p. 157, 1843. "Ammonite-bed (Lower Lias)," Murchison, 'Geol. of Cheltenham,' 2nd edit., p. 42, 1845. "Sable d'Aubange" (partie infer.), Dewalque et Chapuis, 'Luxembourg,' p. 12, 1853. “Die Schichten des Ammonites obtusus," Oppel, 'Juraformation,' p. 50, 1856. "Grès de Virton" (partie infer.), Dewalque, 'Lias de Luxembourg,' p. 48, 1857. "Zone of Ammonites obtusus," Wright, 'Quart. Journ. Geol. Soc.', xvi, p. 404, 1860.

Gloucestershire and Warwickshire.-The beds constituting this zone are well developed in the Vale of Gloucester, and were exposed in cutting the Bristol and Birmingham Railway, near Bredon, from whence the best collection of the fossils from this zone in the Midland Counties was obtained. The rocks consist of dark-grey and bluish shales and clays, with irregular and inconstant beds of dark-grey argillaceous limestone, the shales being in part nodular and laminated, the clays thick and tenacious, and the nodular portions of the shales very fossiliferous. Several of the Arietites obtusus and Arietites stellaris had their shells well preserved, and the outer layers of the same were adorned with numerous parallel, longitudinal, spiral lines, consisting of punctuated elevations, which extend along the sides, dip into the depressions, and rise on the central elevation of the siphonal area. This ornamentation is limited to the external lamina of the shell, as no impression of it is left on either the nacreons layer or the mould. I have rarely found these punctuated lines so well preserved as in the specimens $I$ have figured of Arietites obtusus, from Bredon and Lyme, and in the remarkable specimen of Arietites stellaris, from Lyme, preserved in the original Sowerbyan Collection now in the British Museum. So seldom is this specific shell-structure observed that many palæontologists deny its existence in these species, but after the figures I have given all doubt upon the subject must be removed. In Warwickshire this zone forms part of the Cardinia-bed and contains some very fine specimens of Arietites obtusus, Ar. multicostatus, Ar. Brookii, and Ar. Sauzeanus, d'Orb.

Dorsetshire.-At Lyme Regis the Obtusus-zone attains a considerable thickness, and is well shown in the coast-section. The strata rise on the shore about half a mile west of Charmouth, and consist of thick beds of dark marls, which rest upon the table-bed formed by Broad Ledge. The lower part of the marls contains numerous compressed Aegoceras Birchii, Sow., and layers of nodules forming cement-stones. Above these succeed shales and clays, thin bands of limestone, and thick beds of shale and marls with mudstones. Above these again are inconstant bands of limestone containing septaria, in which gigantic examples of Arietites obtusus, Arietites stellaris, and Arietites Brookii are found. The following section shows the relative position of these beds. 
Section from Broad Ledge to Cornstone Ledge, near Charmouth.

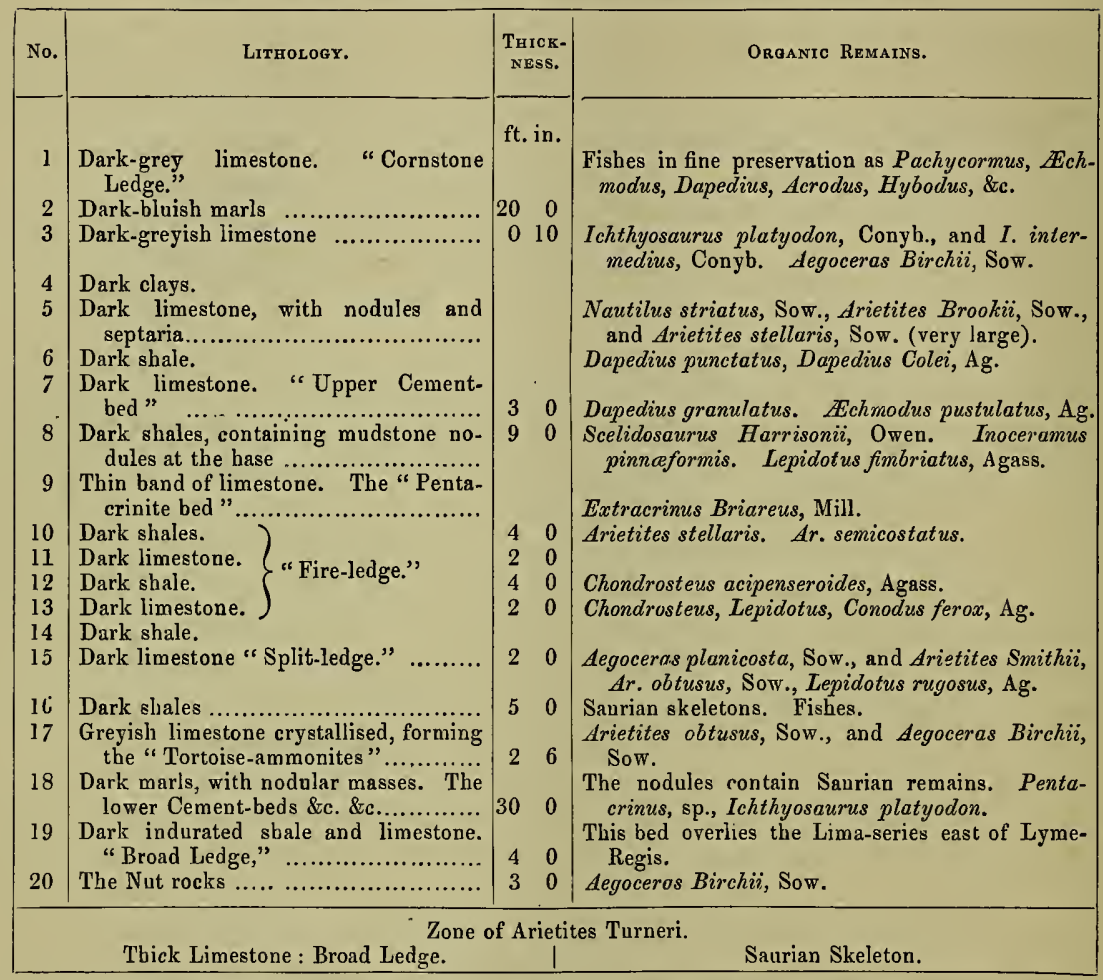

The Obtusus-zone attains a thickness of from 80 to 100 feet; its actual measurement is a matter of difficulty, the marls having covered up the bands of limestone.

In the lower marls are many compressed specimens of Aegoceras Birclii, which fall to pieces when removed from the matrix. Higher up (No. 17) this Ammonite is found in fine preservation, with Arietites obtusus. Here the shells are replaced, and their chambers filled, with crystallised carbonate of lime. These beautiful specimens are the "Tortoiseammonites" of local collectors. About 40 or 50 feet above the latter an irregular band of limestone (5) is seen projecting from the cliff, containing nodules with very large specimens of Arietites obtusus, Sow., Arietites stellaris, Sow., and Arietites Brookii, Sow. Most of the nodules have a septarian structure, the veins of spar intersecting and distorting the fossil contents of the bed.

Below the ammonitiferous nodules (5 of the section) other bands of clay and marl (6 to 14) succeed. In one of these (9) are thin, wide-spread layers of Crinoidal limestone, on the surface of which magnificent specimens of Extracrinus Briareus, Mill., are 
found, with their plant-like arms laid out in all directions, and generally coated with ferric disulphide. The remarkable Liassic Dinosaurian Scelidosaurus Harrisonii, Ow., so fully figured and ably described by my friend Professor Owen, F.R.S., in the Palæontographical Society's volume for 1859, was discovered some years ago by Mr. Samuel Clarke, of Charmouth, in the dark shales of bed No. 8, above the mudstones.

\section{Fossils of the Zone of Arietites obtusus at Lyme Regis.}

Ichthyosarus platyodon, Conby.

Scelidosaurus Harrisonii, Owen.

Dapedius granulatus, Agass.

Pachycormus heterurus, Agassiz.

Æchmodus Leachi, Egerton.

Lepidotus rugosus, Agassiz.

Condostreus crassior, Egerton.

Arietites obtusus, Sow.

- Brookii, Sow.
Arietites stellaris, Sow.

- Sauzeanus, d'Orb.

Aeyoceras planicosta, Sow.

- Birchii, Sow.

Nautilus striatus, Sow.

Belemnites acutus, Mill.

Pleurotomaria similis, Sow.

Inoceramus pinnæformis, Dunk.

Extracrinus Briareus, Mill.

Foreign Correlations.-The zone of Arietites obtusus is developed in Germany, although this Ammonite appears to be rare. Some of the specimens I saw in the collections had been mistaken for Arietites Turneri and were labelied as such. In North Germany argillaceous beds, with Aegoceras planicosta, Sow., and Aeg. ziphus, Hehl., representing this zone, are found resting on Arietensclichten in several localities, as near Harzburg, Liebenburg, Hildesheim, Jexheim, Goslar, the Markoldendorfer Mulde, near Steinberg, Falkenhagen, and the Empelder Ziegelei, near Hanover.

In South Germany the zone is developed in Swabia, at the foot of the Alp from Boll towards Randern. Arietites obtusus, Sow., is found likewise near Betzingen, Balingen, and Aselfingen.

Fossils from the planicosta-beds of North Germany = the obtusus-beds of England.

Arietites obtusus, Sow.

- Sauzeanus, d'Orb.

Aegoceras planicosta, Sow.

- ziphus, Hehl.

- tamariscinum, Schlön.

Belemnites acutus, Mill.

Hydrobia cerithiiformis, Piette.

Turritella undulata, Benz.

Turbo paludiuæformis, Schübl.

Cryptænia expansa, Sow.

Dentalium Etalense, Terq.

Cylindrites fragilis, Dunk.

Pleuromya liasina, Schübl.

Goniomya heteropleura, Agass.

Pholadonya corrugata, Dunk.

Protocardia oxynoti, Quenst.
Lucina problematica, Terq.

Modiola scalprum, Sow.

Avicula inæquivalvis, Sow.

Gervillia olifex, Quenst.

Perna Pellati, Dumort.

Cucullæa Münsteri, Ziet.

Leda complanata, Sow.

Lima gigantea, Sow.

- pectinoides, Sow.

Pecten textorius, Schloth.

Plicatula spinosa, Sow.

Gryphæa cymbium, Lamk.

Waldheimia cor, Lamk.

Spiriferina rostrata, Schloth.

Rhynchonella variabilis, Schloth.

Lingula Voltzii, Terq. 
In France this zone is so closely connected with other Lower Lias beds resting upon it, that it has not been accurately defined and separated from them. Its specific Ammonite forms have, however, been collected in different Departments. Thus, Arietites obtusus, Arietites stellaris, Aegoceras Birchii, Aeg. planicosta, have been collected near Avallon, Yonne; and at Semur, Côte d'Or; also at Couzon, near Lyons ; and at Nancy, Meurthe. 'The same species were likewise collected, according to M. Dumortier, ${ }^{1}$ from St. Fortunat, St. Cyr, Rhône; St. Christophe, Saône-et-Loire ; St. Rambart, Ain ; affording evidence of the existence of this zone of dife through a considerable area of the Sinemurian Lias.

M. Marcou, in the Jura of Salins, ${ }^{2}$ described under the name "Marnes de Balingen ou à Gryphæa cymbium " three stages resting upon the Tuberculatus-beds; these were-lst, beds with Arietites obtusus; 2nd, beds with Amaltheus oxynotus; and 3rd, beds with Arietites raricostatus; and these resembled the formation near Balingen, so that in the Jura the Obtusus-zone is developed, as it is likewise in other localities in Switzerland.

\section{The Zone of Amaitheus oxynotus.}

Synonyms. _ " Oxynoten-Schichte," Fraas, 'Württemb. naturw. Jahreshefte,' p. 206, 1847. "Die Schichten des Ammonites oxynotus," Oppel, 'Die Juraformation,' p. 54, 1856. "Oxynotenlager," Quenstedt, 'Der Jura,' p. 293, 1858. "Oxynotus-bed," Wright, 'Quart, Journ. Geol. Soc.,' vol. xiv, p. 25, 1858. "Zone of Ammonites oxynotus," Wright, 'Quart. Journ. Geol. Soc.,' vol. xvi, p. 406, 1860. "La Zone de " $l$ 'Ammonites oxynotus," Dumortier, 'Études Paléont.,' t. ii, p. 238, 1867. "Zone of Ammonites oxynotus," Tate and Blake, 'Yorkshire Lias,' p. 7, 1876.

Gloucestershire.-This zone consists of beds of dark clays, which often contain much ferrous sulphide and ferric oxide, and the fossils found in these clays are either highly pyritic or charged with the peroxide of iron. This zone was exposed in cutting the Bristol-and-Birmingham, and Great-Western Railways; at Lansdown, near Cheltenham; and in excavating the new docks at Gloucester; I have collected its characteristic fossils at Swindon and at some localities in the Valley of the Severn.

Dorsetshire.-Amaltheus Lymensis, the representative species, in the south, of Amaltheus oxynotus in the Midland Counties-is found in a thin bed of dark, pyritic marl between Charmouth and Lyme Regis, near Black Venn. It is here collected with other species, which properly belong to a higher bed; the talus of the upper marl, from the decay of the bank, making it difficult to separate the beds.

Yorkshire.-The Oxynotus-zone is well seen in Robin Hood's Bay, and the following detailed section by MM. Tate and Blake, ${ }^{3}$ including likewise the Obtusus-zone and

1 'Etudes Paléont. Dépôts Jurassiques du Bassin du Rhône,' tome ii, p. 103, 1867.

2 'Jura Salinois,' Mém. Soc. Géol, de France, 1846.

3 'Yorkshire Lias,' p. 73, 1876. 
raricostatus-zone, is most valuable for showing the stratigraphical distribution of the Ammonites therein. The upper balf of the section, Nos. $1-20$, represents the raricostatus; Nos. $21-26$ the oxynotus; and the lower portion, Nos. $27-45$, the obtususzone.

Section of the Oxynotus-beds, Robin Hood's Bay.

\begin{tabular}{|c|c|c|c|}
\hline No. & LithoLOGY. & $\begin{array}{l}\text { THICK- } \\
\text { NESS. }\end{array}$ & Organic Remains. \\
\hline & & ft. in. & \\
\hline 1 & 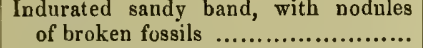 & 16 & Belemnites. \\
\hline 2 & Blue shale................................... & 86 & \\
\hline 3 & Hardened band........................... & $\begin{array}{ll}0 & 3\end{array}$ & $\begin{array}{l}\text { Pecten priscus, Cardinia hybrida, Gryphaa obli- } \\
\text { quata, Belemnites. }\end{array}$ \\
\hline 4 & 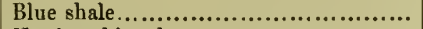 & 70 & Homomya ventricosa. \\
\hline 5 & 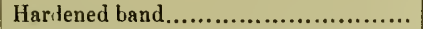 & & \\
\hline 6 & Blue shale................................. & & \\
\hline 7 & $\begin{array}{l}\text { Blue shale, with variable indurated } \\
\text { bands, thick in places ................. }\end{array}$ & 70 & \\
\hline 8 & 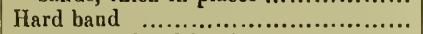 & 04 & \\
\hline 9 & Soft clayey band in places ............... & & \\
\hline 10 & Hard blue shales ........................ & & \\
\hline 11 & Rubbly variegated hard band ............ & & \\
\hline 12 & Blue breakable shales ................... & 210 & Lima pectinoides. \\
\hline 13 & Rubbly variegated band .................. & $\begin{array}{rr}0 & 3 \\
0 & 10\end{array}$ & These three bands run close togetber, and make \\
\hline $\begin{array}{l}14 \\
15\end{array}$ & 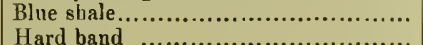 & $\begin{array}{lll}0 & 10 \\
0 & 0\end{array}$ & $\begin{array}{l}\text { a feature in the cliff. } \\
\text {. }\end{array}$ \\
\hline 16 & 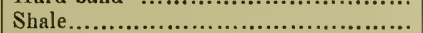 & 10 & Nautilus striatus. \\
\hline 17 & 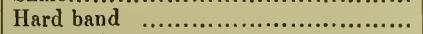 & & \\
\hline 18 & Blue shales ............................ & & Pentacrinus tuberculatus. \\
\hline 19 & Line of fossiliferous nodules ............. & 03 & $\begin{array}{l}\text { Ar. raricostatus, Amal. densinodus, Lima pecti- } \\
\text { noides, Pecten priscus, MLotis incquivalvis. }\end{array}$ \\
\hline 20 & Blue shales $\ldots \ldots \ldots \ldots \ldots \ldots \ldots \ldots \ldots \ldots$ & 18 & $\begin{array}{l}\text { Pecten calvus, Lima pectinoides, Rhynchonella } \\
\text { calcicosta. }\end{array}$ \\
\hline 21 & $\begin{array}{l}\text { Hard limestone band, with erect an- } \\
\text { nelid (?) tubes .......................... } \\
\text { Parting of sbale. }\end{array}$ & $\begin{array}{ll}0 & 8 \\
0 & \end{array}$ & Amal. Simpsoni, Nautilus striatus. \\
\hline 22 & Hard limestone band ................ & $\begin{array}{l}2-4 \\
8-6\end{array}$ & Gryphaa obliquata, Homomya ventricosa. \\
\hline 23 & Blue crumbly shale...$\ldots \ldots \ldots \ldots \ldots \ldots \ldots$ & 13 & $\begin{array}{l}\text { Aeg. gagateum, Lima pectinoides, Nodiola lavis, } \\
\text { ('ardinia hybrida. }\end{array}$ \\
\hline 24 & Hard rubbly stone $\ldots \ldots \ldots \ldots \ldots \ldots \ldots \ldots \ldots \ldots \ldots \ldots$ & 0 & \\
\hline 25 & $\begin{array}{l}\text { Blue crumbly shales, with bands of } \\
\text { scattered irregular doggers ............ }\end{array}$ & & $\begin{array}{l}\text { Amal. oxynotus, Aeg. grgateum, Belemnites acu- } \\
\text { tus, Pecten calvus, Protocardium oxynoti. }\end{array}$ \\
\hline 26 & $\begin{array}{l}\text { Marly stone, with Pentacrinus band } \\
\text { and cone-in-cone structure .............. }\end{array}$ & & $\begin{array}{l}\text { Pentacrinus tuberculatus, Actaonina fragilis, } \\
\text { Hydrobia solidula, Leda Heberti, Lima pecti- } \\
\text { noides. }\end{array}$ \\
\hline 27 & 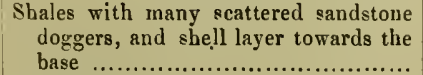 & 510 & $\begin{array}{l}\text { Aeg. planicosta, Lima pectinoides, Cardinia hy- } \\
\text { brida, Gryphaa obliquata. }\end{array}$ \\
\hline 28 & Hardened band ........................ & $0 \quad 5$ & \\
\hline 29 & Soft shale ....................... & 1 & \\
\hline 30 & Whitened calcareous band ............... & $\begin{array}{ll}0 & 3\end{array}$ & \\
\hline & & & \\
\hline
\end{tabular}




\begin{tabular}{|c|c|c|c|}
\hline No. & LithoLOGX. & $\begin{array}{c}\text { THIOK- } \\
\text { NESS. }\end{array}$ & Palantology. \\
\hline $\begin{array}{l}32 \\
33 \\
34 \\
35 \\
36 \\
37 \\
38 \\
39\end{array}$ & 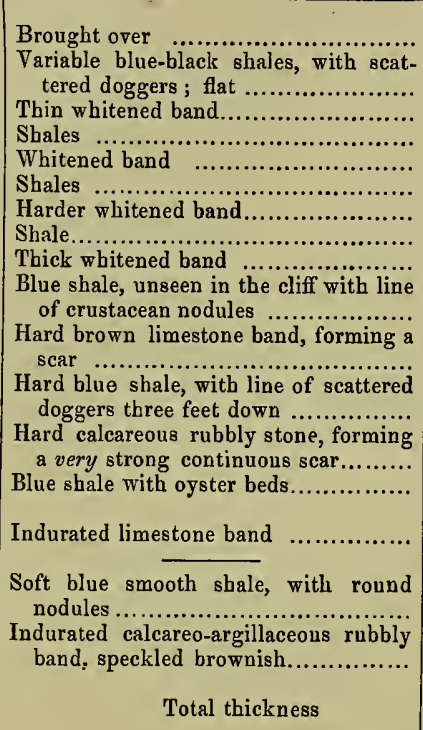 & $\left|\begin{array}{cc}0 & 5 \\
8 & 0 \\
1 & 3 \\
2 & 4 \\
4 & 6 \\
3 & 6 \\
0 & 2 \\
107 & 10\end{array}\right|$ & $\begin{array}{l}\text { Pentacrinus tuberculatus. } \\
\text { Aeg. sagittarium, Bel. acutus, } \\
\text { Ostrea arcuata, Bel. acutus. } \\
\text { deg. sagittarium, Pent. tuberculatus. } \\
\text { Aeg. sagittarium, Bel. acutus, Ostrea arcuata. } \\
\text { Aeg. planicosta, Ar. obtusus, Ar. stellaris, Aeg. } \\
\text { sagittarium, Hippopodium ponderosum. } \\
\text { Pentacrinus tuberculatus, Bel. acutus, Pecten } \\
\text { priscus, Ostrea arcuata. } \\
\text { Pent. tuberculatus, Pecten priscus, Ostrea } \\
\text { arcuata. } \\
\text { Ostrea arcuata, Cardinia hybrida, Hippopodium } \\
\text { ponderosum. } \\
\text { Aeg. planicosta. }\end{array}$ \\
\hline
\end{tabular}

The palæontology of the Oxynotus-zone is remarkable for the sull number of species it contains, when compared with the richness of the Bucklandi- and Angulatum-zones which preceded and the fertility of the Jamesoni-zone which succeeded it.

\section{Fossits of the Oxynotus-zone.}

\section{Cephalopoda.}

Amaltheus oxynotus, Quenst.

- Lymensis, Wright.

- Oppeli, Schlönbach.

- denotatus, Simpson.

- impendens, Young \& Bird.

- Simpsoni, Bean.

- Guibalianus, d'Orbig.

Aegoceras biferum, Quenst.
Aegoceras lacunatum, Buck.

- gagateum, Young \& Bird.

- sagittarium, Blake.

Nautilus intermedius, Sow.

Belemnites acutus, Mill.

$$
\begin{aligned}
& \text { - calcar, Phill. } \\
& \text { - penicillatus, Sow. }
\end{aligned}
$$

\section{GASTEROPODA.}

Pleurotomaria similis, Sow.

Actæonina fragilis, Dunk.

Cerithium gratum, Terq.

Turritella Dunkeri, Terq.

- Zenkeni, Dunk.

Hydrobia solidula, Dunk. 


\section{LAMELLIBRANCHIATA.}

Gryphæa obliquata, Lamk.

Ostrea Goldfussi, Bronn.

Pecten priscus, Schloth.

- æqualis, Quenst.

- calvus, Goldf.

Lima gigantea, Sow.

- pectinoides, Sow.

Monotis inæquivalvis, Sow.

Pinna folium, Young \& Bird.

- Hartmanni, Ziet.

Leda Heberti, Mart.

- suboralis, Goldf.

- Galathea, d'Orb.

Cidaris spines.

Acrosalenia minuta, Buck.
Cucullæa Münsteri, Ziet.

Modiola scalprum, Sow.

Protocardia oxynoti, Quenst.

Astarte obsoleta, Dunk.

Nucula navis, Piette.

Hippopodium ponderosum, Sow.

Cardinia hybrida, Sow.

Unicardium cardioide, Phill.

Homomya ventricosa, Agass.

Arcomya vetusta, $P$ hill.

Gresslya Galathea, Agass.

Rhynchonella calcicosta, Quenst.

Rhynchonella oxynoti, Quenst.

\section{Echinodermata.}

Pentacrinus tuberculatus, Mill.

basaltiformis, Mill.

\section{The Zone of Arietites raricostatus.}

Synonyms.- “ Hippopodium-bed" (pars), Murchison's 'Geology of Cheltenham,' 2nd ed., by Buckman and Strickland, p. 44, 1845. "Raricostatenschicht," Fraas, 'Württemb. naturw. Jahreshefte,' pl. 3, 1847. "Die Schichten des Ammonites raricostatus," Oppel, 'Die Juraformation,' p. 56, 1856. "Raricostatenbank," Quenstedt, 'Der Jura,' p. 293, 1858. “ Raricostatus-bed,” Wright, 'Quart. Journ. Geol. Soc., vol. xiv, p. 25, 1858. "Zone of Ammonites raricostatus," Wright, "Quart. Journ. Geol. Soc., vol. xvi, p. 407, 1860. “Die Schichten des Ammonites ziphus” (pars), Brauns, 'Die Untere Jura,' p. 90, 1871.

The beds forming this zone are exposed in several brick-fields in the Vale of Gloucester. They consist of dark-coloured clays, more or less impregnated with ferric oxide. In an excavation made at Marle Hill, near Cheltenham, for brickearth, the following section was obtained. The beds are enumerated in descending order.

No.

1.

a great many specimens of Gryphaca obliquata, Sow. .................. $3 \mathrm{ft}$. to
2. Coral-band; a thin seam of lightish-coloured unctuous clay, containing a great many small, sessile Corals, Montlivaltia rugosa, Wrt., most of which appeared to have been attached to the curved valves of the Gryphac............... 1 in. to

3. Hippopodium-led; a stiff dark-coloured clay, in some parts ferru taining Cardinia Listeri, Sow., and Hippopodium ponderosum, Sow., in considerable numbers ................................................... from $8 \mathrm{ft}$ to $10 \quad 0$

4. Ammonite-bed; a dark, ferruginous clay, containing selenite, ferric oxide, and ferrous sulphide, and great numbers of a highly pyritic brood of Aegoceras subplanicosta, Opp., Aegoceras densinodum, Arietites raricostatus, drietites Nodotianus, and the other species of the list ft. in.

40

$0 \quad 1 \frac{2}{2}$ ascertained. 
At Cleeve, near Cheltenham, the same beds were formerly worked for brick-earth ; and the finest specimens of Cardinia Listeri, Sow., Hippopodium ponderosum, Sow., Arietites raricostatus, Ziet., and Pleurotomaria similis, Sow., were obtained here. At Bredon these beds were laid open in the railway-cutting, and yielded a rich series of the characteristic fossils. In Warwickshire the railway-cutting at Honeybourne exposed the same zone; and here also the Coral-band contained a considerable number of Montlivaltia rugosa, Wrt., and the Ammonite-bed its leading species.

At Lyme Regis, in Dorsetshire, this zone is found near Black Venn, and some of the beds contain a large quantity of pyrites, so much so that during the winter months they are worked for that mineral, when their characteristic Ammonites are collected in considerable numbers; unfortunately most of the fossils are so much charged with pyrites that they are preserved with difficulty.

At Robin Hood's Bay, on the coast of Yorkshire, this zone is closely associated with the Oxynotus-beds and cannot be separated from them; it is seen resting on the underlying clays with Amaltheus oxynotus, and is overlain by thick clays containing Aegoceras Jamesoni, Sow. In all these localities there appears to be an absence of limestonelayers, the clay, more or less impregnated with iron in different stages of oxidation, constitutes the entire beds.

My friend Mr. E. C. H. Day, F.G.S., collected for me at the small bay of Ballintoy, in the north of Ireland, a number of fossils from this zone. The box he kindly sent me from that locality contained the following species :

\section{Cephalopoda.}

Arietites raricostatus, Ziet.

- Nodotianus, d'Orb. = Macdonnelli, Portlock.

Aegoceras subplanicosta, Oppel.
Aegoceras armatum densinodum, Quenst.

- muticum, D'orb.

Belemnites acutus, Mill.

- penicillatus, Sow.

\section{Gasteropoda.}

Pleurotomaria similis, Sow.

Turritella Dunkeri, Terq.

\section{LAMELLIBRANCHIATA.}

Gryphæa obliquata, Sow.

Plicatula spinosa, Sow.

Leda oxynoti, Quenst.

Pecten Hehlii, d'Orb.

- squalis, Quenst.
Waldheimia perforata, Piette.

Hippopodium ponderosum, Sow.

Protocardia truncata, Sow.

Goniomya rhombifera, Quenst.

Homomya ventricosa, Agass.

\section{BRACHJOPODA.}

Rhynchonella variabilis, Schloth. 
Fossils of the Zone of Arietites raricostatus from near Cheltenham.

\section{Cephalopoda.}

Aegoceras armatum densinodum, Quenst.

- lacunatum, Buck.

- muticum, d'Orb.

- subplanicosta, Oppel.
Arietites Nodotianus, $d \cdot O r b$. - raricostatus, $\boldsymbol{Z}$ iet.

Belemnites acutus, Mill.

Nautilus striatus, Sow.

Gasterofoda.

Chemnitzia parva, Wright.

Pleurotomaria similis, Sow.
Pleurotomaria raricostæ, Tate.

Cryptænia expansa, Sow.

\section{Lamellibranchiata.}

Limea acuticosta, Münst..

Cardinia hybrida, Sow.

Gryphæa obliquata, Sow.

Hippopodium ponderosum, Sow.

Lingula Metensis, Terq.

Rhynchonella variabilis, Schloth.

Berenicea striata, Haime.

Acrosalenia minuta, Buck.

Montlivaltia mammiformis, Dunc.

- mucronata, Dunc.
Ostrea raricostæ, Wright.

Pecten æqualis, Quenst.

Pleuromya oblonga, Wright.

Unicardium cardioide, Phill.

BrachIOPODA.

Spiriferina Walcotii, Sow.

Waldheimia numismalis, Schloth.

PolyzoA.

Stromatopora antiqua, Haime.

\section{Echinodermata.}

ANTHOZOA.
Montlivaltia radiata, Dunc.

- rugosa, Wright.

Foreign correlations.-The Oxynotus-beds in Württemberg so closely resemble those near Cheltenham, both in their Petrology and Palæontology, that when examining the fossils from these rocks in the Stuttgart and Tübingen Museums I failed to see any difference between the German and the English specimens; so much alike were they that, without marking the fossils before comparing them, I should have mistaken the one for the other. This was especially the case with Aegoceras biferum, Aeg. lacunatum, and Amaltheus oxynotus. 'This zone is feebly developed in some of the Departments of France. M. Marcou has found its fossils in the Jura Department. Few of the Ammonites appear to have passed into M. d'Orbigny's hands, as neither of the three leading species enumerated above is figured in the 'Paléontologie Française,' unless it may turn out 
on closer study that Amaltheus Lynx, d'Orb., and Amal. Coynarti, d'Orb., from the Middle Lias "du Bois-de-Trousse, près de Saint Amand (Cher), où elle est passée à l'état de fer sulfuré ou de fer hydraté," be French forms of Amal. oxynotus. I failed to find the type of Amal. Lynx and Amal. Coynarti in the d'Orbignyan Collection in the Jardin des Plantes.

From the Bassin du Rhône M. Dumortier has given a very full list of the fossils in his collection which he refers to this zone, and observes, ${ }^{1}$ when studying the fossils of the zone de l'Ammonites oxynotus, the fact that strikes one most is the important place which the Ammonites occupy. The number and variety of the species, the abundance of certain types, and above all the invariable regularity of their stratigraphical position, well deserve attention. In relation to their form, the Ammonites of the superior zone cannot be attached by preference to any particular type, inasmuch as we recognise at the same time shells with numerous and narrow whorls extremely evolute and provided relatively with an enormous umbilicus, as well as species entirely convolute and without a trace of umbilicus; certain forms having large, round backs, whilst others are provided with sharp and prominent carinæ. The external ornamentation exhibits the same variety ; sometimes the shell is simple and without ornament, whilst in others the surface is provided with the richest decoration.

The Gastropods, less rare than in the lower zone, are not, however, of much importance. Among the Lamellibranchiata the Gryplica obliqua occupies an exceptional position by the immense number of its individuals. The Pleuromya in this division of the Lias attain their maximum development ; and the Cardinia plitea, d'Orb., and Hippopodium ponderosum, Sow., in consideration of their remarkable forms and the certainty of their horizon, ought to be especially noted. The Brachiopods are here represented by Spiriferina and Rhynchonella, abounding in individuals, and above all by the Waldheinia cor, Lamk., a species of the highest importance. The Echinoderms are in general few in number and species, but Pentacrinus tuberculatus is inferior to no other fossil in the zone for its importance and the number of its individuals. The following list gires the characteristic fossils of the zone of Ammonites oxynotus as defined by M. Dumortier :

\section{Cephalopoda.}

Belemnites acutus, Mill.

Nautilus pertextus, Dumort.

Ammonites resurgens, Dumort.

- Hartmanni, Oppel.

- Berardi, Dumort.

- Patti, Dumort.

- lacunatus, Buck.

- obtusus, Sow.

- stellaris, Sow.
Ammonites CEduensis, Pharmasse.

- Landrioti, d'Orb.

- Locardi, Dumort.

- Birchii, Sow.

- Sauzeanus, d'Orb.

- Victoris, Dumort.

- Aballoensis, d'Orb.

- oxynotus, Quenst.

- altus, Hauer.

1 'Etudes Paléontologiques sur les Dépôts Jurassiques du Bassin du Rhône,' tom. ii, p. 238, 1867. 
Ammonites Driani, Dumort.

$\begin{array}{ll}\text { - Salisburgensis, Hauer. } \\ \text { - } & \text { Sæmanni, Dumort. } \\ \text { - } & \text { Bonnardi, d'Orb. } \\ \text { - } & \text { Nodotianus, d'Orb. } \\ \text { - } & \text { Pellati, Dumort. } \\ \text { - } & \text { armentalis, Dumort. } \\ \text { - } \quad \text { Edmondi, Dumort. }\end{array}$

Ammonites Oosteri, Dumort.

$\begin{array}{ll}\text { - } & \text { planicosta, Sow. } \\ \text { - } & \text { subplanicosta, Oppel. } \\ \text { - } & \text { tardecrescens, von IIauer. } \\ \text { - } & \text { viticola, Dumort. } \\ \text { - } & \text { raricostatus, Ziet. } \\ \text { - } & \text { vellicatus, Dumort. } \\ \text { - } \quad \text { zipluus, Hehl. }\end{array}$

\section{Gasteropoda.}

Pleurotomaria gigas, Deslong.

Pleuromya Toucasi, Dumort.

- cylindrica, Dumort.

Hippopodium ponderosum, Sow.

Gryphæa obliqua, Goldf.
Pleurotomaria Charmassei, Dumort.

\section{Conchifera.}

Myoconcha oxynoti, Quenst.

Harpax nitidus, Dumort.

Waldheimia cor, Lamk.

Terebratula Sinemuriensis, $O_{p} p$.

M. Dumortier includes in his zone of Ammonites oxynotus many species already enumerated in my description of the Obfusus- and Raricostatus-zones; it is well, therefore, to understand this author's definition of the group he has so well described and so fully illustrated. He says, "the superior part of the Lower Lias, which I comprehend under the name of the 'zone de l'Ammonites oxynotus,' offers an ensemble of beds of a total inconsiderable thickness, but which may be represented by the following theoretical section, taking the beds in descending order from above downwards."1

\begin{tabular}{|c|c|c|c|}
\hline Zones. & Petrology. & $\begin{array}{l}\text { THICK- } \\
\text { NESS. }\end{array}$ & PaLeONTOLOGY. \\
\hline $\begin{array}{l}\text { Couches à } \\
\text { Am.raricostatus. }\end{array}$ & $\begin{array}{l}\text { Calcareous beds, consisting of } \\
\text { light-coloured limestones ... }\end{array}$ & $\begin{array}{cc}\text { metres } \\
1 & 0\end{array} \mid$ & $\begin{array}{l}\text { Am. raricostatus, } A \text {. planicosta, A. viticola, } \\
\text { Cardinia philea. }\end{array}$ \\
\hline $\begin{array}{l}\text { Couches à } \\
\text { Am. oxynotus. }\end{array}$ & $\begin{array}{l}\text { Subcrystalline calcareous beds, } \\
\text { reddish, or brown-yellow } \\
\text { compact limestone ............ }\end{array}$ & 150 & $\begin{array}{l}\text { Am. oxynotus, A. Aballoensis, A. Driani, } A \text {. } \\
\text { Bonnardi, Nautilus pertextus, Avicula Sine- } \\
\text { muriensis. }\end{array}$ \\
\hline \multirow{3}{*}{$\begin{array}{c}\text { Couches à } \\
\text { Am. stellaris. } \\
\text { Couches a } \\
\text { Am. Davidsoni. }\end{array}$} & 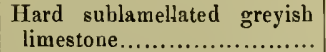 & & $\begin{array}{l}\text { Ain. stellaris, A. Eduensis, } A \text {. obtusus, Gry- } \\
\text { phæe obliqua, Waldheimia cor. }\end{array}$ \\
\hline & $\begin{array}{l}\text { Hard sublamellated bluish- } \\
\text { grey limestone................... }\end{array}$ & & $\begin{array}{l}\text { Am. Davidsoni, A. locunotus, } A \text {. Hartmanni, } \\
\text { Pentacrinus tuberculatus. }\end{array}$ \\
\hline & Total thickness & 70 & \\
\hline
\end{tabular}

It is evident from the above table that Dumortier's "zone de l'Ammonites oxynotus" comprehends the Raricostatus-, Oxynotus-, and Obtusus-beds of this Monograph.

The distribution of the Ammonites in this zone has been very carefully observed and noted by this author, and he has therefore called the special attention of palæontologists

1 'Etudes Paléontologiques sur les Dépôts Jurassiques du Bassin du Rhône,' tom. ii, p. 95, 1867. 
to the subject by remarking " above all, the invariable regularity of the different horizons they occupy." He has further summarised his observations in the following table, which shows how the species are distributed vertically, and how each of the four stages of life is characterised by a certain number of species.

These observations on Ammonite-zones made by so careful and thoughtful a student of Liassic palæontology as Dumortier proved himself to be, I commend to the consideration of all those who doubt the value of sueh divisions of the Secondary rocks which I have maintained and followed out in this and other memoirs during the last twenty years.

Distribution of Ammonites in the Zone of Ammonites oxynotus, after Dumortier.

\begin{tabular}{|c|c|c|c|}
\hline $\begin{array}{c}\text { Beds with } \\
\text { AM. DAvidsoni. }\end{array}$ & $\begin{array}{l}\text { Beds with } \\
\text { AM. STELLARIS. }\end{array}$ & $\begin{array}{c}\text { Beds with } \\
\text { AM. oxynotus. }\end{array}$ & $\begin{array}{c}\text { Beds with } \\
\text { AM, RARICOSTATUS. }\end{array}$ \\
\hline $\begin{array}{l}\text { Am. Davidsoni } \\
\text { - resurgens } \\
\text { - Hartmanni } \\
\text { - Berardi } \\
\text { - Patti } \\
\text { - lacunatus } \\
\text { - Sauzeanus } \\
\text { - Scipionianus } \\
\text { - spiratissimus }\end{array}$ & $\begin{array}{l}\text { Am. stellaris } \\
\text { - obtusus } \\
\text { - Eduensis } \\
\text { - Landriati } \\
\text { - Lacardi } \\
\text { - Birchii } \\
\text { - semicostatus } \\
\text { - Boucaultianus } \\
\text { - Guibalianus }\end{array}$ & $\begin{array}{l}\text { Am. oxynotus } \\
\text { - Victaris } \\
\text { - Aballoensis } \\
\text { - Buvigneri } \\
\text { - Freenoughi } \\
\text { - tamariscinus } \\
\text { - altus } \\
\text { - Driani } \\
\text { - Salisburgensis } \\
\text { - Samanni } \\
\text { - Bannardi } \\
\text { - Dudressieri } \\
\text { - Ziphus } \\
\text { - Badleyi }\end{array}$ & $\begin{array}{l}\text { Am. planicosta } \\
- \text { raricostatus } \\
- \text { Cluniacensis } \\
- \text { jejunus } \\
- \text { Nodotianus } \\
- \text { Pellati } \\
- \text { Pauli } \\
\text { - armentalis } \\
- \text { subplanicosta } \\
\text { - tardecrescens } \\
\text { - viticola } \\
- \text { vellicatus } \\
- \text { Edmundi } \\
- \text { Oosteri }\end{array}$ \\
\hline
\end{tabular}

In this table the two lowest zones have nine, and the two uppermost fourteen, species in each. In the Davidsoni-beds Aeg. Davidsoni and Aeg. Berardi have affinities with Aeg.planorbis; Arietites Sauzeanus, Ar. Scipionianus, Ar. resurgens, and Ar. Hartmanni with Arietites bisulcatus; Ar. spiratissimus with Ar. Conybeari; and Aeg. lacunatum with Aeg. Charmassei, from which it is derived.

In the Stellaris-beds Aeg. Eiduensis has affinities with Aeg. Johnstoni; Aeg. Locardi, with Aeg.Birfii; Aeg. Boncaultianum, with Aeg. Charmassei; Amal. Guibalianus, with Amal. Aballoensis; whilst Ar.obtusus, Ar. stellaris, and Ar. semicostatus are the expiring forms of the genus Arietites.

The Oxynotus-beds are characterised by new types of Ammonite life belonging to the genus Amaltheus, which now appear for the first time as Amal. oxynotus, Amal. Victoris, Amal. Aballoensis, Amal. Greenoughi, Amal. Buvigneri, and Aeg.planicosta $=z i p h u s=$ Dudressieri, which last are morphological conditions of one species Aeg. planicosta.

The Raricostatus-beds are characterised by forms which depart from the Arietites type; they have a wide umbilicus, narrow whorls, and were slowly developed as Ar. Nodotianus, Ar. viticola, Ar. vellicatus, Ar. Edmundi, which are all nearly allied to Ar. raricostatus. 


\section{The Lias Fishes from Lyne Rugis.}

I have stated (p. 48) that I have no authentic observations nor reliable notes on the stratigraphical distribution of the Fossil Fishes obtained at Lyme Regis from the Lias beds of the coast by the workmen, who have carefully kept their secret for their own advantage. Still, as most of these Ichthyolites were collected from the Lower Lias, and chiefly, I understand, from the Bucklandi- and Turneri-beds, I am unwilling to allow such an important gap to remain a blank in my otherwise complete lists of the Fauna of this classical region; and so I applied to my friend Sir Philip de Malpas Grey-Egerton, Bart., F.R.S., the highest living authority on Fossil Ichthyology, to prepare a list of the Fossil Fishes of the Lyme Lias beds. With his uniform courtesy and kindness Sir Philip has complied with my request, and I have now the pleasure of adding to my work his important addition, for which I return my very best thanks.

Alphabetical Catalogue of Fossil Fishes found in the Lias at Lyme Regis, with references to the authorities for the names and descriptions. By Sir Philip de Malpas GreyEgerton, Bart., M.P., F.R.S., G.S., \&c.

Acrodus, Agassiz.

\begin{tabular}{|c|c|c|}
\hline 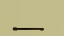 & & \\
\hline & & \\
\hline- & gibberulus, $\mathrm{Ag}$. & Id., vol. iii, p. 144 \\
\hline & latus, $A g$. & Id., vol. iii, p. 144 . \\
\hline- & nobilis, $A g$. & Id., vol. iii, p. 140. \\
\hline & undulatus, $A g$. & Id., vol. iii, p. 144 . \\
\hline $\mathrm{HM}$ & s, Egerton (Tetragono & pis, Agassiz). \\
\hline - & confluens, $A g$. & Id., vol. ii, p. 199. \\
\hline & heteroderma, $A g$. & Id., vol. ii, p. 206. \\
\hline - & Leachii, $A g$. & Id., vol. ii, p. 203. \\
\hline- & leiosomus, $A g$. & Id., vol. ii, p. 202. \\
\hline - & pholidotus, $A g$. & Id., vol. ii, p. 207. \\
\hline - & pustulatus, $\mathrm{Ag}$. & Id., vol. ii, p. 201. \\
\hline 一 & radiatus, $A g$. & Id., vol, ii, p. 201. \\
\hline & speciosus, $A g$. & Id., vol. ii, p. 199. \\
\hline & ;, Agassiz. & \\
\hline & macrostomus, $\mathrm{Ag}$. & Id., vol. ii, p. 220 . \\
\hline
\end{tabular}


Arthropterus, Agassiz.

Rileyi, Ag. Poissons Fossiles, vol. iii, p. 379.

Belonostonus Agassiz (Belonorhynchus, Bronn).

Anningiæ, Ag. $\quad$ Id., vol. ii, part 2, p. 143.

Caturus, Agassiz.

$$
\text { tenellus, } A g \text {., doubtful, probably B. Anningiæ. }
$$

- Bucklandi, Ag.

Centrolepis, Egerton.

Chondrosters, Agassiz.

- acipensiroides, Ag. Poissons Fossiles, vol. ii, part 2, p. 280.

- crassior, Eg.

- pachyurus, Eg.

Conodus, Agassiz.

- ferox, $A g$.

Cyclarthrus, Agassiz.

Id., vol. ii, part 2, p. 119.

Mem. Geol. Surv., decade 9, pl. v.

macropterus, $A g$. Id., vol. iii, p. 382.

Dapedius, De la Beche.

- arenatus, Ag.

- Colei, $A g$.

- granulatus, $\mathrm{Ag}$.

- politus, De la Beclie.

- punctatus, $A g$.

Endactis, Agassiz.

\section{- Agassizi, Eg.}

Eugnathus, Agassiz.

- chirotes (Conodus, Ag.). Poissons Fossiles, vol. ii, part 2, p. 102.

- leptodus, $A g$.

Id., vol. ii, part 2, p. 105.

- mandibularis, $A g$.

Id., vol. ii, part 2, p. 105.

- minor, $A g$.

Id., vol. ii, part 2, p. 103.

- opercularis, $A g$.

Id., vol. ii, part 2 , p. 104.

- ornatus, $A g$.

Id., vol. ii, part 2, p. 105.

- orthostomus, Ag.

- Philpotæ, $A g$.

Id., vol. ii, part 2, p. 98 .

- polyodon, Ag. (Platysiagum, Eg.) Id., vol. ii, part 2, p. 104.

- scabriusculus, $A g . \quad$ Id., vol, ii, part 2, p. 105.

- speciosus, $A g$.

HaRpactira, Egerton.

Id., vol. ii, part 2, p. 100.

velox, $E g$.
Geol. Mag., 1876, p. 441. 
Heterolepidotus, Egerton (Lepidotus, Ag.).

- $\quad$ latus (Lepidotus fimbriatus, $A g$.). Poissons Fossiles, vol. ii, p. 247; Mem. Geol.Surv., decade $13, \mathrm{pl}$. ii.

Holophagus, Egerton.

- Samroides, Eg. Mem. Geol. Surv., decade 13, pl. iii.

- gulo, Eg. Id., dec. 10, p. 19, and dec. 13, pl. x.

Нуворus, Agassiz.

- carinatus, $A g . \quad$ Poissons Fossiles, vol. iii, p. วั2.

- crassispinus, $A g$. Id., vol. iii, p. 48.

- curtus, $A g$. (Hybodus reticulatus, 2nd spine). Id., vol. iii, p. 50.

- De-la-Bechei, Charlesworth. Mag. Nat. Hist., 1839, p. 242.

- ensatus, Ag. Poissons Fossiles, vol. iii, p. 51.

- formosus, $A g$. Id., vol. iii, p. 51 .

- medius, $A g$. Id., vol. iii, p. 184.

- pyramidalis, $A g$. Id., vol. iii, p. 182.

- reticulatus, $A g$. Id., vol. iii, pp. 50 and 180 .

Ischyodus, Egerton (Chimæra, Ag.).

- Johnsoni, Ag. (Prognathodus, Eg.). Id., vol. iii, p. 344; Journ.

Geol. Soc., 1872, p. 233.

Isocolum, Egerton.

- orthorlinus, Eg. Journ. Geol. Soc., 1871, pl. xiii.

- granulatum, Eg. Id., 1865; Mem. Geol. Surv., decade 13, pl. iv.

Lepidotus, Agassiz.

- rugosus, $A g$. (Heterolepidotus, Eg. ?). Poissons Fossiles, vol. ii, p. 246.

- undatus, $A g$. $\quad$ - $\quad$ Id., vol. ii, p. 245 .

Leptacanthus, Agassiz.

Leptolepis, Agassiz.
- tenuispinus, Ag. Id., vol. iii, p. 27.

tenuis

- Bronni, $A g$.

- candalis, $A g$.

Mrriacanthus, Agassiz.

$\begin{array}{lll}\text { - } & \text { granulatus, } A g & \text { Id., vol. iii, p. } 40 . \\ \text { - } & \text { paradoxus, } A g . & \text { Id., vol. iii, p. } 38 . \\ \text { - } & \text { retrorsus, } A g . & \text { Id., vol. iii, p. } 39 .\end{array}$

Noтноsомus, Agassiz.
Id., vol. ii, part 2, p. 133.

Id., vol. ii, part 2, p. 133.

- octostychius, Ag. Id., vol. ii, part 2, p. 221 ; Mem. Geol. Surv, dec. 9, p. 6 . 
Osteorachis, Egerton.

- macrocephalus, Eg. Mem. Geol. Surv., dec. 13, pl. v. Oxygnathus, Egerton.
- ornatus, $E g$.
Id., dec. 8, pl. ix.

Pach ycormus, Agassiz.

- branchialis, Ag. MS.

- heterurus, Ag. Poissons Fossiles, vol. ii, part 2, p. 113.

- latipennis, $A g$. Mem. Geol. Surv., dec. 9, pl. iii.

- macrurus, $A g$. Poissons Fossiles, vol. ii, part 2, p. 113.

Paldesospinax, Egerton (Thyellina, Agassiz.)

- $\quad$ priscus, $A g . \quad$ Mem. Geol. Surv., dec. 13, pl. vii.

Pholidophorus, Agassiz.

- Bechei, Ag. Poissons Fossiles, vol. ii, p. 272.

- crenulatus, Eg. Mem. Geol. Surv., dec. 6, pl. v.

- latiusculus, Ag. Poissons Fossiles, vol. ii, p. 287.

- limbatus, $A g$. Id., vol. ii, p. 282.

- onychius, $A g$. Id., vol. ii, p. 274. - pachysomus, Eg. Mem. Geol. Surv., dec. 6, pl. iv.

Platrsiagum, Egerton.

- sclerocephalum, Eg. Id., dec. 13, pl. vi.
Prognathodus, Egerton.

- sclerocephalum, Eig. Id., dec. 13, pl. vi.
Prognathodus, Egerton.

Ptrcholeprs, Agassiz.

Güntheri, Eg. Journ. Geol. Soc., 1872, p. 233.

- Bollensis, Ag. Poissons Fossiles, vol. ii, pt. 2, p. $10 \mathrm{~s}$.

Semionotus, Agassiz.

Mem. Geol. Surv., dec. 8, pl. viii.

- rhombifer, Ag. (Heterolepidotus? Fg.). Poissons Fossiles, vol.

Squalorara, Riley (Spinacorhinus, Agassiz).

ii, p. 228 .

'Thrissonotus, Agassiz.

polyspondyla, Riley. Poissons Fossiles, vol. iii, p. 379.

- $\quad$ Colei, Ag.

Id., vol. ii, part 2, p. 128; Mem. Geol. Surv., dec. 2, pl. ii.

After a comparison of my original notes on the Lyme sections with a stratigraphical table in manuscript of the same beds, made by my friend Mr. Etheridge, F.R.S., which he has kindly allowed me to examine, I find we are in perfect accordance on the position of the Ichthyolites. Few remains of this class are found in the Angulatumzone. The dark marls of the Bucklandi-and Turneri-beds appear to be the chief repositories of the Lyme Lias Fishes, as already indicated in my sections at pp. 38, 48, 
and 50. A few specimens of Echmodus were found in the marls above the Belemnitebeds at Golden Cap, but few remains are known in other beds of the Middle Lias.

A Table showing the extension of the Lower Lias in the British Islands, Belgium, France, Switzerland, Germany, Austria, and Italy, with indications of the Sinemurian Ammonite Zones, found in some typical regions of the European area.

\begin{tabular}{|c|c|c|c|c|c|c|c|c|c|c|c|c|c|}
\hline \multirow{2}{*}{$\begin{array}{c}\text { Ammonite Zones } \\
\text { of the } \\
\text { Lower Lias. }\end{array}$} & \multicolumn{3}{|c|}{ British IsLands. } & \multirow{2}{*}{ 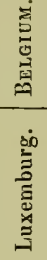 } & \multicolumn{4}{|c|}{ France. } & \multirow{2}{*}{ 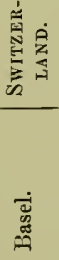 } & \multicolumn{2}{|c|}{ Germany. } & \multirow{2}{*}{ 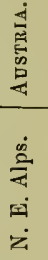 } & \multirow{2}{*}{ 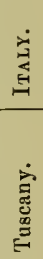 } \\
\hline & 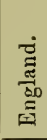 & $\begin{array}{l}\stackrel{\vec{\Xi}}{\Xi} \\
\stackrel{\Xi}{\Xi}\end{array}$ & & & 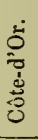 & $\stackrel{\Xi}{\Xi}$ & 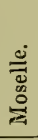 & 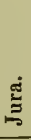 & & 离 & 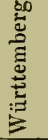 & & \\
\hline RARICOSTATUS $\ldots \ldots \ldots \ldots \ldots$ & * & * & $\ldots$ & $\ldots$ & * & * & .. & * & * & * & * & * & $*$ \\
\hline oXYNOTUS $\quad \ldots, \ldots \ldots \ldots \ldots$ & * & $\cdots$ & $\cdots$ & $\cdots$ & * & * & $\cdots$ & 䊑 & * & $\cdots$ & * & * & $\cdots$ \\
\hline OBTUSUS $\ldots \ldots \ldots \ldots \ldots \ldots$ & * & $\cdots$ & $\ldots$ & $*$ & * & * & $\ldots$ & * & * & * & * & * & * \\
\hline TURNERI $\ldots \ldots \ldots \ldots \ldots \ldots$ & * & $\ldots$ & $\cdots$ & * & * & $*$ & * & 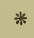 & $*$ & $\cdots$ & * & $\cdots$ & * \\
\hline BUCKLANDI $\ldots \ldots \ldots \ldots \ldots \ldots$ & $*$ & * & * & * & * & $*$ & * & * & * & * & * & * & * \\
\hline ANGULATUM $\ldots \ldots \ldots \ldots \ldots$ & * & * & $\cdots$ & * & * & * & * & * & * & * & * & * & * \\
\hline PLANORBIS $\ldots \ldots \ldots \ldots \ldots$ & * & * & $\cdots$ & * & * & * & * & $*$ & $*$ & * & * & * & $\cdots$ \\
\hline AVICULA CONTORTA... & * & * & $\cdots$ & * & * & * & * & * & * & * & * & * & * \\
\hline
\end{tabular}

My learned friend, Professor Edward Suess, of Vienna, whose valuable and suggestive memoir " Uber die Ammoniten " formed the basis of the new generic classification of Ammonites, writes to me, "we have now discovered a number of Ammonite horizons only a few inches in thickness, as for example the Aeg. planorbis 18 inches, Aeg. angulatum 20-36 inches, upon thousands of feet of Rhætic deposits in the midst of our Alps. This contiguity of single horizons surely gives the Jurassic formation, or at least a part of it, a character rather different from other European deposits, and well worth the exact analogies which you offer." 
A Table showing the stratigraphical distribution of the Ammonoida in the Lower Lias zones of the British Islands.

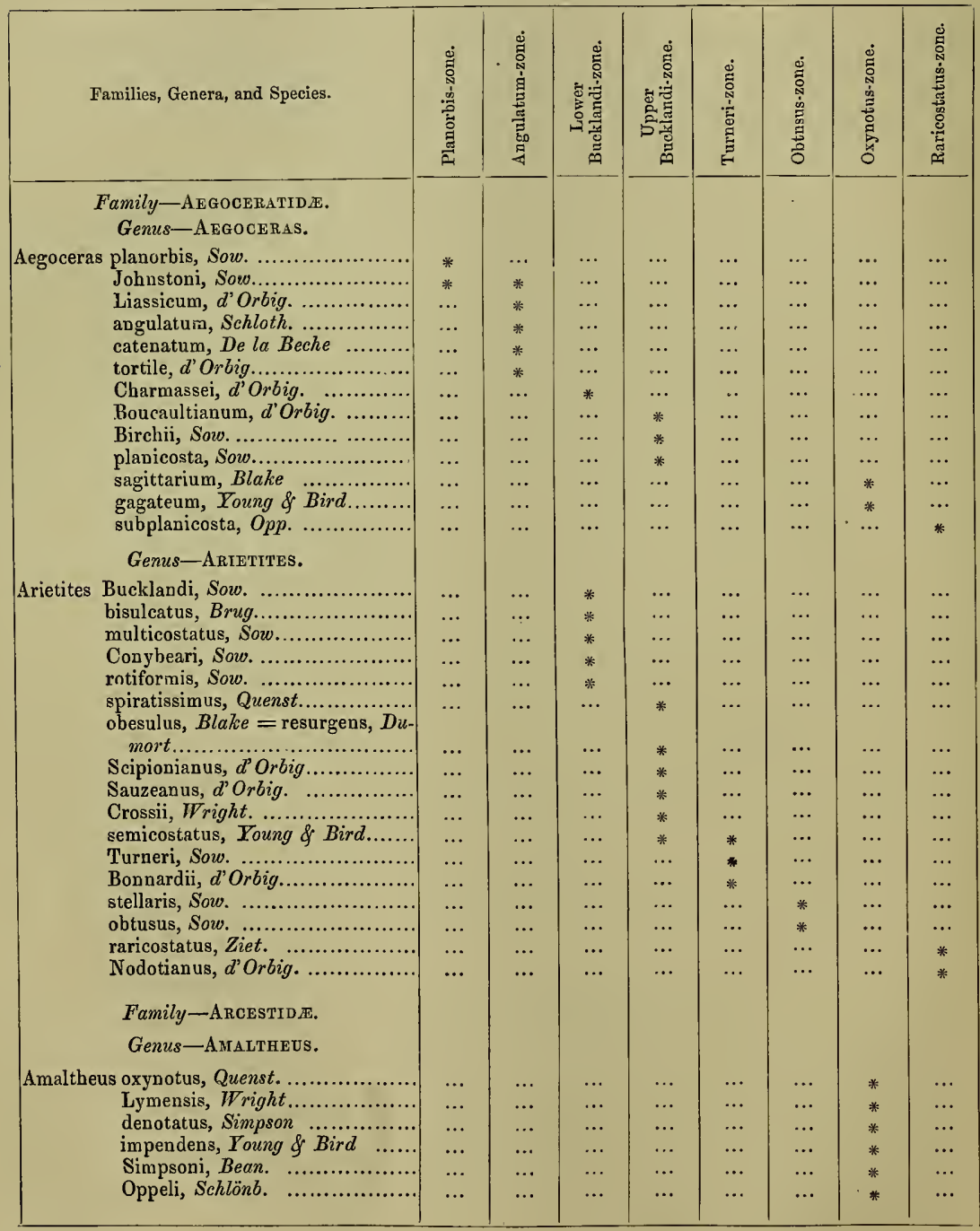




\section{THE MIDDLE LIAS.}

The Middle Lias is well developed in England, and fully exposed in the grand natural sections of the Yorkshire and Dorsetshire coasts. In the Midland Counties some of the zones are only partially shown. I have therefore selected a section of the cliffs east of Charmouth, Dorset, which I made for this work many years ago, as one that affords a good general view of the whole, and at the same time shows the relation of its spinatus-bed to the Upper Lias which rests conformably upon it; the Middle Lias here attains a thickness of about 450 feet, and is divisible into five stages, each characterised by well-determined Ammonite forms. In ascending order these are-1st. The zone of Aegoceras Jamesoni. 2nd. The zone of Amaltheus Ibex. 3rd. The zone of Aegoceras Henleyi. 4th. The zone of Amaltheus margaritatus. 5th. The zone of Amaltheus spinatus.

Section of Down Cliffs, at Toad's Cove, near Bridport Harbour.

UPPER LiAs.

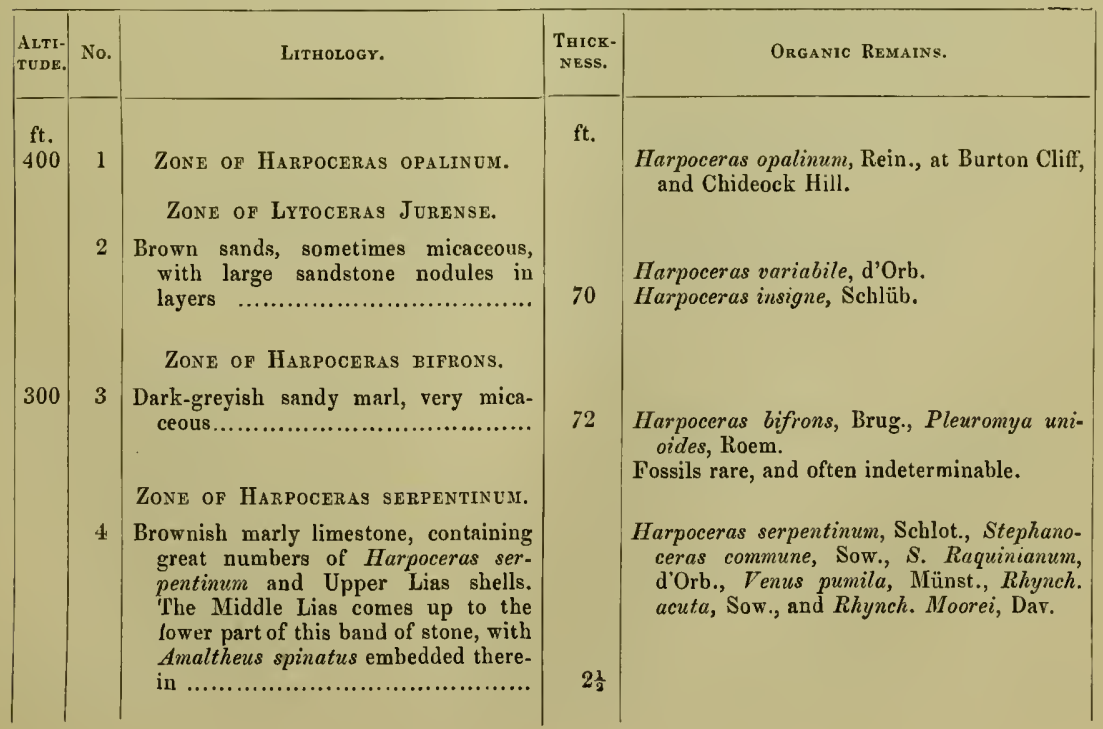


Middle Lias.

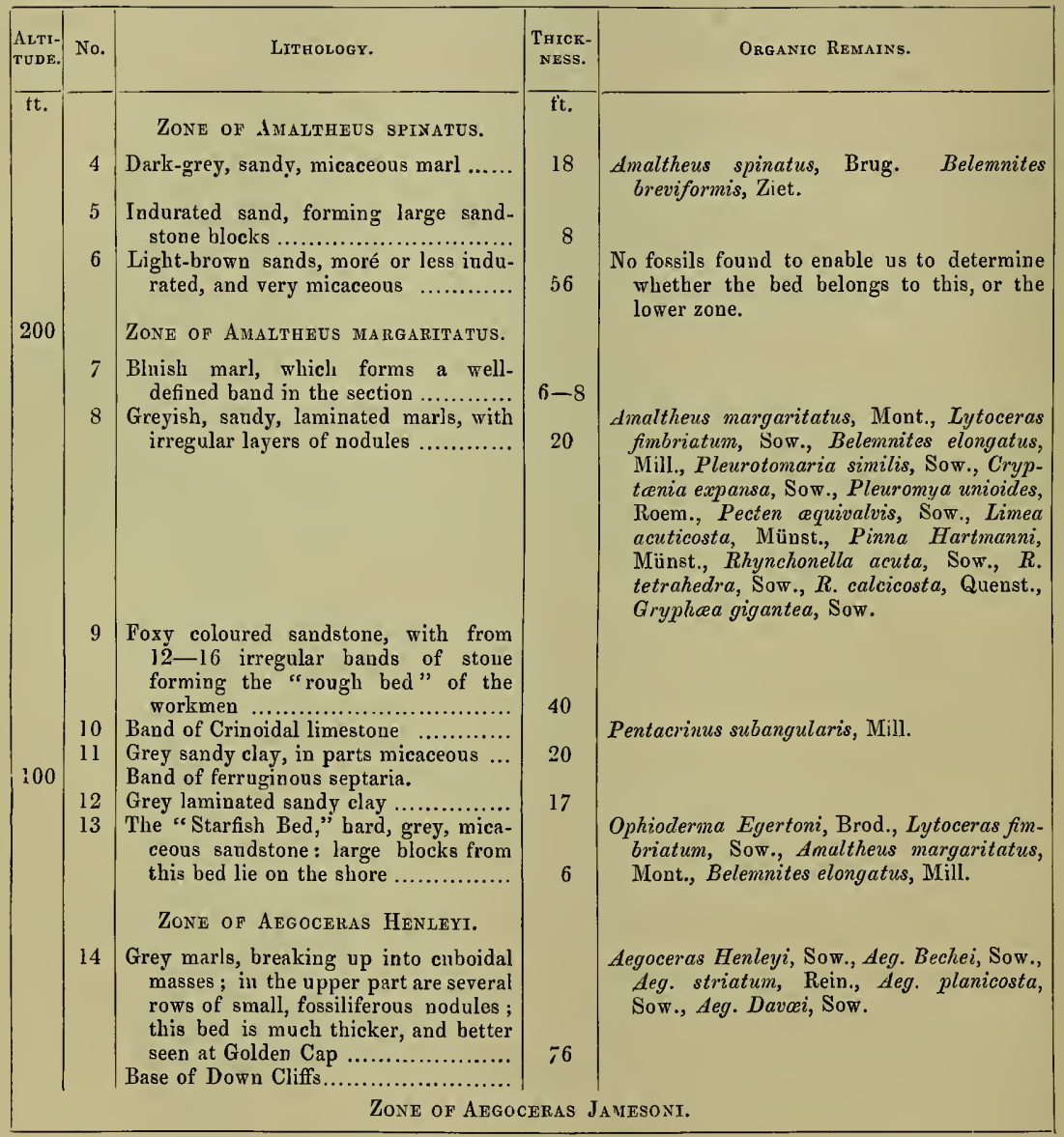

The grey or micaceous marls attain a great thickness at Golden Cap, where they rest on the Belemnite-bed. These marls contain several stages of life, which have not been worked out with sufficient accuracy to enable me to define the limits of the different zones. Fragments of Aegoceras Jamesoni and Aeg. submuticum have been collected in the lower part of this deposit, and Aegoceras Davcei, Henleyi, and Bechei, in the upper.

In Gloncestershire, beneath the zone of Aegoceras Henleyi, two other zones are characterised by Amaltheus Ibex and Aegoceras Jumesoni, and these are probably comprised in the grey, micaceous marls at Golden Cap, which here attain so great a thickness. 


\section{The Zone of Aegoceras Jamesoni.}

Synonyms.-“ Micaceous marl," in part, De la Beche's section. "Numismalismergel oder Belemnitenmergel," Quenstedt, 'das Flötzgebirge Württembergs,' 1843. “Die Schichten des Ammonites Jamesoni," Oppel, 'Die Juraformation,' p. 118, 1856. " "Lias Gamma," pars, Quenst., 'Der Jura Uebersichtstafel,' p. 293, 1858. “Jamesoni-bed," Wright, 'Quart. Jour. Geol. Soc.,' vol. xvi, p. 25, 185̌s. "Die Schichten des Amm. Jamesoni," Brauns, “Untere Jura,'p. 100, 1871. "Zone of Ammonites Jamesoni," Tate and Blake, 'Yorkshire Lias,' p. 78, 1876.

Gloucestershire.-Upwards of twenty years ago I collected several fragments of the whorls of a large Aegoceras Jamesoni in some deep brick-pits near Leckhampton, which was the first evidence we had that this zone existed near Cheltenhan. Since that time I have accumulated many of the leading fossils of the beds, and important additions have from time to time been made by Professor Tate, all of which are now recorded in the following list :

\section{Cephalopoda.}

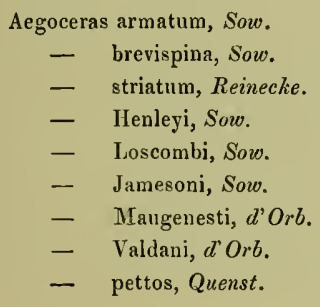

Cerithium armatum, Miinst. Chemnitzia Blainvillei, MIünst. - liassica, Quenst. Cryptænia expansa, Sow.

Astarte striato-sulcata, Röm. Avicula novemcostæ, Brown. - substriata, Münst. Cardinia crassissima, Sow. Cypricardia cucullata, Münst. Cucullæa Munsteri, Goldf. Isocardia cingulata, Goldf. Inoceramus ventricosus, Sow.

Leda acuminata, Goldf. substriatus, Goldf.

- Galatea, d' Orb.

Nucula cordata, Goldf.
Aegoceras Taylori, Sow. Arietites Nodotianus, $d$ Or $b$. Lytoceras fimbriatum, Sow. Belemnites acuarius, Schloth.

$$
\begin{array}{ll}
\text { - } & \text { apicurvatus, Blainv. } \\
\text { - } & \text { breviformis, Voltz. } \\
\text { - } & \text { elongatus, Sow. } \\
\text { - } & \text { Milleri, Phill. } \\
\text { - } & \text { clavatus, Schloth. }
\end{array}
$$

Gasteropoda.

Dentalium minimum, Strick. - elongatum, Münst.

Phasianella paludinaria, Münst.

Trochus Thetis, Münst.

\section{LAMELLibranchiata.}

Opis Carusensis, d' Orb.

Pecten liasinus, Nyst.

- acutiradiatus, Goldf.

- personatus, Münst.

Pholadom ya decorata, Hartm.

Plicatula spinosa, Sow. - alternans, Deslong. Mytilus scalprum, Sow. Pinna folium, $\boldsymbol{I}$. \& $B$. Gryphær obliquata, Sow. - cymbium, Lamk. Limea acuticosta, Goldf. 
Discina Holdeni, Tate.

Rhynchonella variabilis, Sehloth.

furcillata, Theod.

- rimosa, Theod.

Spiriferina verrucosa, von Buch.

Plumaster ophiuroides, $W$ right .

Serpula plicatilis, Goldf.

\section{BRACHIOPODA.}

Terebratula punctata, Sow.

Waldheimia indentata, Sow.

$$
\begin{array}{ll}
\text { - } & \text { numismalis, Schloth. } \\
\text { - } & \text { Waterhousei, David. } \\
\text { - } & \text { subovoides, Röm. }
\end{array}
$$

\section{ECHINODERMATA.}

\section{ANNELIDA.}

Pentacrinus basaltiformis, Miller.

I Serpula tricristata, Goldf.

Yorkshire.-The Jamesoni-beds are found at the north side of Robin Hood's Bay, where the following important section was made by Messrs. Tate and Blake, ${ }^{1}$ the thickness of the beds there amounting to 225 feet: the position of the fossils so carefully noted in each is of great value in reading correctly the Palæontology of this zone.

\section{Jamesoni-beds, Robin Hood's Bay.}

Base of the Henleyi-heds : the section to be read in a descending order.

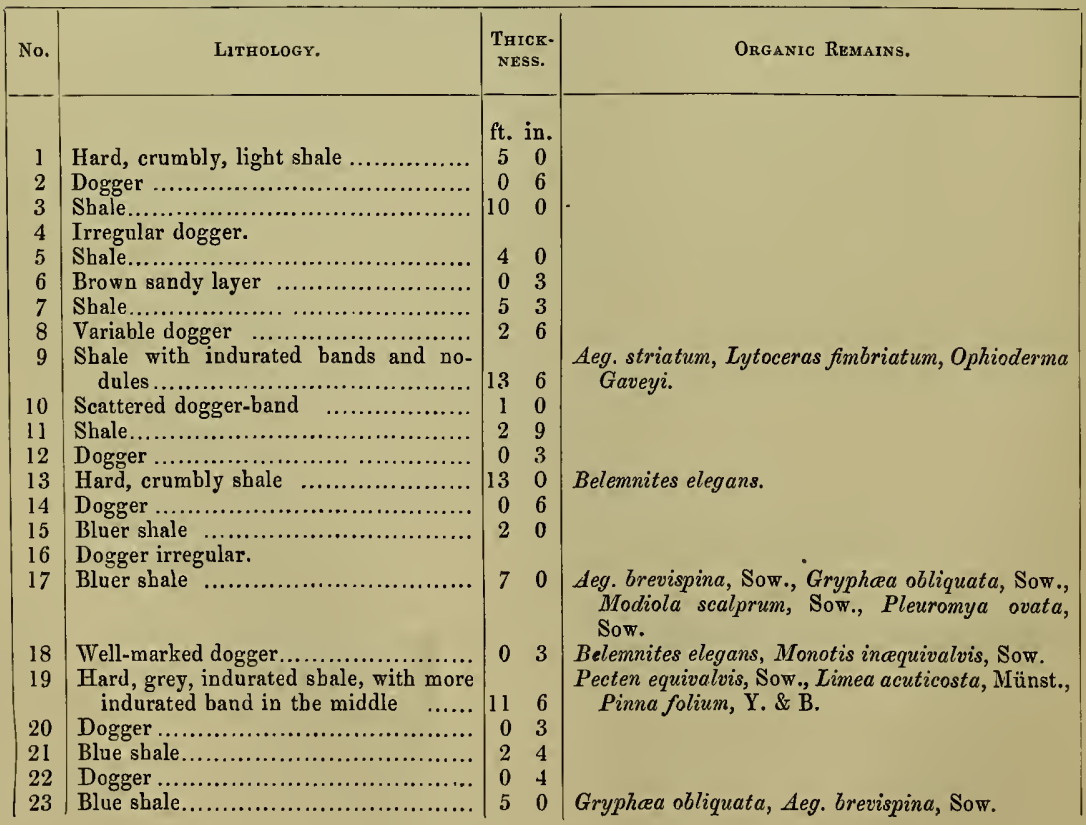

1 'Yorkshire Lias,' pp. 79-81. 


\begin{tabular}{|c|c|c|c|}
\hline No. & Lithology. & $\begin{array}{l}\text { Thick- } \\
\text { NESS. }\end{array}$ & Organic Remains. \\
\hline & & ft. in. & \\
\hline $\begin{array}{l}24 \\
25\end{array}$ & 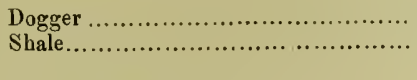 & $\begin{array}{rr}0 & 3 \\
1 & 10\end{array}$ & $\begin{array}{l}\text { Pecten priscus, Schl., Chemnitzia Blainvillei, } \\
\text { Münst. }\end{array}$ \\
\hline 26 & Regular dogger. & 06 & \\
\hline 27 & Shale............... & 310 & $\begin{array}{l}\text { Gresslya striata, Agass., Leda Galathea, d'Orb., } \\
\text { Plicatula spinosa, Sow., Pinna folium, Y. \& B., } \\
\text { Belemnites araris, Dumort., Bel. virgatus, } \\
\text { Mayer. }\end{array}$ \\
\hline 28 & Irregular dogger . & 06 & \\
\hline 29 & Shale................... & 30 & $\begin{array}{l}\text { deg. brevispina, Sow., deg. polymorphum, Quenst., } \\
\text { Ditrypa circinata, Tate. }\end{array}$ \\
\hline 30 & Dogger .... & $0 \quad 5$ & \\
\hline 31 & Shale.... & 10 & \\
\hline 32 & Dogger.. & $\begin{array}{rr}0 & 5\end{array}$ & Modiola scalprum, Sow. \\
\hline 33 & Sbale............ & 148 & $\begin{array}{l}\text { Amaltheus lynx, deg. polymorphum, Pleuromya } \\
\text { ovata, Pholadomya decorata, Pecten priscus. }\end{array}$ \\
\hline $\begin{array}{l}34 \\
35\end{array}$ & Dogger .... & 6 & Pholadomya decorata. \\
\hline $\begin{array}{l}35 \\
36\end{array}$ & Shale................ & & Pholadomya decorata. \\
\hline $\begin{array}{l}36 \\
37\end{array}$ & Dogger, irregular. & & Pecten priscus, Sclotlı, Lima Hermanni, Voltz. \\
\hline 38 & $\begin{array}{l}\text { Shale................ } \\
\text { Dogger, irregular. }\end{array}$ & & Pecten priscis, Scloti., Lima Hermanni, Voltz. \\
\hline 39 & Shale ................. & 5 & Unicardium cardioide, Phill. \\
\hline 40 & Dogger, irregular. & & \\
\hline $\begin{array}{l}41 \\
42\end{array}$ & 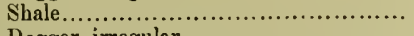 & $\begin{array}{ll}3 & 0\end{array}$ & Arcomya elongata, Pinna folium. \\
\hline $\begin{array}{l}42 \\
43\end{array}$ & 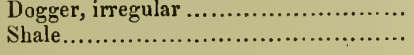 & 40 & $\begin{array}{l}\text { Ditrypa circinata, Khyn. placatissma. } \\
\text { Pecten priscus, Gryphea obliquata, Gresslya }\end{array}$ \\
\hline 44 & Dogger, strong... & 08 & $\begin{array}{l}\text { ovata. Crustacean remains. } \\
\text { Pinna folium. }\end{array}$ \\
\hline
\end{tabular}

This forms the base of the Jamesoni-beds proper.

Blue shale.

Ironstone dogger

Blue shale, with pyritons nests full of fossils, about five feet down

Is at the base of the cliff, making the south point of the north cheek of the bay.

Dogger

Blue shale.

Band of rotted clay

Ironstone dogger, well marked in the cliff

Blue shale

Strong ironstone dogger ...................

Blue shale, with doggers and nests of fossils scattered

Thin line of broken fossils ...............

Blue shale field of Belemnites and Gryphæas .

Ironstone dogger
$10 \quad 0$

$\begin{array}{ll}0 & 8\end{array}$

$\begin{array}{ll}0 & 4 \\ 1 & -2\end{array}$

120

$\begin{array}{ll}0 & 2\end{array}$

$\begin{array}{ll}0 & 3\end{array}$

$5 \quad 0$

$\begin{array}{ll}0 & 4\end{array}$

240

$\begin{array}{lll}0 & 1\end{array}$

56

$\begin{array}{ll}0 & 3\end{array}$
Pinna folium, Cucullcea Münsteri, Limea acuticosta, Arcomya vetusta, Glyphae Terquemi, Lima Hermanni.

Lima Hermanni, Monotis incequivalvis, Gryphcea obliquata, Aeg. armatum, deg. Taylori, Pecten priscus, Protocardia oxynoti, Nucula contorta, Gresslya ovata, G. striata, Pleurotomaria procera, Spiriferina Walcotii, Rhynchonella calcicosta.

Inoceramus ventricosus, Pecten calvus, Chemnitzia Blainvillei.

Gryphea obliquata.

Aeg. armatum, Pecten priscus, Belemnites clavatus, Ditrypa circinata.

Ammonites, Belemnites, Pecten, Cerithium.

Aeg. armatum, Aeg. planicosta, Belemnites, Gryphra obliquata, Limea acuticosta, Pecten priscus, Cucullaa Münsteri, Pinna folium. 


\begin{tabular}{|c|c|c|c|}
\hline No. & LITHOLOGY. & $\begin{array}{c}\text { ThICK- } \\
\text { NESS. }\end{array}$ & Organic Remains. \\
\hline $\begin{array}{l}57 \\
58 \\
59 \\
60\end{array}$ & 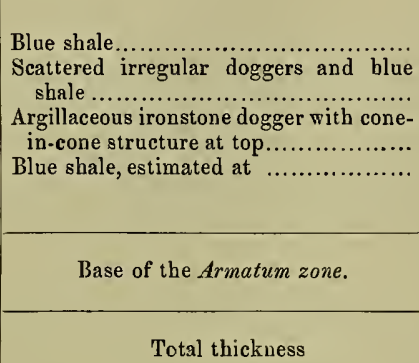 & $\begin{array}{cc}\text { ft. } & \text { in. } \\
3 & 0 \\
3 & 0 \\
& \\
0 & 4 \\
8 & 6\end{array}$ & $\begin{array}{l}\text { Aegoceras armatum. } \\
\text { Ariet. tardecrescens, Pecten calvus, Pecten sub- } \\
\text { Bestriatus, Cucullcea Münsteri. } \\
\text { Aeg. armatum, Ar. Macdonnelli }=\text { Nodotianus, } \\
\text { Belemnites elegans, Pentacrinus, L. acuticosta. }\end{array}$ \\
\hline
\end{tabular}

Warwickshire.-The Jamesoni and Ibex beds are developed at Fenny Compton, Warwickshire, where they have been carefully studied and well described by Mr. T. Beesley, F.C.S., of Banbury. ${ }^{1}$ The rocks are about 100 feet in thickness, and the following section affords an idea of their petrology, thickness, and organic remains.

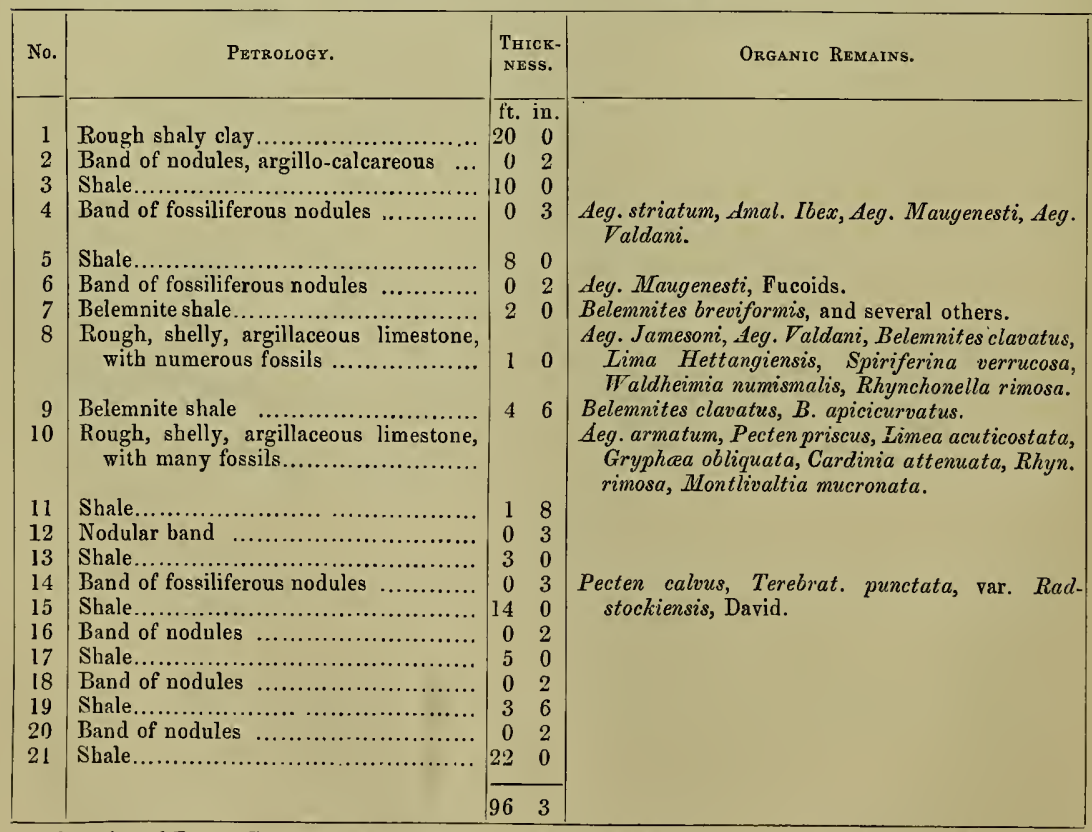

1 "Lias of Fenny Compton, Warwickshire." Reprinted from the 'Proceedings of the Warwickshire Nat, and Archæul. Field-Club,' p. 14, 1877. 


\section{List of Fossils from the Jamesoni Zone, Fenny Compton.}

Ichtbyosaurus, bones and teeth.

\section{Vertebrata.}

Fishes; vertebræ and other remains.

\section{Cephalopoda.}

Harpocerns arietiforme, Oppel. Aegoceras armatum, Sow.

- biferum, Quenst.

- brevispina, Sow.

- Buvignieri, d'Orb.

- Centaurus, d'Orb.

- densinodum, Quenst.

- striatum, Reinecke.

- Ibex, Quenst.

- Maugenesti, d'Orb.

- Jamesoni, Sow.

- Loscombi, Sow.

- Lynx, d'Orb.

- pettos, Quenst.

- Valdani, d'Orb.

Lytoceras fimbriatum, Sow.

Belemnites acutus, Mill.

- apicicurvatus, Blainv.

- araris, Dumort.

- breviformis, Voltz.
Belemnites brevis, Dumort.

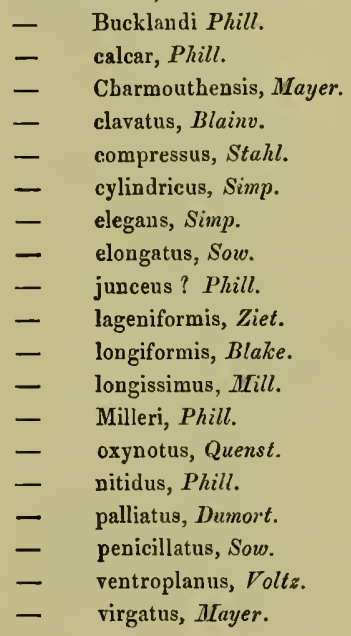

\section{Gasteropoda.}

Actæonina Ilminsterensis, Moore.

- marginata, Simp.

- numismalis, Quenst.

Tornatella capricornus, Tate.

Cerithium Camertonense, Moore.

- Brodiei, Tate.

- Ibex, Tate.

- Slatteri, Tate.

Chemnitzia Blainvillei, Mïnst.

- citharella, Tate.

- crassicosta, Tate.

- foviolata, Tate.

Dentalium angulatum, Buck.

- minimum, Strick.
Encyclus Gaudryanus, d'Orb.

- imbricatus, Sow.

Pitonellus conicus, $d^{\prime} \mathrm{Or} b$.

- lineatus, MLoore.

- turbinatus, Moore.

Pleurotomaria similis, Sow.

Cryptænia expansa, Sow.

Trochus limbatus, Schloth.

- Pandion, Dumort.

- Pluto, d'O•b.

- Thetis, Goldf.

Turbo admirandus, Tate.

- Lucilius, d'Orb.

Turritella anomala, Moore. 


\section{LAMELLIBRANCHIATA.}

Anomia numismalis, Quenst. Arcomya elongata, Römer. Astarte striato-sulcata, Goldf.

- Camertonensis, Moore.

- obsoleta, Dunk.

Avicula calva, Schlönb.

- inæquivalvis, Sow.

- papyria, Quenst.

Cardinia attenuata, Stutch.

Cardita multicostata, Phill.

Protocardia bombax, Tate.

- oxyuoti, Quenst.

- truncata, Sow.

Ceromya bombax, Quenst.

- rugata, Quenst.

Cypricardia cucullata, IIünst.

Cucullaa Münsteri, Ziet.

Gervillia lævis, Buck.

Groniomya hybrida, Münst.

Gresslya lunata, Tate.

- punctata, Simp.

- striata, Agass.

Gryphæa obliquata, Sow.

Harpax Parkinsoni, Dumort.

Hinnites tumidus, Ziet.

Hippopodium ponderosum, Sow.

Leda complanata, Goldf.

- Galathea, d'Orb.

- graphica, Tate.

- nunor, Simp

- subovalis, Goldf.
Leda Zieteni, Brauns.

- acuminata, Ziet.

Lima eucharis, $d^{\prime} O r b$.

- Hettangiensis, Terq.

- Hermanni, Voltz.

- punctata, Sow.

- pectinoides, Sow.

- scabricula, Tate.

Limea acuticosta, Goldf.

Macrodon intermedium, Simp.

Modiola numismalis, Oppel.

- scalprum, Sow.

Myoconcha decorata, Münst.

Nucula cordata, Goldf.

Ostrea Groldfussi, Brauns.

- semiplicata, Römer.

Pecten acuticostatus, Lam.

- acutiradiatus, Goldf.

- calvus, Goldf.

- fortunatus, Dumort.

- liasinus, Nyst.

- priscus, Schloth.

- substriatus, Röm.

- textorius, Schloth.

Pholadomya ambigua, Sow.

- decorata, Hartm.

Pinna folium, Young \& Bird.

Pleuromya ovata, Römer.

Plicatula sarcinula, Goldf.

- spinosa, Sow.

Unicardium cardioides, Phill.

\section{Brachiopoda.}

Discina Holdeni, Tate.

Lingula sacculus, Chap. \& Dewal.

Rhynchonella calcicosta, Quenst.

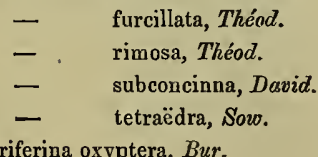

Spiriferina oxyptera, Bur.
Spiriferina pinguis, Tiet.

\section{- Walcotii, Sow.}

Terebratula Radstockensis, Dav. punctata, Sow.

Waldheimia indentata, Sow.

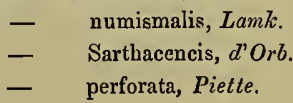

Polyzoa. 


\section{Crustacea.}

Bairdia dispersa, Blake.

- liassica, $B l$.

Polycope cerasia, $B l$.

Cythere Redcarensis, $\boldsymbol{B l}$.

- translucens, $B l$.

Galeolaria socialis, Goldf.

Ditrypa circinata, Tate.

- Etalensis, Piette.

- globiceps, Quenst.

- quinquesulcata, Goldf.

Cidaris Edwardsii, Iright. Ophioderma Gaveyi, Wright

Extracrinus subangularis, Mill.

Millericrinus Hausmanni, Röm.

Montlivaltia mucronata, Dunc.

- rugosa, Wright.

Cristellaria matutina, Terq.

- recta, $d$ Orb.

- rustica, Terq.

Dentalina irregularis, Terq.

- nodosa, d'Orb.

- pauperata, d'Orb.

- perlucida, Terq.

- quadrilatera, Terq.

- striata, Terq.

- torta, Terq.

Flabellina rugosa, d'Ort.

Frondicularia sulcata, Born.

- Terquemi, $d$ Orb.

Glandulina conica, Terq.
Cythere triangulata, $B l$.

Glyphæa, $s p$.

Pseudoglyphæa, $s p$.

Eryma lævis, $B l$.

Annelida.

Serpula limax, Goldf.

- plicatilis, Goldf.

- tricristata, Goldf.

- mundula, Dumort.

\section{ECHINODERMATA.}

Pentacrinus basaltiformis, Mill.

$$
\begin{array}{ll}
\text { - } & \text { Milleri, Austin. } \\
\text { - } & \text { scalaris, Quenst. } \\
\text { - } & \text { punctiferus, Quenst. }
\end{array}
$$

\section{AnthozoA.}

Montlivaltia nummiformis, Dunc.

\section{ForaminIFera.}

Lagena, $s p$.

Lingulina tenera, Born.

Marginulina 12-costata, Terq.

Miliola, $s p$.

- interliweata, Terq.

- prima, var. acuta, Terq.

Nodosaria nitida, $d^{\prime} \mathrm{O} \cdot \mathrm{r}$.

- raphanistrum, Linn.

- raphanus, Linn.

- Simoniana, Terq.

Orbulina universa, Terq.

Polymorphia nodosaria, Reuss.

Spiroloculina, $s p$.

Trochammina gordialis, $P . \& J$.

This rich fauna of the Jamesoni-beds at Fenny Compton has been collected by Mr. Beesley, F.C.S., of Banbury, and forms part of his valuable collection of Lias fossils.

The Middle Lias has been shown by Professor Ralph Tate, ${ }^{1}$ F.G.S., to be well developed near Radstock, and he has ascertained tho existence of the Jamesoni, Ibex, 
and Henleyi beds in the Munger Quarry, near Paulton, Somersetshire. The Jamesonibed here consists of a soft, yellow, ironshot limestone, indistinctly bedded, rather lumpy, and very fossiliferous, and from this and the upper beds the following fauna was. collected. In consequence of the thinuing out of the Lias strata in this locality the three zones are comprised within three yards of rock.

\section{Fossits from the Jamesoni-beds of the Radstock District.}

\section{Cephalopoda.}

Aegocerns Henleyi, Sow.

$$
\begin{array}{ll}
\text { - } & \text { Maugenesti, d'Orb. } \\
\text { - } & \text { Jamesoni, Sow. } \\
\text { - } & \text { armatum, Sow. } \\
\text { - } & \text { striatum, Reinecke. } \\
\text { - Buvignieri, d'Orb. } & \text { pettos, Quenst. }
\end{array}
$$

Aegoceras brevispina, Sow.

$$
\text { - polymorphum, Quenst. }
$$

Lytoceras fimbriatum, Sow.

Amaltheus Ibex, Quenst.

Nautilus intermedius, Sow.

Belemnites clavatus, Schloth.

elongatus, Mill.

\section{Gasteropoda.}

Dentalium elongatum, Mïnst.

Cryptænia expansa, Sow.

- heliciformis, Deslong.

Pleurotomaria granosa, Schloth.

Turbo cyclostoma, Ziet.

- Socconensis, d'Orb.

- bullatus, Moore.

Pitonellus conicus, d'OrZ.

Phasianella turbinata, Stoliczka.
Trochus acutus, Schloth.

- mammillaris, Moore.

- Thetis, Goldf.

- limbatus, Schloth.

- Ægion, d'Orb.

Eucyclus Guadryanus, d'Orb.

Chemnitzia undulata, Ziet.

- Blainvillei, Gold.

Actæonina marginata, Simp.

\section{LAMELLIBRANCHIATA.}

Ostrea simplicata, Münst.

Pecten lunularis, Römer.

- priscus, Schloth.

- substriatus, Römer.

Hinnites tumidus, Ziet.

Lima Hermanni, Ziet.

- Hettangiensis, Terq.

- eucharis, d'Orb.

Limea acuticosta, Goldf.

Plicatula spinosa, Sow.

Avicula longiaxis, Buck.

Inoceramus ventricosus, Sow.

Pinna folium, Young \& Bird.

Macrodon Buckmani, Richard.
Macrodon intermedium, Simp

Nucula cordata, Goldf.

Leda Galathea, d'Orb.

Cardita consimilis, Tate.

Astarte striato-sulcata, Goldf.

- Camertonensis, Moore

Myoconcha decorata, Goldf.

Cypricardia cucullata, Goldf.

Cardinia attenuata, Stutch.

- crassissima, Sow.

- concinna, Sow.

Ceromya bombax, Quenst.

Pleuromya ovata, Röm.

Pholadomya ambigua, Sow. 


\section{Brachiopoda.}

Waldheimia indentata, Sow.

$$
\begin{aligned}
& \text { - numismalis, Lamk. } \\
& \text { - Waterhousei, David. } \\
& \text { - cornuta, Sow. }
\end{aligned}
$$

Terebratula punctata, Sow.

$$
\begin{aligned}
& \text { - Edwardsi, David. } \\
& \text { - } \quad \text { subovoides, Röm. }
\end{aligned}
$$

Spiriferina rostrata, Schloth.

Rhynchonella furcillata, von Buch.

$$
\text { - } \quad \text { rimosa, von Buch. }
$$

Thecidea Bouchardi, David.

Leptæna rostrata, David.

- Bouchardi, David.

The Hebridean Jura.-More than twenty years ago my friend Professor A. Geikie, ${ }^{1}$ F.R.S., made a collection of Lias fossils from the islands of Skye, Scalpa, Pabba, Raasay, \&c., which he sent to me to examine and determine. Most of the specimens were collected from the dark brown micaceous shales of Pabba, beyond Corry, and around the syenite of Beinn Bhindh, as far as the entrance to Scalpa Sound. These specimens were carefully stndied and compared with the same species obtained out of the Middle Lias of Yorkshire, Dorsetshire, and Gloucestershire; and this comparative study led me to determine the series to belong to the zone Aegoceras Jamesoni. This collection formed the subject of the notes appended to Professor Geikie's paper communicated to the Geological Society, ${ }^{2}$ and of which the following is a résumé revised:

Lias Fossils from Pabba, Scalpa, and Skye, Hebrides.

\section{Cerhalopoda.}

Aegoceras armatum, Sow.

$$
\begin{array}{ll}
\text { - Jamesoni, Sow. } \\
\text { - Milleri, Wright, n. sp. } \\
\text { - } \quad \text { polymorphum, Quenst. } \\
\text { - brevispina, Sow. } \\
\text { - Davci, Sow. }
\end{array}
$$

Arietites tardecrescens, von Hauer.

Belemnites elongatus, Sow.

$$
\begin{array}{ll}
\text { - } & \text { paxillosus, Schloth. } \\
\text { - } & \text { elegans, Simp. } \\
\text { - } & \text { breviformis, Voltz. } \\
\text { - } & \text { clavatus, Blainv. }
\end{array}
$$

\section{Gasteropoda.}

Chemnitzia Blainvillei, Münst.

Cerithium Slatteri, Tate.
Tectaria imbricata, Sow.

Trochus limbatus, Schloth.

${ }^{1}$ Geikie, 'Quart. Journ. Geol. Soc.;' vol. xiv, p. 5, 1858.

2 Wright, "Notes on the Fossils collected by Mr. Geikie from the Lias of the Isles of Pabba, Scalpa, and Skye," 'Quart. Journ.,' vol. xiv, p. 24, 1858. 


\section{Lameilibranchiata.}

Pholadomya decorata, Hartm.

$$
\text { - ambigua, Sow. }
$$

Pleuromya ovata, Römer. Scotica, Wright.

Unicardium Ianthe, $d^{\prime} \boldsymbol{O} \boldsymbol{r} \boldsymbol{b}$.

Pinna folium, Young \& Bird.

Mytilus scalprum, Sow.

- numismalis, Oppel.

Leda Zieteni, Brauns.

- Galathea, d'Orb.

Cardinia attenuata, Stutch.

Avicula novemcostæ, Brown.

Lima Hermanni, Ziet.

- eucharis, $d: O r b$.

Rhynchonella tetraëdra, Sow.

- furcillata, Theod.

- variabilis, Schloth.

Pseudoglyphæa, sp.

Ditrypa circinata, Tate.

$$
\begin{aligned}
& \text { Linea acuticosta, Goldf. } \\
& \text { Inoceramus ventricosus, Sow. } \\
& \text { Pecten æquivalvis, Sow. } \\
& \text { — liasinus, Nyst. } \\
& \text { Plicatula spinosa, Sow. } \\
& \text { Gervillia Maccullochii, Wright. } \\
& \text { Gryphæa cymbium, Lamk. } \\
& \text { - obliquata, Sow. } \\
& \text { Hippopodium ponderosum, Sow. } \\
& \text { Astarte striatosulcata, Römer. } \\
& \text { Arcomya vetusta, Phill. } \\
& \text { Cucullæa Münsteri, Goldf. } \\
& \text { Cardita multicosta, Phill. } \\
& \text { Plicatula spinosa, Sow. }
\end{aligned}
$$

\section{Brachiopoda.}

Waldheimia numismalis, Schloth.

Spiriferina oxyptera, Buvig.

- verrucosa, Buck.

\section{Crustacea.}

Glyphæa, sp.

\section{AnNelida.}

Echinodermata.

Pentacrinus robustus, Wright.

Pentacrinus lævis, Miller.

Foreign Correlations.-In North Germany the Jamesoni-beds form the base of the Middle Lias, and are, in part, the equivalent of the Numismalis-marl of Swabia. According to the late Dr. U. Schlönbach, who made a special study of these beds, and recorded the results in an exhaustive memoir,' the ironstones of the Middle Lias worked near Harzburg, Liebenburg, Bodenstein, Kalefeld, and Markoldendorf, \&c., are obtained from this zone. Aegoceras armatum lies in the lowest stratum, Aeg. Jamesoni and its other associated Mollusca in higher strata, and the upper portion of the marls passes into beds containing Aeg. Loscombi, Aeg. Valdani, Aeg. fimbriatum, and Amaltheus Ibex, so that the "Schichten des Ammonites Jamesoni" of Brauns include beds which form the whole of the Ibex-beds and part of the Henleyi-beds of this work. Last year I obtained from Hechingen three beautiful specimens of Aeg. Jamesoni, almost exact replicas of the type of this Ammonite which I had from its original locality, the island of Pabba, and, associated with it, from like beds, Aeg. Valdani from the ferruginous marls. Emerson?

1 “Ueber den Eisenstein des mittleren Lias im N.-W. Deutschland," p. 503, 1863; "Zeitschr. d. deutschen geol. Gesellschaft,' Jahrg. 1863.

2 'Die Liasmulde von Markoldendorf,' p. 27, 1870. 
gives the following section in the lower half of the Middle Lias, " in dem 'Klef' und am Abhange des Beryes," in descending order : 1st, Aeg.-Centaurus-beds ; 2nd, Aeg.brevispina-beds; $3 \mathrm{rd}$, Aeg.-armatum-beds. In the first are found Lyloceras fimbriatum and Aegoceras striatum, in the second Aeg. Jamesoni and Aeg. brevispina, and in the third Aeg. armatum and Terebratula subovoides $=T$. punctata.

In South-west Germany, at the foot of the Swabian Alps, the marls of the Middle Lias are seen resting upon Lower Lias clays containing Arietites raricostatus. In these, the Numismalis-marls of Quenstedt, are found Gryphaa obliqua and Belemnites elongatus, which now appear for the first time, Belemnites acutus, so common in the older beds, being absent. Pecten priscus, Lima Hermanni, and other bivalved shells, as Pholadomya decorata, are likewise fonnd with Rhynchonella tetraëdra, Rhyn. calcicosta, and Spiriferina Münsteri. Above these forerunners of the new Fanna are large Ammonites, embedded in a calcareous matrix, representing varieties of Aegoceras armatum; and in marls still higher in the sections Aegoceras Jamesoni appears for the first time associated with Aegoceras brevispina, Aegoceras Taylori, Harpoceras Masseanum, and Harpoceras arietiforme. Associated with the Cephalopods are Brachiopods, represented by $W$ aldheimia numismalis, Rlynnchonella rimosa, Rhynchonella variatilis, also Pentacrinus basaltiformis, with many Mollusca, which represent the zone of Aegoceras Jamesoni in Württemberg. It is important to note the very great change that takes place in the life of the Molluscan Fauna with the dawn of the Middle Lias, and to observe the great contrast between the palæontology of the Jamesoni, Ibex, and Henleyi zones, when compared with those we have studied in examining the various successive horizons of life in the Lower Lias.

In France the Jamesoni-beds are well developed in several Departments. In Normandy they would appear to be included by Prof. Deslongchamps ${ }^{1}$ in the " Calcaires et Marnes à Terebratula numismalis." Although not described as marking a distinct zone, the Aeg.Jamesoni = Regnardi, d'Orb., has been collected at Evrecy, Calvados. In the Côte d'Or the Jamesoni-beds are described by M. Collenot, ${ }^{2}$ who divides the Middle Lias near Semur into four zones, designating each by a characteristic species of Ammonite, and in descending order he gives the following:

$$
\begin{gathered}
\text { Zone of Aeg. Henleyi, Sow. } \\
\text { " Aeg. Daveei, Sow. } \\
" \quad \text { Aeg. Venarense, Opp. } \\
" \quad \text { Aeg. Valdani, d'Orb. }
\end{gathered}
$$

In the Valdani-beds Aegoceras Jamesoni is found.

1 Deslongchamps, ‘Etudes Jurassique Inf. de la Normandie,' p. 42, 1864.

2 'Description GĆologique de l'Auxois,' p. 260, 1873. 
In the Department of the Cher, at Saint-Amand this zone is represented by Aeg. Jamesoni $=$ Regnardi, d'Oxb., Phyll. Loscombi, Sow., Aeg. Valdani, d'Orb., Aeg. Maugenesti, d'Orb., Amal. Ibex, Quenst., Aeg. Centaurus, d'Orb., Aeg. Zrevispina, d'Orb. In the Department of the Aveyron there is a considerable thickness of Middle Lias composed of limestones and marls. The limestones form the base, the "Zone à Lyt. fimbriatum," and the marls occupy the upper portion, the "Zone à Amal. margaritatus." Specimens of Aeg. Jamesoni have been found in the region, so that the fossils of this zone have not been separated from the fimbriatum-beds, as in other localities. In the Department of the Rhone M. Dumortier has studied the fossils of the Middle Lias with great care, and has shown that this division of the formation attains a considerable development in the Basin of the Rhone. He observes, "Considered in relation to its fossils the Middle Lias may be regarded as the reign of Belemnites, for in no other division of the Secondary strata do we recognise the remains of these Cephalopods accumulated in such considerable numbers and appertaining to so many species. The Ammonites also furnish always in lower portions of the stage a very remarkable contingent of large species, and all characteristic of special horizons. The Acephala, Gastropods, and Brachiopods also give a considerable number of species." This author divides the Middle Lias of the Basin of the Rhone into two great zones, very unequal otherwise in their thickness.

The lower is much more developed vertically, and comprises an assemblage of marly limestones and marls, having a total thickness often exceeding eighty mètres $=260$ feet, and forming the zone of Belemnites clavatus. The upper zone is very clearly separated from the lower by its mineralogical composition and by its fossils ; and is characterised by the presence of Pecten aquivalvis. The limestones which compose it are throughout very hard, of various colours, very badly stratified, and form a thickness which, in the centre of the basin, does not appear to exceed from six to eight mètres $=20$ to 26 feet.

Table of the Middle Lias in the Basin of the Rhone.

\section{UPPER LIAS.}

\begin{tabular}{|c|c|c|}
\hline \multicolumn{3}{|c|}{ Zone of Pecten aquivalvis. } \\
\hline Petrology. & Thickness & Fossies, \\
\hline Calcareous "lumachelle," yellowish or reddish & $\begin{array}{l}\text { Mètres. } \\
2 \text { to } 3\end{array}$ & Limea acuticosta, Goldfuss. \\
\hline 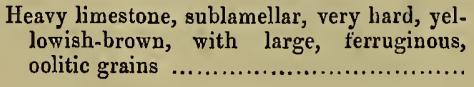 & 2 to 5 & Ostrea sportella, Dumort. \\
\hline
\end{tabular}




\section{Zone of Belemnites clavatus.}

Petrolog.

THICK-

Fossils.

NESS.

(n)

Grey-bluish marls, tender, plastic, without interposed calcareous layers

A thin layer of bluish "Inmachelle," very hard, charged with pyrites, forming very resisting plaquettes

Greyish-blue marls, without hard beds

Marly limestones, alternating with yellowish marls and greyish ferruginous nodules......

Greyish marly limestone, coarse, hard, and earthy, very often colonred blood-red ......
Mètres.

5 to 10 Tisoa siphonalis, Marcel de Serres.

Lingula Toltzii.

60 to 70 Tisoa siphonalis, Marcel de Serres.

2 to 3 Belemnites paxillosus, Schloth.

2 to 3 Aegoceras armatum, Sow.

$$
\text { Total thickness ............. }\left\{\begin{array}{c}
73 \text { to } 94 \\
\text { in the } \\
\text { two zones. }
\end{array}\right.
$$

\section{Lower LIAS.}

It was not possible in this region to correlate the beds by the Ammonites as he had done in other Departments of the Rhone basin, so M. Dumortier selected Pecten aquivalis and Belemnites clavatus as the organic forms that characterise the different horizons into which he has divided his zone of Belemnites clavatus.

\section{The Zone of Amaltheus Ibex.}

Synonyms._-"Upper Marls," pars, De la Beche, "Lias of Lyme Regis," " Geol. Trans., 2nd series, vol. ii, p. 22, 1823. " Ochraceous Lias," Murchison, 'Geol. of Cheltenham,' 2 Ed., p. 42, 1S45. “Dic Schichten des Ammonites Ibex," Oppel, 'Die Juraformation,' p. 122, 1856. "Ibex-bed," Wright, 'Quart. Jonr. Geol. Soc.,' vol. xiv, p. 25, 1858. "Schicht. des Ammonites Centaurus," Emerson, 'Die Liasmulde v. Markoldendorf," p. 34, 1870. “Die Schichten des Ammonites Centaurus," Brauns, 'Untere Jura,' p. 111, 1871.

This zone was originally exposed at Battledown Hill, near Cheltenham, where it was worked for brick-earth : the bed consisted of an unctuous, tenacious, yellowish clay, containing numerous hard ferruginous nodules, many of which enclosed fossil shells. The same stratum was found in Leckhampton, Charlton Kings, and Churchdown to the south, and at Dumbletou, north of Cheltenham; everywhere the nodules yielded many wellpreserved Mollnsca, and the following list is characteristic of this zone. 


\section{Crphalopoda.}

Amaltheus Ibex, Quenst.

Aegoceras Valdani, $d$ 'Orb.

- Maugenesti, d'Orb.

- Actæon, d'Orb.

- Centaurus, d'Orb.

Trochus imbricatus, Sow.
Lytoceras fimbriatum, Sow.

Phylloceras Loscombi, Sow.

Aegoceras striatum, Reinecke.

Belemnites clavatus, Schloth.

elongatus, Miller.

\section{Gasteropoda.}

Trochus lævis, Schloth.

\section{LAMELLIBR ANCHIATA.}

Cardinia attenuata, Stutch.

Mytilus scalprunı, Now.

Pinna folium, Young and Bird.

Pecten priscus, Schloth.

Lima pectinoides, Sow.

Avicula inæquivalvis, Sow.

Macrodon Buckmani, Rich.

\section{BRACHIOPODA.}

Spiriferina rostrata, $L a m k$.

Rhynchonella furcillata, Théod.

Waldheimia numismalis, Lamk.

Rhynchonella rimosa, Buck.

The fossils of this zone in other localities are often catalogued with those from the Jamesoni-beds, on which they rest, and it is rare that we are able to define so distinctly the limits of the Ibex-beds as formerly we were able to do near Cheltenham.

Mr. E. B. Tawney, F.G.S., has made a careful study of the Lias around Radstock, and embodied his observations in an exhaustive memoir ${ }^{1}$ on this subject. From this we learn that the Ibex-beds were found by him at Munger, near Radstock, associated with the Jamesoni-beds; and that near the top of an old quarry, formerly worked for road-material, he collected Aegoceras Maugenesti, Aegoceras Valdani, Aegoceras striatum, and Lytoceras fimbriatum. Aegoceras brevispina, Aegoceras Jamesoni, and Amaltheus Ibex seem to occur throughout, and in the same locality Belemnites were abundant, but not easily extracted. Belemnites paxillosus and B. apicicurvatus, Littorince and other minute Gastropods were found in fine preservation with Cryptania expansa. Among the bivalve shells Astarte striato-sulcata, Inoceramus ventricosus, Pholadomya ambigua; and of Brachiopods, Rhynchonella rimosa and Rhyn. furcillata. We have here a very good account of the Ibex-beds of Munger, with the distribution of some of the leading fossils therein.

" "Notes on the Lias in the Neighbourhood of Radstock," 'Proc. Bristol Naturalists' Soc.,' vol. i, p. 178,1875 . 
This zone appears to extend into Northamptonshire, as the specimens of Anal. Ibex, and Aeg.Valdani in the British Museum, marked from Watford, testify.

In Dorsetshire I lave collected at Lyme Regis fragments of the leading fossils of this zone, as, for example, $A$. Valdani, $A$. Maugenesti, in greyish coloured clay beneath a bed with Aeg. Davei, so that the zone of Amaltheus Ibex appears to maintain an independent position above the Jamesoni-beds in the localities I have cited wherever we are able to ascertain the position of its fossils with sufficient accuracy to determine the limits of the zone.

Foreign Correlations.-In Sonth-West Germany this zone was first separated from the Jamesoni-beds by Dr. Oppel, ${ }^{1}$ as he found in beds of clay and marl a few feet thick, resting upon the Jamesoni-beds, a group of Ammonites that werc constantly associated together, namely, Amal. Ibex, Aeg. Maugenesti, Aeg. Valdani, Aeg. Aetaon, and Aeg. Centaurus, whilst in the Jamesoni-beds the group of associates consisted of Aegoceras Jamesoni, Aeg. Masseanum, Aeg. submuticum, Aeg. Taylori, and Aeg. pettos; and a like distribution of species is found in the two zones in Gloucestershire. The Ibex-beds are much more easily discovered round Cheltenham than the Jamesoni-beds, which are only reached in some deep brick-earth diggings.

In several of the exposures for obtaining ironstone out of the Middle Lias of North Germany some good sections of the Jamesoni, Henteyi, and Margaritatus-zones have been discovered. The following section, made by the late Dr. U. Schlönbach, ${ }^{2}$ of a cutting near Oldershansen shows the relation of the Ibex and Jamesoni zones to each other in that region.

\section{Section near Oldershausen, between Oldenrode and Echte; the beds taken in deseending Order.}

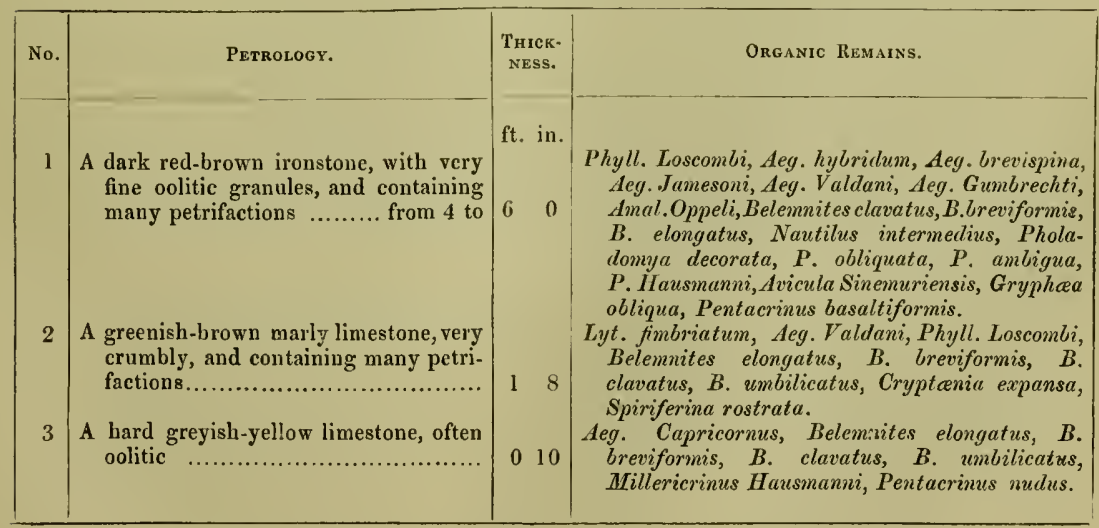

1 ' Juraformation,' p. 122, 1856.

2 'Eisenstein des mittleren Lias im N.-W. Deutschland,' p. 493, 1863. 
At Markoldendorf, ${ }^{1}$ near Einbeck, in a similar exposure for ironstone, he found the above strata with Aeg. armatum, Aeg. Centaurus, Aeg. brevispina, Aeg. Jamesoni, Trochus lavis, Pholadomya ambigua, Inoceramus ventricosus, Gryphaa obliqua, and many Brachiopods.

Dr. Emerson ${ }^{2}$ states that the beds with Aeg. Centaurus in the Markoldendorf district yield the richest ironstones in the Middle Lias, and that they alone afford that beautiful granular oolitic structure which is absent from most of the other ironstone masses of that region. In some parts the Centaurus-beds rest upon the Brevispina-beds, and contain a great number of Gasteropods. The following Mollusca were obtained by this author from these ironstones.

\section{Fossils from the Aegoceras Centaurus-beds at Hullersen.}

Lytoceras fimbriatum, Sow.

Aegoceras striatum, Rein.

- Centaurus, d'Orb.

Phylloceras Loscombi, Sow.

Herberti, Opp.

Nautilus intermedius, Sow.

Belemnites elongatus, Mill.

- clavatus, Schloth.

Trochus læris, Schloth.

- Retbergi, Schlön.

- Thetis, Goldf.

Pleurotomaria multicincta, Schlïb.

- $\quad$ tuberculato-costata, Münst.
- $\quad$ granosa, Schloth.
- solarium, Koch.
Phasianella phasianoides, $d$ 'Orb.

Cemoria costata, Emerson.

- punctata, Emerson.

Opis Carusensis, d'Orb.

Isocardia cingulata, Goldf.

Unicardium Ianthe, $d$ 'Orb.

Nucula cordata, Goldf.

Leda subovalis, Goldf.

- Galatbea, d'Orb.

Inoceramus ventricosus, Sow.

Limea acuticosta, Goldf.

Pecten velatus, Goldf.

Spiriferina rostrata, Schloth.

Pentacrinus basaltiformis, Mill.

- nudus, Schlön.

In Swabia the three zones of the lower half of the Middle Lias-the Jamesoni, Ibex, and Davai beds-closely resemble each other, and are only distinguished by the characteristic Ammonites they contain, most of their Gastropods and Lamellibranchs having a wider range in the beds than the Cephalopods, a stratigraphical condition which we have seen to prevail in other zones of life. According to Dr. Oppel ${ }^{5}$ the following section fairly represents the actual state of the lower half of the Middle Lias of Swabia.

1 'Eisenstein des mittleren Lias im N.-W. Deutschland,' p. 496, 1863.

2 'Die Liasmulde v. Markoldendorf bei Einbeck,' p. 34, 1870.

3 'Die Juraformation,' p. 123, 1856. 
Middle Lias of Swabia.

Upper part of Middle Lias.

Amaltheus margaritatus begins.

\begin{tabular}{|c|c|c|c|}
\hline & Petrology. & $\begin{array}{l}\text { THick- } \\
\text { NESS. }\end{array}$ & Organic Remains. \\
\hline $\begin{array}{l}\text { HenLeYY } \\
\text { beds }\end{array}$ & $\begin{array}{l}\text { Hard marly beds, alternating } \\
\text { with bluish clay; shells cal. } \\
\text { careous ...................................... }\end{array}$ & ft. & $\begin{array}{l}\text { Belemnites umbilicatus begins here; Aeg. Davei, } \\
\text { Aeg. Henleyi, Lyt. fimbriatum; Aeg. striatum; } \\
\text { Inoceramus ventricosus, Pentacrinus subangu- } \\
\text { laris. }\end{array}$ \\
\hline $\begin{array}{l}\text { IBEX } \\
\text { beds }\end{array}$ & $\begin{array}{l}\text { Light grey, hard, marly beds, } \\
\text { with alternate layers of clay; }\end{array}$ & $15-18$ & $\begin{array}{l}\text { Amal. Ibex, Aeg. Maugenesti, Aeg. Vuldani, Aeg. } \\
\text { Centaurus, Aeg. Actaon, Waldheimia numis- } \\
\text { malis, Rhyn. rimosa. }\end{array}$ \\
\hline $\begin{array}{l}\text { JaMESONI } \\
\text {.beds }\end{array}$ & & & $\begin{array}{l}\text { Aeg.Jamesoni, Aeg. Masseanum, Aeg.Taylori, Aeg. } \\
\text { pettos, Amal. Lynx, Pentacrinus basaltiformis. }\end{array}$ \\
\hline $\begin{array}{l}\text { Armatum } \\
\text { bed }\end{array}$ & Grey marls & 2 & Aegoceras armatum. \\
\hline
\end{tabular}

So that the stratigraphical character of the lower half of the Swabian Middle Lias very much resembles the section I have given of the same beds in North Germany at p. 31 of this work, where the classification of Professor von Seebach, Dr. Schlönbach, and Dr. Emerson are arranged for comparison in parallel columns.

In France this zone has been found in Normandy. Professor E. Deslongchamps ${ }^{1}$ las described the "Nivean des Ammonites Valdani et des grosses A. fimbriatus," which is always well characterised at Bully, Maltot, Fresnay-le-Pnceux, and in the environs of Caen, where the Ammonites Valdani strata lave a thickness of 3 mètres $=10$ feet. They consist of granular limestones, sometimes sonorous and siliceous, which cleave sometimes into plates, and enclose a great number of fossils. Large and magnificent specimens of Lytoceras fimbriatum, Amaltheus Engelhardti, Amaltheus Ibex, and Aegocercs Taylori, are here found. The most abundant, and most characteristic Cephalopod of this small horizon is the Ammonites Valdani, of which the rock, especially at Maltot, sometimes consists. Among the Gastropods are Trochus, Chemnitzia, Pleurotomaria suturalis, and P. similis, with a large number of Lamellibranchs,-Panopaa elongata, Pholadomya Hausmanni, Lyonsia unioides, Inoceramus ventricosus, I. substriatus, Hinnites velatus, Pecten orbicularis, P. aquivalvis, Harpax Parkinsoni. Certain Brachiopods are very characteristic of this zone; in the first line are varieties with a ventral groove, as Terebratula subovoides, Spiriferina

1 'Etudes sur les Etages Jurassiques Inférieurs de la Normandie,' p. 48, 1864. 
Hartmanni, S. oxyptera, and Rhynchonella furcillata. Other species are found which pass up into higher beds, such as Terebratula cornuta, T. Waterhousei, T. subnumismalis, Spiriferina rostrata, Rhynchonella tetraëdra, and Waldheimia numismalis rarely.

In the Department of the Cher the late Professor Alcide d'Orbigny ${ }^{1}$ well defined the presence of this zone in giving the localities of Am. Boblayei=Ibex, Aeg. Maugenesti, and Aeg. Valdani. These Cephalopods, so characteristic of the stage, were collected from the Middle Lias at Coutards, and in the valley of Saint-Pierre, near Saint-Amand, Cher; by MM. Boblaye, Valdan, Maugenest, and d'Orbigny, in beds a little above those descending order, with Gryphaa arcuata.

In the Department of Côte-d'Or the lower portion of the Middle Lias is divided by M. Collenot ${ }^{2}$ into four zones, each designated by a characteristic Ammonite, in descending order as follow :
1. Zone of Aegoceras Henleyi, Sow.
2. Zone of - DAVEI, d'Orb.
3. Zone of - Venarense, Opp.
4. Zone of - VALDANI, d'Orb.

The "zone of Am. Valdani" is locally known as "Calcaire à ciment de Venarey," where it is extensively worked for hydraulic lime, and from whence many fossils are obtained. It was at Venarey, near Semur, Côte-d'Or, and in the environs of Avallon and Yonne, that M. d'Orbigny obtained the type specimens of Aeg. Valdani. I found several other species of Cephalopods in the Museum at Semur, which had been obtained from the Calcaire à ciment, but they were found in higher beds than those which had yielded Aeg. Valdani, Aeg. brevispina, Aeg. Venarense, Phyll. Loscombi, Amaltheus Boblayei, and Amal. Alisiensis, all of which appear, from the character of their matrix, to have been derived from the Valdani-zone. The leading Ammonite of this zone, Aegoceras Henleyi, has been mistaken by d'Orbigny for Aeg.planicosta, Sow., from the Obtususbeds of the Lower Lias, and figured as such in the 'Paléontologie Française,' pl. 65. The localities therein given for this Ammonite are important, and prove that this stage of the Middle Lias exists in many other Departments, as Calvados, Meurthe, Moselle, Cher, Ain, Ardennes, Meuse. M. Dumortier, ${ }^{3}$ who has corrected the former error as to the identity of A. Capricornus, Schloth., says, "L'Ammonites Capricornus est avec $l^{\prime} A m m$. Davcei l'espèce la plus caractéristique et la plus répandue dans les couches inférieures de la zone à Bel. clavatus; on la rencontre partout ou ces couches sont abordables." Saint-Fortunat, Rhône, is one of his type localities for this and its other Ammonite associates.

1 'Paléontologie Française, Terrains Jurassiques,' tom, i, p. 253, 255, 257, 1842.

2 'Description Géologique de l' Áuxois,' p. 260, 1873.

3 'Etudes Paléontologiques,' tom. 3, p. 82, 1869. 


\section{The Zone of Aegoceras Henleyi.}

Synonyms._- Upper Marls” (pars med.), De la Beche, 'Geol. Trans.,' 2nd ser., vol ii, p. 23, pl. iii, 1823. “Der mittlere schwarze Jura," Quenstedt, pars, 'Flötzgebirge Württ.,' p. 172, 1843. “Die Schichten des Amm. Davai,” Oppel, 'Juraformation,' p. 126, 1856. "Schiste d'Ethe," Dewalque, 'Lias de Luxembourg,' p. 55, 1857. "Lias Gamma" (pars Davœikalk), Quenstedt, "Der Jura Uebersichstafel," p. 293, 1858. “Davcei-bed,” Wright, 'Quart. Journ. Geol. Soc.,' vol. xiv, p. 25, 1858. “Zone of Am. Capricornus," Wright, 'Oolitic Asteroidea,' Pal. Soc., vol. for 1S61, p. 79, 1863. "Zone de la Belemnites clavatus," pars Dumortier, 'Études Paléontologiques sur les Dépôts Jurassiques du Bassin du Rhône,' 3me partie, Lias Moyen, p. 16, 1869. “Die Schichten des Ammonites Davœi," Brauns, 'Der untere Jura,' p. 124, 1871. "Zone of Ammonites Capricornus" Tate and Blake, 'Yorkshire Lias,' p. 89, 1876.

This zone is very well developed in England; and wherever the Middle Lias is complete it is found beneath the rock-bed forming the "Marlstone" of British Geologists. The beds consist of laminated clays, sometimes containing micaceous particles, or they are largely charged with ferric oxide, whilst in other localities the zone is represented by irregular beds of brown micaceous sandstone. The inconstant stony bands found in the clay contain sometimes an assemblage of fossils, and in a few of the beds several interesting forms of Asteriade and Oplizuride have been found. At Mickelton, ${ }^{1}$ Worcestershire, where the shales of this zone were perforated for a railway tunnel, a considerable number of fossils in fine preservation were obtained; the shales, partly arenaceous and partly micaceous, formed thin slabs of fine bluish sandstone, on which many of the Pentacrinites, Brittle-stars, and Starfishes, lay in high relief. There were also large slabs of ironstone, many inches in thickness, composed almost entirely of shells, with many immature specimens of Aegoceras Ilenleyi. All the specimens of Uraster Gaveyi, Forb., Tropidaster pectinatus, Forb., Ophioderma Gaveyi, with Cidaris Edwardsii, Wrt., and Pentacrinus robustus, Wrt., were found adherent to the under side of a thick slab of ironstone which lay twenty feet below the surface. The Cidaris, and its spines attached to the tubercles of the plates and the ossicles, and species of Uraster, Tropidaster, and Ophioderma were as well preserved for anatomical description as if they had been prepared by a taxidermatist for the purpose.

Beds of laminated shales and ferruginous clays, the equivalent in age of those at Mickelton, were exposed in making excavations at Hewlett's Hill for the reservoirs of the Cheltenham water-works; many of the ironstone bands were full of fossils in varions stages of decay, from the decomposition of the calcareous matter of the shell. Another exposure on the same contour line was made at Witcombe, and several of the Ammonites

1 "On the Railway Cuttings at Mickelton Tunnel, \&c.," by G. E. Gavey, F.G.S., 'Quart. Journ. Geol. Soc.,' vol. ix, p. 29, 1853. 
and Nautili from that locality, now in my collection, were obtained in fine preservation; the Witcombe shells rivalling those from Mickelton; but no Echinoderms were found with the Mollusca. The following list represents the leading species collected from these beds.

Fossils collected from the Zone of Aegoceras Henleyi, Gloucestershire.

\section{Cephalopoda.}

Belemnites umbilicatus, Blainv.

- elongatus, Mill.

- paxillosus, Schloth.

Nautilus striatus, Sow.

Gasteropoda.

Chemnitzia capricorni, Wrt.

Cylindrites capricorni, Wrt.

Trochus imbricatus, Sow.

\section{LAMELLIBRANCHIATA.}

Pholadomya ambigua, Sow.

- decorata, Hartm.

Pleuromya unioides, Röm.

Leda rostralis, Lamk.

- complanata, Röm.

- acuminata, Goldf.

- cordata, Goldf.

- inflexa, Röm.

Astarte capricorni, Wrt.

Mytilus hippocampus, Young \& Bird.

Cypricardia cucullata, Goldf.

Cardinia attenuata, Stutch.

Goniomya capricorni, Wrt.

Protocardia truncata, Phil.

Unicardium Ianthe, $d^{\prime}$ Orb.

Cucullæa Münsteri, Ziet.
Arca elongata, Quenst.

- truncata, Buck.

Modiola scalprum, Sow.

Limea acuticosta, Goldf.

Avicula longiaxis, Buck.

Monotis inæquivalvis, Sow.

Inoceramus ventricosus, Sow.

Pecten æquivalvis, Sow.

- priscus, Schloth.

- diversus, Buck.

- liasinus, Nyst.

Gervillia lævis, Buck.

Plicatula spinosa, Sow.

Gryphæa cymbium, Lamk.

Ostrea Goldfussi, Bronn.

\section{BraCHIOPODA.}

Terebratula punctata, Sow.

Spiriferina rostrata, Schloth.

Rhynchonella rimosa, von Buch.
Rbynchonella variabilis, Schloth.

Orbicula scaliformis, $W r t$.

Lingula Beanii, Phil. 


\section{Echinodermata.}

Cidaris Edwardsii, Wright.

Rabdocidaris Moraldina, Cott.

Hemipedina Jardinii, Wright.

Uraster Gaveyi, Forb.

Tropidaster pectinatus, Forb.
Ophioärma Gaveyi, Wrt. Brodiei, $W r t$.

Pentacrinus robustus, $\boldsymbol{T r}$.

- punctiferus, Quenst.

- subangularis, Mill.

In Dorsetshire this zone occupies a conspicuous position in the cliff sections, as at Black Ven, Stonebarrow Hill, Westhay Cliff, and at the Golden Cap, all of which exhibit profiles of the beds. Mr. E. C. H. Day, F.G.S., ${ }^{1}$ has given an exhaustive description of these in his excellent memoir; and, as I had the pleasure of working over some of the sections with my friend, I select that at the Golden Cap as the most typical for a general view of the whole. The lower portion of this headland consists of -

I. The Upper Marls, without mica, of De la Beche's section, in which a greater number of Belemnites are found than in any other division of the Lias; seams of grey marls full of these fossils are seen along the shore at low tide. Belemnites longissimus, Mill., B. elongatus, Mill., and B. clavatus, Schloth., appear to be the prevailing forms. Here, likewise, are found Lytoceras fimbriatum, Aeg. Bechei, Aeg. Henleyi, Aeg. striatum, Phylloceras Loscombi, Nautilus semistriatus, d'Orb., Nautilus inornatus, Trochus imbricatus, Eucyclus Gaudryanus, Chemnitzia Periniana, Pleurotomaria similis, Cryptania expansa, Inoceramus ventricosus, Hinnites tumidus, Plicatula spinosa, Pecten sp.

II. The next strata in ascending order are known to local collectors as the "Green Ammonite-beds," as they afford a rich harvest of fossils, which are well preserved in the greenish non-micaceous marls that constitute this stage. It was in these I found the specimens of Aegoceras Henleyi, which have enabled me to demonstrate the remarkable history of this species, so long misunderstood by palæontologists, and Aegoceras Daveei, the rarest Cephalopod in the locality, associated with Aeg. Bechei and Monotis incequivalvis in the same small slab.

\section{Fossils of the Green Ammonite-beds, near Charmouth.}

Ichthyosaurus.

Plesiosaurus.

Aegoceras Henleyi, Sow.

- Bechei, Sow.

- striatum, Reinecke.

- Davœi, Sow.

Lytoceras fimbriatum, Sow.

Phylloceras Loscombi, Sow.
Nautilus semistriatus, d'Orb.

Belemnites longissimus, Mill.

- compressus, Stahl.

Cryptænia expansa, Sow.

Chemnitzia Carucensis, d'Orb.

Pterocera liasina, d'Orb.

Inoceramus ventricosus, Sow.

Monotis inæquivalvis, Sow.

1 "The Middle and Upper Lias of the Dorsetshire Coast," 'Quart. Journ. Geol. Soc.,' vol, xix , p. $278,1863$.

2 lbid., p. 283. 
III. Grey marls with the green Ammonite nodules are estimated at one hundred feet in thickness, and are overlain by what is locally called "The Three Tiers," consisting of three beds of hard micaceous sandstone, interstratified with sandy micaceous shale and greyish marls. These beds contain few fossils. The bones of Saurians are sometimes found in the rock beds, together with impressions of Phylloceras Loscombi and Lytoceras fimbriatum. Over "The Three Tiers" are about 160 feet of grey micaceous marls. Two or three thin bands of mudstone and occasional nodules occur in the lower part of the mass, and at rather more than 100 feet above "The Three Tiers" a thicker band, containing shells and calcareous concretions, stands out from the face of the cliff. Underneath this thick band is a curious and persistent layer of small nodules containing chiefly fragments of Ammonites.

The mass of grey marls terminates with a layer made up of shells and fragments of Pentacrinites, and this is immediately overlain by a bed of large sandstones, from 4 to 6 feet in thickness, belonging to the zone of Amaltheus margaritatus.

Robin Hood's Bay. - The north cheek of this bay presents a fine exposure of the Henleyi-beds, consisting of hard marly shales interstratified with oyster-bands, forming strong rock beds, having a thickness of 60 feet, with blue sandy shales, becoming more argillaceous towards the base with fossiliferous nodules containing Aeg. Henleyi and Lytoceras fimbriatum. Messrs. Tate and Blake ${ }^{1}$ have carefully measured these beds and drawn up the following section:

Henleyi-beds, North Cheek, Robin Hood's Bay.

Base of the Margaritatus-beds.

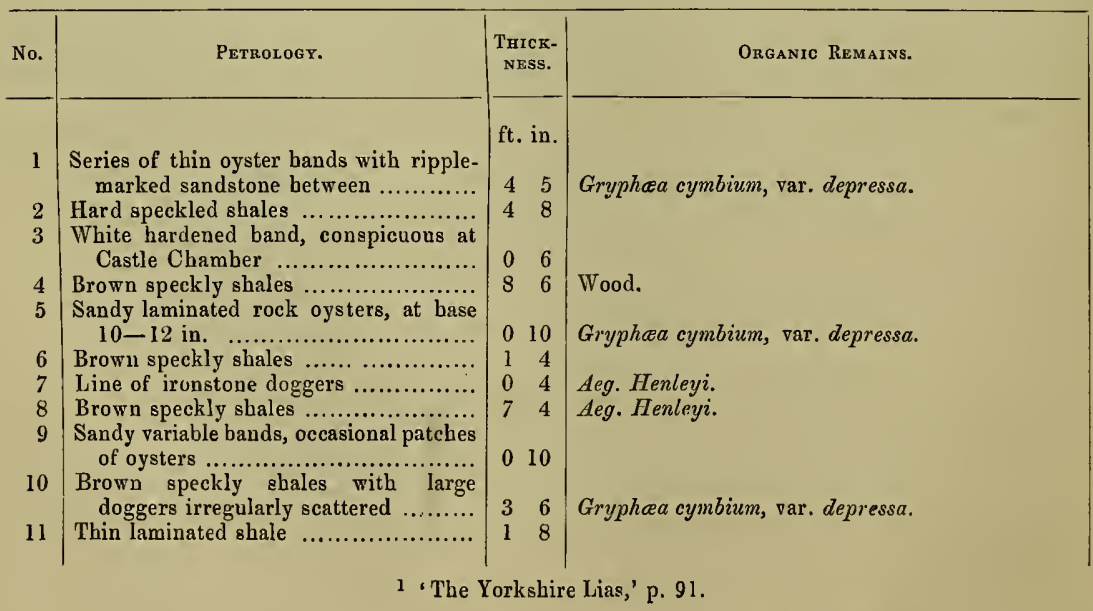




\begin{tabular}{|c|c|c|c|}
\hline No. & Petrology. & $\begin{array}{l}\text { THICK- } \\
\text { NESs. }\end{array}$ & Organic Remains. \\
\hline $\begin{array}{l}16 \\
17 \\
18 \\
19 \\
20 \\
21 \\
22 \\
23 \\
24 \\
25 \\
26\end{array}$ & 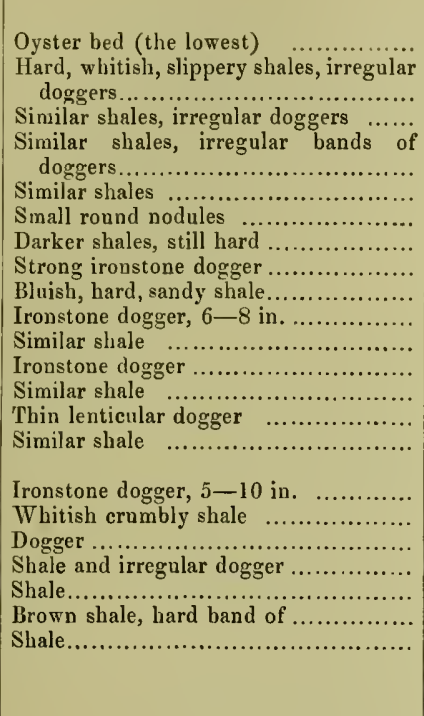 & $\begin{array}{rr}\mathrm{ft} & \text { in. } \\
0 & 5 \\
& \\
4 & 9 \\
4 & 6 \\
& \\
5 & 0 \\
11 & 0 \\
0 & 2 \\
2 & 10 \\
0 & 8 \\
15 & 6 \\
0 & 6 \\
8 & 4 \\
4 & 6 \\
5 & 0 \\
0 & 3 \\
4 & 5 \\
& \\
0 & 5 \\
5 & 0 \\
0 & 6 \\
11 & 0 \\
4 & 0 \\
0 & 3 \\
5 & 3 \\
128.2\end{array}$ & $\begin{array}{l}\text { Aeg. Henleyi, Modiola scalprum. } \\
\text { Monotis incquinalvis. } \\
\text { Aeg. Henleyi, Inoceramus ventricosus, Modiola } \\
\text { numismalis. } \\
\text { deg. Henleyi. } \\
\text { Lytoceras fimbriatum. } \\
\text { Lytoceras fmbriatum. }\end{array}$ \\
\hline & & & \\
\hline
\end{tabular}

Foreign Correlations.-The Henleyi $=$ Capricornus-beds are found in different regions of North Germany, where they have been discovered in cuttings for railroads and in mining for ironstone, which appears to abound in the lower portion of the Middle Lias of that country; in proof, I may state that Ammonites Capricornus has been found in forty different localities in North Germany.

In Brunswick this zone has been described by H. von Strombeck $;^{1}$ in the province of Saxony, by Ewald $;^{2}$ near Göttingen, by Bornemann $;^{3}$ at Harzburg, Oldershausen, Markoldendorf, and in other ironstone districts, by Dr. U. Schlönbach ; ${ }^{4}$ and from these and other localities Dr. Brauns ${ }^{5}$ has been able to make out the following list of species forming the Molluscan Fauna of the Davei-beds = Henleyi-beds of North Germany.

1 'Zeitschrift der Deutscben geol. Gesellsch.' vol. iv., p. 65, 1852 ; 'Sitzungher. der Berliner Akademie,' 1859, p. 354.

2 'Über 'die Jurassischen Bildungen der Provinz Sachsen;' 'Verh. d. Rön Akad. d. Wisscnch. Berlin,’ p. 347, 1859.

3 'Liasformation in der Umgegend von Göttingen,' p. 23, 1854.

4 'Den Eisenstein des mittleren Lias im N.-W. Deutschland,' p. 487-496, 1863.

5 'Der untere Jura in N.-W. Deutschland,' p. 133, 1871. 
Palcontology of the Davæi-beds of North-West Germany.

\section{Cephalapoda.}

Aegoceras striatum, Reinecke.

- Henleyi, Sow.

- Darœi, Sow.

Lytoceras fimbriatum, Sow.

Phylloceras Loscombi, Sow.

Amaltheus margaritatus, Mont.
Amaltheus Normanianus, d'Orb.

Nautilus intermedius, Sow.

Belemnites umbilicatus, Blainv.

$$
\begin{array}{ll}
\text { - } & \text { compressus, Stahl. } \\
\text { - } & \text { clavatus, Schloth. } \\
\text { - } & \text { paxillosus, Schloth. }
\end{array}
$$

\section{Gasteropoda.}

Actæonina variabilis, Brauns.

Cryptænia expansa, Sow.

- helicinoïdes, Röm.

Pleurotomaria similis, Sow.

$$
\text { - granosa, Schloth. }
$$

Discohelix calculiformis, Dunkr.

Trochus lævis, Schloth.

- turriformis, Koch and Dunk.
Trochus limbatus, Schlot $h$.

- imbricatus, Sow.

- umbilicatus, Koch and Dunk.

Rotella turbilina, Schloth.

Turbo paludinæformis, Schlüb.

- Nic1as, d'Orbig.

- marginatus, Ziet.

Turritella undulata, Ziet.

\section{LAMELLibRANCHIATA.}

Gryphæa cymbium, Lamk.

Ostrea semiplicata, Münst.

Anomia numismalis, Quenst.

Plicatula spinosa, Sow.

Hinnites tumidus Ziet.

Pecten priscus, Schloth.

- æquivalvis, Sow.

- substriatus, Röm.

- lunularis, Röm.

Lima Hermanni, Ziet.

Limea acuticosta, Goldf.

Leda complanata, Goldf.

- Galathea, d'Orb.

- subovalis, Goldf.

Nucula cordata, Goldf.
Cucullæa Münsteri, Ziet.

Macrodon Buckmani, Rich.

Inoceramus ventricosus, Sow.

Avicula inæquivalvis, Sow.

- calva, Schlub.

- cygnipes, Toung and Bird.

Pinna folium, Young and Bird.

Modiola elongata, Koch and Dunk.

Astarte striatosulcata, Röm.

Myoconcha decorata, Munst.

Cardium cingulatum, Goldf.

Protocardia truncata, Sow.

Thracia Grotriani, Brauns.

Pholadomya decorata, Ziet.

\section{BrachIOPODA.}

Rhyuchonella variabilis, Schloth.

$$
\begin{array}{ll}
\text { - } \quad \text { tetraëdra, Sow. } \\
\text { - } \quad \text { rimosa, Buch. } \\
\text { - furcillata, Théod. }
\end{array}
$$

Spiriferina rostrata, Schloth.

Waldheimia numismalis, Lamk.
Waldheimia cornuta, Sow.

$$
\begin{array}{ll}
\text { - } & \text { Waterhousei, Dav. } \\
\text { - } & \text { Heyseana, Dunk. } \\
\text { - } & \text { punctata, Sow. } \\
\text { - } & \text { subovoides, Röm. }
\end{array}
$$

Terebratella subpentagona, Koch and Dunk. 


\section{Echinoderuata.}

Cidaris octcceps, Quenst.

- sp. (from Göttingen).

Pentacrinus subangularis, Mill.
Pentacrinus basaltiformis, Mill.

Millericrinus Hausmanni, Röm.

Foraminifera.

Glandulina vulgata, Born., and nine other species.

Nodosaria novemcostata, Born.

Orthocerina multicostata, Born. pupoides, Born.

Frondicularia bizæformis, Born., and four other species.
Lingulina tenera, Born.

Vaginulina Hansmanni, Born.

Marginulina rugosa, Born.

Cristellaria protracta, Born., and nine other species.

Robulina Grottingensis, Born.

- nautiloides, Born.

All the above thirty-three species of Foraminifera were obtained from the Belemnite-beds of Göttingen, and figured and described by Dr. Bornemann, in his memoir, "Ueber dic Liasformation in der Umgegend von Göttingen."

\section{The Zone of Amaltieus margaritatus.}

Synonyms.—“Blne Lias Marl," pars sup., William Smith, 'Mem. of Map.,' 1815. "Micaceous Marl," De la Beche, 'Geol. Trans.,' 2nd series, vol. ii, pl. 3, 1823. "Marlstone," Williamson, "Fossil Remains on the Yorkshire Coast," 'Geol. Trans.," 2nd ser., vol. v, p. 224, 1836. "Lias Delta, Amaltheenthon," Quenstedt, 'Flözgeb., p. 540, 1843. "The Marlstone," Murchison, 'Geol. of Cheltenham,' 2nd edit., p. 37, 1845. "Marnes à Ammonites analtheus ou margaritatus," Marcou, 'Jura Salinois,' p. 50, 1846. “Amaltheenschichten,” v. Strombeck, 'Zeitschrift d. Deutsch. Gessell.,' p. SS, vol. v, 1853. "Macigno d'Aubange," Dumont, Dewalque et Cliapuis, 'Luxembourg,' p. 273, 1853. "Die oberen Schichten des Ammonites margaritatus," Oppel, 'Juraformation,' p. 133, 1856. “Marlstone,” Hull, ‘Memoirs of the Geol. Survey,' descrip. of sheet 44, p. 18, 1857. "Oberer Theil des mittleren Lias," Ewald, "Sitzung. Berlin Akad, 1859. "Margaritatus-bed," Wright, 'Quart. Journ. Geol. Soc.' vol. xv, p. 25, 1860. "Obere Zone des Am. margaritatus, Zone des Am. spinatus," U. Schlönbach, 'Eisenstein des mittleren Lias,' p. 507, 1863. "Amaltheenthone," von Seebach, 'Hannoversche Jura,' p. 25, 1864. "Lias Moyen, Partie Supér., Zone of Pecten cquivalvis," Dumortier, 'Etude Pal.,' vol. iii, p. 206, 1S69.“ Amaltheenthone," Brauns, 'Untere Jura,' p. 141, 1871. "Marlstone and ironstone series," Phillips, 'Geol. of York,' 3rd edit., p. 156, 1875. "The Marlstone of the Middle Lias," Judd, 'Geology of Rutland,' p. 64, in 'Mem. of the Geol. Surv.', 1875. "Zone of Am. margaritatus," Tate and Blake, 'Yorkshire Lias,' p. 103, 1876. 
The "Marlstone" of English Geologists forms a marked division of the Middle Lias. In the Midland Counties it consists of a lower portion, composed of yellowish-brown sandy beds, with thin bands of limestone and ferruginous nodules, and of an upper portion or rock-bed, formed of impure limestone containing many fossil shells in good preservation; it weathers brown externally from the oxidation of the iron it contains, whilst it is blue internally when broken with the hammer. This rock-bed forms a solid capping to the lower arenaceous beds, the more rapid erosion of which along their outcrop in Marlstone districts produces those terraces and tabulated promontories, as at Gretton, Alderton, Dumbleton, Churchdown, and Stinchcombe Hills, which impart such a picturesque effect to the physiographic features of the western escarpment of the Cotteswolds; whilst the steep slopes descending from the edges of the platforms to the Lower Lias plain below are composed of softer beds of Liassic sands and clay that have undergone a greater amount of atmospheric erosion.

North of Cheltenham the Marlstone is exposed in large quarries at Bredon, Alderton, Dumbleton, and Gretton Hills, where it was formerly worked for road-material. From Gretton I collected a large number of fossil shells, many of which had their tests in good preservation. In these localities, however, it is difficult to separate the Margaritatusfrom the Spinatus-bed. South of Cheltenham the Marlstone is found at the sunmit of Churchdown Hill, a remarkable circumdenuded outlier of the Cotteswolds, and on the western slope of Robin's Wood Hill, another outlier of the same; at Frocester Hill it forms a terrace of hard calcareo-siliceous limestone, which rests upon brown and greyish sands, containing bands and nodules of ferruginous ironstone; the whole of the Middle Lias here measuring about 150 feet in thickness, and divisible into Jamesoni, Ibex, Henleyi, and Margaritatus beds very similar in their petrological characters to those already described. The fine mass of Stinchcombe Hill, which projects like a bold headland into the valley, exhibits a greater thickness of Marlstone than any other section in the Cotteswolds; the Newent quarry near the village of Stinchcombe has twenty feet of Marlstone, covered by five feet of Upper Lias clay. At Wotton-under-Edge the Middle Lias is 186 feet thick, as measured by my old esteemed friend Professor A. Ramsay, F.R.S., Director-General of the Geological Survey, who many years ago surveyed this district, and was kind enough to draw for me the following profile of this interesting bit of the Cotteswold range.

\section{Turnpike Road.}

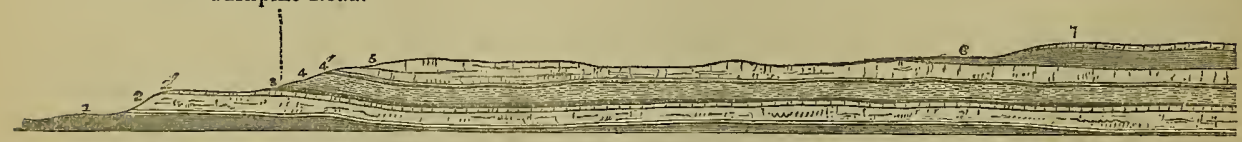

Diagram showing the Strata between Symond's Hall Hill and Wottor-under-Edge ('Journ. Geol. Soc.,' vol. xvi, p. 307.

This section shows the succession of Jurassic strata from Symond's Hall Hill to the Vale of Gloucester, and which, read in ascending order, includes- 
1. The Lower Lias shale and limestone of the Valley of the Severn; thickness unknown.

2. The sauds, shales, and clays of the Middle Lias; 186 feet in thickness.

2'. The hard, brown, fossiliferous Rock-bed, or Marlstone capping the terrace; 12 feet.

3. The Upper Lias shales in thin beds, with nodules of limestone at the top; 10 feet thick.

4. The Upper Lias sands, containing hard sandy nodules and lenticular concretions in the upper part, and brown, ferruginous, loose sand in the lower portion; 123 feet thick.

4'. Hard, brown, calcareous, sandy bands, freely speckled with granules of ferrisilicate, and interstratified with layers of softer sand containing Ammonites, Belemnites, Nautili, \&c., in considerable numbers, and forming a Cephalopoda-bed, sixteen feet thick; this is correlative with the one to be described at Frocester Hill.

5. The Inferior Oolite Limestone, similar to the Frocester and Painswick rocks, forming the freestone or building-stone of the district. Eighty feet thick.

6. The Fullers Earth ; 128 feet thick.

7. The Great Oolite, forming the summit of Symond's Hall Hill and the plateaux of the Cotteswolds in this region.

At South Petherton in Somersetshire the Marlstone was formerly extensively worked for road-material; the beds are thin but very fossiliferous, and many fine specimens were obtained therefrom. All my finest Amaltheus margaritatus and Amal. Engelhardti, and several Lamellibranchiata and Brachiopoda, with their tests in a beautiful state of preservation, came from this locality.

\section{Fossils from the Marlstone or Margaritatus-zone in Gloucestershire.}

Vertebrata.

Vertebræ of Ichthyosaurus.

Teeth and scales of Fishes.

\section{Cephalopoda.}

Belemnites clavatus, Blainv. - Milleri, Phill.

Nautilus striatus, Sow. - truncatus, Sow.

Amaltheus margaritatus, Montf.
Amaltheus Englehardti, d'Orb. Harpoceras Normanianum, $d$ Orb. Phylloceras heterophyllus amalthei, Quenst. = zetes, $d$ 'Orb.

\section{Gasteropoda.}

Pleurotomaria similis, Sow.

$$
\text { - undosa, Deslong. }
$$

- Sabrina, Tate.

Cryptænia expansa, Sow.
Chemnitzia Blainvillei, Münst.

Discohelix aratus, Tate.

Eucyclus imbricatus, Sow. 


\section{LAMELLIBRANCHIATA.}

Pholadomya ambigua, Sow.

Pleuromya granata, Simp.

$$
\begin{aligned}
& \text { - concinna, Goldf. } \\
& \text { - } \quad \text { costata, Young and Bird. } \\
& \text { ovata, Röm. }
\end{aligned}
$$

Cardinia crassissima, Sow.

Goniomya capricorni, Wrt.

Cucullæa Munsteri, Ziet.

Gresslya intermedia, Simp.

Cypricardia cucullata, Münst.

Modiola scalprum, Sow.

Limea acuticosta, Goldf.

Monotis inæquivalvis, Sow.

Terebratula punctata, Sow.

Waldheimia resupinata, Sow,

$$
\text { - } \quad \text { cornuta, Sow. }
$$

Cidaris Edwardsii, $W r t$.

Hemipedina Jardinii, $W r t$.

Ophioderma Milleri.
Ceromya lineata, Will

Arcomya elongata, Röm.

Unicardium cardioides, P.hil.

Protocardium truncatum, Phil.

Cardinia crassiuscula, Sow.

Lima Hermanni, $V_{\text {oltz }}$.

- duplicata, Sow.

- pectinoides, Sow.

Pecten calvus, Goldf.

- æquivalvis, Sow.

- lunularis, Röm.

Gryphæa cymbium, Lamk.

Ostrea margaritacea, $W r t$.

\section{Brachiopoda.}

Rhynchonella tetraedra, Sow.

$$
\text { - variabilis, Schloth. }
$$

Lingula Beanii, Phil.

\section{Echinodermata.}

Ophiolepis Murravi, Wright.

Extracrinus subangularis, Mill.

Pentacrinus gracilis, Charlesworth.

The Marlstone attains a great development in Yorkshire, and is fully exposed in the coast sections near Staithes, Colborn Nab, and Boulby. "The sandy, conchiferous marlstone beds," says Prof. Phillips, " "which in Colborn Nab cover the Lower Lias shale, are seen rising with it and contributing to swell the altitude of Boulby and Rockcliff. The lower part of this series is generally the most solid, and projects in broad, compact floors above the Lias. On the surfaces of such beds lie innumerable multitudes of Oysters, Dentalia, Pectens, Protocardium truncatum, Monotis incequivalvis, and more rarely, about Staithes, beautiful fossil Star-fishes of the genus Ophioderma." In Boulby Cliffs $^{2}$ the ironstone and Marlstone series consist of-

a. The ironstone bands, which are numerous layers of firmly connected nodules of ironstone, often septariate, and enclosing coniferous wood, Pectines, Aviculæ, Terebratulæ, and from twenty to forty feet thick.

b. The Marlstone series, consisting of alternations of sandy Lias shale and sandstones, which are frequently calcareous, and generally full of shells. The lower beds are usually more solid, and project from the cliffs in broad floors, covered with Pectens, Cardia, Dentalia, Aviculæ, Gryphææ, \&c. The thickness variable from forty to 120 feet.

The molluscan fauna of these beds closely resembles the list already given from the Marlstone of Gloucestershire. Among the Echinodermata, however, are found species

$$
1 \text { 'Geology of Yorkshire,' p. } 101 . \quad 2 \text { Ibid., p. } 102 .
$$


which are limited to the Yorkshire series, as Uraster carinatus, Wr., Astropecten Hastingsia, Forb., Ophioderna Milleri, Phil., Aspidura loricala, Will., and Opliura Murravii, Forb., all collected from the Marlstone series near Staithes, where one of the most instructive sections of the Margarilatus-beds is exposed in the cliff. The following section, by Messrs. Tate and Blake, ${ }^{1}$ has more detail than mine, so I have selected it.

Section of the Margaritatus-beds at Staithes.

\begin{tabular}{|c|c|c|c|}
\hline No. & Petrology. & $\begin{array}{l}\text { THICK. } \\
\text { NESS. }\end{array}$ & Organic Rematis. \\
\hline \multicolumn{4}{|c|}{ Zone of Ainaltheus spinatus. } \\
\hline \multirow[b]{2}{*}{1} & & ft. in. & \\
\hline & $\begin{array}{l}\text { Bottom seam of impure ironstone : shells } \\
\text { enveloped in a calcareous matrix ... }\end{array}$ & 2 & $\begin{array}{l}\text { Amal. margaritatus, Belemnites, Pecten aquivalvis, } \\
\text { Gryphaca cymbium, Cypricardia cucullata. }\end{array}$ \\
\hline \multirow[t]{2}{*}{2} & $\begin{array}{l}\text { Blue marly shale ; top surface } \\
\text { crowded with Belemuites........... }\end{array}$ & 43 & $\begin{array}{l}\text { Amal. margaritatus, Belemites, Pecten cequivalvis, } \\
\text { fossil Wood. }\end{array}$ \\
\hline & Blne shale ............................. & & \\
\hline 3 & Fine-grained argillaceous limestone $\ldots$ & $0 \quad 1$ & \\
\hline 4 & 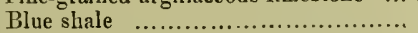 & & \\
\hline 5 & $\begin{array}{l}\text { Band of clay-ironstone, slightly spec- } \\
\text { kled with white grains; forms a scar }\end{array}$ & & $\begin{array}{l}\text { Amal. margaritatus, Protocardium truncatum, } \\
\text { Nonotis cygnipes. }\end{array}$ \\
\hline 6 & $\begin{array}{l}\text { on the flat shore } \\
\text { Black splintering shale } \ldots \ldots \ldots \ldots \ldots \ldots \ldots \ldots\end{array}$ & $\begin{array}{lr}0 & 10 \\
9 & 8\end{array}$ & \\
\hline 7 & $\begin{array}{l}\text { Oval argillaceous limestone doggers } \\
\text { Black splintery shale }\end{array}$ & 54 & \\
\hline 8 & $\begin{array}{l}\text { Clay-ironstone in two blocks, weather- } \\
\text { ing brick-red }\end{array}$ & & Amal. margaritatus, Gryphac cymbium, Protocay' \\
\hline 9 & 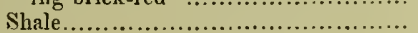 & & $\begin{array}{l}\text { cardium truncatiem. } \\
\text { cons }\end{array}$ \\
\hline 10 & Argillaceous limestone dogger ............. & & \\
\hline 11 & 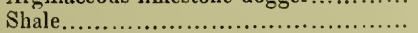 & 02 & Gryphcea cymbium. \\
\hline 12 & Small doggers ............................ & & \\
\hline 13 & 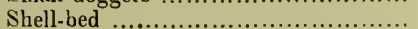 & $0 \quad 1 \frac{1}{2}$ & Belemnites and oysters. \\
\hline 14 & Sandy shale with scattered doggers ... & 211 & Gresslya Seebachii. \\
\hline 15 & Blue, with doggers and shell nıasses ... & 60 & $\begin{array}{l}\text { Gresslya Seebachii, Protocard. truncatum, Pecten } \\
\text { cequivalvis, Aracrodon intermedius. }\end{array}$ \\
\hline 16 & Shale, with doggers and shell-masses... & 10 & \\
\hline 17 & Dogger band ........................... & & Amal. margaritatus, $A$. Capricornus, and many \\
\hline 18 & Marly shale ............................ & & other fossils. \\
\hline 19 & Sandy shale and doggers................. & 70 & \\
\hline 20 & Calciferous sandstone …...................... & $0 \quad 3$ & \\
\hline 21 & Sandy marls.............. & & Gresslya. \\
\hline 22 & Dogger band,.. & 0 & \\
\hline 23 & Sandy marls .... & & \\
\hline 24 & Blne limestone ......................... & 10 & \\
\hline 25 & Striped sandy shales, with fossiliferouns & & Amal. margaritatus, Cheminitzia Blainvillei, Proto- \\
\hline 26 & Reddish sandstone with bands of fossils & & Dentalium giganteum, Protocardium truncatum, \\
\hline 27 & Grey sandstone and flags, false bedded & & Lima Hermanni, MLonotis cygnipes, \&c. \\
\hline 28 & Ca]ciferous sandstones.................... & 62 & \\
\hline 29 & Soft marly sandstone and calciferous & & \\
\hline & sandstone bands $\ldots \ldots \ldots \ldots \ldots \ldots \ldots \ldots$ & & \\
\hline
\end{tabular}

At the base of the cliff, on the sonth side of the harbour, the following lower beds are exposed at low tide. 
Sandy shales, impure limestone bands, grey marly sandstone, blue micaceous sandstone; about ten feet thick, containing Protocardium truncatum, Pecten aquivalvis, Belemnites virgatus.

My friend Professor Judd, in his able and exhanstive 'Memoir on the Geology of Rutland,' gives the following account of the Marlstone or Middle Lias in that county. "The upper part is a mass of ferruginous limestone, known as the Rock-bed; the lower, a series of sandy and micaceous clays and iron-stone with some beds of sand. The succession of beds in the Marlstone is as follows in ascending order, beginning at the base:

" $a$. Soft, yellowish-brown, sandy, and micaceous ironstone, crowded with casts of shells. and alternating with light blue clays. These ferruginous bands vary very greatly in number and thickness, and are sometimes nodular. They are especially characterised by the abundance of several small varieties of Ammonites margaritatus, Montf., and Protocardium truncatum, Sow.

" $b$. Beds of blue, highly micaceous clay, with large septaria crowded with fossils." Only in two brick-yards. "The most abundant species in these beds are Ammonites margaritatus, Mont. (the large typical form), Belemnites elongatus Mill., Cryptania expansa, Sow., Avicula inaquivalvis, Sow., Mytilus tipppocampus, Young and Bird, Modiola scalprum, Sow. (very abundant), Protocardium truncatum, Sow., Pleuromya unioides, Röm., and Pentacrinus subangularis, Mill.

" $c$. Beds of blue clay, with septaria, the latter not unfrequently containing Specular Iron, and weathering to a red colour. They contain many of the fossils recorded from the preceding beds, but less abundantly .

" $d$. Light blue clays, with bands of ir onstone balls of concentric structure, and usually very unfossiliferous. These beds are exposed in some brick-yards." At some places they contain beds of green and browu sands, as near Horninghold.

" $e$. "The Rock-bed." This is a mass of limestone, more or less ferruginous, and occasionally passing into a good ironstone. When unweathered it is a hard crystalline rock, of a blue or green colour, but as usually seen it is brown and moderately soft. It is usually crowded with fossils, its mass being often made up of fragments of crinoids, spines of Echinoderms, Serpulæ, and fragments of shells, whilst certain beds in it consist of an agglomeration of shells of Rhynchon ella tetrahedra, Sow., and Terebratula punctata, Sow., often filled with finely crystallized calc-spar. Belemnites paxillosus, Schloth., and B. elongatus, Mill., are extremely abundant in the Marlstone Rock-bed, and serve to distinguish it from the Northampton Sand, which often resembles it in mineralogical characters, but in which Belemnites are exceedingly rare. Ammonites are not abundant in the Rock-bed in this district, but at some points, as Edmondthorpe, Loddington, and Horninghold, Ammonites commun is, Sow., and Am. annulatus, Sow., occur in considerable numbers: Am. spinatus, Brug., and some varieties of Am. margaritatus, Montf., are also fonnd in it, but much more rarely, in this district. Large specimens of Pecten 1 "The Geology of Rutland," 'Memoirs of the Geological Survey,' p. 64, 1875. 
requivalvis, Sow., with the highly characteristic $P$. dentatus, Sow., also $P$. sublevis, Phil., Hinnites abjectus, Phil., and Avicula incquivalvis, Sow., are among the most abundant forms in the Rock-bed.

"The Marlstone Rock-bed is very variable, both in thickness and mineralogical character; it is finely developed in the neighbourhoods of Tilton-on-the-Hill and Somerby, near the former of which places it is seen to measure 18 feet 6 inches in thickness; towards the east and south, lowever, it attenuates very rapidly.

Besides being greatly diminished in thickness, the Rock-bed sometimes loses its calcareous character and becomes sandy. . . . When the junction of the Upper Lias clay and the Marlstone Rock-bed is seen, the latter often presents the appearance of having suffered erosion before the deposition of the former."

I have given my learned friend's description in extenso, as it is a very clear and concise account of the Marlstone Rock-bed of the Midlle Lias as it exists throughout the midland district of England. The Lias $a, b, c, d$, according to the classification I have followed in this work, would belong to the zone of Analtheus margaritatus, and $e$, the Rock-bed, would fairly represent the zone of Amaltheus spinatus. It is noteworthy in passing that both in this section, and in another which I shall give of Down Cliff when describing the spinatus-berls in Dorsetshire, we shall find that the Ammonites of the upper Lias, Stephanoceras comnune and Steph. annulatum, are sometimes found side by side with Analthens spinatus, which dies out in the upper part of this zone.

I must refer the student for ample details about these two zones to Professor Judd's memoir, as it is replete with instructive sections of the Margaritatus-beds and their fossils from the different brick-yards examined, and of the Spinatus-bed or Marlstone Rockbed at Robin-a-Tiptoes.

In Warwickshire this zone is very well developed near Banbury, where it has been long and carefully studied by Mr. Beesley, F.C.S., who has given a very good account of the formation. ${ }^{1}$ According to this author the MIargaritatus-beds form the base of the Upper Middle Lias, and consist of blue micaceous marly clay, with nodules of hard marl. or claystone; above this are hard bluish calcareons sandstone embedded in sand, and overlain by sandy marl or clay, containing the usual fauna of the Maryaritalus-beds of Rutland, with many additional species collected through several years by local geologists.

The Marlstone Rock-bed, or Ammonites spinatus zone forms the top of the Upper Míddle Lias, and is its most characteristic fenture, being largely spread over the district, and forming a broad table-land. On the west and south, and a terrace on the east side of the valley, the disintegration of its friable stone has produced the rich red land so well adapted for wheat-growing. ${ }^{2}$ 'The Rock-bed is a ferruginous often sancly limestone, externally brown, but of a greenish-blue colour in the interior of the blocks, and is nsually separated by thin partings of sandy loam or clay into two or three beds,

1 'Sketch of the Geology of the Neighbourhood of Banbury,' p. 5, 1872.

2 Ibid., p. 6. 
containing flattened concretionary nodules, which are rich in phosphates, the decomposition of which contributes to the fertility of the soil. Silicate of iron in small, rounded, highly polished, often hollow grains, is sometimẹs so abundant as to give almost an oolitic structure to the rock.

At Adderbury and at King's Sutton extensive workings for ironstone are now carried on in these beds, which are the correlative series in the midland districts of the great ironstone beds of Yorkshire, and are estimated to yield from 18 to 24 per cent. of iron.

Mr. Beesley has collected eighty species of Mollusca from the Spinatus-beds; and in this list are included, with Amaltheus spinatus and Amal. margaritatus, two Ammonites which belong to the Upper Lias. It would appear that here, as in other localities, it is extremely difficult to separate certain forms from each other along the confine lines of these zones, and hence we learn how the Spinatus- and Margaritatus-beds have been united and considered as one by most British geologists.

The Middle Lias zones above the Jamesoni-beds are exposed in the Island of Raasay, along the stream-courses on the Hallaig Močx ; and, according to Professor Tate, ${ }^{1}$ form a grand section on the east side of the island, displaying a gradual passage from argillaceous sediments into the calcareo-arenaceous rocks which constitute so striking a feature in the lithology of the Middle Lias of this area. A section of 150 feet shows the following beds :

I. Spinatus-beds: 1, yellow calciferous sandstone with ferruginous nodules.

II. Margaritatus-beds consisting of, 2, fissile sandstone; 3 , shelly, ferruginons sandstone; 4, marly sandstone; 5 , grey marls ; 6 , greenish-yellow sandstone, with shaly partings ; 7, yellow sandstone; 8 , greenish marly sand beds.

III. Henleyi-beds : 9, greenish-yellow calcareous sandstone; 10, greenish calcareous sandstone, with indurated tops.

In the cliff section on the east coast of Skye these three zones are repeated with similar petrological conditions; and from the Henleyi-beds the following fossils were collected by Messrs. Tate and Bryce, near Portree, Isle of Skye.

\section{Fossils from the Henleyi-zone, Skye.}

Aegoceras Henleyi, Sow.

- Darœi, Sow.

- striatum, Reinecke.

Pecten æquivalvis, Sow.

- liasinus, Nyst.

Avicula novemcostæ, Brown.

Limea acuticosta, Mü̈nst.

Unicardium Janthe, d'Orb.

Protocardium truncatum, Phil.

Pholadomya ambigua, Sow. decorata, Ziet.

Pleuromya ovata, Röm.
Mytilus scalprum, Sow.

Arca Stricklandi, Tate.

Cypricardia cucullata, Goldf.

Inoceramus ventricosus, Sow.

Gryphæa cymbium, Lamk.

- obliqua, Sow.

Hippopodium ponderosum, Sow.

Pinna folium, Young \& Bird.

Cucullæa Münsteri, Ziet.

Rbynchonella tetraedra, Sow. 
On the south side of Portree harbonr thin-bedded, bluish, micaceous sandstones, forming the Margaritatus-beds, are exposed, and yielded the following shells, which were chiefly collected in Raasay :

Fossils from the Margaritatus-zone, Island of Raasay.

Amaltheus margaritatus, Montf.

Belemnites paxillosus, Schloth.

- breviformis, Voltz.

- longissimus, Mill.

Tectaria Gaudryana, d' Orb.

Chemnitzia Blainvillei, Münst.

Pecten æquivalvis, Sow.

- liasinus, Nyst.

- strionates, Tate.

Avicula novemcostæ, Brown.

- cygnipes, Young and Bird.

Lima Hermanni, Voltz.

Limea acuticosta, MIünst.

Pleuromya ovata, Röm.

Pholadomya ambigua, Sow.

Mytilus scalprum, Sow.
Leda graphica, Tate.

Ostrea cymbium, Lamk.

Plicatula spinosa, Sow.

Cypricardia cucullata, Goldf.

Macrodon intermedius, Simp.

Arcomya arcacea, Seebach.

Ceromya liassica, Tate.

Lingula Voltzii, David.

Rbynchonella acuta, Sow.

- subconica, David.

- tetraedra, Sow.

Terebratula punctata, Sow.

Spiriferina Münsteri, Davil.

- rostrata, Schloth.

Eryma propinqua, Blake.

Pentacrinus amalthei, Quenst.

Foreign Correlations. - The Margaritatus and Spinatus zones are widely distribnted in North Germany, and, although these two horizons may sometimes be separated, they often are so closely united that they must be studied together. Von Strömbeck ${ }^{1}$ has made careful studies of the Amaltheenschichten in different regions of that country, and found them in the Helmsted, Schöppensted, and Harzbirg Jura, containing Amal. margaritatus, Amal. spinatus, Cryptania expansa, Turbo cyclostoma, Gresslya ventricosa, Astarte striato-sulcata, Leda elliptica. Inoceramus substriatus. Ewald ${ }^{2}$ fond the same species near Halberstadt; H. Römer, near Hildesheim; Bornemann, near Göttingen; Credner, ${ }^{3}$ in Hilsmulde, near Stroit; and Schlönbach, ${ }^{4}$ near Liebenburg and near Salzgitter, with a similar asscmblage of Mollusea; so that the upper zones of the Middle Lias are well represented in the north. In South Germany the Margaritatus beds are found in Swabia, and were long ago described by Professor Quenstedt in his 'Flötzgebirge Württembergs,' and afterwards by Dr. Oppel in 'Der mittlere Lias Schwabens,' whilst in his 'Juraformation' he divided the Margaritatus-beds into a lower and upper zone.

In the lower zone Amal. margaritatus is often associated with Lytoceras fimbriatum

1 'Zeitschrift d. D. geol. Gesellschaft,' vol. $\nabla$, Jahrg., 1853.

\& Ibid., 1859.

3 'Jabrbuch f. Min.,' 1860.

4 'Zeitschrift d. D. geol. Gesellschaft,' vol. $x{ }^{2}$, Jahrg., 1863. 
and Lyt. lineatum, and in the upper zone Amal. margaritatus is associated with Anal. spinatus. It would appear that Amal. magaritatus has a considerable vertical range, both in Germany and France, and thereby links together the Henleyi and Spinatus horizons in these countries by a persistent Cephalopodous type. Amaltheus margaritatus is thus remarkable alike for its zoological characters, and its wide distribution in time and space.

In France the Margaritatus-beds are exposed at Vieux-Pont, Calvados. Professor Deslongchamps ${ }^{1}$ has given a section of this, which evidently represents the English Marlstone; it consists of a Rock-bed about five feet in thickness, enclosing a large assemblage of fossils, of which the most characteristic are Amal. margaritatus, Amal. spinatus, Belemnites niger, Pecten aquivalvis, Pecten disciformis, Lima punctata, Terebratula quadrifida, Ter. cormuta, Ter. punctata, Ter. Edwardsii, Rhynchonella acuta, Rhyn. tetraedra, Syiriferina rostrata. Its upper portion is characterised by a particular stratum charged with small Gastropods of the genera Turbo, Cerithium, Tornatella, Actconina, and sometimes Pleurotomaria precatoria. In the adjoining region, as at Evrecy, Landes, Curcy, and Croisilles, the same bed is found maintaining its lithological and palæontological characters with a remarkable constancy. This zone has an extensive distribution in other Departments of France, and the characteristic Ammonites are found near Nancy, Meurthe; Saint-Rambert, Ain; Venarey, near Semur, and Pouilly in Auxois Côte d'Or; St. Amand, Cher; Metz, Moselle; Avallon, Yonne; near Lyons, Rhône; Clapier and Bosc, Aveyron; where it is associated with a number of new Ammonite forms that appear to be special to the Mediterranean area.

The late Dr. Reynès, of Marseilles, collected, figured, and described these Cephalopods, which were chiefly obtained from the Margaritatus-beds at Clapier, Bosc, Rivière, Tournemire; and has given the following remarkable list ${ }^{2}$ from this portion of the Department of the Aveyron :

\section{Cephalopoda.}

Belemnites el ongatus, Mill.

- niger, Mill.

- breviformis, Voltz.

Nautilus, sp.

Ammonites spinatus, Brug.

- margaritatus, Montf.

- mimatensis, d'Orb.

- Egion, d'Orb.

- Ragazzonii, Hauer.

- acanthoides, Reynès.

- pseudoradians, Rey.

- Nilssoni, Hébert.
Ammonites Algovianus, Oppel.

$\begin{array}{ll}\text { - } & \text { Alberti, Rey. } \\ \text { - } & \text { Herbeti, Rey. } \\ \text { - } & \text { ruthenensis, Rey. } \\ \text { - } & \text { Partschi, Stur. } \\ \text { - } & \text { Boscensis, Rey. } \\ \text { - } \quad \text { Loscombi, Sow. } \\ \text { - } \quad \text { Kurrianus, Oppel. } \\ \text { - } \quad \text { instabilis, Rey. } \\ \text { - } \quad \text { Fieldingi, Rey. } \\ \text { - } \quad \text { plainspira, Rey. } \\ \text { - } \quad \text { disciformis, Rey. }\end{array}$


Ammonites frondosus, Rey.

- Coquandi, Rey.

- Maresi, Rey.

- Woodwardi, Rey.

Turritella Zieteni, Quenst.

Chemnitzia undulata, Benz.

Cryptænia expansa, Sow.
Ammonites Spinelli, Hauer.

- lineatus, Quenst.

- globosus, Ziet.

- Phillipsi, IIauer.

Gasteropoda.

Pleurotomaria Amalthei, Quenst.

Turbo Dunkeri, Goldf.

Trochus imbricatus, Sow.

\section{LAMELLIBRANCHIATA.}

Pholadomya Heberti, Rey.

Nucula Palmæ, Suw.

- Bruni, Rey.

- complanata, Phil.

- variabilis, Ziet.

- acuminata, v. Buch.

Venus bombax, Quenst.

Arca strigillata, Münst .

- Sauvairei, Rey.

Cucullæa Mïnsteri, Goldf.

Avicula cygnipes, Phill.

Cardium cucullatum, Goldf.

Plicatula Parkinsoni, Deslong.

- pectinoides, Lamk.

Pecten æunivalvis, Sow.

Lima Hermanni, Goldf.

Ostrea Maccullochii, Sow.

BRACHIOPODA.

Terebratula Ruthenensis, Rey.

- perforata, Piette.

- Heyseana, Deslong.

Rbynchonella Boscensis, Rey.

Rhynchonella liasica, Rey. rimosa, von Buch.

Spiriferina verrucosa, von Buch.

- rostrata, Schloth.

\section{Echinodermata.}

Diademopsis Cotteaui, Rey.

Eugeniocrinus, sp.

Pentacrinus basaltiformis, Mill.

\section{The Zone of Amaltilues spinatus.}

Synomyms. - "Upper portion of the Micaceous Marls," De la Beche, 'Geol. Trans., 2nd ser., vol. ii, 1829. "Amaltheenthone" (pars sup.), Queustedt, 'Flözgebirge," p. 540, 1843. “Marnes à Plicatules,” Marcon, “Jura Saliuois,' p. 51, 1846. “ Region des Amm. costrtus," Oppel, 'Mittl. Lias Schwabens,' p. 23, 18.53. "Die Schichten des Amm. spinalus," Oppel, 'Iuraformation,' p. 138, 1856. "Spinatus-bed," Wright, 'Quart. Journ. Geol. Soc.,' vol. xiv, p. 25, 185S. "Thone mit Amm. spinatus," Ewald, " Sitz. d. Berl. Akad., p. 349, 1559. "Horizont von Amm. spinatus," Wagener, 'Lias von Falkenhagen,' ]S60. "Zone of Amm. spinatus," Wright, 'Fossil Asteroidea, Palæont. Soc.,' 
vol. 1862. "Zone des Am. spinatus," Schlönbach, 'Eisenstein des mittl. Lias.,' p. 489, 1863. "Schichten des Ame. spinatus," Emerson, 'Die Liasmulde von Markoldendorf," p. 35, 1870. “Zone àPecten aquivalvis" (pars sup.), Dumortier, 'Etudes Pal. Bassin du Rhône,' tom. iii, p. 213, 1869. " Marlstone Rock-bed" (pars), Judd, "Mem. on the Geol. of Rutland," 'Mem. of Geol. Survey,' 1875. "Zone of Am. spinatus," Tate and Blake, 'Yorkshire Lias,' p. 118, 1876. "The spinatus zone," Rev. Dr. Fred. Smithe, 'Trans. Cotteswold Nat. Club for 1876,' p. 349.

The bed with Amaltheus spinatus is so closely united with the zone of Amal. margaritatus that it appears to form the upper part of the Marlstone Rock-bed in the Midland Counties. It in general consists of a light-coloured, friable, sandy marlstone, containing many nodules, rock fragments, and fossiliferous concretions which form inconstant bands in the mass of the strata, and yield a considerable number of organic remains at Grettan, Alderton, and Churchdown Hills. I have collected Amaltheus spinatus, Belennites breviformis, Lima Hermanni, Terebratula punctata, and Spiriferina rostrata from these nodules.

At Down Cliff, on the coast of Dorset, the Spinatus-beds form the uppermost portion of the Micaceous Marls of De la Beche. They consist of brown sands and sandstones in which Amaltheus spinatus is the characteristic Cephalopod, and with it many Gastropods and other fossils; the light-brown sands are overlain by non-fossiliferous clay, on which rests a remarkable bed of Marlstone containing a great number of Gastropods, with their shells in a fine state of preservation; as the rock is very hard and ferruginous these beautiful fossils are extracted with difficulty. I have collected from this bed Amaltheus spinatus, Brug., Belemnites breviformis, Voltz., Pleurotomaria precatoria, Deslong. $P$. bitorquata, Deslong., $P$. rustica, Deslong., $P$. mirabilis, Deslong., $P$. procera, d'Orb., Cryptenia expansa, Sow., Straparollus sinister, d'Orb.; and resting on this remarkable conglomerate of well-preserved shells are beds of Upper Lias Limestone, with Harpoceras serpentinum, Rein., Harp. radians, Rein., and Harp. Holandiei, d'Orb. So closely do these strata repose upon the Middle Lias fauna of the Spinatus-zone that they all appear to belong to the same bed.

In Yorkshire the upper portion of the Middle Lias consists of argillaceous shales with bands of ironstone, some of these belong to the Margaritatus, others to the Spinatus-beds; the workable beds of liassic ironstone are now ascertained to be found only in these two horizons. The Spinatus-beds are well seen at Hawsker bottoms, where Aw. spinatus = Hawskerensis, Simp., is found in beds of red ironstone doggers, the probable equivalont of the Cleveland main seam, as well as in shale interstratified therewith. Another section of the zone is found at Kettleness, where the beds form the base of the cliff, and at Old $\mathrm{Nab}$, where the strata are very fossiliferous, and exhibit a fine profile of the whole. The following section was carefully measured by MM. Tate and Blake, ${ }^{1}$ as it affords a good type of the ironstone series of the Yorkshire coast. 
Section of the Ironstone series at old Nab, near Staithes.

\begin{tabular}{|c|c|c|c|}
\hline No. & Petrology. & $\begin{array}{c}\text { THICK- } \\
\text { NESS. }\end{array}$ & Organic Contents. \\
\hline 1 & $\begin{array}{l}\text { Black, micaceous, marly shales, with } \\
\text { a row of limestone balls .............. }\end{array}$ & $\begin{array}{c}\text { ft. in. } \\
15\end{array}$ & $\begin{array}{l}\text { Pleuromya costata, Pecten aquivalvis, Pholadomya } \\
\text { costata, Pinna spathulata. }\end{array}$ \\
\hline 2 & Laminated shales ........................ & $\begin{array}{ll}0 & 9\end{array}$ & \\
\hline 3 & $\begin{array}{l}\text { Friable sandy shales, with limestone } \\
\text { nodules at the bottom } \ldots \ldots \ldots \ldots \ldots \ldots \ldots\end{array}$ & 16 & Pleuromya costata, Rhynchonella lineata. \\
\hline 4 & Greyish-brown marly sandstone ......... & $0 \quad i$ & $\begin{array}{l}\text { Amal. spinatus, Pleuromya costata, Pholadomya } \\
\text { costata, Pecten aquivalvis, Unicardium sub- } \\
\text { globosum, Modiola scalprum, Limea acuti- } \\
\text { costa, Protocardium truncatum, Rhynchonella } \\
\text { tetraëdra. }\end{array}$ \\
\hline 5 & 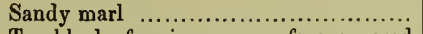 & & \\
\hline 6 & $\begin{array}{l}\text { Top block of main seam surface, covered } \\
\text { with small branching fucoids ........ }\end{array}$ & 30 & $\begin{array}{l}\text { Amal. spinatus, Pecten aquivalvis, } P \text {. lunularis, } \\
P \text {. substriatus, Unicardium janthe, Pleuromya } \\
\text { rostrata, } R \text {. lineata. }\end{array}$ \\
\hline 7 & 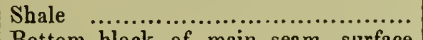 & & \\
\hline 8 & $\begin{array}{l}\text { Bottom block of main seam, surface } \\
\text { covered with long tortuous fucoids... }\end{array}$ & & \\
\hline 9 & 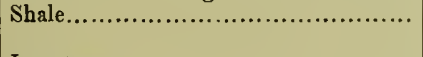 & 08 & $\begin{array}{l}\text { Pholadomya ambigua, Plicatula spinosa, Ostrea } \\
\text { submargaritacen, Rhynchonella lineata. }\end{array}$ \\
\hline 10 & Ironstone ....... & & \\
\hline 11 & Shale.............................. & & \\
\hline 12 & 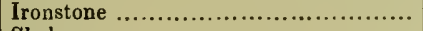 & 4 & \\
\hline 13 & 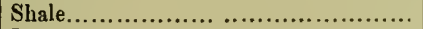 & 6 & \\
\hline 14 & 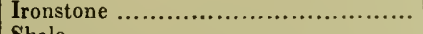 & & Belemnites breviformis. \\
\hline 15 & & 010 & $\begin{array}{l}\text { Belem. breviformis, Pecten aquivalvis, MLonotis } \\
\text { cygnipes. }\end{array}$ \\
\hline 16 & 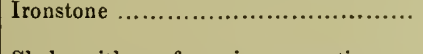 & $\begin{array}{ll}0 & 6\end{array}$ & $\begin{array}{l}\text { Monotis cygnipes, Arcomya arcacea, Ostrea sub- } \\
\text { margaritacea, Rhynchonella tetraedra. }\end{array}$ \\
\hline 17 & $\begin{array}{l}\text { Shale with a ferruginous parting or } \\
\text { narrow ironstone band..................... }\end{array}$ & 08 & $\begin{array}{l}\text { Pecten aquivalvis, } P \text {. lunularis, Monotis cygnipes, } \\
\text { Plicatula spinosa, Rhynchonella calcicosta, } \\
\text { Waldheimia punctata. }\end{array}$ \\
\hline 18 & Ironstone ................... & 0 & Lima Hermanni, Rhynchonella tetraedra. \\
\hline 19 & Marly shale $\ldots \ldots \ldots \ldots \ldots \ldots \ldots \ldots \ldots \ldots \ldots \ldots \ldots \ldots \ldots$ & 26 & Pecten aquivalvis. \\
\hline & Total & 218 & \\
\hline & \multicolumn{3}{|c|}{ Zone of Amaltheus margaritatus. } \\
\hline 20 & \multicolumn{3}{|l|}{ Bottom seam of ironstone. } \\
\hline
\end{tabular}

My much esteemed friend, the late Professor John Phillips, F.R.S., ${ }^{1}$ who had often examined the Yorkshire Coast with great care, observed that " the Ironstone courses, which have been worked to some extent, may be examined with the greatest advantage in the cliffs and on the shore to the eastward of Staithes, for a space of three fourths of a mile, with .. . the superincumbent shales" in natural position. "These present hard shales, with septaria and petroleum, jet rock and hard shale below it, and softer shales enclosing one hard bed, which elsewhere is ironstone. Then the ordinary ironstone bands appear. These,

1 'Gcology of Yorkshire; the Yorkshire Coast,' 3rd edition, p. 156, 1875. 
examined on five different occasions, have presented some local differences, partly laid bare in the working, partly by waste of the coast." The alternations of shale and ironstone, with sandy shale forming the Ironstone series or Spinatus-beds, and the laminated sandstone shale, with occasional ironstone balls, forming the Marlstone series or Margaritatus-beds, are well seen in this section, which is intended to give a fair average idea of the whole when made in 1867 .

FIg. 4.-Section east of Staithes Harbour, Yorkshire Coast.

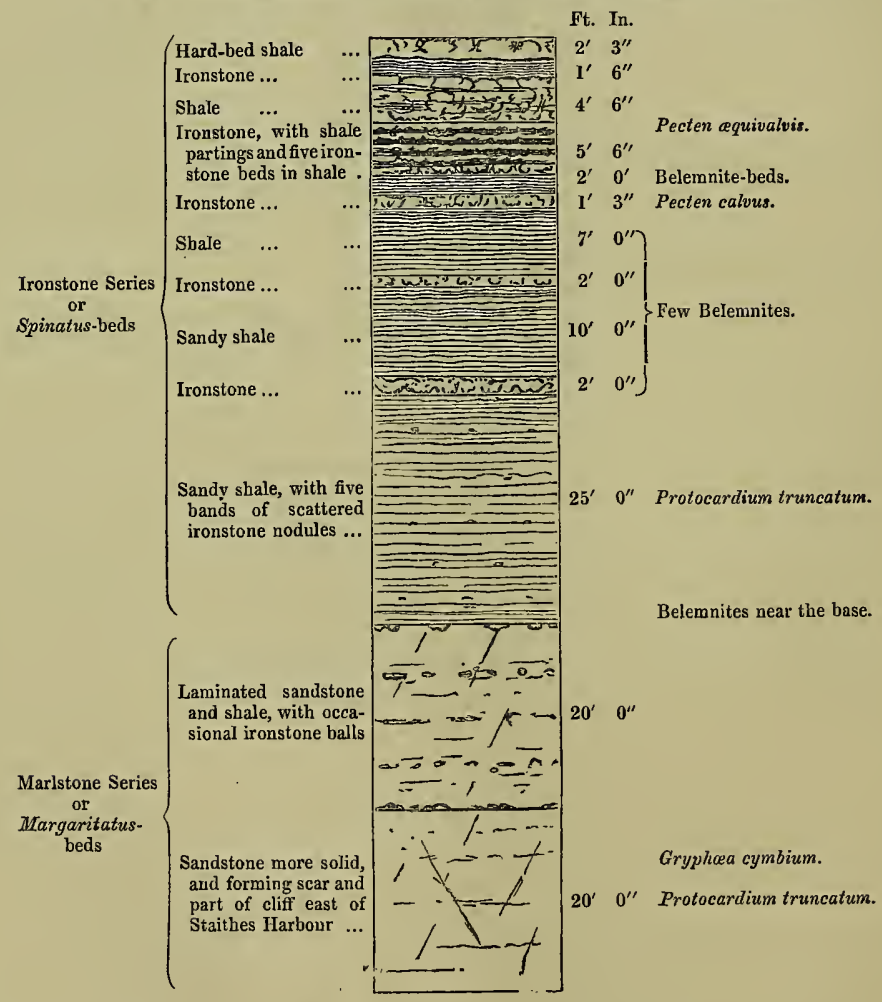

"In the above section the Ironstone courses above the Marlstone are in all 16 feet 6 inches thick, and the shales above and below them (including the sandy portions below) are 45 feet 6 inches (including the hard-bed shale above the thicker Ironstones, 50 feet 6 inches). Total from 62 to 67 feet. The shales are in some places 8 to 10 feet thicker." 1 
On the south side of Portree Harbour, Isle of Skye, Professor Tate found the Spinatusbeds to consist of a hard, calcareous, yellowish-grey, thick-bedded sandstone, about 40 feet in thickness; the uppermost 5 feet of the Rock-bed is more bluish and calcareous, and appears to form the basement-bed of the Upper Lias; from these strata he collected the following Molluscan fauna.

\section{Fossils from the Spinatus-zone at Portree, Skye.}

Amaltheus spinatus, Brug.

- margaritatus, Montf.

Belemnites paxillosus, Schloth.

- elongatus, Sow.

- clavatus, Blainv.

- micrastylus, Phil.

Cryptænia expansa, Sow.

Pecten æquivalvis, Sow.

Lima Hermanni, Voltz.

Plicatula spinnsa, Sow.

Avicula novemcostæ, Brown.

Gresslya Seebachii, Brauns.
Astarte Amalthei, Quenst.

Terebratula punctata, Sow.

Rhynchonella acuta, Sow.

Pecten liassinus, Tate.

Ostrea cymbium, Lamk.

Mytilus scalprum, Sow.

Cypricardia cucullata, Munst.

Waldheimia resupinata, Sow.

Rhynchonella tetraedra, Sow.

Pentacrinus Amalthei, Quenst.

Ditrypa quinquesulcata, Münst.

\section{Palcontology of the Zone of Amaltheus spinatus.}

\section{VERTEBRAT'A.}

Plesiosaurus, sp.

Ichthyosaurus, sp.

\section{Cephalopoda.}

Amaltheus spinatus, Brug.

- Engelhardti, d'Orbig.

- margaritatus, MIont.

Phylloceras zetes, d'Orbig.

Stephanoceras Holandrei, d'Orbig.

Belemnites clavatus, Blainv.

- apicicurvatus, Blainv.

- vulgaris, Young \& Bird.

Belemnites cylindricus, Simp.

$$
\begin{array}{ll}
\text { - } & \text { paxillosus, Schlot. } \\
\text { - } & \text { longiformis, Blake. } \\
\text { - } & \text { compressus, Stahl. } \\
\text { - } & \text { breviformis, Voltz. } \\
\text { - } & \text { rudis, Phil. } \\
\text { - } & \text { microstylus, Phil. }
\end{array}
$$

\section{Gasteropoda.}

Cerithium acriculum, Tate.

- liassicum, Moore.

Chemnitzia Blainvillei, Mü̈nst.

- semitecta, Tate.

- nuda, ALünst.

Cryptænia consohrina, Tate.

- expansa, Sow.
Dentalium elongatum, Miünst.

Eucyclus conspersus, Tate.

- undulatus, Phil.

- cingendus, Tate.

- nireus, d'Orbig.

Nerita alternans, Tate.

Pitonnillus turbinatus, Tate. 
Pleurotomaria helicinoides, Römer.

$$
\begin{array}{ll}
-\quad & \text { rustica, Deslong. } \\
\text { - } & \text { undosa, Deslong. } \\
\text { - } \quad \text { similis, Sow. }
\end{array}
$$

Turbo latilabrus, Stoliczka.
Turbo lineatus, Moore.

- cyclostoma, Benz.

- aciculus, Stolicza.

Actæonina Ilminsterensis, Moore.

- chrysalis, Tate.

\section{LAMELLIBRANCHIATA.}

Ostrea sportella, Dumort.

- submargaritacea, Brauns.

Anomia numismalis, Quenst.

Pecten æquivalvis, Sow.

- lunularis, Römer.

- verticillıs, Stoliczka.

- substriatus, Römer.

Hinnites tumidus, Ziet.

Lima eucharis, d'Orbig.

- Hermanni, Voltz.

Limea acuticosta, Münst.

- Juliana, Dumort.

Plicatula spinosa, Sow.

- calva, Deslong.

Monotis inæquivalvis, Sow.

- cygnipes, Young \& Bird.

- substriatus, Münst.

- calva, Schlönb.

- papyria, Quenst.

Inoceramus substriatus, Münst.

Perna Lugdunensis, Dumort.

Pinna spathulata, Tate.

Modiola scalprum, Sow.

- Thiollieri, Dumort.

- numismalis, Oppel.

Mytilus Aviothensis, Buvig.

Nucula cordata, Goldf.

Macrodon Clevelandicus, Tate.

- intermedius, Simp.

- Buckmani, Rich.

Leda subovalis, Goldf.
Leda Galathea, $d^{\prime} O r b$.

- graphica, Tate.

Astarte striato-sulcata, Römer.

- rugata, Quenst.

Lucina pumila, Münst.

Cardita multicosta, Phil.

Protocardium truncatum, Sow.

Cardinia lævis, Young \& Bird.

Cypricardia cucullata, Münst.

Myoconcha decorata, Münst.

Hippopodium gigas, Tate.

Trigonia Lingonensis, Dumort.

Tancredia Broliensis, Buvig.

- lucida, Terq.

- longicostata, Buvig.

Tellina Lingonensis, Dumort.

- fabulis, Simp.

Unicardium subglobosum, Tate.

Pholadomya ambigua, Sow.

- Simpsoni, Tate.

- lunata, Simp.

Goniomya hybrida, Münst.

Pleuromya costata, Young \& Bird.

Gresslya intermedia, Simp.

Arcomya areacea, Seebach.

- concinna, Tate.

- longa, Buvig.

Ceromya bombax, Quenst.

- petricosa, Simp.

- sublævis, Tate.

Thoracia Grotiana, Brauns.

\section{BRACHIOPODA.}

Lingula sacculus, Chapius.

Spiriferina Walcotti, Soro.

- Signiensis, Buvig.

Waldheimia punctata, Sow.

$$
\text { - resupinata, Sow. }
$$

Rhynchonella tetraedra, Sow.
Rhynchonella lineata, Young \& Bird.

$$
\begin{aligned}
& \text { - } \quad \text { acuta, Sow. } \\
& \text { - } \quad \text { capitula, Tate. } \\
& \text { - } \quad \text { fodinalis, Tate. } \\
& \text { - } \quad \text { calcicosta, Quenst. }
\end{aligned}
$$




\section{ANNelid A.}

Ditrypa circinata, Tate.

- capitata, Phil.

Pentacrinus, sp.

Cidaris amalthei, Quenst.

Ditrypa quinquesulcata, Münst.

Serpula limax, Goldf.

\section{Echinodermata.}

Foreign Correlations.-Dr. Oppel ${ }^{1}$ has shown that the upper half of the Swabian Middle Lias admits of the following division :

Upper Lias-Posidonomya-beds.

\begin{tabular}{|c|c|c|c|}
\hline Horizons. & Petrology. & $\begin{array}{l}\text { THICK } \\
\text { NESS. }\end{array}$ & Organic Remains. \\
\hline $\begin{array}{l}\text { Amaltheus } \\
\text { SPinatus } \\
\text { beds }\end{array}$ & $\begin{array}{l}\text { Light argillaceous marly } \\
\text { strata, alternating with } \\
\text { clays } \ldots \ldots \ldots \ldots \ldots \ldots \ldots \ldots\end{array}$ & feet. & $\begin{array}{l}\text { Amal, spinatus, Belemnites breviformis, } B \text {, crassus, } \\
\text { Lima Hermanni, Spiriferina rostrata, Rhyn- } \\
\text { chonella quinqueplicata, Wald.punctata, Wald. } \\
\text { subovoides. }\end{array}$ \\
\hline $\begin{array}{l}\text { Upper } \\
\text { MARGARITATUS } \\
\text { beds }\end{array}$ & $\begin{array}{l}\text { Blue clay with geodes, pyri- } \\
\text { tic nodules, and separate } \\
\text { argillaceous marly strata }\end{array}$ & 45 & $\begin{array}{l}\text { Amal. margaritatus, Phylloceras zetes, Belemnites } \\
\text { paxillosus, Bel. compressus, Chemnitzia undu- } \\
\text { lata, Turbo paludinaformis, Leda acumixata, } \\
\text { Pentacrinus lavis. }\end{array}$ \\
\hline $\begin{array}{l}\text { Under } \\
\text { Margaritatus } \\
\text { beds }\end{array}$ & $\begin{array}{l}\text { Bluish clay, with argilla- } \\
\text { ceous marls ................. }\end{array}$ & 10 & $\begin{array}{l}\text { Lyt. fimbriatus, Aeg. globosus, Harpoceras Nor- } \\
\text { mannianum, Belemnites umbilicatus, B. elon- } \\
\text { gatus, B. longissimus. }\end{array}$ \\
\hline
\end{tabular}

Amaltheus margaritatus begins bere. .

Henleyi-bed. Aegoceras Henleyi. Inoceramus ventricosus.

The Petrology of the Spinatus-bed in Swabia differs from the blue clays of the Margaritatus-bed on which the lighter argillaceous Marls rest, and the organic remains have enabled Dr. Oppel to define their limits, as he has done in the above profile.

In North Germany, Dr. U. Schlönbach ${ }^{2}$ adopted a division of the upper portion of the Middle Lias, which closely resembles the preceding section of the South German series, and this careful observer has given a very instructive profile of an Ironstone exposure near Liebenburg, where the spinatus were found to be very distinct from the margaritatus beds.

1 'Jura Formation,' p. 139, 1856.

2 "Den Eisenstein des mittleren Lias N.W. Deutschland," "Zeitsch d. Deutschen geol. Gessellsch. Jahry.,' vol, xv, p. 489, 1863. 


\section{Hils-Eisenstein, Middle Lias, near Liebenberg.}

\begin{tabular}{|c|c|c|c|}
\hline Horizons. & Petrology. & $\begin{array}{c}\text { THICK- } \\
\text { NESS. }\end{array}$ & Organic Remains. \\
\hline $\begin{array}{l}\text { Spinatus } \\
\text { bed. }\end{array}$ & $\begin{array}{l}\text { Thick grey and brownish } \\
\text { clay, with ironstone no- } \\
\text { dules and "Nagelkalk } \\
\text { Schichten." } \\
\text { Greyish-blue clay ............ }\end{array}$ & $\begin{array}{l}\text { feet. } \\
15\end{array}$ & $\begin{array}{l}\text { Appears to be non-fossiliferous. } \\
\text { Amaltheus spinatus only, and very abundant in } \\
\text { upper half. }\end{array}$ \\
\hline $\begin{array}{l}\text { Upper } \\
\text { MaRGARTTATUs } \\
\text { bed }\end{array}$ & Greyish-blue clay ........... & 15 & $\begin{array}{l}\text { Amal. margaritatus abundant; Belemnites com- } \\
\text { pressus in the lower part. }\end{array}$ \\
\hline $\begin{array}{l}\text { Lower } \\
\text { MaRgaritatus } \\
\text { and } \\
\text { HENLEYI beds }\end{array}$ & $\begin{array}{l}\text { Grey, somewhat oolitic } \\
\text { limestone, not very hard, } \\
\text { half a mètre thick......... }\end{array}$ & 18 & $\begin{array}{l}\text { Amal. margaritatus, Phylloceras Loscombi, Lyt. } \\
\text { fimbriatum, Aeg. Henleyi, Belemnites paxillosus, } \\
\text { Bel. clavatus, Pleurotomaria granosa, Rhyn- } \\
\text { chonella triplicata, Terebratula numismalis. }\end{array}$ \\
\hline \multirow[t]{2}{*}{$\begin{array}{l}\text { Raricostatus } \\
\quad \text { and } \\
\text { OBtusus beds }\end{array}$} & $\begin{array}{l}\text { Thick blue clay, with sepa- } \\
\text { rate rockybands laid close } \\
\text { on one auother ............ }\end{array}$ & ? & $\begin{array}{l}\text { Aegoceras planicosta, Aeg. Ziphus, Aeg. lacu- } \\
\text { natum, Arietites raricostatus, Belemnites } \\
\text { acutus. }\end{array}$ \\
\hline & Marly limestone band ....... & ? & \\
\hline $\begin{array}{l}\text { Semicostatus } \\
\text { beds }\end{array}$ & $\begin{array}{c}\text { Thick blue clay, in parts } \\
\text { speckled with reddish } \\
\text { points } \ldots \ldots \ldots \ldots \ldots \ldots \ldots\end{array}$ & $?$ & $\begin{array}{l}\text { Arietites semicostatus, }=\text { geometricus, Led. Ro- } \\
\text { mani. }\end{array}$ \\
\hline $\begin{array}{l}\text { BuckLandi } \\
\text { beds }\end{array}$ & $\begin{array}{l}\text { Thick bluish-grey clay with } \\
\text { geodes, above alternating } \\
\text { with reddish-brown clay }\end{array}$ & $?$ & \\
\hline $\begin{array}{l}\text { ANGULATUM } \\
\text { beds }\end{array}$ & $\begin{array}{l}\text { Small compact limestone } \\
\text { hed with Cardinias and } \\
\text { other Mollusca ............. }\end{array}$ & $?$ & Aegoceras angulatum, Cardinia concinna. \\
\hline $\begin{array}{l}\text { Angulatum } \\
\text { beds }\end{array}$ & $\begin{array}{l}\text { Sandy clays and shales, } \\
\text { passing downwards into } \\
\text { blue clay } \ldots \ldots \ldots \ldots \ldots \ldots\end{array}$ & $?$ & Aegoceras angulatum. \\
\hline $\begin{array}{l}\text { Plamorbis } \\
\text { beds }\end{array}$ & 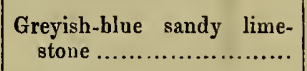 & $?$ & $\begin{array}{l}\text { Aegoceras Johnstoni, Pecten Hehli, Lima suc- } \\
\text { eincta, Pinna Hartmanni. }\end{array}$ \\
\hline
\end{tabular}

The entire thickness of the Lias in this section attains at least from 110 to 120 mètres. 
Dr. Emerson found the Spinatus-Schichten well exposed at Lüthorst, near Markoldendorf, and in a soft, greyish, shaley clay he collected Amaltheus spinatus, Brug., Belemnites clavatus, Mill., Turbo paludinaforniis, Schüb. The rich Ammonite-ironstone, which was formerly worked between Lüthorst and Hünnesrück, probably belonged to this zone.

A. von Strombeck ${ }^{2}$ described the upper beds of the Amaltheenthone with Amal. spinatus in the Helmsted Jura; and Senator H. Römer found the same in his garden near Hildesheim with Anal. spinatus, Gresslya ventricosa, Limea acuticosta, and Pecten aquivalvis. Other localities described in the works of Ewald, Bornemann, and Wagener, might be enumerated to show that this upper portion of the Amaltheenthone is widely distributed in North Germany.

In France Professor E. Deslongchamps ${ }^{3}$ gives a good profile of the Lias à Belemnites near Caen, in which we find (No. 4) the thick limestone separated by thin argilocalcareous layers with Aegoceras Bechei, Lytoceras finbriatum, Belemnites clavatus, Gryphaa cymbium, Terebratula subovoides, Wald. punctata, Rhyn. tetraedra, Rhyn. rimosa, and Spiriferina rostrata. This bed is overlain by (No. 5) a bank of sandy limestone, in part finely oolitic, containing Amal. spinatus, Amal. margaritatus, Belemnites niger, B. arcuarius, Pleurotomaria suturalis, Pecten cequivalvis, P. disciformis, Gryphaa cymbium, Terebratula quadiifida, T. punctata, T. Edwardsii, Rhyn. tetraedra, and Spiriferinu rostrata. This appears to be the equivalent of the Marlstone rock-bed of English authors, as it is overlain by (No. 6) the Couche à Leptæna, which, as we shall presently learn, forms the lower ber of the Upper Lias. Amaltheus spinatus is collected in other localities in Calvados; and is found likewise at Avesnes, Doubs, at Saint-Amand Cher; at Grundershofen and Selzbrumnen, Bas Rhin ; in the Departments of Meurthe, Moselle, Lozere, Haute-Saône, and Aveyron. In the Jura Department Marcou separated his "Marnes à Plicatules," with Amal. spinatus, Belennites Bruguerianus, Lima Hermanni, Plicatula spinosa, Gryphca cymbium, from the underlying beds containing Amal. margaritatus, and was the first to point out the important differences which exist between these two zones.

In Luxembourg Amal. spinatus has been collected from the "Macigno d'Aubange," near Athus, which is considered by Chapuis and Dewalque ${ }^{4}$ as the equivalent of the Marlstone and ironstone of English authors.

Dumortier $^{5}$ says that Amal. spinatus is found only in the uppermost portion of the Middle Lias, in the horizon of Limea acuticosta, where it is accompanied by Avicula vol. xxii.

1 "Die Liasmulde von Markoldendorf ;" 'Zeitsch. d. Deutschen geol. Gessellsch.' Jahrg., 1870, p. 303,

2 'Geognost. Karte des Herzog. Braunschweig,' 1856.

3 'Etudes Jurassiques Infér. de Normandie,' pp, 59-60, 1864.

4 'Fossiles des Terr. second. de Luxembourg,' p. 12, 1853.

5 'Etudes Paléont. du Bassin du Rhône,' tom. iii, p. 213, 1869. 
cygnipes and Cardinia crassissima; and he observes that the appearance of this beautiful species has only an instant of duration in time, for in all the Basin of the Rhone it occupies only a very limited vertical space, whilst the remains of Amaltheus margaritatus. fills nearly all the enormous thickness of the Middle Lias.

Table showing the extension of the Middle Lias in the British Islands, Belgium, France, Switzerland, Germany, Austria, and Italy, with indications of the Liasian Ammonitezones found in some typical regions of the European area. ${ }^{1}$

\begin{tabular}{|c|c|c|c|c|c|c|c|c|c|c|c|c|c|c|c|c|}
\hline \multirow{2}{*}{$\begin{array}{l}\text { Ammonite-zones } \\
\text { of the } \\
\text { Middle Lias. }\end{array}$} & \multicolumn{3}{|c|}{ British Islands. } & \multirow{2}{*}{ 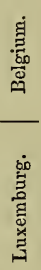 } & \multicolumn{6}{|c|}{$\begin{array}{c}\text { France, } \\
\text { Departments of. }\end{array}$} & \multicolumn{2}{|c|}{ 惢 } & \multicolumn{2}{|c|}{ Germany. } & \multirow{2}{*}{ 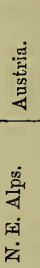 } & \multirow[b]{2}{*}{ 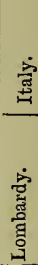 } \\
\hline & 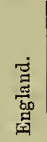 & 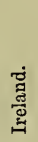 & 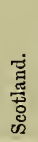 & & 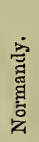 & $\begin{array}{l}\dot{\delta} \\
\dot{1} \\
\dot{0} \\
8 \\
8\end{array}$ & $\begin{array}{l}\text { हีं } \\
\text { ह્र }\end{array}$ & $\begin{array}{l}\text { हैं } \\
\text { छे }\end{array}$ & 㺃 & 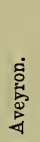 & 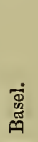 & 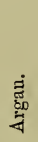 & 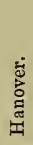 & 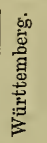 & & \\
\hline SPINATUS ....... & * & $\cdots$ & * & * & * & * & $\cdots$ & * & * & $*$ & $\cdots$ & $\ldots$ & * & * & $\cdots$ & * \\
\hline MARGARITATUS ...... & * & $\cdots$ & * & $\cdots$ & * & * & * & * & * & * & $\cdots$ & * & * & * & * & $*$ \\
\hline HENLEYI $\quad \ldots \ldots \ldots \ldots$ & * & $\cdots$ & * & $\cdots$ & * & * & * & * & * & * & * & * & * & * & * & * \\
\hline IBEX $\ldots \ldots \ldots \ldots \ldots \ldots$ & * & $*$ & $\cdots$ & $\cdots$ & * & * & * & * & ‥ & * & $\cdots$ & * & * & * & 米 & $\cdots$ \\
\hline JAMESONI $\ldots \ldots \ldots \ldots$ & * & * & $*$ & * & * & * & $\cdots$ & * & $\cdots$ & * & $\cdots$ & * & * & $*$ & * & * \\
\hline ARMATUM ...... & * & * & * & $\cdots$ & $\cdots$ & * & $\cdots$ & * & .. & $\cdots$ & $\cdots$ & $\cdots$ & * & * & & $\cdots$ \\
\hline
\end{tabular}

In the above table I have separated the Armatum from the Jamesoni zone, although united with it in the text, because the stratum with Aegoceras armatum forms a good Ammonite-zone, although most of its other Molluscan Fauna ascend into higher beds. When the Armatum-group is described and figured it will be shown that a most interesting series of forms range themselves around the original Sowerbyan type, although differing in many specific characters from that Ammonite; the whole forming a remarkable assemblage of the Aggoceratide, which appeared with the dawn of the Middle Lias, and had, it would seem, a very limited life in time.

1 In addition to the works already cited in the description of the different zones of the Middle Lias on the European Continent I have to add 'Géologie der Schweiz,' by Professor B. Studer, Zurich, 1851 ; 'Dîe Cephalopoden aus dem Lias der Nordöstlichen Alpen," by Franz Ritter von Hauer, Wien, 1856; 'Studii geologici et paleontologici sulla Lombarảia,' by Stoppani, Milan, 1857; 'Der Jura in Franken, Schwaben, und der Schweiz, verglichen nach seinen palæontologischen Horizonten,' by Dr. W. Waagen, Munich, 1864. 
A Table showing the stratigraplical distribution of the Ammonoida in the Middle Lias of the British Islands.

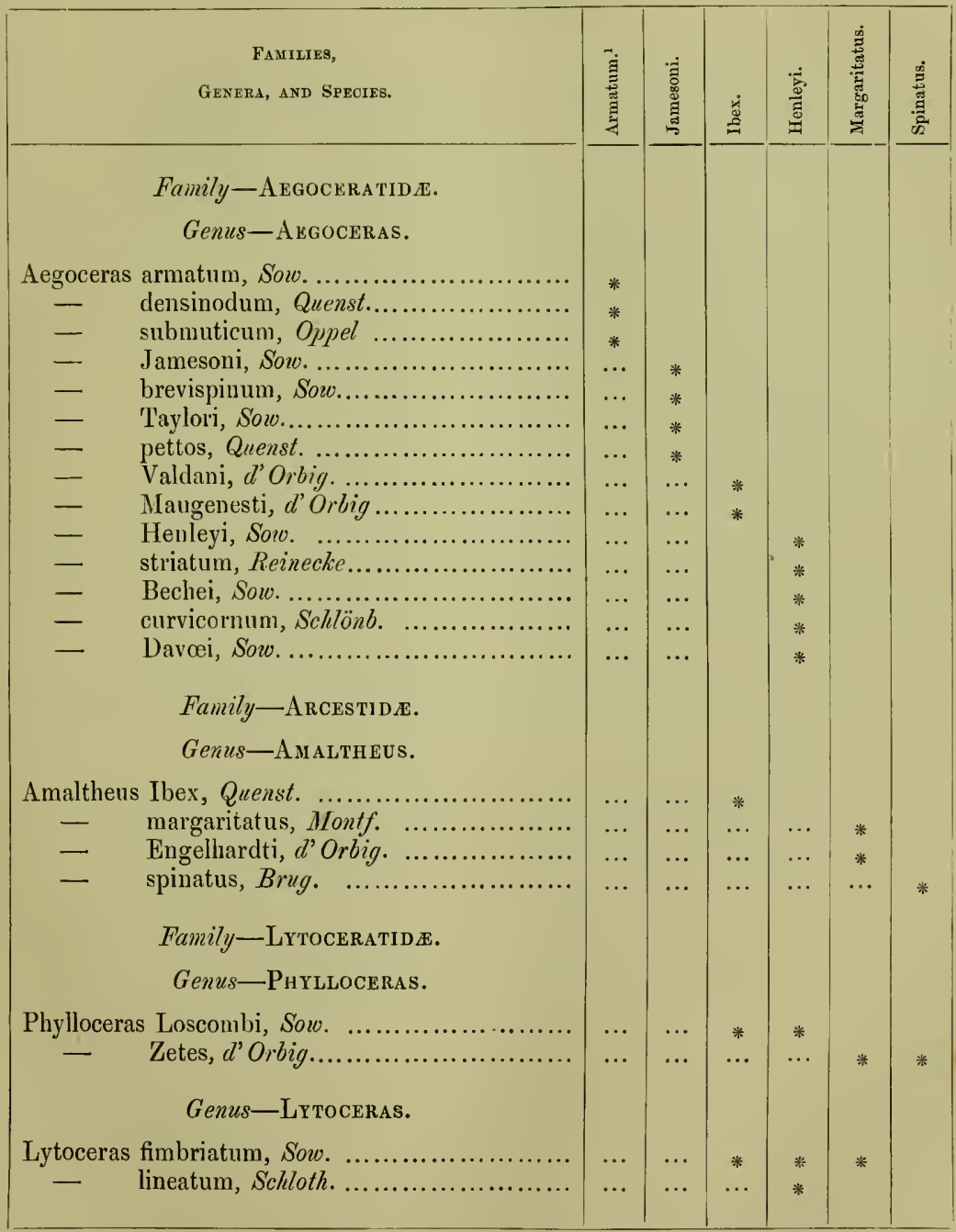

1 In this table I have separated the drmatum from the Jamesoni zone, because Aeg. armatum and its allied forms are limited in their range to the lowest portion of the latter, and are the most characteristic fossils of the basement bed of the Middle Lias. 


\section{THE UPPER LIAS.}

I include in the Upper Lias all the argillaceous, shaley, laminated, marly, and arenaceous deposits interposed between the Spinatus-beds of the Middle Lias, and the basement-beds of the Inferior Oolite, containing Harpoceras Murchisona. This group of strata nearly corresponds to the "Posidonienschiefer mit Stinksteinen" and "Lichtgraue Kalkmergel mit Ammonites jurensis" of Professor Quenstedt, ${ }^{\mathrm{I}}$ and the "Neuvième Etage; Toarcien" of the late Professor Alcide d'Orbigny."

The Upper Lias exhibits great differences in thickness as we follow the beds northwards through the midland districts of England, in some parts of which it measures 300 feet, but rapidly diminishes in North Oxfordshire to 30, and disappears entirely in the south of that county. In South Lincolnshire it attains 200 feet, and thins away entirely in South Yorkshire, whilst in North-East Yorkshire it thickens out again, and forms some fine bold instructive sections on the Yorkshire coast.

The Petrology of this group, which in some parts of Gloucestershire is upwards of 300 feet in thickness, enables us to subdivide it into a lower portion, consisting of dark argillaceous, shaley, or thinly laminated beds, and an upper portion composed of marly, ferruginous strata, or fine yellowish and brownish sands.

By a careful study of the Palæontology of the Upper Lias I have been able to distinguish among the numerous organisms contained therein four faunas, having several well-defined species characteristic of each. The details of each of these zones will be given in the sequel.

It is very difficult to find a section in which all the zones are present and exposed in their natural sequence, so I select that of Frocester Hill, near Stonehouse, between Gloucester and Bristol, on the Midland Railway, as the best I know.

All the divisions of the Upper Lias are here seen in sitú, and may be satisfactorily studied in one day's work; and this instructive section may be afterwards advantageously compared with other exposures of the Liassic sands forming the Jurense-zone at Haresfield Beacon, a mile and a half from the railway-station, and at an elevation of 700 feet above the sea; in lane cuttings near Nailsworth; in sections at Uley Bury; Stinchcombe Hill; Wotton-under-Edge; and along Ozleworth Bottom; all localities of easy access, in which are well displayed the Liassic sands, and at the same time affording magnificent pictures of the vale scenery of Gloucestershire.

1 'Flötzgebirge Würtembergs,' pp. 213 and 267, 1843.

2 'Cours Élément. de Paléontologie et de Géologie stratigraphiques,' tom. ii, p. 463, 1852. 


\section{Fig. 5.-Section of Frocester Hill, near Stonehouse, between Gloucester and Bristol, Midland Railway.}

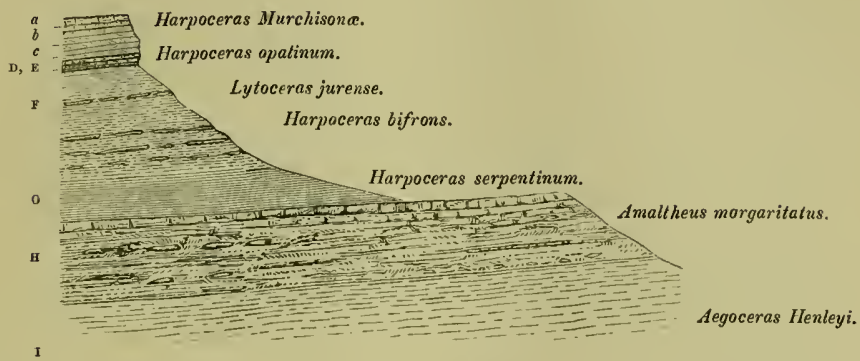

$a, b, c$. Inferior Oolite; $70 \mathrm{feet}=$ zone of Harpoceros. I/urchisonce.

D, E. Caleareo-ferruginous sandstone (Cephalopoda hed); 6 feet $\left\{\begin{array}{l}\text { zones of Harpoceras opali- } \\ \text { num and Lytaceras jurense. }\end{array}\right.$

F. Grey, yellow and brown sands, with inconstant and concretionary bands of calcareous sandstone; 150 feet ? = zone of Harpoceras bifrons.

G. Upper Lias shale; 80 feet $=$ zone of Harpoceras serpentinum.

H. Marlstoue; hard ealcareous sandstone, resting on brown and grey sands, with bands and nodules of ferruginous sandstone; $150 \mathrm{feet}=$ zone of Amaltheus margaritatus.

I. Middle Lias shale $=$ zone of Aegoceras Henleyi.

\section{Inferior Oolite.}

a. A fine-grained oolitic limestone, similar to the freestones of Birdlip, Painswick, and Leckbampton Hills; the upper beds exhibit a most remarkable example of oblique bedding, the flaggy layers of which rest horizontally on inclined beds of freestone ; thickness about

b. A coarse, light, cream-coloured, gritty, crystalline oolite, traversed at intervals by extremely crystalline shelly layers; a great part of the rock appears to be composed of fragments and plates of Crinoidal plates and spines of Echinida, and comminuted fragments of the shells of Mollusca. This white rock has a most remarkable lithological character, and glistens brilliantly when lit up by the sun's rays. The shelly and pisolitic seams which traverse this bed resemble those in the Pea-grit. The surface of weathered slabs exposes numerous microscopic objects ; the rock, in fact, is almost entirely composed of organic dibris, and measures about hard, fine-grained, oolitic, sandy limestone, of a light browu colour, lithologically different from $b$. It contains many fossil shells, which are extracted with difficulty, and passes into a bard yellow oolite with few fossils, attaining a thickness of from

[The lithological character of this rock is very different to that of $d$, on which it rests.] 


\section{The Cephalopoda Bed-Upper Lias.}

ZoNes of HaRpoceras opajinum and Lytoceras juRense.

D. A coarse, dark-brown, calcareo-siliceous rock, full of small, dark, flattened grains of hydrate of iron. It contains an immense quantity of fossils, but Ammonites and Belemnites are the dominant forms ; some of the hivalve shells are well preserved; the matrix adheres to their surfaces with such tenacity that they can seldom be cleaned without injury. The Ammonites and Nautili, for the most part, want the shell. Harpoceras opalinum and Rhynchonella cynocephala lie in the upper part of the bed, and Lytoceras jurense, Harpoceras insigne, Harp. variabile, Harp. striatulum, Belemnites, Nautili, and other Mollusea in the middle part; the lower part is not so fossiliferous; this bed measures

ZoNe of HaRpoceras bifrons.

E. A hard, coarse, brown mudstone, with hard irregular nodules of a calcareo-siliceous sandstone, highly micaceous and ferrnginous, and passing downwards into the sands

F. Fine, brown and yellowish, micaceous sands, passing into greyish coloured micaceous sands, with inconstant and concretionary bands of bighly calcareous sandstone; nodules of various sizes occur in these hauds, which are sometimes fossiliferous, containing chiefly Harpoceras bifrons in nodules with Belemnites....

ZoNe of Harpoceras Serpentinum.

G. Blue clay and shale, marked by the ontburst of springs and by pools of water on the terrace formed by the Upper Lias Clay

\section{Middle Lias.}

\section{Zone of Amaltheus margaritatus.}

H. Marlstone; a hard calcareous sandstone, resting on brown and grey sands, with bands and nodules of ferruginous sandstone 1500

\section{Zone of Aegoceras Henlexi.}

I. The shales of the Middle and Lower Lias, sloping down into the valley.

\section{3. ${ }^{1}$ The Zone of Harpoceras serpentindu.}

Synonyms.— “ Alum shale," Young and Bird, 'Geol. of York.,'p. 133, 1822. “ Upper Lias," part, of English authors. " Posidonien-Schiefer," Römer, “Oolit. Geb.,'p. 5, 1836. "Lias-Schiefer," von Buch, "Jura Deutsch.," "Berl. Akadem," 1837. “ PosidonienSchiefer," Quenst., 'Flötzgebirge,' p. 538, 1843. " $9^{\circ}$ Étage, Toarcien (pars infér.)," d’Orbigny, 'Cours. Élément. de Paléontol.,' p. 463, 1852. “Die Schichten der Posidonomya Bronni," pars, Oppel, 'Juraformation,' p. 197, 1856. "Communisbed," Wright, 'Quart. Journ. Geol. Soc.,' vol xiv, p. 25, 1858. "Communis Zone," Rev. Dr. Smithe, 'Cots. Club Trans.,'Aug., 1861. ' Serpentinus-bed,' Judd, ' Geology

1 The zone of Stephanoceras commune, named in p. 3, may be advantageously divided into the zones of Harpoceras serpentinum, and Harpoceras bifrons. 
of Rutland,' p. 79, 1875. "Jet Rock series $=$ Zone of Ammonites serpentinus," Tate and Blake, 'Yorkshire Lias,' p. 73, 1876.

The argillaceous beds of this zone in Gloucestershire consist of bluish clay, containing occasional and irregular bands of nodular argillaceous limestone resembling "cementstones." In the escarpments of the Cotteswold Hills the Serpentinum-zone of the I'pper Lias attains in some places a thickness of 80 feet, interposed between the Marlstone or rock-bed of the Margaritatus-zone and the beds with Harpoceras bifrons. The Upper Lias clay is generally concealed by débris derived from the Oolitic strata, and its position is therefore most readily ascertained by surface indications, such as springs and marshes. This clay-bed forms the retentive water-bearing stratum at the base of the superincumbent porous strata, so that the rain, which falls upon the table-land of the Cotteswold Hills, after saturating the Oolitic rocks and subjacent sands, bursts forth as springs along their slopes and escarpments, at the junction of these beds with the impervious clay. All the springs in this district arising from the drainage of the Inferior Oolite have their origin in this arrangement of the strata, and break out as sources at an elevation of about 700 feet above the level of the sea.

On the summits of Bredon, Alderton, Gretton, and Churchdown Hills, all outliers of the Cotteswolds, we find sections of the Serpentinum beds, which consist in general of the following subdivisions :

1st. Brown marly clays of variable thickness, according to the extent of denudation of the upper beds; they contain many of the fossils of our list.

2nd. A band of nodular argillaceous limestone, from six to eight inches in thickness, called the "Fish-bed;" this stratum has yielded many interesting remains. I obtained from a nodule at Gretton a large and nearly perfect specimen of Pachycormus latirostris, Ag., and from nodules at Alderton, Dumbleton, and Gretton have been extracted Leptolepis concentricus, Egert., Tetragonolepis discus, Egert. Wings and elytra of Insects have been found in nodules at Dumbleton and Gretton, of which the most remarkable is a fine Neuropterous wing belonging to Libellula Brodiei, Buck.

3rd. Is a thick bed of bluish mottled clay, several feet in thickness, and more or less laminated, at Alderton, where I saw it many years ago well exposed; it contained a great many small Gastropods, among them were Cerithium, Rostellaria, Trochus, and Natica; of Lamellibranchs, I found Avca, Leda, and Posidonomya; of Echinoderms I observed Acrosalenia crinifera, Quenst., Pseudodiadema Moorei, Wrt., Ophioderma, n. sp., and fragments of Pentacrinus. The shells were compressed moulds, which looked beautiful when the clay was first split open, but as it dried, the fossils unfortunately broke into fragments and could not be preserved for specific determination.

4th. The Leptæna-bed, composed of a brown friable marl, one to two inches thick, contains many species of small Brachiopods, belonging to the genera Leptana, Spiriferina, Terebratula, Rhynchonella, and is separated from the upper beds of the Marlstone by- 
5th. A thin band of blue and yellow clay, containing many Harpoceras falciferum, Sow., Belemnites acuarius, Schloth., and Rhynchonella pygmaa, Moore. This bed rests upon the light-coloured marls of the Spinatus-stage.

From a railway cutting near Stroud, I obtained many fine specimens of Harpoceras serpentinum, Rein., and during the execution of works for drainage, and the formation of a new road near Nailsworth, good sections of the Upper Lias were exposed; from the bands of limestone numerous fossils were obtained, as Stephanoceras commune, Sow., Harpoceras bifrons, Brug., Harp. falciferum, Sow., Phylloceras heterophyllum, Sow., Lytoceras cornucopia, Young., Harp. Lythense, Young., Belemnites compressus, Voltz., Nautilus latidorsatus, d'Orbig., Turbo capitaneus, Münst., Pleurotomaria sub-decorata, Münst., Astarte lurida, Sow., Posidonomya Bronni, Voltz., Nucula Hausmanni, Roem., Gresslya gregaria, Roem., Lima bellula, Mor. and Lyc., Lima gigantea, Sow., Tancredia lecviuscula, Lyc., and several undescribed forms.

The Rev. Dr. Smithe, ${ }^{1}$ F.G.S., has given an interesting account of two quarries of Upper Lias, on the top of Churchdown Hill, and known as north and south, the latter being the larger and better of the two for its section. The beds are nearly horizontal, and exhibit only slight traces of disturbance.

\section{Stephanoceras commune Zone at Churcldown.}

\begin{tabular}{|c|c|c|c|}
\hline No. & Petrology. & $\begin{array}{l}\text { THick- } \\
\text { NESS. }\end{array}$ & Organic Remains. \\
\hline 1 & Alluvial soil & ft. in. & \\
\hline 2 & Brown marly soil... & 20 & Fish, Crustacea, and all the fossils of list. \\
\hline 3 & Concretionary argillaceous limestone.... & $04-6$ & $\begin{array}{l}\text { "Fish bed," Leptolepis concentricus, Thrissops, } \\
\text { sp., Stephanoceras commune, Posidonomya } \\
\text { Bronni, AIytilus gryphoides. }\end{array}$ \\
\hline 4 & Blue and drab mottled clay............... & $\begin{array}{ll}6 & 0\end{array}$ & $\begin{array}{l}\text { "Alga bed," fossils of No. 2, with Alga, Aptychi, } \\
\text { \&c. }\end{array}$ \\
\hline 5 & Brown mariy shale .... & 10 & $\begin{array}{l}\text { "Leptæna bed," Spiriferina, Leptana, Terebra- } \\
\text { tula, and Rhynchonella, with Nucula and } \\
\text { otber Lamellibranchs. }\end{array}$ \\
\hline 6 & Blue and yellow clay $. . . \ldots \ldots \ldots \ldots \ldots . . . . . .$. & 10 & $\begin{array}{l}\text { Stephan. commune, Bel. acuarius, Rhyn. pygmaa, } \\
\text { Terebrat. globulina. }\end{array}$ \\
\hline
\end{tabular}

Light-coloured “ nodular bed," Spinatus-zone, containing Belemnites.

We have in the above a replica of the Upper-Lias section so well shown at Ilininster, Somerset, and of that at Curcy, la Caine, Calvados, described by Professor Deslongchamps. ${ }^{2}$

1 “The Geology of Cburchdown Hill," 'Cotteswold Club,' August, 1861.

2 'Etudes sur les Etages Jurassiques Infer, de Normandie,' p. 75, 1864 
The Upper Lias at Ilminster, Somerset, has become famous for the large number of species it has yielded to the long, patient, and careful investigations of Mr. Charles Moore, F.G.S., now of Bath, but formerly a resident in Ilminster, where he availed himself of exceptional advantages for making his collection. The following is the succession of the beds at Strawberry Bank, near Ilminster, described in descending order. ${ }^{1}$

Section of the Upper Lias at Strawberry Bank, Ilminster.

a. Yellow micaceous sands of the Inferior Oolite, unfossiliferous.

b. Eight bands of clay and stone, containing Harpoceras Moorei=opalinum, Harp. variabile, Lytoceras insigne $=$ Zone of Lytoceras jurense.

c. Light blue clay, 4' 6", with Crania Mloorei. '

d. Three layers of drab-coloured clay and stone, Belemnites Ilminsterensis.

e. Alternate layers of light-grey clay and rubbly stone, containing Harpoceras bifrons, Harp. radians, Harp. falcifernm = Zone of Harpoceras bifrons.

$f$. Blue mottled clay, with many Foraminifera.

g. Beds of rubbly stone and light-coloured clays, with Harpoceras serpentinum, Stephanoceras commune, Stephan. fibulatum = Zone of Harp. serpentinum.

h. Concretionary blue clay, with Foraminifera, and a layer of sandy stone, with Rhynchonella Bonchardii. These form the upper Cephalopoda-beds which overlie-

i. "The Saurian" and "Fish Beds" about twelve inches thick, which consist of a yellow septarian limestone, inchding Fishes in fine preservation, as Pachychormus, Eugnathus, Lepidotus, Pholidophorus, Leptolepis, Dapedium, and Iybodus. The Saurian remains are, Ichthyosaurus acutirostris, Owen, Teleosaurus temporalis, Blainville, Teleosanrus Moorei, Deslongchamps.

J. "The Leptæna-beds" consist of thin layers of yellowish clay, resting immediately on the Middle Lias, and forming the basement bed of the Upper Lias. They measure about eighteen inches in thickness, and contain Leptana Bouchardii, L. Moorei, Thecidium rusticum, Spiriferina Ilminsterensis, Zellania liassica, Leptana granulosa, Alaria unispinosa, and other Gastropods.

Mr. Moore's museum in the Philosophical Institution, Bath, contains Teleosaurus, Ichthyosaurus, and other Reptiles, and a magnificent collection of Fishes, representing many new species of Pachycormus, Lepidotus, and other Upper-Lias forms, in the finest possible preservation; the brown, enamelled scales of the fish beautifully contrasting with the pale yellow rock in which they are entombed. It was here likewise that the Leptænabed was first discovered in England, which contained so many interesting ancient forms of

1 "Middle and Upper Lias of the South-west of Englanil," 'Proc. of the Somerset Archæol. Soc., p. 16 , vol. xiii, $1865-6$. 
small Brachiopods belonging to the genera Leptana, Spiriferina, Thecidium, Rhynchonella, and Terebratula, together with a number of Gastropods and Lamellibranchs, amounting to upwards of 150 species. The Leptcena-bed forms a remarkable stratum, and was found by Professor E. Deslongchamps to occupy the same stratigraphical position at Curcy, la Caine, and other localities in Normandy, as it does in Somersetshire and Gloucestershire. The following note, January, 1862, from my learned friend Thomas Davidson, Esq., F.R.S., explains the discovery of the Lias Leptance: "When at Boulogne, in 1847, M. Bouchard received a parcel of fossils from the Lias of Pic de St. Loup, anong which were several specimens of a small Leptana, and about the same time I received a small parcel from Mr. C. Moore, among which I recognised two or three species of Lias Leptana, which M. Bouchard and myself described, for the first time, in the 'Annals and Mag. of Natural History' for October, 1847. The discovery of the Lias Leptcence is therefore due to M. Bouchard and Mr. Moore. It was my description and publication of these species which first directed public attention to the subject."

In Yorkshire the lower zones of the Upper Lias attain a remarkable development, and have long been found to contain jet-rock and alum-shale, and an immense number of organic remains in a fine state of preservation. I shal! select two from among the coast sections which afford the most instructive exposures of these beds. The first is the cliffs and scars at Saltwick, south of Whitby. My old and esteemed friend, the late Professor John Phillips, ${ }^{1}$ made a sketch of this locality, which I introduce with a few additions, as a faithful outline of this instructive bay, whose bold promontory and conspicuous island, formed of dark Lias, offer uncommon facilities for examining the whole section, and collecting from each bed its characteristic fossils. In descending from the encircling cliffs to the great hollow below, in which the alum-works were situated, we pass over-(1 and 2$)$ the thick capping of the lower shales and sandstones, with remains of plants ; (3) the dogger, a rough, uneven rock, with much ferruginous material in the mass, overlying (4) the Leda ovum-bed, which characterises the top of the alum-shale, and in which Harpoceras bifrons, Harp. Lythense, Phylloceras heterophyllum, Phyll. subcarinatum, Stephanoceras commune, Stephan. fibulatum, Stephan. subarmatum, and several other species of our list are found. This bed is about 34 feet thick, and overlies (5) a lumpy irregular band of nodules; beneath this (6) another bed of dark-grey alum-shale, containing an irregular band of nodules, but not many fossils, about 34 feet thick, and forming the lowest stratum worked for alum. It rests upon (7) a flat bed of ironestone, 4 inches thick, and very persistent in its character. Beneath the ironstone is (8) a bed of hard, dark alumshale, 16 to 18 feet in thickness, which contains a great number of Belemnites entombed in two seams of shale, the one three feet below the ironstone, the second a foot from the bottom of the bed. Belemnites vulgaris, Bel. subtenuis, Bel. tubularis, Bel. lavis. Then follows (9) an irregular band of calcareous nodules, lumpy, spheroidal, or flattened, one foot thick. Beneath is (10) a dark, firm shale, with some 

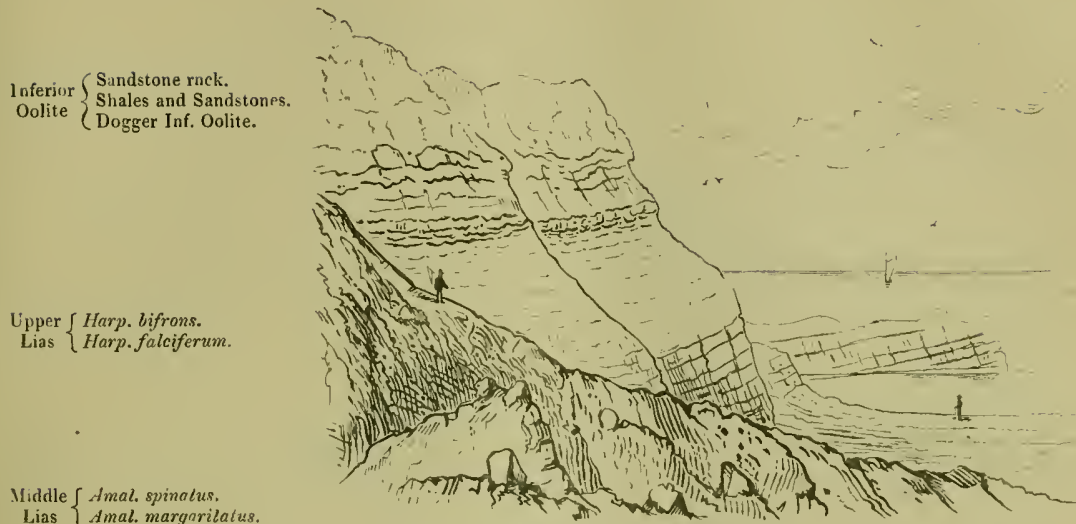

Middle $\int$ Amal. spinalus,

Lias $\{$ smal. margarilatus.

Fig, 6.-SAltwick From the South.

Belemnites and ferv fossils, about 18 feet thick, and resting upon (11) a dark, hard, reddish, shale bed, changing into a ferruginous band, from 3 to 6 inclies thick, and underlain by (12) hard, dark shales, 12 feet thick, containing Belemnites subtenuis, and Inoceramus dubius; a band of remarkable, flattened spheroidal balls (13) separates the above from the hard, dark shales of (14) the Serpentinum-zone, 20 feet thick, which underlie the above. There are many fossils in this lower zone, as Harpoceras serpentinum, Harp. exaratum, Harp. ovatum, Harp. Levisoni, Belemnites tubularis, Inoceramus dubius, and Extracrinus Phillipsii. 'I'hen (1う) a band of pyritized, irregular balls, covering 20 feet of hard grey shales (16). Beneath is another bed of dark shale (17), with calcareous concretions and considerable portions of Jet; this rock stands firm against the sea, and is broken up by the workmen who mine it for Jet, which is here of good quality, and used in manufacture. Below the Jet-rock are 20 feet of hard shales with large nodules, which overlie 30 feet of soft shales, containing Belem. cylindricus.

1 I have to thank Mr. Wiliam Smith, of Cheltenham, consin and executor of the late Professor Phitlips, F.R.S., for his kind permission to use the above, and two other woodcuts, from the Professor's last work on the 'Yorkshire Const,' p. 145, 1875. 
FIG. 7.-Profile of Saltuick Nah, south of Whitby.

No,

1. Cap grit.

2. Alternations of sandstone and shale.

3. Dogger, Inferior Oolite.

4. Cement-nodules in the alumshale.

5. Lumpy bed.

6. Dark alum-shale, with irreggular band of nodules. Lowest bed worked for alum.

7. Thin, flat ironstone band.

8. Dark alum-shale, somewhat harder than the upper strata.

9. Double band of nodules.

10. Dark shale, with Belemnites.

11. Red shale bed.

12. Hard dark shale : fossils.

13. Flattened spheroidal nodules.

14. Hard dark sbales.

15. Band of pyritic nodules.

16. Hard grey sbales.

17. Jet-rock, hard shale.

18. Hard shales.

19. Annulatus-bed of nodules.

20. Soft sbales

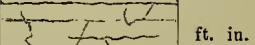

Irregularly stratified.

600 Occasional coal-bands, with Zamiacea.
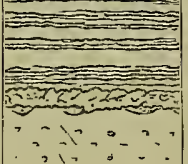

40 Ferruginous.

Harpoceras bifrons, Stephanoceras commune, Belemnites Toltzii, Leda ovum.

340

340 Contains fossils.

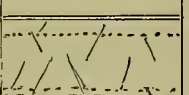

0 4 Non-fossiliferous.

180

I 0 Harpoceras ovatum, Belemnates vulgaris.

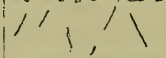

180 Fossils rare, Belemnites top and bottom.

$\begin{array}{lll}0 & 6\end{array}$

120 Belemniles sublenuis, Inoceramus dubius.

200 Harpoceras serpentinum, Belemnites tubularis, Inoceramus dubius, Extracrinus Phillipsi, Wright.

200

- 0 - 0 i 0

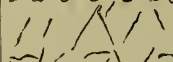

$1 \div-1,1-10$

100

Belemnites tripartitus, Aptychus.

200

Stephanoceras annulatum.

Belemnites cylindricus. 


\section{Detailed description of the Saltwick Section.}

No. 1. Saudstone rock belonging to the Lower Sandstone series.

2. Alternating beds of saudstone and shales, with remains of plants, chiefly Zamiacea. $\} 60$ feet.

3. Rough ferruginous Dogger in Inferior Oolite, with inconstant bands formed of harder, more ferruginous, irregular, spheroidal masses of rock, 4 fcet thick.

4. Grey alum-shale, the upper part a little sandy, with few or no fossils. At about 5 feet in depth layers of small limestone nodules appear, and continue for about that space in sufficient plenty to be worked for the making of "cement." Lower down the nodules are fewer, and admit of a larger proportion of carbonate of iron, alumina, and silica. The shale is pyritous, and abounds with fossils, as Harpoceras bifrons, Stephanoceras commune, Belemnites Voltzii, Leda ovum, Gresslya donaciformis. Thickness 34 feet.

5. A conspicuous, irregular band, occasionally swelling out into lumpy masses, more calcareous than most of the hard layers that accur below.

6. Dark alum-shale, 34 feet thick, with an irregular band of nodules. This bed is not rich in fossils, and appears to be the lowest bed worked for alum.

7. Is a thin flat bed of ironstone, somewlat remarkable for its continuity, 4 inches thick.

8. Dark alum-shale, 16 to 18 feet thick, somewhat liarder than the strata above. The fossils are chiefly Belemnites, of which a kind of bed is formed 3 feet below No. 7. There is also another bed of Belemnites 1 foot from the bottom; both are of limited extent. Monotis substriatus.

9. An irregular, frequently double band of subcalcareous nodules, large and small, lumpy, spheroidal, or flatiened, $\frac{1}{2}$ to 1 foot.

10. Dark firm shale, 16 to 18 feet thick, poor in fossils; Belemnites occur near the top and botton.

11. Hard, dark, reddened shale bed, occasionally changing to a ferruginous band, 3 to 6 inches thick.

12. Hard dark shales, 12 feet thick, containing Belemnites subtenuis, Inocerumus dubius.

13. Band of remarkable flattened splieroidal balls.

14. Hard dark shales, 20 feet thick, with numerous fossils, often pyritized, Harpoceras Mulgravium, Belemnites tubularis, Inoceramus dubius, Extracrinus Phillipsii, Wright.

15. Band of irregular balls, pyritized.

16. Hard grey shales, 20 feet.

17. Jet-rock, hard shale, 10 feet thick, with calcareous concretions and considerable portions of Jet. Belemnites tripartitus, Aptychus, \&c.

18. Hard shales, witl large nodules in the upper part, 20 feet.

19. Stephanoceras annulatum bed of nodules.

20. Soft shales, 20 to 30 feet thick, and containing Belemnites cylindricus. 
Section of the Upper Lias at Rockliff, Easington Heights, north of Whitby, altitude 681 feet above the level of the sea. ${ }^{1}$

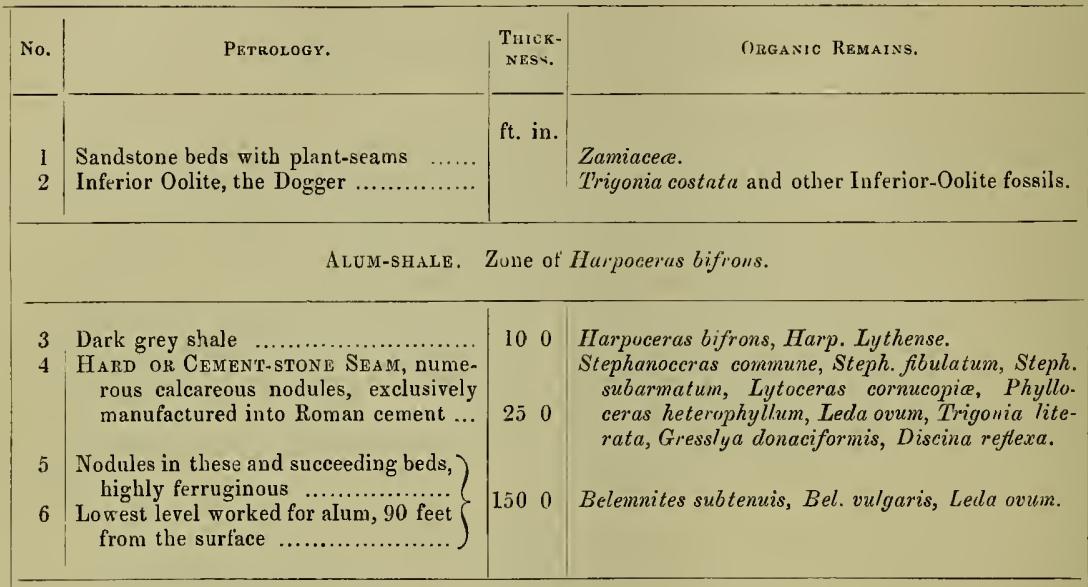

JEт-воск. Zone of Ilarpoceras serpentinum.

\begin{tabular}{|c|c|c|c|}
\hline 8 & $\begin{array}{l}\text { Many pyritous nodules, very much } \\
\text { flattened ........................... } \\
\text { Hard compact shale, very sandy, a few } \\
\text { small nodules mostly barren in fossils }\end{array}$ & $\begin{array}{l}200 \\
300\end{array}$ & $\begin{array}{l}\text { Harpocerus serpentinum, Harpo. exaratum, Harpo. } \\
\text { ovatum. } \\
\text { Lepidotus, Pachychormus, Ptycholepis, Lepto- } \\
\text { lepis, Gyrosteus mirabilis. }\end{array}$ \\
\hline
\end{tabular}

Zone of Amaltheus margaritatus.

Professor Judd ${ }^{2}$ describes the Upper Lias of Rutland as occupying a large area in Sheet 64 of the 'Geological Survey.' This division of the Lias is usually concealed by Drift except on the steep slopes of the Oolitic escarpments, where it attains a thickness of about 200 feet, and consists almost entirely of clays, which Prof. Judd divides into the following beds. The section is in a descending order.

1. The Leda-ovum Beds form the highest beds of the Upper Lias, and consist of clays, with numerous layers of septaria, everywhere distinguished by the abundance of Leda ovum, Sow. The prevailing Ammonite is Harpoceras bifrons, which occurs in great numbers. Here are also Stephanoceras commune, Steph. annulatum, Steph. crassum, Steph. fibulatum, Steph. Holandrei. Phylloceras heterophyllum, is tolerably abundant, but

1 Louis Hunton, 'Trans. Geol. Soc.,' vol. v, second series, p. 215, 1836.

2 "Geolegy of Rutland," 'Memoirs of the Geological Survey,' p. 79, 1875. 
species of the Harpoceras genus are comparatively rare. Belennites compressus, Gresslya donaciformis, Arca truncata, and Discina reflexa, are also abundant.

2. The Commune-Beds are found at a little distance above the Serpentinum-beds; they are crowded with small specimens of Stepl. commune, Steph. annulatum, Belemnites irregularis, Astarte striatosulcata.

3. The Serpentinum-Beds lie below the preceding, and consist of clays and layers of nodules of limestone, of much coarser texture than those of the "Fish and Insect Beds." Harpoceras serpentinum, Harp. falciferum, Harp. Lythense, Harp. elegans, and Harp. radians, are found in abundance with some Belemnites and other shells.

Professor Judd gives several sections of the Upper Lias, two of which I will quote as examples of the petrology of the series. On the left bank of the stream at Hallaton Ferns the junction of the Middle with the Upper Lias is well seen in a number of drainfields. The succession of the beds liere is as follows :
UPPER Lias $\left\{\begin{array}{l}\text { 1. Dark blue clays. } \\ \text { 2. Ferruginous beds, with Harpoceras serpentinum (abundant) and Harpoceras bifrons. } \\ \text { 3. Paper-shales, with fish and insect limestone and usual fossils. }\end{array}\right.$
Midde Lias $\left\{\begin{array}{l}\text { 4. Sandy, ferruginous band, with moulds of shells. Marlstone rock-bed. } \\ \text { 5. Light-coloured clays, with ironstone balls. }\end{array}\right.$

From a railway cutting near Market Harborough we have the following section :

1. Soil. 1 foot.

2. Boulder clay. 2 to 3 feet.

3. Upper Lias clay, with Stephanoceras commune and Belemnites compressus. It consists of laminated blue clay, weathering to a yellow colour. 1 to 4 feet seen in the pit. UPPER LIAS :
SERPENTINUM
BED

Middle Lias :

Margaritatus BED
4. Hard, brown, ferruginous band of impure ironstone. $9 \mathrm{in.}$

5. Sufter and more sandy bed, completely full of Harpoceras serpentinum, Harp. bifrcns, Stephanoceras commune, Steph. Holandrei, Belemniter compressus, and other shells. 9 in.

6. Hard, very ferruginous bed. $3 \mathrm{ft} .6 \mathrm{in}$.

7. Light-blue, laminated clays. $3 \mathrm{ft} .4 \mathrm{in}$.

8. A thin vein of sandstone, very inconstant. I ft.

9. Light-blue laminated clays. $5 \mathrm{ft}$.

10. Marlstone rock-bed of the Middle Lias. Amaltheus margaritatus, Bel. paxillosus, Cardium truncatum, Avicula novemcosta.

11. Brown clay. 2 to 3 feet.

12. "Skerry," with nodules containing Cardizm truncutum, dricula cygnipes, Lima sp.

13. Brown clay. 2 to 6 feet.

14. Blue clay. 7 to 9 feet.

15. "Skerry" (brown sandstone). 1 to 6 feet.

16. Brown clay. 2 to 3 feet.

17. Rock, water-bearing stratum, further sinking prevented. 
The fossils collected here show that the Serpentinum-and Bifrons-beds are those divisions of the Upper Lias which are best developed in Rutland, as the following list demonstrates :

\section{Cephalopoda.}

Harpoceras serpentinum, Rein.

- bifrons, Brug.

- elegans, Sow.

- falciferum, Sow.

- radians, Rein.

Stephanoceras commune, Sow.
Stephanoceras crassum, Phil.

$$
\text { - } \quad \text { Holandrei, dOrb. }
$$

Phylloceras heterophyllum, Sow.

Belemnites compressus, Tolt $z$.

- tenuis, Phill.

\section{Lamellibranchiata.}

Leda ovum, Sow.

Inocramus dubius, Sow.

Ostrea subauricularis, $d^{\prime}$ Ortb.
Posidonomya Bronni, Voltz.

Nucula cordata, Goldf.

Astarte striatosulcata, Röm.

From the above list it appears that the Serpentinum- and Bifrons-beds are so blended together in the Upper Lias of Rutlandshire that they have not yet been separated from each other, and that these two lower zones of the Upper Lias are the most persistent and widely developed of the upper division of the Lias formation in this County.

\section{List of Fossils from the Zone of Harpoceras serpentinum (Gloucestershire).}

\section{RePTILIA.}

Teleosaurus temporalis, Blainv.

Ichthyosaurus acutirostris, Owen.

Pachycormus latirostris, Agass.

Leptolepis concentricus, Egert.

Coleia, sp.

Libellula Brodiei, Buck.

Belemnites tripartitus, Sow.

- Voltzii.

- $\quad$ subtennis, Phil.

Nautilus astacoides, Young and Bird.

Stephanoceras commune, Sow.

- annulatum, Sow.

Harpoceras serpentinum, Reinecke.

\begin{abstract}
Plesiosaurus (vertebræ).
Pterodactylus (coracoid of).
\end{abstract}

\section{Fishes.}

$\mid \begin{aligned} & \text { Tetragonolepis discus, Egert. } \\ & \text { Dapedius, sp. }\end{aligned}$

\section{Crustacea.}

INsECTA.

1 Agrion Buckmanni, Brod.

\section{Cephalopoda.}

Harpoceras bifrons, Brug.

-- falciferum, Sow.

- Lythense, Young and Bird.

- Raquinianum, d'Orbig.

Lytoceras cornucopiæ, Young and Bird.

Phylloceras heterophyllum, Sow.

Belemnosepia (ink-bag aud osselets). 


\section{Gasterofoda.}

Eucyclus capitanens, Mïnst.

Trochus bisertus, Phil.

Cerithium, sp.
Plcurotomaria subdecorata, Mïnst.

Rostellaria, sp.

Natica, sp.

\section{Zone of Harfoceras bifrons.}

Synonyms. - "A. communis-bed,” part, Wright, 'Quart. Journ. Geol. Soc.,' vol, xiv, p. 25, 1858. "Zone of Am. communis," part, Wright, 'Oolitic Asteroidea,' Palæont. Soc., p. 38, 1862. "Zone à Am. bifrons," Reynès, 'Géol. et Paléont. Aveyron,' p. 65, 1868. “ "Leda-ovum-beds," Judd, “Geol. of Rutland," “Mem. Geol. Surv.,' p. 80, 1876. "Zone of Am. communis or Alum-shale," Tate and Blake, "Yorkshire Lias," p. 181, 1876.

This zone at Frocester Hill consists of fine sandy marls, with inconstant bands of a harder sand rock, which form several layers of nodules in the bank, and many of these contain fossils. I have found sometimes clusters of Harpoceras bifrons in some of these masses when broken up-a fact which first taught me the true stratigraphical position of Harp. bifrons. Along other escarpments of the Cotteswolds I have collected Harp. bifrons in brownish marl at the southern base of Crickley Hill, and in soft grey clays above the Serpentinum-bed at Stinchcombe Hill.

In the Saltwick profile near Whitby, and at Rock Cliff, near Staithes, on the Yorkshire coast, we have already seen that Harp. bifrons belongs to the alum-shale, and has for its associates Stcplan. commune, Belemnites Voltzii, Leda ovum, and Gresslya donaciformis, and that it there forms a well-marked horizon of life resting upon the Jet-rock, with Harpoceras serpentinum, and Harp. falciferum.

On cutting the eastern portion of the Banbury and Cheltenham Direct Railway some instructive sections of the Upper Lias have been exposed on nearing Bloxam, Oxfordshire. Mr. Beesley ${ }^{1}$ notes, " about 300 yards before reaching the Barford-road Bridge, a snuall fault brings down the Upper Lias about four feet against the Spinatus-beds. For 100 yards further the banks are all Marlstone of this zone; then comes another fault, dipping to the east, which throws down the Upper Lias to the base of the section, a depth of fifteen feet; the white marly limestone of the Serpentinum-beds, crowded with Harpoceras bifrons, Stephanoceras commune, Lytoceras cornucopia, Phylloceras heterophyllum, Phyll. subcarinatum, and species of the Serpentinum group, with Belemnites 1 minsterensis and B. regularis and Nautili, now forming the floor of the line, and over it blue or green shale fifteen fect thick. The faults pass obliquely across the line from north-west to sonth-east."

1 "Geology of the Banbury and CheItenham Railway," 'Proc. Geol. Assoc.,' vol. $v, 1877$. 


\section{Fossils from Bloxam Railway-Cutting. ${ }^{1}$}

Harpoceras bifrons, Brug.

- latescens, Simp.

- subplanatum, Oppel.

- Levisoni, Simp.

Stephanoceras commune, Sow.

-. crussum, Young.

- Holandrei, d'Orb.

- fonticulum, Simp.

- gracile, Simp.

Lytoceras cornucopix, Young \& Bird. Phylloceras heterophyllum, Sow.

\section{Cephatopol)a.}

Phylloceras subcarinatum, Young \& Bird.

Nautilus astacoides, Young $\&$ Bird.

\section{- Jourdani, Dumort.}

Belemnites Ilminsterensis.

$\begin{array}{ll}\text { - } & \text { striolatus, Phil. } \\ -\quad & \text { pyramidalis, Ziet. } \\ \text { - } & \text { quadricanaliculatus, Quenst. } \\ \text { - } & \text { regularis, Phil. } \\ \text { - } & \text { subaduncatus, Voltz. } \\ -\quad & \text { subtenuis, Simp. } \\ \text { - } & \text { tripartitus, Sehloth. }\end{array}$

\section{Gasteropoda.}

Alaria angulata, Moore.

Cerithium, sp.

Chemnitzia Blainvillei, Münst.

Eucyclus capitaneus, Münst.

Natica Pelops, d'Orb.

Neritopsis transversa, Moore.
Pleurotomaria Joannis, Dumort. - Theresæ, Dumort.

Purpurina armata, Tate.

Solarium, sp.

Actronina, sp.

Trochus, sp.

\section{LAMELLIBRANCHIATA.}

Astarte subtetragona, Goldf:

Monotis inæquivalvis, Sow.

- Münsteri, Goldf.

- substriatus, Münst.

Cucullæa, sp.

Cypricardia Dumortieri, Jaubert.

Exogyra Berthandi, Dumort.

Hinnites tumidus, Ziet.

Inoceramus cinctus, Goldfuss.

$$
\text { - } \quad \text { dubius, Sow. }
$$

Leda, sp.

Limea acuticosta, Goldf.
Lima Elea, d'Orbig.

- eucharis, d'Orbig.

- Galathea, d'Orbig.

- punctata, Sow.

Nucula cordata, Goldf.

- subglobosa, Röm.

Pecten pumilus, Lamk.

- textorius, Schloth.

Pholadomya Zieteni, Agas.

Pleuromya, sp.

Posidonomya Brouni, Voltz.

Plicatula catinus, Deslong.

Unicardium subglobosum, Tate.

\section{Brachiopoda.}

Discina reflexa, Sow.

Rhynchonella amalthei, Quenst.

$$
\begin{aligned}
& \text { - jurensis, Quenst. } \\
& \text { - Moorei, Dav. }
\end{aligned}
$$

Waldheimia punctata, Sow.

Thecidium, sp.

1 This list has been prepared and most kindly communicated to me at my request by Mr. Beesley, F.C.S., from his unpublished notes on the interesting and instructive section at the Bloxam RailwayCutting, Oxfordshire; and for his courtesy I beg to record my best thanks. 


\section{AnNelida.}

Serpula gordialis, Schlïth.

- limax, Goldf.

- tricristata, Goldf.
Serpula ramentum, Dumort.

- segmentata, Dumort.

- lumbricalis, Schloth.

\section{Echinodermata.}

Rhabdocidaris impar, Dumort.

Cidaris Dumortieri, Wright.

Pentacrinus jurensis, Quenst.

Millericrinus Hausmanni, Röm.

Chondrites Bollensis, Kurr.

The fragments obtained from washing the bottom clay at Bloxam contained the remains of Ophiuridæe with the plates and spines of several species of Echinidx.

\section{Crustacea.}

Bairdia, sp.

Cythere, sp.

\section{Foraminipera.}

Cristellaria Bronni, R̈̈m.

- cultrata, Montf.

- antiquata, d'Orb.

- matutina, d'Orb.

- rhomboidea, Czjek.

- rotulata, Lam.

- recta, $d^{\prime} O r b$.

- varians, Born.

Dentalina Burgundiæ, Terq.

- communis, d'Orb.

- filiformis, d'Orb.

- nummulina, Gümb.
Dentalina obscura, Terq.

- ornata, Terq.

- pauperata, d'Orb.

- quadricostata, Terq.

Flabellina rugosa, $d^{\prime} \mathrm{Or} b$.

Nodosaria raphanistrum, T'erq.

- Badenensis, d'Orb.

Planularia harpula, d'Orb.

- pauperata, J. \&P.

- reticulata, Corneil.

Lingulina teuera, Born.

Vaginulina striata, $d^{\prime} O r b$.

In Rutland the Serpentinum and Bifrons zones approach so close together that their fossils in many cases cannot be separated. The Serpentinun-zone, with its "Fish-bed and Insect limestone," appears to be the one most fully developed in this county.

In North-West Lincolnshire the Rev. J. E. Cross, F.G.S., ${ }^{1}$ has noted the Upper Lias in the Santon Railway-cutting, and collected therefrom Harpoceras serpentinum, Stephanoceras commune, Lytoceras cornucopice, and Amaltheus spinatus.

Foreign Correlations.-The Upper Lias in South-west Germany was divided by Professor Quenstedt ${ }^{2}$ into Posidonienschiefer and Jurensis-Mergel; the former corresponding to the Serpentinum and Bifrons zones, and the latter to the Jurense and Opalinum zones of this work. The "Poisidonienschiefer" are characterised by the presence of Fish, as Ptycholepis Bollensis, Eugnathus, Tetragonolepis, Pholidotus semicinctus, Lepidotus Elvensis, semiserratus, dentatus, Semionotus leptocephalus, Aspidorynchus, Pachy-

I 'Quart. Journ. Geol. Soc.' vol. xxi, p. 124, 1875.

2 'Flözgebirge Würtembergs,' p. 539, 1843. 
cormus, Thrissops, Leptolepis. Saurians, as Ichthyosaurus, Plesiosaurus, and Teleosaurus. Cephalopods, as Harpoceras serpentinum, bifrons, Lythense, Phylloceras heteroplyllum, Lytoceras cornucopia, Belemnites acuarius. Laméllibranchs, as Inoceramus dubius, Posidonia Bronni, Minotis substriatus, Leda ovum; and Brachiopods, as Discina reflexa, and others. The "Jurensis-ITergel" is characterised by the absence of Fish remains and the appearance of a new suite of Cephalopods, as Lytoceras jurense, Harpoceras insigne, variabile, striatulum, radians, Aatense, and many others.

At Pliensbach, north-west of Boll, and Holzmaden, south-west of Kirchheim, the following section by Dr. Oppel may be considered as typical of the Württemberg Upper Lias.

\section{Upper Lias near Boll, Württemberg.}

Torulosus-bed.

\begin{tabular}{|c|c|c|c|}
\hline & Petrologx. & $\begin{array}{c}\text { Thick } \\
\text { Ness. }\end{array}$ & Organic Remains. \\
\hline $\begin{array}{l}\text { Zone of } \\
\text { PosIDONOMYA } \\
\text { BRONNI }\end{array}$ & 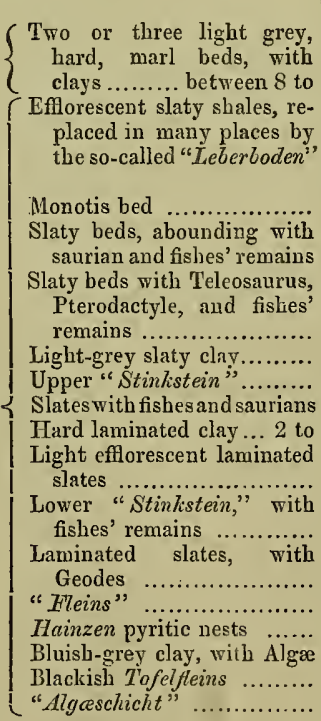 & $\left|\begin{array}{cc}10 & 0 \\
8 & 0 \\
0 & 2 \\
0 & 2 \\
& \\
0 & 5 \\
1 & 0 \\
0 & 8 \\
1 & 0 \\
0 & 4 \\
2 & 0 \\
0 & 8 \\
5 & 0 \\
0 & 8 \\
0 & 2 \\
0 & 3-5 \\
1 & 6\end{array}\right|$ & $\begin{array}{l}\text { Am. jurensis, discoides, insignis, radians, hir- } \\
\text { cinus, Belemnites tricanaliculatus, exilis, } \\
\text { longisulcatus, irregularis. } \\
\text { Am. bifrons, fibulatus, serpentinus, falcifer, } \\
\text { heterophyllus, cornucopia, communis, crassus, } \\
\text { Holandrei, subarmatus, Bel. irregularis, Bel. } \\
\text { tripartitus. } \\
\text { Monotis substriatus, Münst. } \\
\text { Belemnites acuarius. } \\
\text { Teleosaurus Chapmani, Pterodactylus Ban- } \\
\text { thensis, Ptycholepis Bollensis. } \\
\text { Posidonomya, Bronni, Monotis substriatus. }\end{array}$ \\
\hline
\end{tabular}

The Midd̄le Lias,-Zone of Am. spinatus. ${ }^{2}$

.' 'Juraformation,' p. 201, 1856. 
Dr. Waggen states that the Upper Lias in Franconia closely resembles that of Swabia, ${ }^{1}$ and that the zone of Posidonomya Bronni is very well developed there.

Professor Quenstedt ${ }^{2}$ has given a good account of the palæontology of the Lias Epsiton at Boll, and has described in detail Teleosaurus Chapmani, König, T. Bollensis, Quenst., Pclagosaurus, sp. Plesiosaurus Sucvicus, Ichthyosaurus longirostris, Ichthyo. triscissus, Ichthyo. quadriscissi, Ichthyo. trigonodon, and added the following list of fossils :

Palcontology of the Lias Upper "Epsilon" at Boll, Wiirttembery.

\section{Fishes.}

Hybodus pyramidalis, Agass.

- reticulatus, $A g$.

Acrodus nobilis, $A g$.

Lepidotus Elvensis, Blainv.

Dapedius cælatus, Quenst.

- punctatus, $A g$.

- Leachii, $A g$.

- pholidotus, $A g$.

Tetragonolepis semicinctus, Bronn.

- cinctus, Quenst.
Ptycholepis Bollensis, Agass.

Pholidophorus Germanicus, Quenst.

Belonostomus acutus, Agass.

Pachycormus curtus, $d g$.

- macropterus, $\mathrm{Ag}$.

- Bollensis, Quenst.

Thrissops micropodius, $A g$.

Leptolepis Brounii, Ag.

Lycodus gigas, Quenst.

Pachylepis, sp.

\section{Cephalopoda.}

Loliginites Schubleri, Quenst.

- Bollensis, Ziet.

- simplex, Voltz.

- coriaceous, Quenst.

- sagittatus, Münst.

Onychoteuthis conocauda, Quenst.

Onychites uncus, Quenst.

- runcinatus, Quenst.

Belemnites acuarius, Schlüth.

- digitalis, Quenst.

- tripartitus, Schlïth.
Belemnites incurvatus, Ziet.

Ammonites Lythensis, Young \& Bird.
- capellinus, Quenst.
- serpentinus, Reinecke.
- bifrons, Brug. = Walcotti, Sow.
- communis, Sow.
- crassus, Phill.
- Bollensis, Quenst.
- heterophyllus, Sow.
- cornucopir, Sow.
- anguinus, Reinecke.

\section{Gasteropoda.}

Chemnitzia repeliana, d'Orb.

Natica Pelops, d'Orb.

Turbo Sedgwicki, d'Orb.
Pleurotomaria subdecorata, Münst .

- intermedia, Münst.

1 'Der Jura in Franken, Schwaben und der Schweiz,' p. 47, 1864.

2 'Der Jura,' p. 210, 1858. 


\section{LAMEjLIBRANCHIATA.}

Ostrea subauricularis, d'Orb.

Pecten incrustatus, Defrance.

Gervillia Eseri, Oppel.

Avicula striata, Ziet.

Lima galatea, d'Orb.

Trigonia literata, $\boldsymbol{P h i l l}$.

Leda ovum, Sow.

Goniomya rhombifera, Goldf.

Discina papyracea, Münst.

Acrosalenia crinifera, Quenst.

Pentacrinus Bollensis, Schlöth.

Posidonomya Bronni, Voltz.

- radiata, Goldf.

- orbicularis, Münst.

Inoceramus undulatus, Ziet.

- cinctus, Goldf.

- dubius, Sow.

Solemya Voltzi, Römer.

\section{Brachiopoda.}

I Spiriferina villosa, Quenst.

\section{EchINODERMATA}

In France the Posidonomya-beds attain a considerable development and are found in many Departments; they have been described in the Moselle by M. Terquem, ${ }^{1}$ where they consist of (a) "Marnes bitumineuses," (b) "Calcaire noduleux," and (c) "Calcaire gréseux." The petrology of these divisions is certainly distinct, but several of the species of organic remains are common to the three, and all are characteristic of the lower portion of the Upper Lias.

In Luxembourg these beds have been described by Drs. Chapuis and Dewalque ${ }^{2}$ as "Marne de Grand-Cour," which consists of a bituminous schist at the base and bluish marls with calcareous nodules in the upper part. The Marne de Grand-Cour has been worked at Aubange for the preparation of bitumen, and from these exposures the remains of Reptiles, Fishes, Crustacea, and Cephalopods have been collected. The following Ammonites from the lower zone have been figured by these anthors:Harpoceras serpentinum, Harp. Lythense, Harp. complanatum, Phylloceras heterophyllum, Lytoceras cornucopia, Stephanoceras Raquinianum, Steph. Holandrei, Steph. mucronatum, Steph. Braunianum. And from the upper zone : Harv. radians, Harp. Levesquei, Harp. variabile, Harp. Comense.

In the Department of the Ardennes it has been described by Buvignier as the upper marls of the Upper Lias; here, likewise, a bituminous schist forms the base, and marls the upper portion, of the series.

In the Meurthe M. Lavallois describes these strata as "Marnes schistobitunineuses."

1 'Paléontologie du Départ. de la Moselle, Ext. de Satist. de la Moselle,' p. 20, 1855.

2 'Lias de la Province de Luxembourg,' p. 60, 1857. 
In the Yonne M. Cotteaul calls this series "Licas supérieur masse argilobitumineuse." The following section, made at Vassy, from the summit of the hill to the plain which surrounds the town of Avallon, exhibits the sequence and relation of the Upper, Middle, and Lower Lias as developed in Yonne and described by M. Moreau, "Réunion extraordinaire à Avallon (Yonne) Soc. Géol. de France," 1845 :" $^{2}$

1. Alternations of calcareous and marly beds with Harpaceras bifrans, Brug., H. falciferum, Sow., Lytoceras cornucopice, Sow., Turbo ornatus, Sow., Pasidonomya Branni, Voltz., Nucula Hammeri, Defr., Thecocyathus mactra, Edw.

2. Argillaceous schist and beds of argillaceous limestone from $0.01 \mathrm{~m}$. to $0.02 \mathrm{~m}$. thick alternate throughout this bed; the lower bed, of $0.40 \mathrm{~m}$. to $0.80 \mathrm{~m}$., is worked First Stage: especially for the manufacture of the Ciment de Vassy. Teins of the carbonate of UPPER IIAS lime traverse all the mass of the hill, parallel with each other, and directed E. $40^{\circ} \mathrm{N}$., like the soulèvement of the Côte-d'Or, inclining to the $\mathrm{W}$., where they rise towards the ancient mass of Morran. The fossils in these beds are common to No. 1 and 2.

Harpaceras serpentinum, Rein., Phyll. heteraphyllum, Sow., Stephanoceras annulatum, Stephan. commune, Stephan. Desplacei, d'Orb., Aptychus, Pasidanomya Branni, Voltz., and the skull and jaws of Ichthyosaurus.

3. Beds of limestone with Gryphcea cymbium, separated by thin beds of calcariferous clay. Belemnites are very abundant, with Amaltheus margaritatus, Mont., Lytaceras fimbriatum, Sow., Pectcn aquivalvis, Sow., Terebratula quadrifida, Sow., T. ringens,

SecondStage: MIDDLE LraS

Third stage : Lowen Lras
Sow., Rhyn. tetraedra, Sow., Rhyn. variabilis, Schlöth., Spiriferina Walcatti.

4. Argillaceous marls, without fossils, with Septaria.

5. Limestone very argillaceous, with Belemnites clavatus, Blain., Bel. umbilicatus, Blain., Bel. Bruguierianus, d'Orb., Terebratula numismalis, Lam., Rhyn. rimosa, Spiriferina Walcatti, Sow., Aegaceras Daræi, Sow., Aeg. Henleyi, Sow., Aeg. hybrida, d'Orb.

6. Limestones with Gryphcea arcuata, Lam., divisible into two beds.

a. Upper bed with Gryphoea arcuata, Lam., Arietites Bucklandi, Sow. = bisulcatus, Brug., Rhyn. variabilis, Schloth.

6. Lower bed with Gryphea arcuata, Lam., Gryph. Maccullochii, Sow., Arietites bisulcatus, Arietites Coneybeari, Sow., Spiriferina Walcotti, and Pentacrinus basaltiformis, Mill.

In the Côte d'Or a similar condition of the Posidonomya-beds prevails at Flavigny, where M. Collenot says ${ }^{3}$ an exposure by erosion shows-First, the zone with Harp. serpentinum resting upon schists containing Grypliaa cymbium, and consisting of their paper-like shales without bitumen. Here are found, also, Stephanoceras Holandrei, Phylloceras heterophyllum, rarely Harpoceras bifrons. Second zone with Harpoceras complanatum. The rock is less bituminous and more aluminous than the preceding, and the fossils are large and widely distributed throughout the beds. The third zone is characterised by Pecten pumilus and Turbo subduplicatus, which is limited to this one

1 'Etudes sur les Echinides Foss. de Départ. de l’Yonne,' p. 32, 1949.

2 'Bulletin de la Soc. Géol. de France,' 2e série, tom. ii, p. 664, 1843.

3 'Description Géologique de I'Auxois,' p. 288, 1873. 
horizon with Hellispongia fasciculata. The fourth zone, composed of compact marls with few fossils, is characterised by the presence of Steph. mucronatum.

In the Isère at Verpillière and St. Quentin the Posidonomya-beds are formed of ferruginous layers with very fine fossil shells in a high state of preservation; and the relation of the Posidonomya to the Jurense-zone is likewise very well displayed. The following species are characteristic of the Posidonomya-beds at Verpillière :

Belemnites acuarius, Schlöth.

Harpoceras bifrons, Brug.

Lytoceras cornucopir, Young \& Bird.

Stephanoceras annulatum, Sow.

- commune, Sow.
Stephanoceras Holandrei, d'Orb.

$\begin{array}{ll}\text { - } & \text { crassum, Phil. } \\ \text { - } & \text { fibulatum, Sow. } \\ \text { - } & \text { subarmatum, Sow. } \\ \text { anguinum, Rein. }\end{array}$

In the Loère and the Aveyron the Upper Lias is well developed, and both the Posidonomya- and Jurense-beds are here found in natural superposition. The late Dr. Reynès, ${ }^{1}$ after carefully studying these beds in the Aveyronnaise, divided them into four zones, and observed that the faunas have very little affinity with each other,- "we only ascertain but very rarely the appearance of a species beyond the zone in which it has taken its entire development, and it is still more rare that we see isolated examples ever appearing in beds of a later horizon." To facilitate the stratigraphical and palæontological study of the Upper Lias this author divided the Upper Lias into four parts :-1. The zone of Harp. serpentinum; 2, the zone of Harp. bifrons; 3 , the zone of Lyto.jurense; and 4, the zone of Harp. opalinum.

1. The schists with Posidonia Bronni are from 3 to 30 mètres in thickness; they split into thin laminæ, on which are impressed the marks of fossils, as Aptyclus Lythensis, Harp. serpentinum, Posidonia Bronni, and others. The shells are so much compressed that it is difficult to restore their former character; fortunately, however, these laminated shales contain many large, hard, calcareous, fossiliferons nodules, which contain uncrushed shells in good preservation. On breaking up the nodules the following species were collected :

Harpoceras serpentinum, Rein.

- Levisoni, Simp.

Stephanoceras commune, Sow.
Aptychus Lythensis.

Posidonia Bronni, Toltz.

Anodonta Bollensis, Quenst.

. "The fauma is not numerous, and none of the species of this list ascend into the zone of Harp. bifrons. It is true that some palrontologists have considered Harp. Levisoni as the prototype of Harp. bifrons. In this case they are under the necessity of recognising two distinct varieties, the one having a lateral groove, and the other deprived of that canal; they are also forced to admit that these two varieties bave lived at two distinct epochs and withont any intermixture, and that this modification is made in a sudden manner with the appearance of the fauna of Harp. bifrons. These diverse 
considerations have led me to regard the supposed varieties as distinct species, whatever may be the affinities or the minglings they have had in common in other conntries."

2. The zone of ITarp. bifions. "This zone is marly, and the change which lias taken place permits us to assign to it a precise lower limit. But it is not so easy to find the upper boundary, and it is even necessary to make the palmontological characters intervene; but we often meet at the base of the zonc following with Lyto. jurcnse, a bed of Tissoa-the compressed condition of which gives it the aspect of a true limestone. It is this bed, the thickness of which is $10-15$ centimitres, entirely enclosed in the marls of the two zones, which appears to form the upper limit of the zone of Harp. bifrons; it is, in fact, above and below this bed that we observe a considerable cliange in the two faunas. The marls are black and entirely argillaceons; and enclose a large number of species, of which the representatives are distributed according to fixed laws in different levels of that zone."

"a. At the base we find Stephan. Brauniamm. It is in this horizon that we discover that fauna so curious and so new, and which is enclosed in a marly bed immediately in contact with the Posidonia-shales. The marls in which this fauna is enclosed do not exceed a mètre and a half in thickncss, and the principal species found here are :

Stephanoceras Braunianum, d'Orb.

$$
\begin{array}{ll}
\text { - } \quad \text { crassum, Phill. } \\
\text { - } \quad \text { Zitteli, Oppel. }
\end{array}
$$

Phylloceras subcarinatum, Sow.

Lytoceras Nilssoni, Hebert.

- cornucopix, Sow.
Lytoceras Argelliezi, Rey.

Aegoceras acanthopse, $d$ Or $\mathrm{r}$.

Harpoceras falciferum, Sow.

Nucula Paulæ.

Cerithium hexagonum.

Rhynchonella Julii.

“ $b$. In the middle zone we recognise the true station of Harp. lifrons, and the fossils are very numerons.

Belemnites irregularis, Schlüth.

- acuarius, Schlöth.

- tripartitus, Schlöth.

Nautilus semistriatus, $d$ Orb.

Harpoceras falciferum, Sow.

- bicarinatum, Münst.

- bifrons, Brug.

Lytoceras Nilssoni, Helert.

Stephanoceras crassum, Phil.

- subarmatum, Young.

- Emilianum, Rey.
Aegoceras Gervaisi, Rey.

Harpoceras Erbaense, Hauer.

Plicatula Neptuni.

Lima gigantea,

- pectinoides.

Pecten incrustatus.

Arca Bixa.

Nucula ovum.

- Delila.

Avicula Delia.

"c. The upper part of this zone no longer includes Itarpoceras bifrons, and we only meet in this horizon with Lytoceras Nilssoni, IIarp. bicarinatum, Harpoccras falciferum, Harp. Erbaense, Stephanoceras subarmatum, and Pliylloceras heterophyllum.

"This remarkable distribution of the species, according to distinct horizons, is almost general, with rare exceptions, and we are able to assign beforehand to each species the 
position which it ought to occupy in the extent of the marls of the Lias. The same species are not equally abundant in all localities; and this proves to us that the species of former times, like those of the present day, did not frequent indiscriminately such and such regions."

In Normandy the lower zones of the Upper Lias have been studied with great care by Professor Deslongchamps, and many of the remarkable fossils they contain have been figured and described in his interesting 'Mémoire sur la Couche à Leptana du Lias,' already referred to, p. 119, in correlation with similar beds in the Upper Lias of Gloucestershire and Somersetshire. The quarries of Curcy, d'Évrecy, May, \&c., near Caen, are good localities for the study of this zone, and the following section at Curcy affords a clear exposure of the Upper and Middle Lias in natural position there.

\section{Section at Curct, Calvados.}

UPPER LIAS.

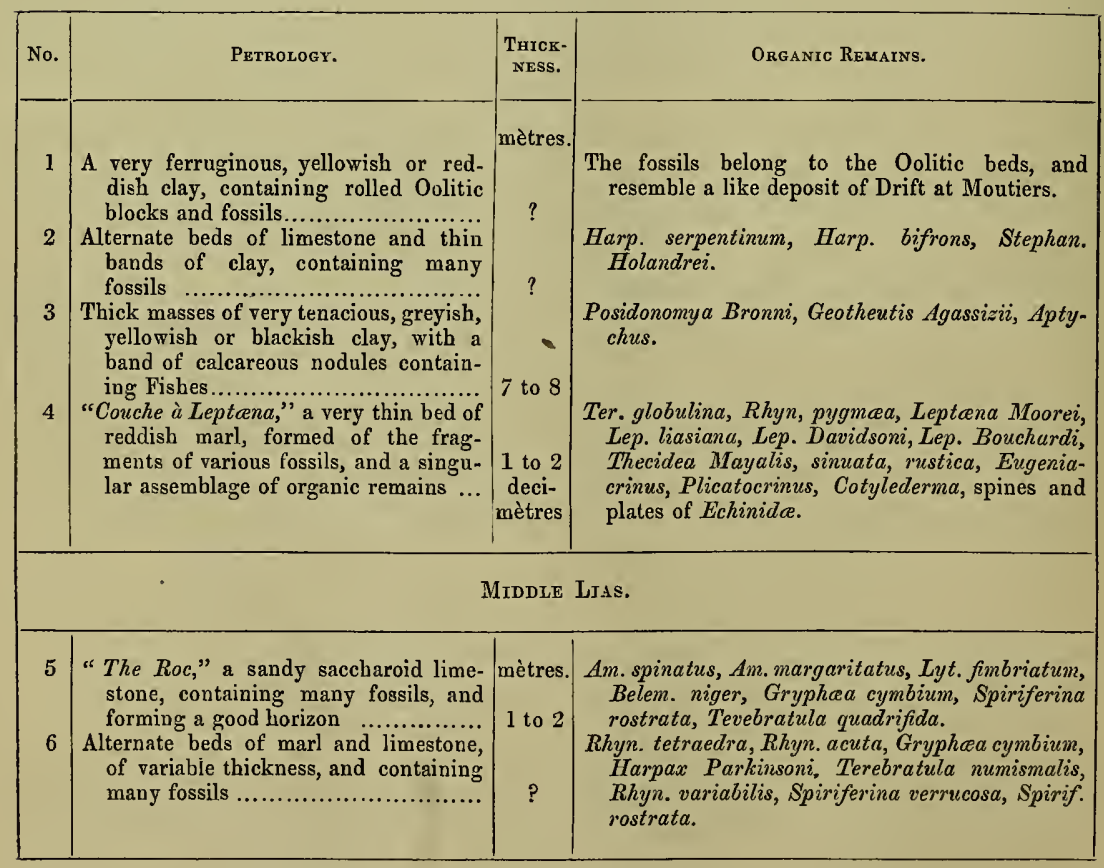

1 Ibid., p. 66.

2 ‘Bulletin de la Société Linnéene de Normandie,' vol. iii, 1859. 
The following typical section of the Upper Lias, "l'etage Toarcien," was made by Professor Alcide d'Orbigny at Thouars, Deux-Sèvres, ${ }^{1}$ where the daily working of the beds exposes beautiful natural profiles. The relation of the Jurense and Serpentinum zones are here likewise well seen in situ.

Section of the "Toarcian" at Thouars, Deux-Sèvres.

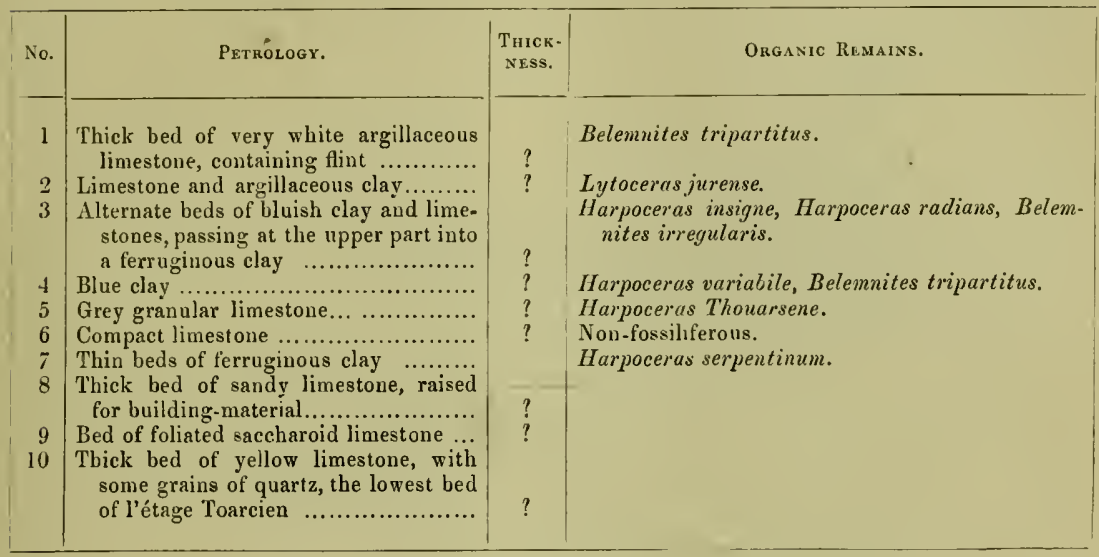

\section{The Zone of Lytoceras Jurense.}

Synonyms. - "Sands of the Inferior Oolite," Smith, De la Beche, Conybeare, and other English authors. “Jurensismergel.," Quenst., 'Flözgeb. Würtemberg,' p. 599, 1843. " $9^{\mathrm{e}}$ étage Toarcien (pars sup.)," d’Orbigny, 'Cours élément. de Paléontologie,' p. 469, 1552 (sect. at Thouars $h$ to $l$ ). "Zone des Amm. torulosus nnd Zone des Amm. Jurensis," Oppel, 'Juraformation,' p. 296, 1856. "Cephalopoda-bed and Upper-Lias Sands," Wright, 'Quart. Jour. Geol. Soc.', vol. xii, p. 292, 1856. "Marnes d'Aresche, et Marnes de Pimperdu, Jura franc-comtois," Marcou, 'Les Roches du Jura,' p. 119, 1857. "Ammonite Sands," Hull, 'Mem. of the Geol. Surv., Country around Cheltenham,' p. 25, 1857. "Cynocephala stage," Lycett, 'Cotteswold Hills,' p. 16, 1857, “ Jurensis bed,” Wright, 'Quart. Jour. Geol. Soc.,' vol. xiv, p. 25, 1857. “Lias Zeta," Quenstedt, 'Der Jura Uebersichtafel,' p. 293, 1858. “Zone of Am. Jurensis," Wright, 'Oolitic Asteroida, Pal. Soc.' Vol. 1862. "Midford Sands," Phillips, 'Geol. of Oxford and the Valley of the Thames,' p. 118, 1871.

This younger member of the great Lias formation is well developed in the counties 
of Gloucester, Somerset, Dorset, and at Blue Wick, or Blea-Wyke, near Robin Hood's Bay, on the Yorkshire coast. It may be most advantageously studied in the fine section at Frocester Hill, and in other smaller exposures in the Nailsworth and Brimscombe Valleys in Gloncestershire. The following section of Frocester Hill, near Stonehouse, affords one of the best types of the zone of Lytoceras Jurense in the county of Gloucester.

Fig. 8.-Section of Frocester Hill, near Stoneltouse.

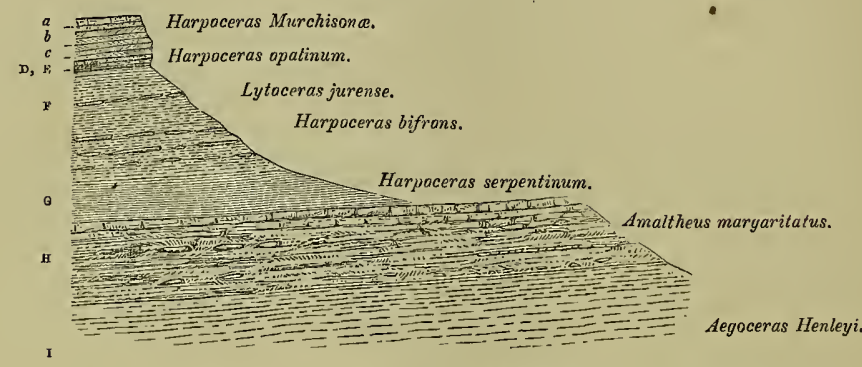

$a, b, c$. Inferinr Oolite; 70 feet. Zone of Harpoceras Murchisona.

D, E. Calcareo-ferruginous sandstone (Cephalopoda hed); 6 feet. $\left\{\begin{array}{l}\text { Zones of Harpoceras opali- } \\ n u m \text { and Lytoceras jurense. }\end{array}\right.$

F. Grey, yellow, and brown sands, with inconstant, concretionary bands of calcareous sandstone; 150 feet? Zone of Harpaceras bifrons.

G. Upper Lias shale; 80 feet. Zone of Harpoceras serpentinum.

H. Marlstone; hard calcareous saudstone, resting on brown and grey sands, with bands and nodules of ferruginous sandstone; 150 feet. Zone of Amaltheus margaritatus.

I. Middle Lias shale. Zone of Aegoceras Henleyi.

In very few localities, where the sands are exposed along the escarpments of the Cotteswolds or in the beautiful valleys intersecting these hills, are they found to contain organic remains; but fossiliferous seams have, however, been discovered at Frocester, Brimscombe, Nailsworth, Uley Bury, North Nibley, and Ozleworth, and doubtless will be detected in other localities in this neighbourhood when the strata are exposed.

The fossiliferous bed at Nailsworth lies near the base of the sands 4 or 5 feet above the Upper Lias clay, and consists of a fine soft ferruginous marly sandstone, of a rich brown colour, containing much peroxide of iron, with many shells, mostly of the same species found in the Cephalopoda-bed at Frocester. The difference between these two beds is important, and deserves to be noted, as the Cephalopoda-bed at Frocester overlies the sands, whilst the fossiliferous bed at Nailsworth underlies them near their base, clearly proving that the sands and Cephalopoda-bed form one stage.

In Somersetshire the Jurense-zone is met with in several sections south of the Mendips, resting upon the Crania-clays of the Upper Lias, as in the section at Straw- 
berry Bank, Ilminster, already described at p. 119; where the rock consists of alternate strata of clay and stone, in which are found Harpoceras insigne, Harpoceras variabile, and $H$. opalinum, var. Moorei. These Ammonites have not migrated, as some geologists state, from the Upper Lias sea into the Cephalopoda-bed of the sands above, inasmuch as neither of the species are ever found in the Serpentimum and Bifrons zones, but are truly characteristic forms of the Jurense-zone, of which they form the leading species.

South of the Mendips the sands attain a thickness of 160 feet, whilst north of that range they diminish much, are extremely variable, and are absent in several localities. Near Bath they are about 40 feet thick, and are well exposed in the railway tunnel under Combe Down; also at Midford, near the late Dr. William Smith's house, hence the origin of the name, "Midford Sands."

In Dorsetshire this zone is found in several localities. I have carefully examined it in the following; at Chideock Hill, between Bridport and Charmouth, it is exposed near the summit, and consists of a very fine sandy rock of a light yellow colour, sometimes micaceous, in which I found good specimens of the following Ammonites, Harpoceras insigne, Harp. variabile, and Harp. opalinum, all characteristic species in good preservation. From Burton Bradstock I have obtained some large Harp. opalinum and Harp. variabile in a fine yellow sandy matrix; the sands here attain a considerable thickness, and have several inconstant bands of sandstone intersecting the deposit. At the east side of Bridport Harbour there is a magnificent coast section of the sands, estimated at upwards of 200 feet in thickness; and between Bridport Harbour and Burton Bradstock there are several good quarry sections, which show the upper ragstones of the Inferior Oolite resting upon the Cephalopoda-bed. These two rocks so closely resemble each other in their petrology, that, but for the organic remains they contain, it would be impossible to separate them. Fortunately, however, the Inferior Oolite contains many Ammonites, Bivalve shells, Echinides, and Corals, which are typical of the Lower Oolitic beds, so that the divisional line between them can be surely drawn by palæontological evidence where lithology fails to do so. At the west side a fault has depressed the sands, which are here overlain by thin beds of Inferior Oolite and Fuller's Earth. Near Yeovil several instructive sections of the sands are exposed in the raikway-cuttings around that town, and in the neighbourhood of Sherborne the sands are about 140 feet thick.

My friend Dr. Lycett, in his notes on the Ammonites of the sands intermediate to the Upper Lias and Inferior Oolite, intending to afford a concise analytic examination of their natural-history, characters, and geological distribution, assumed that it had been generally considered that all the species belonged to the lower horizons of the Upper Lias, but this was not the teaching of my Memoir, in which, by many sections and carefully prepared lists of the palæontology of the Upper-Lias sands ${ }^{1}$ in the counties of

1 "Notes on the Ammonites of the Sands intermediate to the Upper Lias and Inferior Oolite," 'Traus. Cotteswold Naturalists' Club,' p. 3, 1862. 
Gloucester, Somerset, Dorset, and York, the Cephalopoda-bed and its underlying sands were showl to represent a well-marked horizon with specific forms of Ammonoida that were found neither in the Alum-shale or Bifrons-bed below, nor in the Inferior Oolite or Murchisone-zone above, and certainly represented a horizon of life, the correlative of the Jurensis-Mergel of Quenstedt.

The late Professor John Phillips" proposed the name "Midford Sands" for " the last of the Liassic strata to which the Inferior Oolite had not quite relinquished its ancient claim. .... They are covered in many districts of the south of England by calcareous and shelly beds, which on first view appear naturally associated with the Oolitic rocks above; but they contain many fossils which are frequent in the Sands and not common in the Oolites. . . . . If we wish to draw a hard limit of mineral deposits it should probahly be between the sand and its calcareous cover (which is often absent), but if we desire to study organic sequence we shall mite the sands and their shelly cap into a transition group. In this point of view the facts which have come out by inquiry are very instructive. Taking first the group Cephalopoda, we find some of the well-known species of the Upper Lias to be continued through the sands into the shelly bed above, as Ammonites bifrons, $A$. opalinus, A. striatulus, A. concavus, Belemnites compressus, $B$. irregularis, B. tripartitus. On the other hand several Conchiferous Molluses, which occur with these Cephalopoda, have decided Oolitic and not Liassic affinity. Such are Hinnites abjectus, Trigonia striata, Modiola Sowerbii, Pholadomya fidicula. Before the Liassic life has come to an end the Oolitic life has begun; a point of great importance in the reasoning on the causes of successive variation in the oceanic population, and one which will come before us again on several occasions while following the course of Oolitic time. The Cephalopoda-bed . . . . is not known in the valleys of the Cherwell or Evenlode, and very partially in any of the branches of the Windrush, Coln, or Churn. But on the western front of the Cotteswold cliffs it extends from Cleeve-Cloud to Wotton-1nder-Edge, appears on the Dorsetshire coast, near Bridport, and is recognised in France."

In the palæontological table which accompanies this section it will be shown that Harp. striatulum and Harp.opalinum are not found in the Upper Lias properly so called, but appertain to the Jurense-bed, and that Harp. bifrons is a leading fossil of the clay bed of the Upper Lias, but is not found in the Jurense-zone unless as a fossil washed out of an older bed and redeposited in a newer formation.

Dundry Hill, near Bristol, 769 feet in altitude above sea-level, is the most westerly outlier of the Cotteswold range, from which it is nine miles distant ; this is a locality of great interest to the naturalist, as it affords capital sections of the Jurassic strata, adnirable examples of rock-sculpture by denudation, and a commanding point for surveying the grand panorama in the midst of which it stands. The following profiles of this hill show its structure very clearly.

$$
1 \text { 'Geology of Oxford and the Valley of the Thames, p. 118, } 1871 .
$$


Fıc. 9.-Section across Dundry Hill, showing its cap of Inferior Dolite.

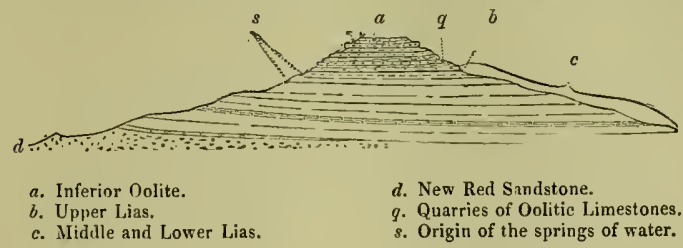

Fig. 10.-Lateral profile of Dundry IIill.

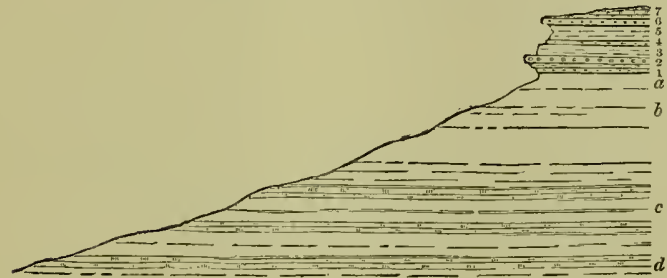

7. Freestone Building Oolite, 12 feet.

6. Fune-grained Oolite 4 "

5. Shelly Ragstones

4 \& 3. RubhIy Shelly limestones, 12 "

2. Zone of Harp. Sowerbii 3 " q. Quarries of Oolitic Limestones.
s. Origin of the springs of water.

1. Ironshot Pleurotomaria Bed, 2 feet

a. Upper Lias Sands

b. Upper lias Clay

c. Middle Lias

d. Lower Lias

2-3,

4

369 "

The Oolitic rocks exposed at the summit of the hill belong to the Inferior Oolite, which, in the south of England, admits of a division into three zones of life. The lower l'esting upon the Upper-Lias Sands has Harpoceras Murclisonce as its leading fossil; the middle contains a large assemblage of Mollusca, among which the Ammonoida predominate, and these chiefly belong to Stephanoceras Humphriesianum, Steph. Brongniarti, and Steph. Broccliii; the upper zone is characterised by Cosmoceras Parkinsoni, Perisplinctes Martinsii, and Oppelia subradiata, with many Echinidæ and a large series of reef-building Corals. These three subdivisions are rarely all found together in the same locality, but the order of their sequence in nature is, as stated, in Dundry.

1. In the ironshot shelly beds are many Lamellibranch Molluses and a rich assemblage of Pleurotomarias. These are covered by the second Ammonite-zone with Stepluanoceras Humpliriesianum. Many of these are beautifully preserved Ammonoida with the shell entire, the mouth-processes developed, and the Aptychi in sitü, as Stephan. Humphriesianum, Steph. Brocchii, Steph. Brongniarti, Steph. Blaydeni, Steph. Gervillei, and others. The Conchifera beds 3 and 4 contain IIarpoceras Sowerbii and a large assemblage of Lamellibranchs with Echinidæ and Anthozoa belonging to the middle 
beds of the Inferior Oolite. The Ragstones rest on them, and here appear for the first time small Cosmoceras Parkinsoni, Pleurotomaria proteus, Plioladomya Heraulti, P. ovulum, Ceromya Bajociana, Terebratula perovalis, Ter. spheroidalis, Ter. globata, Rlynchonella spinosa, Rhyn. plicatella, with Echinoderms, as Magnotia Forbesii, Stomechinus intermedius, Echinobrissus clunicularis, and Holectypus depressus, all forms of Echinidx found for the first time in the Parlinsoni-beds.

The fine-grained oolite or building-stone, No. 6, resting upon the preceding, which much resembles Portland stone, is extensively raised as a valuable building material.

The coarse oolite or Freestone beds are the highest set of strata observable at Dundry Hill. Shells are not common in these rocks, but several Corals are here located, as Isastraa explanata, Stylina solida, Thamnastraa Defranciana, Latomcandra Flemingii, Isastrea tenuistriata, with Crinoids as Pentacrinus Milleri.

The Oolitic rocks rest upon the Upper-Lias Sands, $a$, or zone of Lytoceras jurense, which is seen at the western side of the hill. The sands are only from 2 to 3 feet in thickness, and contain dwarfed specimens of Modiola plicata, Ploladomya fidicula, Lima bellula, Belemnites irregularis, Bel. compressus, and small Harp. insigne, so that this arenaceous deposit, which attained 80 feet in thickness at Frocester and 125 feet at Wootton-under-Edge, has almost disappeared at Dundry.

The zone of Harpoceras bifrons is feebly developed at Dundry, only a few small, dwarfed specimens of Harp. bifions, Steplian. commune, Belemnites tripartitus, with a Pholadomya, and a Modiola, have been found in these Upper Lias clays. ${ }^{1}$

The Middle Lias is here feebly represented, and in this respect presents a remarkable contrast to the great development this division attains in the escarpments of the Cotteswold Hills, and in the country around Bath.

The Lower Lias in the Dundry district is well seen at Bedminster Down, Keynsham, Whitchurch, Queen Charlton, Norton Malreward, Winford, and Barrow; in ascending from all these localities to the summit of the Hill we pass in succession from the Red Marl at Bedminster, over the Avicula contorta, Planorbis, Bucklandi, Turneri, and Obtusus-beds, which have a collective thickness of 450 feet.

I beg to refer the student to the section of the Buclclandi-beds at Saltford, near Bath, pp. 36 and 37, and of the Planorbis, and Avicula-contorta-beds in the same cutting, as affording all the details of these strata yet known on the subject in this district.

Those readers who may be interested in the Palæontology of the Dundry district will find in the 'Proceedings of the Bristol Naturalists' Society;' vol. i, p. 9, new series, 1874, a most valuable memorr by Mr. E. B. Tawney, F.G.S., entitled "Museum Notes-Dundry Gasteropoda." This paper contains a list. of sixty-four species, many of which are beautifully figured for the first time, and the whole are most minutely and accurately described. It is an important addition to British Jurassic palæontology.

1 For full details on the Dundry Hill section, I beg to refer to my friend Mr. R. Etheridge, F.R.S., notes on Dunỏry Hill, in my Mernoir on the "Subdivisions of the luferior Oolite," "Quart. Journ. Geul. Soc.,' p. 21, vol. xvi, 1860 . 
Whilst this sheet was passing throngh the press my esteemed friend Mr. W. W. Stoddart, F.G.S., of Bristol, kindly sent me a detailed section of Dundry Hill, measured by himself, with the vertical thickness and barometrical height of the chief beds in the section in feet. This I have endeavoured to embody in the form adopted in this work; and I thank my friend for the same.

Section of Dundry Hill. Dip $20^{\circ}$ N.N.E.

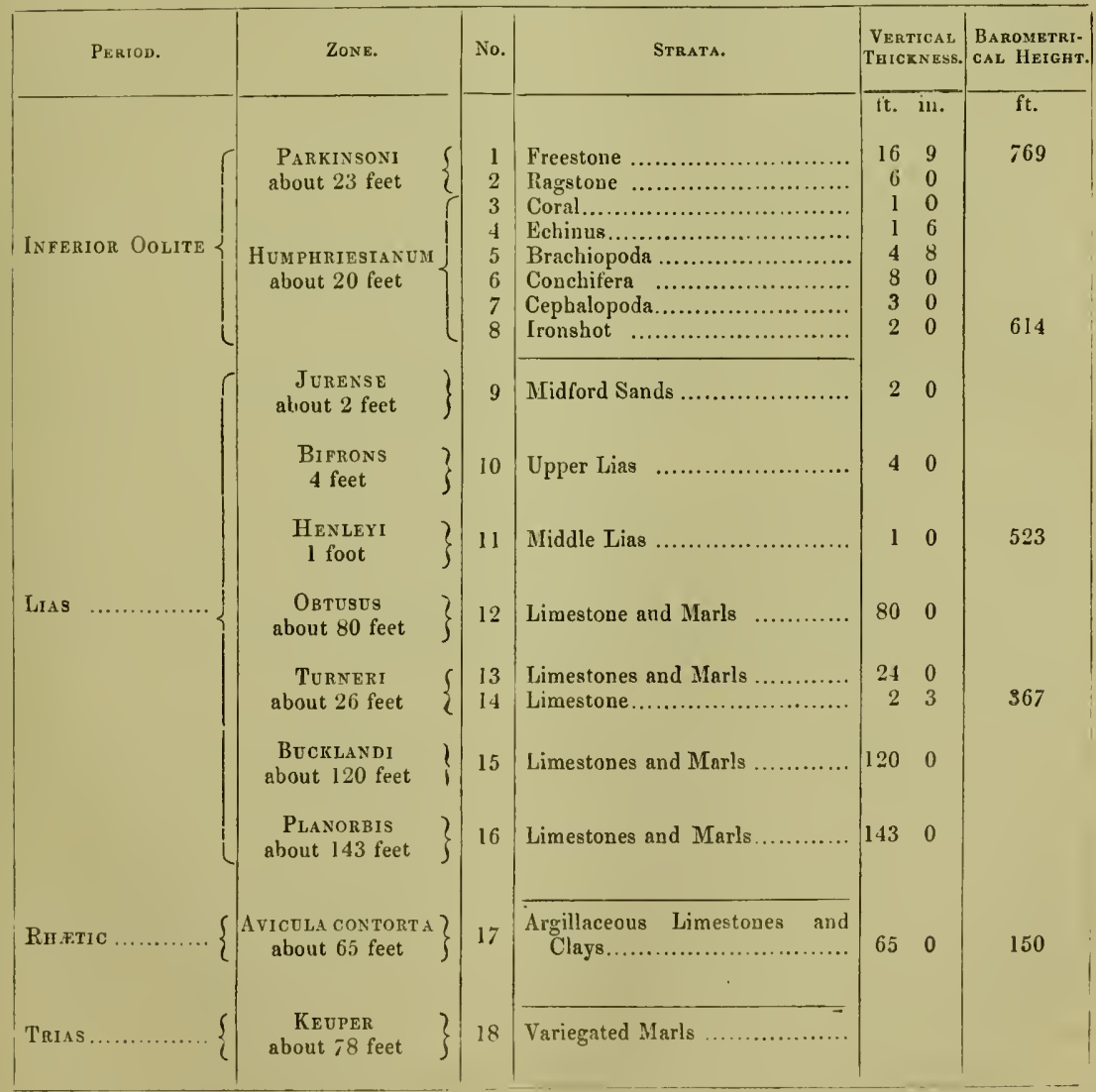


It is now twenty years ago since I discovered the Jurense-zone at Blue Wick, near Robin Hood's Bay, on the Yorkshire coast, ${ }^{1}$ beneath a rock which I considered the equivalent of the basement bed of the Dogger or Inferior Oolite. It was a yellowish sandstone, containing several seams of small round pebbles, which lie near the bottom. The pebbly conglomerate is about 4 inches in thickness, and occurs at intervals. The sandstone contains fragments of Belemnites, Cerithia, and Monotis nitescens, Simp. The bed is about 5 feet thick, and lies on No. 1, a band of dark friable shale, resting on a hard ironstone band full of fossils. This bed is very micaceous in parts, and many of the shells are stained with ferric oxide. I found Terebratula trilineata, Young and Bird, in clusters in the sandstone, with Belemnites compressus, Voltz, Bel. irregularis, Schloth., Trigonia Ramsayi, Wright, and Rhynchonella cynocephala, Rich. These species occur also in a ferruginous seam of sandstone at Glaizedale. This bed is 18 inches thick, and rests on No. 2, the Yellow Sandstone, which is well exposed at Blue Wick. It consists of irregular layers of soft yellow sandstone, unequally indurated; some portions weather out and leave hollows in the cliff, whilst others are fine-grained, yellowish, highly micaceous, thick-bedded, and variously jointed. The upper part of this rock is ochraceous, and contains fossiliferous seams. Here I found in one large block Harpoceras Comense, von Buch, Harp. insigne, Schübl., Goniomya angulifera, Sow., Monotis inaquivalvis, Sow., Trigonia Ramsayi, Cerithium sp., Turritella sp., Astarte sp., Gresslya pinguis, Glyphoa Birdii, Bean. This bed is about 20 feet in thickness.

No 3, the Serpula-bed, a fine-grained greyish-yellow sandstone, which forms a reef, dips gently to the south-east, and presents a low escarpment to the north ; it is regularly jointed, and the exposed upper surface contains masses of Serpula diplexa, Bean, Vermetus compressus, Will., Pecten intercostatus, Wright, Harpoceras Aalense, Ziet. (var. Moorei, Lyc.), and Heterocidaris Wickensis, Wright. This bed is 10 feet in thickness; the upper 4 feet are most fossiliferons; in the lower six feet the same species of shells are sparsely distributed.

No. 4, the Lingula-bed or grey sandstone is a soft argillo-micaceous sandstone of a bluish-grey colour, and partly fissile. This rock is divided by long joints, and forms "scars" at Blue Wick. Its upper, fissile portion is fossiliferous, and contains Lingula Beanii, Phil., Discina reflexa, Sow., and Monotis nitescens, Simp. About the middle of the bed a layer of small nodules occurs, fragments of Crustacea, Glyphcea Birdii, Bean, and Glyphaea, n. sp., allied to rostrata, are found in these nodules. The lower portion is rough and sandy, and passes into hard, argillaceous, nodular layers: I collected the following species from the sand:

Harpoceras Aalense, Ziet.

- variabile, d'Orb.

Belemnites compressus, Voltz.

- irregularis, Schloth.
Alaria Leckenbi, n. sp., Wright.

Cerithium quinque-punctatum, Deslong.

- vetustum, Phil.

Mytilus Wickensis, Wright.

1 'Quart. Journ. Geol. Soc.,' vol, xvi, pp. 3 and 4. 
Pecten Wickensis, Wright.

Goniomya angulifera, Sow.

Pholadomya fidicula, Sow.

- obliquata, Phil.

Monotis substriata, Münst.

Gresslya peregrina, Phil.

Gervillia Hartmanni, Goldf.

Pinna cuneata, Bean.
Cucullæa cancellata, Phil.

Lingula Beanii, Phil.

Rhynchonella cynocephala, Rich.

Discina reflexa, Sow.

Terebratula trilineata, Young \& Bird.

Glyphra Birdii, Bean.

- n. sp. allied to G. rostrata.

Heterocidaris Wickensis, Wright.

No. 5, hard argillaceous shales with layers of nodules, which lie at the base of the sand, and rest upon the Alum-shale. In this band, however, are found certain species of Ammonoida not met with in any other rock on the Yorkshire Coast, and they are all leading fossils of the zone of Lytoceras jurense, Ziet., as

Lytoceras jurense, Ziet.

Harpoceras insigne, Schübl.

$$
\begin{array}{ll}
\text { - } & \text { variabile, d'Orbig. } \\
\text { - } & \text { Aalense, Ziet. } \\
\text { - } & \text { striatulum, Sow. }
\end{array}
$$

Monotis substriata, Mü̈nst.

Goniomya angulifera, Sow.

Discina reflexa, Sow.

Lingula Beanii, Phil.

Rhynchonella Jurensis, Quenst.

The dark-grey calcareo-argillaceous nodules rest on the clays of the Upper Lias, or the true Alum-shale containing Stephanoceras crassum, Stepl. commune, Steph. fibulatum, Leda ovum, and Trigonia literata.

\section{Fossils of the Zone of Lytoceras Jurense.}

\section{Reptilua.}

Vertebræ of Ichthyosaurus.

\section{Pisces.}

Teeth of Hybodus.

\section{Cephaloyoda.}

Lytoceras Jurense, Ziet.

$$
\text { - hircinum, Schlöth. }
$$

Harpoceras insigne, Schübler.

$$
\begin{array}{ll}
- & \text { Comense, von Buch. } \\
\text { - } & \text { Aalense, Ziet. } \\
- & \text { discoides, Ziet. } \\
-\quad & \text { Thouarsense, d'Orb. } \\
-\quad & \text { striatulum, Sow. } \\
-\quad & \text { radians, Reinecke. } \\
-\quad & \text { Raquinianum, d'Ort. } \\
-\quad & \text { Levesquei, d'Orb. }
\end{array}
$$

Harpoceras Leckenbyi, Lyc.

- variabile, $d^{\prime}$ Orb., var. Beanii, Simp.

- variabile, d'Orl., var. dispansum, Lyc.

- obliquatum, Young \& Bird, the aged form of variabile.

Nantilus latidorsatus, $d^{\prime} O r \cdot b$.

Belemnites compressus, Voltz.

- tripartitus, Schloth.

- irregularis, Schloth.

- Nodotianus, d'Orb. 


\section{Gasteropoda.}

Pleurotomaria subdecorata, d'Orb.

Chemnitzia lineata, Sow.

*Turbo capitaneus, Münst.
Trochus duplicatus, Sow.

* Natica adducta, Phil.

- Oppelensis, Lyc.

\section{LAMELLLIBRANCHIATA.}

*Lima bellula, var., Lyc. \& Mor.

* Modiola plicata, Sow.

*Perna rugosa, Münst.

*Hinnites abjectus, Phil.

*Pecten articulatus, Goldf.

* Gresslya abducta, Phil.

* - coníormis, Agass.

Myacites arenacea, $L y c$.

*Homomya crassiuscula, Lyc.

Goniomya angulifera, Sow.

* Myoconcha crassa, Sow.

* Cypricardia cordiformis, Desh.

* Pecten comatus, Münst.

Opis carinatus, Wright.

* - lunulatus, Sow.

Cypricardia brevis, Wright.

Cardium Hullii, Wright.

- Oppelii, Wright.

Cucullæa ferruginea, Lyc.
Cucullæa olivæformis, Lyc.

*Lima electra, d'Orb.

Unicardium, nov. sp.

Tancredia, nov. sp.

Trigonia Ramsayii, Wright.

* - striata, Sow.

* - costata, Sow.

Pecten textorius, Goldf.

*Ploladomya fidicula, Sow.

- arenacea, Lyc.

Lima ornata, Lyc. MS., nov. sp.

Astarte lurida, Sow.

* - excavata, Sow.

- detrita, Goldf.

- complanata, Roemer.

- rugulosa, Lyc.

Gervillia fornicata, Lyc., MS.

* - Hartmanni, Goldf.

Nucula Jurensis, Quenst.

\section{BRACHIOPODA.}

Terebratula subpunctata, $D a v$. - trilineata, Young.

Rhynchonella cynocephala, Rich.

- Jurensis, Quenst.

In the above list the species marked with an asterisk are found likewise in the Inferior Oolite; but the specimens from the sands are nearly all dwarfed forms, showing that the physical conditions under which they lived were unfavorable to their development. The stunted growth of the stationary Lamellibranchs forms a striking contrast to the size, number, and variety of the locomotive Cephalopods interred with them in the same bed; the dawning existence of the former appears to have been a struggle for life, whilst the conditions under which the Cephalopods existed were favorable to their continuance in time, as shown by the number of species and individuals found in the Frocester beds; their life, however, was abruptly brought to a termination by some great plysical change which took place about the commencement of the deposition of the Oolitic formations.

Foreign correlations. - The Jurensis-mergel was first pointed out by Professor Quenstedt ${ }^{1}$ as the uppermost member of the "Shwarzer Jura," its importance in 1 'Flözgebirge Würtembergs,' pp. 267 and 539, 1843. 
Württemberg as a distinct horizon demonstrated, and its leading fossils, Lyt. Jurense, Harp. insigne, Harp. radians, Bel. digitalis, and many others special to this zone, found at Balingen, Heiningen, Wasseralfingen, and other localities, were described. Upon the hard grey marls with Lyt. Jurense follow in Swabia beds of dark clay with Lyt. torulosum, as at Laufen and Metzingen. In Baden, ${ }^{1}$ as at Langenbrïcken and Mingolsheim, light grey calcareous marls with Lyt. Jurense, Harp. radians, Bel. irregularis, Bel. tripartitus, and Bel. acuarius, rest upon the Posidonomya-clays and form the uppermost beds of the Lias in this region.

In North Germany the Jurense-zone has been described by von Strombeck, Ewald, and Credner as found in the Helmstedt, Halberstadt, and Harzburg Jura, and in all these yielding its leading fossils as Lyt. Jurense, Harp. insigne, Lyt. lircinum, Harp. variabile, Harp. striatulum, and Bel. irregularis.

M. Terquem² has described a "Grès supra-liassique ou marly sandstone," near Metz, Moselle, which appears to represent this zone, as he has collected therefrom, in the environs of Thionville and at Longwy, several of the characteristic fossils of the Jurensebed, as Harp. insigne, Harp. radians, Bel.tripartitus, together with Gastropods and Lamellibranchs belonging to this horizon.

At Silzbrumnen, Lower Elsace, my friend Professor R. Lepsius ${ }^{3}$ has described the Jurensis-Mergel. The fossils he found were in very good condition, and the Ammonites had their shells well preserved. In the marl the group of IIarpoceras radians was the most abundant. Here he collected likewise Lyt. Jurense, Lyt. liircinum, Ilarp. insigne, Harp. Aalense, Harp. subplanatum, Harp. discoides, with Nucula Hammeri, Lima Galatea, Lima duplicata, Pecten textorius, Pentacrinus Jurensis, and Diastopora liasica.

On the right bank of the Drôme, in the quarries of Suble, near Bayeux, above the calcareous and argillaceous strata, with IIarp. bifrons and Stephan. commune, M. I. Harlét discovered marly beds, two mètres thick, containing Harp. opalinum, Harp. radians, Harp. Conense, Harp. variabile, Bel. tripartitus, Bel. abbreviatus, Bel. longisulcatus, and Rluyn. ringens, which evidently represent the Opalinum- and Jurense-zones in Calvados.

At Thouars, Deux Sèvres, it will be seen (p. 137) that the strata Nos. 1-6 represent the Jurense-zone, which here rests conformably on the Serpentinum-beds. At Verpillière and St. Quentin (Isère) Dr. Oppel ${ }^{5}$ collected Harp. radians, Harp. costula, Harp. Thouarsense, Harp. Comense, Harp. insigne, Harp. Aalense, Harp. comptum, Harp. variabile, Lyt. Jurense, and Lyt. Lircinum.

1 Leonhard, 'Geognost. Skizze des Grossherzog Baden,' p. 98, 1861.

2 'Paléontol. du Départ. de la Moselle,' p. 23, 1855.

3 'Beiträge zur Kenntniss der Juraformation in Unter-Elsass,' p. 13, 1875.

4 ' Aperçu de la const. géologique du Dép. Calvados,' Annuaire, 1853.

5 'Juraformation Englands, Frankreichs, und des S.-W. Deutschlands,' p. 233, 1856. 
M. Marcou, ${ }^{1}$ in his 'Jura Salinois,' has described some beds as "Marnes à 'Trochus ou de Pinperdu," which contain the leading fossils of the "Jurensis-Mergel." In other Departments of France the same species of Ammonites have been collected, as, for example, near Fontenay (Vendée); Charolles, Saône-et-Loire; Mont d'Or, near Lyons, Rhône; Semur, Côte d'Or ; \&c., so that the Jurense-zone forms a well-defined horizon of life in the uppermost portion of the Upper Lias of France.

\section{Zone of Harpoceras opalinum.}

“ Opalinus-Thone," Quenstedt, 'Flözgeb. Würtemb.,' pp. 281, 539, 1843. "Schict. des Am. torulosus," pars, Oppel, 'Jura-Formation,' p. 306, 1855. "Zone à Am. opalinus," Reynés, 'Géol. et Pal. Aveyron,' p. 63, 1868. "Zone à Am. opalinus," pars, Dumortier, 'Bassin du Rhône,' tom. iv, p. 278, 1874. "Thone der Trigonia navis," pars; "Zone des "Am. torulosus" Lepsius, 'Jura-Formation Unter-Elsass,' pp. $3,14,1875$.

This zone was formerly grouped with the Cephalopoda-bed at Frocester; but, as it contains some species which are limited to this horizon and are associates of Harpoceras. opalinum, it is best to treat it as the highest zone of the Lias. At Haresfield it forms a thin band of hard, ferruginous marl, which lies at the base of the Inferior Oolite in conformable position thereto. From this I have collected Harpoceras opalinum, Rein., Macrodon Hirsonensis, d'Arch., Terebratula punctata, David., var. Rlynnclionella cynocephala, Rich., Rhyn. furcillata, Théod. I have had few Ammonites from this bed, and the other shells are not abundant. At Frocester Hill the upper portion of the Cephalopoda-bed contains several Ammonites, which have been described and figured by my old and esteemed friend Dr. Lycett. ${ }^{2}$ One of these, Harp. Moorei, appears to resemble so much several specimens of Harp. opalinum from Gmünd, Boll, and Gundershofen, that I have no hesitation in regarding Harp. Moorei as a variety of Harp. opalinum, the form of the keel and the fine limes on the shell clearly showing the affinities. These localities are the only two I know in Gloucestershire, where this Ammonite is found. In Dorsetshire I have collected large beautiful specimens at Burton Bradstock, and at Chideock Hill, near Bridport, and have always found this species immediately beneath the Inferior Oolite. From the Haresfield bed I have taken a piece of rock having the impression of Harp. opalinum on its underside, whilst the block itself contained Inferior Oolite fossils; a fact which may afford an explanation how this Ammonite is considered by some to be an Oolitic species, and the progenitor of Harp. Murchisona. The Opalinum-

1 'Jura Salinois,' pp. 54 and 66, 1846.

2 'The Cotteswold Hills Handbook,' p. 122, pl. i, fig. 2, 1857. 
bed at Haresfield and Frocester appears to be the boundary-line between the Lias and Inferior Oolite. In some lists of fossils I observe $A m$. torulosus entered as a species found at Frocester Hill ; this, in my judgment, is a mistake. Lyt. lircinum occurs there, and may have been mistaken for it: I have not yet seen Lyt. torulosum in any English stratum or collection.

At Blue Wick, near Robin Hood's Bay, Yorkshire, this zone is represented by a band of dark friable shale, in parts micaceous and stained with ferric oxide, and containing Terebratula trilineata, Rhynchonella cynocephala, Trigonia Ransayi, Belemnites compressus, and Bel. irregularis. The same species occur in a ferruginous seam of sandstone at Glaizedale, measuring eighteen inches in thickness, so that this bed in the north, as in the midland counties, is only feebly developed.

Foreign correlations. - The "Opalinus-Thone" was well described by Prof. Quenstedt," as it occurs in Swabia, and Am. opalinus, Am. torulosus, Bel. tripartitus, Trigonia navis, Gervillia pernoides, Cardium striatulum, Mya angulifera, Nucula Hammeri, and Astarte lurida were enumerated as its leading fossils.

Dr. Oppel found the beds in Württemberg in the Swabian Alps; and near Gmünd, Boll, Metzingen, Gomaringen, and Mässingen, in Bavaria, in the neighbourhood of Altdorf, and Neumarkt, and in Baden, near Kander. Many of the leading shells figured by Goldfuss in his 'Petrefacta Germaniæ' were collected from this bed at Banz, and near Boll.

In North Germany this zone has been detected in many localities. Reinecke ${ }^{3}$ first figured Harp. opalinum from a specimen collected near Alten-Banz, Coburg. Rolle recognised the stratum near Hildesheim, Goslar, and Quedlinburg, and first compared the fossils he collected from these beds with those he liad found in strata of the same age in Swabia. Von Strömbeck ${ }^{6}$ discovered the zone near Schoppensted, and Ewald ${ }^{6}$ found the same near IIoym in Saxony. Von Seebach ${ }^{7}$ met with this horizon near Wentzen, at the southern margin of Hils, and likewise in a railway-cutting sonth-east of Greene, from which he obtained a collection of its leading fossils, including Lyt. lircinum and Harp. opalinum. Dr. Lepsins ${ }^{8}$ carefully studied this zone in Lower Elsace, and has given an exhaustive account of the beds in his interesting memoir. I had the pleasure of showing my friend the Frocester Hill section of the Cephalopodabed and Jurense-sands, and he at once recognised the marked lithological resemblance they had to their correlative zone in Lower Elsace, upon the study of which he was then engaged.

1 'Flözgebirge Würtembergs,' pp. 243 and 539, 1843.

2 'Juraformation,' p. 308, 1856.

3 'Maris protogaei Cornu Amm. in Agro Coburgico,' pl. i, fig. 1, 1818.

4 'Versuch einer Vergl. des Norddeutschen Lias mit dem Schabischen,' 1853.

s 'Thon mit Am. opaliuus,' Zeitschr. d. Deut. geol. Gessell., vol. v, p. 102, 1853.

6 'Schict. des Am. opalinus,' Sitzber. d. Berlin Akad., April, p. 350, 1859.

7 'Der Hannoversche Jura,' p. 3, I864.

8 'Der Juraformation in Unter-Elsass,' p. 4, 1875. 
In France Harp. opalinum and Lyt. torulosum, which may be regarded as the leading fossils of this zone, have been collected at Vassy, Yonne; at Villenote, near Sémur, Côte d'Or; at Salins, Jura ; and Besançon, Doubs; at Amende, Lozère ; at Fontenay, Vendée; and at Charolles, Saône-et-Loire; and I obtained a number of Ammonites from Milhau, Aveyron; which all belong to the same zone. Dumortier ${ }^{1}$ has given a list of several localities in which he has found this zone in the Rhone Valley, and has especially noted la Verpillière, Isère; where the workings for iron-ore in this regiou bring the many beautiful fossils of this zone into collectors' hands, as Belemnites exilis, Bel. tricanaliculatus, Bel. Dorsetensis, Bel. pyramidalis, Nautilus lineatus, Harp. opalinum, Harp. Aalense, Harp. mactra, Harp. costula, Harp. fuitans, Harp. subinsigne, Harp. crassifulcatum, Harp. Briordense, Harp. Allconi, Harp. Lorteti, Harp. fallax, Lyt. hircinum, and Lyt. torulosum, all of which Dumortier refers to the Opalinumzone.

\section{The Inferior Oolite and its Ammonite-zones.}

The zone of Harpoceras opalimum is so closely related to that of Harpoceras Murclisone that I consider a short account of the latter a proper complement to my sketch of the Upper Lias. The affinities and differences between these two formations will then be placed fairly before the student, and the reasons be made evident for my definition of the limits of the Lias formation.

Leckhampton Hill, near Cheltenham, exhibits one of the most typical sections in Gloucestershire of the three sub-divisions of the Inferior Oolite, where the following beds are admirably exposed :-Fig. 11, Nos. 1, 2, and 3 represent the zone of Cosmoceras PasKinsoni; No. 4t the zone of Stephanoceras Humpliriesianum; Nos. 5, 6, and A, B, c, the zone of Harpoceras Murchisona ; those rest comformably on $\mathrm{D}$, the Cephalopoda- or Jurensebed, which is here very thin ; $\mathrm{E}, \mathrm{F}, \mathrm{G}$, is the Upper Lias resting on $\mathrm{H}$, the Marlstone.

No. 1. The Upper Trigonia-bed is a coarse brown ragstone, containing many fossils, chiefly as moulds and impressions of Trigonia costata, Sow., T. decorata Lyc., Lima cardiiformis, Sow., Rhynchonella concinna, Sow., Terebratula spinosa, Schl., Cosmoceras Parkinsoni, Sow., Eclinobrissus clunicularis, Lhywdd, Holectypus depressus, Leske, and Clypeus Plotii, Klein; in thickness it is about seven feet.

No. 2. The Grypluad-bed, an ancient oyster-bank, is almost entirely composed of Gryplıa sublobata, Desh., accompanied with Pholadomya Heraulti, Agass., Terebratula Meriani, Opp., Tancredia donaciformis, Lyc., Gervillia tortuosa, Phil., and many other species; but the dominant shell is the Gryplaca; this bed is about eight feet in thickness. 
Fig. 11.-Section of Leckhampton Hill, near Cheltenham.

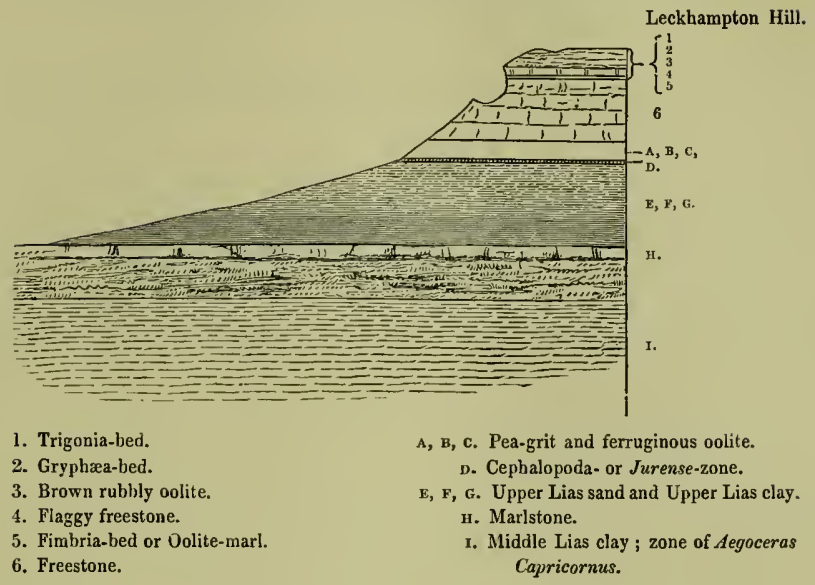

No. 3. The Lower Trigonia-bed, a light-coloured, thin-bedded oolitic ragstone, containing a large assemblage of Lamellibranchiata, which in general have their shells preserved, with several species of Echinodermata and Anthozoa.

No. 4. Upper flaggy bastard-freestone, well seen above the Oolite-marl : twenty-six feet thick. It represents the zone of Stephanoceras Humpliriesianum; this rock is here almost non-fossiliferous, although the equivalent bed at Cleeve Hill contains a rich fauna.

No. 5. The Fimbria-bed or Oolite-marl, is a cream-coloured mud-stone, not unlike chalk-marl; the dominant shells are Terebratula fimbria, Sow., Tereb. carinata, Lamk.; it contains likewise Lucina Wrighti, Oppel., Lima punctata, Phil., L. Pontonis, Lyc., Natica Leckhamptonensis, Lyc., Natica adducta, Phil., Mrytilus pectinatus, Sow., Astarte elegans, Sow., Nerinaa, sp., Chemnitzia, sp., and masses of Coral, chiefly Thamnastraa Mettensis, Edw. This bed was deposited under conditions very different to that of the freestone on which it rests; its lower portion is slightly brecciated, and the surface of the freestone on which that breccia was deposited had been for some time exposed to aqueous action and made smootl thereby. The marl measures abont seven feet in thickness, and passes upwards into a marly limestone, becoming oolitic in the uppermost layers. This division of the bed is about ten feet thick. The Fimbria-bed is a constant feature in the Lower Oolite of the Cheltenham district, and in the northern and middle Cotteswolds, but is absent in the southern parts of the range. It forms the upper part of the zone of Harpoceras Murchisona.

No. 6. The Freestone is a compact light-coloured oolitic limestone; the uppermost 
beds are the best for building-purposes; the middle beds are of an inferior quality, and are stained in part with ferric oxide ; the lower beds, called "Roestone," contain large oolitic grains; the freestone in all is about 110 feet in thickness.

\section{The Pea-grit (Zone of Harpoceras Murchisona), Inferior Oolite.}

A. A brown, coarse, rubbly oolite, full of flattened concretions cemented together by a calcareous matrix. When the blocks weather, the concretions, which resemble flattened

peas, form a very uneven surface. It contains many fossils in good preservation .........
B. A hard, cream-coloured, pisolitic rock, made up of flattened concretions, with a thickness about similar to those in A

Ft. in.

c. A coarse, brown, ferruginous rock, composed of large oolitic grains; it is readily disintegrated by the frost, and is of little economical value. About tegrated by the frost, and is of little economical value. About....

The Cephalopoda-bed (Zone of Lytoceras Jurense), Upper Lias.

D. A brown marly rock, full of small dark oolitic grains of the hydrate of iron, which are strewed in profusion in a calcareous paste. About

$D^{\prime}$. A thin seam of yellowish sand

\section{Upper Lias Sand and Clay.}

E. A dark-grey crystalline limestone, extremely hard, aud resembling some beds of the Carboniferous Limestone; it is bored in different places by Fistulana? the shells of which remain in the excavations. Thickness not exposed.

F. A brown, argillaceous, sandy bed, full of micaceous particles; passing downwards into fine brown and yellow sands. Thickness unknown 200

G. Upper Lias clay, of a dark blue colour. Thickness probably..

\section{Fossits of the Pea-grit and Freestones.}

\section{Cephalopoda.}

Harpoceras Murclisonæ, Sow. Nautilus truncatus, Sow.
Belemnites spinatus, Quenst.

- abbreviatus, Mill.

\section{Gasteropola.}

Patella rugosa, Sow.

- inornata, Lyc.

Pileolus lævis, Sow.

Nerita costata, Sow.

- minuta, Sow.

Monodonta Lyelli, d'Arch.

- sulcosa, d'Arch.

Natica adducta, Phil.
Cirrus nodosus, Sow.

Trochotoma carinata, $L y c$.

Turbo elaboratus, $L y c$.

Trochus monilitectus, Phil.

Solarium Cotswoldiæ, Lyc.

Nerinæa cingenda, Bronn.

Actæonina Sedgvici, Phil.

Alaria spinifera, Lyc. 


\section{LAMELLIBRANCHIATA.}

Ostrea costata, Sow.

Placunopsis Jurensis, Roem.

Hinnites velatus, Goldf.

Limea duplicata, Goldf.

Lima sulcata, Münst.

- lyrata, Münst.

- Lycetti, $W$ right.

- bellula, Mor. \& Lyc.

Pecten comatus, Münst.

- Dewalquei, Oppel.

Mytilus furcatus, Mïnst.

- striatulus, Goldf.

Modiola Sowerbyana, d'Orb.

Avicula complicata, Buck.

Corbula involuta, Goldf.

Tancredia axiniformis, Phil.

Arca Prattii, Mor. \& Lyc.

Terebratula simplex, Buck.

$$
\begin{aligned}
& \text { - } \quad \text { plicata, Buck. } \\
& \text { - } \quad \text { submaxillata, Dav. } \\
& \text { carinata, Lamk. }
\end{aligned}
$$

Serpula grandis, Goldf.

- convoluta, Goldf.

- plicatilis, Münst.

Cidaris Fowleri, Wright.

- Bouchardii, Wright.

- Wrighti, Desor.

Rhabdocidaris Wrightii, Desor.

Acrosalenia Lycettii, Wright.

Pseudodiadema depressum, Agass.

Stomechinus germinans, Phil.

Polycyphus Deslongchampsii, Wright.

Pedina Bakeriæ, Tright.

Stromatopora dichotomoides, $d$ Orb.

Diastopora Waltonii, Haime.

$$
\text { - Mitchelini, Haime. }
$$

Spiropora straminea, Phil.
Area pulchra, Sow.

- cancellata, Phil.

- lata, Dunk.

Trigonia costata (var. pulla), Sow.

- exigua, Lyc.

Astarte interlineata, $\boldsymbol{L} y \boldsymbol{c}$.

- rhomboidalis, Phil.

Sphæra Madridi, d'Arch.

Cyprina trapeziformis, Roem.

Unicardium, nov. sp.

Myoconcha crassa, Sow.

Ceromya Bajociana, d' Orb.

Myopsis rotundata, Buck.

Cardium striatulum, Phil.

- lævigatum, Lyc.

Goniomya angulifera, Sow.

Pinna cuneata, Beun.

\section{BRACHIOPODA.}

Rhynchonella Wrightii, Dav.

- decorata, Dav.

- angulata, Sow.

oolitica, Dav.

Annelida.

Serpula quadrilatera, Goldf.

- flaccida, Goldf.

\section{EChinOdermata.}

Hemipedina tetragramma, Wright.

$$
\begin{aligned}
& \text { - } \quad \text { perforata, Wright. } \\
& \text { - Bonei, Wright. }
\end{aligned}
$$

Pygaster semisulcatus, Phil.

- conoidens, $W^{\top}$ right.

Galeropygus agariciformis, Forb.

Stellaster obtusus, Wright.

Pentacrinus Desori, Wright.

$$
\text { - Loriolii, Wright. }
$$

\section{Polyzoa.}

Lichenopora Phillipsii, Haine.

Neuroptera demicornis, Lamour.

Heteropora conifera, Lamour.

- pustulosa, Mechelini.

Theona Bowerbankii, Haime.

Berenicea diluviana, Lamour. 


\section{AnthozoA.}

Montlivaltia Delabecbei, Edw. \& Haime. Waterbousei, Edw. \& Haime. - cupuliformis, Edw. \& Haime. Axosmilia Wrightii, Edw. \& Haime.

Latomæandra Flemingii, $E d w$. \& Haime.
Isastræa tenuistriata, $E d w . \&$ Haime.

- limitata, Edw. \& Haime.

Thamnastræa Mettensis, Edw. \& Haime.

- Defranciana, Edw. \& Haime.

The annexed generalised section of Cleeve Hill, Gloucestershire, gives all the Inferior Oolite beds in their relative position, and at the same time shows how they rest conformably on the Lytoceras Jurense zone beneath. The beds are described in descending order, commencing with those exposed at the summit of the hill.

I divide the Inferior Oolite in this county into three zones :-
A. Zone of Cosmoceras Parkinsoni.
в. Zone of Stephanoceras Humphriesianum.
c. Zone of Harpoceras Murchisonce.

\section{Description of the Cleeve Hill Section.}

\section{A. The Zone of Cosmoceras Parkinsoni.}

No. 1 in fig. 12 , consists of $a$, rubbly oolite above, hard slabs of ragstone in the middle, and a clayey bed below, passing into $\beta$, a sandy oolite of a rich brownish colour, freely specked with ferruginous grains of silicate of iron. I have obtained the following fossils therefrom :-

\section{Cephatopoda.}

Cosmoceras Parkinsoni, Sow.

Perisphinctes Martinsii, $d^{\prime}$ Orb.

Pleurotomaria fasciata, Sow.

Trochotoma carinata, Lyc.
Nautilus lineatus, Sow.

Belemnites canaliculatus, Schloth.

\section{Gasteropoda.}

$\mid \begin{aligned} & \text { Natica adducta, Phil. } \\ & \text { Monodonta lævigata, Sow. }\end{aligned}$

\section{LAMELLIBRANCHIATA.}

Trigonia costata, Sow.

Pholadomya ovulum, Agass.

- fidicula, Sow.

- Heraulti, Agass.

Myopsis dilatata, Phil.

Goniomya angulifera, Sow.

Lima proboscidea, Sow.

- gibbosa, Sow.
Lima compressa, Wright.

Gryphæa sublobata, Desh.

Trichites undulatus, $L y c$.

Gervillia Hartmanni, Goldf.

Opis cordiformis, $L y c$.

Modiola Sowerbii, d'Orb.

- bipartita, Sow.

- imbricata, Sow. 
FIG. 12.-Section of the Inferior Oolite at Cleeve Hill, Gloucestershire.

INo. ft. in.
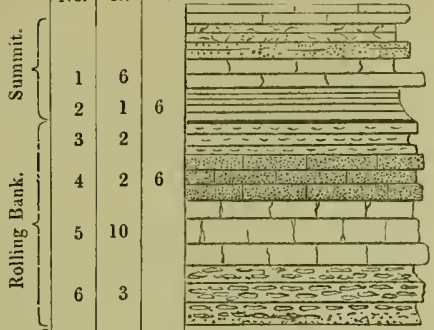

8

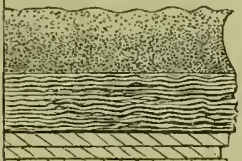

12

11. 4

12

4
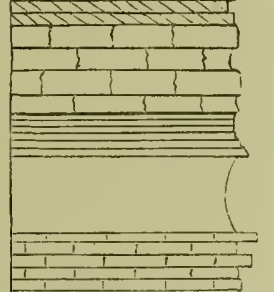

TRIGON1A-GRIT. Cosmoceras Parkinsoni and Corals.

Thecasmilia gregaria, Thamnastrea, Isastraa, \& c.

Gryphcea sublobala, Lima proboscidea, Trigania costata. CHEMNITZIA-GRIT. Chemnitzia procera.

Rubbly Oolite.

BRACHIOPODA-BED. Terebratula Phillipsii, in clusters.

ROAD-STONE. Slephanoceras IHumphriesianum, Chemnitzia Samanni.

OYSTER-BED. Ostrea flabelloides, Lima Elheridyii.

\section{Not known.}

Yellow and brown Sands, with lenticular nodules of Sandstone.

Hard wavy Sandstone. Serpula socialis, abundant.

Marly Oolite.

UPPER FREESTONE, with old T'erebratula fimbria.

Thin flaggy Oolite.

OOLITE-MIARL. Lucina Trightii, Terebralula fimbria.

Thin hard bands of Limestone.

Thin beds of fine-grained oolitic Limestone.

Hard rubbly oolitic Marl, in broken masses.

LOWER FREESTONE : the Upper Terrace.

LOWER FREESTONE: the Lower Terrace.

Hard beds of pisolitic Oolite.

Buff-coloured pisolitic Limestone.

ROE-STONE. Pseudodiadema depressum, Acrosalenia Lycetti, Trochotoma carinata.

PEA-GRIT, Pygaster semisulcatus, Harpoceras Murchisone, Patella ruyosa, Hinnites velatus, Avicula complicata, Terebratula simplex, Terebratula plicata.

Coarse ferruginous Oolite.

LIASSIC SANDS or JURENSE-ZONE, Highly ferruginous.

UPPER LIAS. Harpoceras bifrons Zone. 


\section{ANTHOZOA.}

Thecosmilia gregaria, Edw. \& Haime. Isastræa teuuistriata, $E d w$. \& Haime. Thamnastræa Defranciana, Mrichelin.
Latomæandra Davidsonii, Edw. \& Haime. Montlivaltia Wrightii, Edw. \& Haime. Delabechei, Edw.\& Haime.

No. 2. Chemnitzia-grit is a thin band of brownish marl and clay, in which are sometimes found specimens of Chemnitzia procera, DesLong., and moulds of Nerinaa. Fishes' teeth are occasionally collected in this band.

No. 3. Rubbly Oolite.-Consisting of oolitic ragstones, in a fragmentary state, with few fossils. This bed caps the next division.

\section{в. The Zone of Stephanoceras Humphiesianum.}

No. 4. The Brachiopoda-bed is a compact crystalline buff-coloured limestone; many blocks of great hardness are almost entirely composed of the shells of Terebratula Phillipsii. It measures two feet six inches, and contains the following species of fossils :

Lima proboscidea, Sow.

Terebratula Phillipsii, Mor.

- perovalis, Sow.

- carinata, Lamk.
Terebratula Buckmani, Davids.

Rhynchonella spinosa, Schloth.

- subtetrahedra, Davids. angulata, Sow.

On one occasion, by digging into the floor of the quarry, I found a bed of marly oolite, or mudstone; it contained many fossils, the shells of which were in such a perished condition that I could not determine all the species. I noted, however, the following :-

\section{Chemnitzia.}

Nerinæa.

Modiola plicata, Sow.

Pecten comatus, Münst.
Cypricardia cordiformis, Desh.

Terebratula Etheridgii, Davids.

Montlivaltia, species.

No. 5. The Road-stone consists of a coarse, brown, ferruginous, oolitic limestone, hard and crystalline in some parts, and in others traversed by sandy layers, containing concretionary masses of calcareo-siliceous rock, having an unequal fracture and crystalline structure. It contains a small assemblage of Mollusca, many of which are specifically distinct from those of the upper beds, as Chemnitzia Samanni, Oppel, nearly identical with the Coralline-oolite species, C. striata, Sow., gigantic forms of Pholadomya Heraulti, Ag., and very large shells of Trichites undulatus, Lyc. This bed varies in thickness from ten to fifteen feet. 


\section{Cephalopoda.}

Steplanoceras Orbignianum, $\mathbb{W}$ right.

- Humphriesianum, Sow.

- Sowerbii, Mill.
Stephanoceras Brocchi, Sow.

- Braikenridgii, Sow.
- Sowtilus lineatus, Sow.

\section{Gasteropoda.}

Chemnitzia Srmanni, Oppel. - lineata, Sow.

Turbo lærigata, Sow.

Pleurotomaria fasciata, Sow.

$$
\text { - } \quad \text { elongata, Sow. }
$$

\section{Lamellibranchiata.}

Ostrea flabelloides, Lamk.

- large flat, new species.

Hinnites tuberculasus, Göldf.

Lima proboscidea, Sow.

- Etheridgii, Wright.

- duplicata, Sow.

Trichites undulatus, Lyc.

Astarte excavata, Sow.

'yprina (mould).

Cypricardia cordiformis, Desh.

Myacites calceiformis, Sow.
Gervillia consobrina, $d$ 'Orb.

Mytilus explanatus, Mor.

Pholadomya Heraulti, Agass.

Homomya crassiuscula, Lyc.

Myoconcha crassa, Sow,

Pteroperna plana, Lyc.

Trigonia costata, Sow.

- striata, Sow.

- decorata, Agass.

Modiola imbricata, Sow.

Pinna fissa, Phil.

No. 6. The Oyster-bed consists of a coarse, brown, ferruginous, sandy marl, with inconstant layers of hard rock, which breaks up unequally. It is chiefly in the sandy seams that the fossils are found. The bed is about a yard in thickness. The bottom is seldom exposed, as it is mainly for the roadstone that the working is carried on. It contains :

\section{CONCHIFERA.}

Ostrea flabelloides, Lamk, and several wellmarked varieties of the species.

- pyxiformis, Wright.

Pecten demissus, Goldf.

Lima proboscidea, Sow.

- Etheridgii, Wright.

Monotis tenuicostata, Wright.

Serpula grandis, Goldf.

Clypeus Michelini, Wright.

Stomechinus germiuans, Phil.
Gresslya abducta, Phil.

Pleuromya tenuistriata, Agass.

Pholadomya Heraulti, Agass.

-n ovulum, Agass.

- media, Agass.

- Dewalquei, Lyc.

Annulosa.

I Serpula limax, Goldf.

\section{ECHINOdERMa'ta}

Pseudodiadema depressum, Agass.
Acrosalenia Lycetti, Wright. 
No. 7. Calcareo-siliceous Sand.-Of a brown, grey, or yellow colour. It forms the uppermost bed in the North Quarry, and constitutes the subsoil over a considerable area of this part of the hill. It has been much denuded in parts; measures in some places five feet in thickuess, and is unfossiliferous. I know of no other bed in our district which presents lithological characters similar to those of this sandy stratum.

No. 8. Wavy Sandstone.-This is a bard, brown, thin-bedded rock, with a wavy stratification; it is siliceous in some parts, and calcareous in others. The siliceous portions are unfossiliferons; the calcareous are represented by slabs of thin ragstones, containing many fossils. On some of these I found Serpula socialis, Goldf., in great abundance. This bed has a thickness of three feet, and rests on

No. 9. Marly Oolite.-Broken up into fragmentary portions. It appears to be the upper portion of the Upper Freestone.

No. 10. Upper Freestone.-A thick-bedded, coarse-grained oolitic limestone, used for rough work. This rock was long thonght to be unfossiliferous; and considerable doubts were entertained as to the precise position of these beds in the series. During my last visit, however, I succeeded in obtaining from the lower and middle beds a few specimens of large, old, deformed Terebratula fimbria, Sow., which enabled me to determine its position as superior to the Oolite-marl, and to identify the rock as the Upper Freestone. It has a thickness of twelve feet.

\section{c. THe Zone of Harpoceras Murchisona.}

No. 11. Thin flaggy Oolite.-This rock splits into thin layers. Numerous shelly fragments are found in some slabs, but fossils are rare; thickness, four feet.

No. 12. Fimbria-bed or Oolite-marl.-This bed is well exposed on the western side of the hill, and consists of a cream-coloured marl, like indurated Chalk, interstratified between two beds of oolitic limestone, resting upon the uppermost bed of the Lower, and overlain by the thin flaggy beds of the Upper Freestone. It forms a very persistent stratum in the Northern and Middle Cotteswolds, extending across this portion of the plateau, from the vales of Morton and Bourton on the east, to the mural escarpments of the Inferior Oolite on the west, but thinning out and disappearing in the southern part of the range. In some localities, as at Leckhampton, Sheepscombe, and Swift's Hill, near Stroud, it contains masses of Corals, of the genera Thamnastrcea and Isastrcea; in others, as near Nailsworth, it abounds with numerous shells of the genus Nerinca, forming there a "Nerinæan Limestone;" in otherŝ́, as at Cleeve and Cubberley, the marl is charged with Bracliopoda, chiefly Terebratula fimbria, Sow., associated with a few Terebratula carinata, T. submaxillata, and Rlynchonella Lycetti. The fauna of the Oolite-marl induced me, in a former paper thereon, to consider this bed as the product of an ancient Coral-bank. "The direct evidence of the existence of Antliozoa in 
cousiderable numbers, added to the abundance of " long spiral univalves belonging to the genera Chemnitzic and Nerinaa, which are known to "nestle in Coral-formations, together with the indirect evidence of a superabundance of Brachiopoda, added to the lithological character of the marl itself, which appears to be the product of Coral-mud and other reef débris, leads to the conclusion that the Oolite-marl is a portion of a Jurassic Coral-bank." I

\section{Mollusca.}

Chemnitzia procera, Deslong.

Nerinæa gracilis, Lyc.

Natica adducta, Phil.

Trochotomia calyx, Lyc.

Trochus monilitectus, Phil.

Monodouta lævigata, Sow.

Natica macrostoma, Roem.

Terebratula submaxillata, Davids.

$$
\text { - fimbria, Sow. }
$$

- carinata, Lamk.

Stomechinus germinans, Phil.

Pedina Smithii, Forb.
Mytilus imbricatus, Sow.

Lima punctata, Phil.

- Pontonis, Lyc.

Area cancellata, Phil.

Lucina Wrightii, Oppel.

Myopsis punctata, Buck.

Ceromya concentrica, Sow.

\section{Brachiopoda.}

Rhynchonella Lycelti, Davids.

- $\quad$ concinna, Sow.

Echinodermata.

Pseudodiadema depressum, Agass.

Acrosalenia Lycetti, Wright,

No. 13. Thin hard bands of Oolitic Limestone, without fossils, eighteen inches.

No. 14. Thin beds of finc-grained Oolitic Limestone, four feet six inches.

No. 15. Hard Rubbly Oolite-marl.-This occurs in broken masses five feet thick.

These three beds are well exposed in a small escarpment on the western slope of the hill, near the large Freestone Quarry. They contain few fossils, and the rock is much shaken.

No. 16. The Lower Freestone attains a considerable thickness in Cleeve Hill, and has long been extensively raised there for building-purposes. It is divisible into two terraces, the upper of which contains the best beds of stone. The rock is a fine-grained thick-bedded oolitic limestone, remarkably free from organic remains and ferruginous stains. The upper terrace is twenty-six feet in thickness.

No. 17. The Lower Freestone.-The lower terrace is exposed on the western escarpment of the hill. The rock is not equal in quality to the beds in the upper terrace, and it is therefore not now worked for building-stone. Its exact thickness I have not ascertained, but I estimate it at forty feet.

1 Wright, "On the Sub-divisions of the Inferior Oolite," 'Quart. Journ. of .the Geol. Soc.,' vol. xvi, p. 13,1860 . 
No. 18. Hard beds of Pisolitic Oolite, and

No. 19. Buff-coloured Pisolitic Limestone, forming a kind of transitional lithological condition from the oolitic limestones of the Freestone to the beds of Roestone and Peagrit.

No. 20. The Roestone forms the base of the Freestone series. It consists of a whitish limestone, composed of large oolitic grains, and containing a great variety of small Shells, Corals, and Echinoderms, in very fine preservation. In some respects the general facies of the fauna of the Roestone resembles that of the Great Oolite of Minchinhampton. Many of the Mollusca are specifically distinct, and others are identical with those of that formation. The shells are nearly all small, and well preserved. In some the colouring matter of the shell is present, and there are many undescribed species in the series; many beautiful Alarice, with their long spines, were obtained from this bed at Leckhampton; and my old friends, the Rev. P. B. Brodir and Dr. Lycetr, collected, determined, and published, in 1850, a full list of these remains. I have not worked this bed at Cleeve Hill with much attention, but in a short time I collected many of the species of my friends' list.

\section{AnthozoA.}

Caryophyllia. Thecosmilia. I Montlivaltia. Isastræa.

\section{Echinodermata.}

Pseudodiadema depressum, $A g$. Acrosalenia Lycetti, Wright.

Stomechinus germinans, Phil.

Polycyphus Deslongchampsii, $W r$.

\section{LAMELLIBRANCH IATA.}

Astarte orbicularis, Sow.

- depressa, Münst.

Arca pulchra, Sow.

Avicula complicata, Buck.

Cardium cognatum, Phil.

Cucullæa elongata, Sow.

- oblonga, Phil.

Corbula curtansata, Phil.

Hinnites velatus, Goldf.

Psammobia lævigata, Phil.

Terebratula simplex, Buck.

Patella rugosa, Sow.

- nitida, Deslong.

Pileolus lævis, Sow.
Gervillia costatula, Deslonig.

Cypricardia cordiformis, Desh.

Limea duplicata, Sow.

Lucina despecta, Phil.

Mytilus asper, Sow.

Nucula variabilis, Sow.

Ostrea costata, Sow.

Pecten comatus, Münst.

- Dewalquei, Oppel.

Trigonia striata, Sow.

\section{Brachiopoda.}

Gasteropoda.

Terebratula plicata, Buck.

Natica adducta, Phil.

Nerita costata, Sow.

Alaria (three new species). 
Rimula clathrata, Sow.

Solarium (two new species).
Emarginula tricarinata, Sow.

Fissurella acuta, Deslong.

No. 21. The Pea-grit is one of the most remarkable beds of the Inferior Oolite in the district. It invariably claims the most marked attention from all the continental Oolitic Geologists to whom I have shown our local sections, as it is unlike any bed they are acquainted with in France or Germany. Its upper part consists of-a. A hard, coarse, brown, rubbly Oolite, full of flattened concretions, cemented together by a calcareous matrix. When the blocks weather, the concretions resemble flattened peas, and form an uneven surface. In the cavities of the Pisolite beautiful Echinidæ are often found in great perfection, and many other fossils are very well preserved therein. $\beta$. A hard, cream-coloured, pisolitic rock, made up of compressed, flattcned concretions like those of $a$; the bed is more compact in parts. $\gamma$. A coarse, brown, ferruginous Ragstone, full of large oolitic grains and much ferric oxide; it is readily disintegrated by frost. The three beds measure from thirty to forty feet in thickness. The Pea-grit varies considerably in development in different localities. Crickley, Leckhampton, Birdlip, and Cleeve Hills afford the best types of this bed.

\section{Cephalopoda.}

Harpoceras Murchisonæ, Sow.

Nautilus truncatus, Sow.

atella rugosa, Sow.

- inornata, Lye.

Pileolus lævis, Sow.

Nerita costata, Sow.
Belemnites spinatus, Quenst.

- abbreviatus, Mill.

\section{Gasteropoda.}

Natica adducta, Phil.

Cirrus nodosus, Sow.

Turbo capitaneus, MIünst.

Trochotoma carinata, $L y c$.

\section{LAM ELLIBRANCHIATA.}

Ostrea gregaria, Sow.

Placunopsis, sp.

Hinnites abjectus, Phil.

Mytilus imbricatus, Sow.

Lima sulcata, Münst.

- pectiniformis, Schloth.

- duplicata, Goldf.

- lyrata, Münst.

- Lycetti, Wright.
Astarte excavata, var., Sow.

Myopsis rotundata, Buck.

Goniomya angulifera, Sow.

Avicula complicata, Buck.

Ceromya Bajociana, d'Orb.

Cardium striatulum, Phil.

- lævigatum, Lyc.

Pinna cuneata, Bean.

Pecten comatus, Münst.

\section{BRACHIOPODA.}

Terebratula simplex, Buck. plicata, Buck.
Rhynchonella Lycetti, David. subtetrahedra, David. 


\section{ECHINOdermata.}

- Pseudodiadema depressum, Agass.

Cidaris Fowleri, Wright.

- Bouchardii, Wright.

- Wrightii, Desor.

Diplocidaris D sori, Wright.

- Wrightii, Desor.

Stomechinus germinans, Phillips.

Acrosalenia Lycetti, Wright.

Hemipedina Bakeriæ, Wright.
Hemipedina perforata, Wright.

- tetragramma, Wright.

- Waterhousei, Wright.

Polycyphus Deslongchampsii, I'right.

Pygaster semisulcatus, Phillips.

- conoideus, $W$ right .

Galeropygus agariciformis, Forbes.

Goniaster obtusus, Wright.

Pentacrinus Austenii, Wright.

\section{ANTHOZOA.}

Latomæandra Flemingii, Edw. \& Haime.

Davidsonii, Edw. \& Haime.

Axosmilia Wrightii, Edw. \& Haime.

Thamnastræa Terquemi, Edw. \& Haime.
Thamnastræa Mettensis, Edw. \& Haime.

- Defranciana, Edw. \& Haime.

- fungiformis, Edw. \& Haime.

Isastræa tenuistriata, Edw. \& Haime.

No. 22. The Coarse Ferruginous Oolite is composed of large oolitic grains of calcic carbonate, having incorporated therewith a. considerable percentage of the ferric oxide. This rock has a fine rich brown colour, and when exposed in the escarpment, and lit by the sun's rays, it imparts a warm colouring to the surrounding landscape, varying in its tones from one hour to another. I know of no part of the Cotteswold range which exhibits more picturesque effects and play of colour than the bold naked escarpment of Cleeve Hill, and to which the beds forming this portion of the section so largely contribute by their deep rich tints. The rock is of little value as a road-stone, because it is readily disintegrated by rain and frost; it might have some economic value for the Iron it contains, if the percentage of that mineral were sufficiently large to be remunerative, but no quantitative analysis has yet been made to ascertain its proportions. I have found few fossils in this bed at Cleeve. Belemnites and Pholodomyæ are occasionally met with.

No. 23. The Upper Liassic Sands or zone of Lytoceras Jurense so well developed at Cooper's Hill, Haresfield Beacon, Nailsworth, the Long Wood near Frocester, Uley Bury, Stinchcombe, the hills around Dursley, and at Nibley, Wotton-under-Edge, Ozleworth, and all along the chain of the southern Cotteswolds as far as Bath, are only feebly represented at Cleeve. These Sands afford an example of that thinning-out process which is seen to a greater or less extent in all the other beds in our section, if traced in certain directions from the point where they attain their maximum development. As a general rule it may be stated that all the Inferior-Oolitic rocks thin out from their western escarpment in the Catteswolds when traced eastwards, and that the Liassic Sand or Jurense zone gradually thickens when traced from the northern to the southern part of the chain. 
A Table showing the Stratigraphical Distribution of the Ammonoida in the Upper Lias of the British Islands.

\begin{tabular}{|c|c|c|c|c|}
\hline Families, Genera, and Species. & 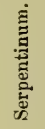 & 离 & 总 & 竎 \\
\hline \multicolumn{5}{|l|}{$\begin{array}{c}\text { Family-Lytocerattox. } \\
\text { Genus-Lytoceras. }\end{array}$} \\
\hline \\
\hline & $\cdots$ & *. & *. & $\begin{array}{l}\cdots \\
\cdots\end{array}$ \\
\hline & $\cdots$ & $\ldots$ & * & ... \\
\hline torulosum, Schlübler..................... & $\cdots$ & $\cdots$ & * & $\cdots$ \\
\hline Genus-Phylloceras. & & & & \\
\hline Phylloceras heterophyllum, Sow. ................... & $\cdots$ & * & ... & $\cdots$ \\
\hline subcarinatum, Young \& Bird........... & $\cdots$ & * & $\cdots$ & $\cdots$ \\
\hline Family-Aegoceratrda. & & & & \\
\hline Genus-HARPoceras. & & & & \\
\hline \multicolumn{4}{|l|}{ Harpoceras serpentinum, Reinecke. .. } & $\ldots$ \\
\hline elegans, Sow. ............................ & * & $\ldots$ & $\ldots$ & $\ldots$ \\
\hline falciferum, Sow. ....................... & * & $\ldots$ & $\cdots$ & ... \\
\hline exaratum, Young \& Bird. ............ & * & $\cdots$ & $\cdots$ & $\cdots$ \\
\hline Lythense, Young \& Bird. ............ & $\cdots$ & $*$ & $\cdots$ & ... \\
\hline $\begin{array}{l}\text { latescens, Simpson, ..................... } \\
\text { ovatum, Young \& Bird.............. }\end{array}$ & $\begin{array}{l}\cdots \\
\cdots\end{array}$ & * & $\cdots$ & $\cdots$ \\
\hline $\begin{array}{l}\text { ovatum, Young \& Bird................. } \\
\text { subplanatum, Oppel. ................ }\end{array}$ & $\ldots$ & * & $\cdots$ & $\begin{array}{l}\cdots \\
\cdots\end{array}$ \\
\hline primordiale, Schlotheim............... & $\ldots$ & * & ... & $\ldots$ \\
\hline bifrons, Bruguiére = Walcotti, Sow... & $\cdots$ & * & $\cdots$ & ... \\
\hline Levisoni, Simpson. .................. & $\cdots$ & * & $\cdots$ & $\cdots$ \\
\hline insigne, Schübler. ; …............. & $\cdots$ & $\cdots$ & * & $\cdots$ \\
\hline $\begin{array}{l}\text { Comense, Von Buch. } \ldots \ldots \ldots \ldots \ldots \ldots \\
\text { discoides, Zieten } \ldots \ldots \ldots \ldots \ldots \ldots \ldots \ldots \ldots \ldots \ldots\end{array}$ & $\begin{array}{l}\cdots \\
\ldots\end{array}$ & $\cdots$ & * & $\cdots$ \\
\hline 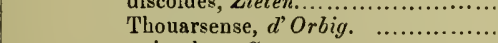 & $\cdots$ & $\begin{array}{l}\cdots \\
\ldots\end{array}$ & $\begin{array}{l}* \\
*\end{array}$ & $\cdots$ \\
\hline striatulum, Sow. .................... & $\ldots$ & $\cdots$ & * & ... \\
\hline radians, Reinecke. ................... & $\ldots$ & $\ldots$ & * & $\cdots$ \\
\hline Raquinianum, d'Orbig................ & $\cdots$ & $\cdots$ & * & $\cdots$ \\
\hline undulatum, Stahl .................... & $\cdots$ & $\cdots$ & * & $\cdots$ \\
\hline variabile, d'Orbig. = var. Beanii...... & $\cdots$ & $\cdots$ & * & $\cdots$ \\
\hline 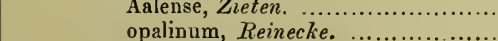 & $\begin{array}{l}\cdots \\
\ldots\end{array}$ & $\begin{array}{l}\cdots \\
\cdots\end{array}$ & $\begin{array}{l}* \\
\ldots\end{array}$ & * \\
\hline 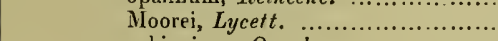 & $\ldots$ & $\ldots$ & $\cdots$ & $*$ \\
\hline subinsigne, Oppel. .................... & $\cdots$ & $\cdots$ & $\cdots$ & * \\
\hline Genus-STEPHANoceras. & & & & \\
\hline \multirow{5}{*}{ 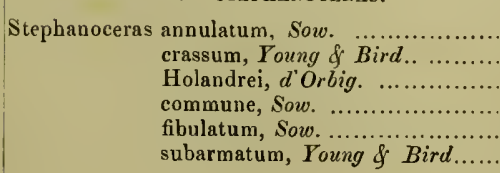 } & & $\ldots$ & $\cdots$ & ... \\
\hline & * & * & $\cdots$ & ... \\
\hline & * & * & $\ldots$ & $\cdots$ \\
\hline & $\cdots$ & * & $\cdots$ & $\cdots$ \\
\hline & $\begin{array}{l}\cdots \\
\cdots\end{array}$ & * & $\cdots$ & $\begin{array}{l}\cdots \\
\cdots\end{array}$ \\
\hline
\end{tabular}


Table slowing the extension of the Upper Lias in the British Islands, Belgium, France, Switzerland, Germany, Austria, and Italy, with indications of the Toarcian AmmoniteZones found in some typical regions of the European area.

\begin{tabular}{|c|c|c|c|c|c|c|c|c|c|c|c|c|c|c|c|c|}
\hline \multirow{2}{*}{$\begin{array}{c}\text { Ammonite Zones } \\
\text { of the } \\
\text { Upper Lias. }\end{array}$} & \multicolumn{3}{|c|}{$\begin{array}{l}\text { British } \\
\text { IsLaNDS. }\end{array}$} & \multirow{2}{*}{ 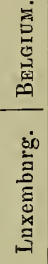 } & \multicolumn{6}{|c|}{$\begin{array}{c}\text { FRANCE, } \\
\text { DEPARTMENTS oF. }\end{array}$} & \multicolumn{2}{|c|}{$\begin{array}{l}\text { SWITZER- } \\
\text { LAND. }\end{array}$} & \multicolumn{2}{|c|}{ 㫘 } & \multirow{2}{*}{ 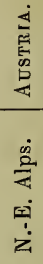 } & \multirow{2}{*}{ 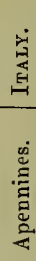 } \\
\hline & 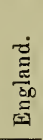 & 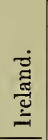 & 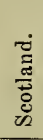 & & $\frac{\dot{d}}{\stackrel{0}{0}}$ & 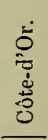 & 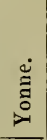 & 离 & & 产 & 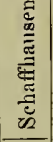 & 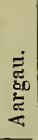 & 㐫 & 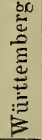 & & \\
\hline OPALINUM , & $\%$ & $\cdots$ & $\cdots$ & $\cdots$ & * & $\cdots$ & $\cdots$ & * & * & * & $?$ & ? & * & * & $\cdots$ & . \\
\hline JURENSE & * & $\cdots$ & * & * & * & * & * & * & * & * & $\%$ & $*$ & $*$ & * & $*$ & * \\
\hline BIFRONS & * & $\cdots$ & * & * & * & * & * & * & * & * & $*$ & $\approx$ & * & * & * & * \\
\hline SERPENTINUM & * & $\cdots$ & $\cdots$ & * & * & * & * & * & * & $*$ & * & * & * & * & * & * \\
\hline
\end{tabular}

This table concludes our sketch of the Lias formation, so rich in new and varied forms of animal life, which all became extinct with its close. In taking a retrospective glance at this chapter of the Geological Record, probably the most complete of all the Mesozoic formations, one is forcibly struck with the number of new, remarkable, and varied animal forms it contains, of which we find neither traces of ancestry nor natural affinities in any of the older strata. In its basement-bed the teeth of the oldest known Mammal, Microlestes, were discovered, and in its different horizons the remains of Reptiles of the most singular structure are found. The Enaliosaurians comprise in a single organism the most diverse anatomical characters; the vertebral column of a fish united to the body of a lizard, having the skull, jaws, and teeth of a crocodile, with the paddles of Cetacea articulated to the scapular arch of a Platypus. The Plerodactylians have affinities with birds and bats through the mechanism of their anterior extremities, the phalanges of the fifth finger being enlarged and elongated to form a rod for supporting a wide-spreading membranous wing, whilst the rest of the hand retained the reptilian type. The Ganoid Fishes belong to genera that are nearly all special to the Lias, and they are as remarkable for the beauty and novelty of their forms as for the fine state of preservation in which they are found. The Molluscan Faunas are singularly characteristic of the different zones ; and the Cephalopods, above all others, are the most important class, from the certainty with which these divisions of time are characterised by them, each new group making its appearance in succession, and passing away to give place to other generic forms destined to succeed it in time and space. 


\section{PALAONTOGRAPHICAL SOCIETY.}

INSTITUTED MDCCCXLVII.

VOLUME FOR 1880.

L O N D O N :

MDccouxxx. 



\section{MONOG RAPH}

ON THE

\section{LIAS AMMONITES}

OF

\section{THE BRITISH ISLANDS.}

BY

\section{THOMAS WRIGHT, M.D., F.R.S., F.G.S.,}

VICE-PRESIDENT OR THE PALEONTOGRAPHICAL SOCIETY; CORRESPONDING MEMBEK OF THE ROYAL SOCIETY OF SCIENCES OF LIÈGE; THE SOCIETY OF NATURAL SCIENCES OF NEUCHÂTEL; VICE-PRESIDENT OF THE COTTESWOLD NATURALISTS' FIELD CLUB; CONSUlTLNG SURGEON TO THE CHELTENHAII HOSPITAL; AND MEDICAL OFFICER OF HEALTH TO THE URBAN SANITARY DISTRICTS OF CHELTENHAM, CHARLTON KINGS, AND LECKHAMPTON.

PART THIRD-CLASSIFICATION.

Pages 165-264; Plates XIX-XL.

\section{$\mathrm{LONDON}_{\text {: }}$}

PRINTED FOR THE PALÆONTOGRAPHICAL SOCIETY. 
J. E. ADLARD, BARTHOLOMEW CLOSE. 
Fig. 13.-A Vertical Profile of the Penarth Cliffs.

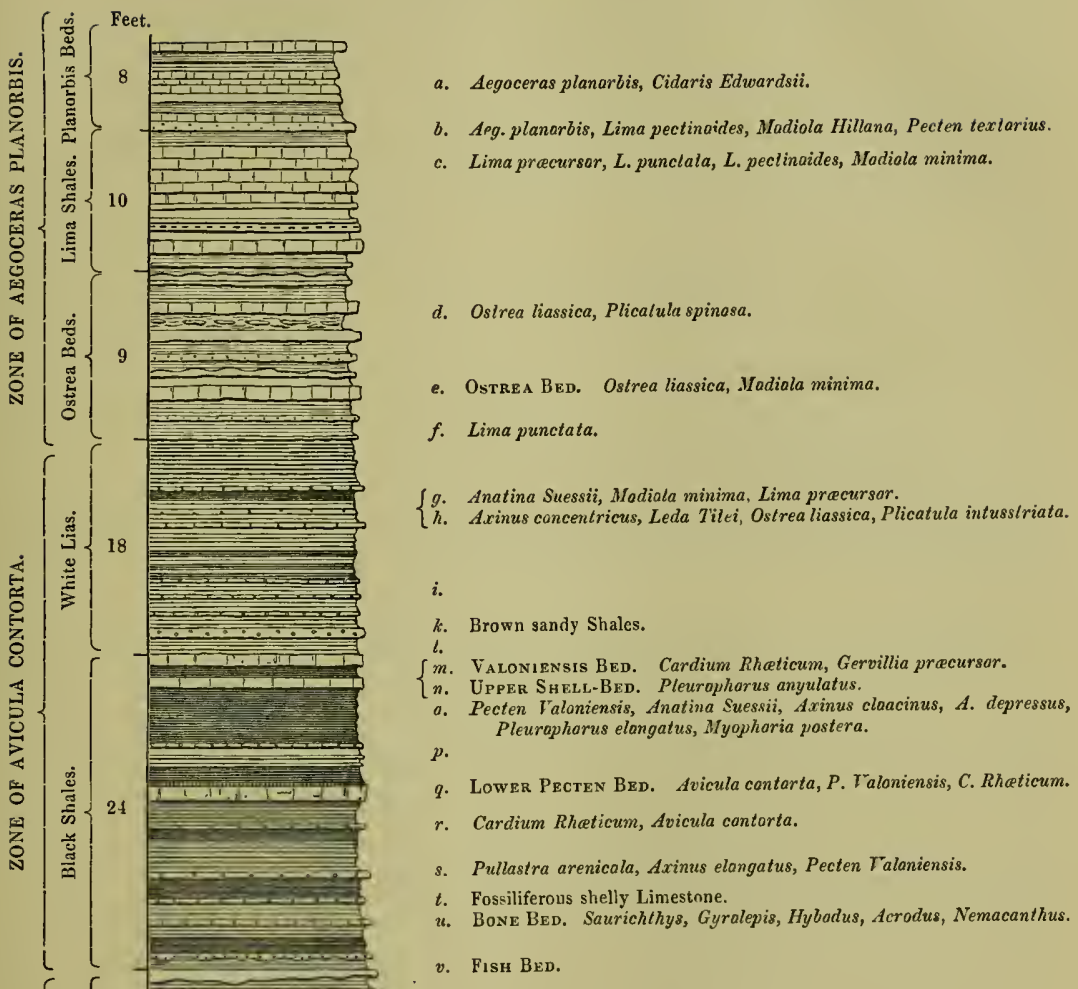

Cream-coloured, grexish-green, and pale-red marly limestones, breaking into conchoidal masses and destitute of fossils.

Alternations of greenish-grey, conchoidal marls, hreaking up into cuhical fragments, and having thin veins of gypsuro filling the joints.

Red Marls of the lieuper Beds. 
The profile on the preceding page was drawn by my friend, Mr. R. Etheridge, F.R.S., to illnstrate his lecture on the Rhætic beds of Penarth and Lavernock, delivered at a meeting of the Cardiff Naturalists' Society in July, 1871. Mr. W. Adams, F.G.S., to whom the woodcut belongs, kindly offered the use of the block to illustrate my remarks on this section, and for this courteous act I beg to return him my best thanks.

The zone of Aegoceras planorbis $(a, b)$ occupies the summit of the cliff, and the Ammonite beds consist of dark grey shales, with hard compact limestones; they are well seen at Lavernock, where they occupy the foreshore. The lowest beds consist of finegrained argillaceous limestones and shales, with a few Ammonites and remains of Cidaris Edwardsii; above these are beds with Aegoceras planorbis, Lima pectinoides, Modiola Hillana, Pecten textorius. Then follow two beds of limestone, each six inches, without fossils, which are capped by two feet of shales crowded with $A$. planortis, and interstratified with a concretionary limestone. The Ammonite beds are about eight feet thick.

The Lima Shales $(c)$ form the middle portion of the Planorbis zone. They consist of a grey-brownish argillaceous limestone with brown shales ; the limestones are concretionary, and inconstant bands of the rock ruil through the shales, which measure about ten feet. Lima precursor, Quenst., Lima punctata, Sow., Lima pectinoides, Sow., are found in the Upper beds.

The Ostrea Beds $(d, e)$ consist of alternate layers of clays and limestones. Many of the beds are very fossiliferous, and contain Ostrea liassica, Sow., Modiola minima, Sow., Pleuromya Dunkeri, Terq., Plicatula spinosa, Sow., Hemipedina Boucerbankii, Wr.

The White Lias series $(f-l)$ measures about eighteen feet, and forms the upper portion of the zone of Avicula cortorta; the strata consist of pale brown, arenaceous shales, with inconstant bands of hard limestone containing a few fossils. The true White Lias limestone of Somersetshire is not found in this locality, but the shells it yields serve to identify the beds with that series. Monotis decussata, Axinus concentricus, Moore, Anatina Suessii, Stopp., Lima pracursor, Quenst., Pecten pollux, d'Orb., Modiola minima Sow., Leda Titei, Moore, Plicatula intusstriata, Emmr., may fairly be correlated with the contents of the beds in the Garden Cliff profile (fig. 1, p. 7), which contain Estheria Brodieana, Jones, and other fossils.

The Black Shales $(m-u)$ form the lower portion of the Contorta-zone, which measures twenty-four feet in thickness. These shales contain a fauna special to the beds, remarkable for the number of small Mollusca abounding in them. There are two shell beds in these shales, both characterised by the presence of innumerable fine large specimens of Pecten Valoniensis, Defrance., Avicula contorta, Port., Cardium Rhaticum, Mer., Axinus cloacinus, Quenst., Gervillia pracursor, Quenst., Pullastra arenicola, Strick., Pleurophorus angulatus, Moore, Myophoria postera, Quenst.

The Bone $\operatorname{Bed}(u)$, a dark grey grit, or pyritic limestone, containing many small fragments of fishes' teeth, bones, and scales, forms the Bone-breccia. I have collected Saurillthys apicalis, Ag., Gyrolepis Alberti, Ag., Hybodus reticulatus, Ag., Acrodus minimus, Ag., 
and Nemacanthus filifer, Ag. The Bone-bed rests upon four feet of black unfossiliferous shales, very fissile and papery; and this bed, parted by a ferruginous band in the middle, rests upon a very irregular bed of grey, earthy, fine-grained sandstone, graduating downwards into a grey earthy limestone, containing lignite and some fishes' scales, marked $(v)$ in the section; this is the last trace of life observed in the Marls which lie beneath, consisting of eighteen feet of cream-coloured, grey-green, and pale-red marly limestones, breaking up into unfossiliferous cuboidal masses; which overlie two feet of greenishgrey marls, breaking up like the precediug beds, and having thin seams of gypsum filling some oblique and vertical joints. These rest upon the deep-red marls of the Keuper beds.

This detailed section of the Penarth cliffs ${ }^{1}$ may be considered as the complement to my notes on the same at p. 10 , and the vertical profile now introduced will enable the reader to make an interesting and instructive comparison between the Avicula contorta zone at Garden Cliff (fig. 1, p. 7), Aust Cliff (fig. 2, p. 8), and the fine coast section at St. Andrey's Slip, near Watchett (p. 12). It will be observed that a certain amount of uniformity prevails throughout the series exposed on both banks of the Severn and on the opposite shores of the British Channel, whilst in the Palæontology of the different beds certain differences are noted which deserve study. Thus, the Estheria-bed and underlying shales, so characteristic of Garden Cliff, are not found at Penarth, but appear to be represented by a set of strata which occupy the position of the Lower White Lias series of Dorset and Somerset.

The Pallastra-sandstone, with its large slabs of ripple-marked ledges, the ripples being parallel to the strike of the bed, and which sandstone is interposed between upper and lower bone beds at Garden Cliff, is absent at Peuarth and the other localities.

The Bone-bed at Aust, with its large Ceratodus teeth, representing several species of fossil fishes, and numbering many hundreds of individuals is unique. I am not aware that the teeth of this genus of fishes are found in any other Rhætic Bone-bed in the British islands. The assemblage in the Bristol Museum was collected through several years by Mr. Higgins, and purchased from him by subscription for the Institution. Professor Miall ${ }^{2}$ has lately figured and described several of these fossils, to which I beg to refer.

1 See Mr. Etheridge's description and woodcut in the 'Transact. Cardiff Nat. Soc.,' vol, jii, part 2, pp. 48, \&c., 1872.

2 Palæontographical Society's vol, for 1878, ‘On Sirenoid and Crossopterygian Ganoids,' pp. 27-32, Pl. II-V, 1878. 


\section{SYSTEMATIC PART.}

\section{THE STRUCTURE AND CLASSIFICATION OF THE CEPHALOPODA.}

The Cephalopoda form the highest class of the Mollusca, in which the head is situated between the trunk and the arms, hence the name ( $\kappa \varepsilon \phi a \lambda \eta^{\prime}$, head, $\pi$ oüs, foot). The existing forms are nearly all naked animals without shells, whilst the extinct groups were with a few exceptions the inhabitants of polythalamous shells, fashioned after the structure of the many-chambered shell possessed by the Pearly Nautilus.

The trunk or body is symmetrical, thick, and soft, and has a spherical, oblong, elongated, or cylindrical form, enclosed in a fleshy muscular sheath or mantle, which envelopes all the viscera, furnishes a pair of lateral fins or appendages for locomotion, and in the naked species lodges in its substance the rudiments of an internal skeleton.

The head, more or less distinct from the trunk by a contraction or neck, is large and round; it contains the organs of sense, mastication, and deglutition, and gives off from its anterior circumference a number of long fleshy processes or arms, which are either short hollow sheaths with retractile tentacles, as in the Pearly Nautilus, forming the order 'Tentaculifera (fig. 24), or form eight or ten solid arms, more or less elongated and flexible in all directions, supporting on their internal surface numerous suckers, by which the arms become powerful instruments for adhesion, prehension, and locomotion, hence the name Acetabulifera for this order (fig. 14).

The mouth, situated at the bottom of a conical cavity formed at the base of the arms, is provided with two horny or calcareous mandibles, resembling in form those of a parrot, and like them playing vertically upon each other, and enclosing a large fleshy tongue, partly covered with short, recurved, horny spines.

The two eyes are very large and placed on each side of the head; they are comparable in their structure with those of the Vertebrata; and are sessile in the AcETabdurfera, pedunculated in the Tentacolifera.

A fleshy tube, the infundibulum or locomotive pipe, forms the passage through which the respiratory currents of water to and from the branchial chamber, and the excrement fron the intestine, are discharged; it is a musculo-mucous organ situated at the anterior part of the neck, like an inverted funnel, with a pipe projecting from the visceral cavity and directed forwards and ontwards. 
The branchiæ are lodged in a chamber formed by the mantle; they are symmetrical in size, form, and position. In the Acetabulifera there are two branchiæ, in the Tentaculifera four branchiæ; hence the former are called Dibranchiate, the latter Tetrabranchiate Cephalopods. The systemic circulation in all is aided by a muscular ventricular heart.

'The brain and nervous system are more highly developed and the ganglia more concentrated than in other Mollusca, and they have special organs for all the senses, and the brain is protected in the naked species by a cephalic cartilage.

The sexual organs are separate and exist in distinct individuals, the males are much less numerous than the females, and in many species are at present unknown.

All Cephalopods are aquatic and marine, and natation is retrograde by the forcible ejection of sea water from the branchial chamber through the funnel.

'The shell is internal or external; when internal it consists of one or more horny or calcareous osselets embedded in the layers of the mantle, which serve for the protection of the brain and other internal organs. The external shells are univalve, and are either unilocular, as in the Argonaut (fig. 16) or multilocular, as in the Pearly Nautilus (fig. 24), in which the air-chambers form so many floats for lightening the specific gravity of the animal. The last chamber alone is the dwelling chamber, to which the body of the animal is attached by two powerful adductor muscles and a membranous tube, which passes backwards from the body of the Nautilus to traverse all air-chambers of the shell (fig. 24).

The Cephalopoda admit, therefore, of a natural division into two orders, characterised by organic characters which do not admit of a doubt.

In one order the head is surrounded by numerous retractile tentacula; they have four branchiæ, and the Mollusc lives in the last chamber of a polythalamous shell; these form the order Tetrabranchiata or Tentaculifera. The second order have a naked body (with two exceptions, the Argonauta and Spirula) : the arms are solid, fleshy, flexible, and acetabuliferons, and the respiratory chamber contains two branchiæ; these form the order Dibranchiata of Owen, or the Acetabulifera of d'Orbigny. All the Naked Cephalopods have the power of secreting a dark-coloured fluid, very miscible in water, and contained in an ink-bag formed of a tough fibrous membrane covered with a thin silvery outer lamina; this bag discharges its contents, at the will of the animal, through a duct which opens near the base of the funnel. The ink, as it is called, was formerly used for writing (Cicero) and in the preparation of sepia, and from its indestructible nature is often found in a fossil state; and so well is the colour of the contents of the fossil ink-bags preserved in some fossils from the Upper Lias that I have frequently coloured diagrams with fossil sepia collected from these Lias beds.'

1 In the Museum of the Geological Society of London is a print of an Ichthyosaurus, drawn by De la Beche with fossil sepia on a lithographic stone of English Lias. 


\section{Order I.-DIBRANCHIATA, Owen, 1832.}

\section{Acetabulifera, d'Orbigny, 1840.}

Body naked, built for swimming. Head distinct, eyes large, sessile, prominent. Mandibles horny, moving in a vertical direction, arms eight to ten, provided with acetabula. Branchiæ two. Heart with three chambers, one systemic and two branchial. Ink-bag always present. Funnel parietes entire. Shell in one family monothalamous external, and not adherent to the body of the animal. Other families have an internal siphoniferous polythalamous shell, or the rudiments of an internal skeleton in various stages of development are found in the substance of the mantle.

With the exception of the Nautilus all the living Cephalopods belong to this order; they appeared, as far as we at present know, for the first time in the Trias. One family only, the Belemnitida, is entirely extinct.

Section A.-Octopoda, Leuch, 1817.

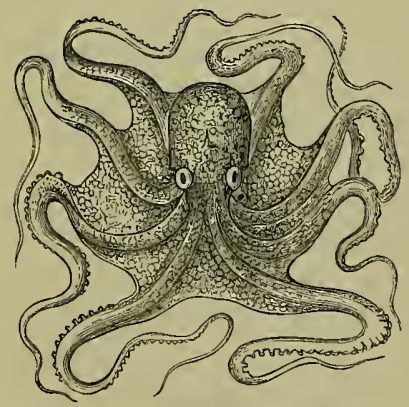

Fig. 14.-Octopus vulgaris, Lamarck.

Arms eight, suckers sessile. Eyes fixed, incapable of rotation. Nuchal band between the head and mantle broad. Funnel without a valve. No distinct nidamental gland. Shell external, one-celled, and non-adherent. Internal shell, when present, colssisting of rudimentary pieces.

1. Family Octopodide, Gray, 1847. - Arms similar, elongated, and united at their base by a membrane; the eight arms are each provided with a double series of sessile acetabula, without bony circles. Shell represented by two short styles, according to Owen, embedded in the substance of the mantle. The Octopus vulgaris, Lam. (fig. 14), is the type of this family.

2. Family Argonadride, Reeve, 1841.-The two dorsal arms of the female Argonaut

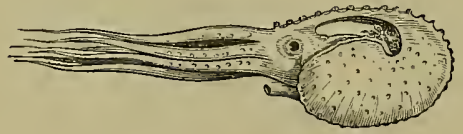

Fig. 15.-Argonauta argo, Linn.

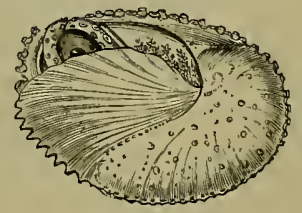

FIG. 16.-Argonauta argo, Linn.

are expanded at their extremities, and secrete a symmetrical involuted shell, which is thin and translucent, and not moulded on the body of the animal, nor attached to it either by muscles or a siphonal tube. The coil of the spire is occupied by clusters of ova (fig. 16). 
According to Madame Power and M. Rang, the Argonaut sits in its boat with its siphon towards the keel, as in figs. 15 and 16, swimming by the aid of its funnel action only, its dorsal arms being closely applied to the sides of the shell. It swims backwards by ejecting water from its funnel, and crawls at the bed of the sea in a reversed position, carrying its shell over its back. The Argonaut, like other testaceous Mollusca, secretes and forms the shell which it inhabits, although it does not adhere at any point to the shell, an observation long ago made and recorded by Aristotle.

\section{Section B.-Decapoda, Leach, 1817.}

Naked Cephalopods, with an ovoid, cylindrical, or elongated body, having eight symmetrical arms provided with pedunculated suckers, surrounded with horny rings, and two long tentacular arms, proceeding from near the third and fourth pair of arms, and expanded at their extremity, as in Sepia elegans, d'Orb. (fig. 17). The body has a pair of lateral fins, and the funnel is usually provided with an internal valve. The eyes are large, movable in their orbits, and without lids. The nidamental gland is largely developed. The shell is calcareous and internal, and loosely lodged in the dorsal portion of the mantle in the Sepias. The style is formed of a cartilaginous blade or horny pen in the Calamaries. It is an internal siphoniferous polythalamons shell in the Spirulide, (fig. 23); and a phragmacone divided by numerous concave septa fitted upon a style or pen, in the extinct BELEMNITIDE; and in other fossil genera it varies from these types.

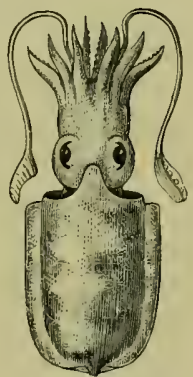

Fig. 17.

Sepia elegans, $d^{\prime}$ Orbig.

1. Fanily Loligopside, Gray, 1840.-Body elongated and tapering posteriorly ; fins large, broad, and mostly terminal. Shell an internal pen or gladius of horny structure, and consisting of a shaft and two lateral expansions. The Calamaries swim well, and crawl head downwards on their oval disc.

2. Family Снiroteuthide, Gray, 1849.-Body resembles preceding, but differs in the unequal length of the arms, which are six times as long as the animal itself. The subjoined (fig. 18) Chiroteuthis Veranyi, Ferussac, shows the external development of the acetabular and tentacular arms. The gladius is elongated, enlarged at each end and tapers in the middle.

3. Family Sepiade, d'Orbigny, 1835.-Body oval, fins lateral, as long as the mantle. Head large, united to the body by a broad nuchal band. Tentacular arms long, wholly retractile. Sessile arms having four rows of acetabula, with horny circles. Funnel with an internal valve. Shell long and wide, thick in front, concave internally behind, and terminating in a prominent mucro, composed of calcareous laminæ, with intervening spaces 


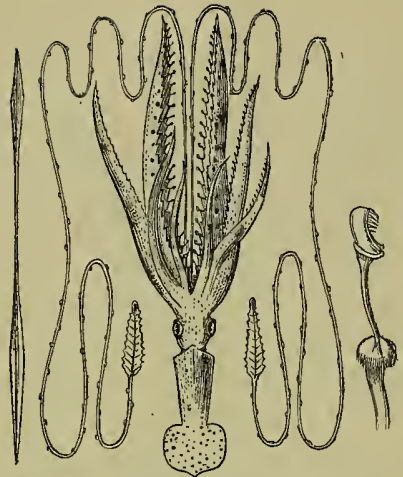

Frg. 18.-Chiroteuthis Veranyi, Ferussac.

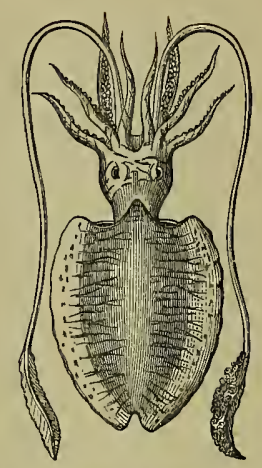

FIG. 19.--Sepia vermiculata, d'Orb.

filled with air and supported by columns, but not perforated by a siphon (figs. 17 and 19).

4. Family Belemnitide, Owen, 1836.-An extinct family. Shell consisting of a pen, terminating posteriorly in a chambered cone, sometimes inclosed in a sheath or guard.

FIG. 20.

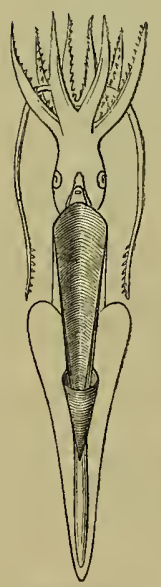

Fig. 21 .

Frg. 22.

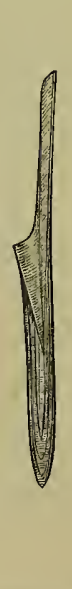

Fị̦s. 20-22.-Belemnites restored by d'Orbigny.
The air-cells of the phragmacone are connected by a siphuncle close to the ventral side. The animal possessed an ink-bag, which is often found fossil in sitû. The arms were provided with recurved hooklets, seen in situi in specimens found in the Oxford Clay. The figures $20,21,22$, on the margin are ideal restorations of the animal of the Belemnites, and drawn by the late Professor Alcide d'Orbigny, who considered that the complete test of Belemnites was composed of four parts intimately united together. These parts are-1st. Anteriorly a horny spatuliform blade, enlarged before and contracted behind. 2nd. A deep cup or conical alveolus containing a series of air-chambers. 3rd. An inferior siphon traversing the whole series of chambers. 4th. A calcareous sheath, more or less elongated, covering and protecting the alveolus, and constituting a true terminal rostrum, all which parts are shown in sitîi in the above figures of the restored forms.

5. Family Spirulide, d'Orbigny, 1837.-Body oblong, with small terminal fins; 
rows of sessile suckers. Tentacular arms elongated, funnel-valved. The sbell, placed vertically in the posterior part of the body, with the involute spire towards the ventral side (fig. $23 a$ ), is delicate, polythalamons, subinternal, entirely nacreous, discoidal with separate whorls, and has a marginal or ventral siphon, $c$, concave septa, and round opening. The animal is retained in place by the tendinous filament which penetrates the siphon as shown in the subjoined figures, and by the retractor muscular masses surrounding the last cliamber (fig. 23 $b, c)$. The dead shells are scattered profusely on the beach throughout the tropics. The animal is as yet imperfectly known, only one specimen was taken in the trawl by the Scientific Staff of H.M.S. Challenger, during ber exploring voyage round the world in $1873-76 .^{1}$ An important

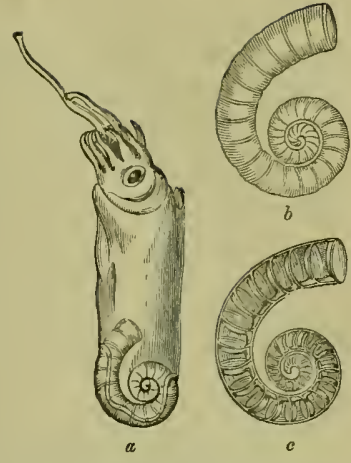

Fic, 23.-Spirula australis, Lamarck. $a$. Animal and shell in sitû.

b. Shell entire showing chambers.

c. Section showing septa, chamher, and siphuncle.

addition to our knowledge of this form, however, has been recently made in the valuable memoir by Professor Owen, F.R.S. ${ }^{2}$

\section{Order II.-TETRABRANCHIATA, Owen, 1832.}

T'entaculifera, d'Orbigny, 1840; Ćéphalopodes polythalames, Lamarck, 1812.

With the exception of one genus of which the Pearly Nautilus (fig. 24) may be regarded as a type, the whole of the Cephalopods of this order belong to fossil forms. They were all provided with an external polythalamous or many-chambered shell, symmetrical in form, like the body of the animal which is lodged in its last or outer chamber. As we only know the anatomy of the living representative of this extensive extinct order, all our observations on the structure of the animal refer to the Nautilus pompilius, so carefully dissected and admirably figured and described by my old esteemed friend, Professor Owen. ${ }^{3}$ The head, which is closely approximated to the

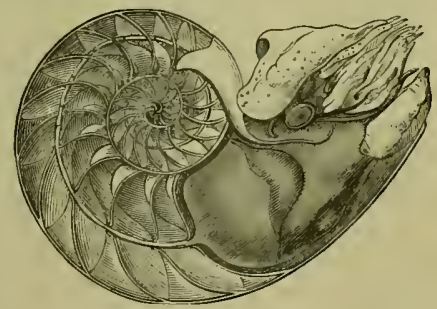

Frg. 24.-Vertical section of the shell of Nautilus pompilius, showing the siphoncle and the situation of the animal in the last chamber. body, is provided with a great number of cylindrical, annulated, retractile tentacles without acetabula, which surround the mouth, and are grouped as brachial, digital, ophthalmic, and labial, according to their position. The brachial, forty in number, are supported on

1 Sir C. Wyville Thomson, 'The Voyage of the Challenger,' vol. ii, p. 350, 1877.

2 "Supplementary Observations on the Anatomy of Spirula Australis," "Ann. and Mag. of Nat. Hist.' for Jannary, 1879.

3 'Memoir on the Pearly Nautilus' ('Nautilus pompilius, Linn.), 8 plates, 4to, 1832. 
short conical processes, and the two superior or dorsal pair are conjoined and dilated into a muscular disk covering the whole upper part of the head; the remaining thirtyeight are disposed nineteen on either side, closely overlapping one another, and all are directed forwards towards the mandibles. The labial tentacles, forty-eight in number, extend from orifices situated on the anterior margins of four broad flattened processes arising opposite the base of the mandibles. The oplithalmic tentacles, four in number, project laterally, one before and one bebind each eye ; they appear to be sensory instruments, and resemble the cephalic tentacles in Doris and Aplysia. The eyes are pedunculated, and of a simple structure: the organ of hearing was not detected.

The branchiæ, four in number (fig. $25 b, b$ ), are inclosed in the respiratory sac, without branchial hearts.

'The circulating system is provided with one ventricle which is systemic, and propels arterial blood throughout the body (fig. $25 d$ ). There is no ink-bag in the animals inhabiting these camerated shells. The funnel, which occupies the floor of the bodychamber, is divided by a longitudinal slit, and inside there is a valve-like fold (fig. $25 s$ ).

A large dilatable and contractile tube is continued from the posterior part of the animal through all the partitions and chambers of the shell, as shown in fig. 24 ; this is the siphuncle, which is a vascular tube that opens into the cavity of the pericardium containing the heart, and is probably filled with sea water from the branchial (fig. $25 c$ ) chamber.

Soon after the appearance of Dr. Buckland's "Bridgwater Treatise," I published, in the 'Philosophical Magazine,'1 a paper on the action of the siphuncle in the Pearly Nautilus, in which I pointed out what appeared to me, as an anatomist, the discrepancy between the structure of the animal and the explanation given by the author, who observed, "The last contrivance, which I shall here notice, is that which regulates the ascent and descent of the animal [the Nautilus] by the mechanism of the Siphuncle. The use of this organ has never yet been satisfactorily made out; even Mr. Owen's most important Memoir leaves its manner of operation uncertain; but the appearances which it occasionally presents in a fossil state, supply evidence, which taken in conjunction with Mr. Owen's representation of its termination in a large sac surrounding the heart of the animal, appears sufficient to decide this long disputed question. If we suppose this sac to contain a pericardial fuid, the place of which is alternately changed from the pericardium to the siphuncle, we shall find in this shifting fluid an hydraulic balance, or adjusting power, causing the shell to sink when the pericardial fluid is forced into the siphuncle, and to become buoyant whenever this fluid returns to the pericardium. On this hypothesis also the chambers would be continually filled with air alone, the elasticity of which would readily admit of the alternate expansion and contraction of the siphuncle in the act of admitting or rejecting the pericardial fluid."”

1 ‘The London and Edinburgh Philosophical Magazine,' vol. xii, p. 503, 1838.

2 Bridgwater Treatise, 'Geology and Mineralogy,' vol. i, p. 325, 1836. 
The Nautilus passes the greatest portion of its life at the bed of the sea, but it has been seen occasionally at the surface, and the question naturally arises, What are the conditions necessary to accomplish its ascent and descent, so that the animal should possess the will and power of rendering itself specifically lighter and heavier than the ambient element? Dr. Buckland's theory allows only of a change of place in the adjusting fluid from the pericardial cavity into the siphuncle, and vice versá. The accompanying outline, fig. 25, from Prof. Owen's dissections, slows the relative position of the internal organs :- $a a$ is the enveloping fleshy mantle, dissected off to expose $b b$, the branchix, floating in $c$, the branchial chambcr for the reception of the water; $d$ is the heart, with its large vascular canals surrounded by clusters of glandular follicles, $e e$; the capacious pericardium, $f f$, is laid open to show its boundary and relation to the central organs of the circulation; it is partially divided internally by thin muscular septa, $g g$. From the posterior wall of the musculo-membranous bag there proceeds the siphuncle, $s s$, destined to traverse all the chambers of the shell, and the arrow shows the direction of this aquiferous tube. Anteriorly the pericardium communicates with the branchial chamber, $c$, by two

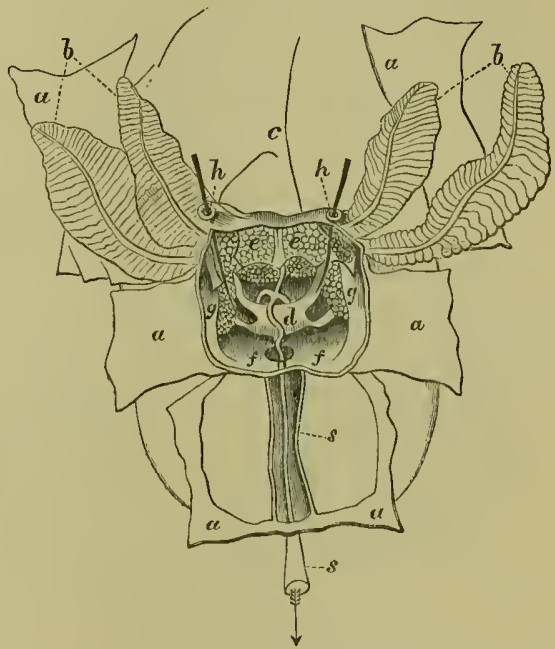

Frg. 25.-Animal of the Nautilus pompilius, dissected by Prof. Owen to show the manner in which the siphuncle terminates in the pericardium, and bow the pericardium opens by two orifices into the branchial chamber. apertures, $h h$, through each of which a bristle is passed to indicate the channels of communication. From this arrangement it is evident that the pericardial bag has three openings, one behind, which conducts the water into the siphon, and two before, which open into the branchial chamber, into which sea water is constantly flowing to bathe the respiratory organs, so that water alone is the ballast by which the Nantilus is retained at the bottom, and its ejection the means by which it lightens its shell and is enabled to rise to the surface at pleasure. Thus, by relaxing the anterior orifices, $h h$, that communicate with the branchial chamber, the water will flow into the pericardial sac, and thence into the siphuncle, $s$. During this distension the animal and shell will be specifically heavier, and the Nautilus, without any other muscular effort, remains at the bottom, whilst by emptying the tube it becomes specifically lighter and floats up to the surface.

The body of the Nautilus is firmly attached to the shell by two lateral muscles which are inserted into the walls of the last or dwelling chamber. 
The head is provided with a large ligamento-muscular plate, or flattened disk, formed by the junction and dilatation of a pair of dorsal tentacles, which, besides acting as a defence to the opening of the shell, serves probably for creeping along the bed of the sea, like the foot of a Gasteropod, as the Nautilus has neither fins nor natatory organs, and moves through the ocean by the ejection of the sea water out of its locomotory funnel.

The mandibles are strengthened by a dense external calcareous coating, which forms a dentated margin on the jaws.

The shell is involute or discoidal, few-whorled, and many-chambered, as seen in the shell of Nautilus umbilicatus, Lam. (fig. 26), and in the section of Nautilus pompilius (fig. 27), as well as in the section of the fossil species Nautilus striatus (fig. 28) from

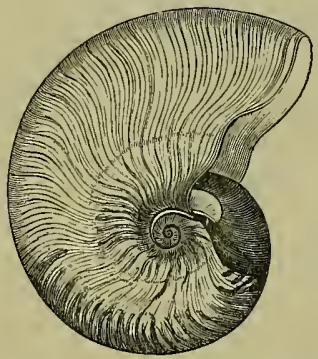

Fig. 26.-Nautilus umbilicatus, Lam.

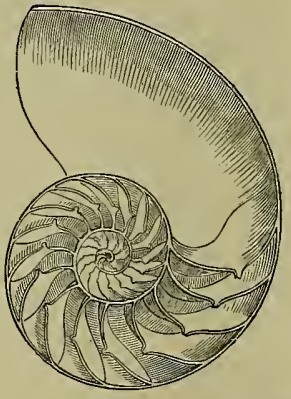

Fig. 27.-Section of the shell of Nautilus pompitius, Linn.

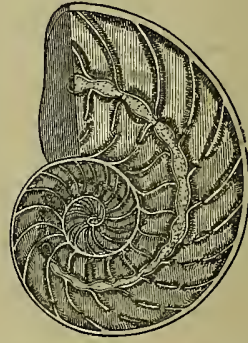

Fig. 28.-Nautilus striatus, Sow. Section of a fossil Nautilus, showing the position of the siphuncle.

the Lias Formation. The septa are here seen to be concave towards the aperture, and convex towards the spire; near the centre of each septum a short funnel-shaped process projects backwards (fig. 27); around this the membranous siphuncular tube is firmly attached, by which a continuous pipe extends from the pericardium to the first chamber of this polythalamous shell (fig. 24). The outer laminæ of the shell are porcellaneous, and the inner nacreous; and the Chinese and others carve a variety of patterns out of the opaque porcellaneous portion of the Nautilus shell, which are relieved by the pearly layer beneath, which forms the background of the object. The living Nautili have the external surface of the shell smooth, but among the fossil forms many of the species are variously sculptured. The aperture of the shell in the Pearly Nautilus is closed by a disc or hood formed by the union of the two dorsal arms which are homologous to the shell-secreting "sails" of the Argonaut (figs. 15, 16). In the Ammonitids we shall sometimes find the dwelling-chamber provided with a singular body, the Trigonellites, Park., or Aptyclus, Von Meyer, which played an important part in the organic functions of this large extinct group of tetrabranchiate Cephalopods.

This order is divided into two sub-orders, the NaUtiloida and the Ammonorda. 
The cluaracters are entirely derived from the structure of the shell. With the exception of the two living species of the genus Nautilus all the others are extinct. It will, therefore, be necessary to review these genera in detail in order to understand their natural relations and true affinities with the other members of the sub-order to which they belong.

\section{Sub-order A.-NAUTILOIDA, Wright, 1880.}

Shell with a large body-chamber, simple aperture. The siphuncle for the most part central or columellar, with the tube directed backwards. Septa simple and concave towards the aperture; on the removal of the shell the margin of the septa shows simple curved lines, corresponding with the curve of the septum (fig. 27).

The following groups belonging to this order have been described:

1. Family Nadtilide, Owen, 1836. - Shell always convolute and discoidal.

Genus.-NautiLus, Breynius, 1732. Shell camerated, spiral, discoidal; whorls regularly convoluted on same plane, chambers separated by concave septa; siphuncle central or subcentral; Silurian to present period.

2. Fanily Liturtide, Wright, 1880.--Shell convolute and discoidal in youth, and in old age projecting forwards in a straight line

Genus.-Lituites, Breynius, 1732. Shell camerated, spiral, discoidal ; early whorls distinct and contiguous, but the last ceases to be contiguous, and projects forward in a straight line, so as to form, with the first, a kind of crooked staff. The last chamber very large, with a simple circular opening, destined to contain the animal. Siphuncle central or sub-central. Silurian.

Genus.-Hortolus, MIontfort, 180s. Shell camerated, spiral, discoidal, with whorls non-contiguous. The last projects in a straight line; and the whole forms an elongated crooked staff. Silurian.

3. Family Aploceratide, Wright, 1880.-Shells more or less bent.

Genus.-Aploceras; d'Orbig., 1847; Corniculina, Münster, 1843. Shell resembles a bent horn, regularly arched. Siphuncle subcentral. Carboniferous Limestone.

4. Family Orthoceratide, Woodward, 1851.-Shells straight.

Genus.-Orthoceras, Breynius, 1732. Orthoceratites, Auct.; Conilites, Lamarck, 1822 ; Hrolithes, Eichwald, 1840; Crcloceras, M’Coy, 1844. Shell 
straight, elongated, conical, camerated in the greatest portion of its length. Septa transverse, simple, concave forwards. Siphuncle complicated, central or subcentral. Aperture simple, circular, sometimes banded. A very extensive genus; some of the species attained large dimensions; and, from fragments, it is estimated that $O$. giganteum might have been six feet long and above a foot in diameter. From Silurian to Triassic strata. The Orthoceratida now form a family composed of many genera that have been dismembered from Breynius' group.

Genus.-Cameroceras, Conrad, 1842 ; Melia, Fischer, 1829. Shell straight, elongated, conical ; siphuncle lateral, sometimes large. Moulds of these large siphuncles were called Hyolites by Eichwald. L. Silurian to Trias.

Genus.-Actinoceras, Bronn, 1835. Siphuncle very large, inflated between the chambers, and connected with a central tube by numerous radiating plates. Silurian, Devonian, Carboniferous ; North America, Baltic, and British Islands.

Genus.-Ormoceras, Stokes, 1838. Siphuncular beads constricted in the middle, making the septa appear as if united to the centre of each. They are essentially the same as Actinoceras. Lower Silurian; North America.

Genus.-Horonia, Bigsby, 1824. Shell very thin. Siphuncle very large and central, the upper part of each joint inflated, connected with a small central tube by radiating plates. Lower Silurian; Drummond Island, Lake Huron. Dr. Bigsby saw some specimens in the Limestone of Drummond Island six feet in length.

Genus.-Endoceras, Hall, 1847. Shell straight, elongated, conical. Siphuncle large and marginal, thickened internally by repeated layers of shell, or partitioned off by a series of funnel-shaped diaphragms. Lower Silurian; North America.

5. Family Trochoceratrde, Wright, 1880.-Shells bent into a turbinated form.

Genus.-Trochoceras, Barrande, 1847. Shell spiral, helicoidal. Position of siphuncle unknown. Lower Silurian, Bohemia.

6. Family Gomphoceratide, Pictet, 1855.- Shell fusiform, narrower before than in the middle, and with a contracted aperture.

Genus.-Gomphoceras, Sowerby, 1839. Apioceras, Fischer, 1844, Poterioceras, 1844, $M^{\circ} \mathrm{Coy}$. Shell fusiform or globular, with a tapering apex. Aperture contracted in the middle. Siphuncle moniliform, subcentral. Silurian, Devonian, Carboniferous; North America and Europe.

Genus.-Oncoceras, Hall, 1847. Shell like Gomphoceras, but curved. Siphuncle external. Silurian; North America. 
Genus.-Srcoceras, Pictet, 1844 Shell short, straight, oviform. Septa transverse, numerous, simple. Silurian to Devonian.

Genus.-Phragmoceras, Broderip, 1834; Campulites, in part, Deshayes, 1830 ; Phragmolithes, Conrad, 1838. Shell compressed laterally, conical, regularly bent in its length, but not spiral. Septa simple, transverse. Siphuncle very large, subcentral, near the internal margin. The outer chamber large, expanded, terminated by a longitudinal aperture contracted into a fissure, the posterior extremity of which is dilated into a large transverse sinus; and the anterior extremity is prolonged into a smaller subcircular sinus, forming a tube. Upper Silurian and Devonian.

7. Family Groceratide, Pictet, 1854.-Shell spiral; septa simple; siphuncle external; aperture large.

Genus.-Cryptoceras, d'Orbigny, 1847. Shell spiral, discoidal; whorls contiguous, embracing. Septa simple, arched, without lobes and sinuosities. Siphuncle dorsal. The species are found in the Devonian and Carboniferous formations.

Ex. C. subtuberculatum, d'Orb. (fig. 29).
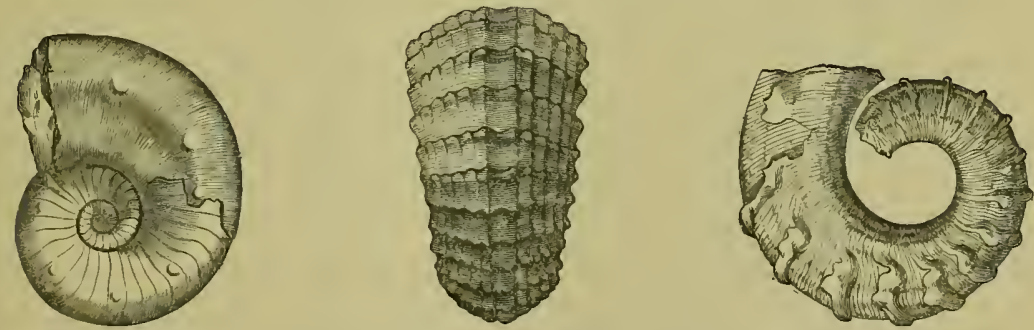

F1G. 29.-Cryptoceras subtuberculatum, d'Orb. FIG. 30.-Gyroceras Eifeilense, d'Orb. FIG. 31.-Gyroceras ornatum, d'Orb.

Genus.-Grroceras, von Meyer, 1829. Inachos, Hisinger, 1837. Shell multilocular, discoidal, with a regular spire, composed of non-contiguous whorls, rolled on the same plane. Septa regular, with simple and symmetrical uargins; the last chamber very large, occupying a third of the last whorl. Siphuncle thin, subdorsal. Aperture oval or angular. Gyroceras is to the Nautilus what Crioceras is to the Ammonite. Upper Silurian and Devonian. Ex. G. ornatum, d'Orb. (fig. 31).

Genus. - Crrtoceras, Goldfuss, 1833. Campyloceras and Trigonoceras, $M I^{\circ} \mathrm{Coy}$, 184.4. Shell multilocular, not spiral, representing an oblique horn more or less bent. Septa transverse, oblique, with simple borders. Aperture in general oval and compressed. Siphuncle continuous, often dorsal; the last chamber much larger than the others. Found in Silurian, Devonian, and Carboniferous formations. 
8. Family Clrmenide, Edwards, 1849.-Shell discoidal, more or less involute ; septa simple or slightly lobed; siphuncle internal or columellar.

Genus.-Clymenia, Münster, 1832. Endosiphonites, Ansted, 1840. Shell spiral, discoidal, with contiguous whorls, more or less involute; septa form a distinct lobe on the sides, with angles more or less acute; siphon small, internal, situated against the turns of the spire. Species numerous in the Devonian of Europe and N. America. Ex. Clymenia Sedgwickii, Münster (fig. 32) ; C. striata, Münst. (fig. 33).

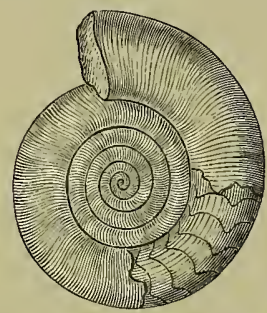

FrG. 32.-Clymenia Sedgwickii, Mïnst.

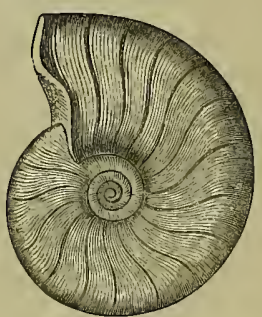

FıG. 33.-Clymenia striata, Münst.

Sub-order B.-AMMONOIDA, Wright, 1880.

Shell spiral, bent, or straight, with a capacious dwelling-chamber. Margins of the septa angular, digitate, or much ramified, forming large lobes. Siphuncle marginal, external with regard to the shell, or anti-columellar. This section is divided into three Families, the Goniatites, the Ceratites, and the Ammonites.

1. Family Goniatitid 2 , Wright, 1880.--Shell rolled into a close spiral ; septa with angular margins.

Genus.-Goniatites, De Haan, 1825. Aganides, Montfort, 1808. Shell spiral, regularly rolled on the same plane, with convolute contiguous whorls. Septa transverse,

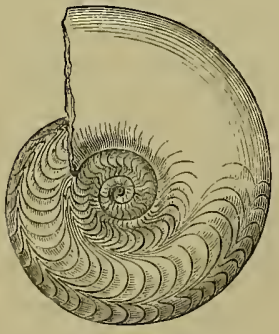

F1G. 34.-Goniatites Hoeninghausi, Bronn.

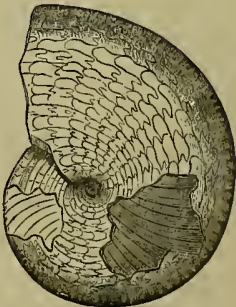

Fig. 35.-Goniatites Orbignyanus, d'Archiac.

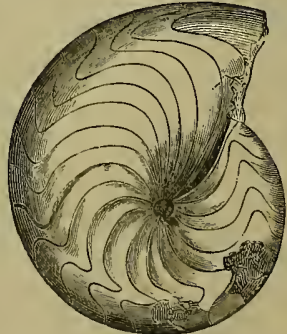

FIG. 36.-Goniatites rotatorius, de Koninck. 
forming deep angular sinuses without denticulations, with a prominent siphonal lobe (figs. 34, 35, 36). An extensive genus, containing many species, distributed from the Silurian to Triassic strata. Ex, Goniatites Orbignyanus, d'Archiac (fig. 35).

2. Family Ceratrude, Mojsisovics, 1879.-Shell spiral, discoidal; septa undulate, with denticulate borders.

Genus.-Ceratires, De Haan, 18:5. Shell spiral, discoidal; whorls contiguous, convolute. Septa undulating, but not ramified, with denticnlate borders. Siphonal

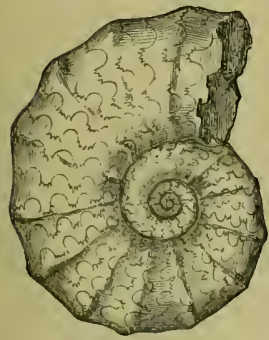

Fig. 37.-Side view. Fig. 38 - Back view. Ceratites nodosus, De Haan.

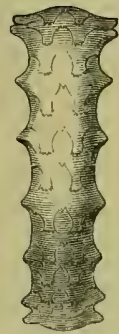
Fig. 38

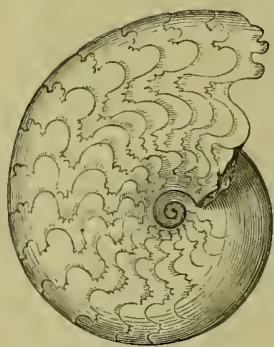

Frg. 39.-Ceratites Rolini, Thiollière.

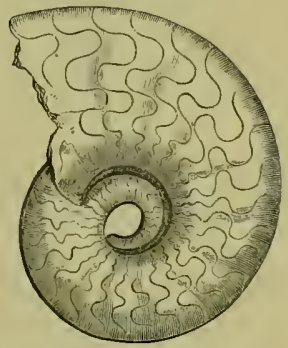

FrG. 40.-Ceratites semipartitus, von Buch.

lobe deep, separated on the median line by a small saddle (fig. 35). The Ceratites range from the Triassic to the Cretaceous. Ex. C. nodosus, De Haan (fig. 37); C. Robini, Thiollière (fig. 39). C. semipartitus, von Buch (fig. 40).

\section{Family Annonitide, Oven, 1836.}

Shell external, spiral, bent or straight, the last chamber large for a dwelling-place. Siphuncle central on the external or ventral side of shell. The margins of the septa ramified, with deeply lobated borders, divided into six lobes. 1st. The siphonal (D, figs. 41 and 43), embraces the siphon, and divides into two arms, which are attached by a shelly layer to the siphuncular tube. 2nd. The two that adjoin are called the superior lateral lobes (L). 3rd. The two that lie beneath them are the inferior lateral $\left(L^{\prime}\right)$, which often are much developed and very complicated in the ramifications of their lobes (figs. 41 and 43). 4th. The lobe which rests upon the side opposite the siphonal lobe and siphon is the columellar lobe ( $v$, fig. 46). Between this and the inferior lateral are several anxiliary lobes $(a, a, a, a$, fig. 43). Thus there are in each septum six primary, viz. one siphonal, one columellar, and four lateral lobes, also a variable number of auxiliaries. When we examine an Ammonite in which the 
marginal septal foliations are well shown, we observe that all their points are directed away from the aperture (figs. 41 and 43), and the concavities or rounded parts are directed towards the aperture (fig. 45). The outlines of the septa are termed

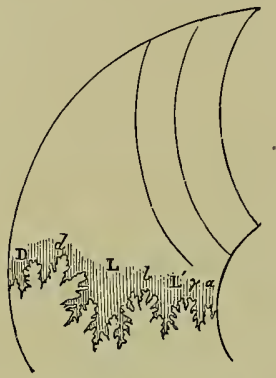

FIG 41,-Disposition of the lobes in Amaltheus margarilatus, Montf.

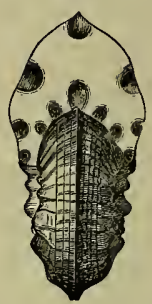

Frg. 42.-Mould of the lobes in Amaltheus pustulatus, Münst.

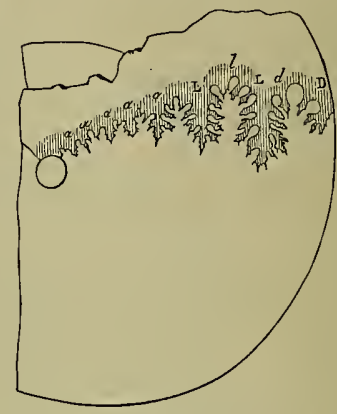

FIG. 43.-Disposition of the lobes in Phylloceras heterophyllum, Sow.

sutures; when they are folded, the elevations are called saddles, and the intervening depressions lobes. In the Ceratites (figs. 37-40, and 44) these parts are very

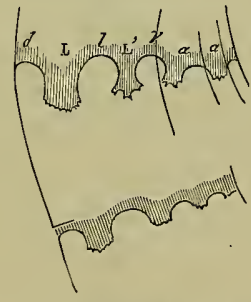

FIG. 44.-Disposition of the lobes in Ceratiles nodosus, De Haan.

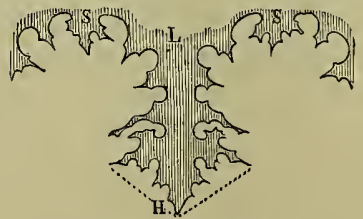

F1G. 45.-Form of the subdivisions of the lobes in Ammonitidæ.

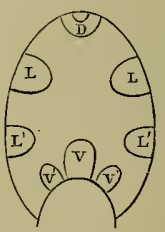

Fig. 46.-Mould of the disposition of the lobes of Phylloceras.

simple, and here we see the rounded saddles directed forwards and the dentated lobes turned backwards; the same is the case in Amaltheus margaritatus (fig. 41), and Pliylloceras lieteropliyllum (fig. 43), with this difference, that in all the Ammonitidæ the sutures are very long, and the lobes and saddles lighly complicated accordingly.

In the dwelling-chamber of Ammonitida we sometimes find a remarkable body, having some resemblance to a bivalve shell widely opened; this is called the Aptychus, which has been the subject of much speculation and difference of opinion as to what it is and what it did in the economy of the Ammonite. Its form and structure differ materially in the different species, so that whenever the Aptychus of an Ammonite is found in position it ought to be correctly drawn and accurately described. In the plates of this work several authenticated forms in connection with their shells are figured, and will be 
described in the sequel. My late friend, Dr. Oppel, in his 'Mittheilungen,' figured and described many species of Ammonites from the "Malm" or upper Jurassic of Germany

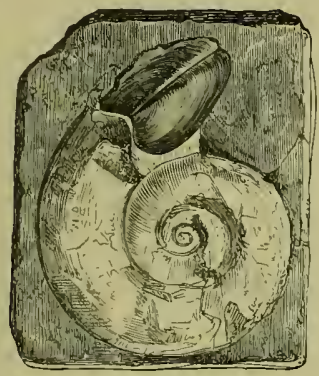

FIG. 47.

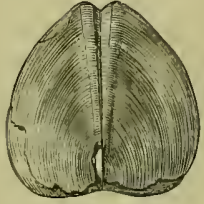

Fig. 48.

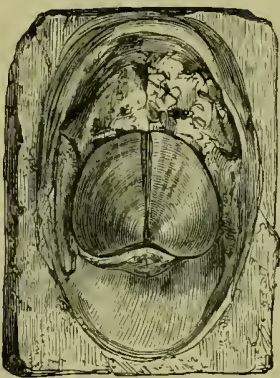

Fig. 49.

and Switzerland, in the outer chamber of which the Aptychi are preserved. These fossils are very instructive, and teach us that each species had its own special form of Aptychus just as it had its own form of aperture and ornamentation (figs. 47, 48, and 49).

It is interesting and curious to note the various ideas that have prevailed about these bodies. Dr. Scheuchzer ${ }^{2}$ first noticed the Aptychus, and described it as Concha fossilis tellinoides porosa lavis. Dr. Knorr ${ }^{3}$ considered the Aptychus as the valves of Lepas anatifera, with which it has some resemblance in form, but differs in structure. Parkinson ${ }^{4}$ called it Trigonellites, and described it "as a slightly rounded, trigonal, thick shell, gaping on each side. The anterior margin nearly on a straight line, the posterior in a gently waving, and the upper side in nearly a circular direction. The outer surface of each valve thickly pierced by foramina, which passing nearly through its substance gives it the cancellous appearance of bone, the inner surface smooth, but marked with striæ, concentric with the upper margin. The hinge completely linear withont teeth, there being only an appropriate surface on the anterior margin of each valve for the attachment of the cartilage externally. No appearance of muscular attachment." Bourdet, ${ }^{5}$ of Nièvre, considered Aptychi to be the palatine teeth of fishes, and proposed the name Iclithyosagones for these fossils. H. von Meyer, in his 'Memoir on the Aptychus,' described the form structure of Aptychus lavis as essentially cellular and entirely different from that of the ordinary bivalve shells of Mollusca, inasmuch as the lines of growtl are never visible on

1 'Palaeontologische Mittheilungen aus dem Museum des Koenigl., Bayer Staates, 1862, see plates lxviii to lxxiv.

2 'Specimen Lithogr. Helvet.,' p. 21, 1718.

3 'Lapides diluvii universalis testes,' 1755.

4 'Organic Remains,' vol, iii, p. 184, pl. xiii, figs. 9-12, 1811.

5 'Notice sur des Fossiles inconnus,' Paris, 1822.

6 'Nov. Act. Acad. Coes. Leop.-Car. Nat. Cur.,' xr, 2, p. 125, 1831. 
the internal surface of the valve, that surface being covered with a nacreous layer, which retains the muscular and pallial impressions of the animal. In the Aptyclus we never see these impressions on the inner, whilst the lines of growth are visible on the external surface. M. Voltz ${ }^{1}$ attempted to prove that the Aptyclus was the operculum of an Ammonite, because it resembled the opercula of Gastropods in the structure of its shelly laminæ, and the style of its lines of growth, and likewise because it was frequently found in the last chamber of the shell; and this opinion was held by Professors Rüppel, Quenstedt, and Deslongchamps, on the Continent, and by Professors Owen, Morris, ${ }^{2}$ and Dr. Woodward, ${ }^{3}$ in England. M. Deshayes ${ }^{4}$ contended that the Aptychus was not the operculum of an Ammonite, but belonged to some of the interual organs of the animal, probably the inner walls of the stomach. M. Coquand ${ }^{5}$ regarded the Aptychus as the analogue of the internal osselets of some Dibranchiate Cephalopods, as the Teudopsis, and thought the two genera ought to be grouped in the same family. This author had found specimens where the two halves of the Aptychus were united and formed a single bilobed body, traversed in the middle by a carina, and this he compared to the stem of the osselets or pen of the Teudopsis (figs. 47 and 49). The lines of growth and absence of muscular impressions M. Coquand considered to be important analogies in support of his views.

Professor Pictet, ${ }^{6}$ after reviewing the opinions expressed in the different works already cited, and giving the results of his own studies on the Aptychus, avowed that amidst all these diverse opinions it was difficult to pronounce upon the true affinities of these singular fossils, which he grouped into three sections :

1st. The ConneI, with a thin, smooth, horny shell; all from the Lias and Inferior Oolite.

2nd. The Imвricari having the same horny plate, but covered by a calcareous test, with large folds representing an imbrication; these are found from the Lias up to the Craie marneuse (étage turonien) of the Cretaceous Formation.

3rd. The Cellulosi the thickest of all. The horny lamina is covered by a cellular layer, which resembles the structure of certain Madrepores, and this cellular portion is again covered by a smooth compact deposit. This group is found in the Oxfordian stages of the Jurassic Rocks, and extends upwards into the Upper Greensand of the Cretaceous Formation.

Keferstein ${ }^{7}$ thought these bodies were sexual characters, and suggested that the Aptychus formed the protector to the nidamentary gland in the female Ammonite; and

1 'Mém. de la Soc. d'Hist. Nat. de Strasbourg,' t. ii, 1836.

2 Note on Aptychus in 'Ann. and Mag. Nat. Hist.,' vol. x (2nd series), p. 356, pl. v D, fig. 1, 1852.

3 'Manual of Mollusca,' p. 80, 1851 .

4 'Mém. Soc. Géol. de France,' t. iii, p. 31, 1838.

5 'Bull. de la Soc. Géol. de France,' t. xii, p. 376, 1841.

6 'Traité Élément. de Paléontologie,' t. ii, p. 385, 1845.

7 'Bronu's Klassen und Ordnungen des Thier.,' III $b$, tab. 113, 1860. 
Dr. Waagen, ${ }^{1}$ in view of clearing away the difficnlties that surrounded the question, dissected a female Nautilus pompilius, and has given beautiful drawings of the nidamental gland in that Mollusc, showing the abdominal surface of the Nuutilus, the position of these glands, and their relation to the other viscera. After a careful and exhaustive exammation of all the anatomical facts disclosed by his dissection, he concluded that the Aptychus appears to have belonged to the nidamentary gland of the female Ammonite.

In his recent memoir on the chambered shells of Cephalopods, Professor Owelı ${ }^{2}$ reviewed in detail the various opinions expressed on the functions of the Aptychus, and remarked "in respect to the nidamental glands, that they are subject to seasonal changes and gain the relative buik with which the size of the aptychal plates accord only at the period of discharge of the impregnated ova, for which they have to furnish the protective coat or nidıs. Such seasonal change is exenuplified in the fignre of these glands given in the 'Memoir on the Nautilus,' of 1\$32, and in that which is shown in taf. xix of Waagen's treatise in 1871. Moreover, in not one of the existing genera or species of Cephalopoda, Nautilus included, in which these glands are superadded to the more essential organs of generation, are they encumbered in any way or degree with such calcareous plates, as Keferstein's hypothesis applies to them in the Ammonite.

"In the application of the auatomy of the constructor of the Pearly Nantilus to the solution of the problem of the nature and function of the Trigonellites I was led to regard them as the homologne of the organ, or a portion of the organ in Nautilus, which is of a fibrous texture resembling dense corium, called, from its shape and position, the hood (fig. 24), and which, when the animal had withdrawn into its dwelling, would serve as a rigid defence at the outlet of the shell. ${ }^{3}$ It needed only that this part shonld be more or less calcified to form the preserved portions of an operculum like that ascribed to the Ammonite. The relative size of the Aptychus agrees with that of the shell. It has been found to measure seven inches six lines in length, and six inches in breadth, in gigantic Ammonites." [I myself have a specimen collected from the Middle Zone of the Lower Oolite which measures five inches in length and four in breadth, and probably belonged to a large Harpoceras Sowerbyi, which is the only Ammonite with a whorl of that size and shape found in the bed from whence it was collected.]

"It may be doubted whether the nidamental glands ever increased in the same ratio; and it is still less likely that they needed such defensive plates in their season of rest and attenuation. If, therefore, my homology of the symmetrical balves of the Nautilus hood with the parial Trigonellites (Aptychus, v. M.) be preferably accepted the supposition that these parts are calcifications of an Ammonite's hood may be deemed

1 "Ueber die Ansatzstelle der Haftmuskeln beim Nautilus und dem Ammoniden," ' Palæontographica,' Band xvii, p. 185, pl. xxxix, Cassel, 1867-1870.

2 "On the Relative Positions to their Constructors of the Chambered Shells of Cephalopods," 'Pro. of the Zool. Soc. of London,' p. $955,1878$.

s 'Memoir on the Pearly Nautilus,' p. 12, pl. iii, fig. 1, 1832. 
reasonable. That the fibrous basis of the hood was retained in different degrees in the Ammonites is indicated by the simply corneous or chitinous condition of the Aptyclus which has been preserved in some examples of "Harpoceras Levisoni, Aegoceras planorbis, Sow., Pl. XIV, fig. 3, and many other forms from the Lias, and Oppelia subradiata, Sow., from the Inferior Oolite of which a beautiful specimen with its Aptyclus in situ is to be seen in the British Museum. ${ }^{1}$

"The conjoined plates of the Aptyclus (figs. 47, 48, 49) form a triangular disc, of which the base is backward, excavated to receive the involute part of the shell, with the sides of the base, like the corresponding lobes of the hood, bent down to cover the laterally extencled parts of the wider terminal coil of the shell. Even in the contrast between the papillose wrinkled outer surface and the smooth inner surface of the 'hood' of Nautilus the resemblance to the "Aptychus ' of the Ammonite is carried out."

Leopold von Buch, ${ }^{2}$ in 1830 , introduced an important reform in the grouping of Ammonites by showing how the foliations of the septa retained certain fixed forms in the species, and considerable differences in each of the twelve groups into which he classified these fossils, and which he thus defined :

I. Arietes.-Upon the sides of the whorls a large number of thick simple ribs or radii are developed, which all bend forward near the back. The siphuncle projects outwards from a channel which extends on each side of it, and this bisulcation of the siphonal area separates the ribs on the sides from each other (fig. 52). The lobes of the division wall of the chambers have the following form :-The siphonal is almost as deep

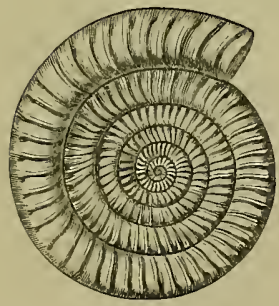

FIG. 50.-Arietites ratiformus, Sow. Side view.

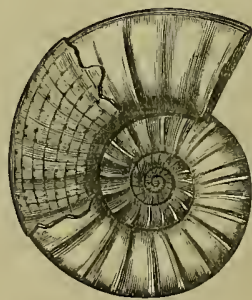

Fig. 51.-Arietites obtusus, Sow. Side view.

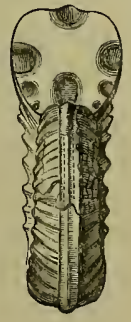

Fig. 52. Back view.

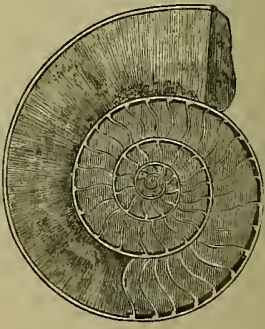

Frg. 53.-Section of Arietiles obtusus, Sow. Showing the size of the dwelling chamber.

as it is broad. The point of adhesion to the sheath of the siphuncle is exactly in the middle of its depth. The upper lateral does not extend to half its depth, and is sometimes

1 Described by Dr. S. P. Woodward in a short memoir on "An Ammonite from the Inferior Oolite with its operculum in situ," 'Geologist,' vol. iii, p. $328,1860$.

2 'Ueber die Ammoniten in den älteren Gebirgs-Schichten,' p. 135; Akademie der Wissenschaften zu Berliu, ausdem Jahre 1830. 
even as broad as it is deep. The lateral saddle rises far above all the others, and stands upon the ground of the upper lateral, in general twice the height of the siplional saddle. The lower lateral is likewise much broader than deep ; and the columellar saddle is so small that it does not reach to half the height or breadth of the lateral saddle. This remarkable disposition of the lobes is constant in all the species, and occurs in no other group.

The Ammonites of this family are in general found in great numbers together. Whole strata are sometimes composed of them; and they often grow to a very large size, from one to two feet in diameter. They are exclusively and only special to the Lias formation, and particularly in the lower beds thereof, where we find many different species. It is still remarkable that this group stands wholly isolated from all the others. The following are typical forms, and for the structure of the foliations of the septa see Pl. III and IV.

$$
\begin{array}{r}
\text { Arietites Bucklandi, Sow. } \\
\text { - Conybeari, Sow. } \\
\text { - bisulcatus, Bruy. }
\end{array}
$$

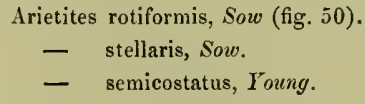

II. Falciferi.-In this group it appears that the mantle which formed the lobes and radii had been capable of a certain amount of pliability, for all rigidity among these forms vanishes. The extremely ramified lobes surprise us through their digitations, always more or less dependent, by which the lobes in their deepest part appear not only pointed, but of considerable breadth, scarcely narrower than at their mouth. The less incised are especially flat and lie almost all at the side of the lateral saddle, in a line behind one another, which is almost also the radius of the whorl. The siphonal lobe, much shorter than the upper lateral, pushes the pointed ends

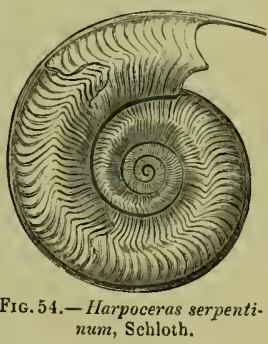
of both its arms obliquely against the lateral, so that both arms diverge considerably, and its walls do not ascend vertically, but obliquely towards the siphonal saddle. (Fig. 54.)

When the shell is complete the radii and folds upon the sides are in the highest degrec fine and delicate. It is the external layer of the shell, which fills in all nneveness between the thickness and divisions of the folds of the under layer. All these folds and radii first bend forward, then turn backward, and near the back again turn towards the mouth opening, so that a well-marked, strongly-bent sickle is formed thereby. The iuner border of the whorl is always blunted by an especial sharp plane surface. The siphonal area in most cases runs out into a sharp ridge, which consists of the siphuncle. This family is extremely rich in species, most of which are special to the Upper Lias, some are found in the Middle Lias and others in the Lower Oolite. The Falcifers never occur in the upper members of the Oolitic series. The following are good types of the genus Harpoceras, which comprehends the FALCIFERI, von Buch. 
Harpoceras serpentinum, Schlotheim (fig. 54).

- radians, Reinecke.

- bifrons, Bruguière.
Harpoceras insigne, Schübler.

- thouarsense, d'Orbigny.

opaliunm, Reinecke.

III. Amalthei.-The sickle vanishes, the radii have a very long stem, which bends

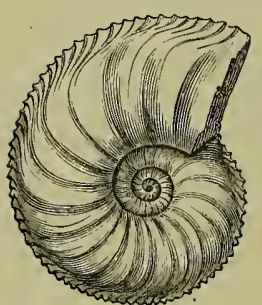

Fig. 55.-Amaltheus cordatus, Sow. only near the siphonal area, becoming here very prominent. The margin is sharp, the keel often divided by the folds as if into scales. The siphonal lobe is here also much shorter than the upper lateral, and its wall ascends obliquely up to the siphonal saddle, but not by any means so obliquely as in the Falciferi. 'The upper lateral is very broad, almost as broad as it is deep, so also is the under lateral. The saddles, as well as the lobes, are extensively foliated, so that in these lobes large and wide outstretched processes are formed in the middle of the saddles, with very deep secondary lobes. The points of the dentations do not hang down, but in general stand perpendicularly upon the axis of the lobes. By this means the sides of Amaltheus in all the species, even when the shell is wanting, have an especially foliated, incised appearance, in which great intricacy appears to prevail. Notwithstanding, with some attention we easily, even to the least detail, find the ever-repeated symmetry as well in the individual points as in both sides of the whorls. These Ammonites are much inclined to become involute. The family ascends from the Lias up to the Coralline Limestone of the Middle Oolite, and each intermediate formation possesses its own special forms. The following are typical species from the Lias and Coral rag.

Amaltheus margaritatus, Montfort.

- Guibalianus, d'Orbigny.

- Greenhoughi, Sowerby.
Amaltheus oxynotus, Quenstedt.

- spinatus, Bruguière.

- cordatus, Sowerby (fig. 5.5):

IV. Capricorni.-This group connects itself very closely with the Amaithei. From Amaltheus margaritatus, through Amal. cordatus, Amal. Lamberti, and Amal. omplialoides, we arrive at Aeg. capricornum. The scales upon the keel of these

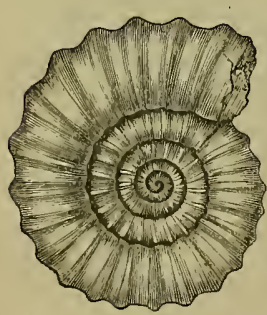

Fig. 56.-Aegoceras capriconnim, Schloth. Ammonites have even raised themselves higher, and are first bent forward, then become broad folds with a point before. 'I he siphonal area of the CAPRICORNI is broad, often broader than the sides. The siphuncle is not specially prominent, the ribbing of the folds on the sides is in general unusually strong, always single, even on the back; without much flexion, and rarely with knobs or spines upon the sides. The siphonal lobe in general goes out perpendicular with vertical walls. The lateral lobes are, as in the AMauthei, less deep than broad, and often at their bases are broader than at the mouth, they are all very slightly or almost not at all involute. The following species are typical forms. 
A egoceras capricornum, Schloth (fig. 56).

- catenatum, Sow.

- Charmassii, d'Orbig.
Aegoceras Henleyi, Sow.

- planicosta, Sow.

- planorbis, Sow.

V. Planulati.-The siphonal area is always perfectly round, and is joined to the sides without a border. The whorls lie almost on the same plane, whereby all

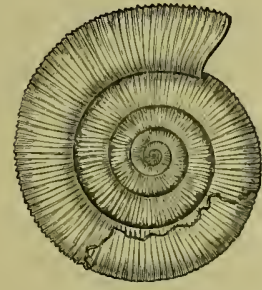

Fig. 57.-Stephancceras annulatum Sow.

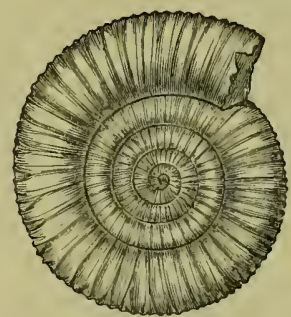

Fig. 58.-Stephanoceras commune, Sow.

the species receive a more or less strikingly discoidal form. The numerous close-set ribs divide near the half or two thirds of their height into two, three, or many small folds, without any tubercle at the point of bifurcation. The lower portion of the rib is thicker and directed backwards, as in the modern genus Stephanoceras, which is the type of this group. The disposition of the lobes is very peculiar and complicated in the Planatuli. The upper lateral is large and very deeply sunk, and occupies the middle of the side; the lower lateral is smaller, and there proceeds from it two or three auxiliary lobes with branches directed obliquely backwards or sometimes even horizontal, and these form together a compound lobe larger than the lower lateral, under which it retires, the whole constituting a most intricate arrangement which is very difficult to trace out.

The Planulati are abundant in the Middle Oolites and in the Upper White Jurassic limestone of Germany. They are also found in some of the beds of the Upper Lias. They are entirely absent from the Chalk. The following forms are characteristic of this group.

Perisphinctes biplex, Sow.

$$
\begin{array}{ll}
- & \text { giganteus, Sow. } \\
\text { - } & \text { plicatilis, Sow. } \\
\text { - } & \text { polygyratus, Schloth. }
\end{array}
$$

Perisphinctes polyplocus, Rein.

Stephanoceras commune, Sow. (fig. 58).

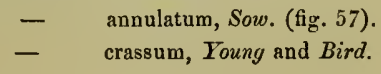




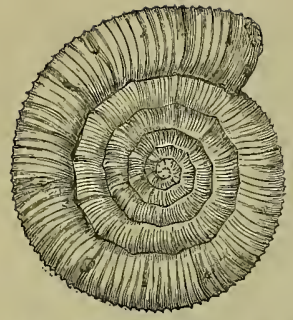

FIG. 59.-Aegoceras Davcer, Sow.

VI. Dorsatr.-The broad siphonal area is united with the sides almost at a right angle. A series of simple tubercles extend round near the margin, through which the simple lateral folds become divided into double ones, before crossing the area. The siphonal area is always smaller than the sides, whereby most of the species preserve a tolerably discoidal form. The auxiliary lobes often extend obliquely against the upper lateral, although not in all the species. The Dorsati unite the Prandlati with the CoronariI. The following are typical species.

Aegoceras Davœi, Sow. (fig. 59). armatum, Sow.

Stephanoceras fibulatum, Sow.

Brocchii, Sow.

VII. Coronarit.-A well-marked series of tubercles so widens the siphonal area that it becomes wholly flat, and a good deal broader than the sides. The sharp, wide, forward-directed folds become divided by the tubercles, the whorls are much involuted and

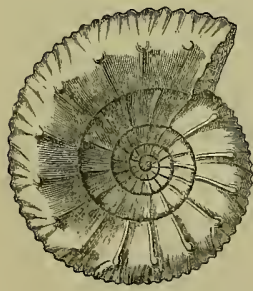

Fig. 60. Stephanoceras Blagdeni, Sow.

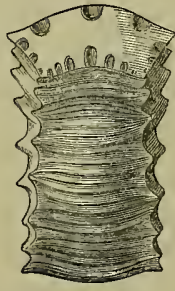

Fig. 61. Side view.

Front view.

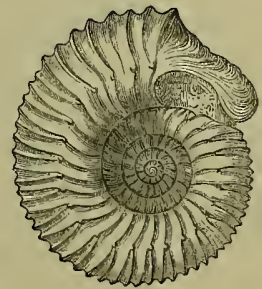

FIG. 62. Stephanoceras Braikenridgii, showing labial prolongation. Side view.

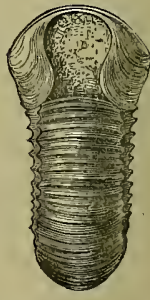

Frg. 63. Front view.

proportionally short, and form a deep umbilicus. The upper lateral lobe stands always above the tubercles, the under lateral beneath. By this character they are readily, and with greater certainty, distinguished from other forms. The siphonal lobe is longer than the upper lateral; and there are several auxiliary lobes, which in their form and position entirely resemble those of the Plandlatr. This group is very characteristic of the middle division of the Inferior Oolite as the following species demonstrates.

Stephanoceras Humphriesianum, Sow.

- Brongniartii, Sow.

- Brocchii, Sow.
Stephanoceras Gervillii, Sow.

$$
\begin{array}{ll}
\text { - Blagdeni, Sow. (fig. 60). } \\
\text { - } \quad \text { Braikenridgii, Sow. (fig. 62). }
\end{array}
$$

VIII. MacrocephaLI. - The increase of the whorls is unusually rapid, especially in the breadth of the mouth. The siphonal area and sides are joined imperceptibly together 
in a complete half circle; and the sides fall off towards the suture, which have often a sharper border, and sometimes a perpendicular surface.

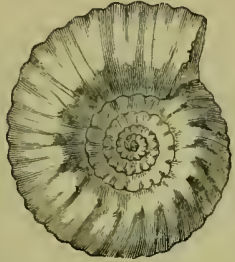

FiG. 64.-Stephanoceras coronatum, Brug. Side view.

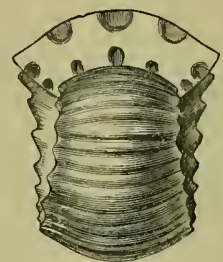

FiG. 65.-Steph. coronatum, Brug. Front view.

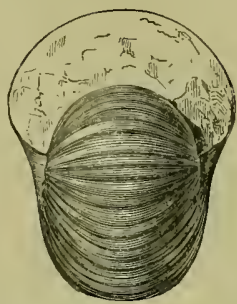

FIG. 66.-Stephanoceras tumidum, Ziet. Front view.

The lower lateral stands always above the inner border, not under it, as in the CoroNARII. The very large ventral lobe is accompanied by two extended arms, and besides by two auxiliary lobes. The upper lateral stands always directly opposite the arms of the columellar, the under lateral directly opposite the lower auxiliary.

Stephanoceras coronatum, Brugière (fig. 64). modiolare, Lhwyd.
Stephanoceras macrocephalum, Schloth.

tumidum, Zieten (fig. 66).

IX. Armati. - Two or more rows of tubercles form a longitudinal parallel series upon the sides, but rarely on the siphonal area, which is flat, often broader than the sides, and joined to them by an almost right-angled border. The upper row of tubercles stand upon the border; then follows a vacant space between them and the lower series, in which the upper lateral lobe comes in; then follows either one or more rows of tubercles. The siphonal lobe is somewhat deeper than the upper lateral, which is sometimes almost three times as deep as it is broad. The siphonal saddle is always of a remarkable breadth, more than double that of the upper lateral, with a deep secondary lobe in the middle and quite even above. The

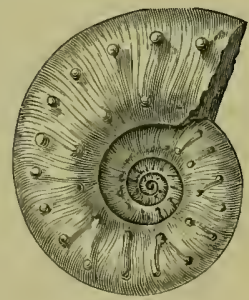

FrG. 67.-Aspidoceras longispinum, Sow. lower lateral, on the other hand, is not larger than the secondary lobes of the siphonal saddle. This is a remarkable group, and very rich in species, found chiefly in the uppermost strata of the Oolitic series and the Cretaceous formation. Aegoceras Birchii and Aeg. Henleyi occur in the Middle Lias, and Aspidoceras longispinum (fig. 67) in the Oxford clay. Hoplites mammillaris (fig. 69, 70), H. Rhotomagensis, H. Mantelli, and H. Woolgari represent Cretaceous forms. The following are typical species :

Aegoceras Birchii, Sow.

Aspidoceras perarmatum, Sow.

- longispinum, Sow. (fig. 67).

Hoplites mammillaris, Schloth (fig. 69).
Hoplites Deverianus, d'Orbig. (fig. 79).

$-\quad$ Rhotomagensis, Sow.
- $\quad$ Mantelli, Sow.
Woolgari, Mant.


X. Denta't. - In the Argonauts the tubercles which border the narrow margin of their shell are probably formed by the rising of the mantle in the shape of folds, due to the sucking discs of the dorsal or back-folding arms of the female (fig. 68). So probably in the

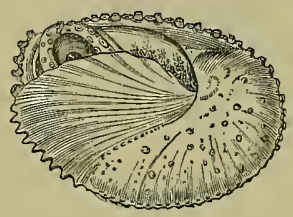

Frg. 68. Argonauta argo, Linn.

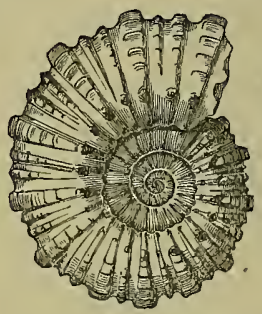

Frg. 69. Hoplites mammillaris, Schloth.

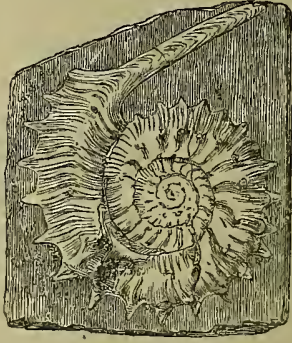

Fig. 71. Cosmoceras Jason, Reinecke.

same manner might the decoration of the shell of the Dentati have been formed. The tubercles grow on both sides of a flat, narrow siphonal area like a double projecting wreath. They do not always stand in the direction of the radii, whereby they are especially distinguished from other prominences and tubercles showing the back folding, which are only strongly elevated folds or arms stretched over the shell. The lateral surfaces are moderately parallel and very large, because the whorls increase, in general, very rapidly in height; at other times they are, in general, without any wider elevation or important processes and points. From the lower part many folds ascend, which, upon half of the sides, are divided, and then, sometimes, a pearl-like series of small tubercles rise up. They are very elegant forms, which are peculiar to the Upper Oolitic formations. The siphonal lobe is much less deep than the upper lateral one. This less depth distinguishes the Dentati from the Armati. The following species are typical forms of the group:

Cosmoceras dentatus, Sow.

- Jason, Reinecke (fig. 71).

Cosmoceras Duncani, Sow. (fig. 72).

- Calloviense, Sow.

XI. Ornati.-Spines or tubercles bound the narrow siphonal area, as in the Dentati. Another series of tubercles are developed upon the middle of the sides. In the flat interspace between these two rows of tubercles the upper lateral lobe is sunk, as in the Armatr. This plain surface is not, as in the latter, the side itself, but only a truncation of the border between the margin of the area and sides. The lower lateral lobe is also separated by a series of tubercles from the suture, and by a surface which converges towards the columellar. The mouth-opening thereby acquires an almost regular hexagonal form. These beautiful Ammonites are in general small, and peculiar to the Oxford Clay and Upper Oolites. 
XII. Flexuosi.-Tubercles are developed on both sides of the siphonal area, which is not sunk flat between two rows of a depressed surface, but is elevated therefrom and divided by a continuous row of tubercles. The radii on the sides are strongly bent forward towards the margin. They are, in general, divided, and here form long knobs, which are somewhat elevated at the lower part of the lateral surface. The siphonal lobe is much shorter than the upper lateral. They are special to the Upper or White Limestone of the Jurassic formation of Germany, and are found, likewise, in the Lower Chalk. The following are typical species :

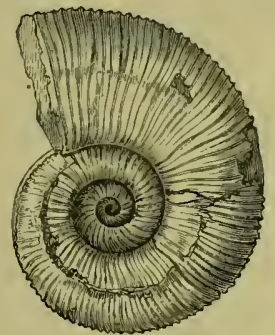

FIG. 72.-Cosmoceras Duncani, Sow.

Cosmoceras flexuosus, Munst.

- Jason, Rein.

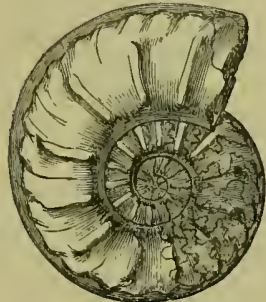

FIG. 73.-Cosmoceras radiatus, Brugière.

Cosmoceras radiatus, Brugière (fig. 73 ).

Hoplites falcatus, MIant.

Professor Quenstedt in 1849 published an important work on the Cephalopoda, together with an atlas of beantiful plates, ${ }^{1}$ in which he divided the Jurassic Ammonites into fourteen groups, retaining those so well established by von Buch, and adding four more to the list :

1. Arieten.

2. CAPRICORNEN.

3. Amaltheen.

4. Heteroph YLLEN.

5. Lineati.

6. Falciferen.

7. DiscI.
8. Denticulaten.

9. Ornaten.

10. Dentaten.

11. Planulaten.

12. Coronaten.

13. Macrocephalen.

14. ArMati.

and divided the Ammonites from the Chalk formations as follows :

15. Cristati, d'Orbigny.

17. Ligati, d’Orbigny.

16. Rhotomagenses, d'Orbigny.

and classed the Ammonites of the Red Alpine Limestone (Triassic), distinguished by Terebratula diphya as : 18. GLoвosi, Quenstedt.

1 'Petrefactenkunde Deutschlands : der ersten Abtheilung, die Cephalopoden,' 8vo., nehst einen Atlas von 36 Tafeln, fol. Tübingen, 1849. 
But the Ammonites of the St. Cassian (Triassic) beds with Ammonites Aon, Münster, were not comprehended in a distinct group.

M. Alcide d'Orbigny divided the Ammonites into twenty-one sections $;^{1}$ in these he included the groups established by von Buch, and added others to receive the many new forms which he had discovered among the very rich materials he had assembled for his great work on the Terrains Crétacée and Terrains Jurassique of France.

\section{a. Species with a siphonal keel entire.}

1st Section. Arietes, von Buch. See page 186.

2nd Section. Falciferi, von Buch. See page 187.

3rd Section. Cristati, d'Orbigny. Shell compressed, sides ornamented with ribs, bifurcated and bent forwards without forming an angle; with or without prominent tubercles. Siphonal area prominent in the keel, which contains the siphuncle. Mouth, when

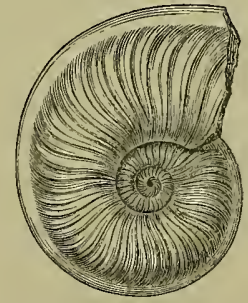

FIG. 74.-Schloenbachia Roissyana, d'Orb.

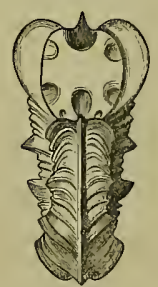

FiG. 75.-Schloenbachia eristata, Deluc.

perfect, prolonged into a prominent rostrum upon the median line of the margin. Septa formed of lobes, in general divided into unequal parts and into equal saddles. Siphonal lobe longer than the superior lateral. The lateral saddle less elevated than the others. The siphonal saddle very high. The best types are Schloenbachia cristata, Deluc (fig. 75), and Schloenbachia Roissyana, d'Orb. (fig. 74), both from the Cretaceous Formations.

\section{b. Species with the siphonal area canaliculated.}

4th Section. Tuberculati, d' Orbigny. The sides of the shell ornamented with ribs and tubercles. Siphonal area provided in the middle with a deep well-defined channel. Mouth, when complete, representing an elongated rostrum corresponding to the siphonal

\footnotetext{
1 'Paléontologie Française; Terrains crétacés,' tom. i, p. 405, 1840.
} 
canal. Septa formed of lobes and saddles divided into single parts. Siphonal lobe shorter than the superior lateral lobe. Hoplites falcatus, Mantell (fig. 76), from the Chalk Marl, and $I$. auritus, Sow., from the Gault, are good types of Tuberculatr.

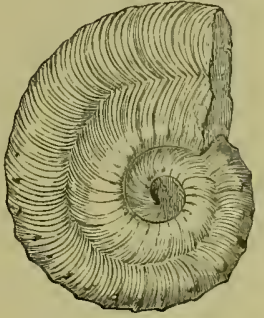

Fig. 76.-Hoplites falcatus, Mantell.

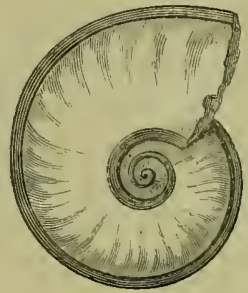

Frg. 77.-Sehloenbaehia Goupiliana, d'Orb.

c. Species with the siphonal urea trenchant without forming a keel.

5th Section. Clypeiformi, d'Orbigny. Shell compressed, generally smooth or little ornamented with undulating folds or radii. Siphonal area sharply bevelled, without a keel. Spire with large whorls mostly much involuted. Septa divided into a great number of lobes formed of single parts, and of saddles partly in pairs and partly single. Siphonal lobe shorter than the superior lateral lobe; the saddles and the lobes large and short. S. Goupiliana, d'Orb. (fig. 77), from the Upper Greensand, is a good type of this section.

d. Species with the siphonal area prominent and crenulated on the median line.

6th Section. Amalthei, von Buch. See page 185.

7th Section. Porchelui, d'Orbigny. Shell elegantly divided on the sides by prominent ribs, straight and not flexed, which passing from one side to the other leave upon

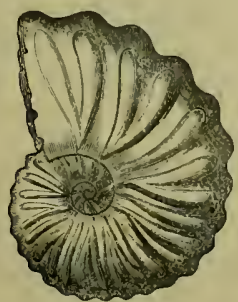

Fig. 78.-Hoplites Brottianus, d’Orb.

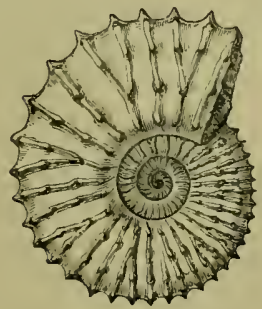

Frg. 79.-Hoplites Deverianus, d'Orb. 
the siphonal area compressed tubercles, which collectively represent a series of crests. Septa formed of lobes divided into single parts, and of saddles divided into pairs of parts. Siphonal lobe nearly equal in length to the inferior lateral lobe. Hoplites Brottianus, d'Orb. (fig. 78), from the Lower Cretaceous Rocks, is a good type of this section.

8th Section. Rнотоmagenses, d'Orbigny. Silell with inflated whorls, square or oval, ornamented with prominent ribs, more or less tuberculated upon four or five lines, one of which runs along the median line of the area, and renders it more or less angular. Septa formed of lobes and saddles partly divided into pairs. The siphonal lobe longer than the superior lateral. The species characterise the Middle Cretaceous Formation, and Hoplites Deverianus, d'Orb. (fig. 79), from the Upper Greensand, is a good type of this section.

e. Species with the siphonal area excavated, and provided with tubercles on the sides.

9th Section. Dentati, von Buch. See p. 192.

10th Section. Ornati, von Buch. See p. 192.

f. Species with the siphonal area more or less square.

11th Section. Flexuosi, von Buch. See p. 193.

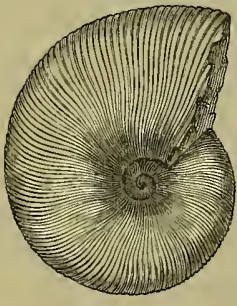

Fic. 80.
Cos. Beaumontianum, d'Orb.

12th Section. Compressi, d'Orbigny. Shell in general very much compressed, composed of large whorls, highly involute. Sides provided with radii or fine striæ, all slightly flexed, and passing on to the margin of the siphonal area, where they develop small tubercles. Siphonal area narrow and squarely truncated. Septa composed of a great number of lobes formed of single parts, and of saddles often formed of pairs of parts. Siphonal lobe very large, much longer than the superior lateral. These Ammonites all appertain to the different divisions of the Cretaceous Formation, Cos. Beaunontianum, d'Orb. (fig. 80), from the Lower Chalk, is a good type.

13th Section. Armati, von Buch. See p. 191.

14th Section. Angulicostati, d'Orbigny. Shell thick, with whorls almost round, each side of the siphonal area ornamented throughout with slight ribs which make this part 
nearly square. Siphonal area much narrower than the sides. Ribs elevated, passing alternately across the area from the one side to the other. Septa composed of lobes formed of single parts, and of saddles often in pairs. Siphonal lobe shorter than the superior lateral; the auxiliary lobes oblique towards the umbilicus. Found in the Lower Chalk, Gault, and Neocomian Formations. Hoplites Martinii, d'Orb. (fig. 81), from the Neocomian, or Lower Greensand of the Isle of Wight, is a fair type of this group.

15th Section. Capricorni, von Buch. See p. $18 S$.

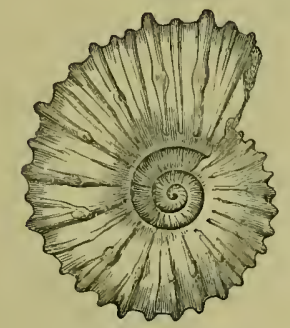

Fic. 81.-Hoplites Martinii, d'Orb.

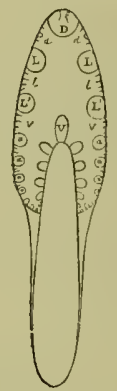

FIG. 82.

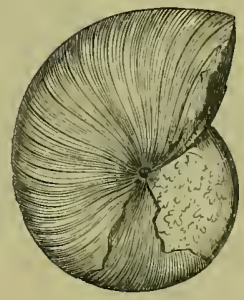

Fig. 83.

Phylloceras heterophyllum, Sow.

g. Species with the siplonal area convex.

16th Section. Heterophyll, d'Orbigny. Shell compressed, formed of whorls almost completely involute, rarely appearing in the umbilicus. The sides are smooth, slightly striated, or furrowed with fine lines. Siphonal area narrow and very convex. Septa symmetrical, divided into a great number of lobes, very much ramified, forned of single parts, and of saddles often in pairs. Siphonal lobe always shorter than the upper lateral. The great number of ramifications of the lobes produces a most complicated, foliated structure on the siphonal area and sides of the casts of this section.

Phylloceras heterophyllim (figs. 82, 83), from the Upper Lias, is typical of this group.

17th Section. Ligati, d' Orbigny. Shell in general compressed, smooth, or a little undulated, and usually marked with grooves or ribs at regular distances apart, indicating the former position of labial appendages. The siphonal area convex, sometimes a little compressed. Septa composed of lobes formed of single parts and of saddles, often in pairs. 'The siphonal lobe shorter' than the superior lateral. The last auxiliary lobes often directed obliquely backwards towards the umbilicus. The saddles very much divided and never 
foliated. The Ligati are all Cretaceous forms, and Haploceras ligatum, d'Orb. (fig. 84), from the Neocomian, is a typical species.

18th Section. Plandlati, von Buch. See p. 189

19th Section. Coronarit, von Buch. See p. 190.

20th Section. Macrocephali, von Bucl. See p. 190.

21st Section. Fimbriatr, d'Orbigny. Shlell discoidal ; formed of cylindrical whorls ; often contiguous and without involution; smooth, or ornamented transversely at regular distances apart, with prominent ribs or grooves, which are the remains of a portion of the mouth appendages of the species. Mouth circular. Septa symmetrical, formed of lobes and saddles divided in part into pairs, always enlarged at their extremity and narrow at the base; siphonal lobe often the longest. Aegoceras fimbriatum, Sow. (fig, 85), of the Middle. Lias, is a good type of this group. The Finbriati are found in the Jurassic rocks and Lower Cretaceous strata.

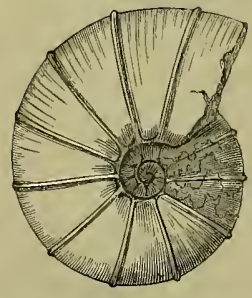

FIG. 84.-Haploceras ligatum, d’Orb.
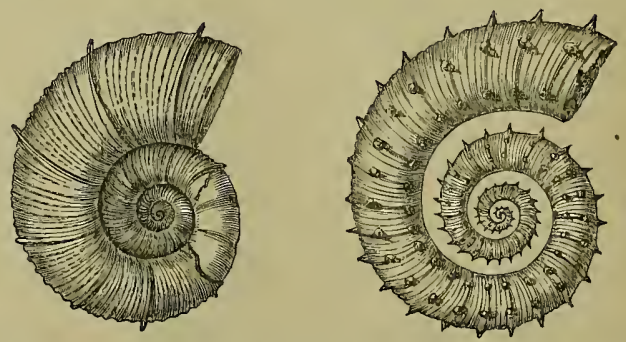

FIG. 55.-Aegoceras fimbriatum, Sow.

FIG. 86.-Crioceras Emerici, Léveillé.

h. Species with ramified septa; whorls coiled spirally on the same plane, not contiguous.

Genus Crioceras, Léveillé. Animal unknown. Shell discoidal, rolled on the same plane, whorls round or oval, and not contiguous. Septa transverse, divided regularly into six lobes, mostly formed of single parts, the siphonal lobe excepted, and the saddles formed of parts nearly always in pairs. The superior lateral lobe is longer than the siphonal lobe. The lobes and the saddles are narrow at the base and much enlarged at their extremity. Siphuncle continuous, always marginal. Two thirds of the last whorl formed the dwelling chamber of the animal. Found in the lower strata of the Cretaceous formation. Crioceras Emerici (fig. 86) is a typical form.

Genus Scaphites, Parkinson. Shell spiral, rolled on the same plane; whorls at 
first contiguous, then separated from the others and projected in nearly a straight line, afterwards bent upwards and forwards, forming a horse-shoe curve. Septa transverse, symmetrical, divided regularly into unequal lobes. The recurved portion always without

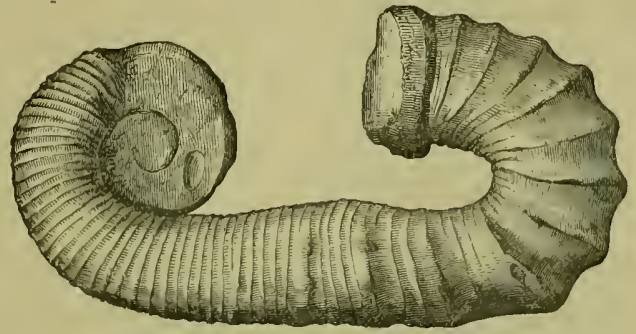

FIG. 87.-Scaphiles gigas, Sowerby.

septa, formed the dwelling chamber of the animal. Siphuncle continuous and marginal. Mouth oval, provided with large protuberent bands, more or less prominent. All the species are obtained from the Cretaceous formation, and very large forms are obtained from the Neocomian strata. Scaplites gigas, Sow. (fig. 87), and Scaplutes Ivanii, Puzos. (fig. 88), are typical forms of this group.

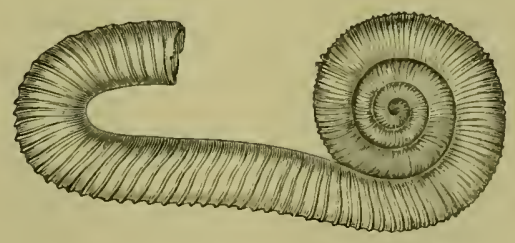

Fif. 88.-Scaphites Ivanï, Puzo8.

Genus Ancyioceras, d'Orbigny. Shell spiral, rolled on the same plane, with very few whorls perfect, and not contiguous; the last separated from the others and projected

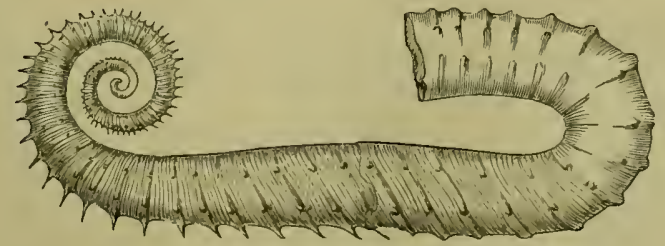

Fig. 89.-Ancyloceras Matheronianum, d'Orb.

outwards in a horizontal line, then turned upwards and inwards, forming an arch opposed to the turns of the spine, the recurved portion without septa formed the dwelling chamber. 
Septa symmetrical, divided into unequal lobes. Mouth round or oval, and provided with tubercles at the circumference. Siphuncle marginal. This genus ranges from the Inferior Oolite to the upper strata of the Chalk, and Ancyloceras Matheronianum, d'Orb. (fig. 89), from the Upper Neocomian, and Ancyloceras Puzosianum, d'Orb. (fig. 90), from the lower Neocomian, are typical of the genus.

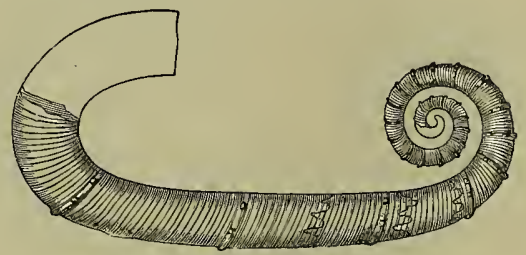

Fig. 90.-Ancyloceras Puzosianum, d'Orb.

i. Species only arched.

Genus Toxoceras, d'Orbigny. Shell conical, subcylindrical or compressed, symmetrical, much elongated, and more or less arched, but never forming a spire. Septa transverse, deep, sinuous, and presenting six unequal lobes, foliaceous on their border. Siphuncle marginal. Mouth oval, compressed or round, prominent at the inner border. The species belong to the Jurassic and Cretaceous formations. Toxoceras Honnoratianum, d'Orb. (fig. 91), is typical of the group.

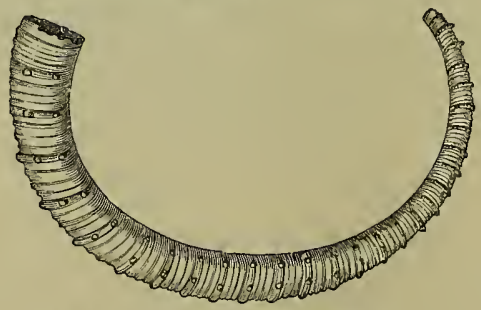

Fig. 91.-Toxoceras Honnoratianum, d'Orb.

Genus, Hamites, Parkinson. Shell conical, symmetrical, bent upon one plane, spire irregular, very elliptical, formed of bends at the two extremities of the ellipse,

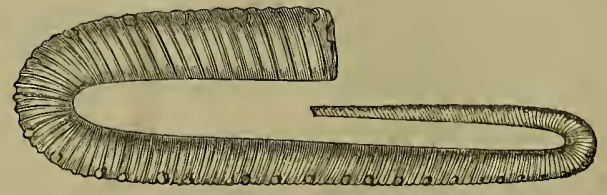

FIG. 92.-Hamites elegans, d'Orb. 
and more or less straight in the interval. The bends few and never in contact. Septa transverse, divided regularly into six unequal lobes. Siphuncle marginal. Mouth round or oval, with or without processes or oval bands. All are Cretaceons forms, of which Hamites elegans, d'Orbigny (fig. 92), is a good type from the Gault.

\section{k. Species straight.}

Genus BAculites, Lamarck. Shell straight, conical, cylindrical or compressed, with parietes articulated by sinuous sutures. Septa approximate, perforate, and much fringed

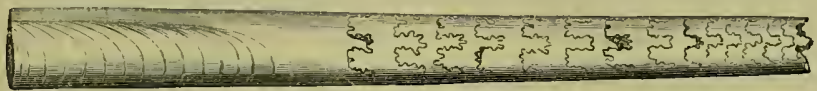

Fic. 93.-Baculites anceps, Lamarck.

near the circumference. The last dwelling chamber is very large, and formed a long sheath. Siphuncle marginal. These straight Ammonites are found from the Neocomian formation to the Upper Cretaceous. Baculites anceps, Lamarck (fig. 93), is a type.

\section{l. Species with shell spiral and turreted.}

Genus Turril.rTes, Lamarck. Shell spiral, turreted; whorls contiguous, and exposed, with articulated walls formed by sinuous sutures (fig. 94). Spire dextral or sinistral, umbilicated thronghout. Septa transverse, divided into six lobes, foliated at their margin. Mouth round. Siphuncle marginal, continuous. The TurriLires are true Cretaceous forms. Some species from the Lias were referred by d'Orbigny to this genus. These, however, have been proved to be only distorted species of Ammonites well known in the beds in which they are found. Type, Turrilites catenatus, d'Orb. (fig. 94).
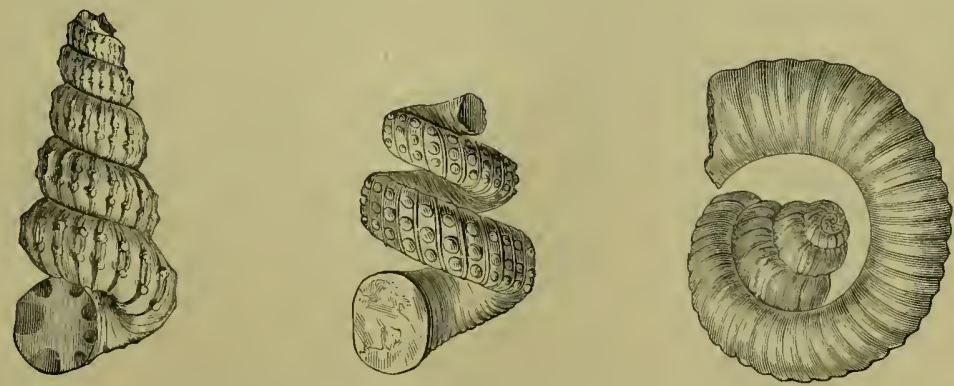

FıG. 91.-Turrilites catenatus, d’Orb. FIG. 95.-Helicoceras Robertianum, d’Orb. FIG. 96.-Hetoroceras Emerici, d“Orb. 
Genus Helicoceras, d'Orbigny. Shell turbinoid, spiral, composed of a few whorls obliquely coiled and rather widely separated." Spire dextral or sinistral, and elevated above the plane of the last large whorl, which was the dwelling chamber of the animal. Septa.transverse, oblique, and deeply sinuous. Siphuncle marginal. Helicoceras Robertianus, d'Orb. (fig. 95), forms the type. The species are found in the Jurassic and Cretaceons rocks.

Genus Heteroceras, d' Orbigny. Shell spiral, turreted, whorls contignous in youth ; with age, the last whorl separates from the others and becomes produced and recurved, forming an arch without septa, and which doubtless constituted the dwelling chamber of the animal. Heteroceras is a Turrilite with the dwelling chamber in the adult shell detached, produced, and recurved. The most typical specimen is Heteroceras Emerici, d’Orb. (fig. 96).

Genus Anisoceras, Pictet. Turns of the shell at first spiral not in the same plane, next tangentially divergent, and finally recurved, none of the turns in contact. Found in Oolitic and Cretaceous formations.

Professor Pictet, ${ }^{1}$ in his excellent 'Traité Élémentaire de Paléontologie,' gave a copious résumé of the Cephalopoda, in which he closely adhered to the system of Von Buch and d'Orbigny.

Professor H. B. Geinitz, in his 'Grundriss der Versteinerungen Kunde,' followed out the same method.

Dr. C. G. Giebel, ${ }^{3}$ in his 'Fauna der Vorwelt,' gave a valuable synopsis of the Fossil Cephalopoda, and brought together a great quantity of material bearing upon this subject, in the arrangement of which he followed the methods of von Buch and d'Orbigny.

The late Mr. Daniel Sharpe, F.R.S., ${ }^{4}$ contributed an unfinished monograph on the British Cretaceous Nautili and Ammonites to the volumes of the Palæontographical Society in 1853, 1857. In this important work its learned author followed the lines laid down by d'Orbigny in the systematic arrangement of the groups, and illustrated his work with well-executed plates.

The Jurassic geology of the north-eastern Alps received an important illustration from the researches of Franz Ritter von Hauer, ${ }^{6}$ whose exhanstive monograph, illustrated with beautiful plates, 'Die Cephalopoden aus dem Lias der Nordöstlichen Alpen,' marked an epoch in our knowledge of the Liassic groups of that region. In this important work the learned author followed the grouping of von Buch.

1 .Traité élémentaire de Paléontologie,' tom. ii, p. 309, pl. xị -xx, 1845.

2 'Grundriss der Versteinerungens Kunde,' pp. 256-315, pl. $x$-xii, 1846.

3 'Fauna der Vorweit Cephalopoden,' Band iii, 1852.

4 'Cretaceous Ammonites, 'Palæontogr. Soc., vols. for years 1853 and 1855.

5 'Ueber die Cephalopoden aus dem Lias der Nordöstlichen Alpen,' 1856. 
Dr. Oppel, in his ' Juraformation," and in his later and larger work on the Ammonites of the Malm formation of Germany, and the Jurassic formations of India, delineated in "Palaeontologische Mittheilungen," adhered to the classification of von Buch.

Between 1863 and 1870 the late lamented Prof. Phillips, of Oxford, contributed five parts of his unfortunately unfinished Monograph on another important group of the Fossil Cephalopoda, viz. the Belennites, in the volnmes of the Palæontographical Society, issued for the years $1863,1864,1866,1868$, and 1869 .

My old esteemed friend, the learned Secretary of the Palæontographical Society, the Rev. Thos. Wiltshire, M.A., F.G.S., in 1867 contributed a valuable memoir on the chief groups of the Cephalopoda to the Geologists' Association, ${ }^{3}$ and in an Appendix to this work added an Analysis of the Families and Genera of the Fossil Cephalopoda, with their range in time. This résumé of a very difficult subject has been so carefully prepared by its author that I shall, with permission, insert it in extenso (at pages 204 to 218), as it clearly exhibits the actual state of the systematic classification of the Cephalopoda at the date of its publication, and before changes in several of the groups composing the different sections of these remarkable fossils had been rendered inevitable by subsequent discoveries.

1 'Die Juraformation Englands, Frankreichs, and S.-W. Dentschlands,' 1859.

2. 'Palaeontologisclue Mittheilungen,' vols. i, ii, 1862-63.

3 Geologists' Association, 'Chief Groups of the Cephalopoda,' 1869. 


\section{ANALYSIS OF THE FAMILIES AND GENERA OF THE FOSSIL CEPHALOPODA. ${ }^{1}$}

First Order.-Dibranchiata, containing Section I. Octopoda, and Section II. Decapoda.

Section $1 .-$-Octopoda.

I.-Shell involute, the turns in the same plane, thin, one chambered. Family, Argonautidæ (Reeve, 1841). One fossil genus, Argonauta.

1. Argonauta, Linné, 1758.

Tertiary.

Section II.-Decapoda.

II.-Shell Jance-shape, slender, with central ridge, generally terminating in a slight expansion of no great length without air chambers. Family, ONYснотеUтнide (Gray, 1847). Three fossil genera, Enoploteuthis, Plesioteuthis, and Ommastrephes.

2. Enoplotedthis, D’Orbigny, 1840.

Sides sinuous, with lateral expansions; central ridge keeled; Oolitic.

3. Plesiotedthis, Wagner, 1860.

Sides sinuous, with central and two side ridges; projection arrow-shaped; arms with hooks ; Liassic.

\section{Ommastrephes, D’Orbigny, 1840.}

Sides generally straight, contracted towards base, point expanded, central and side ridges; Oolitic.

1 Drawn up by the Rev. T. Wiltshire, M.A., F.G.S., in 1867, see page 203. 
III.-Shell lance-shape, slender, with central keeled ridge, and side expansions of some length. Family, Gonatide. One fossil genus, Loligo.

5. Loiıgo, Lamarck, 1799.

Liassic.

IV.--Shell lance-shape, subovate, with central ridge, and side expansions of some length. Family, Beloteutride. Five fossil genera, Teudopsis, Phylloteuthis, Beloteuthis, Geoteuthis, and Leptoteuthis.

6. Teudopsis, Deslongchamps, 1835.

Narrow at top, enlarged below, with a concavity at base, and narrow central rib; Liassic into Oolite.

7. Phyllotedthis, Meek and Hayden, 1858.

Narrow at top, enlarged below, with slight concavity at base, where the lateral margins are obtusely angular; Cretaceous.

\section{Beloteuthis, Münster, 1843.}

Pointed at top and bottom, lateral expansions forming a sudden angle on the sides towards the lower half of total lengtl; Liassic.

9. Geoteuthis, Münster, 1843. = Belemnosepia, Agassiz, 1835. = Loliyosepia, Quenstedt, 1839. = Coccoteuthis (pars), Owell, 1855.

Wide at top, pointed at base, side expansions forming a sudden angle on the sides towards the upper half of total length; Liassic.

\section{Leptoteuthis, von Meyer, 1834.}

Wide and rounded at top, pointed at base, lateral expansions gradually angular, ribs slight and diverging; Oolitic.

V.-Shell ovate, thick, with thin lateral projections, inclined to the sides, terminating in a projecting point imperfectly chambered. Family, Stpiade (Owen, 1836). One fossil genus, Sepia.

11. SePis, Linné, 1735. = Belosepia, Voltz, 1830. = Sepiolithes, Münster, 
1843. = Trachyteuthis, Meyer, 1846. = Coccoteuthis, Owen, 1855. = Palæoteuthis, Roemer, 1856.

Oolitic and Tertiary.

VI.-Shell conical, slightly bent, having at its upper part a cavity containing chambers with a siphuncle. Family, Betemnoside. Four fossil genera, Belemnosis, Beloptera, Helicerus, and Spirulirostra.

12. Betemosis, Edwards, 1849.

Shell conical, and suddenly bent at a short distance from the base, no side expansions; Tertiary.

\section{Beloptera, Deshayes, 1830.}

Shell conical, and slightly bent, side expansions at the angle; Tertiary.

14. Helicerus, Dana, 1849.

Shell conical, the chambers at the upper part, slender and terminating in a spiral arrangement ; Liassic?

\section{Spirdlirostra, d'Orbigny, 1842.}

Shell conical, the chambers at the upper part, of some size and terninating in a spiral arrangement, the portion covering the commencement of the spiral projected forwards, the extremity pointed; Tertiary.

VII.-Shell straight, with a series of conical chambers at its upper portion. Family, BeLemnitide (Owen, 1836). Five fossil genera, Belemnites, Belemnitella, Belemnoteuthis, Conoteuthis, and Xiphoteuthis.

16. Belemnites, Lister, 1678. = Belemnitis lapis, Agricola, 1546. = Belemnitis, Gesner, 1565. = Acamas, Montfort, ]808. = Hibolithes, Montfort, 1808. $=$ Thalamus (= alveolus, \&c.), 1808. = Actinocamax, Miller, 1823. = Pseudobelus, Blainville, 1827. = Belemnosepia, Buckland, 1836. = Belopeltis, Voltz, 1840 (a proostracum). = Notosiphites, Duval-Jouve, 1841. = Gasterosiphites, Duval-Jouve, 1841.

Shell (guard) straight, generally long, somewhat cylindrical, conical below, with a hollow cone (alveolus) in the upper part, containing a chambered cone (phragmacone), 
which has a marginal canal (siphuncle); the thin, shelly covering (conotheca) investing the chambers, prolonged on one side into a broad lobe (pro-ostracum, pen); animal not clearly known, double rows of hooks on the arms; from Liassic into Cretaceous formations.

\section{Belemini'ella, d'Orbigny, 1840.}

Shell (guard) in its highest part, marked by a short longitudinal slit; Cretaceous.

18. Belemnoteuthis, Pearce, 1842. = Kelæno, Münster, 1836. = Acanthoteuthis, Münster, 1S39. = Plesioteuthis, Wagner, 1860.

Shell cousisting of a chambered cone, having at its upper part a horny pen with thin side bands, and at its lowest part a thin fibrous guard, with two diverging ridges; animal with arms and horny looks, fins large; Oolitic.

\section{Conoteuthis, d'Orbigry, 1840.}

Chambered cone slightly curved, pen elongated and very narrow; Cretaceous.

\section{Xiphoteuthis, Huxley, 1864.}

Shell cylindrical ; chambered cone long and narrow; pen very long and slender, section an ellipse; Liassic.

\section{Second Order.-T'TeTRABRANCHIATA.}

VIII.-Shell many chambered; the last (exterior) chamber large, siphuncle generally subcentral; the edges of the partitions (septa) which separate the cliambers either without folds, or slightly undulating. Family, NaUtulide. Thirty fossil genera: Nautilus, Discoceras, Ophidioceras, Gyroceras, Cyrtoceras, Cyriocerina, Oncoceras, Streptoceras, Piloceras, Lituites, Lituunculus, Orthoceras, Tretoceras, Huronia, Actinoceras, Ormoceras, Aulacoceras, Endoceras, Cameroceras, Trochoceras, Hercoceras, Gomphoceras, Phragmoceras, Ascoceras, Glossoceras, Aphragmites, Aturia, Nothoceras, Bathmoceras, and Gonioceras.

\section{Division A.-Edges of sepla without folds.}

1. Shell spiral, in the same plane.

21. Nautruus, Belon, 1553. = Nautilus, Breynius, 1732. = Planorbites, 
Lamarck, 1799. = Angulithes, Montfort, 1808. = Oceanus, Montfort, 1808. $=$ Ammonites (pars), Montfort, 1808. = Bisiphites (pars), Montfort, 1808. = Conchyliolithus, Martin, 1809. = Ammonellipsites, Parkinson, 1811. E Ellipsolithes (pars), Sowerby, 1812. = Rhabdites, de Haan, 1825. = Omphalia, de Haan, 1825. = Globites, de Haan, 1825. = Aganides (pars), d'Orbigny, 1826. = Aganites (pars), Quenstedt, 1834. = Aturia (pars), Bronn, 1835. = Hamites (pars), Fischer, 1837. = Trocholites (pars), Conrad, 1838. = Simplegas (pars), Sowerby, 1842. = Discites (pars), M'Coy, 1844. = Discus (pars), King, 1844. $=$ Cryptoceras (pars), d'Orbigny, 1850. = Trematodiscus (pars), Meek, 1861.

Turns (whorls) of the shell, in contact, partially overlapping; siphuncle almost central; aperture of exterior chamber open without folds; Silurian into Tertiary, still living.

Rнyснолітнеs, Faure-Biguet, 1819. = Conchorhynchus, De Blainville, 1827. $=$ Rhynchoteuthis, d'Orbigny, 1847.

Comprising the beaks of the Nautilus animal.

22. Discoceras, Barrande, 1867.

Turns of the shell touching, siphuncle variable; aperture of exterior chamber open, its edge not contracted; Silurian.

23. Ophinjoceras, Barrande, 1867.

Turns of the shell touching; siphuncle variable; aperture of exterior chamber contracted; Silurian.

24. Gyroceras, de Koninck, 1844. = Gyroceratites, H. von Meyer, 1829. $=$ Hortolus, Steininger, 1831. = Spirula, Goldfuss, 1832. = Lituites, Quenstedt, 1834. = Cyrtocera (pars), Münster, 1839. = Cyrtoceras (pars), Phillips, 184.1. $=$ Cyrthoceratites (pars), D'Archiac, 1842.

Turns of the shell not in contact; siphuncle marginal on external (convex) side; last chamber somewhat small, edge without fold; from Silurian into Carboniferous.

2. Shell an arc of a spiral, in the same plane.

25. Cyrtoceras, Goldfuss, 1832. = Orthoceratites, Lamarck, 1799. = Orthocera (pars), Sowerby, 1812. = Campulites, Deshayes, 1832. = Lituites (pars), Quenstedt, $1836 .=$ Cyrtoceratites, d'Archiac, 1842. = Trigonoceras, M'Coy, 1844. $=$ Campyloceras, M'Coy, I844. = Aploceras, d'Orbigny, 1850. 
Shell slightly curved, never forming a complete revolution; siphuncle variable in position, generally on convex side; exterior chamber open, its edge not contracted; from Silurian into Devonian.

\section{Cyrtocerina, Billings, 1866.}

Shell like Cyrtoceras, but shorter and thicker; Silurian.

27. Oncoceras, Hall, 1847.

Shell slightly curved, pear-shaped; siphuncle lateral, edge of exterior chamber contracted in the middle; Silurian.

\section{Streptoceras, Billings, 1866.}

Shell slightly curved, pear-shaped, edge of exterior chamber contracted to form three lobes; Silurian.

\section{Pitoceras, Salter, 1859.}

Same as Cyrtoceras, but the septa forming a series of conical partitions, pointing towards the smaller (earliest) part of the shell; Silurian.

3. Shell a combination of curved and straight lines in the same plane.

30. Liruires, Breynius, 1732. = Hortolus, Montfort, 1808. = Spirulites, Parkinson, 1811. = Clymenia (pars), d'Eichwald, 1842. = Ancistroceras (pars), Boll, 1857 .

Turns of the shell at first generally in contact, afterwards tangentially divergent; siphuncle variable; edge of exterior chamber contracted; Silurian.

\section{0a. Lituenculus, Barrande, 1867.}

Same as Lituites, but with the edge of the exterior chamber not contracted, the form ideal, not yet discovered in rocks; Silurian ?

\section{Shell straight.}

31. Orthoceras, Breynius, 1732. = Molossus, Montfort, 1808. = Echidnis, Moutfort, 1808. = Achelois, Montfort, 1808. = Hyolithes, d'Eichwald, 1842. = Koleoceras, Portlock, 1843. = Cycloceras, $\mathbf{M}^{\prime}$ Coy, 1844.

Siphuncle small, almost central, bead-like ; aperture of exterior chamber open, without folds; from Silurian into 'Trias. 


\section{Tretocrras, Salter, 1859.}

Siphuncle small, almost central, bead-like; the chambers surrounding the siphuncle pierced by a longitudinal tube; Silurian.

\section{Huronia, Stokes, 1824.}

Siphuncle large, central, the upper part of each division expanded and connected with a small central tube by radiating plates; Silurian.

\section{Actinoceras, Stokes, 1840.}

Siphuncle large, central, the middle part of each division expanded and connected with a small central tube by radiating plates; Silurian into Carboniferous.

\section{Ormoceras, Stokes, 1840.}

Siphuncle large, almost central, bead-like, the middle of each division contracted; Silurian into Devonian.

\section{Aulacoceras, Hauer, 1860.}

Siphuncle small, lateral, plain; shell externally corrugated, thickening towards the base. Trias.

\section{Endoceras, Hall, 1847.}

Siphuncle large, lateral, with cone-like partitions inserted in each other, their points being directed towards the small or earliest portion of the shell ; Silurian.

38. Cameroceras, Conrad, 1847. = Melia, Fischer, 1829. = Thoracoceras, Fischer, 1844.

Siphuncle sometimes large, lateral, not complex; Silurian into Trias.

5. Shell spiral, not in the same plane.

39. Trochoceras, Barrande, 1847. = Semicornu, Klein, 1770. = Inachus, Hisinger, 1837.

Turns of the shell at first in contact, not overlapping, afterwards generally spirally divergent, occasionally tangentially divergent; siphuncle mostly near the margin on the outer (convex) side, edge of exterior chamber without fold; Silurian. 
40. Hercoceras, Barrande, 1865.

Turns of the shell at first in contact, slightly overlapping, afterwards spirally divergent; siphuncle marginal on outer side, edge of exterior chamber contracted and compressed transversely ; Silurian.

6. Shell neither spiral nor linear.

41. Gomphoceras, Sowerby, 1839. = Orthoceras (pars), Sowerby, 1812. = Conilites, Pusch, 1837. = Nelimenia, Castelnau, 1843. = Bolboceras, Fischer, 1844. $=$ Apioceras, Fischer, 1844. = Poterioceras, M'Coy, 1S44. = Lituites (purs), Quenstedt, 1846. = Syncoceras (pars), Pictet, 1854.

Shell straight, pear-shaped; aperture of exterior chamber contracted, small and lobed, the exterior chamber somewhat globular; position of siphuncle variable; from Silurian into Carboniferous.

42. Phragmoceras, Broderip, 1839. = Campulites (pars), Deshayes, 1830.

$$
=\text { Orthoceratites, Steininger, } 1831 .
$$

Shell slightly curved, pear-shaped; aperture of exterior chamber contracted, small and lobed; siphuncle generally on the internal (concave) side; from Silurian into Devonian.

43. Ascoceras, Barrande, 1846. = Cryptoceras, Barrande, 1846.

Shell slightly curved, flask-shaped, lower portion more globular than the upper; partitions of the chambers few and running parallel to the long axis of the shell, leaving a space the whole length of the shell for the body of the creature; aperture of exterior chamber not lobed; Silurian.

44. Glossoceras, Barrande, 1867.

Shell same as in Ascoceras, but with the aperture of the exterior chamber lobed; Silurian.

\section{Aphragmites, Barrande, 1867.}

Shell same in general form as Ascoceras, but without several internal partitions; aperture not lobed; Silurian. 


\section{Division B.-Edges of septa with a single marked fold.}

1. Shell spiral in the same plane.

46. Aturia, Bronn, 1836.

The turns of the shell in contact overlapping; siphuncle almost marginal, on concave (inner) edge, and formed of a series of inserted cone-shaped partitions; edges of the partitions separating the chamber with a strong lateral lobe. Cretaceous into Tertiary.

47. Nотносеras, Barrande, 1856.

Turns of the shell slightly overlapping, siphuncle marginal, on convex (outer) side, and furnished with internal radiating plates; septa with a slight lobe on the back of the shell, corresponding in direction to that of the Ammonites; aperture not lobed; Silurian.

\section{Shell straight.}

48. Bathmoceras, Barrande, 1867.

Siphuncle marginal, containing a series of inserted cone-like partitions, whose points are directed towards the final chamber, being the reverse of that observed in Endoceras. Septa incomplete towards the final chamber, and with a slight lobe, planned as in Nothoceras; aperture not lobed; Silurian.

49. Gonioceras, Hall, 1847.

Siphuncle marginal. Septa waved, shell compressed into an elliptic form; Silurian.

IX.-Shell many chambered; the last (exterior) chamber large; siphuncle marginal; the edges of the partitions (septa), which separate the cliambers, angulated or

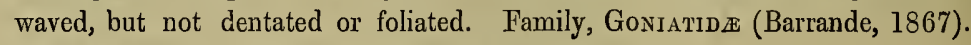
Three Genera: Goniatites, Clymenia, and Bactrites.

1. Shell spiral in the same plane.

50. Goniatites, de Haan, 1825. = Nautilus, Lamarck, 1799. = Orbulites, Lamarck, 1801. = Aganides, Montfort, 1808. = Nautellipsites, Parkinson, 1811. $=$ Ellipsolithes (pars), Sowerby, 1812 . 
The turns of the shell in contact, overlapping; siphuncle near the outer (convex) side; edges of the partitions separating the chambers much waved, but not having at their base small, convex, tooth-like projections; from Silurian into Trias.

51. Clymenia, Münster, 1832. = Endosiphonites, Ansted, 1835. = Subclymenia,

The turns of the shell in contact, overlapping; siphuncle near the inner (concave) side; edges of partitions waved with slight angular depressions. ('l'his genus has affinities with Aturia, but the turns of the shell are more overlapping in the latter, and the siphuncle is larger). Devonian into Carboniferous.

2. Shell straight.

52. Bactritus, Sandberger, 1842. = Stenoceras, d'Orbigny, $1850 .=$ Trematoceras, d'Eichwald, 185 l.

Siphuncle marginal; septa gently waved, a single augular depression (lobe); external chamber not known; from Silurian into Devonian.

X.-Shell many chambered; the last (exterior) chamber large ; siphuncle unarginal ; the edges of the partitions (septa), which separate the chambers, nany-waved, with single circular or subcircular depressions at their base. Family, Clrdonirida. Four genera: Clydonites, Choristoceras, Rhabdoceras, and Cochloceras.

1. Shell spiral, the turns touching. in the same plane.

53. Clydonites, Hauer, 1860.

Triassic and Cretaceous.

2. Shell spiral, the turns not touching, in the same plane.

54. Choristoceras, Hauer, 1865.

Triassic.

3. Shell straight.

55. Rhabdoceras, Hauer, 1860.

Triassic.

4. Shell spiral, the turns touching, not in the same plane.

56. Сochloceras, Hauer, 1860.

Triassic. 
XI.-Shell many chambered; the last (exterior) chamber large; siphuncle marginal (dorsal); the edges of the partitions (septa), which separate the chambers, waved, with many small circular elevations (crenulations) at the base of each wave. Ceratitide. Two genera: Ceratites and Baculina.

1. Shell spiral, the turns touching, in the same plane.

57. Ceratites, de Haan, 1825.

From Triassic into Cretaceons.

2. Shell straight.

58. Bacclina, d'Orbigny, 1850.

Cretaceous.

XII.-Shell many chambered; the last (exterior) chamber large; siphuncle marginal (dorsal); the edges of the partitions (septa), which separate the chambers, foliaceous. Ammonimide (Owen, 1836). Thirteen genera: Ammonites, Crioceras, Toxoceras, Scaphites, Ancyloceras, Ptychoceras, Hamites, Hamulina, Baculites, Turrilites, Helicoceras, Heteroceras, and Anisoceras.

1. Shell spiral, in the same plane.

59. Ammonites, Bruguière, 1789. = Ammonis cornu, Auctorum. = Planorbites, Lamarck, 1799. = Planulites, Lamarck, 1801. = Amaltheus, Montfort, 1808. $=$ Orbulites, Montfort, 1808. = Globites, de Haan, 1825. = Planites, de Haan, 1825 .

Turns of the shell in contact, overlapping; siphuncle on the exterior side; Triassic into Cretaceous.

Aptrchus, H. von Meyer, 1831. = Trigonellites, Parkinson, 1811. = Tellinites, Schlotheim, 1820. = Münsteria, Deslongchamps, 1835. = Ichthyosiagones, Bourdet, 1822.

Opercula, or doors, closing the external opening of the Ammonite shell.

$$
\text { Peltarion, Deslongschamps, } 1859 .
$$

Circular, or somewhat oval calcareous plates, with an undulating margin, supposed to be connected with the mandibles of the Ammonite animal; Lias into Oolite. 
2. Shell spiral, turns of the shell not in contact, in the same plane.

60. Crioceras, d’Orbigny, 1840. = Crioceratites, Leveillé, 1S37. = Tropæum, Sowerby, 1840.

Cretaceous.

3. Shell an arc of a spiral, in the same plane.

61. Toxoceras, d'Orbigny, 1840.

From Oolitic into Cretaceous.

4. Shell changing from a spiral, in the same plane.

62. Scafhites, Parkinson, 1811.

Turns of the shell at first spiral, in contact, and overlapping, afterwards tangentially divergent; finally recurved and not in contact; Cretaceous.

63. Ancyloceras, d'Orbigny, 1840.

Turns of the shell at first spiral, not in contact, afterwards tangentially divergent; finally recurved, and not in contact; from Oolitic into Cretaceous formations.

5. Shell forming straight and curved lines, in the same plane.

64. Ptychoceras, d'Orbigny, 1840. = Ptychocerus, King, 1844.

The shell at first straight, afterwards curved, and next straight, the turns in contact ; Cretaceous.

65. Hamites, Parkinson, 1811. = Baculita, Fleming, 1828. = Toxerites, Rafinesque, 1819.

The shell at first straight, afterwards curver, and next twice repeating the process; the arrangement forming a species of compressed spiral; the turns not in contact; Cretaceous.

66. Hamulina, d'Orbigny, 1850.

The shell at first straight, afterwards curved, next straight; the turns not in contact; Cretaceous.

6. Shell forming a straight line.

67. Baculites, Lamarck, 1801. = Homaloceratites, Hüpsch, 1781. = 'Tiranites, Montfort, 1803.

The shell slightly conical; Cretaceous. 
7. Shell spiral, not in the same plane.

68. Turrilites, Lamarck, 1801. = Turrites, de Haan, 1825. = Turrilithes, Bronn, 1832.

Turns of the shell spiral, in contact; Oolitic into Cretaceous.

69. Helicoceras, d'Orbigny, 1840. = Helicocerus, King, 1844.

Turns of the shell spiral, not in contact; Oolitic into Cretaceous.

8. Shell forming straight and curved lines, not in the same plane.

70. Heteroceras, d'Orbigny, 180 o.

Turns of the shell at first spiral and in contact, not in the same plane, afterwards tangentially divergent, finally recurved and not in contact, and produced at a different angle to that of the spiral; Cretaceous.

\section{Anisoceras, Pictet, 1854.}

Turns of the shell at first spiral, not in the same plane, next tangentially divergent, and finally recurved, none of the turns in contact; Oolitic into Cretaceous. 


\section{RANGE OF THE GENERA OF THE FOSSIL CEPHALOPODA IN GEOLOGICAL TIME. ${ }^{1}$}

Dratw up be the Rev. T. Wiltshire, M.A., F.G.S., in 1S67. See page 203.

\begin{tabular}{|c|c|c|c|c|c|c|c|c|}
\hline • & 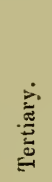 & 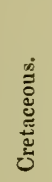 & 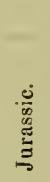 & 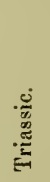 & 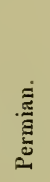 & 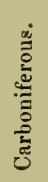 & 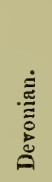 & 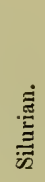 \\
\hline $\begin{array}{l}\text { 1. Argonauta . } \\
\text { 2. Enoplotenthis } \\
\text { 3. Plesioteuthis } \\
\text { 4. Ommastrephes } \\
\text { 5. Ioligo . } \\
\text { 6. Teudlopsis . } \\
\text { 7. Phyllotenthis } \\
\text { 8. Beloteuthis . } \\
\text { 9. Geoteuthis . } \\
\text { 10. Leptoteuthis } \\
\text { 11. Sepia . } \\
\text { 12. Belemnosis . } \\
\text { 13. Beloptera . } \\
\text { 14. Heliceras . } \\
\text { 15. Spirulirostra } \\
\text { 16. Belemnites . } \\
\text { 17. Belemnitella } \\
\text { 18. Belemnotenthis } \\
\text { 19. Conoteuthis } \\
\text { 20. Xiphotenthis } \\
\text { 21. Nautilus . } \\
\text { 22. Discoceras . } \\
\text { 23. Ophidioceras } \\
\text { 24. Gyroceras . } \\
\text { 25. Cyrtoceras . } \\
\text { 26. Cyrtocerina } \\
\text { 27. Oncoceras . } \\
\text { 28. Streptoceras } \\
\text { 29. Piloceras . } \\
\text { 30. Lituites }\end{array}$ & 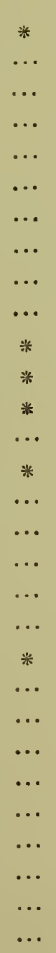 & 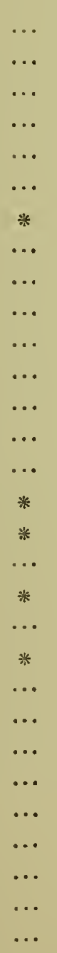 & 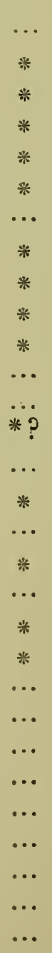 & $\begin{array}{c}\cdots \\
\ldots \\
\ldots \\
\ldots \\
\ldots \\
\ldots \\
\ldots \\
\ldots \\
\ldots \\
\ldots \\
\ldots \\
\ldots \\
\ldots \\
\ldots \\
\ldots \\
\ldots \\
\ldots \\
\ldots \\
\ldots \\
\ldots \\
* \\
\ldots \\
\ldots \\
\ldots \\
\ldots \\
\ldots \\
\ldots \\
\ldots \\
\ldots \\
\\
\ldots \\
\\
\ldots \\
\end{array}$ & $\begin{array}{c}\cdots \\
\ldots \\
\ldots \\
\ldots \\
\ldots \\
\ldots \\
\ldots \\
\ldots \\
\ldots \\
\ldots \\
\ldots \\
\ldots \\
\ldots \\
\ldots \\
\ldots \\
\ldots \\
\ldots \\
\ldots \\
\ldots \\
\ldots \\
* \\
\ldots \\
\ldots \\
\ldots \\
\ldots \\
\ldots \\
\ldots \\
\ldots \\
\ldots \\
\ldots \\
\\
\ldots \\
\\
\ldots \\
\end{array}$ & 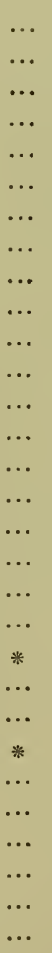 & $\begin{array}{c}\ldots \\
\ldots \\
\ldots \\
\ldots \\
\ldots \\
\ldots \\
\ldots \\
\ldots \\
\ldots \\
\ldots \\
\ldots \\
\ldots \\
\ldots \\
\ldots \\
\ldots \\
\ldots \\
\ldots \\
\ldots \\
\ldots \\
\ldots \\
* \\
\ldots \\
\ldots \\
* \\
* \\
\ldots \\
\ldots \\
\ldots \\
\ldots \\
\ldots\end{array}$ & $\begin{array}{c}\cdots \\
\ldots \\
\ldots \\
\ldots \\
\ldots \\
\ldots \\
\ldots \\
\ldots \\
\ldots \\
\ldots \\
\ldots \\
\ldots \\
\ldots \\
\ldots \\
\ldots \\
\ldots \\
\ldots \\
\ldots \\
\ldots \\
\ldots \\
* \\
* \\
* \\
* \\
* \\
* \\
* \\
* \\
* \\
* \\
* \\
*\end{array}$ \\
\hline
\end{tabular}

1 The stars opposite a genus in one or more of the columns show that the genus existed in the geological period referred to in the column or columns.

2 The Jurassic formation includes the Oolite and the Lias. 


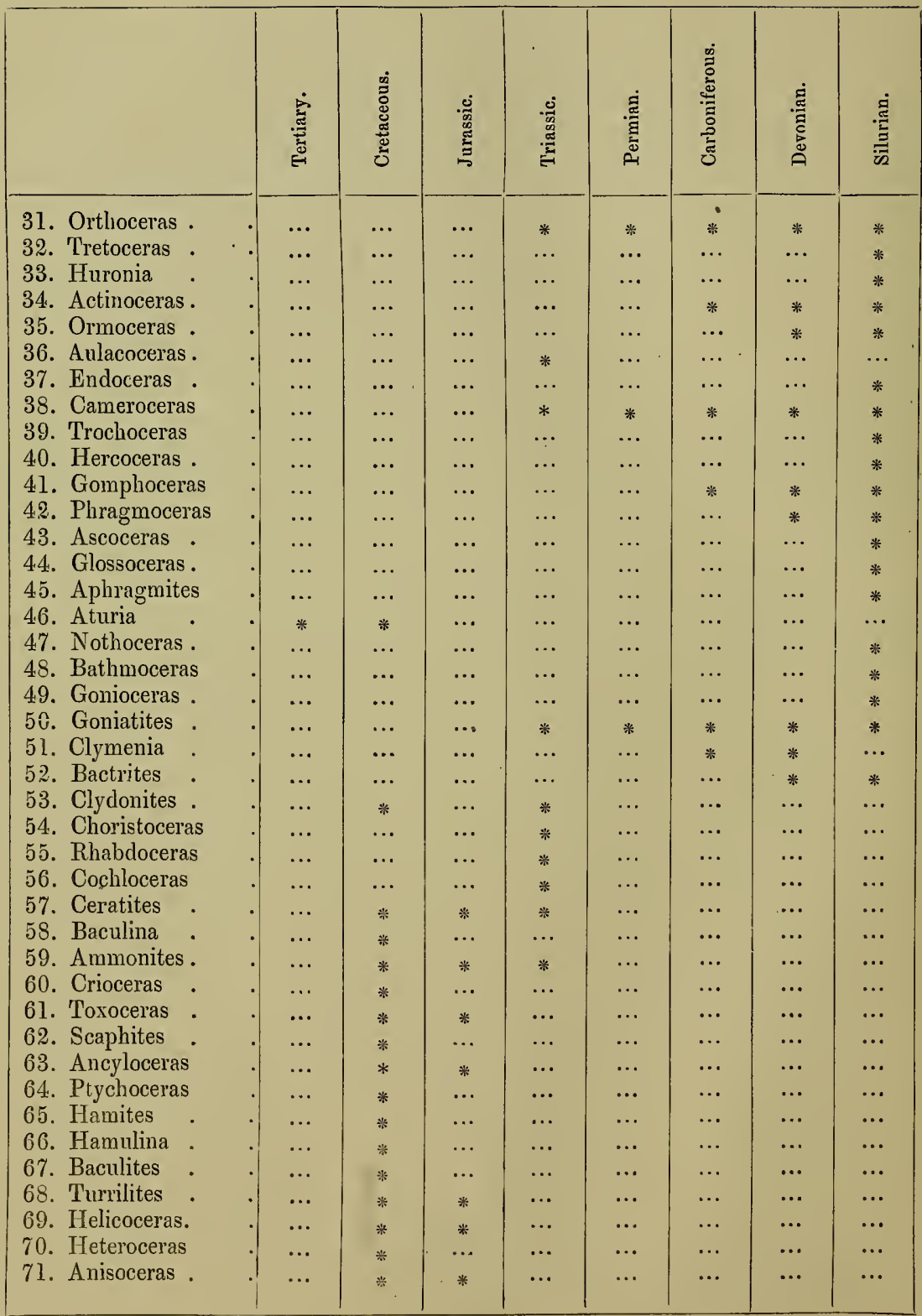




\section{MODERN CLASSIFICATION OF THE AMMONITIDA.}

The essential characters on which Von Buch and d'Orbigny based their Ammonite groups were derived-lst, from the greater or lesser complication in the ramifications of the suture-line, and the character of the lobes and saddles formed therefrom; 2nd, the position and structure of the siphuncle; and, 3rd, the form of the spiral of the shell.

The first, we have already seen, Von Buch considered of primary importance, and on this alone proposed the families, as he called then, in his classical memoir, of which I lave given a résumé. Subsequent observations, however, made by many independent students have taught them that this character, although an important one, is not so stable as the great naturalist believed-a fact which we liave ascertained by noting the changes from simplicity to complexity in the morphology of Goniatites, Ceratites, and Ammonites. In adult life, however, the form of the suture-line is a valuable claracter, and ought to be accurately drawn from careful tracings made on the specimens themselves over the natural lines, and not given as mere sketches by the artist, as is often the case; in tracing the lines we have a natural autograph, by the other mode a mere ideal representation; so that, whenever suture-lines are exposed and can be traced on the specimen, they should be carefully noted and recorded.

In all the Aммолттір the position of the siphuncle is invariably in the centre of the abdomen, and in the outer margin of the greater curvature of the spiral of the shell opposite to the columella or dorsal border. The presence or absence of a keel in which it is sometimes lodged, and the roundness or flatness of the siphonal or abdominal area, all afford specific characters which it is important to note.

The form of the spiral described by the growth of the shell has been taken by Parkinson, Lamarck, d'Orbigny, Hauer, and Léveille as a basis for the establishment of several genera, and from this character alone we have the following sixteen genera :

$$
\begin{aligned}
& \text { Ancyloceras, d'Orb. } \\
& \text { Anisoceras, d'Orb. } \\
& \text { Buculina, d'Orb. } \\
& \text { Buculites, Lam. } \\
& \text { Choristoceras, Hau. } \\
& \text { Cochloceras, Hau. } \\
& \text { Crioceras, Lév. } \\
& \text { Hamites, Park. }
\end{aligned}
$$

Hamulina, d'Orb.

Helicoceras, d'Orb.

Heteroceras, d'Orb.

Ptychoceras, d'Orb.

Rhabdoceras, Hau.

Scaplites, Park.

Toxoceras, d'Orb.

Turrilites, Lam. 
The character derived from the spiral of the shell is only valuable when taken in counection with others, to which it becomes subordinate.

The careful study of the immense collections of Ammonites that have been slowly accumulating during the last twenty-five years from the Triassic, Jurassic, and Cretaceous rocks has disclosed the fact that the earlier Palæontologists established very many of their species on characters derived either from young specimens, or from fragments belonging to different phases of growth of the same species. This cause has helped to explain the hopeless nature of the task which the practical Palæontologist had to encounter some years ago, when he attempted to correlate species found in strata of the same age in different regions of Europe, so that an analysis of the synonyms of many forms discloses the circumstance that the species had been described under different names by the same author, from his having unwittingly studied different stages of growth of the same shell, an error which was only detected many years afterwards, when more perfect specimens of the fossil had been discovered, so that much confusion resulted from premature attempts to generalise when the necessary details were absent. Having often lost my way in this vast labyrinth of "species," and noted that one cause of the difficulty arose from the fragmentary nature of the materials at the disposal of the earlier observers, and likewise from the fact, unknown at the time, that most Ammonites change their form during growth, I felt it imperative on the Palæontologist to examine the morphology of every species in order to place its history on a scientific basis. I have for many years pursued this method in the study of Liassic and Oolitic forms, and learned therefrom the numerous sources of error and perplexity which beset my early studies, and have discovered that many species pass through important changes of structure between youth, maturity, and old age, the amount of change varying considerably in the different generic groups, and that this character should form an important element in their diagnosis. ${ }^{1}$

After Leopold von Buch, the first great reform in the classification of the Ammonimid was made by my learned and esteemed friend Professor Edward Suess, of Vienna, who, in a memoir," 'Ueber Ammoniten,' communicated to the Vienna Academy, pointed out some important characters in the structure of the Ammonite shell which had been overlooked or underestimated by former observers, such as the form of the aperture and the structure of the central and lateral processes, which were often developed from its margin; and, secondly, the size of the body-chamber, considered in relation to the length of the last whorl. The study of these characters of course necessitated the discovery and study of perfect specimens, and the whole anatomy of the shell received more attention from him than it had done in the hands of his predecessors. By an application of the facts obtained therefrom Suess established three new genera, Arcestes, Lytoceras, and Pliylloceras on a very solid foundation. Five years later he extended his studies on the spiral

I “On the Development of Ammonites," 'British Association Reports,' Bath Meeting, p. 73, 1864.

2 'Ueber Ammoniten,' erste Abth., Sitzungsber. Nat,-wiss. Classe Wiener Akademie, Band 52, 1865. 
of the Ammonite shell," "Die Zusammensetzung der spiralen Schale." The reform so well inaugurated by Professor Suess was ably followed up by Dr. W. Waagen, ${ }^{2}$ who directed attention to the importance of the study of the Antychus and Anaplychus, and the presence or absence of this body in the Ammonite shell. The observations made by Waagen on the Aptychus he described and applied in the diagnosis of the genera proposed for several Jurassic species. In the following figure the Aptychus carinatus (fig. 9S) is seen apart from the shell. In figure 97 it is seen lying in the body-chamber of an Amuonite, and in figure 99 the Aptychus is vertical, as if closing the aperture of the shell.

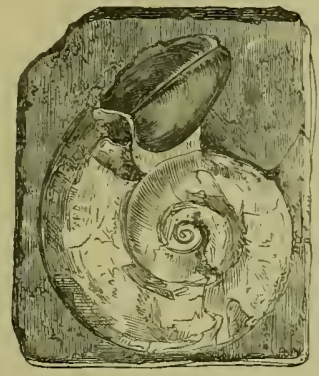

Fig. 97 .

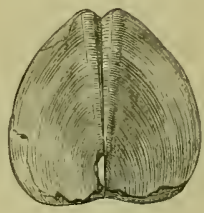

Fig. 98.

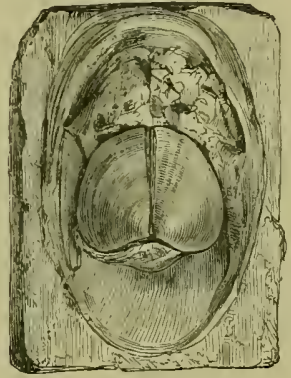

Fig. 99.

The following organic features are considered as elements of primary importance in studying the Ammonite shell, and their combination constitutes characters for the diagnosis of the generic groups.

Firstly.-The structure of the lobes and their suture-line have been fully studied by

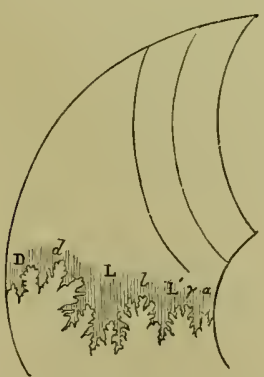

Fig. 100.-Disposition of the lobes $\left(\mathrm{D}, \mathrm{L}, \mathrm{L}^{\prime}, \mathrm{a}\right)$ in Amal. margaritatus, Montf.

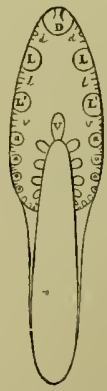

Fig. 101.-Disposition of the lobes $(\mathrm{D}, \mathrm{L}, \mathrm{L}, \mathrm{a})$ in Phylloceras heterophyllum.

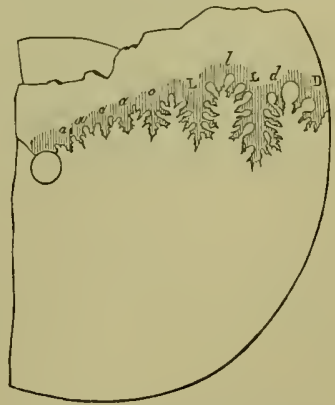

Fig. 102.-Disposition of the Jobes $\left(\mathrm{D}, \mathrm{L}, \mathrm{L}^{\prime}, a\right)$ in Phyll. heterophyllum, Sow.

1 'Ueber Ammoniten,' 2 Abth., Sitzungsber. der Mathemat. Classe der Wiener Akademie Band 61, Abth. 1, 1870.

2 "Die Formenreihe des Ammonites subradiatus," Benecke's 'Geogn.-Palæont, Beiträge,' Bd. ii, 1869. 
Von Buch, d'Orbigny, Quenstedt, and Oppel. I have given a résumé (pp. 181, 182) of the descriptions of the lobes and ramifications of the margin of the septa in treating of the

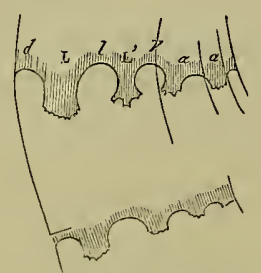

Frg. 103.-Disposition of the lobes $\left(\mathrm{L}, \mathrm{L}^{\prime}\right.$, $a, a)$ in Ceratites nodosus, De Haar.

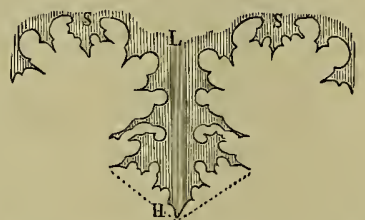

Fig. 104.-Form of the subdivisions of the lobes $(\mathrm{L})$ and saddles $(\mathrm{s})$ in Ammonitidæ.

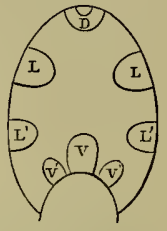

FIG. 105.-Monld of the disposition of the lobes $(L, D, v)$ of Phylloceras.

classification of the Ammoniтide, and have shown that the points of the foliations are all directed backwards towards the winding of the spire, and the convexities all look forward towards the aperture (as seen in figs. 100, 102) in
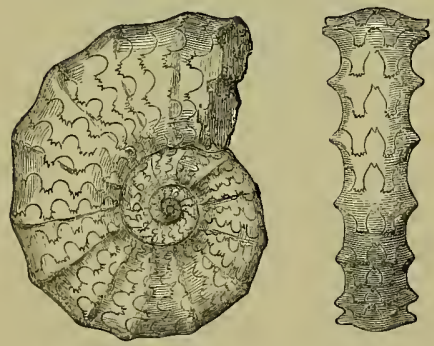

Fig. 100 Side view, Fig, 107 -Ventral view. Ceratites nodosus, De Haan.

the ramified foliations of the suture-line; where they are folded the elevations are called saddles and the intervening depressions lobes. In the Ceratites these parts are very simple, as shown in Ceratites nodosus (fig. 106), where the dentated lobes are seen to point backwards and the rounded saddles look forwards. Those parts are more complicated in Amaltheus margaritatus (fig. 100), and still more so in Phylloceras heterophyllum (fig. 102), in which the auxiliary lobes are numerous and well developed. Figs. 101, 102 show the disposition of the lobes of this beautiful Ammonite from the Upper Lias.

Secondly.-The shape of the aperture and the structure and development of the month-border of the shell vary very much in the different groups, and the special form which the border presents in different Ammonites affords an element of importance in defining the diagnosis of genera. The difficulty which the palæontologist experiences in obtaining Anmonite shells, or moulds of such, in which the aperture with its border is preserved, has long prevented this anatomical character from being used in constructing the diagnosis of the different groups; at length, however, many specimens have been found, and we have ascertained that important differences do exist, and, perhaps, many more will be discovered by continued researches made along the same line of investigation.

In Arietites, as seen in Arietites rotiformis (fig. 108) and Arietites obtusus (fig. 109), the sides of the mouth-border are simple, and the ventral portion is more or less produced, as indicated by the forward direction of the ribs in this region, these folds of the 
shell being formed in fact by the secretion from the mantle during the stages of growth. We note likewise in $A$. obtusus (figs. 109, 110), and in its allied form A. stellaris, that

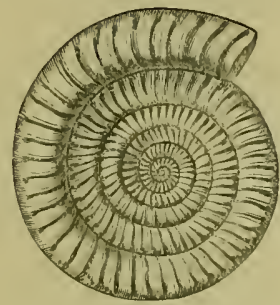

FIG. 108.-Arietiles rotiformis, Sow. Side view.

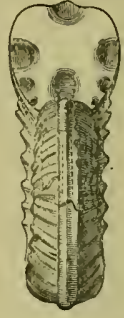

Fig. 110. Ventral view.

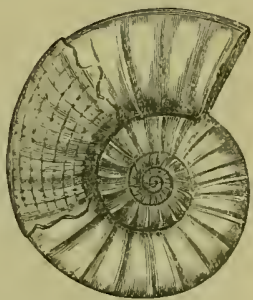

Fig. 109.-Arietiles oblusus, Sow. Side view.

in these species the structure of the outer lamina of the shell itself presents remarkable transverse and lougitudinal lines, which form pits or punctations at the angles of their intersection, a character not observed in other allied species.

In Aegoceras the form of the shell varies much, the mouth-border is simple, withont lateral processes, and sometimes with a ringed contraction near the aperture and a projecting ventral fold. The shell of Aeg.planorbis shows this structure well in one of the oldest Liassic forms of this group, and we see the same repeated in the young condition of Aeg. Henley $i=$ A. capricornus of Schloth (fig. 111).

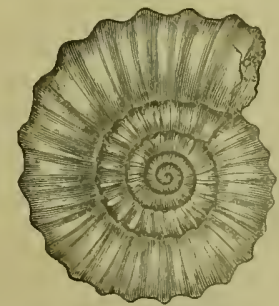

Fig. 111.-Aegoceras capri. cornum, Schloth.

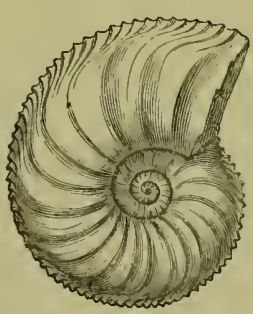

Fig. 112.-Amallheus cordalus, Sow.

In Amaltheus the siphonal or abdominal side of the shell, forms in general, a more or less sharp keel, often with an imbricated edge, which projects forward in a long pointed process. This is very well seen in Amaltheus cordatus (fig. 112), where the lateral ribs are observed bending obliquely forwards towards the aperture, and the keel when perfect projects forward in a spear-shaped process. In Amal. margaritalus the keel is beaded and prominent, the ribs bending forward in graceful sweeps towards the aperture. In Amal.oxynotus (fig. 113) the shell is discoidal, and the siphonal area bas an edge almost as sharp as a currier's knife (fig. 114); the sides are undulated, with falciform ribs derived from the original form of the aperture, and witl a projecting ventral process. 


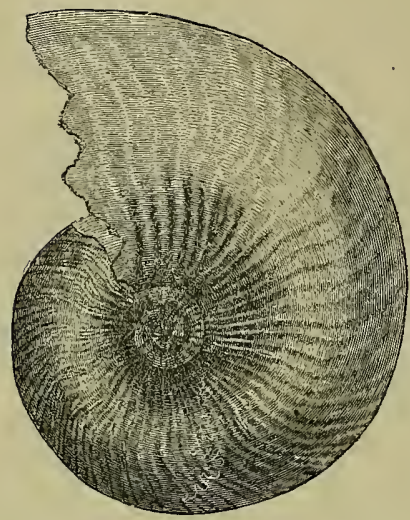

FIG. 113.-Amaltheus oxynatus, Quenst.

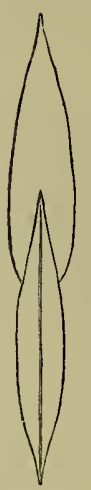

FIG, 114.-Front view.

In Harpoceras, which embraces the true Falcifers of von Buch, the sickle-shaped ribs announce a complicated structure of the mouth-border, with a projecting siphonal or abdominal area, and with lateral lappets of greater or less extent; they are small in Harpoceras serpentinum (fig. 115), in Harp. bifrons, Harp. Levisoni, and long and projecting in Harp. opalinum. I must refer to the plates of these species, and the descriptive text thereof, for many important details concerning the mouth-borders of Harpoceras.

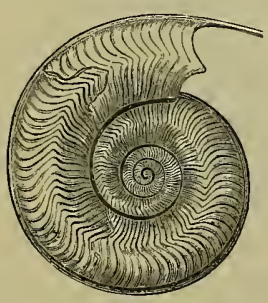

Fig.115.-Harpoceras serpenti. num, Schloth.

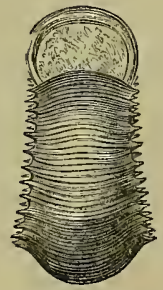

Fig. 116.-Stephanoceras Deslongchampsii, Defrance.

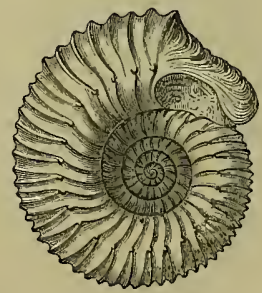

Fig. 117

Slephanoceras Braikenridgii, showing labial prolongations.

In Siephanoceras the shell varies in form; the siphonal or abdominal area is, in general, rounded and without a keel or furrow, and the lateral ribs terminate in tubercles on the sides, from whence numerous folds branch out and extend over the abdomen to join their fellows from the opposite side. The mouth-border in Stephanoceras Deslongchampsii consists of a thick band which encircles the aperture, as in fig. 116, and, by its prominence and inflexion on the sides, forms the main lateral portion of the ribs up to the tubercles which are prominent in this species. In Stephan. Humphriesianum the oral 
band is more voluminous, and in like mamer, as the moutl was developed onwards, the receding band formed the ribs and tubercles so well shown in that Ammonite. In Stephan. Braikenridgii the sides of the border develop long, inflected, lateral lappets, which bend over the aperture, as seen in figs. 117 and 11S. A like form of mouthborder is seen in the shells of Stephan. Sauzei and Stephan. linguiferum, and a still more marked variation of the lateral lappets is found, in Stephan. Gervillii, Stephan. Brongniartii, all derived from the Stephanoceras Humphriesianum zone of the Inferior Oolite, and Stephan. bullatum, from the Great Oolite.

In Cosmoceras the sides are often highly ornamented with ribs and tubercles, which bespeak a corresponding development in the mouth-border of the shell. In Cosmoceras Jason (fig. 119) the lateral processes are very loug, equalling two thirds the diameter of the last whorl. Many years ago a large number of this species were collected from the Oxford Clay near Chippenham, in a very perfect state of preservation, with the bodyclamber and mouth-border complete. In other species of this group I have not been fortunate in finding the termination of the shell.

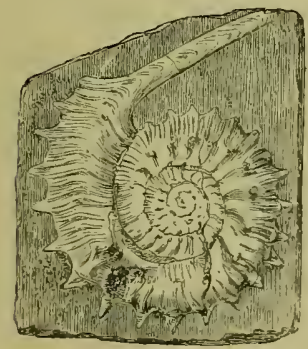

Fig. 119 Cosmoceras Jason, Reinecke.

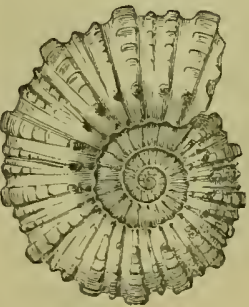

Fig. 120. Hoplites mammillaris, Schloth.

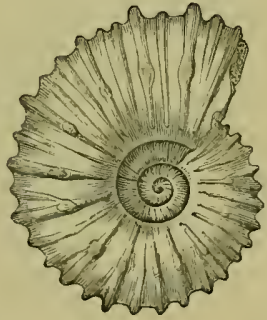

Fig. 122. Hopliles Martini, d'Orb.

In Hoplites mammillaris (figs. 120, 121) we have another example showing how the remarkable ornamentation of some of the shells of this group depends on the development of the mouth-border. Here the ridges with their spines, and the valleys with their smooth surface succeed each other, owing to the advance of the calcarenus oral band, and its temporary cessation of growth, producing the remarkable form of shell this species assumes (fig. 120). A similar condition of the mouth-border has formed the ornamented shell of Hoplites Martini (fig. 122), which I have collected in the Lower Greensand (Neocomian) from the Atherfield section, Isle of Wight.

In Lytoceras the mouth is circular and without lateral processes: the shell is distinguished especially among its Liassic forms for the reticulate structure of the test and the prominent frills that are developed at intervals, as in Lytoceras fimbriatum (fig. 123). These fimbriæ originated from a periodic activity in the secreting power of the 
mantle around the mouth-border of the species possessing these fimbriated projections. A similar structure is likewise found in Lyt. lircinum, from the Lytoceras Jurense zone.

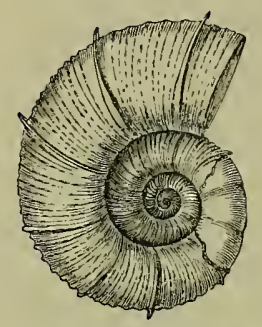

FIG. 123.-Lyloceras ${ }^{\mathrm{T}}$ fimbrialum, Sow.

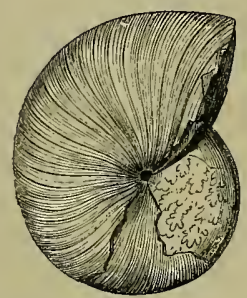

FIG. 124.-Phylloceras heterophyllum, Sow.

In Phylloceras the involute shell of this group is marked with true forward inclined lines of growth, indicating the presence of a ventral process at the abdominal side of the mouth-border, and this appears to have been the case in the only specimen with a fanshaped body-chamber, Phylloceras heterophyllum (fig. 124), which I obtained from the Upper Lias at Whitby, of which I have given a figure on my Plate two thirds natural size.

A remarkable form of mouth-border has been figured by Count Münster under the name Scaphites refractus (fig. 125). In this species the abdominal or siphonal area forms a beak-shaped process, curved downwards towards the aperture, and the lateral processes rise into angular projections, producing a curious pentagonal-shaped oral aperture in this shell.

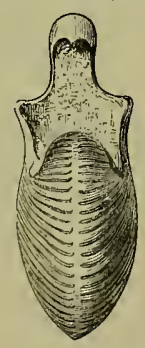

FIG. 125. Scaphites refracıus, Münst. Lobiles delphinocephalus, Haver.

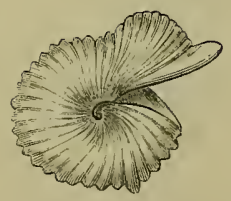

Fig. 126

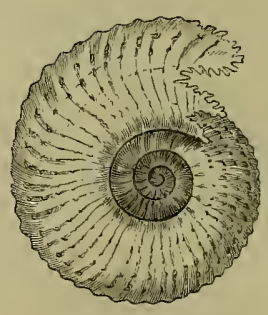

Frg. 127 .

A still more remarkable mouth-border is seen in the curious example figured (fig. 126) Lobites delphinocephalus, Von Hauer, in which the siphonal area becomes inflated and projects forward as in a Scaphite in a remarkable peak-shaped prominence ; Count Münster, has figured a remarkable fossil, Traclyceras Aon (figs. 127, 128), in which the ornamentation of the shell indicates a singular structure of the mouth-border.

I Written Aegoceras in error on page 198. 
Thirdly.-If the structure of the mouth-border shows that Ammonites varied much in the anatomy of their head, mantle, and arms, the length of the body-chamber affords another character from which important deductions may be made. The capacity of this chamber was doubtless proportioned to the size of the contained animal, as seen in the Nautilus pompilits (fig. 129) of our seas, where the Mollusc is represented occupying the entire body-chamber, the outer margin corresponding to the ventral surface, and the columellar side to the dorsal surface of the animal. We have here likewise to note the position of the tentacles and the place of the hood, which may probably be the homologue of the Aptychus. The septa are likewise seen to he concave towards the aperture, and convex towards the spire of the shell, and they all are perforated at the centre by the siphuncular tube, which proceeds from the posterior side of the Cephalopod to traverse the septa up to the last air-chamber.

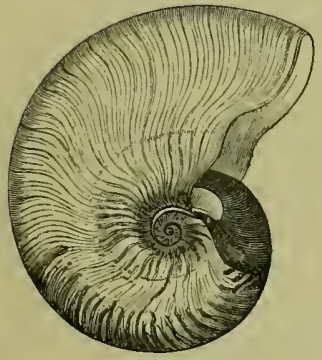

Fug. 130.-Nawtilus umbilicatus, Lan.

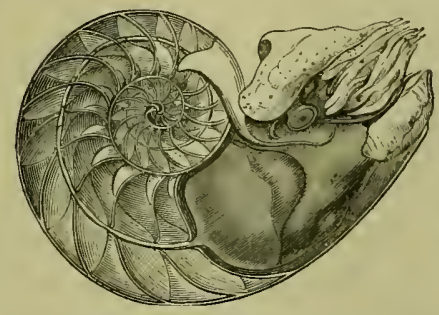

Frc. 129.-Vertical section of the shell of Nautilus pompilius, showing the siphuncle and the situation of the animal in the last chamber.

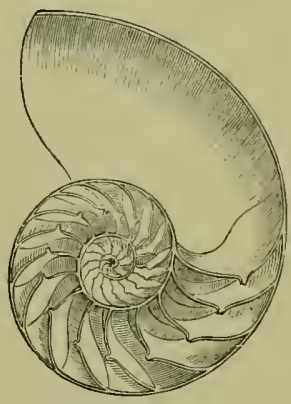

Fig. 131.-Section of the shell of Nautilus pompilius, Linn.

In fig. 131 we have a vertical section of the Nautilus shell (fig. 130). The body in the section is seen to extend to one half of a whorl, and from the inner side of each septum we observe a short funnel-shaped process projecting backwards, which affords attachment to the membranous siphuncle seen fully in sitú in fig. 129. The length and capacity of the body-chamber vary considerably in the different genera, and are found to have proportionate dimensions to that of the onter whorl; this appears to be constant in several of the groups on which careful observations have been made; the difficulty experienced in obtaining specimens in which the body-chamber is preserved is, however, a sufficient reason why more has not hitherto been done in this line of inquiry.

In Arietites (fig. 132) it will be observed that the septa are convex towards the aperture and concave towards the spire, whilst in Nautilus we have seen that the opposite condition prevails. The body-chamber in Arietites is likewise very long, extending from one whorl to one whorl and a half in length. 


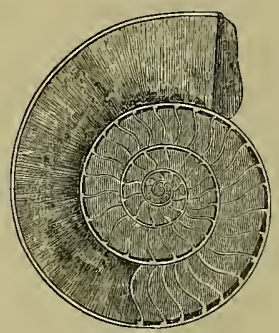

FiG. 132.-Section of Arietites obtusus, Sow. Shnwing the size of the body-chamber and outward convexity of the septa.

In Aegoceras the length of the body-charuber varies from two thirds of a whorl to an entire whorl.

In Amaltheus the body-chamber is short, and varies from one half to two thirds of a whorl.

In Harpoceras it is about two thirds of a whorl.

In Stephanoceras it is from one whorl to one and a quarter in length. In Perisphinctes from two thirds to a whole whorl, and in Cosmosceras it is about half a whorl in length. In Phylloceras it is short and wide, and in Lytoceras it is round and two thirds of a whorl long.

Fourthly.-T'he shell of the Ammonitide is a cone, which is more or less rolled up upon the same plane or in a spiral; and the various turns of the shell or the whorls, as they are called, in general cover to a greater or less extent the preceding whorl; this is called the amount of involution of the whorls, a feature in the diagnosis of the shell which requires consideration when taken in connection with the other features $I$ have described, as the extent of the involution is found to be generally the same in the different species of different groups. Some shells, for example, as those of Lytoceras (fig. 123), are only slightly involute; and others, like Arietites (fig. 108), have a wide umbilicus, with their inner whorls largely exposed; in others, as Amaltheus and Harpoceras, the whorls are much covered by the preceding whorl; in some species of Phylloceras they are entirely 'enveloped; and in others the umbilicus is completely closed. This character, the amount of whorl involution, appears to depend on the angle at which the shell bends round in the process of growth, and as it appears to be a very constant feature, is of value in forming a diagnosis of generic characters. On this subject the Rev. J. F. Blake observes, " If we take any fixed point in relation to the shell--say a point in its surface or in the centre of its apertures, that point will describe a curve with the growth of the shell; and if this curve be projected on a plane it nearly forms the well-known 'equiangular spiral ;' not exactly, however, because the growth does not begin from a point as it should, but from the circumference of the embryo; and it has, therefore, been proposed by 
Mr. Naumann to call it a 'concho-spiral.' Taking, however, the former curve as an approximation to the form produced, we know that this depends for its shape entirely on the angle at which it is bent; and this depends on the law of the growth of the shell. Now, since this law is the same for all the parts of the shell, it follows that the curve described by every point in the same plane is the same, only representing earlier or later portions of one and the same curve. If, therefore, in an Ammonite which is coiled on one plane it is necesśary to go back an exact revolution of $360^{\circ}$ to reach the part of the curve corresponding to the inner edge of the whorl, it is plain that this will be just in contact with the outside of the preceding whorl, which is an exact revolution behind. If we must go back further the inner edge of the last whorl will lie within the outer edge of the preceding, or the shell will be more or less involute; if, on the contrary, we have to go back less, it will be uncoiled. The slape, then, of any shell coiled in one plane depends on the magnitude of two angles, viz. the angle of the spiral and the angle of retardation of the inner edge."

Fifthly.-The absence or presence of the Aptyclus is the fifth character in the anatomy of the shell which requires our consideration. In several extensive groups the Aptychus is supposed to be absent, as in Phylloceras, Lytoceras, Arcestes, Trachyceras; at all events it has not yet been found in these. It is present as a horny undivided body in Arietites, Aegoceras, and Amaltheus. It is divided or bivalved and calcareous in Harpoceras, Oppelia, and Haploceras. It is thin, bivalved, and granulated externally in Stephanoceras, Perisplinctes, and Cosmoceras. It is thick, smooth, and punctated externally in Simoceras and Aspidoceras, and greatly resembles the large flat grinding teeth of certain genera of fishes from the Carboniferous Limestone; these thick calcareous Aptychi consist of two layers, an inner and outer. The inner alone exhibits lines of growth concentric with the angle of each plate, which is situated on that side of its broad end which is applied to its fellow of the opposite side. The outer layer is composed of many laminæ, which in sone forms have a porous structure and a punctated and polished surface; there is a remarkable contrast between the thick porous Aptychi of the Kimmeridgian Clay, and Upper Jurassic rocks of Germany, and the thin shelly Aptycli of the Ammonites from the Inferior Oolite, or the horny Anaptychi of the Lias formation. When found undisturbed they occupy the lateral wall about the middle of the body-chamber, having their base in general turned towards the mouth, as seen in figs. 97 and 99. The Solenhofen Lithographic Limestones contain several species of Ammonites with the body-chamber, mouth border and lateral processes of the shell all complete, and in these specimens the relative position of the Aptychi agrees with what I have stated.

Having described in detail the five characters upon which palæontologists have based the diagnosis of genera, I now proceed to give the classification proposed by Dr. W. Waagen, as it exhibits, in an analytical form, the results of modern investigations on the different groups of the Ammonitidæ. 
The difficnlty of finding the Aptychus in sitî in the shells to which it belongs will long render this important anatomical character of little practical value as a factor in the diagnosis of the different groups, and for this reason it has not been employed by Dr. E. Mojsisovics or by Professor Neumayr in the classifications given by them.

The following classification of the new Ammonite genera was proposed by Dr. W. Waagen, ${ }^{1}$ and a like grouping has since been published by M. E. Favre. ${ }^{2}$

\section{Genera of Ammonites.}

\section{A. Aptychus a BSENT.}

Body-chamber short; appendage ventral.

Body-chamber short, appendage dorsal.

Body-chamber very long, one and a half to two whorls, mouth border dissimilar.

Body-chamber short, mouth-border falciform, appendage ventral, sculpture Argonautiform.
Phylloceras, Suess.

Triassic and Cretaceous.

Lytoceras, Suess.

Trias. Juras. Cretaceous.

Arcestes, Suess.

Triassic.

Trachyceras, Laube.

Triassic.

\section{B. Aptyclius PRESENT.}

I. Aptychus undivided.

1. Horny (Anaptychus)-

Body-chamber long, one to one and a half whorls, Arietites, Waagen. mouth-border with pointed ventral appendage.

Body-chamberfrom two thirds to an entire whorl, mouth-border with rounded ventral appendage.

Triassic and Liassic.

Aegoceras, Waagen.

Triassic and Liassic.

Body-chamber short, one half to two thirds of a whorl, mouth-border with long ventral appendage. Amaltheus, Montfort.

Trias., Juras., Cretaceous.

2. Calcareous,-Aptyclius Numida, Coquand.

Shell unknown (Sidetes?) Cretaceous.

1 ' Ueber die Ansatzstelle der Haftmuskeln beim Nautilus und den Ammoniden, Palæontographica, Band xvii, 5, p. 197, 1867-1870.

2 "Sur la Classification des Ammonites," M. E. Favre, 'Bulletin de Soc. Géol. de France,' 3e série, tom. i, p. 353,1873 . 
II. Aptychus divided (bivalved) calcareous.

1. Aptychus, externally furrowed.

Aptychus thin, body-chamber short, mouth-border falciform, with pointed ventral process

Aptychus thick, body-chamber short, mouthborder falciform, appendage rounded ventral.

Body-chamber short, mouth-border with a groove or enlargement near the aperture, month-border with lateral auricles, and rounded ventral appendage.

2. Aptyclus thin, granulated externally. Bodychamber long, montl-border simple, or furnished with bands or auricles.

Body-chamber long, aperture narrowed by a furrow, simple, or provided with auricles.

Body-chamber short, aperture simple, or furnished with auricles.

3. Aptychus thick, smooth, and punctated externally. Body-chamber long, umbilicus wide; shell with furrows, aperture with a ventral nasiform appendage.

Body-chamber short, mouth-border in general simple.

Harpoceras, Waagen.

Jurassic.

Oppelia, Waagen.

Jurassic, Cretaceous.

Haploceras, Zittel.

Jurassic and Cretaceous.

Stephanoceras, Waagen.

Jurassic and Cretaceous.

Perisphinctes, Waagen.

Jurassic and Cretaceous.

Cosmoceras, IVagan.

Jurassic and Cretaceous.

Sinoceras, Zittel.

Tithonic $=$ the uppermost

Jurassic strata.

Aspidoceras, Zittel.

Jurassic and Cetaceous.

Since the above scheme was proposed many important additions have been made to the number of genera. Dr. E. Mojsisovics has revised the family Arcestids, and grouped therein several new generic forms discovered by him in the Zlambach und Hallstatter-strata, and which are figured in detail in his splendid Monograph. ${ }^{1}$

Professor M. Neumayr, of Vienna, has proposed the genera Olcosteplanus, Iloplites, Acanthoceras, and Stoliczkaia for certain forms which have been detached from other genera owing to the discovery of new characters in these special forms, and Dr. Waagen has proposed the genus Peltoceras for certain forms which he has described in his great work on the Jurassic Cephalopoda of Kutch in India.

As new discoveries are made in the intricate structure of these polythalamous shells many error's will be corrected, omissions supplied, and new genera erected for the reception of the revised types of this wonderful assemblage of Cephalopoda which have been collected from the Secondary (Mesozoic) rocks of the Continent of Europe, and from beds of the same age in Asia. The Cephalopoda of the Cretaceous Rocks of Southern India have been admirably figured and described: Belemnitide and Nautilida, by Henry 
F. Blanford, Esq., F.R.S. ; Ammonitide, with revision of the Nautilide, \&c., by the late Dr. Ferd. Stoliczka; and the Jurassic Fauna of Kutch, Belemnitide, Nautilide, and Ammonitida, by Dr. W. Waagerl. All these works are contained in the Palaontologia Indica, and form part of the Memoirs of the Geological Survey of India.

I beg to return my best thanks to H. B. Medlicott, Esq., F.R.S., Director of the Geological Survey of India, for a copy of these valuable works so useful to me at present, and most important to all Students of Palæontology.

Professor Alpheus Hyatt published in the Bulletin ${ }^{1}$ of the Museum of Comparative Zoology, Harvard College, Cambridge, Mass., U. S., a remarkable memoir on the Fossil Cephalopods contained in the Museum of that College, in which he gave an outline of a new classification and nomenclature of these fossils. He states that the Ammonoids includiug all the Cephalopods with serrated or foliated septa, the Clymenice, Goniatites, Ceratites, and Ammonites proper, were separated by the late Professor L. Agassiz from the Nautiloids and Dibranchiate Cephalopods, as a distinct order. For many years past Agassiz had considered some of these groups as natural families, and deemed them capable of a division into subordinate groups of generic importance. He imparted this fundamental idea to Professor Hyatt, at the beginning of Hyatt's studies on these interesting fossils, and selected the five genera which are referred to his anthority (Arnioceras, Discoceras, Rhacoceras, \&c.) as examples of the manner in which the subject should be treated at the time the investigation was recommended to his pupil.

The materials in possession of the Museum were all derived from typical European collections, as those of Professors Bronn and de Koninck, MM. Boucault and Duval, the late Dr. Krantz, and the Museum of Stuttgart.

The position of the female Argonauta in its shelly case, says Prof. Hyatt, and of the Nautilus in its shell, show conclusively that the periphery of the whorls of an Ammonite is the abdominal side, as stated by Professors Owen and Pictet. This view, therefore, is adopted, and the outer side of the whorl is called the "abdominal," and the inner the "dorsal" side, in accordance with their opinion.

The Lower Lias Ammonites are distributed into four families-PsILoceratid $E$ Discoceratide, Liparoceratide, Deroceratide.

The Middle Lias forms are grouped into seven families-Liparoceratide, Deroceratide, Thysanoide, Dactyloide, Phymatoide, Amaltheoide, CrcloCERATID $\approx$.

The Upper Lias species are distributed into the following six families:-Drscoceratide, Deroceratide, Dactyloide, Thysanoide, Phimatoide, Hildoceratide.

In the following analysis of this memoir I shall select the most typical examples of each genus under the name they will be described in this Monograph.

1 'Bulletin of the Museum of Comparative Zoology, Harvard College, Cambridge, Mass.,' vol. i, No. 5, p. 71 (No. 5 bears no date, but No. 4 is dated June, 1865, and No. 6 is dated December 26th, 186 ) $^{\text {) }}$ 
Lower Lias.

\section{Psiloceratide.}

Shell smooth. Umbilicus open, exposing the sides of the whorls; sides depressed.

Genus Psiloceras, Hyatt.-Abdomen smooth; shell often folded; sides depressed. Whorls enveloped to the line of the superior lateral lobes. Example: Aegoceras planorbis, Sow. The other forms described by Hyatt appear to me to be well-known varieties of Aeg. planorbis (Pl. XIV, figs. 1, 2, 3, 4).

\section{Discoceratide. ${ }^{1}$}

Genus Arnioceras, Agassiz.-Abdomen keeled and channelled, but both parts are variable, being sharply defined in some and very shallow in others. Ex. Arietites semicostatus, Young and Bird (Pl. I, fig. 4).

Genus Ophioceras, Hyatt.-Keel constant, sometimes obscure. Pilee ${ }^{2}$ straight, depressed; umbilicus open; sides exposed. Ex. Arietites raricostatus, Zieten (PI. VII, fig. 2).

Genus Discoceras, Agassiz.-Abdomen keeled and channelled; both characters constant, although the channels are sometimes nearly obsolete. Pilæ smooth. Geniculæ curved forwards. Umbilicus open; sides flattened and exposed. Abdomen depressed. Ex. Arietites Conybeari, Sow. (PI. II, fig. 1).

Genus Coroniceras, Hyatt.-Keels prominent, constant; channels well defined. Pilæ tuberculated and bent. Umbilicus open, sides of the whorls exposed. Pilæ preceded by a line of tubercles in the young, which gradually elongate to form the tuberculated pilæ of the adult. Ex. A. Bucklandi, Sow. (PI. I, fig. I), Arietites bisulcatus, Brug. (Pl. III, fig. 1).

Genus Asteroceras, Hyatt.-Keel well-defined, but varies from prominent and narrow to depressed and broad. Channels obscure to deep and well-defined. Pilæ smooth, depressed, often bent on the sides, and appear in the young as lateral folds or large tubercles. Ex. Arietites obtusus, Sow. (Pl. XXI), A. stellaris, Sow. (PI. XXII).

\section{Liparoceratide.}

Genus Microceras, Hyatt.-Abdomen flattened; sides rounded or depressed. The

1 This group equals drietites.

2 Pilce means ribs; and genicula, the knees or bending of the ribs. 
pilæ in the adult are undivided on the abdomen, and continuous with the large, single lateral pilæ, which last may be ornamented with one or two rows of small tubercles, or may be bare. Ex. Aegoceras polymorphum, Quenst. (Pl. XL, fig. 1).

\section{Deroceratid at.}

Genus Deroceras, Hyatt.-W'horl circular; pilæ depressed; linear between, and bifurcated on the tubercles. Tubercles large, prominent, pointed, and in a single row. Ex. Aegoceras planicosta, Sow. (Pl. XXIV).

\section{Middle Lias.}

\section{LIPA ROCERATIDE.}

Genus Mrcroceras, Hyatt.-Ex. Microceras planicosta $=$ Aegoceras planicosta, Sow. (PI, XXIV); Microceras maculatum, Young and Bird = Aegoceras capricornus, Schloth.

Genus Androgynoceras, Hyatt.-The sides of the adult whorl slope outward and are ornamented with pilæ, usually single, and set with two rows of tubercles. Abdomen narrow. The large pilæ of the young are split into smaller pilæ on the abdomen of the adult, but usually retain the characters of Microceras until a late period of growth. Ex. Aegoceras heterogenum, Young and Bird=Aeg. liybridum, d'Orb. (PI. XXXVI).

Genus Liparoceras, Hyatt.-This genus difiers from both of those previously described in the greater breadth of the abdomen, the greater increase of the radii of the spiral, consequently smaller number of whorls and the larger size of the species. Ex. Aegoceras Henleyi = Aeg. striatum, Reinecke;Aeg. Bechei, Sow. (Pl. XXXIII).

\section{Deroceratidide.}

Genus Deroceras, Hyatt.-Ex. Deroceras Davoi = Aeg. Davoi, Sow. (Pl. XXXI, fig. 1) ; Deroceras densinodum = Aegoceras densinodum, Quenst. (Pl. XXXVIII, fig. 5); Deroceras armatum $=$ Aegoceras armatum, Sow. (Pl. XXVIII, fig. 1).

Genus Peronoceras, Hyatt.-Abdomen depressed; pilæ flattened; linear between the tubercles; usually but not invariably bifurcated by the tubercles on the sides, though invariably bifurcated on the abdomen. Ex. Stephanoceras fibulatum, Sow., and Steph. subarmatum, Sow.; both are Upper-Lias species.

\section{ThysanOIDAX.}

This family includes the Fimbriati, Ligati, and Heterophylli, which agree in the foliaceous character of the septa. 
Genus Thysanoceras, Hyatt.-Abdomen rounded; whorls exposed; amount of involution about one thircl of each interior whorl. Ex. Lytoceras fimbriatum, Sow. (Pl. XLIV).

Genus Rhacoceras, Agassiz.-Abdomen rounded; sides of the whorls flattened; envelopment extends about two thirds over each of the interior whorls, or entirely encloses them, covering up the umbilicus. Ex. Pliylloceras Loscombi, Sow. (Pl. XL, fig. 4), Aegoceras Ibex, Quenst. (Pl. XXXIX, fig. 4).

\section{Dactyloide.}

This family includes the Planulati and part of the Macrocephati.

Genus Celoceras, Hyatt.-Pilæ on abdomen bifurcated; lateral pilæ single, or bifurcated with one external row of tubercles on each; the young fiatter than the adult; the first two whorls smooth, the others tuberculated. Ex. Aegoceras pettos, Quenst. (Pl. XXXVII, figs. 5-7).

\section{Phymatoide.}

Genus Phymatoceras, Myatt.-Abdomen rounded or flattened, never acute; no channels in the adult. Young smooth on the first or second whorl, tubercles appear on the second or third, and, gradually dividing, spread themselves ont upon the abdomen as bifurcated pilæ, which disappear on the borders of the channels. Keel makes its appearance at an early age. Ex. Phymatoceras robustum, Hyatt.

Genus Hammatoceras, Hyatt.-Abdomen rounded or acnte, always keeled, but never sulcated. Pilæ prominent and straight. Envelopment extending over one balf the width of the sides, or covering only the abdomen of each internal whorl. The two species cited are $H$. insigne, Schnbl., and $H$.variabile, d'Orb. ; these, however, are found only in the Jurense-zone of the Upper Lias, and not in the Lower Lias, as our author has placed them.

\section{Amaltheold $x$.}

Genus Pleuroceras, Hyatt.-Abdomen flat, with keel and channels well-defined; keel crenulated; channels vary from obsolete to deep and well-defined. Pilæ swelling below, tuberculated; genicular bend prominent. Tubercles lateral, arranged along the line of envelopment. Umbilicus open. Ex. Amaltheus spinatus, Brug. (Pl. L), the other species cited by our anthor P. Hawskerense, costatum, \&c., are mere varieties that well-known species of Bruguière.

Genus Amaltheus, Montfort.-Abdomen acute, keeled, and channelled; whorls 
compressed. Keel crenulated and well-defined. Umbilicus open, whorls exposed, or only partially involuted. Ex. Amaltheus margaritatus, Mont. (Pl. XLIX); the other forms named are all varieties of Montfort's capital typical species.

\section{Cycloceratide.}

This family is remarkable for containing species which, on one side, ally it with Liparoceratide, and, on the other, with Hildoceratider. The form is more compressed than the former, and the tuberculations of the pilæ separate it from the latter.

Genus Platypledroceras, Hyatt.-Abdomen nearly as broad, or broader than the dorsal side of the whorl. Pilæ single, tuberculated, and extending across the rounded abdomen. Septa minutely divided by minor lobes. Ex. Aegoceras latecosta, Sow. (Pl. XXXII, fig. 1).

Genus Cxcloceras, Hyatt.-Abdomen rounded or keeled, not so broad as the dorsal side of the whorl. Pilæ single, tuberculated, and not extending across the abdomen in the keeled species, young smooth for the first two or three whorls, then becoming ribbed. Ex. Aegoceras natrix, Schloth. Aegocer. Valdani, d'Orbig. (Pl. XXXVIII, figs. 1-4).

Genus Tropidoceras, Hyatt.-Abdomen invariably keeled, much narrower than the dorsal side of the whorl. Pilæ single, smooth, or tuberculated in the same species, do not extend across the abdomen in any species. Young smooth for one or two whorls, keel and pilæ appear simultaneously. Ex. Harpoceras Masseanum, d'Orb.

\section{Upper Lias.}

\section{Discoceratide.}

Ophioceras Levesquei, d'Orb. = Harpoceras Levesquei, d'Orb.

\section{Deroceratid 死.}

Deroceras subarmatum, Sow. = Steplanoceras subarmatum, Sow.

\section{DactyLoide.}

Coeloceras Grenouillouxii, d'Orb. = Aegoceras pettos, Quenst. (Pl. XXXVII, figs. 5-7).

Genus Dactrlioceras, Hyatt.-Abdomen equal in breadth, or less in width than the back, instead of being broader than, or equal in breadth to the back, as in the preceding genera. The lateral pilæ in the adult are smooth, and invariably single; the abdominal pilæ may be either bifurcated or single. Ex. Steplanoceras commune, Sow. 


\section{ThySANOID止.}

Thysanoceras cornucopia, Th. Jurense, Th. hircinum, and Th. torulosum, given as examples, all belong to the genus Lytoceras.

Rhacoceras heteroplyyllum, Sow. = Ex. Phylloceras heterophyllum, Sow.

\section{Phymatolde.}

Plymatoceras enervatum, Hyatt.

Ammatoceras insigne, Schubl., and A. variabile, d'Orb.-These species had been already referred to the genus Hammatoceras, and placed, through an oversight of the author, in the Middle Lias.

Genus Pelecoceras, Hyatt.-This genus is not well defined. Pelecoceras attenuatum, Hyatt.

\section{Hildoceratide.}

Genus Hildoceras, Hyatt.-Abdomen keeled and channelled; pilæ large and broad. Young with first whorl smooth. Ribs, keel, and channels appear on the second whorl. The ribs begin as folds, and bend, as in the adult, but with the abdominal bend inclined more towards the apex. Ex. Harpoceras bifrons, Brug. (Pl. LIV) $=H$. Walcotii, Sow., which our author makes a distinct species: $H$. Walcotii is the true $I$. bifrons, Brug.

Genus Grammocrras, Hyatt.-Abdomen keeled, but not channelled; whorls flattened laterally giving a discoidal aspect to the shells. Ribs finer and less prominent than those of Hildoceras. The young also continue smooth much longer, and channels never appear. Ex. Harpoceras serpentinum (Pl. LIII).

Genus Leioceras, Hyatt.-Abdomen keeled, acute; sides of the whorls flattened; envelopment uniformly greater than in Grammoceras Ex. Leioceras opalinum, Rein.

Professor M. Neumayr, of Vienna, has contributed an important memoir, 'Die Ammoniten der Kreide, und die Systematik der Ammonitiden," in which is brought into a continuous and connected form the progressive stages which the systematic study of Ammonites has made in the hands of the younger palæontologists of the German school since the time Professor Suess called their attention to the subject, in his classical memoir 'Ueber Ammoniten,' already cited in these pages. The works of Waagen, Mojsisovics, Hauer, Zittel, Laube, and his own important papers have all been put under contribution to bring the subject up to our present stand-point of knowledge. The Ammonites are grouped into four families :

1 'Zeitschrift der Deutschen geologischen Gesellschaft,' p. 854, Jahrgang, 1875. 
“I. ARCestidis.

1. Arcestes, Suess.

2. Dinymites, Mojsisovics.

3. Lobites, Mojs.

4. Pтrchites, Nojs.
5. Pinacoceras, Mojs.

6. Sageceras, Mojs.

7. A.ral'rheus, Montfort.

S. Schloenbachia, Neumayr.

II. Tropitide.

9. Tropites, Mojs.

10. Trachyceras, Laube.

11. Choristoceras, Mojs.
12. Rhabdoceras, Suess.

13. Cochloceras, Hauer.

III. Lytoceratid

14. Lytoceras, Suess.

15. Hamites, Parkinson.

16. 'I'urrilit'es, Lamarck.
17. Baculites, Lamarck.

18. Phyllocerras, Suess.

IV. Aegoceratides.

19. Amgoceras, Wuagen.

20. Arietites, W a ag.

21. Harpoceras, IV aag.

22. Oppelia, Waag.

23. Haploceras, Zittel.

24. Stephanoceras, Waag.

25. Cosmoceras, IW aag.

26. Ancyloceras, d'Orbigmy.

27. Baculina, d'Orbig.

28. Simoceras, Zitt.
29. Perisphinctes, Waag.

30. Olcostephanus, Neumayr.

31. Scaphites, Parlinson.

32. Hoplites, Neum.

33. Acanthoceras, Neum.

34. Stroliczkaia, Neum.

35. Crioceras, Léveillé.

36. Heteroceras, d' Orbig.

37. Peltoceras, Waag.

38. Aspidoceras, Zitt."

NoтE.-The diagnoses of the families are here given in abstract from Prof. Neumayr's work.

\section{Family.-Arcestuda, Mojsisovics.}

Shell smooth or provided with transverse folds, ribs, or longitndinal lines. The wrinklelayer (Runzel-schicht) ${ }^{2}$ present in the more ancient forms; the lobes consist mostly of short, abruptly interrupted lines, seldom (only in Sageceras) granular. Mantle-impression, in the forms from the Trias, with more or less contraction around the mouth-opening

1 This word has no equivalent in the English language, but it clearly means the wrinkled marginal layer of the mantle of the Mollusc, which formed the lobe-lines of the septa, and imparted such an important character to the shells of the Ammonitidæ. 
which is seen on the mould of the body-chamber, but is seldom visible on the chambered portion of the shell. Horny Aptychus probably present in Arcestes, certainly in Amaltheus, for the other forms doubtful.

Genus Arcestes, Suess.- Shell in general smooth, seldom with longitudinal lines; body-chamber long, from one to one and a half whorls. Spiral increase moderate; strongly involute; mouth-opening contracted, either by an eversion of the shell, or through a thickening of its inner lamina around the border. Lobes strongly incised, so that the saddles cousist of a small stem, with numerous approximated horizontal branches, from which other bifurcations proceed. The umbilicus is often closed by shelly eversion.

Dr. Ed. v. Mojsisovics divides the genus into the following groups:-Extra-labiati, Sub-labiati, Bi-carinati, Coloni, Intus-labiati, Galeati, and Sub-umbilicati, all of them characterised by more or less modified body-chambers of the full-grown individuals, and by a contraction of the umbilicus, frequently entirely occluded by a callosity. All these forms are accurately figured from perfect specimens in his splendid Monograph. ${ }^{1}$

The typical Arcestes belong to the Trias. The species number about 130, and the Muschelkalk contains some highly developed forms. I cite three well-known species as types of this genus: Arcestes sub-umbilicatus, Bronn, Arcestes Gaytani, Klipstein, Arcestes Johannis-Austria, Klipstein.

Genus Didxmites, $v$. Mojs.-General form and length of chamber as in the preceding; shell provided with folds and well-defined lines of growth; through the whole length of the body-chamber up to the month-border there rises upon the convexity of the inner side of the shell a median ridge (normal line). The whorl is contracted near the mouth. The lobe-line is formed by a few pairs of small incised saddles which frequently alternate with single saddles. The radial lines of growth on the shell, the median ridge on the ventral surface, and the pecnliar arrangement of the lobe-line distinguish Didymites from Arcestes. All are collected from the Noric stage or division (Norische Stufe) of the Trias, near Hallstatt.

Genus Lobites, $v$. Mojs. - In the general form and length of the body-chamber it agrees with Arcestes and Didymites. Shell with transverse folds which are abundantly intersected with fine longitudinal lines. The last whorl takes on frequently a shape different from the form of the internal cast, and not unfrequently closes the nmbilicus with a callosity. Most of the species are found in the Triassic beds (Carinthian division) with Lobites ellipticus at Rothelsteins. I have cited as a typical example (fig. 133) Lobites delphinocephalus, Haner, from that locality.

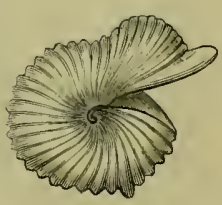

F1G. 133.-Lobiles delphinocephalus. 
Genus Pтrсhites, $v$. Mojs. - In its general form and length of the body-chamber it resembles Arcestes, but differs from that group in the structure of the lobes. The external lobe is very shallow, the external saddle very short, the first lateral saddle is, on the contrary, very high ; the saddles are indented, and show an appearance of a branched formation. The smooth shell is covered with straight or winding radial folds. The species are all Triassic. Ex. Ptyclites Studeri, Haner, Ptychites Dontianus, Hauer.

Genus, Pinacoceras, v. Mojs.-Shell small, with a high month-opening, surface smooth, rarely with any elevations thereon; body-chamber from one half to two thirds of a whorl long. Mouth-border with short lappet-formed processes on the ventral side. Lobe-line distinguished by the presence of an additional external lobe. The species are all Triassic. Ex. Pinacoceras imperator, Hauer, Pinacoc. Daonicum, Mojs.

Genus Sageceras, v. Mojs.-In the form of the shell and length of the bodychamber this genus is nearly related to Pinacoceras. It is distinguished from it by the structure of the "wrinkle-layer," the form of the lobes, and the direction of the lines of growth on the concave part of the shell. The "wrinkle-layer" "is granular, as in Nautilus, and does not consist of long lines and threads as in other Arcesticla. The saddles are small, strongly marginate, or linguiform; the lobes symmetrical with simple conical indentations, single or double; there are three lobe groups as in Pinacoceras. Three species belong to the Permian formation, Sag. Hauerinum, Kon., Sag. Orbignyanum, Vern., Sag. primas, Waag., the others are found in the Triassic rocks, Sag. Gabbi, Mojs., Sag. Haidingeri, Han., Sag. Walteri, Mojs., Sag. Zignondyi, Mojs.

Genus Amaltheus, Montfort.-Siphonal side of the shell sharpened or keeled; ribs, when present, flexed forward, and ending in a granular (fig. 135) or plaited ridge or keel (fig. 134); the external shelly lamina in some species develops fine spiral lines; body-

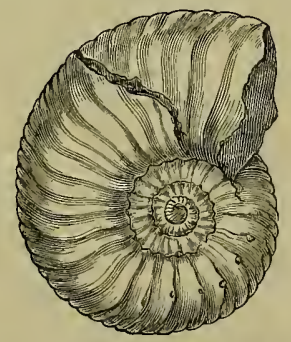

Fig. 134.-Amallheus margaritatus, Mont.

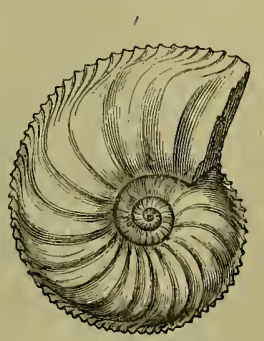

Fig. 135.--dmaltheus cordatus, Sow.

chamber short; one half to two thirds of a whorl. Month-border simple, ventral portion ending in a long projecting process. Lobe-line extremely ranified, the siphonal lobe 
shorter than the principal lateral lobe, which is mostly broad and wedge-shaped. A divided horny Anaptychus has been found in this genus.

The genus Amaltheus has an extensive geological range; it is found in the Trias, Amal. megalodiscus, Beyr., Amal. floridus, Wulf.; it is largely developed in the Jurassic strata, commencing with Amal. Guibalianus, d'Orb., Amal. margaritatus, Mont. (fig. 134), and Amal. spinatus, Brug., in the Lias, and many forms are found in the higher Oolitic beds, as Amal. cordatus, Sow., Coral Rag (fig. 135); numerous species are likewise discovered in the Cretaceous rocks, as Amal. Gevrilianus, d'Orb., Amal. Vibrayeanus, d'Orb.

Genus Schloenbachia, Neum.- - Shell keeled, with strong forward-bent ribs on the sides, sometimes developing lateral tubercles. Body-chamber two thirds of a whorl long. Mouth-border falciform, ventral side with a forward directed process. Siphon

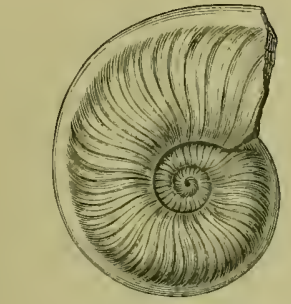

Frg. 136. - Schloenhachia Roissyana, d'Orb.

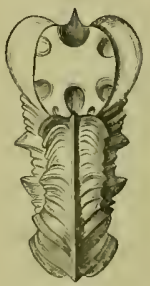

F1G. 137.-Schloenbachia cristata. Deluc.

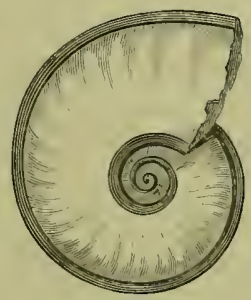

FıG. 138.-Schloenbachia Goupilanus, d'Urb.

large, mostly lodged in the high keel (fig. 13i); this genus is entirely limited to the Cretaceous rocks; figs. 136, I37, and 135 represent typical forms of the group.

\section{Family.-Tropltide, Mojs.}

Shell more or less richly ornamented, and provided with radial ribs, which almost always support tubercles or spiny processes on the border of the siphonal area. Wrinklelayer and impression on the surface of the mantle entirely wanting.

Genus Tropites, v. Mojs.-Body-chamber from one and a half to one and three quarters of a whorl in length. The strong-ribbed sculpture is interrupted upon the ventral surface, and rises as a median keel on the same. The ventral side of the mouthborder projects forward in a short broad lappet; the last whorl seldom loses the form and sculpture of the inner whorls. The lobes are characterised by a broad saddle stem with transverse incised branches, a transverse placing of the lobe points, great development of the chief lobes, and a remarkable diminution of the auxiliaries. All the species are Triassic. Ex. Tropites Pamplagus, Dittm., Trop. Saturnus, Dittm. 
Genus Trachyceras, Laube.-Body-chamber short, from one half to two thirds of a whorl in length. The sculpture interrupted on the ventral surface (fig. 140.) In

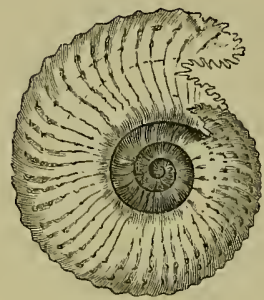

Fig. 139.

Trachyceras Aon, Münst.

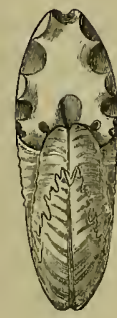

Fig. 140.

some species there is a deep median furrow, at which the ribs with their tubercles end. The mouth-border has a short ventral process. All the species are Triassic. Ex. Trachyceras Aon, Münst. (figs. 139, 140). Trach. binodosum, Hau., Trach. Attila, Mojs.

Genus Choristoceras, Hauer.-This genus is nearly allied to the preceding. The. body-chamber is short; the lobes are very slightly incised. The inner whorls have their sculpture interrupted on the ventral surface, whilst on the last whorl it extends uninterruptedly across the abdomen. The structure of the lobes shows a persistent relation to an older type, whilst in the sculpture on the ribs there is an evident inclination towards the Trachycerces type. All the species belong to the Trias formation. Ex. Choristoceras decoratum, Hauer, Chor, noricum, Mojs., Chor. nasturtium, Dittm.

Genus Rhabdoceras, Mauer.-Staff-shaped and tubular, with expanded mouth, and with a transverse ring-like sculpture and simple bent lobes; the genus is very little known, and probably connected with Choristoceras, to which it stands very near. $R$. Suessi, Haner.

Genus Cochloceras, Hauer.-The whorls are screw-shaped, with continuous ribs and simple bent lohes. This form is also near to Choristoceras; it is found in the Trias beds at Zamblach and Salzkammergut. Cochl. Fischeri, Hau.

\section{Family.-Lytoceratide, Neumayr.}

This family includes several groups which differ much from each other as regards their external form, but which nevertheless appear to have a close relationship in their 
internal structure. They are characterised by having a short body-chamber, about two thirds of a whorl in length, a simple mouth-border slightly produced on the columellar side; but in all the other features there is a wide difference of structure.

This family includes the typical groups Lytoceras and Plylloceras, and others which differ much from them in external form, as Hamites, Turrilites, and Baculites.

The Aptychus appears to be absent in this family; at least, it has not as yet been found.

Genus Lrtoceras, Sucss.-Shell discoidal, more or less flat; umbilicus large and open ; involution slight, whorls round, only slightly embracing each other around the spire. Body-chamber two thirds of a whorl in length; mouth-border simple, with intermittent contractions and prominent fimbriæ; columellar side with a lappet which rests on the preceding whorl; the ventral and lateral sides without any prolongation. The sculpture and lines of growth parallel with the mouth-border; near the spiral suture they bend a little forward. Sculpture feeble, consisting mostly of small radial lines, and intermittent contractions of the shell, with corresponding fimbriæ or prominent fringed ribs at certain intervals of growth (fig. 141). Suture line very complicated. Lobes few, much branched; lateral lobes and saddles divided into smail uniform symmetrical digitations; only two lateral lobes; and a large columellar lobe covered by the former whorl. No Aptychus has as yet been found.

This genus commences in the Trias. Lyt. Morloti, Hauer; Lyt. sphcrophyllum, Hauer; Lyt. patens, Mojs.

It is represented in the Lias formation by Lytoceras fimbriatum, Sow. (fig. 141). By Lyt. Cornucopic, Young; Lyt. Jurense, Zitt.; Lyt. hircinum, Schloth.; and Lyt. torulosum, Schübl.; Lyt. Eudesianum, d'Orb., in the Inferior Oolite. By Lyt. Adela, Lyloceras fimbrialum, Sow. d'Orb., in the Kelloway. In the Cretaceous rocks by Lyt. Duvalianum, d'Orb.; Lyt. Honoratianum, d'Orb. ; Lyt. sub-fimbriatum, d'Orb.

Dr. Waagen ${ }^{1}$ has figured and described Lytoceras rex., Waag., from the middle Oolite of Kutch, Western India, which is nearly allied to Lytoceras Eudesianum, d'Orb. ; it is a magnificent specimen $11 \frac{3}{4}$ inches in diameter, with thirty fimbriæ on its last whorl.

Genus Hamises, Parkinson.-With reference to the Cretaceous forms having a conical shell bent in one plane or more without the beuds being in contact, Professor Neumayr remarks that a spiral curve of a particnlar curvature does not give sufficient data for the establishment of a distinct genus. With this view the recognised genera Anisoceras, Ancyloceras, Baculina, Hamulina, Helicoceras, Ptychoceras, and Toxoceras, where the

'Palæontologia Indica, Jurassic Fauna of Kutch.' pl. viii, p. 36, 1875. 
curvature receives many modifications, and exists in some of the examples in more than one plane, are all suppressed, and the whole series is reduced to the single genus Hamites, which, in the primary significance of the word, implied a conical straight shell, as Hamites elegans, d'Orb. (fig. 142), bent in one plane, without the bends being in

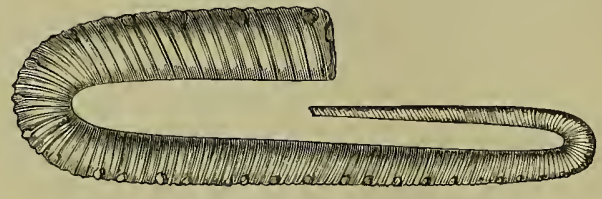

Fig. 142.-Hamites elegans, d'Orb.

contact. The suture-line is divided into six lobes; the upper lateral lobe always, the under lateral mostly, divided into pairs of branches.

Genus Turrilites, Lamarck.-Under this genus Professor Neumayr classes Helicoceras (fig. 143), with an open spiral not in one plane, and Heteroceras, with a closed spiral only in the earlier stage of growth. In Turrilites (fig. 143) the suture-line is

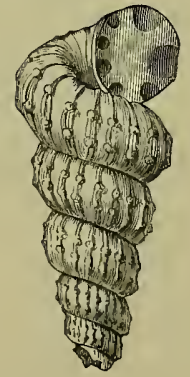

FIG. 143.-Turrilites catenatus, d'Orb.

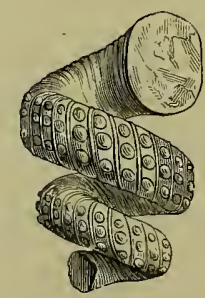

Fig. 144.-Helicoceras Robertsoni, d'Orb.

divided into six lobes, each formed of a single pair of digitations. The ventral lobe formed of a pair which are a little longer or shorter than the lateral.

Genus Bacdlites, Lamarck.-This genus connects, according to Professor Neumayr, Lytoceras with Hamites in the structure of the principal lateral lobe. Baculites (fig. 145) has a straight conical shell. Mouth oval or compressed, provided on the ventral

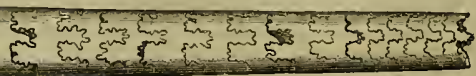


side with a projecting linguiform process and two lateral grooves which extend to the opposite side of the shell. Septa symmetrical, divided into four or six lobes each formed of a pair of digitations. The ventral lobe equals in length the adjoining principal lateral, which is longer than the lower lateral, and the columellar is small or absent.

Genus Phylloceras, Suess.-Shell discoidal, highly involute, covered with very fine striæ which describe graceful forward bent lines (fig. 147). Body-chamber short, mouthborder simple, with lateral alappets directed forward. Lobes numerous and very complicated, as many as eight or nine on each side. Saddles bladder-shaped and well rounded (fig. 148); body-chamber widely expanded and fan-shaped, with undulating radiations in Phylloceras heterophyllum, Sow.

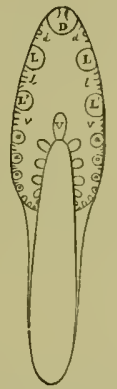

Fig. 146.-Disposition of the lobes $\left(\mathrm{D}, \mathrm{L}, \mathrm{L}^{\prime}, a\right)$ in Phylloceras heterophyllum.

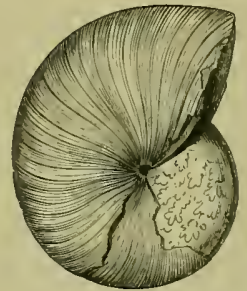

FIG. 147.-Phylloceras helerophyllum, Sow. Side view showing the lines of growth.

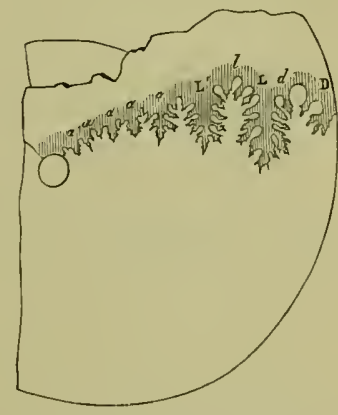

Frg. 148.-Disposition of the lobes and saddles (D, L, L', a) in Phyll. heterophyllum, Sow.

Professor Neumayr' distinguishes, from the Dogger and Malm, four groups in this genus, of which the following are types:-I. Phyll. heteroplyllum, Sow.; II. Phyll. tatricum, Pusch; III. Phyll. Capitanei, Catullo; IV. Phyll. ultramontanum, Zitt.

This genus commences in the Trias with Phyll. debile, Hauer; Phyll Neojurense, Quenst.; Phyll. despectum, Mojs.; Phyll. occultum, Mojs. In the Middle Lias Phyll. Loscombi, Sow., Phyll. Zetes, d'Orb. In the Upper Lias Phyll. heterophyllum, Sow., Phyll. subcarinatum, Young. In the Oxfordian Phyll. tatricum, Pusch., Phyll. viator, d'Orb., Phyll. Hommairei, d'Orb., Phyll. Zignoanum, d'Orb. In the Cretaceous rocks Phyll. subalpinum, d'Orb., Phyll. Velleda, d'Orb. Dr. W. Waagen has figured and described $^{2}$ several interesting species, closely allied to European forms, collected from the Upper Jurassic rocks of Kutch, Western India, by the Geological Survey of India.

1 Neumayr, "Phylloceratten des Dogger und Malm," 'Jahrbuch der Geol. Reichsanstalt,' 1871, bd. xxi.

2 'Palæontologia Indica,' pls. v, vi, vii, p. 25, 1875. 


\section{Family.-Aegoceratide, Neumayr.}

This family includes a considerable number of Ammonite groups which have widely different forms and affinities, so that it is almost impossible to give a general description of the family which shall be correct and comprehensive at the same time.

The lobes present a great variety of ramified figures; the sutnre-line is in general complicated; the siphonal lobe large, and the principal lateral and secondary laterals attain considerable dimensions.

The siphonal or ventral area is in general round and well developed; in some there is a keel with lateral channels more or less deeply grooved; in others the shell is flattened and discoidal, with a wide open umbilicus; or it is round and inflated, with highly involute whorls and a small umbilicus, sometimes nearly occluded by the last. In the presence of so much diversity in form and structure this family is subdivided into three sections :

I. Aegoceratites.-Aegoceras and Arietites.

II. Har poceratites.-Harpoceras, Oppelia, Haploceras.

III. Sitephanoceratites.-Stephanoceras, Cosmoceras, Ancyloceras, Baculina, Simoceras, Perisphinctes, Olcostephanus, Scaphites, Hoplites, Acanthoceras, Stoliczlaia, Crioceras, Heteroceras, Peltoceras, Aspidoceras.

Genus Aegoceras, Waag.-The furm of the shell in this genus is very variable; it is flat and discoidal, with a wide umbilicus, or round and involute with a small umbilicus ; in some shells the ventral side is convex and enlarged, and the sides highly ornamented with ribs, tubercles, or elongated spines; in other species the sides have simple folds or undulations, as Aeg. Jamesoni, Sow. (Pl. XI, figs. 4-6) and some are smooth,

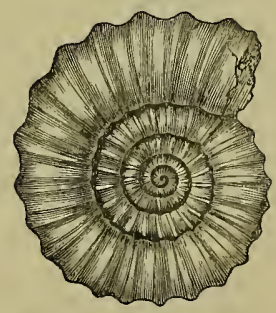

Fig. 149.-Aegoceras capricornum, Schloth.

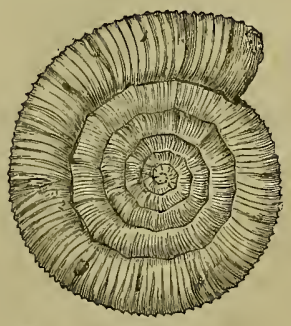

FIG. 150.-Aegoceras Davai,

as Aeg. planorbis, Sow. (Pl. XIV, figs. 1-4). The ventral side is in general round, as Aeg. capricornum, Schlot. (fig. 149), and Aeg. Davai, Sow. (fig. 150); sometimes it is grooved by a median channel, which interrupts the passage of the ribs from the right to the left side of the shell, as is especially the case in Aeg. angulatum, Schlot. (PI. XIV, 
fig. 6) and Aeg. Charmassei, d'Orb., (Pl. XX, figs. 2, 3). In all the species a keel is absent, and there are no lateral longitudinal chammels in the siphonal or ventral area.

The body-chamber varies in levgth from two thirds to an entire whorl. The mouthborder is simple; the edge has sometimes a thickened withdrawn lip and a ventral prolongation, and in Aeg. planorbis there is a contraction near the aperture (P). XIV, fig. 3), with no lateral auricles. The Anaptychus is horny, thin, and bivalved (Pl. XIV, fig. 3).

The lobe-line is much ramified, and the lobes in general are very complicated. There is a highly branched principal lateral, a smaller lower lateral, and the siphonal lobe, less than the principal lateral, ends in two divergent branches. There are several small auxiliary lobes near the suture, which are concealed by the involution of the spire, as in Aeg. Charmassei, d'Orb. (Pl. XX). This genus may be naturally divided into four sections :

First Section-PsiLonoti.

Sides smooth, or with undulated folds or straight ribs; suture-line simple; ventral area round and smooth. Aeg. planorbis, Sow.; Aeg. Jolnstoni, Sow.; Aeg. torus, d'Orb.; Aeg. intermedium, Portlock; Aeg. Belcheri, Simp.; Aeg. liassicum, d'Orb.

All these forms are found in the Planorbis zone of the Lower Lias.

Second Section-Angulati.

Sides covered with sharply flexed ribs, interrupted on the ventral area by a channel more or less developed. Aeg. angulatum, Schl.; Aeg. Charmassei, d'Orb.; Aeg. catenatum, Sow.; Aeg. lacunatum, Buck.; Aeg. Boucaultianum, d'Orb.

All these forms, the two last excepted, are from the Angulatum-zone of the Lower Lias.

\section{Third Section-Armati.}

Sides with numerous ribs, many of which develop tubercles or elongated spines; in some forms they are absent. Aeg. Davai, Sow.; Aeg. planicosta, Sow.; Aeg. Birchii, Sow.; Aeg. armatum, Sow.; Aeg. Taylori, Sow.; Aeg. densinodum, Quenst.; Aeg. brevispinum, Sow.; Aeg. Valdani, d'Orb.; Aeg. Maugenesti, d'Orb.

Aeg. planicosta and Aeg. Birchii are from the Upper Bucklandi beds of the Lower, and all the others are from the Jamesoni-zone of the Middle Lias. 


\section{Fourth Section-InvouU'r.}

Shell highly involute ; inner whorls sometimes almost entirely concealed. Shell during middle age often undergoes a great change of form, and the involution become less and the umbilicus widens. Aeg. Henleyi, Sow.; Aeg. striatum, Reinecke; Aeg. Bechei, Sow.; Aeg. curvicornum, Schloenb. ; Aeg. pettos, Quenst. ; Aeg. heterogenes, Young.

All the forms of this section are from the Henleyi zone of the Middle Lias.

This genus begins in the Muschelkalk zone of Arcestes Studeri with Aeg. incultum, Beyr., Aeg. Palmai, Mojs., and became extinct in the Middle Lias.

Genus Arietrtes, Waag.- Shell discoidal, with a wide umbilicus; the sides of the whorls covered with straight simple ribs, which often have tubercles developed on them

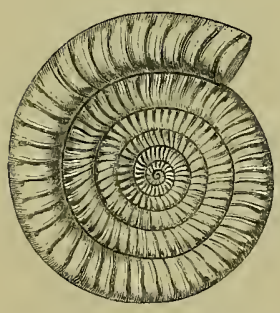

Fig. 151.-Arietites rotiformis, Sow.

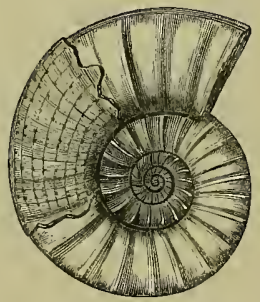

Fig. 152.-Arietites obtusus, Sow. Side.

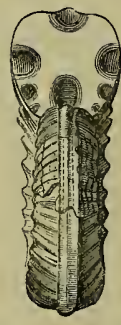

Fig. 153.-Arietites obtusus, Sow. Front.

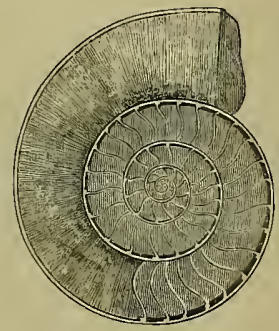

Fig. 154.-Section of Arietites oblusus, Sow.

near the ventral angle, as seen in Arietites rotiformis (fig. 151) and especially in Pl. IX. In all the species the keel is large and prominent, and accompanied by two lateral channels (fig. 153). The mouth-border is simple, scooped away on the sides, with a long, projecting, ventral process. The body-chamber is from one to one whorl and a quarter in length.

The lobes are very characteristic (Arietites bisulcatus, Brug., Pl. III, fig. 3). The siphonal lobe is nearly as deep as it is broad, and the union of its wall with the siphuncle is nearly in the middle of its depth. The principal lateral lobe does not reach to half its depth, and is sometimes as broad as it is deep. The lateral saddle rises above all the others, and stands upon the ground of the principal lateral lobe ; in general double the height of the outer saddle. The lower lateral lobe is likewise much broader than deep, and the columellar saddle is so small that it does not reach to half the height or breadth of the lateral saddle, and ends in two branches.

The Anaptyclus is thin, horny, and undivided; in some species is bell-shaped. I have found it so in Arietites semicostatus, Young and Bird; also in Ariet. stellaris, Sow. 
The genus Arietites, as long ago remarked by Leopold von Buch, is very characteristic of the Lower Lias, in which we find the following species :

Arietites Bucklandi, Sow. Pl. I.

- Bonnardii, d'Orb. Pl. XI.

- Crossii, Wright. Pl. X.

- obtusus, Sow. Pl. XXI.

- semicostatus, Simp. Pl. I.

- bisulcatus, Brug. Pl. III.

- raricostatus, Ziet. Pl. VII.
Arietites rotiformis, Sow. Pl. V.

- Sauzeanus, $d$ 'Orb. Pl. VIII.

- stellaris, Sow. Pl. XXII.

- Scipionianus, d'Orb. Pl. XIII.

- Conybeari, Sow. Pl. II.

- Brooki, Sow. PI. VI.

- Turneri, Sow. Pl. XII.

Genus Harpoceras, Waag.-The external outline of the shell is of various forms, the ventral area always keeled with a round or angular border; the sides of the whorls ornamented with elegant falciform ribs of various degrees of thickness. Mouth-border sickle-shaped, with lateral auricles, and a long, pointed, ventral process (fig. 155). Body-chamber from one half to two thirds of a whorl in length. Suture-line moderately ramified. Siphonal lobe short and bifurcate, with divergent branches, and always shorter than the principal lateral lobe,

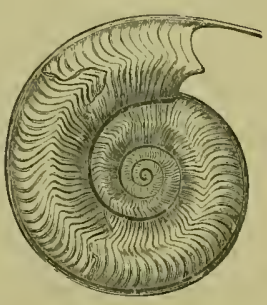

which is largely ramified. The second lateral lobe much smaller Frg. 155. - Harpoceras serpentithan the principal, and passing inwards into several auxiliaries.

The Aptychus bivalved, thin, and calcareous, with a shelly covering and several longitudinal folds, as seen in Harp. Levisoni, Simp.

Harpoceras first appears in the Middle Lias, in the zone of Aeg. Jamesoni; it attains its highest development in the Upper Lias, and is found in the Lower and Middle Jurassic rocks, disappearing in the Upper Kimmeridgian with Harp. Zio, Opp., collected from the zone of Pterocera Oceani, at Mahringen, near Ulm, Württemberg. The distribution is as follows :

Middle Lias.

Harpoceras, sp.

Normanianum, d'Orb.
Harpoceras impendens, Foung and Bird. arietiforme, $O p p$.

\section{UpPer Lias.}

Harpoceras serpentinum, Rein.

$$
\begin{array}{ll}
\text { - } & \text { Levisoni, Simp. } \\
\text { - } & \text { bifrons, Brüg. } \\
\text { - } & \text { falciferum, Sow. } \\
\text { - } & \text { Lytbense, Young. } \\
\text { - } & \text { ovatum, Young. } \\
\text { - } & \text { variabile, d'Orb. }
\end{array}
$$

Harpoceras insigne, Schübl.

$$
\begin{array}{ll}
\text { - } & \text { opalinum, Rein. } \\
\text { - } & \text { radians, Rein. } \\
\text { - } & \text { striatulum, Sow. } \\
\text { - } & \text { Aalense, Ziet. } \\
\text { - } & \text { Thouarsense, d Orb. } \\
\text { - } \quad \text { primordiale, Schloth. }
\end{array}
$$




\section{INFERIOR OOLITE.}

Harpoceras Murchisonæ, Sow.

- Tessonianum, d'Orb.
Harpoceras Sowerbyii, Mill.

Edwardianum, d'Orb.

Genus Oppelia, Waag.-Shell discoidal and highly involute; umbilicus very small; whorls much elevated. Ventral edge either more or less acute, or rounded, on different portions of its extent. Sculpture slightly falciform, with a double set of ribs on the sides. Body-chamber sometimes ribbed, neither keeled nor angular; from one half to two thirds of a whorl in length. Mouth-border falciform, sometimes with auricles, always having round external lappets. Siphuncle large, with a calcareous sheath. Aptyclus thick, calcareous, bivalved, and folded. Adductor muscles situated near the border of the shell in the lower half of the whorl. Suture-line extremely ramified. Siphonal lobe mostly shorter than the principal lateral, which is large and much branched. The second lateral is in like manner well developed, and there are several large auxiliaries between the second lateral and the umbilicus. Lobe-bodies small, with almost paraliel borders; lateral lobes unequally branched. The genus Oppelia appears first in the Lower Oolite, zone of Cosmoceras Parkinsoni, as Oppelia subradiata, Sow.; and the last representative of the group, as far as our knowledge at present extends, is in the Upper Jura of Stamberg, where a considerable number of different forms are found.

The English species of this genus are not numerous. Oppelia subradiata, Sow., from the Inferior Oolite, is a good example. Dr. Waagen has figured a number of beautiful forms of Oppelia, amounting to twelve species, from the Golden Oolite of Keera Hill, near Charee, Kutch, and other higher Oolitic Beds. "Oppelia subcostaria, Opp., closely resembles the European $O p p$. subradiata, not only in form, but even by similar varieties, as in Europe, in the same stratum" (Waagen).

Genus Haplocerras, Zittel.-The forms included in this group have been separated from the genus Oppelia, as they present certain characters in common by which they differ from the typical lines of that genus; they are all distinguished by a narrow umbilicus,

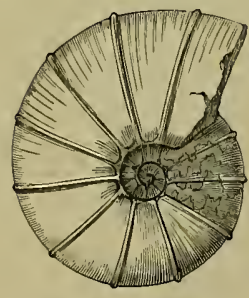

Fig. 156.-Haploceras ligatum, d'Orb. a smooth surface, marked with fine lines of growth, like Hapl. ooliticum, d'Orb., from the Inferior Oolite, with its thin undivided falciform sculpture passing round the shell. Sometimes there are a series of straight parallel ribs at intervals, as in Hapl. ligatum, fig. 156, between which a number of very fine, undivided, smaller, and thinner folds are placed. The ribs are not bifurcated in this genus, and there is neither a keel nor a channel in the siphonal area. The body-chamber is short and the structure of the Aptychus unknown. 'l'he number of the lobes is variable. In addition to the siphonal lobe and the principal and smaller laterals, 
there are from two to four auxiliaries present. The ranifications of the principal laterals are not symmetrically divided; and in the forms from the Neocomian strata the lobes have a more simple structure than in those found in the Upper Cretaceous. This genus has a very wide stratigraphical range from the Lower to the Uppermost stages of the Jurassic series, and likewise in the Neocomian and Upper Cretaceous formations.

Genus Stephanoceras, Waag.-The general form of the shell is very variable in this genus; the ventral side is in general large and round, without keel, border, or channels. The sculpture is often highly ornamental. From the suture rises a short, stout rib, which often ends in a tubercle at the middle of the side. From the tubercle two or three smaller ribs arise, which pass over the ventral surface and unite with their fellows from the opposite side. Sometimes the tubercles are wanting, and a number of fine encircling ribs make up the entire sculpture.

'The mouth-border is often provided with broad lateral lappets, which are produced and inflected, as in Stephanoceras Brackenridgii (fig. 159), where they are very conspicuous, and often well preserved.

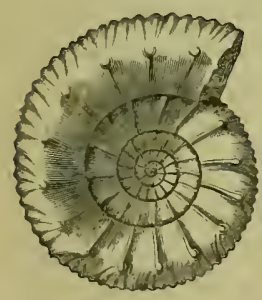

FIG. 157 .

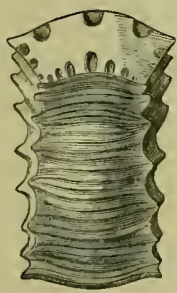

Fig. 158 ,

Slephanoceras Blagileni, Sow.

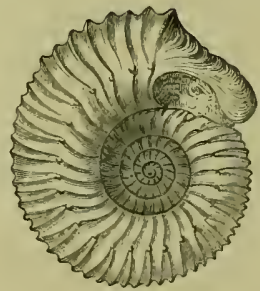

Fig. 159 Stephanoceras Brackenridgii, showing labial prolongation.

In Steph. Blagdeni (fig. 157), and Steph. Humphriesianum, the mouth is encircled by a thick band, from whence the strong ribs in these species is derived. The body-chamber is from one to one and a quarter whorls in length. The suture-line is much ramified. The siphonal and principal lateral lobes are nearly of equal length; the lower lateral is much smaller, and there are several branched auxiliaries. There is considerable diversity among the species. The genus Stephanoceras appears to have a certain family relationship with the sub-group Involuti of the genus Aegoceras of the Middle Lias. Many characteristic species appear for the first time in the Upper Lias, as Steph. annulatum, Sow. (fig. 161), and Steph.commune (fig. 162), with Steph.crassum, Steph.fibulatum, and Steph. Hollandrei, all from the same beds. The zone of Steph. Humphriesianum, Inferior Oolite, is one great depository of the species both in France and England. We have the following list therefrom : 


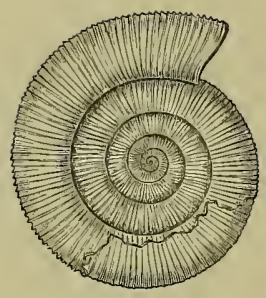

Fig. 161.-Stephanceeras annulatum Sow.

Stephanoceras Brackenridgii, Sow.

$$
\begin{array}{ll}
- & \text { Brocchi, Sow. } \\
\text { - } & \text { Brongniarti, Sow. } \\
\text { - } & \text { coronatum, Brug. } \\
\text { Blagdeni, Sow. }
\end{array}
$$

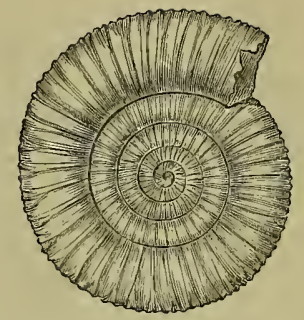

Fig. 162.-Stephanoceras commune, Sow.

Stephanoceras Deslongchampsii, d'Orb.

$\begin{array}{ll}\text { - } & \text { Gervillii, Sow. } \\ \text { - } & \text { Humphriesianum, Sow. } \\ \text { - } & \text { Sauzei, } d^{\prime} \text { Orb. } \\ & \text { linguiferum, d'Orb. }\end{array}$

The group which Stephanoceras macrocephalum, Schloth., represents, appears to stand apart from the preceding forms, for all these shells are characterised by their globose figure, arising from the extreme involution of the shell, by the narrowness of the umbilicus, with its steeply-inclined walls, and remarkable lobe-line. The siphonal lobe is extremely long, and much broader, but not longer nor extending more downward than the principal lateral ; the second lateral is smaller and reaches to the umbilical border. Such is the condition of the lobes in Stephan. modiolare, Llwyd. This group has very few species in the European rocks. They all occupy a very limited horizon, commencing with Stephan. macrocephalum in the Cornbrash of England, and from the same horizon in Germany. They are found likewise in the Kelloway Rock, and in the dark clay bed which lies above the Kelloway, and belongs to it, at the base of the Oxford clay.

The Indian species are numerous and well preserved, twenty-three species having been figured and described from the Kachh Jura of Cutch, by Dr. W. Waagen." "Of these species those identical with European forms occupy also in Kachh, as in Europe, the true 'Macrocephalus-beds.' The other species, however, range from the uppermost beds of the Pachum-group up to the Kuntkote sandstone, i.e. from the highest beds of the Bathto the uppermost beds of the Oxford-group, each of them keeping in the meantime strictly to its own layer.

"Long since it was apparent that the group of the Macrocephali was one of the most important among all the Jurassic Ammonites, not only because they characterised a welldefined horizon in the European Jurassic series, but also because very nearly allied forms had been found over the whole world ; and it was to a certain degree supposed that these also ought to signify about the same geological time, indicating for the beds in which they

$$
1 \text { 'Jurassic Cephalopoda;' “Palæontologia Indica,” p. 108, } 1875 .
$$


were enclosed, a nearly Callovian age." Dr. Waagen has found, however, that some of the Indian species range throngh the greater part of the Jurassic series, and "even reappear in the Upper Cretaceous beds."

Genus Cosmoceras, Waag.-Shell flat, discoidal; sides provided with ribs of various forms, which are all bent forward, and impart a bighly ornanental character to the shell ; spines and tubercles are often developed therefrom. The ventral edge has sometimes a smooth channel in the middle, which interrupts the course of the ribs across the siphonal area, as in Cosm. Parkinsoni, Sow., and Cosm. Garantianum, d'Orb. The body-
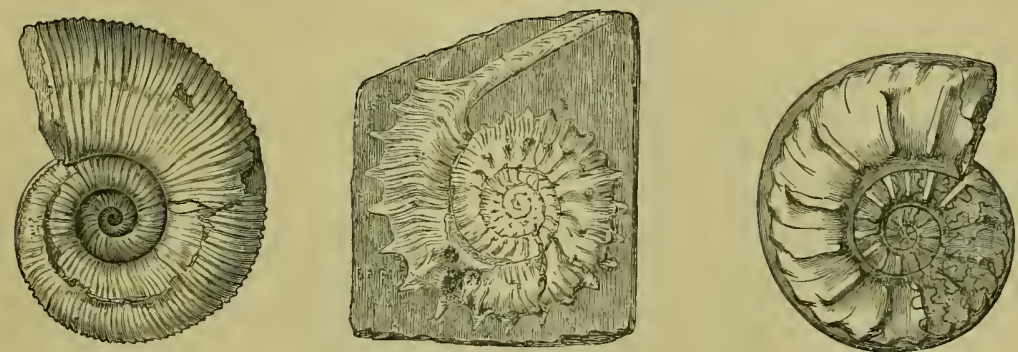

Fig. 163.-Cosmoceras Duncani, Sow. Fig. 164.-Cosmoceras Jason, Reinecke. Fig. 165.-Cosmoceras radiatum, Bruguière.

chamber is about half the length of a whorl. The mouth-border develops lateral auricles in youth, which disappear in old age. The suture-line is very much ramified. The siphonal lobe often equals, but is sometimes shorter than the principal lateral, which is large and branched; the second lateral is small, and there are several auxiliaries. The Aptychus is the same as in Stephanoceras.

This genus appears first in the upper beds of the Inferior Oolite with Cosm. Parkinsoni, Sow., and Cosm. Garantianum, d'Orb. In the Kelloway Rock and Oxford Clay are several other species, as Cosm. Calloviense, Sow., Cosm. Duncani, Sow. (fig. 163), Cosm. Koenigi, Sow., Cosm. Gowerianum, Sow., Cosm. Jason, Rein. (fig. 164), Cosm. Julii, d'Orb.; in the Chalk by Cosm. verrucosum, d'Orb., Cosm. radiatum, Brug. (fig. 165).

Genus Ancrloceras, d'Orbig.-Shell spiral, rolled on the same plane, with few whorls, all of which are disjointed and separate from each other; the last projected outwards in a lorizontal line, and then turned upwards and inwards, forming an arch opposed to the turns of the spire. 'The recurved portion without septa is the bodychamber. The mouth-border is simple, round, and thickened by a shelly eversion. The septa are transverse and symmetrical, divided into six lobes, which are very unequal in size, and formed of very ramified, elongated digitations.

This genus first appeared in the Jurassic seas; in the upper beds of the Inferior 
Oolite of France and England we find Ancyloceras annulatum, d'Orb.; in Germany Ancyl. baculatum, Quenst. ; and in the Kelloway Rock of England we have a third species, Ancyl. Calloviense, Morr. It is in the Cretaceous rocks where this genus attains its chief

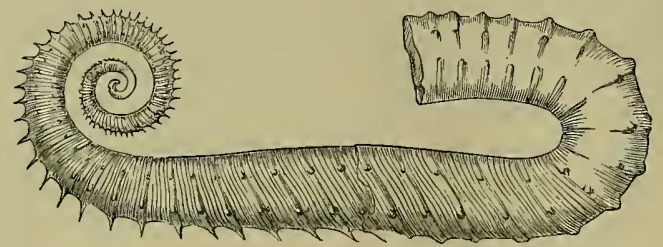

Fig. 166.-Ancyloceras Matheronianum, d'Orb.

development. Ancyloceras Matheronianum, d'Orb. (fig. 166), is from the Upper Neocomian, and Ancyloceras Puzosianum, d'Orb. (fig. 167), is from the Lower Neocomian.

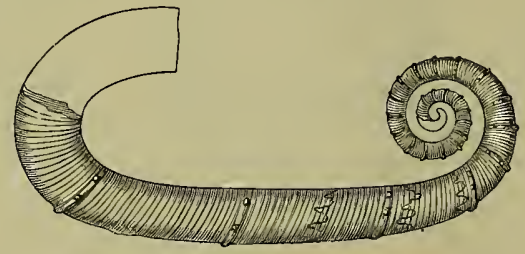

Fig. 167.-Ancyloceras Puzosianum, d'Orb.

Genus Baculina, d'Orbigny.- - Shell straight, with a surface destitute of ornamentation. Baculina resembles Baculites except in the lateral lobes being single-pointed.

Genus Perisphinctes, Waag.--Shell in general discoidal, with a wide umbilicus and a round ventral edge. The sculpture consists of straight or oblique ribs, inclined forward,

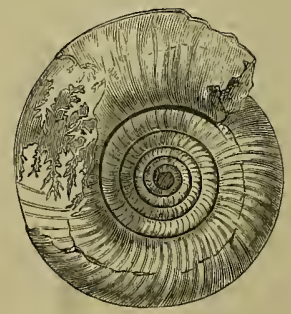

Fı. 168,-Perisplinctes Martinsii, d'Orb.

in general polytomate (much divided), and without tubercles. Mouth-border simple or with auricles; a circular contraction visible on the shell near the outlet at certain stages of 
growth. Body-chamber from two thirds to an entire whorl. Lobes similar to those in Stephanoceras, differing, however, in being more ramified, and having pendant columellar lobes. Aptychus bivalved, calcareous, very thin, and externally granular. Perisphinctes Martinsii, d'Orb. (fig. 168), from the Inferior Oolite of France and England, is geologically the oldest of this group, which is largely developed in the Middle and Upper Jurassic strata of Europe; a few species are found in the Chalk.

The genus Perisphinctes is represented in the Kachh Jura (Kutch) by more than fifty species, which can be distributed, according to Dr. W. Waagen, into six large sections, nost of which comprise several groups embedded in strata which find their equivalents in the Middle and Upper Jurassic rocks of Europe among the Kelloway, Oxford, Corallian, Kimmeridgian, and Portlandian stages.

Genus Olcostephands, Neum.-This genus was erected to receive a certain number of species that were formerly grouped with the preceding, but which are now separated from Perisplinctes. The type of this group is Olcos. Cautleyii, Opp., from the Indian Jura. Olcostephanus, in contrast with Perisphinctes, has a shorter body-chamber, two thirds of a whorl in length. Moutly-border in some has a simple smooth band, and in others lateral auricles are developed. The ribs project broadly from the border of the umbilicus, and separate on the sides into many smaller branches.

Genus ScaphITES, Park.-Shell spiral, rolled on the same plane. Whorls at first contiguous and united, then separated from the others and projected outwards in nearly

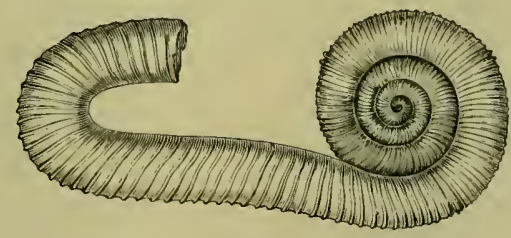

Fıs. 169,-Scaphites Ivanii, Puzos.

a straight line, afterwards turned upwards, bent round, and curved inwards, forming a kind of horse-shoe shape. The septa transverse, symmetrically and regularly divided into more than six very unequal_sized lobes, invariably composed of short bilateral ramifications ; the saddles formed of bladder-like cells. The siphonal lobe is as long as the principal lateral. The form of the inner whorls of Scaphites corresponds with those of Olcostephanus. Mouth-border round or oval, provided with large protuberant bands more or less prominent. All the species are found in the Cretaceous rocks. Scaplites gigas, Sow. 
(fig. 170). I have collected magnificent examples of this grand form, occuring in nodules, from eighteen inches to two feet long, in the Lower Greensand at Whales Chine,

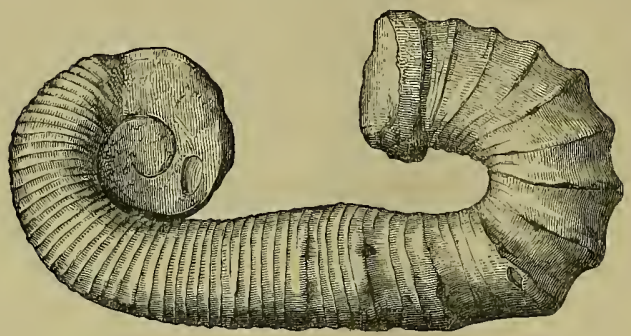

FrG. 170.-Scaphites gigas, Sowerby.

near Black-Gang, Isle of Wight. Scaphites Ivanii, Puzos (fig. 169), is from the Lower Neocomian; and Scaplites aqualis, Sow., is found in the Lower Chalk at Lewes, Sussex, and Chardstock, Somerset.

Genus Hopurres, Neum.-This genus is composed of a series of species formerly classed among Perisphinctes, but now separated as a new genus, characterised by having the shell closely involute, with high whorls and a narrow umbilicus. Sculpture consists of numerous small undulating ribs, often polytomate (fig. 171), that is, arising, by a thickened stem or tubercle, from near the umbilical suture, and soon splitting up into smaller divisions; sometimes the ribs encircle the siphonal area, or are interrupted here either by their vanishing away at the border of the area, or by a median channel, which breaks their continuity, or by a kind of crest formed by the abrupt termination

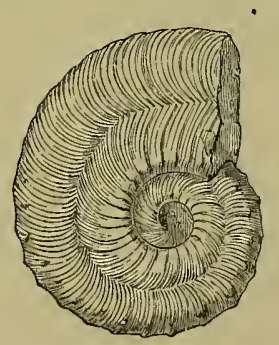

FrG. 171.

Hoplites falcatus, Mantell.

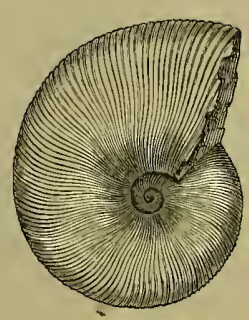

Frg. 172.

Hoplites Beaumontianus, d'Orb.

of the lateral ribs, as in IIopl. splendens, Sow.; or the lateral ribs may be folded and angular, as in Hopl.falcatus, Mant., or large and powerful, as in Hopl. interruptus, Brug. There is a considerable variety in the style of the rib-sculpture and the form it 
assumes in this genus. The moutl-border and the length of the body-chamber is at present unknown.

The lobe-line is much ramified in Hoplites interruptus, Brüg. The siphonal lobe and two principal laterals are abont the same length, with numerous branches having a symmetrical arrangement; the second lateral is much smaller, and there are several auxiliaries. In general the lobe-bodies are slender, the saddles broader than the lobes, the principal lateral is often longer than the siphonal, the second lateral very short, and there are several horizontal or oblique auxiliaries.

This genus is very characteristic of the Cretaceous period, and its highly ornamented shells form conspicuous groups in the different stages of the Chalk age.

Genus Acanthoceras, Neum.-This new group has been proposed to receive several remarkable Ammonites which were included in the genus Hoplites, a more extended study of them having induced Prof. Neumayr to separate these into a distinct genus, of which the following is a diagnosis :-The shell is wider and more massive; the umbilicus more open; the whorls moderately ligh; mouth-border and body-chamber both unknown. The sculpture consists of strong straight ribs, which proceed from the suture-line along the sides, or strong constantly increasing ribs, with a number of tubercles, which adorn the sides and border. The siphonal area presents many differences; sometimes the median line is channelled, with rows of tubercles on the border, so that the ribs are

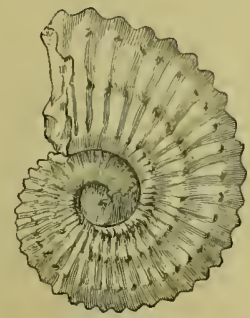

Fig. 173.

Acanthoc. laticlavium, Sharpe.

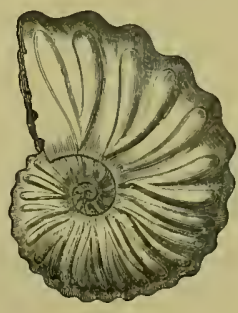

Fig. 174 .

Acanthoc. Brottianum, d'Orb.

interrupted from crossing; in other species the channel is wanting and the ribs pass across. Sometimes the tubercles arrange themselves in a series of rows, or pass along the median line and form a kind of knotted keel. The lobe-line presents considerable variety in these highly ornamented shells. The siphonal and principal lateral lobes are about the same size, sometimes the former is much larger than the latter; and the second lateral is much smaller than the first, and both terminate in single points; there are several small deep standing auxiliaries.

All the species are Cretaceous, and the following are typical forms : 
Acanthoceras Brottianum, d'Orb.

$-\quad$ Deverianum, $d^{\prime}$ Orb.
- $\quad$ mammillare, Schl.
- $\quad$ Martinii, d'Orb.

Acanthoceras Mantelli, Sow.

$\begin{array}{ll}\text { - } & \text { Rhotomagense, Brong. } \\ \text { - } \quad \text { Sussexiense, Sharp. } & \text { Woolgarei, Mant. }\end{array}$

All these species have been separated from Hoplites, and some of them have appeared under that generic name in the earlier part of this Monograph. They are, however, now placed as indicated by Neumayr in his latest work on this subject.

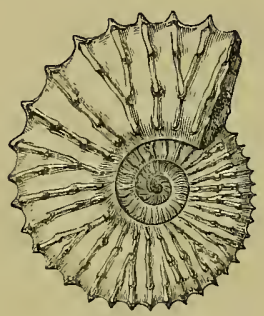

FIG. 175 . Acanth. Deverianum, d'Orb.

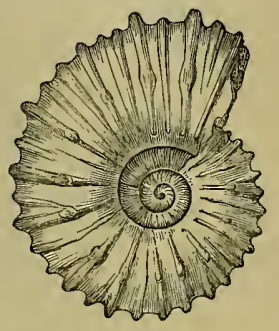

FIG. 176. Acanth. Martinii, d'Orb.

Genus Stoliczkaia, Neum., has been erected to receive a small group of remarkable Ammonites figured and described by Dr. Ferd. Stoliczka ${ }^{1}$ in his great work on the Ammonitidæ from the Chalk of Southern India, some of which were compared with Arcestes from Hallstatt. Stoliczkaia Telinga, Stol., in its external form, certainly resembles some of the gigantic Arcestes from the Alpine Triassic strata of Hallstatt in the form and smoothness of the shell, and in the constriction of the mouth-border; but in the shortness of the body-chamber, and the structure of the suture-line, it has not the most remote resemblance to the Triassic forms from the Austrian Alps, with their very characteristic suture-line, and their long body-chamber of one whor] and a half in length.

The shell is massive, highly involuted, sometimes discoidal, and then with a wider umbilicus. Body-chamber about three fourths of a whorl in length. Mouth-border undulated, produced in the middle of the lateral wall, and slightly excised towards the siphonal or ventral area. The inner whorls provided with radii, which are not interrupted on the ventral area; the ribs attain here their greatest development; the body-chamber has a smooth shell; in some species it has thickened ribs; the ventral side has neither a keel nor channels. The lobe-line is much ramified, consisting of a siphonal lobe and a principal and lower lateral on each side, with a more or less developed columellar lobe having pendant digitations.

I refer the reader to Dr. Ferd. Stoliczka's magnificent volume on the Ammonitidæ from the Cretaceous formations of Southern Iudia for remarkable types of this genus, such as : 
Stoliczkaia argonautiformis, Stol.

- crotaloides, Stol.

- dispar, d'Orb.
Stoliczkaia Telinga, Stol.

- Rudra, Stol.

- Xetra, Stol.

Genus Crioceras, Léveillé.-Shell discoidal, rolled on the same plane, whorls round, spire regular, in all ages composed of turns of the cone disjoined and entirely separate. Mouth round, oval, or compressed, formed by a slight thickening of the inner lamina of the shell. Body-chamber about two thirds the length of a whorl.

The sculpture consists of small encircling ribs, among which larger ribs or rows of tubercles are introduced at intervals; as seen in Crioceras Emerici (fig. 177) the tubercles are usually two smaller on the sides, and two larger and more thorn-like arising from the border of the siphonal area : the disjunction of the whorls extends np to first-formed coil. The lobe-line is highly ramified and consists of a large siphonal lobe, with long symmetrical branches, a principal lateral on each side with long, wide, spreading digitations, which are nearly but not quite symmetrical, a lower lateral on each side, much smaller than the principal, and a columellar lobe which is well developed. Such is the structure of the lobes in Crioceras Duvalii, Léveillé. The large Crioceras shells are found chiefly in the Neocomian strata. I have collected Crioceras Bowerbankii, Sow., from the lower Greensand of Walpen and Ladder Chines, in the Atherfield section, Isle of Wight, many of which were nearly two feet in diameter; some forms are found in the Gault of France, and the Speeton Clay of Yorkshire. This genus is limited to the Lower Cretaceous rocks.

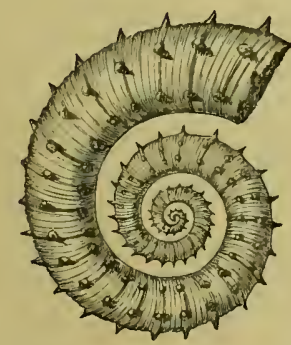

FIG. 177.-Crioceras Emerici, Léveillé.

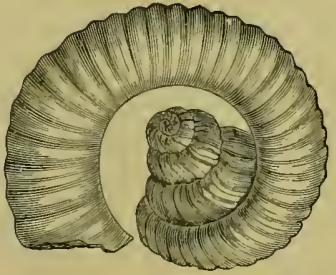

Fig. 178.-Heleroceras Emerici, d’Orb.

Genus Heteroceras, d' Orbig.-Shell spiral, turreted ; whorls in youth contiguous and joined together; in age the last whorl separates itself from the others, and becomes (fig. 178) produced and recurved, forming an arch without septa, which was doubtless the bodychamber. Heteroceras is therefore a Turrilite with the body-chamber in age detached, produced, and recurved. The most typical example is Heteroceras Emerici, d'Orb. (fig. 179). 
Genus Toxoceras, $d$ ' Orb.-Shell conical, subcylindrical, or compressed, symmetrical, elongated, more or less arched, but never forming a spiral. Sides of the shell ornamented with encircling ribs; in some forms stronger ribs are developed at intervals. Or the sculpture consists of two rows of tubercles which grow upon each side of the large ribs, and two rows of larger tubercles on the borders of the siphonal area, as shown in Toxoceras Honnoratianum (fig. 179). The mouth is round, oval, or compressed, with a prominent internal border, and the large ribs on the sides and ventral surfaces represent the different stages of growth of this bent cone. The lobe-line is very much ramified; the siphonal lobe symmetrical, the stem short, and the bifurcate branches long; the superior lateral very large and composed of nearly symmetrical branches; the lower lateral is small, the columellar lobe has considerable dimensions, and is nearly symmetrical in its structure. The affinities of this genus, regarding the structure of its lobes, is with the preceding genus Crioceras; and, like it, it is found in the lower stages of the Cretaceous rocks; all the larger specimens are obtained from the lower and upper Neocomian strata.

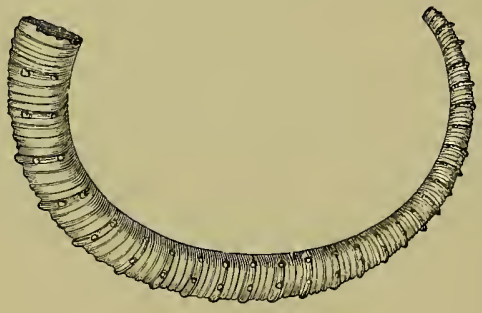

FIG. 179.-Toxoceras Honnoratianum, d'Orb.

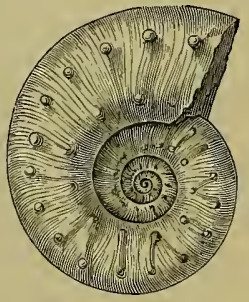

FIG. 180.-Aspidoceras longispinum, Sow.

Genus Aspidoceras, Zittel.-The form of the shell in this genus is very variable. Sometimes it is flat and discoidal with a wide umbilicus, or large, inflated, and highly involute. The siphonal or ventral area is rounded or flattened, the sides are adorned with fine ribs, and the sculpture consists of two rows of tubercles developed at intervals among the finer folds of the shell in its early age, which seem to disappear or are undeveloped in later years. The lobe-line ramifications are simple in Aspid. perarmatum, Sow. The siphonal lobe is large with symmetrical branches, the principal lateral is large and composed of numerous unequal parts, and the lower lateral is much smaller. The body of the lobes and saddles is broad, and the lobes are much slit up into branches. Aspid. longispinum, Sow. (fig. 180), from the Oxfordian of Weymouth, has a thick, discoidal, smooth shell, with two concentric rows of short spines growing upon the sides of the whorls, which are few and more than one half involute. This forms a very good type of the group. The large section of the Perarmati, with a double row of tubercles on the sides of the whorls, appears to want auxiliary lobes. In the group which has Aspid. Altenense, d'Orb., from the Corallian, for its type, one row of tubercles 
grows near the umbilicus, and the sides and ventral area are encircled by small fine undivided lines of growth.

Genus Peutoceras, Waag. - Shell flat, discoidal, with a very large umbilicus ; whorls with strong straight ribs, which are mostly provided with two or three rows of spines in adult specimens ; siphonal side more or less flattened, or even excavated, the ribs passing over it or disappearing before they reach it. Inner whorls with strong, sharp, mostly

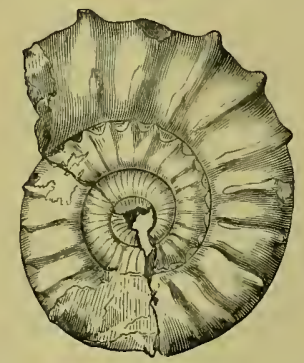

Fig. 181.-Peltoceras athleta, Phillips.

dichotomate ribs, sometimes undivided, outer whorls with strong, blunt, bi-tuberculous ribs, which pass over the siphonal area. The lobe-line highly ramified; siphonal lobe large, with symmetrical divergent branches; superior lateral widely separated from the siphonal, and forming a broad extemal saddle; lower lateral small and imperfectly developed, or even wanting; sometimes the ribs are in part replaced by spines. The amount of involution is small ; the length of the body-chamber not known; and the mouth-border has large lateral auricles developed from its sides. The range of the species is limited in this country to the Oxfordian strata.

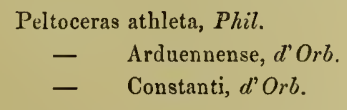

Peltoceras athleta, Phil.

- Constanti, $d^{\prime}$ Orb.

\section{Peltoceras Eugenii, Rasp. \\ - annulare, Rein. \\ - Williamsoni, Phillips.}

Some interesting forms of this group, collected by the Indian Geological Survey, have been figured and described by Dr. Waagen, ${ }^{1}$ who observes "that the general type of the shell is modified in different species in several directions, such as that the spines are entirely wanting, or the ribs nearly entirely replaced by corresponding spines; but the general type of the genus can, nevertheless, even in such forms, be easily recognised.

"There is no doubt that, if we follow up the different developmental series of the genus to their root, we are carried to some form of Perisplinctes wherefrom the genus takes 1 'Palæontologia Indica,' pp. 75-89, and Pls, XV-XVII. 
its origin; but to indicate the species which forms the connecting link between the two genera is absolutely impossible. The near affinity between Peltoceras and Perisphinctes is not only shown by the general appearance of the young specimens of species of the former genus, but also by the occurrence of the faint contractions of the shell in one or other of the Peltocerata. There are, however, yet other genera which take their rise from Perisphinctes, as Aspidoceras and Simoceras, and which are very nearly allied to our genus ; in fact, so much so that I formerly thought it necessary to unite a part of the forms generally comprised under the name of Aspidoceras, the group of Asp. perarmatum and allied species, with Peltoceras. Thus there can be no doubt from the characters exhibited by the younger stages of growth of species of both genera, Aspidoceras and Peltoceras, that the one originates from the group of Perisplinctes Martinsii, d'Orb., to which the larger number of Middle Jurassic Perisphinctes belong; the other, on the contrary, takes its origin from a group of Perisphinctes as yet apparently entirely unknown in the European or any other Jurassic strata, and perfectly distinct from the Perisph. Martinsii or Convolutus group." Dr. Waagen subdivides the genus into three sections :a. Group of Peltoceras annulare, Rein. 6. Group of Peltoceras Eugenii, Raspail. c. Group of Peltoceras athleta, Phill. Of the five species comprised in the three sections no less than two, Peltoceras Arduennense, d'Orb., and Peltoc. athleta, Phill., are identical with the old European type-forms of these well-known species in our Oxfordian strata.

Group Srmoceras, Zitt.-Shell flat, discoidal, with a wide umbilicus; ventral side rounded or channelled. Sculpture seldom absent, and consisting for the most part of straight, simple, or divergent ribs, which, in general, during the entire life of the species, or, at any rate, in youth, are unbroken on the ventral side, and abundantly provided with tubercles. They have the last whorl much swollen out; separate from the forward directed contractions observed on all the inner whorls. Body-chamber three-fourths of a whorl in length. Mouth-border in the geologically youngest forms has upward bent external auricles; in the older forms it is not known. Lobe-line not very complex; siphonal lobe the largest; external saddle very much developed and broad. Lateral lobe single-pointed and very small. This genus is found only in the upper division of the Jurassic rocks, commencing with the upper part of the Middle Jura and extending into the Lower Tithonian or Uppermost Jura. The following are the type forms :

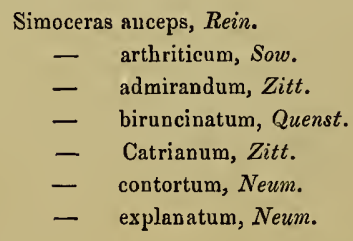

Simoceras Fraasi, $O_{p p}$.

- Greppini, $O_{p p}$.

- Jooriense, Waag.

- lytogyrum, Zitt.

- Rehmanni, Opp.

- sulcatum, Hehl.

- Venetianum, Zitt. 


\section{DESCRIPTIVE PART.}

\section{DESCRIPTION OF THE GENERA AND SPECIES OF AMMONITES.}

BeFore commencing a description of the genera and species of Ammonites figured in the plates of this work I desire to express a few thoughts by way of introduction to the study of species. First, with regard to the method I intend to pursue in the execution of this rather arduous duty, it is my intention to adopt the same lines I laid down and steadily followed in the description of the Jurassic and Cretaceous Echinodermata already published in the volumes of the Palæontographical Society.

In the systematic part of this work I have shown the student the importance of a more accurate and exhaustive study of the Ammonite shell than has hitherto been accorded to it by the majority of ordinary observers, and have proved how necessary a correct knowledge of all its essential features is in order to understand thorougbly the affinities of a species. I intend, therefore, to give a very full account of the characters of the different genera as they come in succession before us in the sequel.

The description of an old species necessarily implies a careful scrutiny of the synonyms by which it has been known and noted by former observers. This section of my work requires very careful study and much research, and should I succeed in clearing away some of the difficulties which surround the synonymy of the Ammonites I have so long studied, it will, I venture to hope, prove to be not labour in vain. The study of the Ammonite shell has shown us how very much many of these extinct Molluscs have changed their forms during the different phases of their lives, and how often species have been described and figured as new which afterwards were found to be only the transient conditions of some other well-known form. This is one of the errors that has greatly complicated the study of the synonymy of many species, and rendered the subject often so complex and difficult that we can scarcely hope to avoid errors in our attempts to unravel the true form of a doubtful species. It has only been by collecting specimens for the last thirty years which represent the young, middle-aged, and adult condition of as many species as I could obtain, that I have slowly learned how to solve some of the complex problems I have encountered, to my own satisfaction, and, I venture to hope, to that of the readers of this Monograph after my demonstrations shall have been madc; 
so that we may be able to take an onward step towards a higher and better knowledge of the natural history of these wonderful extinct polythalamons Cephalopods.

Morphology has taught us that all animals pass through certain changes of form and structure between their escape from the ovum and the period they attain their adult condition, and that the nature and extent of these changes differ in different classes, families, and genera of the animal kingdom.

In the Acalepha a most remarkable metamorphosis is observed in the Medusida, which was first described by M. Sars, ${ }^{1}$ a Norwegian naturalist, and afterwards studied in 1846 by the late Professor John Reid and myself on specimens taken in St. Andrew's Bay, N.B., which showed the marvellous changes Aurelia aurita passes through in the course of its evolution. The egg produces an ovoid embryo, which is covered with a ciliated epithelium and swims freely about for a time like an Infusorian. After some days it fixes itself by a disk, and at the upper side of the small body a depression is seen with four corners, which gradnally become elongated, and by degrees are transformed into tentacles. These rapidly multiply until the whole of the upper margin is covered with them, then transverse constrictions at regular distances apart are seen on the body stem, first appearing above, and afterwards extending downwards towards the disk. These constrictions grow deeper and deeper, and at the same time the edge of each segment begins to be serrated, so that the animal presents the appearance of a pine-cone surmounted by a tuft of tentacles. The separation goes on constantly, until at last the divisions are united only by a very slender axis, the whole resembling a pile of saucers placed one within another at a certain distance apart. The divisions are now ready for separation; the upper ring first disengages itself, and then the others follow in succession. Each separate segment now continues its morphology alone, and afterwards becomes a complete Medusa; whilst the original body-stem remains, and, it is said, produces a new colony. On this subject consult also Sir J. G. Dalyell's Memoirs.

The morphology of the Echinodermata, in the Opliuroidea, Asteroidea, and Echinoidea, has been so carefully observed by Sars, Agassiz, Professor J. Müller, Krohn, and others, that we are now well acquainted with the successive forms these Radiates pass through before they attain their adult state, changes,-in fact, so numerous and remarkable that it was only after the most ample verification by different independent observers that the conclusions first published by the late Professor J. Müller were admitted as real biological facts.

The morphology of the Arthropoda, comprising the classes Insecta, MIyriopoda, Arachnida, and Crustacea, affords abundant illustrations of the great law of change. In the Crustacea, the lower forms of Entomostraca, found in every freshwater pool, are interesting and instructive examples as microscopic objects, and Apus, Daphnia, Cyclops, and Chiroceplaculus, may be mentioned as couvenient subjects for study. The eggs of Crabs and Lobsters among marine forms, and Astacus fuviatilis from freshwater streams, afford good objects for watching the morphology of the Malacostraca.

1 Sars, 'Isis,' 1833, p. 224, taf. x, fig. 4; and 'Beskrivelser og Jagtag,' sc., p. 16, pl. iii. 


\section{THE}

\section{PALÆONTOGRAPHICAL SOCIETY.}

INSTITUTED MDCCCXLVII.

TOLUME FOR 1881.

L O N D N :

MOCCCLXXXI. 



\section{MONOGRAPH}

ON THE

\section{LIAS \\ AMMONITES}

OF

\section{THE BRITISH ISLANDS.}

BY

\section{THOMAS WRIGHT, M.D., F.R.S., F.G.S.,}

VICE.PRESIDENT OF THE PALEONTOGRAPHICAL SOCIETY; CORRESPONDING MEMBER OF THE ROYAL SOCIETY OF SCIENCES OF LIÈGE; THE SOCIETY OF NATURAL SCIENCES OF NEUCHÂTEL; VICE-PRESIDENT OF THE COTTESWOLD

NATURALISTS' FIELD CLUB; CONSULTLNG SURGEON TO THE CHFLTENHAM HOSPITAL; AND MEDICAL OFFICER OF HEALTH TO THE URBAN SANITARY DISTRICTS OF CHELTENHAM, CHARLTON KINGS, AND LECKHAMPTON.

PART FOURTH-DESCRIPTION OF SPECIES.

Pages 265-328; Plates XXII A, XXII в, XLI-XLVIII.

LONDON :

PRINTED FOR THE PALEONTOGRAPHICAL SOCIETY.

1881. 
J. E. ADLARD, BARTHOLONEW CLOSE. 
The sub-kingdom Moldusca contains a vast variety of forms, representing many degrees of perfection in the animal series. One section has no head, and another possesses that important division of the body. The headless section comprises the Molluscoida and the Acephala ; the first consisting of the classes Polyzoa, Tunicata, Brachiopoda; the second of the Lamellibranchiata. The Сернацорнова, possessing a head, includes the classes Gasteropoda, Pteropoda, and Cephalopoda.

The Polyzoa are minute animals in cells, forming colonies of chitinous or calcareous polyzoaria; each zoïd having a tentaculated mouth, a bent alimentary canal, and a nerve ganglion, in a double-walled sac. 'The embryo, leaving the egg, is locomotive for a time, and ultimately gives origin to the polypides by gemmation.

The Tunicata are soft, marine, acephalous Mollusks, with one exception, destitute of a calcareous shell, breathing by reticulate branchiæ which liue an internal sac, and having the body enveloped in an elastic tunic, more or less dense, furnished with at least two apertures. Some of the more simple forms are organically united together into social assemblages; and in one group, the Salpa, there is an alteruation of generations, solitary and colonial forms, succeeding each other in a cycle, as was long ago described by J. C. Savigny, Chamisso, and Edwards. Many of this group are likewise highly phosphorescent, the Pyrosoma, a compound form inhabiting the Atlantic Ocean, being one of the most vividly luminous animals met with in the seas. The simple forms, constituting the order Ascidiada, possess a higher organisation ; their body is enclosed in a cartilaginous tunic lined with a muscular mantle, and having the respiratory aperture surrounded by sensitive filaments, as seen in Cynthia and Phallusia. The morphology of this group has been carefully examined by Krolın, Giard, Lacaze-Duthiers, Kowalevzky; and the homology of the organs of the Tunicata, compared with those of the Polyzoa, has been studied by Allman.

The Bracliopoda are fixed bivalved animals, attached by a pedicle which passes through a hole in the beak of the larger or ventral valve, and anchors it to some submarine body ; the smaller or dorsal valve, always free and imperforate, supports on its imner surface a delicate shelly loop or spiral tube, for the attachment of the peculiar organs from which the name of the class is derived; the valves are without a hinge-ligament, and are joined by horny matter, as in the duck-bill shells, Lingula, or by tooth-like hinges as in the lamp shells, Terebratula. The mantle is a highly vascular respiratory organ, and there are usually three hearts for carrying on the circulation of the blood, the principal organ lying on the stomach, and the two accessory pumps on the mantle wall. The larvæ of the Brachiopoda are freely locomotive, and possess eyes and ear-sacs, but these organs disappear in the fixed adult state, in which the ciliated head-lobe of the embryo becomes converted into the bases of the arms, which are supported on simple shelly loops, or on complicated spiral tubes armed with processes or recurved spines. This class, which playea so important a part in the Silurian, Devonian, and Carboniferous seas, and to a less extent in those of the Jurassic and Cretaceous periods, has only a few representatives 
now living, and some of these have been carefully studied in relation to their structure and morphology by Owen, Huxley, Hancock, and Davidson, in England, and by Vogt, Fr. Müller, Lacaze-Duthiers, and Suess on the Continent, and by E. S. Morse in America.

The Lamellibranchiata are well known to us as Oysters, Mussels, Cockles, and other bivalve shells; they have a two-lobed mantle, under whose folds four lamellæ, or gills for respiration, are concealed, and the circulation is carried on by a heart. The shell consists of, with few exceptions, two valves, which correspond to the right and left sides of the body, the dorsal region being placed under the hinge; from the beak or umbo of each valve of the shell numerous concentric lines of growth running parallel with the margin can be traced; the inner differs from the outer surface by often exhibiting a mother-of-pearl lustre, the cause of difference being seen on examining with a microscope transparent sections of the shell. The development of this class has been carefully studied by Lovèn, Lacaze-Duthiers, and others, from whose observations it appears that important changes take place in the evolution of the embryo, and during the subsequent growth of the Mollusk.

The Cephalophora, or head-bearing Mollusks, comprise the Gasteropoda, Pteropoda, and Cephalopoda.

The Gasteropoda have a body with a large muscular foot extended under the abdomen, adapted for creeping, and a head supporting tentacula and simple eyes. The marine forms breathe by branchix, and the lacustrine and terrestrial genera by a pulmonary sac. The body is in general covered with a solid unilocular shell; some are naked, and others have an internal dorsal or branchial shield; the morphology of these animals has formed the subject of special studies for many observers, who have discovered the important changes that take place in this class in the different genera that formed the special objects of their investigations ; these belong, however, to a treatise on Embryology, and are too numerous and complicated to be summarised here. The memoirs by Fol, Bobretzky, Gegenbaur, Lovèn, Agassiz, and Lankester, abound with important details regarding the evolution of Gasteropoda.

The Pteropoda have the body organised for swimming, the mouth closed above, and the branchiæ external ; the shell when present is thin, unilocular, and generally inoperculate; these small, soft, floating Mollusks are entirely marine, and swim by the contractions of two lateral musculo-cutaneous fins which support the branchiæ. There appears to be a very close agreement amongst Gastropods and Pteropods in the general character of their larvæ, and the changes they pass through in subsequent stages of growth.

The Cephalopoda form the highest class, and their general structure has already been described in the systematic part of this work, where it was shown that the only existing representatives of the order Tetrabranchiata are the different varieties of Nautilus pompilius found in southern seas. The family to which this genus belongs is one of the oldest, as it can be traced through all the fossiliferous rocks down to those of Cambrian age. In the Silurian rocks we find closely allied forms, which differ from Nautitus in the degree of curvature their shell-cone assumes, as in Lituites, Gyroceras, Trochoceras; or straightness of 
shell, as in Orthoceras, Gomploceras; and in the position, structure, and mode of calcification of the siphuncle, as in Actinoceras; Huronia, Endoceras. In the Devonian and Carboniferous rocks the Ammonoida appear as Goniatites, with the edges of their septa forming angular, zigzag, transverse lines, marking the lobes and saddles; in the Muschelkalk as Ceratites, having undulating septa with denticulate borders. In the Triassic, Jurassic, and Cretaceous strata the lobes and saddles become very complicated, and the shells assume a vast variety of forms, being straight, bent, curved, turbinate, or discoidal, as seen in the various groups and genera of the Ammonitida. The morphology of the Cephalopods has been admirably described by Kölliker, and illustrated with beautiful figures; and later important observations have been made by Grenacher and Lankester "On the Embryology and Development of the Cephalopoda."

\section{Family.-AEGOCERATID $\nRightarrow,{ }^{1}$ Neunayr, 1875.}

This family includes a considerable number of Ammonite groups, which have widely different forms and affinities, so that it is almost impossible to give a general description of the family which shall be correct and comprehensive at the same time.

The lobes present a great variety of ramified figures, and the suture-line is in general complicated; the siphonal lobe is large, and the principal lateral and secondary laterals attain considerable dimensions.

The siphonal area is in general round and well developed; in some there is a keel with lateral channels more or less deeply grooved; in others the shell is flattened and discoidal with a wide open umbilicus; or it is round, and inflated, with highly involute whorls, and a small umbilicus sometimes nearly occulted by the last.

In the presence of so much diversity in form and structure this family is subdivided into three sections :

I. Aegocenatites.-Arietites, Aegoceras.

II. Harpoceratites.-Harpoceras, Oppelia, Haploceras.

III. Stephanoceratites.-Stephanoceras, Cosmoceras, Ancyloceras, Baculina, Simoceras, Perisplinctes, Olcostephanus, Scaphites, Hoplites, Acanthoceras, Stolicziaia, Crioceras, Heteroceras, Peltoceras, Aspidoceras.

Section I.-Aegoceratites.

Genus I.-Arietites, Waagen, 1869.

Family-Arietes, von Buch. Ueber die Ammoniten, p. 9, pl. iii, fig. 1, 1832.

- d'Orbigny. Paléont. franç., Ter. Crét., tom. i, p. 405, 1841.

- Pictet. Traité de Paléontologie, 2 ed., tom. ii, p. $671,1854$.

Arieten, Quenstedt. Handbuch, 2nd ed., p. 422, 1867.

1 See pages 238 and 246 of this Monograph. 

Genus-Arnicoceras, Hyatt. Fossil Cephalopoda, Bull. Mus. Camb., U.S.A., p. 73, 1868. Ophioceras, Hyatt, ibid., p. 75 ; Discoceras, Hyatt, ibid., p. 76. Coroniceras, Hyatt, ibid., p. 77 ; Asteroceras, Hyatt, ibid., p. 79.
Family-Discoceratid 2 , Hyatt, ibid., p. 73.
Genus-Arietites, Waagen. Formenreihe des A. subradiatus, Beneckes geog. pal. Beitr., Band ii, p. 247, 1869, and Palæont., Band xvii, p. 198, 1870.
- Neumayr. Zeitschrift Deut. geolog. Gesell., Band xxvii, p. 906, 1875.

Shell discoidal, with a wide umbilicus. The sides of the whorls covered with straight simple ribs, which often have tubercles developed on them near the ventral angle, as seen in Arietites rotiformis, fig. 182, and still better shown in Pl. IX, figs. 1, 2. In all the species the keel is large and prominent, and accompanied by two lateral channels (fig. 184). The mouth-border is simple, scooped away on the sides, and furnished with a long, projecting ventral process. The body-chamber is from one to one whorl and a quarter in length.

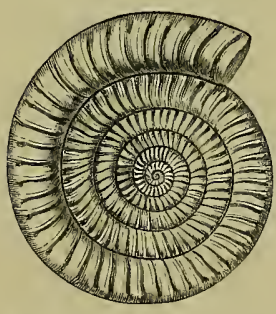

FIG.182.-Arietites rotiformis, Sow. Side.

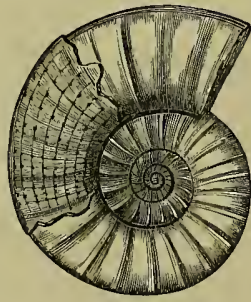

Fr't. 183.-Arietites obtusus, Fra. 184.-Arietites Sow. Side.

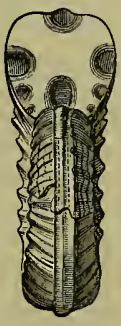

obtusus, Sow. Front.

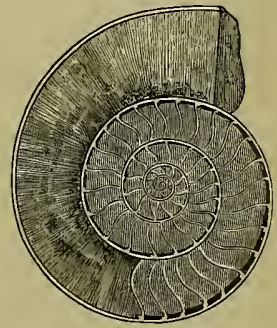

FIG. 185.-Section of Arietites obtusus, Sow.

The lobes are very characteristic (see Arietites bisulcatus, Bruguière, Plate III, fig. 3). The siphonal lobe is nearly as deep as it is broad, and the point of its adhesion to the siphuncle is nearly in the middle of its depth. The principal lateral lobe does not reach to half its depth, and is sometimes as broad as it is deep. The lateral saddle rises above all the others and stands upon the ground of the principal lateral lobe, in general double the height of the siphonal saddle. The lower lateral lobe is likewise much broader than deep, and the columellar saddle is so small that it does not reach to half the height or breadth of the lateral saddle and ends in two branches.

The genus Arietites is readily distinguished from the other genera of the AEgoceraTIDж. Its closest affinities are with Harpoceras and Amaltheus. It differs from Harpoceras in the absence of bent, sickle-shaped ribs, the short body-chamber, the different figuring of the lobe-line, and the want of a bivalved calcareous Aptychus. It differs from Amaltheus in possessing a long body-chamber. In Amaltheus it is short, from two-thirds to one-half of a whorl in length. The mouth-border is likewise simple, the ventral portion ending in.a long projecting process. The lobe-line is moreover 
extremely ramified in Amaltheus, and the siphonal lobe is shorter than the principal lateral lobe, which is mostly broad and wedge-shaped. These characters form a good diagnosis for this genus.

The Anaptyclus is, thin, horny and undivided; in some species it is bell-shaped. I have found Anaptychi in the body-chamber of Arietites stellaris, Sow., and of Arietites semicostatus, Young and Bird, where it exhibited these characters.

The distribution of this genus is limited to the Lower Lias; and its various species characterise the different zones of life in which they are found, a fact which was well known to, and clearly pointed out by, Leopold von Buch, in his classical memoir, " Ceber die Ammoniten in den älteren Gebirgs-Schichten" (1830).

Arietites Bucklandi, Sowerby. Pl. I, figs. 1-3.

Ammonis corve,

Lister. Animal. Angliæ, tab. vi, fig. 1, p. 207, 1678.

- - - striatum striss integris (pars), Lang. Historia Lap. fig. Helvetiæ, tab. xxiv, fig. 1, p. 95, 1708 .

Ammonites BISULCata,

- Buckland,

- ARIETES,

Planites bisuloatus, Ammonites Buckland,

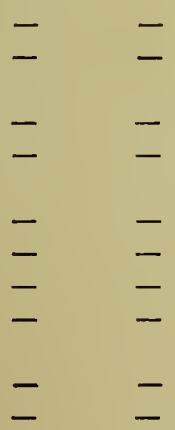

- Bisulcatus

- BuckLand,

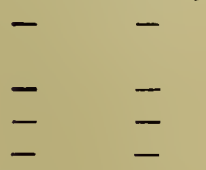

Bruguière. Encyclopédie Méthodique, tom. i, p. 39, 1792.

Sowerby. Min. Conch., vol. ii, p. 69, tab. cxxx, 1816.

Schlotheim. Petrefactenkunde, p. 62, No. 4, 1820.

de Haan. Monogr. Ammonit. et Goniatit., p. 91, 1825.

von. Buch. Physik. Abhandl. Akad. Berlin, über Ammo. niten, p. 142, tab. iii, fig. 1, 1832 (read 1830).

Zieten. Verstein. Württemb., p. 35, tab. xxvii, fig. 1, 1830.

Deshayes. Coquilles charac. des Terrains, p. 240, pl. x, fig. 2, 1831.

Bronn. Lethaea Geognostica. i, p. 421, tab. 22, fig. 1, 1833.

Mandelsloh. Constit. Geogn. AJp. Württemberg., fig. 33, 1835.

Römer. Norddeutsch. Oolithen-Gebirg., p. 182, 1836.

Buckland. Geol. and Min., ii, p. 59, tab. 37, fig. 6, 1836.

Quenstedt. Flözgebirge Württemberg., p. 131, 1843.

Simpson. Monogr. of Lias Ammonites, Yorkshire, p. 52, 1843.

Quenstedt. Petref. Deutsch. Cephalopoden, p. 76, 1846.

Quenstedt. Handbuch der Petrefactenkunde, p. 354, 1852.

Chapuis et Dewalque. Terr. Second. de Luxembourg, p. 42, pl. $\mathbf{v}$, fig. $3,1853$.

Studer. Geologie der Schweiz, Band ii, p. 234, 1853.

Simpson. Monogr. of Yorkshire Fossils, Yorkshire, p. 97, 1855.

Oppel. Die Juraformation, p. 76, 1856.

Quenstedt. Der Jura, p. 67, pl. vii, fig. 3, 1858.

Dumortier. Dépots Jurassiques du Bassin du Rhône, tom. ii, p. 19, 1867.

Arietites - Tate $\&$ Blake. Yorkshire Lias, p. 283, pl. v, fig. 2, 1876. 
Diagnosis.-Shell discoidal, depressed; whorls slightly involute; sides convex and largely costated; ribs thick, bent, remote, twenty-four in a whorl; back flat, strongly carinated, with a deep furrow on each side of the keel ; aperture quadrato-hemispherical.

Dimensions.-Transverse diameter of figured specimen, 230 millimètres; height of the last whorl at the aperture 65 millimètres; width 75 millimètres; whorls about one fifth involute. Many of the large specimens from Keynsham measure 18 inches in diameter.

Description.-This Ammonite attains a gigantic size, it has a flattened discoidal shell, formed of six or seven slightly involute whorls, having the inner ones largely exposed; their sides are convex, sub-cylindrical, and separated by a deep suture, having strong prominent ribs, from twenty-four to thirty-two in a whorl, which are sharp, distant, simple, arched, and terminate abruptly near the border where they are interrupted; the siphonal area forms a broad flattened arch, and the middle line is occupied by a strong thick keel, bounded on each side by a deep furrow; the aperture is rounded or subquadrangular.

The septa are symmetrical, divided on each side into three lobes and three saddles formed of unequal parts. The siphonal lobe is narrow, one third longer, and a little wider than the principal-lateral lobe, and has on each side five nearly equal-sized serrated digitations (Pl. I, fig. 3).

The siplional saddle, one fourth wider than the principal-lateral lobe, is divided into seven leaves of unequal size. The principal-lateral lobe, a little longer than wide, has on each side three elongated foliated digitations. The lateral saddle, twice the size of the principal lateral lobe, is formed of eight or nine subdivided lobules. The infero-lateral lobe, smaller than the principal-lateral, has four external and three internal digitations. The auxitiary saddle is small, with five small lobules. The auxiliary lobe is small, with three digitations.

Affinities and Differences.-This species was first described by M. Bruguière in the 'Encyclopédie Méthodique,' tom. i, p. 39, under the name Ammonites bisulcata. The diagnosis included two forms-(A) Ammonites Bucllandi, Sow.; and (B) Ammonites multicostatus, Sow.

(A) "Ammonites costis simplicibus raris, dorso bisulcato carina acuta intermedia." Brug.

(B) "Ammonis cornu spina in ambitu eminente, striis lateralibus ex toto orbem valde extimum trajicentibus." Lister.

The variety $\mathbf{A}$ had been previously figured by Lang in his "Historia Lapidum figuratorum Helvetiæ,' p. 95, tab. xxiv, fig. 1, and described as "Ammonis cornu striatum valde striis integris in spinam inter duos sulcos eminentem abeuntibus."

I propose to retain Sowerby's name for var. A, and Bruguière's name, bisulcata, for var. B, as the forms are very distinct and readily distinguished from each other. A. multicostatus, Sow., will then be a synonym of $A$. bisulcatus, Brug.

Arietites Bucklandi has twenty-four to thirty-two ribs, which gradually disappear on the outer border, without tubercles near the angle of the sulci. 
Arietites bisulcatus has a quadrate angular form, with from forty-four to fifty ribs, with a tubercle on each near the angle of the siphonal border, from whence they curve forward into the sulcus.

There is no other form in the Lower Lias for which Arietites Bucklandi can be mistaken.

Locality and Stratigraphical Position.-Arietites Bucklandi characterises an important zone of life in the English Lias, the stratigraphical relations of which are best exposed in the magnificent coast section near Lyme Regis. I have collected this Ammonite at Fretherne Cliffs, on the banks of the Severn, and fragments of it from the Lower-Lias Limestones in the counties of Glamorgan, Somerset, Gloucester, Worcester, and Warwick, and from the same formation where it is worked at Scunthorpe in the north-west of Lincolnshire; and also where it is exposed at Redcar, and Robin Hood's Bay, on the Yorkshire Coast. The finest specimens I have obtained were found on the coast near Lyme Regis, and in the Great Western railway cutting, in the Lower Lias, at Salford, near Bath. Several fine specimens are preserved in the collection of the British Museum.

Foreign Distribution.-The two varieties of this Ammonite have a very wide range in space, and form conspicuous leading fossils in the horizon they characterise. In France it has been collected at Saint Rambert, Ain; Paillet, Mont-d'Or, Saint Fortunat près de Lyon, Rhone; Avallon, Yomne; Sémur, Côte-d'Or; Salins, Jura; Pouilly-sousCharlieu, Loire ; Fontenay, Vendée, Moselle.

In North Germany this species has been found at Orsleben and near Harzburg, at Solenhai, near Leibenburg, and Falkenhagen, near Rischenan, and several other localities, by Ewald, Strombeck, and Schlönbach.

In South Germany very fine large specimens of this Ammonite, nearly identical with the large examples found near Bath, are found in Würtemburg, Swabia, and Baden, and are preserved in the Museums of Sémur, Stuttgart, and Tübingen.

In Austria it is found in the north-eastern Alps, associated with other leading fossils appertaining to the same zone. La Spezzia, Tuscany (Pilla).

In Luxembourg this species is collected from the "Grès de Luxembourg."

I beg to refer the reader to the detailed sections I have given of the Bucklandi-beds at Saltford (pp. 36 and 37), and at Broad Ledge on the shore of Lyme Regis (pp. 38 and 39), as the best examples I at present know of the stratigraphical position and relation of this Life-horizon in the British Islands.

In describing this Ammonite Mr. James Sowerby remarks :- "Found in the Blue Lias of Bath and the neighbourhood, measuring from a foot to twenty-one inches or more in diameter, and rather remarkable for having frequently lost the inner whorls; which circumstance, by a sort of friendly pun, has given rise to the name given to it in honour of a meritorious and enlightened geologist, the Rev. W. Buckland, who, having found a large specimen, was induced by his ardour to carry it himself, althongh of considerable 
weight, and, being on horseback, it was not the less inconvenient; but the inner whorls being gone so as to allow his head and shoulder to pass through, he placed it as a French horn is sometimes carried, above one shoulder and under the other, and thus rode with his friendly companions, who amused him by dubbing him an 'Ammon Knight." "'

Arietites Conybeari, Sowerby. Pl. II, figs. 1, 2, 3.

Lister. Animal. Angliæ, p. 206, tab. vi, fig. 2, 1678.

- Synopsis Conchyliorum, tab. 1039, fig. 18; tab. 1041, fig. 20, 1692.

Ammonis cornd, striatum, strits integris (pars), Lang. Hist. Lap. fig. Helv., tab. xxiv, p. 95,1708 .

Ammonites Conybeari, Sowerby. Mineral Conchology, vol. ii, p. 70, tab. 131, 1816.

- Schlotheim. Petrefactenkunde, p. 62, Gotha, 1822.
Planites Conybeari,

Ammonites - Phillips. Geology of the Yorkshire Coast, p. 164, pl. xiii, fig. 5, 1829.

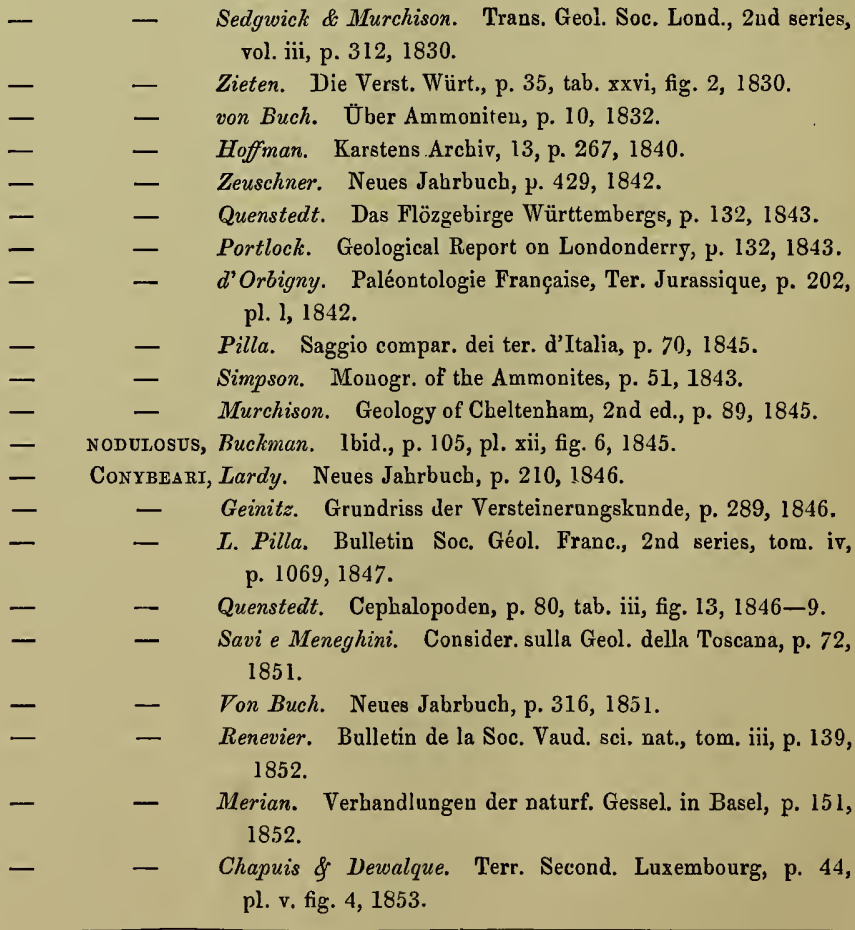

1. 'Mineral Conchology,' vol. ii, p. 69, 1818. 


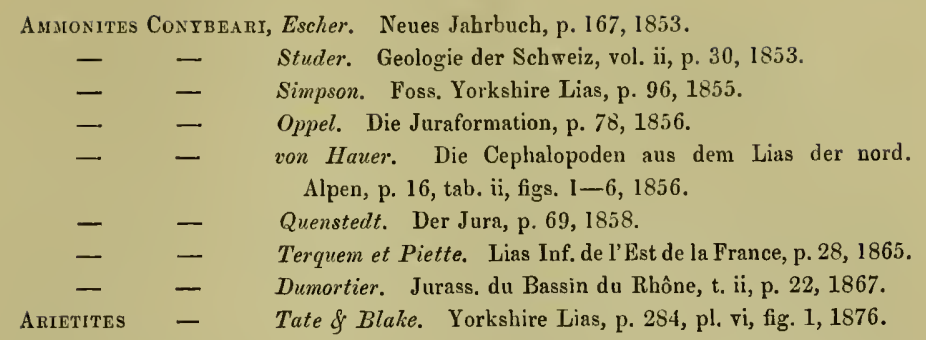

Diagnosis.-Shell discoidal, much compressed; back tricarinated; whorls numerous, eight to ten, slightly involute and numerously ribbed; in adults ribs from forty to sixty in a whorl, small, round, obliquely arcuate, and interrupted, terminating at the onter carinæ; back ronnded, with a large prominent obtuse keel, bounded by two deep sulci and two external lateral carinæ; aperture oblong, nearly quadrate.

Dimensions.-Transverse diameter of figured specimen 340 millimètres; height of aperture 60 millimètres; width of aperture 68 millimètres. A specimen measured by Professor Hauer was 90 millimètres in diameter; height of the last whorl $\frac{22}{100}$; width $\frac{23}{100}$; diameter of the umbilicus $\frac{60}{100}$ of the diameter of the shell.

Description.-This is one of the most characteristic and widely distributed species of the zone of Arietites Bucklandi, as shown by the table of synonyms prefixed to this article. Its form in general is very persistent, and its specific characters are subject to fewer variations than in most of the congeneric species. The specimen $I$ have figured was obtained from the same locality as the type drawn by Sowerby, namely, the Bucklandibeds of Salford, near Bath, from cuttings made during the formation of the Great Western Railway. Another very fine large typical example, which formerly belonged to me, collected at the same time and from the same locality, is now in the British Museum. "It measures 18 inches in greatest diameter, and 4 inches in thickness across its last chamber; eight whorls are capable of being counted, but the innermost portion cannot be made out." Dr. Henry Woodward, F.R.S., has kindly given me these measurements.

The adult shell consists of from eight to ten slightly involute whorls, about the width of their height ; the inner whorls are nearly all entirely exposed, the turn of the spire only concealing a portion of the margin. The sides are convex and costated. The ribs are simple, narrow, obtuse, and slightly arched, and disappear at the ontside of the lateral carinæ, near the dorsal sulci; they are numerous, and increase with the diameter of the shell; in the specimen I have figured there are sixty-eight ribs in the outer whorl; in general terms the number may be said to range from forty to sixty.

The siphonal area is broad and provided with a large obtuse prominent keel; on each side thereof is a deep sulcus bounded by an outer carina, so that the siphonal area of this shell is tricarinated with two sulci between. 
The spire is composed of from eight to ten whorls, with convex costated sides, nearly all fully exposed; the outer whorl has a strongly developed tricarinate area.

Mouth-aperture nearly quadrate, with rounded angles. The septa, according to d'Orbigny, are symmetrical, foliated on each side, and divided into two or three lobes formed of nearly equal branches. The siphonal lobe is much longer and as wide as the principal lateral lobe, formed of a single narrow branch with four double digitations. Siphonal saddle much larger than the principal lateral lobe, and unequally divided by an accessory lobe (Pl. II, fig. 3). Principal lateral lobe formed nearly of symmetrical parts, the external branch sometimes provided with acute elongated digitations. Lateral saddle narrow, irregular and oblique. Inferior lateral lobe provided with two unequal branches. Sometimes there is a small auxiliary lobe. A line extended from the extremity of the dorsal lobe to the centre cuts three branches of the principal lateral, and passes above the three auxiliary lobes.

The following important observations were made by the late M. d'Orbigny, ${ }^{1}$ on the development of $A$. Conybeari:

"This species is smooth only up to the diameter of 2 millimètres-rarely it remains so up to 3 . It afterwards develops ribs similar to those of adult age, and has a small keel without lateral sulci; at the diameter of 12 millimètres it has often thirty-six ribs; at the diameter of 19 millimètres forty-six. In others this number is less, and that upon the less compressed specimens with large whorls. Upon these, for example, at the diameter 55 millimètres, there exists only thirty-five to forty ribs; upon individuals of 100 millimètres to 198 millimètres there were sixty-six ribs. In all the cases the lateral sulci on each side of the keel were not developed on the specimens observed up to the diameter of 30 millimètres. These differences in the number of the ribs, and in their proximity or separation, seem to appertain to the sexes, the shells with numerous ribs being probably those of the males. The lobes from early age have very nearly the same form. From the examination of a very large specimen it appears that the ribs disappear in extreme old age."

Affinities and Differences.-This species resembles A. Kridion, Hehl., from the Lower Lias, and figured in Zieten's 'Versteinerungen Württembergs,' tab. iii, fig. 2, and in d'Orbigny, 'Paléontologie Française,' Ter. Jur., tab. xxi, figs. 1-6. It is distinguished, however, from $A$. Conybeari by having fewer ribs, and these being more sharp and straight, and terminating in a prominent process near the back; the keel is more acute, and there are neither lateral sulci nor carinæ; the siphonal and lateral saddles have likewise a different form, and the phases of development of $A$. Kridion, according to d'Orbigny, are very different from those of $A$. Conybeari, the shell of the former remaining much longer in the embryonic state without ribs.

Locality and Stratigraphical Position.-This is a very characteristic shell of the Lower Lias. I have collected it from the Zone of Arietites Bucklandi in the deep 1 'Paléontologie Française, Ter. Jurassique,' tom. i, p. 204. 
cuttings of the Bristol and Birmingham Railway near Bredon, at Fretherne-on-Severn, Coombe Hill, Purtoul-on-Severn, ${ }^{1}$ and several other localities in Gloucestershire ; Weston, near Bath; Saltford, near Bristol; Lyme Regis, Dorsetshire; and Robin Hood's Bay, Yorkshire.

Foreign Localities.-It characterises the Lower Lias in the Zone of Gryphaca arcuata in many Departments in France, as Cher, Jura, Ain, Meurthe, and Cote-d'Or ; in Swabia It is collected at Vaihingen, Möhringen, Bebenhausen, and Nürtingen : for the other countries in Europe in which it is found the reader is referred to the table of synonyms.

History.-First figured by Sowerby, afterwards by Zieten, d'Orbigny, von Hauer, and Buckland. Their Plates are all good, and leave but little to be desired.

Arietites bisulcatus, Bruguière. PIs. III and IV.

Robert Plot's Natural History of Oxfordshire, tab. 5, fig. 14, p. 110, 1677.

Martin Lister. Historia Angliæ, de Lapidibus turbinatis, tab. vi, fig. 3, p. 207, 1678.

Bourguet. Traité des Pétrefications, pl. 41, No. 270, 1742.

Ammonites bisulcata, Bruguière (pars). Encyclopéd. Méthod., t. i, p. 39, No. 13, 1792.

- Mulricosrata, Sowerby. Mineral Conchology, vol. v, p. 76, tab. 454, 1824.

Zieten. Versteinerungen Württembergs, p. 35, tab. xxvi, fig. $3,1830$.

- Bisulcatus, d'Orbigny. Paléontologie Française, Ter. Jur., p. 187, pl. xliii, 1842.

- Multicostatus, Quenstedt. Die Cephalopoden, p. 80, 1846-9.

- - Quenstedt. Handbuch der Petrefactenkunde, p. 355, 1852.

- Bisulcatus, Chapuis et Dewalque. Foss. Terr. Second. Luxembourg, p. 42, pl, v, fig. 3, 1853.

von Hauer. Die Cephalopoden aus dem Lias Nordöst. Alpen, p. 14, pl. i, figs. 3, 4, 1856.

Oppel. Die Juraformation, p. 77, 1856.

- $\quad$ - Terquem et Piette. Lias Inf. de l'Est de la France,p. 26, 1865.

- Bisulcatus, Dumortier. Dépots Jurass. du Basin du Rhône, tom. ii, p. 20 , pl. iii, figs. $1-3,1867$.

ARIETites - Tate $\&$ Blake. Yorkshire Lias, p. 283, 1876.

Diagnosis.-Shell depressed, discoidal ; siphonal area tricarinated ; whorls subquadrate, with thirty to forty strong, sharp, bent ribs, having a tubercle near the siphonal margin of each; median keel strong, with two sulci and two lateral carinæ; aperture subquadrate, bisinuated anteriorly; lateral septa with three lobes.

1 'Proceedings of the Cotteswold Club for 1863,' p. 135. 
Dimensions.-Transverse diameter of specimen figured on Pl. III, fig. 1, 200 millimètres ; height of aperture 70 millimètres ; width of aperture 64 millimètres.

Description.-The table of synonyms prefixed to this article is very limited when compared with the lists given in the works of Professors d'Orbigny and von Hauer; it is due, therefore, to the reader that I should give my reasons for excluding many of the citations of my contemporaries. In the description of Arietites Bucklandi, Sow., ${ }^{1}$ at p. 270, I have stated that M. Bruguière described, under the name of Ammonites bisulcata, two distinct forms-(A) Ammonites Bucklandi, Sow., and (в) Ammonites multicostatus, Sow.

The variety a had been previously figured by Martin Lister in his 'Conchyl. Angliæ,' p. 207, tab. 6, fig. 3 ; and by Lang in his 'Historia Lapidum Figuratorum Helvetiæ,' tab. 24, fig. 1. The variety B was included in Bruguière's general diagnosis of Ammonites bisulcata, and most authors have followed Bruguière in grouping both forms under one specific name. I am inclined, however, to think that Sowerby was right when he figured the two forms under distinct names. M. d'Orbigny and Professor von Hauer, in their works already cited, have figured good type forms of $A$. multicostatus, Sow. I assume that this is the recognised type of Bruguière's A. bisulcata in France and Germany, whereas the true $A$. Bucklandi, Sow., is seldom figured in any work on Lower-Lias fossils. I have, therefore, determined to retain Bruguière's name for his var. B, and Sowerby's name for var. A (see p. 270). In accordance with this view I have excluded all references to the synonyms of authors, unless $I$ had a figure or a specimen for my guide, to determine the form referred to in the citation; this mode of proceeding has necessarily diminished the list, but makes it more correct for reference.

Arietites bisulcatus has a depressed discoidal shell, with a strongly tricarinated siphonal area and subquadrate whorls. The sides are provided with from thirty to forty simple, narrow, slightly-bent ribs, each terminating in a blunt tubercle, near the siphonal border. From the tubercle the rib bends sharply forwards, and disappears at the outer carinæ. The area is flat and tricarinated, the median keel a little more prominent than the laterals, and the two sulci, although well marked, are not very deep in the specimens I have examined; the lateral carinæ are well defined; the shell is bevelled off from the ridge to the row of tubercles, and presents a series of oblique undulations occasioned by the vanishing of the ribs. The spire is composed of subquadrate whorls; in a specimen, $5 \frac{3}{4}$ inches in diameter, there are six whorls visible; on the outer whorl are thirty-seven ribs; on the second, thirty; on the third, twenty-nine; on the second, twenty-five; so that in this example the number of ribs increases with the number of the whorls. The aperture is quadrate, rather higher than wide, a little enlarged at the spire, and sinuous above, where it is marked by the central keel, the sulci, and lateral carinæ. (Pl. III and IV.)

The septa are symmetrical, foliated on each side, and divided into three lobes, and three saddles formed of unequal parts (Pl. III, figs. 1, 2, 3; Pl. IV, fig. 4). Siphonal 
lobe narrow, one third longer and a little wider than the principal lateral lobe, having on each side five slightly unequal digitations. Siphonal saddle one fourth wider than the principal lateral lobe, and divided into three unequal parts by two unequal accessory lobes. Priucipal lateral lobe, a little longer than wide, has three foliated branches on each side. Lateral saddle nearly double the width of the principal lateral lobe, and divided into many unequal lobules. Inferior lateral lobe nearly as wide as the principal lateral, and divided into numerous unequal digitations. Auxiliary saddle half the size of the principal lateral lobe, divided into several unequal folioles. Auxiliary lobe narrow, descending much lower than the others, and formed of two branches, the one external and the other inferior.

Affintics and Differences.-This Ammonite strongly resembles A. Bucklandi, Sow.; it is distinguished, however, by having the whorls more quadrate, and the general form more angular; the forty to fifty ribs have each a tubercle near the outer border, from whence they curve sharply forwards towards the sulcus. In $A$. Bucklandi there are about twenty-four ribs, which gradually disappear on the siphonal area, and there are no tubercles near the angle of the sulcus. It is distinguished from $A$. obtusus, to which it has a general resemblance, by having narrower whorls, tuberculated ribs, and a much flatter siphonal area.

Locality and Stratigraphical Position.-This species has been found in the Zone of Arietiles Bucklandi (Lower Lias) near Lyme Regis and Charmouth, on the coast of Dorset; at Weston near Bath; in the cleep cuttings of the Bristol and Birmingham Railway, near Defford, Bredon, Cheltenham, and Gloucester, Coombe Hill, Highnam, and Berkeley, and in other localities in the Vale of Gloucester. The Warwick Museum contains some five specimens from the Lima-beds of the Lower Lias in Warwickshire; and my late friend, Mr. John Leckenby, F.G.S., had several fine shells of this species collected from the Lower Lias at Robin Hood's Bay, on the coast of Yorkshire, which are now in the Woodwardian Museum, Cambridge.

Foreign Localities.-Germany-in Swabia and Württemberg (according to Professors Quenstedt and Oppel), it is abundant in the Bucklandi-beds of Bodelshausen, Vaihingen, Möhringen, and Gmünd. The Museums of Stuttgart and Tübingen contain many fine examples. In France from the same zone in the vicinity of Metz, (Moselle); and Avallon, (Yomne). The Museum of Sémur, Côte-d'Or; contains many fine shells from the Lower Lias near that town.

History.-The history of this species is curious and instructive ; towards the end of the seventeenth century it was fignred by Plot and Lister in this country, and by Lang and Bourguet on the Continent. In 1787, it was first correctly described in the 'Encyclopédie Méthodique' by M. Bruguière as $A$. bisulcata; he recognised two distinct forms, one with few ribs without tubercles, the other with numerous ribs having a tubercle on each. Sowerby, in his 'Mineral Conchology,' in 1818, figured the former as A. Buclitandi, the latter, in 18:24, as Ammonites multicostata. Unfortunately this author entirely overlooked the excellent work previously published on Ammonites by 
M. Bruguière. In 1830 , Zieten figured as $A$. multicostata a good type specimen from the Lias Limestone of Altingen, near Tuttlingen, so that Bruguière's specific name was nearly forgotten, when Prof. A. d'Orbigny, in his 'Paléontologie Française,' in 1844, gave an excellent historical account of the species; this author, however, confused $A$. Bucklandi, Sow., with $A$. bisulcatus, Brug., an error which I have endeavoured to rectify in my description of these two forms.

Arıetites rotiformis, Sowerby. (Pl. V, figs. 1-4; Pl. VII, fig. 1 ; Pl. IX, figs. 1-3.)

Ammonites Rotiformis, Sowerby. Mineral Conch., vol. v, p. 76, tab. 453, 1824.

- oblique-costatus, Zieten. Die Verst. Würt., p. 20, t. xv, fig. 1, 1830. ROTIFORMIs, von Buch. Über ammoniten, p. 10, 1832.

- - Zieten. Ibid., p. 35, tab. xxv, fig. 1, 1830.

- - d'Orbigny. Paléontologie Française, Ter. Jurassique, tom. i, p. 293, pl. lxxxix, 1842.

- - Q Quenstedt. Cephalopoden, p. 78, 1846.

- oblique-costatus, Von Hauer. Jahrbuch geologischen Reichsanstalt, bd. vi, p. 736, 1853.

- Rotrformis, Studer. Geologie der Schweiz, bd. ii, p. 30, 1853.

- - Von Hauer. Die Cephalopoden aus dem Lias der

Nordöst. Alpen, p, 13, tab. 1, figs. 1, 2, 5, 1856.

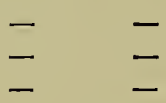

Quenstedt. Der Jura, p. 67, tab. vii, fig. 1, 1858.

Oppel. Die Juraformation, p. 77, 1856.

Dumortier. Dépots Jurass. du Basin du Rhône, p. 22, 1867.

Arietites - Tate \& Blake. Yorkshire Lias, p. 286, 1876.

Diagnosis.-Shell discoidal, compressed; siphonal area tricarinated; whorls numerous, quadrate, slightly involute, and strongly costated; ribs from twenty-seven to thirty in a whorl, simple, strong, arched, and terminating near the areal angle in a large, round, obtuse tubercle; siphonal area large and flat, with a median keel, two lateral sulci, and marginal carinæ; aperture quadrate, depressed, sinuous anteriorly.

Dimensions.-Transverse diameter of specimen figured on PI. IX 175 millimètres; height of aperture 45 millimètres; width of aperture 40 millimètres. M. d'Orbigny's specimen : width of the last whorl $\frac{18}{100}$; portion overlapped of last whorl $\frac{2}{100}$; thickness of last whorl $\frac{20}{100}$; width of the umbilicus $\frac{65}{100}$ of the diameter of the shell.

Description.-Shell discoidal, compressed, with quadrate whorls, strongly ribbed, and slightly involute. In the specimen I have figured (Pl. V, fig. 1) the inner whorls are partly absent, and in part concealed; in Sowerby's type only four whorls can be counted, the central ones being absent; in d'Orbigny's fine specimen, which is almost perfect, there are eight whorls, and this we may regard as the normal number in a shell 180 millimètres in diameter; the number of ribs in a whorl differ much in different 
specimens, thus in Sowerby's and Zieten's shells there are twenty-seven, in von Hauer's thirty-four, and in d'Orbigny's forty-five; they are simple, strong, and arched, and terminate near the margin in a large, round, obtuse tubercle. Sowerby says, "The ribs rising in knobs just as they reach the front give the whorls a very square aspect; the ribs and the hollows between them are nearly equal. The siphonal area is wide, in consequence of the extension given to this region by the size of the costal tubercles; upon the middle line of the back is a strong, thick, rounded keel, having on each side thereof a deep sulcus, bounded by lateral elevations, so that the area is tricarinated with two intervening sulci. The spire is composed of quadrate whorls, with prominent ribs, and a series of nodules along the curvature of the spire. The aperture is quadrate, depressed, and sinuous.

The septa of this species, according to Prof. A. d'Orbigny, are symmetrical, divided on each side into four lobes, of which the two lower lateral are formed of two equal parts. The siphonal lobe ( $\mathrm{Pl}$. V, fig. 2), one third longer than the principal lateral lobe, is ornamented on each side with a long denticulated branch. The siphonal saddle, one third wider than the principal lateral lobe, is formed of three divided lobules, of unequal size, of which the median is the largest. The principal lateral lobe terminates in two points, and has on each side three or four others. The lateral saddle, narrower than the principal lateral lobe, is formed of three unequal lobules, resembling those of the siphonal lobe. The inferior lateral lobe, half the width of the principal lateral, terminates in two points. The two auxiliary lobes are very small, and divide into one median and two lateral points. A line, parting from the extremity of the siphonal lobe, passes at a considerable distance from all the lobes externally visible, but touches the extreme spiral lobe, which is bifurcated, and accompanied on each side by a very large columellar saddle.

Affinities and Differences.-This species resembles in many characters $A$. Conybeari. It is distinguished, however, from that form by having a wider siphonal area and fewer ribs, each terminating in a large obtuse tubercle, the septa are likewise much more complicated than those of $A$. Conybeari. It resembles $A$. bisulcatus, Brug., in possessing simple ribs with marginal tubercles, and two deep sulci on each side of the median keel. It is distinguished, however, from that form in having narrower whorls, a larger umbilicus, and a very different lobe-line. Compare, for example, the sutures in Pl. III, fig. 2, with those in Pl. IV, fig. 2.

Locality and Stratigraphical Position.-This is a very rare Ammonite; my specimen was collected from the Lower Lias, near Lyme Regis; but its precise horizon I could not ascertain. Sowerby's specimen was found in the Lias, near Yeovil. I have seen fragments from a railway-cutting in the Lower Lias of Weston, near Bath, and from near Bristol, Somerset.

Foreign Localities.-Prof. d'Orbigny collected it from the Lower Lias, with Gryphaa arcuata, at Pouilly, Côte-d'Or, where it is rare. The fine shell figured in Pl. IX of this work came from near that locality, and was presented to me by Messrs. 
Collenot and Bréon, of Semur, to help me in my comparative work; and I beg to return these kind friends my best thanks. Professor Quenstedt says it is most abundant in Germany, and is collected at Vaihingen, Möhringen, Gmünd. Professor von Hauer's figured specimen was collected in the Yellow Kössen Beds at Enzesfeld, near Vienna. Professor Studer found it in the Lower Lias of the Bernese Alps, and Lardy at Coulata and Fondement, near Bex, in the valley of the Rhone.

Arietites Brookr, Sowerby. Plate VI, figs. 4, 5.

Ammonites Brooki, Sowerby. Min. Conch., vol. ii, p. 203, tab. 190, 1818.

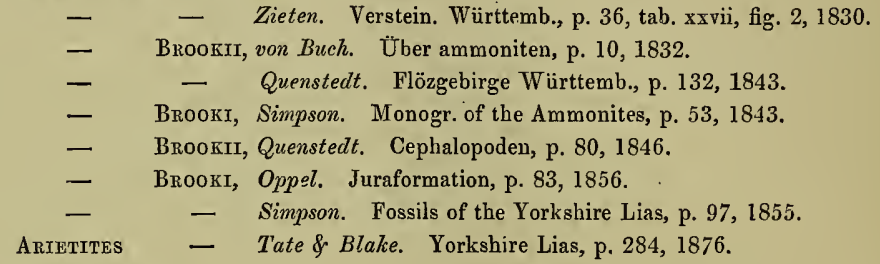

Diagnosis.-Shell depressed, strongly carinated, with a deep narrow sulcus on each side of the keel; whorls costated, with thirty-six strong, simple, arched, ribs, which curve round the inner margin of the whorl, and terminate at the sulcus; whorls half involute, inner volutions well exposed; surface of the shell marked with fine flexed lines of growth; aperture oblong.

Dimensions.-Transverse diameter of fig. 4, 14,0 millimètres ; height of the outer whorl at the aperture 55 millim.; width 40 millim.; amount of involution one half the whorl.

Description.-This handsome, well-marked species is recognised by its compressed shell, ornamented with strong, simple, arched ribs, that are large and prominent, and equal in width to the valleys between them; the ribs curve round the inner margin of the whorl, arch regularly forward, and terminate at the areal angle of the outer margin of the sulcus; the siphonal area is sharp and angular; the keel round and prominent, with a deep furrow on each side, forming a well-marked boundary between the keel and sides. The surface of the shell is marked with fine flexed lines of growth, corresponding in flexure with those of the costæ; the siphuncle is lodged in the strong round keel.

Affinities and Differences.-This fine, boldly marked shell so much resembles $A$. Turneri, Sow., that it is difficult to discover the points of difference between them, whilst their affinities are numerous. In $A$. Turneri the shell is thicker and more quadrate, the siphonal area is broader, the ribs are nearly straight to the upper third of the whorl, where they bend abruptly forward towards the aperture, and form a kind of thickened eminence at the angle of flexure. In $A$. Brooki the upper third of the whorl slopes off, and the ribs, which are not so numerous, arch more regularly forward, forming the angle of flexure found in A. Turneri. This point of difference may be only one of sex, 
for Sowerby says in his description of $A$. Turneri,-_"The more exposed whorls, squarish aperture, and differently curved radii, distinguish this from $A$. Brooki, to which it bears a strong resemblance." If a larger series of both forms could be obtained, it is probable it would be found that they merged by a gradual series of gradations into one species; but, for the sake of convenience and easy reference, until more facts are brought to light, I have thought it best to figure good type forms of each, from which it will be seen that the affinities are many and the differences few and immaterial.

Locality and Stratigraplical Position.-Arietites Brooki is found in fine preservation, with the shell complete, at Lyme Regis, in beds of shale and Lower Lias Limestone ; sometimes it is enclosed in crystallime masses of sulphuret of iron. It is on the whole a rare Ammonite.

Arietites Sauzeanus, d'Orbigny. Pl. VIII, figs. 1 to 6.

Ammonites Sadzeands, d'Orbigny. Paléontologie Française, Ter. Jur., p. 304, pl. xcv, figs. $4-5,1842$.

\begin{tabular}{|c|c|c|}
\hline- & RESUPINATUS, & Simpson. Monogr. of the Ammonites, p. 15, 1843. \\
\hline- & SPINARIES, & Quenstedt. Der Jura, p. 69, pl. vii, fig. 4, I 858. \\
\hline & TRANSFORMATUS, & , Simpson. Foss. of the Yorkshire Lias, p. 91, 1855. \\
\hline & Sauzeands, & $\begin{array}{l}\text { Wright. Monograph on the Asteroidea, Pal. Soc. vol. } \\
\text { for the year } 1861, \text { p. } 72,1863 \text {. }\end{array}$ \\
\hline & - & $\begin{array}{l}\text { Dumortier. Dépôts Jurass. du Bassin du Rhône, p. 132, } \\
\text { pl. xxiv, fig. 1, } 1867 \text {. }\end{array}$ \\
\hline & HALECIS, & $\begin{array}{l}\text { Buckman. Murchison's Geol. of Cheltenham, p. 104, } \\
\text { pl. xi, fig. 9, 1845. }\end{array}$ \\
\hline
\end{tabular}

Arietites spinaries, Tate \& Blake. Yorkshire Lias, p. 286, 1876.

- Saczeanus, Tate \& Blake. Ibid., p. 288, 1876.

Diagnosis. -Shell compressed, whorls quadrate, one third involute, ornamented with twenty costæ; the ribs are slightly bent, the convexity obliquely backwards, and they terminate in a tubercle at the outer margin of the siphonal area, which is flat, with a slightly elevated central ridge.

Dimensions.-The large specimen, transverse diameter 205 millimètres, height of aperture 67 millimètres, width of aperture 68 millimètres.

Description. - This remarkable Ammonite has an extremely quadrate physiognomy, the whorls, about one third involute, are square and ormanented in the large specimen figured with twenty ribs, which are simple, slightly bent with their convexity obliquely backwards, and they terminate at the angle of the margin in small well-marked tubercles (Pl. VIII, figs. $1,2,4)$. The siphonal area is large and quadrate, and a considerable eminence rises in the middle line, which, however, does not form a keel, nor are there any traces of lateral sulci as in the true keeled Arietites. The spire, formed of square-shaped whorls, imparts a 
stair-like character to the open umbilicus (figs. 4 and 5). The aperture is quadrate (fig. 2), the width slightly exceeding the height. The septa are symmetrical, foliated on each side, and divided into four lobes with narrow branches ; the siphonal lobe (fig. 3), long and narrow, projects beyond the others; the outer side has three short simple, two long branched, and one terminal branched digitation; on the inner side of each bilateral segment of the lobe there are five or six simple digits. The principal lateral lobe is small; it has five or six long tooth-like lateral digitations on its outer, three or four on its inner side, and bifurcates into two terminal branches; the inferior lateral lobe is long and slender, with several narrow digitations on the sides, and a bifurcate termination; the auxiliary lobe is small; the siphonal saddle is large, but not sufficiently exposed for accurate description ; the lateral saddle is very large, occupying two thirds of the sides of the whorl ; it has two large terminal folioles, and two lateral folioles, with four or five lobules in each.

Affinities and Differences.-In the quadrate outline of its whorls and its straight simple ribs its resembles $A$. Valdani, d'Orb.; and the terminal tubercle on its ribs likens it in form to $A$. perarmatus, Sow.; whilst the form of the lobes and saddles, and the median ridge on the back distinguish it from both. It is very distinct from the other species of keelless Arietites, and has no affinities with the keeled species of that group, the absence of sulci on the siphonal area affording a reliable diagnostic character.

Locality and Stratigraphical Position.-The large specimen was collected in the zone of Arietites obtusus, near Bredon, during the construction of the Bristol and Birmingham Railway. The smaller specimens were obtained from the same zone at Darlingscott, near Shipton-on-Stour, and given me by my late friend, Mr. John Kirshaw, of Warwick. I bave found one or two small specimens in the Lower Lias of the Vale of Gloucester, and my friend, R. Etheridge, Esq., F.R.S., collected a specimen from the railway-cutting at Horfield, near Bristol. There are several fine large examples of this Ammonite in the stock cases of the British Museum ; unfortunately their locality is unknown. Arietites Sauzeanus has been obtained from Lias nodules found in Drift on the Holderness Coast, and from the Lower Lias, Robin Hood's Bay, Yorkshire Coast. It is the true Ammonites resupinatus and Amm. transformatus of Simpson. It is curious that this remarkable Ammonite should have been found in England, France, and Germany about the same time.

Arietites Sauzeanus is a very rare Ammonite in France, M. d'Orbigny states that he had seen only two specimens of this singular species, which were collected from the Gryphcea arcuata beds of the Lower Lias by M. Boucault, at Champlong, near Sémur (Côte d'Or), where it is very rare. 
Arietutes Crossil, Tright, nov. sp. Pl. X, figs. 1, 2.

Diagnosis. - Shell discoidal, large, compressed, sides with twenty-four ribs, narrow, sharp, and trenchant, much more developed near the line of involution than in any other part of their traject; they first bend backward, then arch forward, and finally vanish near the outer margin. They are thickest at the line of involution and become gradually thinner and less developed towards the margin, which is bevelled away. Siphonal area narrow, with a sharp, prominent keel, and a shallow sulcus on each side thereof.

Dimensions.-Transverse diameter of figured specimen 350 millimètres; height of the last whorl 10 millimètres; diameter of the umbilicus 170 millimètres; amount of involution one-third of the width of the whorl.

Description.-This very remarkable Ammonite was discovered by the Rev. J. E. Cross, F.G.S., in the Scuuthorpe Ironstone of North-west Lincolnshire, in beds belonging to the Upper Bucklandi-series, containing Arietites semicostatus, Aegoceras Boucaultianum, and others. This new species attains gigantic size, as shown by several specimens in Mr. Cross's Collection. The whorls have their greatest thickness near the line of involution, from which they slope gently ontwards toward the margin, so that the siphonal area forms a narrow and contracted space, in which the sharp, prominent keel, and two shallow sulci are found (fig. 2). The ribs likewise differ from those of other congeneric species, being largest and thickest near the line of involution, where in other forms they are most slender. They beud gently backward, then forward, diminishing in size as they ascend and disappearing near the outer bevelled margin of the siphonal area. The last whorl possesses twenty-five ribs, which have a uniform character throughout. The lobe-line was not seen in any of the specimens that passed through my hands. The narrowness of the siphonal area is very well exhibited in the capital drawing of Plate X, fig. 2.

The aperture of the shell is compressed-narrowest towards its outer margin and widest at the line of involution of the spine, and the last whorl embraces nearly one half of the penultimate one; the ribs are likewise nearly equidistant, narrow, and trenchant, and the curve they describe is uniform throughout all the whorls.

Affinities and Differences.-This large Ammonite resembles $A$. Bucklandi, but differs from that well-known species in the shape of the whorls: those of $A$. Bucklandi are square, and as wide at the siphonal as at the umbilical margin, whereas in $A$. Crossii they are contracted at the siphonal and large at the umbilical side; the ribs, moreover, in $A$. Bucklandi are small at the umbilical and large at the siphonal side, a character 
which is quite the reverse in $A$. Crossii. The amount of involution is likewise much less in $A$. Bucklandi, and the keel is thicker and more pronounced in that form than in A. Crossii.

Locality and Stratigraphical Position.-This interesting Ammonite was found in the Scunthorpe Ironstone, associated, according to the Rev. J. E. Cross, with A. Bucklandi, A. Conybeari, A. semicostatus, A. stellaris, Aegoceras Boucaultianum, Nautilus striatus, Belennites acutus, Pleurotomaria Anglica, Cardinia gigantea, and Lima antiquata, which are considered to represent the Upper Bucklandi-series, or zone with $A$. semicostatus. See p. 41.

I know of no other British specimens except those belonging to Mr. Cross's Collection. In the Museum of Stuttgart, however, I observed two very fine specimens of this species in the upright cases, unnamed, as they had been separated by Prof. Fraas from the true Bucklandi forms, and placed there as distinct. In the Museum of Tübingen, Professor Quenstedt kindly showed me another large specimen, and informed me that it came from the Upper Bucklandi-bed at Gmünd and Göppingen. My learned friend, who is most particular about the position of all fossils, assured me that it was the true horizon of this species, which I have named in honour of the Rev. J. E. Cross, F.G.S., its discoverer in the British Lias.

Arietites semicostatus, Young and Bird. Pl. I, figs. 4-S.

Ammonites semi-costatus, Young \& Bird. Geol. Surv. York. Coast., pl. xii, fig. 10, p. 257, 1828. (2nd. Edit.)

- KRIDION, Hehl? Zieten's Verstein. Württemb., p. 4, pl. iii, fig. 2, 1830.

- NATRIX, Roemer. Oolithen-Gebirg. i, p. 193, 1836.

- Kridion, d'Orbigny. Pal. Française, Terr. Jurass., pl. li, figs. 1-6, p. 205, 1842.

- Semi-costatus, Simpson. Monogr. of the Ammonites, p. 51, 1842.

- Bodleyi, Buckman. Murchison's Geol. of Cheltenham, 2nd ed., p. 43 , as crenata, pl. xi, fig. 7,1845 .

- Geometricus, Oppel. Juraformation, p. 79, 1856.

- Nodosariẹs, Wagener. Verh. Nat. Ver., p. 161, 1860.

- SPINARIEs, Wagener. Ibid., 1860.

- Gemetricus, Sehloenbach. Neues Jahrb., 1863, p. 164 ; Zeitsch. d. d. Geol. Gesellschaft, vol. xr, p. 500, 1863.

- - Schloenbach. Beiträge zur Paläontol., Palæontographica, vol. xiii, p. 155, pl. xxvi, fig. 3,1865 .

- Falcaries, Quenstedt. Der Jura, p. 70, tab. vii, figs. 6, 7, 1858.

- Semi-costatus, Simpson. Fossils of the Yorkshire Lias, p. 93, 1855. 
Ammonites geonetricus, Dumortier. Dépôts Jurass. du Bassin du Rhône, tom. ii, p. 31, pl. vii, figs. 3-8, 1867.

Arietites semicostatus, Tate \& Blake. Yorkshire Lias, p. 288, pl, vi, fig. $4 a$ (upper), 1876.

Diagnosis._Shell discoidal, slightly involute, and depressed; whorls six, bearing straight, sharp, prominent ribs, which suddenly bend round the margin and vanish in the sulci; they are separated on the sides by well-defined concave spaces; the three inner whorls are almost always smooth. Siphonal area flat; keel narrow, sharp, and entire, placed between two lateral sulci; aperture quadrate.

Description.-This is a very common shell on the Yorkshire Coast, and a characteristic type of the group Arietites. It often occurs in rocky masses of Lower Lias Limestone in Robin Hood's Bay. One of those now before me contains twenty-five specimens on one side, and as many more clustered together in the slab, showing well the anatomy of the shell and the varieties of shape it assumes. In some the whorls are round and inflated, with the ribs slightly bent; in others the shell is flat and the ribs straight.

In early life, up to three or four whorls of growth, the sides are in general smooth, like $A$.planorbis, or have very slight folds, as indications of rudimentary ribs; and the keel begins to show itself as an elevated ridge without sulci. At this stage of growth the small shell resembles $A$. radians. In one of these young shells I exposed the black horny Anaptychus in sitü. In Pl. I, figs. 7 and 8, I have represented these specimens the natural size. In one (fig. 7) the whorls are smooth; the Anaptyclus is seen in this specimen, and fig. 8 shows the commencement of the ribbing. It was this half-ribbed character of the shell which suggested to Young the specific name semicostatus. In some young shells the keel has not been differentiated at the third whorl, and only then appears as a prominent rudimental ridge with slight crenations on the border.

The whorls are so entirely evolute that only the keel of the pennltimate whorl is embraced by that which succeeds it ; the increase of the whorls is thereby very slow, and their height is proportionately greater to the width in the growth of the shell, and the mouth-aperture forms in consequence a high rectangular opening.

The evolution of the shell is as follows : at first without ribs, and then it possesses only fine radial folds. About the third, fourth, or fifth whorls the ribs begin to show themselves, first as flat and indistinct folds, and soon afterwards as sharp, straight, prominent elevatious. In a small shell with four whorls there are twenty-two ribs, in one with five whorls twentyfive ribs, and in one with six whorls there are thirty-six ribs. They all proceed in a straight line from the umbilical to the siphonal area, and at the marginal angle of the latter they bend abruptly forward and vanish in the sulcus. The body-chamber is three fourths of a whorl in length.

The lobe line is very simple (fig. 6); the siphonal lobe is short, with simple lateral serrations; the principal lateral is large, with small lateral digitations, terminating in two 
branches. A small accessory lobe lies between it and the siphonal lobe, which is exaggerated in size in the drawing. The infero-lateral is small, and leads down to a small umbilical or auxiliary lobe.

Dimensions.-The following are the dimensions of four shells of from three to six whorls in each, with their parts and number of ribs, from some typical specimens before me :

\begin{tabular}{|c|c|c|c|c|c|c|c|c|c|}
\hline Number of whorls & . & & 3 & & 4 & & 5 & 6 & \\
\hline Do. ribs & . & & & & 22 & & 25 & 36 & \\
\hline Diameter of shell & . & & $15 \frac{1}{2}$ & $\mathrm{~mm}$. & $33 r$ & $\mathrm{~mm}$. & $58 \mathrm{~mm}$. & 67 & \\
\hline Width of umbilicus & . & & $7 \frac{1}{2}$ & $"$ & 17 & $"$ & 31, & 34 & \\
\hline Height of the keel a & iture & & & & $\cdot 1 \frac{1}{4}$ & & $2 \frac{1}{2}$ & 3 & \\
\hline Do. last whorl & & & 5 & " & 10 & $"$ & $16 \frac{1}{2}$ & 19 & \\
\hline Do. penultima & & & 3 & , & 6 & , & $9 \frac{1}{2}$ & 11 & \\
\hline Thickness of last wh & & & $4 \frac{1}{2}$ & " & 8 & " & 11, & 12 & \\
\hline Do. penulti & & & $2 \frac{1}{2}$ & ” & $5 \frac{1}{2}$ & & $7 \frac{3}{4}$, & 8 & \\
\hline
\end{tabular}

Young and Bird's figure of this shell is both bad and deceptive, and their description incomplete; hence arose early confusion about the species which they were the first to name, although it was well known to the Yorkshire collectors, who greatly prized the slabs crowded with its shells. Roemer collected it in Brunswick, and described it accurately, but erroneously identified it as $A m$. natrix, and placed it among the Capricorni. Quenstedt, in his 'Jura,' has figured and described it under the name falcaries, and Wagener under the names nodosaries and spinaries. In the Berlin Museum some English specimens, obtained from a dealer, have the true name Am. semicostatus. In the Jardin des Plantes the d'Orbignian collection contains the specimens which were figured in the 'Paléontologie Française' as Am. kridion, which I have examined. These shells have been collected from several well known Lower Lias localities, as Villefranche, Saône-et-Loire ; environs of Lyons, Rhône ; and Sémur, Côte-d'Or ; Avallon, Yonne. An Ammonite was collected from the Lower Lias Limestone near Stuttgart, and called Kridion by Bergrath Hehl, and under this name it was figured by Zieten in his large work on Württemberg fossils. This shell has been frequently mistaken for A. semicostatus, but appears to be distinct; it was erroneously identified by d'Orbigny with the French forms of $A$. semicostatus, and hence our species appears as $A$. kridion in the 'Paléontologie Française.'

Dr. Oppel, overlooking the fact that Young had figured, and Simpson well described, A. semicostatus, considered the shells he found in Robin Hood's Bay and at Lyme Regis a new species, and described them under the name $A$. geometricus, the $A$. geometricus, Phillips, having been found to be a form of $A$. spinatus.

Locality and Stratigraplical Position.-This Ammonite is found in the Turneri-beds or upper portion of the zone of Arietites Bucklandi at Broad Ledge, Lyme Regis, 
whence I obtained a series of specimens in different stages of development, and where it is associated with $A$. Turneri and A. Bonnardii. It is found in the upper part of the zone of A. Bucklandi, Robin Hood's Bay, Redcar, Marske, Nunthorpe, Ellerbeck; and zone of Amal. oxynotus, Robin Hood's Bay, Yorkshire, and in the Lower Lias Shales and Limestones at Bredon, Lansdown, Cheltenham, and other places in the Vale of Gloucester.

Foreign Distribution.-In North Gernany at Scheppau, Achim, Stadtoldendorf, Bundheim am Harz, Langelsheim am Harz, Brunswick; Salzgitter (Haverlah-Wiese), Hullersen and Wellersen, Hanover; and in many other localities.

In South Germany at Gmünd, Krummenacker, Göppingen, and Bebenhausen, near Tübingen.

Arietites Bonnardir, d'Orbigny. Pl. XI, figs. 1, 2, 3.

Ammonites Bonnardi, d'Orbigny. Paléont. Franç., Terr. Jurass., p. 196, pl, xlvi, 1842.

Diagnosis.-Shell discoidal ; sides much compressed and ornamented with numerous (forty) ribs, which first arch backwards, then incline forwards, and finally bend round the margin, inclining obliquely forwards, and vanishing at the outer side of the sulcus. Siphonal area with a medium-sized keel between two deep lateral sulci. Aperture rectangular, subquadrate, compressed at the sides.

Dimensions.-Transverse diameter of the figured specimen, 110 millimètres; height of the last whorl, 25 millimetres; thickness of ditto, 22 millimètres. Amount of involution, 3 millimètres.

Description.-Shell discoidal, much depressed, carinated, and sulcated; whorls numerous (eight). The sides ornamented with forty ribs, mostly simple, rarely bifurcate, much arched, and rounded. The siphonal area broad, provided with a medium-sized prominent keel, having on each side a deep sulcus. The spire is composed of narrow compressed whorls, with very regular ribbing.

The aperture is rectangular, subquadrate, and compressed at the sides, with a prominent ventral process. The lobe-line is not shown on any of my specimens. D'Orbigny ${ }^{1}$ describes the siphonal lube as a little larger, and quite as loug as the principal lateral, and ornamented with many conical digitations. The siphonal saddle is twice the size of the principal lateral lobe, and is divided into four round unequal leaves by three lobules, of which the central one has nine digitations. The principal lateral lobe is ornamented on each side with three branches, which increase in length from above downwards. The first has two digitations, the second three, and the third six ; and the external branch is longer than the other. The lateral saddle, narrower than the principal lateral lobe, is unequally parted 
on the sides into large obtuse festoons. The infero-lateral lobe is small and provided outwardly with three, and inwardly with two, simple digitations, independently of the median point. The auxiliary saddle is very short and thrice festooned; the line from the central radius, in parting from the point of the dorsal lobe, touches the extremity of the principal lateral lobe, but is very distant from the infero-lateral and auxiliaries.

Afinities and Differences-This Ammonite retains its youthful form throughout life, and more nearly resembles Arietites bisulcatus than any other of the congeneric forms in the structure of its siphonal area, the general character of the shell, and the deep sulci on each side of the keel. It is distinguished from A. bisulcatus, however, specifically by the narrowness of the whorls, the compression of the sides, the greater number of ribs destitute of tubercles, and by the marked difference in the figure of the lobe-line, which is seen to be disposed in a different manner when the two species are carefully compared. It resembles Arietites Turneri, Sow., and I have seen $A$. Bonnardii marked A. Turneri in some continental museums; even Dr. Oppel appears to have thought them identical. It differs from $A$. Turneri, however, in having the, whorls not nearly so high, nor the shell so thick as in that species; whilst the difference in the structure of the lobe-line makes a marked specific distinction between these two allied forms, which belong to the horizon containing the beds with Pentacrinus tuberculatus, Miller.

Locality and Stratigraplical Position.-I have collected this species at Lyme Regis, out of the hard limestone beds with Aegoceras Bircliii; in a slab before me the two species are embedded together. It has been found in the same horizon in the Lower Lias of Bredon, Lansdown, near Cheltenham, and in the Vale of Gloucester.

I must refer the reader to p. 48 for an account of the Turneri-beds at Lyme Regis, and a list of the fauna with which Arietites Bonnardii was associated. Aegoceras Bircliii may be now added to the list, as in a recent traverse I discovered the two Ammonites embedded together in the same slab.

Foreign Localities.-The type was found in the Lower Lias with Gryplica arcuata in the environs of Belley (Ain). The type specimens are in the Ecole des Mines, Paris. It has likewise been found by Dr. Oppel, near Stuttgart (Württemberg).

Arietites subnodosus, ${ }^{1}$ Young \& Bird. Pl. VI, figs. 2, 3.

Ammonites subnodosus, Young \& Bird. Yorkshire Coast, p. 258, 1828.

$-\quad$ Simpson. Monogr. of the Ammonites, p. 48, 1843.
Arietrtes obesulus,
Simpson. Fossils of Yorkshire Lias, p. 90, 1855.
Tate \& Blake. Yorkshire Lias, p. 284, pl. vi, fig. 2, 1876

Diagnosis.-Shell discoidal; sides flat, compressed; siphonal area broad, flat; keel 1 Termed nodulosus on the explanation of Pl. TI, figs. 2 and 3. 
prominent; sulci deep; area above the angle covered with oblique folds; ribs nearly straight for two-thirds their length, from suture to angle, where each rises into a small prominent tubercle; they then turn sharply towards the aperture, stretch obliquely forward on the area, vanishing at the outside of the sulcus. Whorls, five or six, inflated at the sides; inner whorls one-fourth concealed, outer whorl one-third the diameter of the shell; aperture subquadrate; diameter one inch and a balf.

Dimensions. - Diameter of the figured shell, 42 millimètres; height of the last whorl, 15 millimètres; thickness of ditto, 11 millimètres; amount of involution, 4 millimètres.

Description.-After carefully examining this fossil I bave arrived at the conclusion that it is not a distinct form of Arietites, but a variety of Amaltheus Hawskerensis, Young and Bird = spinatus, Brug., which has acquired an increased number of ribs, and converted the grooves on each side of the keel into sulci, resembling those of a true Arietites. Simpson says, in some specimens the radii are still closer, and the characteristic tubercles become nearly obsolete, until it can scarcely be distinguished from A. geometricus, Phil., which is in fact Am. spinatus with a notched keel. The rock in which $A$. subnodosus is fossilised appears to be the Marlstone of the Yorkshire coast, this species will, therefore, be noticed more in detail in the description of Amaltheus spinatus, Brug.

Arietites Scipionianus, d'Orbigny. Pl. XIII, figs. 1-3; Pl XIX, figs. 8-10.

Ammonites Scjpionranus, d’Orbigny. Pal. Française, Terrain Jurassique, p. 207, pl. li, figs. 7, 8, 1842 .

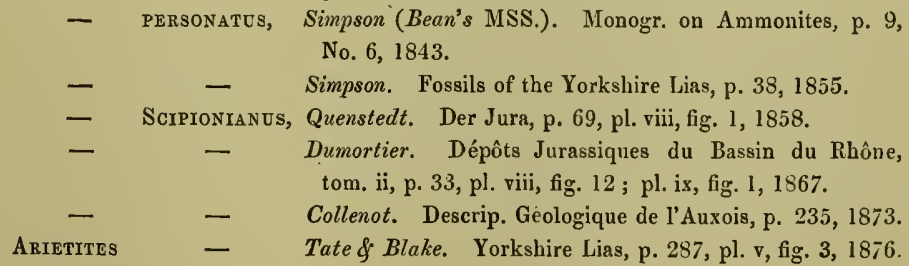

Diagnosis. - Shell discoidal, compressed, acutely carinated; ribs numerous, slightly bent between the suture and marginal angle, where they terminate in blunt tubercles in young and middle-aged shells; sides flat, with from twenty-four to thirty-eight ribs. Siphonal area narrow, rather angular, with smooth sloping declivities, and a narrow, acute, prominent keel. Aperture hexagonal, compressed, and sharply angulated. 
Dimensions.-Transverse diameter of specimen figured on Plate XIII, 150 millimètres; height of the last whorl, 50 millimètres; thickness of ditto, 35 millimètres; amount of involution, 8 millimètres; diameter of the umbilicus 60 millimètres.

Description.-This is a very remarkable Ammonite. In early life, its specific characters are well developed; in middle age it changes much ; after attaining a very large size in its adult state it differs from all the previous conditions, as shown in specimens contained in the Museum at Semur, where this species may be studied in the different states of development. The shell is very thin, much compressed and carinate, provided with an elevated, but not cutting keel. The sides are flat and ornamented with numerous ribs, which vary in number in different individuals (from eighteen to thirty-six). They are thick and well developed when they appear at the umbilicus, and rise in straight lines, gently bent forward towards the aperture, and near the margin of the siphonal area terminate in small blunt tubercles. In the specimen I have figured from the Lower Lias of Gloucestershire (PI. XIX, figs. 8-10) the ribs (seven in number) are far apart, the tubercles are small and conical, and the keel is sharp and prominent. In auother specimen, about the same size as the latter, there are twenty-six ribs, so that the number of these lateral folds is valueless as a specific character in this form. In a larger specimen from the Museum of Semur, 165 millimètres in diameter, there are thirty-six ribs; and the fine specimen I have figured (Pl. XIII) from the same locality has twentyeight ribs. The admirable figure given in this plate shows likewise another important feature in this Ammonite, namely, that the ribs, tubercles, and keel are much sharper and better defined in the cast than in specimens covered with the original shell. A small Semur specimen in my hand shows this very distinctly, and is verified, in Pl. XIII, in that portion of the outer whorl which has retained its shell. The ribs likewise in this species are rarely bifurcated.

The terminal costal tubercles appear to be best developed in early age; they gradually become blunted in the middle period, and finally disappear in the senile condition.

The keel is as well developed upon the cast as in those parts covered with the shell, and has almost always the same prominence; an anatomical fact of some importance, seeing that in a congeneric form, the $A$. Aballoensis, from a higher zone, as pointed out by Mons. Dumortier, the shell possesses a well-developed keel, which is entirely absent in the cast.

The lobe-line is delineated on Plate XIII; a lateral view in fig 1 , and the siphonal and lateral lobes and saddles in fig. 3 ; this outline is essentially the characteristic form of the group Arietites to which this species belongs.

The aperture is compressed on the sides and forms an irregular hexagon; the two siphonal facets form prominent angles, the two sutural obtuse augles, and the lateral facets are inclined outwards.

Since the above description was in type, I have received, through the extreme kindness of M. Collenot, of Sewur, a larger specimen of this species than the one figured 
in Pl. XIII. It is an adult specimen with a considerable portion of the bodychamber and traces of the lobe-line. This fossil is 225 millimètres in dianeter, the outer whorl at the aperture is 85 millimètres in beight and 56 milliuètres in width ; and the aperture is compressed and forms an irregular hexagon; the two outer facets describe acute angles, the two lateral and the two iiner re-entering angles. 'The whorls are widest at the umbilical, and narrowest at the outer margin, where they are bevelled away into the prominent keel. At the umbilical angle there are twenty-four thick, blunt ribs slightly inclined backwards, which ascend on the sides and disappear near the middle of the whorl, and then leave the upper portion smooth. The row of tubercles in which the lateral ribs usually terminate are absent on this more aged shell, so that the outer half of the whorl is bevelled away and rises into a high, prominent keel. A portion of the shell remaining on the cast shows how extremely thin the shell of this species was in so large an Ammonite. The keel, likewise, is as prominent on the cast as at the parts covered by shell.

The spire is formed of angular whorls, which are one half involute; they are all strongly ribbed as they appear near the umbilicus, the upper smooth-bevelled half being concealed by the involution of the spire. The body-chamber is not complete, still it occupies five seventls of the outer whorl of this specimen.

The lobe-line is very tortuous, and forms three lobes and three saddles. The siphonal lobe is long, narrow, and freely digitate on each side. The siphonal saddle is wide and oblique, with numerous festoons on its long inner side (PI. XIII, fig. 3); the principal lateral lobe is as wide, but shorter than the siphonal ; and the lateral saddle is larger than the siphonal, and is oblique and festooned in like manner. The auxiliary lobes are small and indistinct.

This species attains a very great size, as may be seen in the old shells contained in the Semur Museum.

Affinities and Differences.-This Ammonite somewhat resembles A. stellaris, Sow., in the compression of the sides and bevelled surface of the outer maryin. The row of tubercles near the siphonal area, the narrowness of that space and entire absence of sulci from each side of the keel, entirely separate it from $A$. stellaris, and there is no other form in the Lower Lias with which it has any affinities.

Locality and Stratigraphical Position.-It was collected from the Lower Lias Shales, in the Vale of Gloucester, during the deep cuttings made in the formation of the Midland Railway. In Yorkshire it is found in position in the upper part of the Bucklandi Zone at Marske, Redcar; and in Robin Hood's Bay, in blocks, associated with Lima pectinoides, Lucina limbata, Dentalium elatense, indicating the same horizon there.

In France it is found in the upper part of the zone of Arietites Bucklandi with Arietites rotiformis and Ar. semicostatus, Young, and is rarely discovered in the lower layers of the zone. Dunortier says it is collected at Saint-Didier, Rhône; also at Curgy, Borgy, Saône-et-Loire; Salins, Clomot, Nolay, Côte-d'Or; Mont-de-Lans, Isère; and 
Avallon, Yonne. Near Semur, Côte d'Or, many specimens of a large size have been found, and which are now preserved in the Semur Museum.

In Germany, Quenstedt records it from Gmünd.

Arietites Turneri, Sowerby. Pl. XII, figs. 1-6.

Ammonites Turneri, Sowerby. Mineral Conchology, tab. 452, vol. v, p. 75, 1824.

Diagnosis.-Shell discoidal, depressed, strongly carinated, with a deep narrow sulcus on each side of the keel; whorls costated, with forty-two strong, simple, straight ribs, which bend suddenly forward near the back, each rib thickened at the angle; inner volutions of whorls well exposed; aperture oblongo-quadrate.

Dimensions.-Transverse diameter 115 millemètres; height of the aperture 41 millemètres, width 38 millemètres; amount of involution nearly one fourth of the whorl.

Description.-This shell so closely resembles Ammonites Brookii, that I have long suspected it might only be a variety of that species; the want, however, of a good series of specimens of $A$. Turneri, to enable me to compare it with $A$. Brookii in different stages of growth, has induced me to retain, for the present, Sowerby's name, and to give his description of $A$. Turneri from vol. v, p. 75 of the 'Mineral Conchology. "Depressed, radiated, carinated, a furrow on each side of the keel ; inner whorls exposed; radii numerous, equal, curved towards the front; the aperture oblong-quadrangular. Volutions about five, the inner ones almost wholly exposed; the radii are almost straight until they bend rather suddenly toward the front; the aperture is less thau one third the diameter of the last whorl in length. The more exposed whorls, squarish aperture, and differently curved radii, distinguish this from $A$. Brookii, to which it bears a strong resemblance."

The septa are very imperfectly preserved in the specimen I have figured. The lobe-line shows the siphonal lobe (fig. 6) long, narrow, and deeply serrated on both sides, and the terminal branch bifurcated. The siphonal saddle is small, ending in two festoons; the principal lateral lobe (fig. 5) is oblique, and serrated, terminating in three curved digitations ; the lateral saddle is wide, ending in three festoons, with several lobules on each side; the inferior lateral lobe is oblique like the principal lateral, and about the same size, with serrated sides and a trifid termination; the lower lateral saddle is much smaller than the upper lateral, and ends in three festoons of unequal size, with a lateral lobule on each side.

In Pl. XII, fig. 4, I have given an accurate drawing of one of Sowerby's original type specimens, now in the British Museum, to show its identity in form with the shell figured (figs. 1-3) on the same plate. 
Affinities and Differences. -The affinities of A. Turneri to A. Brookii are so numerous, and the differences between them so few and inconsiderable, that $I$ consider the question of their specific distinction one which requires further consideration; the affinities are more fully pointed out in the description of $A$. Brookii.

Locality and Stratigraphical Position.-The specimen figured was collected from a light-coloured clay and limestone in the deep cutting of the Bristol and Birmingham Railway, near Bredon, and was associated with A. Bonnardii, d'Orbigny, A. semicostatus, Y. \& B., and several other Molluscs, with many fragments of the stems and side arms of Pentacrinus tuberculatus, Miller, and Cidaris Edwardsii, Wright.

Aritetites obtusus, Sowerby. Pl. XXI, figs. 1-5.

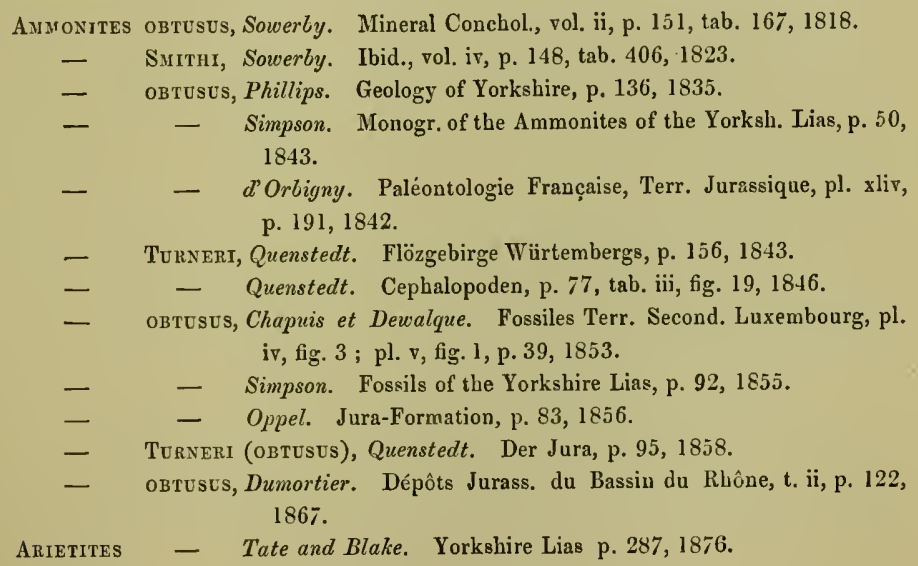

Diagnosis.-Shell thick, compressed, and tricarinate; carinæ obtuse; whorls subrotund, with twenty-five to thirty lateral ribs, which curve toward the aperture, are thick and obtuse, vanishing near the onter carina; lateral septa three-lobed; shell covered on all sides with fine longitudinal lines, twenty-eight on each side of the whorl, producing a series of punctations where they intersect similar transverse lines; aperture rotundocompressed.

Dimensions.-The usual size is from 150 to 200 millimètres in diameter, but it attains 300 to 400 millimètres. Dimensions of the specimen figured in PI. XXI, figs. 1, 2, transverse diameter 155 millimètres; height of the last whorl at aperture 65 millimètres; width 58 millimètres; width of the umbilicus 55 millimètres. The relative dimensions 
calculated from several specimens are-height of the last whorl $\frac{40}{100}$; width, $\frac{35}{100}$; width of the umbilicus, $\frac{45}{100}$; involntion of the whorl, $\frac{25}{100}$ of the diameter of the shell.

Description.-This Ammonite has a discoidal shell, moderately compressed on the sides, but rotund towards the siphonal area, which is furnished with a very thick obtuse keel, having on each side a deep sulcus separating it from two lateral carinæ formed by the angles of the sides and area ; aperture compressed, bi-sinuated at the summit, and strongly grooved by the turn of the spire; whorls slightly compressed in the middle, and more so towards the upper third; provided with from twenty-five to thirty moderately prominent acute ribs, which are arched, and disappear at the angle of the area before they merge into the lateral sulci; the valleys between the ribs are very regularly concave.

The entire surface of the outer lamina of the shell is traversed by fine longitudinal lines, as if they had been cut by a graver. On the specimen before me there are sixtysix such lines on the area and sides of the whorl, and at the point where they intersect similar transverse lines a punctated depression is produced, which imparts a highly ornamental character to the shell of this species.

The septa are symmetrical, divided on each side into four lobes and four saddles, formed of unequal parts (Pl. XXI, fig. 5). The siphonal lobe is long and wide, and divided on the median line one third of its length, presenting numerous small equal-sized digitations around its circumference; the siphonal saddle, as large as the siphonal lobe, has shallow ramifications on its outer side, and three small festoons on its anterior border; the principal lateral lobe is conical, and about two thirds the length of the siphonal lobe; the superior is larger than the siphonal saddle, and presents better developed simple festoons on its border than those on the latter; the inferior lateral lobe is about as large as the principal, and has numerous small round digitations on its circumference; the auxiliary saddle is about one fourth the size of the siphonal, and has a similar form; the auxiliary lobe is nearly as large as the lateral.

Affinities and Differences.-This species very much resembles Arietites stellaris, Sow.; so much so, that the one is often mistaken for the other. Both have longitudinal and transverse lines on the shell, and punctations at their points of intersection ; in $A$. stellaris the shell is more compressed and bevelled, the keel smaller and less obtuse; the digitations of the lobes more complicated, and the saddles longer and narrower.

Locality and Stratigraplical Position.-This Ammonite characterises a well-marked zone of life in the Lower Lias, which was well shown at Bredon during the cntting of the Bristol and Birmingham Railway, from whence $I$ obtained the fine figured specimens. The rock consisted of dark grey-bluish shales and marls, with irregular and inconstant bands of limestone. This Ammonite is found near Stratford-on-Avon, Warwickshire; it is collected in great abundance between Lyme Regis and Charmouth, where the shells are replaced and their chambers filled with crystallised carbonate of lime. These beautiful fossils are called "Tortoise Ammonites" by the local collectors. The young examples of this species found with $A$. planicosta, Sow., in the Marston marble of Somersetshire, 
which belongs to the zone of $A$. obtusus, have been figured by Sowerby under the name of $A$. Smitlii.

In Robin Hood's Bay, on the Yorkshire coast, I have found this species, which, however, is very rare in that county, $A$. stellaris being here the dominant form, and mis-called $A$. obtusus in most of the public and private collections.

On the continent of Europe it has been found in France, in the environs of Avallon (Yonne); Saint-Ramber (Ain); and in the province of Luxemburg, at Ethe; and it is found in South Germany in many localities. Professor Quenstedt regarded this species as A. Turneri, Sow., and figured it as such; in pl. iii, fig. 19, of his 'Cephalopoden' my learned friend recognised the stratigraphical importance of this form, as he found it characteristic of a zone, which he called the "Turnerithone" in his valuable 'Flözgebirge Würtembergs.' It is found at Balingen, Ober-Dingen, Betzgingen, and Betzenrieth.

Arietrtes stellaris, Souerby. Pl. XXII, figs. $1-6$.

Ammonites stellazis, Sowerby. Mineral Conchology, vol. i, p. 211, pl. 93, 1815.

- - De Haan. Mon. Ammon. et Gon., p. 109, 1825.

- $\quad$ - Guidoni. Journal de Géologie (Boué), iii, p. 276, 1831.

- - d'Orbigny. Paléontologie Française, Terr. Jurassique, t. i, p. 193, pl. xlv, 1842.

- $\quad$ - Pilla. Bull. Soc. Géol. de France, sér. ii, t. iv, p. 1063, 1847.

- Turneri, Quenstedt. Die Cephalopoden, p. 261, 1846-9.

- Stellaris, Schafhäutl. Von Leonhard und Bronn's Jahrbucb, p. 139, 1848.

- $\quad$ - Savi e Meneghini. Geologia della Toscaua, p. 104, 1851.

- oвтusus, Ehrlich. Geoguostich. der Nordöstlich. Alpen, p. 22, 1852.

- STEllaris, von Hauer. Jahrbuch der k. k. geolog. Reichsanstalt, iv, p. $747,1853$.

- - Chapuis et Dewalque. Foss. terr. second. Luxembourg, p. 4l, pl. v, fig. 2, 1853.

- - Merian. Verhand. der Natur. Gesellschaft. Basel, p. 77, 1854.

- - von Hauer. Die Cephalopoden aus dem Lias, Nord-Alpen, p. 22 , pl, v, figs. $1-3,1856$.

- - Oppel. Juraformation, p. 82, 1856.

- $\quad$ - Quenstedt. Der Jura, p. 96, pl. xii, fig. 1, 1858.

- - Dumortier. Dépôts Jurass. du Bassin du Rhône t. ii, p. 123, 1867.

Arietites - Tate $\&$ Blake. Yorkshire Lias, p. 287, 1876.

Diagnosis.-Shell discoidal, compressed; whorls four, exposed, one third involute ; sides flattened, covered with thirty ribs, nearly straight on the sides, and bent toward 
the marginal angle; siphonal area squarish with a thick prominent keel, and two deep lateral sulci. Onter lamina of the shell ornamented with elevated longitudinal and transverse lines, growing at some distance apart and forming decussating striæ with a series of elevations at the points of intersection; aperture oblong, subquadrate, deeper than wide ; siphonal area narrow and bisulcate ; dorsal margin widest where it embraces the penultimate whorl.

Original type specimens of Sowerby-the largest shell (PI. XXII, figs. 1, 2) :-

Dimensions.-Transverse diameter 125 millimètres; width of umbilicus 40 millimètres ; height of aperture 50 millimètres ; greatest dorsal width 43 millimètres.

Smaller shell (Pl. XXII, figs. 3-6), the same as figured in the 'Mineral Conchology': transverse diameter 73 millimètres; width of umbilicus 25 millimètres; height of aperture 30 millimètres; greatest siphonal width 25 millimètres.

Description.-The shell is discoidal, compressed; tricarinate on the siphonal area, and its sides ornamented with thirty simple ribs, slightly bent in the inner half, curved forward, and much less prominent as they approach the angle; the shell is bevelled away toward the abdominal side, and here the ribs entirely vanish. The siphonal area is narrow from the bevelling of the shell; the keel is thick and prominent (figs. 2 and 5), with a deep sulcus on each side. The spire is composed of four compressed whorls, which cover more than a third, about $\frac{\mathbf{3} 8}{100}$ th of the embracing whorl, so that the entire umbilicus is exposed. The surface of the outer lamina of the shell is ornamented with distant, elevated, longitudinal, and transverse lines, and the decussating striated surface thus produced forms small tubercles at the points of intersection, which impart a remarkable feature to this and the allied species, Arietites obtusus. These decussating striæ are very well shown in the siphonal areas of both the figured specimens; the aperture is oblong, subquadrate, compressed at the siphonal side, with a sinuous margin, and enlarged at the umbilical side, where it embraces the preceding whorl.

The lobe-line, very well shown in fig. 3 , forms one siphonal, and three lateral lobes, with four saddles on each side. The siphonal lobe is one third longer and wider than the superior lateral lobe, which is small, and the lower lateral and the auxiliary are so likewise. The lateral saddles are very large, and much exceed in size the siphonal and auxiliary saddles, as is very well seen in figs. 3 and 6 . In none of the specimens that have passed through my hands have I seen the form and complexity which d'Orbigny has figured in his plate xlv.

The Anaptychus, which I found in the body-chamber of a large specimen at Lyme Regis, has an uneven, compressed, bell-shaped figure; it has a horny texture, and much resembles the Anaptychus of $A$. semicostatus found very near the obtusus-zone.

Affinities and Differences.-Arietitesstellaris very much resembles $A$.obtusus (Plate XXI) in the general form and punctated character of its shell structure; it differs, however, from that Ammonite in having a more compressed shell, bevelled away toward the margin, with more numerous ribs vanishing as they approach the angle, and leaving no 
trace in the siphoulal area. The lobe-line likewise differs from that species, being in general more simple throughout.

It resembles A. bisulcatus, Brug. (Plates III and IV), in its form, ribs, and keel, but is readily distinguished from it at all ages by the size of the whorls, the more compressed sides, the bevelling away at the outer margin, the complete absence of tubercles on the sides, and the difference in the contour of the lobe-line.

In youth the ribs in $A$. stellaris are more acute, in the adult they become blunted, in old age are nearly effaced and the prominent carina becomes much attenuated.

It very mnch resembles $A$. Turneri (Plate XII), but differs from that form in having fewer ribs, all of which disappear on the bevelled margin; whilst in $A$. Turneri they are bold and well-defined thronghont. The longitudinal and transverse elevated lines, on the shell surface, finely punctated at their intersections, are absent in A. Turneri. The same structural differences distinguish $A$. stellaris from $A$. Brooki (Plate VI), with which it has many affinities in point of form and style of growth. The shell surface, however, forms an important diagnostic character between two such closely allied congeneric forms.

This is a very important species, and lighly characteristic of a well-marked zone of life in the Lias Sea. Prof. Quenstedt described this form as A. Turneri, and assigned its true position in his 'Flözgebirge Würtembergs,' p. 156, from its abundance in a bed of clay of his "Betakalk," called "Turnerithone," which he found at Erms by Betzingen, near Balingen, and Bollerbach between Heiningen and Betzgenrieth.

Dumortier says that it is the most important and characteristic shell of the strata in which it is found, and is the most widely distributed, and is assuredly the fossil the most easy to observe; seeing that its fragments cannot escape observation, inasmuch as the specimens are almost always of large size.

Locality and Stratigraphical Position.-The finest specimens of this species are found in the limestone nodules of the Arietites-obtusus zoue between Broad Ledge and Cornstone Ledge, near Charmonth, Dorset. I have found some large specimens in the same zone in the Bredon cutting of the Midland Railway, and at Robin Hood's Bay, Yorkshire (see page 54). Many of these specimens are preserved in the Leckenby Collection, now in the Woodwardian Museum, Cambridge.

Foreign Distribution.-South Germany, Würtemberg, at Ballingen (Quenstedt); Austria, in the North and South Alps (Von Hauer). France: Avallon, Yonne; St. Fortanat, St. Cyr, Dardilly, Rhône (Dumortier); Mont-de-Lans, Isère (Gras) ; Nancy, Meurthe, and other localities, together with those recorded in the works cited in the bibliography of this species. 
Arietites raricostatus, Zieten. Pl. VII, figs. 2-6; Pl. XXVI, figs. 5-14.

Ammonites raricostatus, Zieten. Versteiner. Würtemb.,p. 18, tab. 13, fig. 4, 1830.

$\begin{array}{ccc}- & - & \text { De Mandelsloh. Const. géolog. Alb. Würtemb., } 1835 . \\ - & - & \text { d'Orbigny. Terr. Jurass., tom. i, p. 213, pl. 54, } 1842 . \\ \text { - } & \text { carusensts, } & \text { d'Orbigny. Terr. Jurass., i, p. 284, pl. 84, figs. 3-6, } \\ 1842 .\end{array}$

Turrilimes Boblayei, d'Orbigny. Terr. Jurass., i, p. 178, pl. 41, 1842.

Ammonites raricostarus, Quenstedt. Flötzgeb. Würtemb., p. 159, 1843.

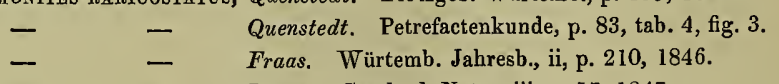

- $\quad$ - $\quad$ Fraas. Würtemb. Jahresb., ii, p. 210, 1846

- - - Giebel. Geogn. Septentr. Hercyn. fast. constit., p. 19, 1848.

- $\quad$ - Hehl. Geogn. Würtemb., p. 218, 1850.

- $\quad$ - Schafhäutl. Südbayr. Alpen, p. 138, 1850.

- $\quad$ - Renevier. Bull. Soc. Vaud. Sc. Nat.s t. iii, p. 139, 1852.

- $\quad$ - Studer. Geologie der Schweiz, ii, p. 30, 1853.

- - Von Hauer. Cephalopod. aus dem Lias N.-O. Alpen,

p. 52 , pl. $x$ vi, figs. $10-12,1856$.

- $\quad$ - $\quad$ Quenstedt. Der Jura, p. 105, pl. xiii, figs. 16-18, 1858.

- Raricostatus, Dumortier. Dépôts Jurass. du Bassin du Rhône, tome ii, p. 173, pl. xxv, figs. 4-7, 1867.

Aegoceras? raricostatum, Tate and Blake. Yorksh. Lias, p. 276, 1876.

Diagnosis.-Shell compressed, discoidal; whorls narrow, numerous, almost entirely evolute; sides with 21 to 30 straight, acute, prominent, and distant ribs, diminishing in size on the siphonal area, which is flat, with a small, narrow, rudimentary keel, without lateral sulci; aperture quadrate, rotundo-cordate.

Dimensions.-The large specimen figured in PI. VII, figs. 2, 3, 4. Diameter 93 millimètres; ditto of umbilicus 56 millimètres; height of aperture 20 nillimètres; width of ditto 18 millimètres.

The smaller specimen figured in Pl. XXVI, figs. 12, 13, 14: diameter 60 millimètres; ditto of umbilicus 35 millimètres; height of aperture 15 millimètres; width of ditto 15 millimètres.

Dimensions of the French specimen measured by A. d'Orbigny : diameter 93 millimètres; size of the last whorl $\frac{20}{100}$; amount of involution $\frac{2}{100}$; diameter of the umbilicus $\frac{62}{100}$; thickness of the last whorl $\frac{28}{100}$. Another, measured by M. Dumortier, gave: diameter 65 millimètres; size of the last whorl $\frac{22}{100}$; thickness $\frac{21}{100}$; size of umbilicus $\frac{64}{100}$. In a smaller shell of 35 millimètres all the other proportions remain the same.

Description.-'This is an important and very characteristic Ammonite, as it marks 
out clearly the boundary line between the Lower and Middle Lias, and has a very limited life in time.

It presents two distinct forms, both of which are met with in the British Lias, and each requires a separate description. The first variety $(a)$ is the form which has been figured by Zieten as the type of the species. It has straight prominent ribs, set far apart, with wide concave spaces between. We count about twenty costæ in the last whorl of a shell of 60 millimètres in diameter; when the Ammonite is larger the whorls have more prominent ribs, which become thicker at the margin. The fossil, Pl. VII, fig. 2, is a good example of this form; in it, however, the ribs are more numerous, on account of the size of the shell. Those which I have collected near Cheltenham, and those found at Ballintoy, in the North of Ireland, belong to this variety.

The second variety $(b)$ has more numerous ribs, nearly thirty in the last whorl, in a shell of 40 millimètres in diameter. The whorls are in general less depressed, and the inner are covered with very delicate, close-set, regular ribs. The evolution of this variety is very well shown in a mass of speciniens $I$ obtained from a bed of shale near Charmoutl. The young shells of 16 millimètres in diameter all have numerous bent ribs, set very regularly apart, which cross the siphonal area without any trace of the carina which appears in larger specimens; so it may be said of this Ammonite that the young shells have many more ribs in a whorl than the older specimens. The carina first appears as a slender central sheath, which only assumes the form of a rudimentary keel when the shell reaches from 20 to 25 millimètres in diameter. This variety is collected in great numbers from the upper beds of the Lower Lias Clay near Charmouth. The shells, however, are so highly charged with iron sulphuret that they unfortunately soou fall to pieces in the drawers of the cabinet by the decomposition of the mineral matrix.

The septa are very distinct in this species, and removed rather wide apart. They form three lobes, and three saddles composed of unequal parts. The siphonal lobe is a little longer than the principal lateral lobe (PI. VII, fig. 5), and has numerous denticles on its sides. The siphonal saddle is one third larger than the principal lateral lobe, and has three groups of lobules nearly equal in size; the principal lateral lobe is irregular in the shape and disposition of its lateral denticles; the lateral saddle is smaller than the principal lateral lobe, and has two terminal lobules with small lateral branches; the lower lateral lobe is small, with several lateral denticles, and the auxiliary lobe ends in simple digitations.

The septa stand wide apart, and the lobe-line occupies the valley between every second rib, as shown in fig. 6, drawn purposely to demonstrate this remarkable character in the structure of $A$. raricostatus, which is really not only raricostate, but likewise rariseptate, in all the specimens $I$ have examined.

The front view (Pl. VII, fig. 4) shows the plain siphonal area deprived of the shell, with the slender keel in the centre of the area; and the back view of the same shell shows 
the same structural character around the whorl (fig. 3); the different examples of this species which I have figured in Pl. XXVI, figs. 5-14, show how permanent these characters are in several varieties of this species from my collection.

Affinities and Differcnces.-Arietites raricostatus stands out very distinct from all its other congeners; the short, straight, acnte, sparse ribs on the sides, with wide concave valleys between; the narrow, slender keel, without lateral sulci on the area, and its simple lobe-lines so widely apart, form an assemblage of characters which readily distinguish this species from the congeneric forms with which it is associated.

Locality and Stratigraphical Position.-I have collected this species in the neighbourhood of Cheltenham, associated with Hippopodium ponderosum, Arietites nodotianus, and Aegoceras densinodum; the zone which it characterises I consider as the uppermost of the Lower Lias. At Black Venn, near Charmouth, Dorsetshire, a very interesting variety is found, unforturately overcharged with iron-pyrites. The larger specimens, such as the one figured, Pl. VII, figs. 2, 3, are found in the limestone, and are well preserved.

At Robin Hood's Bay, Yorkshire coast, I found this species in nodules apparently derived from the Oxynotus-zone, which is here closely united with the Raricostatusbed. I had a very fine series of this Ammonite sent me from the North of Ireländ by my old friend Professor E. C. H. Day, F.G.S., which he collected from the Raricostatusbed so well developed in the small Bay of Ballintoy.

In France it is found with Gryphaa arcuata at Semur, and at Pouilly-en-Auxois, Nolay, Côte-d'Or' near Nancy, Meurthe; Saint-Fortunat, Rhône; Saint-Cyr, Rhône ; Drevaine, Saône-et-Loire, and several other localities in the Valley of the Rhone. In Württemberg it is found at Göppingen, Metringen, Oberdingen, Balingen, and Schlichen, near Schömberg.

Arietites nodotianus, d' Orbigny. Pl. XXXVII, figs. 3 and 4.

Ammonites nodotiands, d’Orbigny. Pal. Française, Terr. Jurass., i, p. 198, pl. xlvii, 1842.

- Macdonelifi, Portlock. Report on Londonderry, p. 134, pl. xxix a, fig. $12,1843$.

- Charpentieri, Quenstedt. Bronn's Jahrbuch für Mineral., p. 810, 1847.

- Quenstedti, Schafhäult. Geog. Sūdbayr. Alpengebirg., p. 142, pl. xvi, fig. 22, 1851.

- Nodotiands, Savi e Meneghini. Geologia della Toseana, p. 122, 1851.

- $\quad$ - Giebel. De Cephalopoden der Vorwelt., p. 734, 1852. von Hauer. Jahrbuch der k. k. geologischen Reichsanstalt, p. $747,1853$. 
Ammonites nodotianos, Studer. Geologie der Schweitz, ii, p. 35, 1854.

von Hauer. Cephalopoden aus dem Lias N.-O. Alpen, p. 24, pl. vi, figs. $1-3,1856$.

Arietites? Macdonnelli, Tate and Blake. Yorksh. Lias, p. 290, pl. v, fig. 8, 1876.

Diagnosis. - Shell discoidal, compressed, carinate; whorls one third involute, flat, and slightly convex, sides with numerous simple, strajght, flat folds, $32-40$ in the last whorl, most distinct between the umbilical border and the margin, and becoming evanescent and disappearing on the siphonal area, which is narrow and acnte, with a thin prominent keel permanent in the cast; aperture narrow, clongated, elliptical, and compressed; on the sides a slight depression on each side of the keel; lobe-line simple; septa remote from each other.

Dimensions.-Diameter of figured specimen, 65 millimètres; width of umbilicus 35 millimètres; depth of the last whorl 15 millimètres; height of aperture 20 millimètres ; transverse diameter of ditto 11 millimètres.

Description.-I am indebted to my old friend Professor Hull, F.R.S., for the loan of General Portlock's original type of Ammonites Macdonnellii, figured in his 'Geological Report of Geology of Londonderry,' and which belongs to the Dublin Museum of the Geological Survey of Ireland. The drawing did not do justice to the specimen. I have, therefore, had this shell carefully redrawn, with front and side views of the fossil.

I was the first to find this Ammonite in the English Lias in the zone of Aegoceras Jamesoni, sub-zone armatus, near Cheltenham. The shale in which it lies is highly ferruginons, and many of the specimens are much decomposed.

The shell is much compressed, discoidal, and strongly carinated; the whorls, seven in number, and about one third involnte, are flat and only slightly convex; the sides are covered with numerous straight, simple folds or fat ribs (fig. 3), which are higher than they are wide, and a transverse section forms a regular ellipse. The height of the last whorl is about one fourth the diameter of the shell. The ribs, from $36-40$ in the last whorl, are slightly elevated, and in shells of 60-70 millimètres are merely flat folds of the shell (fig. 3). In smaller specimens, 25 millimètres in diameter, they are regular and delicate ribs; about this age the keel first makes its appearance. As the shell grows, it becomes a thin, slender, prominent carina, which develops into a trenchant prominence on the shell, and forms (figs. 3 and 4) a well-marked carina on the cast. The ribs are largest between the imbilical border and the margin, where they diminish, and finally disappear on the siphonal area. The aperture is oblong, ellipsoidal, and compressed at the sides.

The lobe-line is very simple, all the lobes and saddles are slightly incised, and the septa placed wide apart ; the siphonal lobe is a little longer than the priucipal lateral, and is tridigitate on each side. The principal saddle has three unequal festoons; the siphonal lateral lobe is fivefold; the lateral saddle is smaller, but similar to the siphonal. The lateral lobe is about two-thirds the size of the principal lateral, and terminates in 
three digitations; the auxiliary saddles have small festoons, and the auxiliary lobe terminates in two points. The septa are placed so wide apart that we often find three ribs intervening between two septa. The radial line, in parting from the extremity of the dorsal lobe, cuts the points of the principal lateral lobe, but passes at some distance from the lateral lobe and the auxiliaries.

Affinities and Differences.-The compressed sides, prominent keel, and absence of lateral sulci, separate this form from other Arietites with which it is grouped, and with which it has many affinities both in the structure of the lobe-line and in the lobes and saddles themselves. It has numerous affinities with the genus Harpoceras in the form and structure of the shell.

Locality and Stratigraphical Position.-General Portlock found his type shell in the Lias at Larne, and others at Portrush and Ballintoy. I have found it in the lower part of the Armatus-bed at the base of the Jamesoni-zone in Lias Clays near Cheltenham, associated with Aegoceras densinodum and Amaltheus oxynotus.

In France it is very rare. The type specimen figured by d'Orbigny was collected in the Lias of Gros-Bois, Côte d'Or ; Dumortier records it from St. Fortunat, Limonest, Rhône ; Jambles, Saône-et-Loire; Nolay, Cốte-d'Or, and other localities. Professor Von Hauer's specimen, figured in his 'Nordöstlichen' Alpen' was found in the Lias of the Alps; at Neustiftgraben, Steinbauer, Adneth, Weidachlahne, in Ammergau. D. Stur collected numerous examples of this species, two to three inches in diameter, in the Carpathians at Modern, at Tureczka, and Arva.

Schafluäutl found it in the Bavarian Alps in several localities; Studer in Switzerland; and Savi and Meneghini in the Apennines at Castlenuovo in Garfagnana.

Arietites impendens, Young and Bird. Pl. XXII a, figs. $1-5$.

Ammonites impendens, Young and Bird. Geol. Surv. Yorksaire Coast, p. 266, 1828.

- - Simpson. Monogr. of the Ammonites, p. 52, 1843.

- Fowleri, Buckman. Geol. of Cheltenham, p. 104, pl. xii, fig. 7, 1845.

- Impendens, Simpson. Fossils of the Yorkshire Lias, p. 96, 1855.

- Radiatos, Simpson. Ibid., p. 88, 1855.

Arietites impendens, Tate and Blake. Yorkshire Lias, p. 290, pl. vi, fig. 7, 1876.

Diagnosis.-Shell discoidal, depressed, and highly carinate; whorls deep ; sides convex and bevelled towards the margin, nearly two thirds involute; when young, sides costate, with thirty-six straight acute ribs, which bend sharply inwards toward the margin; adult, sides smooth or undulated with flat folds, which overhang the edge of the umbilical suture. Siphonal area narrow, with a very prominent acute keel, and two wide, deep lateral furrows; aperture narrow, compressed, or sagittate.

Dimensions (young; costateform, of specimen figured, Pl. XXII A, fig. 4).-Diameter 40 millimètres; ditto of the umbilicus 12 millimètres. 
Middle-aged.-Diameter of specimen figured (PI. XXII A, fig. 1) 80 millimètres; ditto of the umbilicus 26 millimétres; height of aperture 35 millimètres; width of ditto at spire 20 millimètres.

Adult.-Diameter of a specimen not figured, 100 millimètres; width of umbilicus 25 millimètres; height of last whorl 45 millimètres.

Description.-This is a very remarkable Ammonite, and combines in its structure the form of Harpoceras with the lobes and saddles of Arietites. It is likewise a very rare form in the Yorkshire Lias, where it has hitherto been chiefly found. In early age its deep whorls have costated sides, and when 40 millimètres in diameter (fig. 4) its convex sides are covered with thirty straight acute ribs, which bend sharply forwards toward the margin and disappear on the area ; the keel is then acute and prominent, and it has a sulcus at each side. In middle age (when 80 millimètres in diameter, figs. 1-3) the last whorl has become very deep, and resembles a Harpoceras in form; about twenty bent ribs or undulating folds cover the sides near the umbilical sutnre, disappear on the external half, and are bevelled away toward the margin; the outer lamina of the shell is covered with numerous fine striæ, which follow the sweep of the ribs and highly ornament the surface-these lines are seen only on very fine specimens carefully extracted clean out of the shale; the height of the last whorl at the aperture in a specimen before me is about $\frac{50}{100}$ ths of the diameter of the shell, that of the figured shell is $\frac{40}{100}$ ths; the siphonal area is narrow, from the bevelling of outer half of the whorl ; in the centre is a very acute prominent keel with two deep furrows (figs. 2, 3); in some good specimens the keel is beautifully crenated by the fine strix of the shell passing over its edge. The inner margin of the whorls overhangs the umbilical suture, hence the origin of the name impendens given to this species by Young, and the outer margin terminates abruptly at the outer sider of the sulcus (fig. 2). In the adult specimen, 100 millimètres in diameter, the deptlı of the outer whorl, and the size and prominence of the keel form striking characters in the shell, which is here intact; the amount of involution is likewise much increased.

The lobe-line (fig. 5) is very regular, the siphonal lobe is short and wide, and the margins finely striated; the siphonal saddle wide, with two festoons; the principal lateral lobe is less than the siphonal, and formed of unequal parts ; the digitations are more numerous at the inner side; the principal lateral saddle is wide, with several festoons; the lateral lobe is a little smaller than the principal, and, like it, is formed of unequal parts; the lower lateral saddle is small, and the auxiliary lobes are concealed by the turns of the spire.

Affinities and Differences.-This Ammonite closely resembles Arietites Collenotii, d'Orb. They both have the physiognomy of Harpoceras, and might be readily mistaken for that genus, but the structure of the lobes and saddles closely connects them with Arietites, in which I have placed them. They are both rare Ammonites, and, except the specimen I obtained from Robin Hood's Bay, all the others were in the cabinet of my late 
friend, Mr. John Leckenby, F.G.S., to whom the shell I have figured belonged; it was likewise the largest and finest example that had ever been found in Yorkshire. It is now in the Woodwardian Museum, Cambridge.

Locality and Stratigraphical Position.-This Ammonite was collected from the hard shales of the zone of Amaltheus oxynotus at Robin Hood's Bay, on the Yorkshire coast; the young form, figured and described by Prof. Buckman, F.G.S., as Am. Fowleri, was collected in the shales of the Lower Lias, in the deep railway-cutting near the Lansdown Station, Cheltenham.

Anietites Coldenotil, d' Orbigny. PI. VI, fig. $1^{\mathrm{I}}$; Pl. XXII A, figs. 6-9; Pl. XXII в, figs. $1-3$.

Ammonites Coldenorn, d'Orbigny. Pal. Franç., Terr. Jurass., p. 305, pl. xev, figs. 6 $-9,1842$.

- Denotatus, Simpson. Fossils of York. Lias, p. 76, 1855.

- Tenellus, Simpson. Ibid., p. 97, 1855.

Arietites Collenotir, Tate and Blake. Yorkshire Lias, p. 290, 1876.

Diagnosis.-Shell discoidal, compressed, volutions five to six; whorls deep, less than half the diameter of the shell, inner margin rounded, outer part depressed, sides costated; ribs straight for three-fourths of the whorl, then sharply bent towards the border; siphonal area small; keel narrow and acute, with two broad lateral sulci; sides convex, bevelled towards the marginal area; aperture narrow, deep, sagittate; septa. with three lobes and three saddles.

Dimensions.-_Small specimen with shell (Pl. XXIL A, figs. 6-9) : diameter 100 millimètres; ditto of umbilicus 22 millimètres; height of aperture 45 millimètres ; width of ditto 23 millimètres; height of keel 6 millimètres.

Large specimen denuded of shell (Pl. XXII в, figs. 1-3): diameter 140 millimètres; height of the last whorl 65 millimètres; height of aperture 66 millimètres, width 33 millimètres; width of the umbilicus 30 millimètres.

Description.-This Ammonite has a compressed discoidal shell, provided with an acute prominent keel. In early age the sides have close and sharp costæ, which disappear in the adult state. A specimen, Pl. VI, fig. 1, 85 millimètres in diameter, has forty straight acute ribs, which increase in thickness near the margin, and bend sharply forward towards the aperture, entirely disappearing at the outer border of the sulcus. Pl. XXII A, fig. 6, is a specimen in which the shell is preserved; it is covered with minute striæ, which run parallel with the ribs, and these delicate lines passing over the keel give it a finely crenated appearance. The siphonal area is very narrow, from the bevelling away of the sides towards the outer border; the keel is acute and very prominent (Pl. XXII A, figs. 6-8), and on each side has a broad, shallow sulcus, ontwardly

$$
\text { I Named Arietites denotatus on explanation of pl. vi. }
$$


bounded by a sharp carinated ridge, produced by the union of the costal termination, and forming a well-defined limit to the sulci. These marginal carinæ are well seen on the cast, but much better when the shell is preserved.

In the fine large specimen, Pl. XXII в, which measures 140 millimètres in diameter, the ribs begin to disappear from the last half of the whorl, whilst they are well developed upon all the inner turns of the spire. The keel is very sharp, the sulci broad, and the siphonal lobe-line is seen in sitü in fig. 3 ; the sagittal shape of the aperture is well seen in fig. 2, and the structure of the lobe-line in fig. 1. The septa (Pl. XXII A, fig. 9) consist of three lobes and three saddles. The siphonal lobe is much longer and wider than the principal lateral; it has two branches, the sides of which are ornamented with numerous bilateral digitations. The siphonal saddle (Pl. XXII в, figs. 1, 3) is as large as the principal lateral lobe, and provided with numerous rounded festoons. The principal lateral lobe curves outwards, has three digitations on its border, and terminates in several points; the lateral saddle is larger than the principal lateral lobe, and terminates in numerous festoons; the lateral lobe is divided into two parts, and each has several digitations; the lateral saddle is wide and shallow, and ends in six festoons; the auxiliary lobe is small, and terminates in two short branches.

In Pl. XXII A, fig. 9, I have given an enlarged drawing of the lobes and saddles of the specimen figured in No. 6 , which agrees very well with the lobe-lines on the specimen drawn in Pl. XXII в, fig. 1, in which a line passing from the point of the siphonal lobe to the centre passes beneath all the other lobes.

Affinities and Differences.-This Ammonite very much resembles A. impendens; its keel, however, is larger, the last whorl is deeper, and it wants the overhanging projection over the umbilicus so characteristic of impendens. Notwithstanding these differences, $A$. impendens may be only a variety of $A$. Collenotii. It has some resemblance to Arietites Brooki, still the depth of the outer whorl and the absence of ribs in old specimens prove the distinctness of the species.

A. Collenotii is a very remarkable species, as was long ago remarked by Professor Alcide d'Orbigny, who observed that it united in one form two characters, in general widely separated from each other. In its general form it resembles Harpoceras, and in the structure of its lobes and saddles its affinities lie with Arietites. It is certainly very distinct from all the species of both groups, with which it has affinities and differences both interesting and remarkable. In its general form and structure, Arietites Collenotii resembles $A$. Aballoensis, d'Orb., but differs from the latter in having its prominent keel persistent on the cast, whilst in $A$. Aballoensis the keel exists ouly in the shell, and is entirely absent in specimens denuded of the carina; it likewise wants the lateral furrows so characteristic of $A$. Collenotii.

Dr. Oppel erroneously considered $A$. Collenotii to be a young individual of $A$. Guibalianus, and that both species should be united. It will be shown in the sequel, 
however, by figure and description, that my late friend was mistaken in this conclusion, and that both are good type forms of well-marked species.

Locality and Stratigraplical Position.-The specimens I have figured belonged to my late friend Mr. John Leckenby, F.G.S., and are now in the Woodwardian Museum, Cambridge; they were collected from the Lower Lias at Robin Hood's Bay; the specimen figured in PI. VI, fig. 1, from the same locality, has associated with it in the matrix several fragments of Aegoceras lacunatum, Buck. Mr. Blake says that this species comes from the middle portion of the Oxynotus-zone. Professor Alcide d'Orbigny's type was collected from the Lower Lias with Gryphcea arcuata at Champlong, in the environs of Semur, Côte-d'Or, from whence five examples had been obtained.

\section{Family.-AEGOCERATITES-continued.}

\section{Genus II-Aegoceras. Waagen, 1869.}

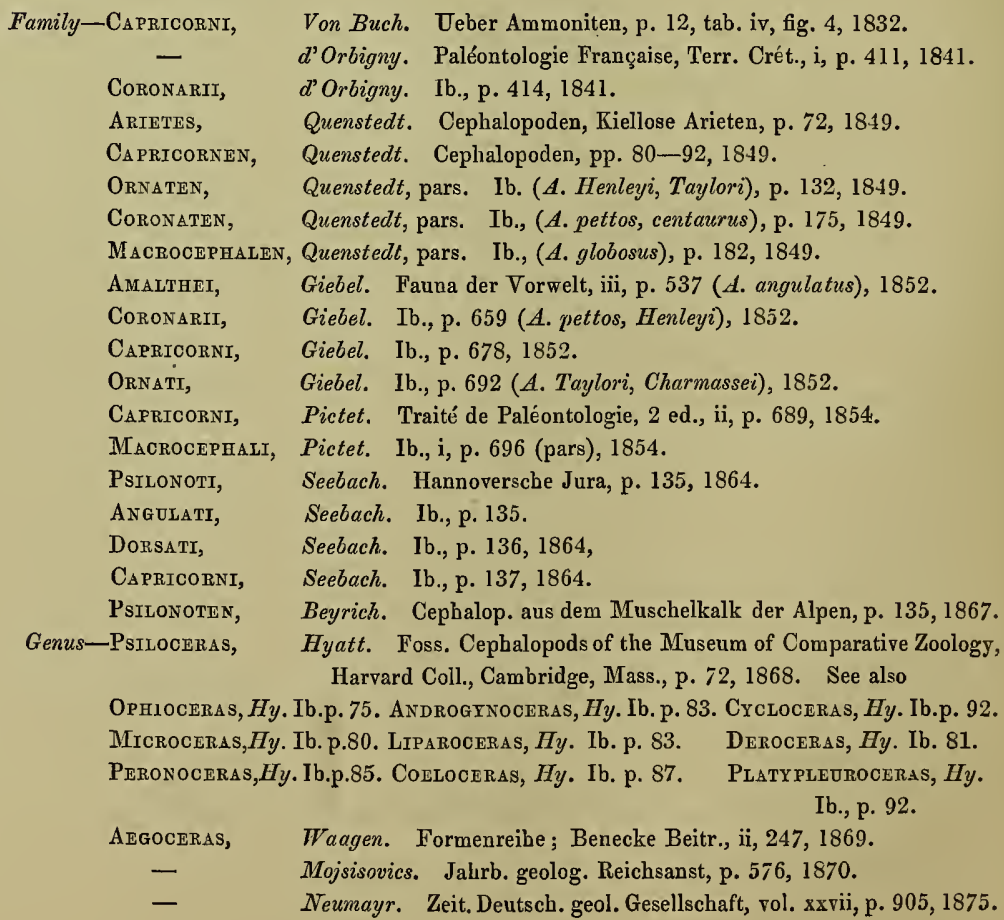


The form of the shell in this genus is very variable; it is flat and discoidal, with a wide umbilicus, or round and involute with a small umbilicus. In some shells the ventral margin is convex and enlarged, and the sides highly oruamented with ribs, tubercles, or elongated spines; in other species the sides have simple folds or undulations, as Aeg. Jamesoni, Sow. (Pl. XI, figs. 4-6); and some are smooth, as Aeg. planorbis, Sow. (Pl. XIV, figs. 1-4). The ventral side is in general round, Aeg. capricornus, Schlot. (fig. 186), and Aeg. Davai, Sow. (fig. 187); sometimes it is grooved by a median channel, which interrupts the passage of the ribs from the right to the left side of the shell, as is especially the case in Aeg. angulatum, Schlot. (Pl. XIV, fig. 6), and Aeg. Charniassei, d'Orb. (Pl. XX, figs. 2,3). In all the species a keel is absent, and there are no lateral longitudinal channels in the siphonal or ventral areas.

The body-chamber varies in length from two-thirds of, to an entire whorl. The mouthborder is simple; the edge has sometimes a thickened withdrawn lip and a ventral

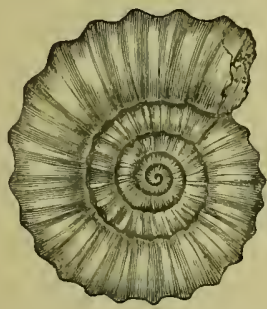

FIG. 186.-Aegoceras capricornus, Schloth.

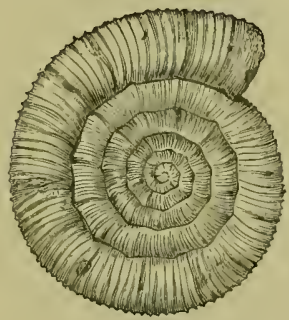

FIG. 187.-Aegoceras Davoi,

prolongation; and in Aeg. planorbis there is a contraction near the aperture (PI. XIV, fig. 3), without lateral auricles. The Aptychus is horny, thin, and bivalved (Pl. XIV, fig. 3).

The lobe-line is much ramified, and the lobes in general are very complicated. There is a highly branched principal lateral, a smaller lower lateral; and the siphonal lobe, less than the principal lateral, ends in two divergent branches. There are several small auxiliary lobes near the suture, which are concealed by the involution of the spire, as in Aeg. Charmassei, d'Orb. (Pl. XX). This genus may be naturally divided into four sections :

\section{First Section, Psilonoti.}

Sides smooth, or with undulated folds or straight ribs; suture-line simple; ventral area round and smooth. Aeg. planorbis, Sow.; Aeg. Jolnstoni, Sow.; Aeg. torus, d'Orb.; Aeg. intermedium, Portlock; Aeg. Belcheri, Simp.; Aeg. laqueolus, Schlönbach.

All these forms are found in the Planorbis-zone of the Lower Lias. 
Second Section, Angulati.

Sides covered with sharply-flexed ribs, interrupted on the ventral area by a channel more or less developed. Aeg. angulatum, Schl.; Aeg. Charmassei, d'Orb.; Aeg. catenatum, Sow.; Aeg. lacunatum, Buck.; Aeg. Boucaultianum, d'Orb.

All these forms, the two last excepted, are from the Angulatum-zone of the Lower Lias.

\section{Third Section, Armatr.}

Sides with numerous ribs, many of which develop tubercles or elongated spines; in some forms they are absent. Aeg. Daveei, Sow.; Aeg. planicosta, Sow.; Aeg. Birchii, Sow.; Aeg. bifer, Quenst.; Aeg. armatum, Sow.; Aeg. Taylori, Sow.; Aeg. densinodum, Quenst.; Aeg. brevispinum, Sow.; Aeg. Valdani, d’Orb.; Aeg. Mangenesti, d'Orb.

Aeg. planicosta, Aeg. Birchii, and Aeg. bifer, are from the Upper Bucklandi-beds of the Lower, and all the others are from the Jamesoni zone of the Middle, Lias.

\section{Fourth Section, InvoLuTr.}

Shell highly involute; inner whorls sometimes almost entirely concealed. Shell during middle age often undergoes a great change of form, when the involution becomes less, and the umbilicus widens. Aeg. Henleyi, Sow.; Aeg. striatum, Reinecke; Aeg. Bechei, Sow.; Aeg. curvicornum, Schloenb.; Aeg. pettos, Quenst.; Aeg. heterogenes, Young and Bird.

All the forms of this section are from the Henleyi-zone of the Middlc Lias. The genus Aegoceras began in the Muschelkalk, zone of Arcestes Studeri, with Aeg. incultum, Beyr., Aeg. Palmai, Mojs.; and became extinct in the Middle Lias.

First Section.-Psilonoti.

Aggoceras Planorbis, Sowerby. Pl. XIV, figs. 1-4.

AMMONITES PLANORBIS,

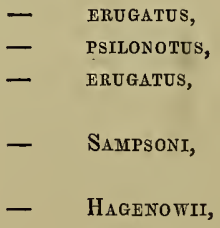

Sowerby. Mineral Conchology, vol. $\nabla$, p. 69, pl. 448, 1825.

Phillips. Geol. Yorksb., pl. 13, fig. 18, 1829.

Quenstedt. Flötzgebirge Würtembergs, p. 127, 1843.

Simpson. Monogr. of the Ammonites of the Yorkshire Lias, p. 11, 1843.

Portlock. Geology of Londonderry, p. 136, pl. 29, fig. 13. 1843.

Dunker. Lias bei Halberstadt; Palæontographica, vol. i, p. 115, pl. xiii, fig. 22 ; pl. xvii, fig. $2,1846$. 
Amaonites Psilonotus Levis, Quenstedt. Cephalopoden, p. 73, pl. iii, fig. 18, 1849.

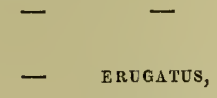
Quenstedt. Handbuch der Petrefactenkunde, tab. iii, fig. 18, p. 354,1852 .
- PLANorbis,
-
- PSilonotos
- Planorbis,
Aegoceras planorbis,
Simpson. Fossils of Yorkshire Lias, p. 42, 1855.
Oppel. Juraformation, p. 73, 1856.
Quenstedt. Der Jura, p. 40, 1858.
Dumortier. Dépôts Jurass. du Bassin du Rhône, tom. i, p. 28. 1866.
Tate and Blake. Yorkshire Lias, p. 270, 1876.

Dimensions.-Figured shell : diameter 85 millimètres; height of the last whorl 21 millimètres; width of umbilicus 47 millimètres.

Diagnosis.-Shell depressed, discoidal; whorls, seven to eight, slightly involute; sides covered with fine, straight, hair-like striæ, which are well seen on the outer lamina of the shell, and faintly visible on the cast; siphonal area narrow and rounded; aperture oblong, with a well-marked circular contraction; Anaptychus horny.

Description.-This Lias Ammonite is found nearly always crushed between shaly laminæ. Sowerby's original specimens from Watchet were in that condition, with the mother-of-pearl lamina well preserved. The natural form of the shell, however, is well shown in my figured specimen from the Yorkshire coast, and in another fine example from Würtemberg. The test is smooth, compressed, and discoidal, and the outer lamina of the shell is covered with fine, straight, hair-like lines of growth (Pl. XIV, figs. 1-3), which sometimes develop into folds; the siphonal area is round and smooth (fig. 2), and the body-chamber contracted near the aperture by a narrow oval band, which appears around that opening (fig. 3). The whorls, seven in number, increase very slowly in height; they are slightly involute, and the inuer whorls are all fully exposed. The aperture is oblong and compressed on the sides (fig. 2); and the shell, almost as thin as paper, is preserved in part on both of the figured specimens, which have escaped compression. In nearly all the Planorbis-beds of England the delicate shells are crushed quite flat, and many of the points described above cannot be seen. In some of the fossils from Lias blocks washed up in Robin Hood's Bay, the casts of this Ammonite occur in a semi-transparent state, in which the sinnous lobe-line is beantifully displayed. The siphonal lobe (fig. 4) divides into two branches, with five serrations on each side; the siphonal saddle is about the same size, with five festoons; the principal lateral lobe is elongated and narrow, with asymmetrical digitations; the principal lateral saddle is larger than the siphonal; the lower lateral lobe is nearly as large and asymmetrical as the principal lateral; the auxiliary lobes are small and multidigitate. The lobe-line is very well seeu in fig. 1 , and an enlarged accurate drawing of the lobes and saddles is given in fig. 4 .

Affinities and Differences.-In a recent important memoir, ${ }^{1}$ Dr. M. Neumayr has added 1 'Zur Kenntniss der Fauna des untersten Lias in den Nordalpen,' p. 24. 1879. 
several new forms to the division Psilonoti. The oldest representatives of this section, according to Beyrich, are found in the Muschelkalk of the Alps and of the Himalayas, as Aeg. incultum, Beyr., Aeg. Salteri, Beyr., Aeg. Palmai, Mojs. In the Rhætic beds of the Bavarian Alps, Dr. Gümbel found Aeg. planorboides, Gümb.; and in the Lower Lias the following species are recorded:

Aegoceras planorbis, Sow.

$\begin{array}{ll}\text { - } & \text { calliphyllum, Neum. } \\ \text { - } & \text { Hagenowi, Dunk. } \\ \text { - } & \text { torus, d'Orbig. } \\ \text { - } & \text { Johnstoni, Sow. } \\ \text { - } & \text { tortile, d'Orbig. } \\ \text { - } & \text { crebrispirale, Neum. } \\ \text { - } & \text { magus, Neum. } \\ \text { - } & \text { Clausi, Neum. }\end{array}$

Aegoceras laqueus, Quenst.

- laqueolus, Schlönb.

- Gernense, Neum.

- Suessi, V. Hauer.

- Aeduense, d'Orbig.

- Belcheri, Simp.

- intermedium, Portlock.

- liassicum, d'Orbig.

- Naumanni, Neum.

In the absence of specimens wherewith to compare the minute differences which have been observed in the lobe-line of several of the forms in the preceding list, I must refrain from giving an opinion on the specific distinctions of the same, seeing that it is extremely difficult to arrive at a satisfactory conclusion as to forms which even have generally been admitted to be distinct, nor can a safe conclusion be attained unless we have before us several specimens showing the changes of form they assume at different phases of growth.

Prof. Quenstedt, in his 'Cephalopoden,' p. 73, admits two varieties, Am. psilonotus lavis, Qu., and Am. psilonotus plicatus, Qu.; the former with a smooth shell, and the latter with a folded or plicated shell. I have before me good examples of these varieties kindly sent by Prof. Fraas from the Stuttgart Museum, which fully bear out my learned friend's description.

The affinities and differences existing between Aeg.planorbis and other species of the section Psilonoti are numerous and not easily determined.

Locality and Stratigraphical Position.-I have collected Aeg. planorbis in the lowest beds of the Lower Lias, and whenever they are exposed it forms their most characteristic leading fossil. It is very abundant in the paper-like shales of this zone at Brockeridge and Defford Commons, Gloucestershire, at Burton, Wilmcote, and Grafton, Warwickshire; at Street, Uphill, and Watchet, Somersetshire; Penarth, Glamorganshire; and Pinhay Bay and Uphill, near Lyme Regis, Dorsetshire, where it is found in the upper part of the light-coloured argillaceous limestone, called there White Lias. On the Yorkshire coast it is found in large water-worn boulders of light-coloured limestone washed up by the tidal currents, and in the North Cliff of Robin Hood's Bay; and in Eston and East Coatham pits. The beds from which the masses are derived are out at sea, as the rock 
is not found in sitú at low-water mark. The fine specimen, now in the Woodwardian Museum, figured in Pl. XIV, fig. 1, was broken out of one of these boulders.

Foreign Distribution.-In Würtemburg it is found in fine preservation at Nellingen and Riedern, near Esslingen, at Bebenhausen, near Tübingen, and in the vicinity of Rottweil. In France at Saulieu, and Beauregard, Côte d'Or, where it is associated with Aeg. Johnstoni, Sow., Aeg. laqueus, Quenst., and Aeg. Burgundice, Mart.; it is found likewise at Avallon, Yonne.

Aegoceras Johnstonil, Sowerby, 1824. Pl. XIX, figs. 3, 4.

Amмonites Johnstonir, Sowerby. Mineral Conchology, vol. v, p. 70, tab. 449, fig. 1, 1824.

- Tonus, d'Orbigny. Pal. Franç., Terr. Jurass., p. 212, pl. liii, 1842.

- Johnstoni, Oppel. Juraformation, p. 74, 1856.

- - Giebel. Fauna d. Vorwelt, vol. iii, p. 738, 1852.

- $\quad$ - Neumayr. Fauna der untersten Lias d. Nordalpen, p. 29, pl. iii, fig. 2, 1879.

Aegoceras - Tate \& Blake. Yorks. Lias, p. 271, 1876.

Diagnosis.-Shell discoidal, compressed; whorls, from eight to ten, depressed; sides convex, with thirty simple, short, oblique ribs, which occupy only the middle of the whorl, and are not developed on the inner or outer margins ; siphonal areas rounded, and smooth; aperture subrotund.

Dimensions.-Diameter 90 millimètres; ditto of the umbilicns 58 millimètres; height of the last whorl 18 millimètres; width of ditto 17 millimètres; septa five-lobed.

Description.-Although this species is often quoted in lists of Lower-Lias Fossils, good specimens are extremely rare. I could not find one for figuring in either of the metropolitan Museums nor in those of the Midland Counties, where it is said to be common. Sowerby's original type belonged to Mr. Johnstone's cabinet, and was extracted from the slaty shales of the Lower Lias at Watchet, where it lies associated with Aegoceras planorbis. It is almost always much compressed, and the shell wants its outer lamina; the pearly inner layer is very brilliant and full of iridescent colouring. When the fossil is not compressed it assumes a different appearance, and comes out as Ain. torus, d'Orbig., of which I have figured a typical specimen from Professor Deslongchamps' collection at Cacn. This specimen is compressed, discoidal, and not carinated; the whorls are numerous, regular, and exposed (fig. 3), the spire consisting of nine whorls, which are extremely regular, and ornamented with thirty short simple ribs that occupy only the convex middle portion of the whorl; they do not extend either to the outer or inner margins of the same, and are wholly limited to the flanks; the other parts being smooth and destitute of ribbing. The siphonal area (fig. 4) is rounded and quite smooth, having 
neither marks of striæ nor the merest rudiment of a keel on the cast (figs. 3 and 4). I have not seen the lobe-line of this species, and therefore quote d'Orbigny's description. The septa are symmetrical, divided on each side into five lobes and five saddles, formed of unequal parts. The siphonal lobe is as large, but shorter than the principal lateral, and its sides are ornamented on each side with four digitations; the siphonal saddle is one third larger than the principal lateral lobe, and divided into three obtuse folioles, the central leaf being the largest. The principal lateral lobe is ornamented on each side with two digitations; the superior is simple and terminates in a digitation with three points ; the lateral saddle, as large as the principal lateral lobe, is divided into four obtuse unequal folioles; the inferior lateral lobe, very oblique and irregular, is half the length of, and imuch narrower than the principal lateral lobe. Besides these there are three oblique auxiliary lobes, represented by as many obtuse points. A transverse line, passing from the extremity of the siphonal lobe, cuts the extremity of the principal lateral, passes below the inferior lateral lobe, touches the extremity of the first auxiliary lobe, and cuts across the others.

Affinities and Differences.-This Ammonite differs from Aeg.planorbis in possessing more whorls, which are not so deep, and in having the middle of their sides covered with thick, short, blunt ribs, which vanish from the outer and inner margins. It has been considered by Dr. Oppel to be the Aeg. psilonotum plicatum, Quenst., still it differs from that Ammonite in possessing narrower and thicker whorls, rounder in form, and slower in growth, the sides of which have short, thick, inflated ribs, and a much wider umbilicus. It much resembles Aeg. intermedium, Portlock, from the Lower Lias of Ballintoy, County Antrim (Pl. XV, figs. 3-6). In this species, however, the ribs are more acute and curve forward toward the aperture (figs. 3 and 4 ); the siphonal area is likewise covered with fine cresentic folds (figs. 5 and 6 ); in other respects the resemblance is very great. The next Ammonite which stands in close relationship with Aeg. Jolnstonii is Aeg. Belchieri, Simp.; the latter appears to resemble Aeg. torus, d'Orb., or the French form of Aeg. Johnstonii. These ribbed species of the Psinonoti section are very puzzling indeed, and a much larger number of specimens are wanted for comparison than we at present possess before correct determinations can be made out regarding them.

Locality and Stratigraphical Position.-At Watchet, Aeg. Jolnstonii is found crushed flat in the shales of the lowest beds of the Lias. The mother-of-pearl layer of the shell is wonderfully preserved, the fossils shining forth in beautiful iridescent colours when the shales are laid open with the hammer; there are some fine large slabs covered with these iridescent Ammonites in the British Museum, which all came from Watchet; the form of the shell, however, cannot be made out from any of the specimens found in this locality. It is the constant associate of Aeg.planorbis, Sow., in British Liassic rocks, just as Aeg. psilonotum plicatum, Quenst., is the associate of Aeg. psilonotum lave, Quenst., in those of Würtemberg. 
Aegoceras Belcheri, Simpson. Pl. XV, figs. 7-9; Pl. XIX, figs. 1, 2.

Ammonites Belcheri, Simpson. Monogr. of the Ammonites Yorksh. Lias, p. 12, 1843.

Simpson. Fossils of the Yorksh. Lias, p. 43, 1855.

Diagnosis.-Shell discoidal, compressed; whorls narrow, numerous, from six to seven, exposed, rather flattened on the sides and rounded on the outer margin; ribs short, bent, blunt, and prominent, separated by concave spaces on the sides; siphonal area rounded, destitute of ribs, and marked with delicate, crescentic lines on the shell, which are partly impressed on the cast.

Dimensions. - Large specimen (Pl. XIX, figs. 1, 2) with shell :- number of whorls $6-8$; diameter 95 millimètres; width of umbilicus 60 millimètres; height of the last whorl 20 millimètres; thickness of last whorl 18 millimètres; amount of involution one third of a whorl; number of ribs on the last whorl 48 .

Small specimen (Pl. XV, fig. 7) without shell :-number of whorls $6-7$; diameter 47 millimètres; width of umbilicus 31 millimètres; height of the last whorl 8 millimètres; thickness of ditto 5 millimètres; amount of involution one third of a whorl.

Description.-The two figures I have given of this Yorkshire Ammonite agree very well in comparative dimensions. 'The small specimen (Pl. XV) is entirely a cast, whilst the large fossil (Pl. XIX) has the shell nearly all preserved. In this Ammonite the ribs are rounded and directed obliquely forwards, the valleys between the elevations being about the widtl of the ribs, which commence near the umbilical margin, maintain an equal thickness on the sides, and disappear at the onter margin, leaving the round siphonal area entirely smooth and ornamented only by the fine crescentic lines of the shell. In those parts of the fossil where the shell is denuded we observe that the casts of the ribs are much more acute than where they are enveloped by shell. The umbilicus is very wide, and the growth of this interesting species was very slow.

The lobe-line is very complicated; Pl. XV, fig. 9 exhibits an enlarged drawing of the lobes and saddles of the smaller specimen figured in this plate. The siphonal lobe is wide, and ornamented with four denticles on each of its sides; the siphonal saddle is narrow and deep, and terminates in seven branched festoons; the principal lateral lobe, much larger than the siphonal, is symmetrical in figure, and its sides are ornamented with long denticles; the lateral saddle is as large as the principal lateral lobe, and ends in five festoons; the second lateral lobe is small, narrow, and turned obliquely inwards; the lower lateral saddle is proportionately small, and there are two small auxiliary lobes with corresponding saddles of a like size.

Afinities and Differences.-Aeg. Belcheri, Simp., closely resembles Aeg. intermedium, Portl. (Pl. XV, figs. 5, 6), in the form of the ribs, their length, curve, and obliquity. A. Belcheri wants, however, the fine elevated lines developed between the ribs near the 
outer margin, and which pass over the siphonal area in a series of arched lines, their convexity being always directed towards the aperture in Aeg. intermedium (figs. 4, 5, 6).

Locality and Stratigraphical Position.-'The two specimens I have figured were collected from the Lower-Lias zone of Aeg. planorbis, North Cliff, at Robin Hood's Bay. Mr. Blake notes this species under the name of A. Jolnstoni from Coatham Marsh, and from the zone of Aeg. angulatum, Cliff, Leigh Dam, Scar, Eston Pit, Yorkshire. I have not found this species in any of the collections of Lias fossils in Gloucestershire.

Aegoceras intermedium, Portlock. Pl. XV, figs. 3-6.

Amimonites intermedius, Portlock. Geology of Londonderry, p. 136, fig. 17, 1843. Morris. Catal. British Eossils, p. 292, 2nd ed., 1854.

Shell discoidal, compressed; whorls narrow, numerous, seven to eight exposed and slightly involute, flattened on the sides and rounded on the outer margin; ribs acute, straight, or slightly bent, enlarged at the outer margin, where they bend round and disappear from the rounded siphonal area; shell with delicate striæ, which bend forward and meet over the front.

Dimensions.-Diameter 70 millimètres; width of umbilicus 42 millimètres; height of the last whorl at aperture 12 millimètres; width of ditto 12 millimètres.

Description.-This Ammonite was first figured by General Portlock ${ }^{1}$ in his valuable and exhaustive report, where it is thus described :- "Section oval, the axis in the plane of the larger whorls being about one-fourth longer than the transverse axis; ribs not extending to the suture on the inside nor over the front on the outside. When the shell is preserved there are very delicate, almost obsolete striæ, which bend forward and meet over the front. The front itself to the eye is quite smooth, but occasionally some irregularity may be discovered by the finger. Ribs are visible almost at the centre, and are sharper and proportionately longer in the inner whorls; occasionally, also, they are slightly bent. This species differs from $A$. communis in not having forked ribs; from $A$. planicosta, in not having the ribs sharply bevelled over the front, though in some specimens traces of a continuation of obsolete ribs over the front may be observed, probably constituting another intermediate variety; from $A$. Conybearii in not having a keel; and from $A$. Jolnstonii, to which it closely approximates, in having the ribs closer together and proportionately longer, though in this latter respect it may be observed that, Sowerby's description having been drawn up from a flattened specimen, the breadth of the volution will necessarily appear greater in proportion to the ribs than in the natural condition. 'The foliaceous septa occupy the space between two ribs, and are extended in broad digitate lobes over the front. 
"In one specimen the foliaceous septa are distinct; they form a succession of sinuous lobes, augmenting in breadth from the interior to the exterior of the whorl. In some specimens the mode of petrifaction appears to have been curious : in one, for example, an outer whorl is at one end filled by the grey gritty limestone of the surrounding rock; whilst at the other, by the section, it appears half occupied by the limestone and half by white calcareous spar; and again, an inner whorl is entirely occupied by the spar. Ballintoy: indurated shale of trap dike.-This specimen held to the light shows the traces of obsolete ribs or striæ over the front, apparently three between each pair. Glenaven, Cairncastle, 'lickmacrevan : calcareous or gritty grey limestone, same as Ballintoy. Where the shell is perfect the front is quite smooth. In the inner whorls the depth is equal to the width, and in the cast the ribs, on coming to the front, where they appear slightly curved, vanish away without visibly passing over, though occasionally there is a trace of such passage sufficient to become perceptible to the finger, or, under a strong light, to the eye. As the whorls augment the breadth increases more in proportion than the depth, and the ribs become comparatively less until at length they have exactly the position of those of $A$. Jolinstoni. Ballygalley Head : there appear to be two varieties of this species; the ribs of one being more distant from each other than those of the other, and its section rounder; the form of the septa is the same. Island Magee, Gobbin's Head : same rock, but with sparry fragments, resembling, therefore, the Aghanloo bed, which contains the A. Sampsoni; one specimen strongly exhibiting the character of $A$. Jolinstoni. Another beautiful mode of petrifaction is exhibited by one of the specimens. The inmer whorls are entirely filled with white calcareous spar; but the outer whorl is empty in the centre, the circumference being lined with spar, for abont 1 of an inch, from which project towards the centre numerous acute crystals, the spaces between their opposite points being unequal, according as the process of filling up has more or less advanced."

Affinities and Differences.-I have figured two examples of this Ammonite belonging to the Museum of the Irish Geological Survey, and kindly lent by my old friend, Professor Hull, F.R.S. The specimen (fig. 5) was General Portlock's type specimen. The affinities between this species with Aeg. Belcheri, and both with Aeg. Johnstoni, are so numerous, and the differences so few, that I am inclined to group them both along with the latter form until better specimens are discovered for a comparison of the species.

Aegoceras laqueolus, ${ }^{1}$ Schloenbach. Pl. XV, figs. 1, 2, 10-12; Pl. XVI, figs. 1, 2. Ammonites laqueouus, Schloenbach. Beitc. Palä., p. 152, pl. sxvi, fig. 1, 1865.

${ }^{1}$ On the explanation of Pl. $\mathrm{xv}$, figs. 1 and 2 are termed A. Liassicum, figs, 10-12, d. tortile; on Pl. xvi, figs. 1 and 2, are termed A. Liassicum. See Synonyms, p. 316. 
Ammonites liassicus, d'Orbigny. 'Pal. franç., T. Jurass., t. i, p. 199, pl. xlviii. - tortilis, - Ibid., t. i, p. 201, pl. xlix.

Diagnosis.-Shell discoidal, depressed; whorls from six to eight, vertically flattened or rounded and slightly involute; umbilicus wide, and spire fully exposed; the convex sides ornamented with from forty to fifty prominent oblique ribs all directed towards the aperture, larger near the umbilical, and diminishing towards the outer margin; siphonal area broad, sometimes marked with slight elevations of obsolete ribs. Lobes and saddles well developed, lobe-line very sinuous.

Dimensions : large specimen (figured Pl. XVI)—transverse diameter 175 millimètres ; width of the umbilicus 120 millimètres; height of the aperture 30 millimètres; width of ditto 36 millimètres.

Smaller specimen (figured Pl. XV, figs. 10-12)-transverse diameter 100 millimètres; width of the umbilicus 68 millimètres; height of aperture 16 millimètres; width of ditto 20 millimètres.

Description.-This interesting Ammonite belongs to the group PsiLonoti in the zone of Angulatum, from whence I collected several fragments in the Harbury cutting of the Great Western Railway, near Southam, Warwickshire, and which I found to be nearly identical with a specimen sent to me by Monsieur Etallon, from the Lower Lias of France, as a type of $A$. tortilis, d'Orbigny. Some time afterwards I obtained the large specimen figured in Pl. XVI, and which resembled some specimens, about the same size, I saw in the d'Orbigny Collection at the Jardin des Plantes, Paris, and labelled,A. Liassicus. As neither of my determinations were quite satisfactory, I have constantly been in quest of other figures, and now I find that all my specimens agree very closely with the Ammonites laqueolus, Schlönbach, carefully figured in his valuable 'Beitrage zur Paläontologie der Jura und Kreide-Formation in Nordwestlichen Deutschland,' from a specimen collected by Herr Beckmann from the Angulatum-beds of Salzdahlum. In consequence of this species being so extremely evolute, it is almost always found in fragments; one of these I have figured (Pl. XV, fig. 1) from a specimen collected in the Angulatum-zone in the Trent Valley, Lincolnshire, by the Rev. J. E. Cross, F.G.S.; and I have seen fragments in the British Museum, collected near Horfield by Bristol, where it is called A. Jolnstoni.

This Ammonite (Pl. XV, fig. 10) is extremely discoidal; the whorls are numerous, very slightly involute, and well exposed. All the specimens I have seen want the centre, so that the number of whorls is uncertain; in Professor Schlönbach's figure of a complete specimen there are seven. They are well rounded, rather convex on the sides, and a little depressed at both margins (figs. 2 and 10), and in some specimens very much so, as in the Harbury specimen (fig. 2) and in the large specimen from Redcar (Pl. XVI). The convex sides of the whorls are ornamented with from fifty-five to sixty ribs, which are sharp and prominent, and all bend obliquely forwards towards the aperture; they are larger and more prominent near the umbilical margin (Pl. XV, figs. 2-10), and become smaller near the outer margin, where they disappear. 
The siphonal area (Pl. XV, figs. 11 and 12 ) is rounded and smooth; this is very well shown in the fine drawing of this region in Pl. XVI, fig. 2 ; but in some specimens there are feeble indications of elevations resembling obsolete ribs, and in others such marks are absent.

The whorls are almost entirely evolute, the outer simply resting on the penultimate whorl without einbracing it (see Pl. XV, figs. 1, 2, 10, and Pl. XVI, fig. 1).

The aperture is transversely oblong or subrotund, owing to the greater or less convexity of the sides of the whorls. None of the specimens I have seen enable me to estimate the approximate length of the body-chamber. One of my fragments, however, from Harbury (fig. 2), exhibits well the very sinuous lobe-line this species possesses, and which is now described for the first time.

The siphonal lobe (Pl. XV, fig. I1) is small, with three digitations on each side and a terminal bifid point. The siphonal saddle is large, with four lateral and three terminal festoons ; the principal lateral lobe is large and oblique with two long lateral and a trifidal terminal digitation ; the lateral saddle is as large as the principal lobe, and its sides have six lateral and one small terminal festoon; the lower lateral lobe is small and oblique, with four lateral and one terminal digit; the two auxiliary lobes are likewise oblique, the largest has four and the smallest a single festoon, so that the lobe-line of this form is extremely sinuous, as is well shown in the very good enlarged fig. 9, which I have carefully compared with the specimen (fig. 11).

Affinities and Differences.-This species has been often mistaken for A. Jolnstonï, which it very much resembles. It differs from that form in having a wider and broader siphonal area, and is less uniformly round, and less angular than that form; this is very evident when we compare (Pl. XV, figs. 4. and 6) Aeg. intermedium with (figs. 11 and 12) Aeg. laqueolus.

The stronger and thicker ribs, as well as the wider interspace between them, serve to distinguish Aeg.laqueolus, Schlönb., from Aeg. laqueus, Qnenst., to which, in other respects, it is nearly related. Probably when a greater number of specimens of $A$. laqueus, Quenst., are discovered, Aeg. laqueolus, Schlönb., may prove to be only a variety of the older species, which is remarkable for being extremely evolute, with a round aperture, having the ribs small, delicate, and numerous, and the body-chamber occupying an entire whorl in length.

It resembles Aeg. tortile, d'Orbig.; the specimen figured in Pl. XV, fig. 10, having been sent to me as a representative of that species. It differs, however, in some respects from Aeg. tortile, in having a rounder and much broader siphonal area, more oblique ribs, with a more complex lobe-line than the one traced from Aeg.tortile.

Locality and Stratigraplical Position.-All the specimens I have collected belonged to the zone of Angulatum, and this accords with the observations made, apparently with great care, by Prof. Schlönbach. MM. Collenot and Bréon collected Aeg. laqueus near Semur in the Angulatum-zone. 


\section{Second Section.-Angulati.}

Aegoceras angulatum, Schlotheim. Pl. XIV, figs. 5, 6; Pl. XVII, figs. $1-6$.

Ammonites angulatus, Schloth. Petrefactenkunde, p. 70, 1822.

- Redcarensis, Young \& Bird. Geol. Surv. Yorksh. Corst, p. 258, pl. xiv, fig. $13,1828$.

- anguliferus, Phillips. Geol. of the Yorkshire Coast, p. 192, vol. i, tab. 13, fig. 19, 1829.

- colubratus, Zieten. Verstein. Würtembergs, tab. 3, fig. I, p. 3, 1830.

- angulatus, Von Buch. Ueber Ammoniten, p. 12, 1832.

- Redcarensis, Simpson. Monograph on Ammonites of the Yorkshire Lias, p. $55,1843$.

- angulatus, Quenstedt. Cephalopoden, p. 74, pl. iv, fig. 2, 1846-9.

- - Q Quenstedt. Petrefactenkunde, p. 354, tab. 27, fig. 7, 1852.

- $\quad$ - Quenstedt. Der Jura, p. 43, tab. 3, fig. 1, 1858.

- $\quad$ - Chapuis et Dewalque. Fossiles Terr. Second. Luxembourg, p. 36, pl. iv, fig. 1, 1853.

- - Oppel. Juraformation, p. 75, 1856.

- Redcarfensis, Simpson. Fossils Yorkshire Lias, p. 100, 18.55. Aegoceras angulatum, Tate \& Blake. Yorkshire Lias, p. 271, 1876.

Diagnosis.-Young shell compressed; whorls involute, half enveloped; sides with twenty-six to thirty, sharp, simple, flexed ribs, which commence at the umbilical margin, pass round the outer border, and terminate abruptly in a furrow in the centre of the siphonal area, or in a smooth truncated surface.

Adult shell, several inches in diameter, compressed; whorls flattened, sloping towards the outer margin; sides smooth, with long, faint, biflexed ribs, and shorter and more marked costæ near the border; area narrow, round, smooth; aperture compressed.

Dimensions.--One of my largest specimens from Lyme Regis measures 180 millimètres in diameter. Height of the last whorl near the mouth 65 millimètres; width 40 millimètres. Whorls one-half covered by the involution of the spire.

Description.-Like many other Ammonites, this species must be studied at different stages of growth, if we wish to understand its true characters. Up to about the diameter of an inch the whorls have from twenty-five to thirty sharp simple ribs, which terminate abruptly and form a marked angle on the back-bence the origin of the specific name; at a later period the ribs divide, become less distinct, and the angle on the back disappears; in advanced age the sides are smooth, the siphonal area is narrow, and without ribs. 
Septa symmetrical (PI. XVII, fig. 1), divided into five lobes and six saddles, formed of unequal parts; the siphonal lobe much shorter and broader than the principal lateral lobe, divided half its length by the median line into two parts, it is formed of two or three short branches on each side, and has a terminal trifid digit; the siphonal saddle is much larger than the principal lateral lobe, and terminates in three festoons, which divide into folioles; the principal lateral lobe has four small lateral digitations, and a terminal digit, which divides into three or four branches; the lateral saddle, about as large as the principal lateral lobe, terminates in one central and two lateral festoons, the former with four, the latter with three, smaller foliations; the inferior lateral lobe is oblique, with three or four lateral, and a terminal, sometimes bifurcate digit; the three auxiliary lobes are placed very obliquely, and gradually diminish in size as they approach the umbilical angle.

In my large specimen the body-chamber consists of four-fifths of the last whorl, its sides are smooth, and slope towards the outer border, which is round and narrow, without the trace of a keel ; there are from thirty to forty long, faint, biflexed ribs, extending from near the umbilical to the outer margin, and shorter intermediate costæ spring from the bifurcation of the former. All the ribs become much more developed as they pass round the siphonal border, before they suddenly disappear.

Affinities and Differences.-This Ammonite belongs to the group Angulatr, and to the genus Aegoceras; in early life its strong, sharp ribs form an angle on the siphonal area (fig. 6). The marginal furrow which interrupts them (fig. 4) likens it to some Gault species; but adult shells call scarcely be mistaken for any other form associated with them in the Lower Lias (figs. 4-6).

This Ammonite presents many varieties of form during different stages of growth, which have been mistaken for distinct species; it is now ascertained that Aegoceras MIoreanum, and Aeg. Leigneletii, d'Orbigny, are different varieties of Aeg. angulatum.

Locality and Stratigraphical Position.-I collected this Ammonite between Charmouth and Lyme Regis, in a dark shale below the grey concretionary limestone with a mamillated surface, which forms the base of the Bucklandi-beds, and in the same stratum south-west of the Cob; the zone which it characterises is of no great thickness in Dorsetshire. This Ammonite is considered one of the rarest found on that coast. In Gloncestershire I have collected small ribbed specimens from the lowest shales of the Fretherne section on the banks of the Severn, and it has likewise been found at Aust Cliff. In Warwickshire some fine specimens were obtained from the Harbury cutting of the Great Western Railway, near Southam, and many good fragments are still to be found on the spoil banks of that line. In Yorkshire it is found only in the lowest beds of Lias at Redcar, where it is very rare, and known to local collectors as Am. Redcarensis. It is found in the same zone of Lower Lias near Portrush, on the north coast of Ireland. 
The varieties of this species figured by d'Orbigny were collected in France from the lowest beds of the Lias with Gryphea incurva, Sow.; at Pont-Auber, near Avallon (Yonne), and Champlong, near Semur (Côte-d'Or) : at Jamoigne (Luxembourg); and in several places in Germany near Balingen, Degerloch, Echterdingen, Vaihingen, Stuttgart, and other localites. It everywhere characterises beds which are interposed between the Planorbis- and the Bucklandi-series.

Aygoceras catenatum, Sowerby. Pl. XIX, figs. 5-7.

Ammonites catenatus, Sowerby. De la Beche, Geological Manual, 3rd ed., p. 334, fig. 74, 1833.

- Trapezoidalis, Sowerby. Ibid., p. 334, fig. 75.

- catenatus d'Orbigny. Pal. Franç., Terr. Jurass., vol. i, p. 301, pl. xciv, 1842.

Diagnosis.-Shell discoidal, compressed; whorls depressed, one third involute, and all exposed; sides flattened, with twenty-eight to thirty strong, simple ribs, which are twice arched, elevated, and enlarged as they approach the outer margin, and interrupted in the siphonal area, which is smooth or crenulated; aperture oblong, compressed, notched by the preceding whorl.

Dimensions.-Diameter 53 millimètres; width of the umbilicus 23 millimètres; height of the last whorl at aperture 18 millimètres; thickness 13 millimètres.

Description.-This rare Ammonite is found in the Lower Lias at Barrow-on-Soar, and is seldom seen in any of the metropolitan Museums. It is a very well marked form, and a fair example of the Angulati group. The species was first found by my old friend the late Sir Henry De la Beche, along with other Lias fossils in limestone at La Spezia, Italy, and is recorded in the following passage:- "As far, therefore, as the evidence of the Ammonites and Orthoceratites extends, we may refer the limestone of La Spezia either to the Lias or the Coal Measures. There will be observed a curious correspondence in the organic character of the rocks of the Savoy and French Alps above noticed, and considered as Lias by M. Elie de Beaumont, with that of the limestones of La Spezia. In the former Coal Measure plants are found with Beleminites; in the latter Coal Measure Ammonites also occur with Belemnites.

"The organic character of the Oolitic group in the Alps is far from being well ascertained, and the undescribed organic remains found in the same series of the South of France are exceedingly numerous, so that it may be possible to discover some of the La Spezia Ammonites in both situations; and the organic remains of the South-east of France, the Alps, and La Spezia, may hereafter mutually assist in determining the relative ages of the rocks in which they are discovered." 1 
I have quoted this remarkable passage from Sir Henry De la Beche's 'Manual,' as it shows how the principles of palæontology were understood in 1833 by one of the greatest masters of geological science in the English or any other school. Had the true value of Ammonites been known in his day, and the limits of the distribution of their species in time and space been understood, the finding of a true Lias Ammonite would have settled the question of the age of the limestone at La Spezia in which it was discovered in spite of mistaking Belemnite phragmacones for Orthoceratites.

The shell of Aegoceras catenatum is compressed; the sides are ornamented with twenty-eight simple, sharp, very prominent ribs, arched upwards, backwards, and forwards, becoming thicker as they approach the margin, and forming an arch over the area, which is rather conspicuous in the figured specimen, whilst in others it is almost smooth. The spine is formed of five convex whorls nearly one third involute, and all seen in the umbilicus. The aperture is a compressed oval, cut out inwards by the turn of the spire. The septa (fig. 7) are symmetrically divided on each side into three lobes formed of unequal parts. The siphonal lobe is smaller than the principal lateral, and terminates in three digitations; the siphonal sardlle is wide, and ends in three cells; the principal lateral lobe is long, with three digits on each side and a terminal seventh having a trifid process; the lateral saddle is as large as the principal lateral lobe, and ends in two cells; the lower lateral lobe is shorter than the principal, and has three digits on one side, rudiments of digits on the other, and ends in three points; the first auxiliary lobe is oblique, with three inner digits, and the second auxiliary is rudimentary.

Affinities and Differences. - This species very much resembles some of the forms of Aeg. angulatum; it differs, however, in the narrowness of the siphonal area, in retaining its ribs entire up to an advanced age, and having a different lobe-line to that form.

Locality and Stratigraplical Position.-The specimens I possess of this Ammonite I owe to the kindness of Mr. W. J. Harrison, F.G.S., late of the Leicester Museum ; they were obtained from the Lower Lias beds at Barrow-on-Soar, and are largely charged with iron-pyrites. I know of no other locality in the British Islands.

Foreign Localities.-Professor d'Orbigny states that this Ammonite was found below the Lower Lias beds with Gryphaa arcuata at Pont-Auber, near Avallon, Yonne ; Semur, Côte-d'Or; and that young specimens, figured by him in his plate 94 were collected on the Gulf of La Spezia; near Coregna (Italy), thus determining the age of that terrain; he further adds that the so-called Orthoceratites of De la Beche, already referred to in my extract as found in the same locality, as well as those from the Lake of Como, were the articulations of the alveoli of Belemnites. This observation clears up the difficulty which Sir Henry experienced in determining the age of the limestone at La Spezia. 
Aegoceras Moreanum, ${ }^{1}$ ' Orbigny. Pl. XVII, fig. 1-6.

Ammonites Moreands, d'Orbigny. Paléont. Franç., Terr. Jurass., p. 299, pl. xciii, 1842.

- ANGULatus, Stur. Jahrbuch der k. k. geolog. Reich., vol. i, p. 165, 1851.

- Moreanus, Studer. Geologie der Schweitz, vol. ii, p. 30, 1853.

- - von Hauer. Jahrbuch geologischen Reichsanstalt, vol. iv, p. 736, 1853.

- - Martin. Infra-Lias du Départ. de la Côte-d’Or, p. 38, 1860.

Terquem et Piette. Lias inf. de l'est de la France, p. 26, 1865.

Diagnosis.-Shell discoidal, compressed; whorls flattened, sides convex, internally smooth and feebly undulated, externally crenulated, with prominent bifurcations of obsolete ribs; siphonal area narrow, smooth in the centre, and costated at the outer margin; aperture compressed, triangular, incised internally by the penultimate whorl, and notched outwardly by the siphonal area; involution one-half the depth of the whorl.

Dimensions.-Transverse diameter 170 millimètres; width of the umbilicus 48 millimètres; height of the last whorl at the aperture 70 millimètres ; greatest width of ditto 43 millimètres. In four specimens before me, including the fossil figured, the relative proportions of these parts vary considerably. Professor d'Orbigny's type specimen measured :-Diameter, 75 millimètres ; in relation to the diameter the size of the last whorl was $\frac{35}{100}$; involution of the last whorl $\frac{8}{100}$; width of the umbilicus $\frac{43}{100}$; thickness of the last whorl $\frac{19}{100}$.

Description.-This Ammonite has a compressed, discoidal shell, with flattened whorls, the sides of which are slightly convex; on the inner or umbilical half of the whorl they are smooth, and have from thirty to forty curved undulations, representing so many obsolete ribs; near the outer or siphonal margin the folds appear to bifurcate, and develop a number of short, transverse, oblique costæ, more or less prominent in different specimens; the spire is formed of very compressed whorls, which are nearly one half concealed by the volutions of the spire, leaving a narrow umbilicus. The siphonal area is contracted, smooth in the centre, and crenulated at the sides by the development of the short oblique costæ which ornament the outer margin of the shell. The aperture is compressed, and more or less triangular, and varies in the proportional measure of its height in different specimens.

The young shells of this form, up to two to three inches in diameter, are provided with simple bent ribs, which terminate near the outer margin; these ribs become enlarged as they approach the margin, and are sharply bent inwards at the side of the siphonal area, where they disappear, leaving the centre of this space quite smooth.

1 Considered to be a variety of Aegoceras angulatum and named Aegoceras angulatum in the explanation of Plate XVIl. 
The lobe-line is very complicated, the symmetrical septa being divided into five lobes and saddles, all formed of unequal parts. The siphonal lobe is small, and terminates in three short branches, two of which are bifid; the siphonal saddle is much wider than the principal lateral lobe, and forms an arch with three terminal festoons. 'The principal lateral lobe is large, and has a branched termination in three irregular digits and three smail lateral prolongations on each side; the lateral saddle is as wide as the principal lateral lobe, and ends in three irregular-shaped festoons; the lower lateral lobe is narrow and oblique, and ends in three digits; the three auxiliary lobes are placed very oblique, they diminish in size as they approach the umbilicus, and end in a small trifid digit (Pl. XVII, fig. 1).

Affinities and Differences.-This Ammonite very much resembles Aegoceras angulatum, but the smoothness of the sides of the whorls, in consequence of the absence of ribs and the development of the short, oblique, crenulated series around the outer margin, with its smooth centre in the siphonal area, and a difference in the dimensions of the lobe-line, induced d'Orbigny to separate it under the name Moreanus. I am inclined to consider it only a variety of angulatum and not a distinct species. This Ammonite characterises a particular horizon of life very rich in fossils in the Côte-d'Or.

Locality and Stratigraphical Position.-This species is found in a dark grey shale near Charmouth, from whence all my specimens have been obtained. Young forms of Gryphaa arcuata make their appearance for the first time in this bed; one of these Oysters has become firmly adherent to the shell I have figured.

Professor d'Orbigny says it characterises the inferior beds of the Lower Lias, which lie below the Gryplica arcuata; the figured specimen was collected at PontAubert near Avallon, Yonne, where it is very rare. M. Martin says this Ammonite distinguishes the zone of Ammonites Moreanus in the Department of the Côte-d'Or, and the reader is referred to his classical work on the Infra-Lias of that Department for an admirable account of the rich fauna it contains.

Aegoceras Charmassei, d' Orbigny. Pl. XX, figs. 1-3.

Ammonites sulcatus, Simpson? Monogr. of Ammonites, York. Lias, p. 55, 1843.

- Charmasser, d'Orbigny. Paléontol. Franç., Terr. Jurass., i, p. 296, pls. xci, xcii, 1844.

- sulcatus, Buckman. Murchison's Geology of Cheltenham, 2nd ed., p. 91 , pl. ii, figs. $1-3,1845$.

- $\quad$ Angulatus, Quenstedt. Die Cephalopoden, p. 262, 1847.

- Снarmassei, Kudernatsch. Jahrbuch der k. k. geologischen Reichsanstalt ii Heft, p. 173, 1851. $-\quad$ Savi e Meneghini. Considerazioni sulla Geologia della Tos-
cana, p. 104, 1851 .

- $\quad$ - Meneghini. Nuovi fossili Toscani, p. 12, 1853. 
Ammonites Charmassei, Studer. Geologie der Schweitz, vol. ii, pp. 30, 34, 1853.

- antiquatus, Simpson? Fossils of the Yorkshire Lias, p. 36, 1855.

- Charmassei, Von Hauer. Cephalopoden Lias N.-O. Alpen, p. 49, pl. xiv, figs. $1-3,1856$.

- - Dumortier. Dépôts Jurass, du Bassin du Rhône, II, p. 29, pl. xvii, figs. 1-4, 1867.

AEgoceras - Tate and Blake. Yorkshire Lias, p. 272, 1876.

Diagnosis._Shell discoidal, depressed; whorls compressed, slightly convex, one half involute, sides ornamented with numerous unequal ribs, variable as to number, in general thirty, bifurcate about the middle of the whorl and terminating at the margin in a blunt thickening. Siphonal area narrow, subcarinate, and furrowed in the middle, sides carinated with the two rows of blunt terminal ribs; aperture high, narrow, sagittate ; umbilicus moderately open; lobe-line very sinuous, forming six lobes and numerous saddles; number of ribs at umbilical margin thirty, at siphonal margin sixty.

Dimensions.-Transverse diameter of figured specimen 170 millimètres; width of the umbilicus 45 millimètres; height of the last whorl at aperture 80 millimètres ; greatest width of ditto 40 millimètres.

Prof. d'Orbigny's type specimen measured:-Transverse diameter, 235 millimètres. The relations to the diameter in an adult were-height of the last whorl $\frac{50}{100}$; involution of the last whorl $\frac{9}{100}$; width of the umbilicus $\frac{20}{100}$; thickness of the last whorl $\frac{11}{100}$. In a young shell the width of the last whorl $\frac{41}{100}$; width of umbilicus $\frac{29}{100}$; thickness of the last whorl $\frac{25}{100}$.

Prof. Von Hauer has given the dimensions of a very fine specimen. The transverse diameter was 6 inches $=154$ millimètres; the height of the last whorl $\frac{41}{100}$ of the diameter; width of last whorl $\frac{20}{100}$; the width of the umbilicus $\frac{31}{100}$.

M. Eug. Dumortier, 'Dépôts Jurassiques,' vol. ii, p. 29, has given the dimensions of three fine specimens with their test, belonging to M. Ed. Pellat's collection, and all obtained from the same quarry of Lower Lias at Drevain, Saône-et-Loire.

\begin{tabular}{|c|c|c|c|c|c|}
\hline Parts Measured. & No. 1. & \multicolumn{2}{|c|}{ No. 2.} & \multicolumn{2}{|c|}{ No. 3.} \\
\hline Diameter ........................................... & $20 \frac{1}{3}$ millim. & & lim. & 225 & $\lim$. \\
\hline Height of the last whorl in relation to the diameter & $\frac{36}{100}$ & 45 & $"$ & 47 & " \\
\hline Thickness of the last whorl $\ldots \ldots \ldots \ldots . .$. & 31 millim. & 25 & $"$ & 21 & $"$ \\
\hline Umbilicus, width of.............................. & 34 & 23 & " & 22 & ” \\
\hline Number of ribs, outer margin & 44 & 52 & ” & 78 & ” \\
\hline
\end{tabular}

Description.-The form and structure of this Ammonite were very variable in the different phases of its growth. In youth, and when it has a diameter of eighty milli- 
mètres, it is moderately compressed, the whorls are nearly one half involute, and their convex sides near the umbilical margin are covered with twenty well-marked ribs, which bifurcate near the middle of their height, and enlarge as they advance toward the margin, where they terminate in thick blunt knobs. The siphonal area is narrow and smooth, sometimes concave in the middle, and ribbed at the sides by the enlarged terminations of the costæ. The spire is composed of several moderately thick whorls, which are convex on the sides and bevelled away near the margin. The aperture is elongated, narrow, and sagittate.

In middle age, which is fairly well represented by the fine specimen from Lyme Regis, figured in $\mathrm{Pl}$. XX, we observe all the characters which distinguished its earlier life very well developed in this specimen. The number of primary ribs on the last whorl at the umbilical margin now amount to thirty, and the secondary ribs arising from the bifurcation of the primaries amount to sixty. The thickening of the secondary ribs as they approach the margin, and their final termination in a rounded knob-like eminence, are very characteristic of this species.

In old age this Ammonite attains a considerable magnitude. I have one specimen which measures 320 millimètres in dianeter, and yet wants a considerable portion of the body-chamber. The shell is much compressed, and the relative proportions of its different parts are much changed. The ribs have gradually become much smaller and less prominent until they have finally disappeared, and left the sides of the fossil quite smooth. The umbilicus is proportionately much less in width to the total diameter of the shell; the last whorl is much higher, and not nearly so wide in proportion; the siphonal area, from the bevelling away of the deep sides, has become very narrow, and its prominent centre forms quite a carina-in fact, had the student not watched and noted the changes that take place in the growth of this Ammonite, he could not believe, on comparing the young with the old shell, that he was only examining the same species passing through its various morphological phases of evolution.

The lobe-line is extremely tortuous in this species, as shown in $\mathrm{Pl}$. XX, fig. 1, and three large and three small oblique auxiliary lobes, with three large and three small oblique saddles, are shown on the sides of the whorls. The windings of the lobe-lines from adjoining septa are, however, so closely approximated that it is extremely difficult to trace the one line continuously from the siphonal to the columellar lobe. The siphonal lobe is as wide, but not so long, as the principal lateral, and has on each side three large branches with multi-digitate terminations; the siphonal saddle is as wide as the principal lateral, and is deeply divided into three irregular folioles with their sides much festooned; the principal lateral is large and very conspicuous, it has a pyramidal form, with three long branches on its outer, and four on its inner side, and a long terminal multidigitate process; the lateral saddle resembles the siphonal in size and in the complexity of its ramifications ; the lower lateral lobe is very much smaller than the principal, which it resembles much in the style of its digitations; the auxiliary lobes, three or four in 
number, diminish in size from without inwards as they approach the columellar suture, and a radial line, drawn from the point of the siphonal lobe inwards to the first auxiliary, cuts the termination of the principal lateral, and leaves all the other portions of the septa much in advance.

Affinities and Differences.-Aegoceras Charmassei very much resembles Aeg. angulatum in youth and middle age, but in old age the whorls are much higher, and the lobe-line is very different. It resembles Aeg. catenatum in youtl in its general outline, but still its ribs are bifurcated, whilst those of Aeg catenutum are simple. It has certain affinities with Aeg. Boucaultianum in the height of its whorls, and in the ribbing of the same. Aeg. Boucaultianum, however, has many more small close-set ribs, with a flatter area, tuberculated on the sides, and with a different and more complicated lobe-line than Aeg. Charmassei. I know of no other forms with which this beautiful Ammonite has any close relations. The Rev. J.F. Blake, F.G.S., ${ }^{1}$ notes " This appears to me a protean species, whose varieties are extreme . . . There is $(a)$ an inflated variety, whose cross section is a transverse rounded rectangle, with great inflated ribs, and whorls scarcely overlapping, not growing to above two inches in diameter; $(\beta)$ the ordinary form flatter and larger (six inches); $(\gamma)$ a far more involute form, with the outer whorl half the diameter, as figured by Dumortier ('Depôts Jurassiques,' part I, pl. xvii, figs. 1 and 2); ( $\delta$ ) the large adult shell nearly smooth, as figured by d'Orbigny (pl. xcii). The variety $a$ includes the $A$. crenularis of Simpson; variety $\gamma$ is the $A$. Boucaultianus of d'Orbigny. The Yorkshire specimens have so decided a connection with Aeg. Charmassei as to force me to include them under the latter name. More characteristic forms of A. Boucaultianus have been found by Mr. Cross in Lincolnshire. The A. antiquatus of Simpson is a fragment of the adult shell; while $A$. sulcatus ( $A$. Leignelettei, d'Orb.) is the young of the ordinary form. Simpson's name, $A$. sulcatus, would have preference of $A$. Charmassei, by which the species is well known, only fortunately the former name was preoccupied by Lamarck."

Localities and Stratigraphical Position.-This species is found in the zone of Arietites Bucklandi at Redcar and Robin Hood's Bay, Yorkshire, and in beds of like age at Charmouth, and Lyme Regis, Dorset, and at Portrush, near Londonderry, on the north coast of Ireland. In France, it is found with Gryphaca arcuata in the centre of France, and has been collected in the Lias quarries at Avallon, Yonne; near Semur, and Clomot, Côte-d'Or ; and at Drevain, Saône-et-Loire.

In South Germany it is found in the Lower Lias between the zone of $A$. planorbis and that of $A$. Buclclandi at Ostdor by Balingen, near Aich, Echterdingen, Degerloch, Vaihingen, Bebenhausen, Bemflingen, Göppingen, Metzingen, Kaltenthal, near Stuttgart, Würtemberg. 
Aegoceras Bodcaulimanum, d'Orbigny. Pl. XVIII, figs. 1-4.

Ammonites Boucaulfiands, d'Orbigny. Terr. Jurass., vol. i, p. 294, pls. xc, xcvii, 1842.

Dumortier. Dépôts Jurassiques du Bassin du Rhône, vol. ii, figs. $3-5$, p. 138, pl. xxxix, figs. 1, 2, 1867.

Collenot. Géologique de l'Auxois, p. 237, 1873.

Diagnosis.-Shell large, discoidal, and much compressed; whorls slightly convex and largely involute; umbilicus very narrow, inner whorls nearly all concealed and covered with a number of small biffexed ribs, unequally bifurcate near the umbilical margin, and terminating at the outer margin in a series of small bead-like tubercles; siphonal area narrow, and convex, sides with the rows of tubercles derived from the terminations of the small costal lines; aperture narrowly oblong; lobe-line extremely tortuous, with a great development of the siphonal and principal lateral lobes.

Dimensions. Figured specimen (fig. 1) :-Diameter 155 millimètres; height of the last whorl near the aperture 90 millimètres; width of the umbilicus 24 millimètres.

Professor d'Orbigny's specimen :-Diameter 120 millimètres. Proportional measurements in relation to the diameter :-width of the last whorl $\frac{18}{100}$; involution of the last whorl $\frac{14}{100}$; width of the umbilicus $\frac{11}{100}$; thickness of the last whorl $\frac{28}{100}$.

Description.-The shell of this rare Ammonite is discoidal and much compressed. The whorls are slightly convex and ornamented with numerous narrow ribs, which, commencing at the umbilical margin, first bend backwards, then incline forwards, and at about the middle of the whorl bifurcate, then sweeping towards the aperture they terminate at the side of the outer margin in a small tubercle, and, without becoming entirely interrupted, pass across the area to the opposite side (fig. 3). The siphonal area is very narrow, slightly convex, feebly ribbed in the middle, and bounded on each side by a row of tubercles, which are developed on the terminal ends of the ribs (figs. 2 and 3 ). In the cast the area is rounded, but when the shell is preserved there is a median depression, with rows of lateral tubercles corresponding to the terminations of the ribs (see figs. 2 and 3 ). The spire is formed of whorls, which largely embrace each other; the last whorl is so extremely involute that it almost completely envelopes the penultimate whorl, and nearly conceals the umbilicus (figs. 1 and 2).

The aperture is narrow, elongated, and much compressed (fig. 3); the lobe-line is extremely tortuous, and d'Orbigny, who had the opportunity of seeing and figuring the septa, has given the following description:-The septa are symmetrical, divided on each side into four very complicated lobes, formed of pairs of parts, and of saddles composed of folioles almost in pairs; the siphonal lobe is as long and almost as wide as the principal lateral lobe, deeply divided into three very ramified and very complicated branches (see Pl. XVIII, fig. 4); the siphonal saddle, wider than the 
principal lateral lobe, is formed of two large unequal leaves, of which the internal one is the largest, and both are very much divided; the principal lateral lobe terminates in two large very much ramified branches. D'Orbigny was however unable to follow the others, as shown in his excellent drawing of the lobe-line which I have copied from his work in my fig. 4, Pl. XVIII.

Affinities and Differences.-M. Eug. Dumortier has figured, in his 'Dépôts Jurassiques du Bassin du Rhone,' pl. xxx, figs. 1 and 2, a fragment found at Jambles, Saône-et-Loire, which agrees very well with the specimen I have figured in Pl. XVIII, fig. 1, from the Rev. J. E. Cross's collection; the sides are convex; the siphonal area narrow, and furnished with a round carina, which is absent from the mould.

Professor Quenstedt has figured and described, 'Der Jura,' p. 98, pl. xii, fig. 7, a fragment from his "Beta" limestone of Ofterdingen, under the name betacalcis, and this comes frorn the same horizon as $A$. Boucaultianum. It has many affinities with our large specimen; the crenulated carina appears to separate it from $A$. Boucaultianum; still it must not be forgotten that this is a single unique specimen, and that some of the type specimens in the Semur Museum, with their shell preserved, measuring from twelve to fifteen inches in diameter, show a disposition to a like crenulation on the central portion of the siplonal area, so that I am inclined to think that Quenstedt's fragment, when better specimens are found, may turn out to be a true $A$. Boucaultianum.

Localities and Stratigraphical Position.-The Rev. J. E. Cross, F.G.S., collected his specimen, the only British one I know, from the Upper Bucklandi-beds of the Scunthorpe Ironstone, North-west Lincolnshire. A suite of several very fine specimens bas been obtained from the Lower Lias near Semur, Côte-d'Or, and is in the Museum of that town. One noble Ammonite, with its shell preserved, which I measured, was upwards of twelve inches in diameter. Pl. XVIII, figs. 2, 3, represent a specimen reduced one third the natural size, in the collection of Monsieur Boucault of Semur, who collected it at Champlong, near that town. Several important characters of this rare Ammonite are here very well shown. I am indebted to my friend, M. Collenot, of Semur, for two specimens of this Ammonite, which he has kindly sent me to complete my description of the species. The largest specimen is 185 millimètres in diameter, the height of the aperture is 110 millimètres, its width 50 millimètres, and the diameter of the umbilicus 23 millimètres; the twenty-six lateral primary ribs are well seen; at the umbilical margin they bifurcate irregularly at about one third the height of the whorl, and toward the aperture become thickened at the side of the siphonal area and develop a tubercle on each; the centre of the area is narrow and flattened, and the ribs pass from one side to the other (fig. 3). The shell is pieserved on a small portion only of a larger specimen, but enough remains to enable me to make out its remarkable structure; the shell is very thin, and bears a delicate sculptured surface, with lines following the flexure of the ribs, as is very well exhibited in Pl. XVIII, figs. 1 and 2 ; the lines, however, are much more delicate in the specimens sent me by M. Collenot than in those represented in d'Orbigny's 


\section{PALAONTOGRAPHICAL SOCIETY.}

INSTITUTED MDCCCXLVII.

VOLUME FOR 1882.

LONDON:

MpcccLxxxix. 



\title{
MONOGRAPH
}

\section{ON THE \\ LIAS AMMONITES \\ or}

\section{THE BRITISH ISLANDS.}

BX

\section{THOMAS WRIGHT, M.D., F.R.S., F.G.S.,}

\author{
VICE-PRESIDENT OF THE PALFONTOGRAPHICAL SOCIETY; CORRESPONDING MEMBER OF THE ROYAL SOCIETY OF SCIENCES \\ OF LIÈGE; THE SOCIETY OF NATURAL SCIENCES OF NEUCHÂTEL; VICE-PRESIDENT OF THE COTTESWOLD \\ NATURALISTS' FIELD CLUB; CONSULTING SURGEON TO THE CHELTRNHAX HOSPITAL; \\ AND MEDICAL OFFICER OF HEALTH TO THE URBAN SANITAKY DISTRICTS \\ OF CHELTENHAM, CHARLTON KINGS, AND LECKHAMPTON.
}

PART FIFIH-DESCRIPTION OF SPECIES.

Pages 329-400; Plates XliX-LII, LIIA, LiII-LXIX.

LONDON :

PRINTED FOR THE PALEONTOGRAPHICAL SOCIETY. 
PRINTED BI

J. E. ADLARD, BARTHOLONEW CLOSE. 
figures; the lines, which are certainly developed in the outer lamina of the shell, appear to resemble the punctated lines I have described in the shells of Arietites obtusus and Ariet. stellaris, and which also exist on Aeg. planicosta, to be described in the sequel. These beautiful and graceful falciform lines in the outer lamina of the shell form a new feature in the listory of this species, and become a good diagnostic character between it and Aeg. Charmassei, to which it otherwise stands in close relationship. The falciform lines on the surface of the shell, and the tubercles on the sides of the siphonal area, serve to distinguish Aeg. Boucaultianum from other Lower-Lias congeneric forms. The largest specimen sent, was collected from the zone of Aeg. Birchii at Port-Royal, and the small specimen came from Ménetreux, near Semur (Côte-d'Or). One of the large specimens of this species, contained in the Semur Museum, has the entire shell most beautifully ornamented with the fine punctated lines which I have so imperfectly described from the weathered specimen now before me.

The group Angulati requires a more detailed study than has been given to it. The neglect has probably arisen from the difficulty experienced in assembling a sufficient number of examples of the different forms for critical comparison; figures, however good, will not suffice for this purpose, as nothing short of the fossils themselves can supply the structural evidence necessary to arrive at a definite conclusion. Dr. Oppel grouped Am. angulatus, Schloth., colubratus, Ziet., catenatus, Sow., Moreanus, d'Orb., Charmassei, d'Orb., Leigneletii, d'Orb., angulatus depressus, and compressus, Quenst., as varieties of angulatus, Schloth. A careful study of Aeg. catenatum, angulatum, Charmassei, however, has disclosed, as we have already seen, certain structural characters in each of these forms which appear to justify the separation proposed by d'Orbigny. This series of forms stands very distinct from those of the section Psilonotr, which preceded them in the Lias sea, and probably derived their parentage from Aeg. incultum, Beyr., and Aeg. Palmai, Mojs., in Trias time. I have not yet satisfied myself as to the true ancestry of Aeg. angulatum, which has a form so distinctly different from all the PsiLonom that it is impossible to confuse it with any form belonging to that series. Here we must range, likewise, Aeg. catenatum, Sow., Charmassei, d'Orb., Boucaltianum, d'Orb., and lacunatum, Buckm., all of which exhibit many characters in common, and many differences in detail of minute structure by which they are separated from each other.

Professor Hyatt, in his "Genetic Relations of the Angulatide,' form a gromp precisely equivalent to Discoceratide, or to the whole of the Falciferi. So far as their involution and the general parallelism of their characteristics are concerned, they are simply a very lighly accelerated series, in which there are as great differences between the extreme forms as there is between the extreme forms of the Discoceratides or of many other groups composed of more numerous forms with less abrupt modifications.

Aeg. catenatum at Semur occurs below Aeg. Charmassei and Aeg. Leigneletii in the Aeg. angulatum-bed, and in the Aeg. tuberculatum-bed is succeeded by Aeg. Boucaultianum.

1 Proceedings of the Boston Soc. of Nat. Hist., vol. xvii, p. 15-33, May, 1874. 
This regularity of succession, which the Semur Collection appears to prove, accords very well with what has been observed in other groups. Not only does the involution greatly increase in each succeeding species, but the septa become more complicated in outline, and the adult characteristics of the ribs and form are repeated at earlier and earlier stages in each species; the same law governs also the inheritance of the old-age characteristics of the individnal. Thus, Aeg. Boucaultianum, which occurs latest in time, has the old-age characteristics sooner developed in its growth than any other form, showing that the acceleration or quicker reproduction of the characteristics extends to the whole life, affecting even the period at which old age begins.

Aegoceras lacunatom, Buckman. Pl. LVI, figs. 16, 17, 18.

Ammonites lacunatus, Buckman. Geology of Cheltenham, 2nd ed., p. 105, pl. 11, figs. 4, 5, 1845 .

$\begin{array}{llll}-\quad & -\quad \text { Quenstedt. } & \text { Cephalopoden, vol. i, p. 151, pl. xi, fig. 13, } 1849 . \\ -\quad & -\quad \text { Quenstedt. } & \text { Der Jura, p. 98, pl. xii, figs. 4-6, 1858. }\end{array}$

Ammontes laconatus, Dumortier. Dépôts Jurass. Bassin du Rhône, vol. ii, p. 120 pl. xxi, figs. 18-20, 1867.

Diagnosis.--Shell small, compressed, not carinated, composed of highly involute whorls, which are convex on the sides, of a uniform thickness throughout, and ornamented near the umbilicus with twenty-five to thirty short ribs, separated by deep valleys; the primary ribs soon divide into two or three branches; this division does not take place on all the ribs either regularly or at an equal distance from the umbilicus; often a second bifurcation takes place; the ribs are then strongly inflected towards the aperture, and form graceful curves on the sides of the shell, ending in from sixty to seventy costæ at the outer margin of a deep sulcus which occupies the middle of the siphonal area, and interrupts the passage of the costæ of the right towards that of the left side of the area; umbilicus very narrow.

Dimensions.-Diameter 30 millimètres; height of the last whorl 16 millimètres; width of the aperture 8 millimètres; amount of involution two thirds of the penultimate whorl.

Description.-This rare little Ammonite was first discovered by Professor Buckman near Cheltenham. It has been thought by some to be the brood of Aeg. Charmassei, and by others to be a young Aeg. Boucaultianum. It differs, however, specifically from both, and is an interesting form of the section Angulati.

'The shell is small, compressed, and not carinated; the whorls, four or five in number, are inflated, convex on the sides, extremely involute, and embrace two thirds of a whorl 
(fig. 16); they are covered with numerous small ribs, separated by valleys of equal width; near the umbilical margin there are twenty-five to thirty short, stout ribs, which soon bifurcate into two or three branches, and about the middle of the whorl become strongly flexed towards the aperture, ending in from sixty to seventy costæ, thickened towards their termination at the side of the sulcus, which occupies the middle of the siphonal area (figs. 17 and 18). In young specimens the sulcus is sometimes converted into a knotted carina, which, by subsequent evolution, afterwards develops the central sulcus. The test is rarely preserved, and is very thick for so small a shell; nevertheless, the ornamentation of the shell is sharply preserved on the mould, and all the inequalities of the exterior are repeated in the cast thereof. When the shell is preserved the sulcus appears to be narrower and not so deep.

Affinities and Differences.-M. Dumortier, ${ }^{1}$ who has had many specimens of this species through his hands, says that the ornamentation of Aeg. lacunatum approaches much to those of young individuals of Aeg. Charmassei of the lower zone. Nevertheless, Aeg. lacunatum is much more compressed, its ribs are smaller and much more bent towards the aperture, and the sulcus is narrower and shallower than in Aeg. Charmassei. It forms part of a group of small Ammonites of the zone Ammonites Davidsoni; but, whilst the others appear to be limited to this zone, Aeg. lacunatum has a wider distribution in time than either of its other zonal associates. It is rarely found below the zone of Arietites stellaris. It is a very abundant species in many regions of the basin of the Rhone; the best specimens have been collected from the quarries of Noylay. It forms in France one of the most important Ammonites of the Amal. oxynotus zone. It is rare to find good specimens entire, still the fragments are abundant, and easily recognised.

Locality and Stratigraphical Position.-The Gloucestershire specimens were collected out of the Lower Lias Shales and Limestone near the Midland Railway-cutting at Lansdown New Road, about the horizon of Amaltheus oxynotus, and this is the only locality in the county from which I have a record of this Ammonite. It occurs in the Amal.oxynotus zone at Robin Hood's Bay, Yorkshire coast, for the specimen of Arietites Collenotii $=$ denotatus, figured in Pl. VI, from the zone Amaltheus oxynotus in Robin Hood's Bay, contains in its body-chamber a quantity of the matrix of the rock from which it was extracted, and in this limestone are several fragments of Aeg. lacunatum, showing both the ribbing on the sides of the whorls and siphonal area, with its deep central sulcus.

1 'Dépôts Jurassiques du Bassin du Rhône,' ii, p. 121. 


\section{Third Section.-ARMati.}

Aegoceras Birchil, Sowerby. Pl. XXIII ; Pl. XXXII, figs. 5-8.

Ammonites BrrchI, Sowerby. Mineral Conchology, vol. iii, p. 121, pl. 267, 1820.

Planites - Haan. Ammon. und Goniatit., p. 82, No. 2, 1825.

Ammonimes - Quenstedt. Petrefactenkunde; Cephalopoden, p. 86, 1849.

- - d'Orbigny. Pal. Française ; Terr. Jurass., p. 287, pl. 86, 1842.

- - Oppel. Die Juraformation, p. 84, 1856.

Aggoceras - Neumayr. Zeitschrift der Deutsch. geol. Gesellschaft, B. xxvii, p. $906,1875$.

- BrrcHI, Tate and Blake. Yorkshire Lias, p. 274, 1876.

Diagnosis.-Shell discoidal, compressed; whorls eight, narrow, sub-rotund, and slightly involute; sides compressed with numerous thick, blunt, straight ribs; on each of these two sharp tubercles are developed, which are all visible in the wide, open umbilicus; the tubercles are very sharp in young, and blunt in old shells; aperture subquadrate, with lateral points only slightly grooved by the turn of the spine.

Dimensions-Large specimen.-PI. XXIII. Diameter 160 millimètres; width of the umbilicus 95 millimètres; height of the last whorl 35 millimètres; width of ditto 35 millimètres.

Small specimen.-Pl. XXXII, figs. 5-8. Diameter 80 millimètres; width of the umbilicus 50 millimètres; height of last whorl 15 millimètres; width of ditto 15 millimètres.

Description.-This very distinct and characteristic Ammonite of the Lower Lias is readily distinguished by the round siphonal area with its numerous bi-tuberculated ribs.

The whorls increase so slowly in diameter, that in a large specimen before me, eight inches in diameter, there are only seven volutions of the shell; the sides of the whorls are convex and slightly flattened in the middle, they have from thirty-two to thirty-four thick, straight, lateral ribs, with two tubercles developed on each; the outer tubercle is the largest, and in some specimens becomes spinous; the inner is smaller and more obtuse, and the ribs disappear near the inner border.

The siphonal area (PI. XXIII, fig. 2) is round, and in some specimens three or four fine transverse bands extend across the area from one outer tubercle to the other, and fine transverse lines of growth are seen on the shell figured in Pl. XXIII.

The spire is formed of very narrow whorls, which are slightly involute, and all are fully exposed.

The aperture is round above, flattened on the sides, and very little diminished by the turn of the spire (PI. XXIII, fig. 2).

The septa are symmetrical, and have an extremely complicated arrangement of lobes and saddles; of these I am only able to figure a portion (Pl. XXXII, fig. 7). The 
siphonal lobe is nearly as long as the principal lateral (fig. 7), it is deeply bifid, and on each side thereof are six or seven long narrow digitations. The principal and inferior lateral lobes have an exceedingly complex arrangement in the distribution of their side branches; this will be much better understood from the excellent figure given of them than by any verbal description. The saddles consist of numerous slender foliations.

This species preserves its specific form through life, and undergoes few morphological changes, with only a very limited variation; the young shells (PI. XXXII, fig. 8), up to 13 millimetres in diameter, are smooth; the onter tubercles are first developed, and the inner ones soon follow, so that when the shell attains 25 millimètres in diameter it exhibits the distinguishing characters of the species, which are closely preserved in the largest specimen, 200 millimètres in diameter.

Affinities and Differences.-This Ammonite is very distinct from all its congeners in the Lower Lias, and is easily identified by its round siphonal area, slow increase in the diameter of the whorls, the bi-tuberculated character of its numerous ribs, and complex ramification of the lobe-line; by these characters it is easily distinguished from them.

Aeg. Valdani, d'Orb., of the Middle Lias, has likewise bi-tuberculate costæ, but the flatness of this shell and the elevated median ridge on its back, with the simpler character of its lobes, and the great size of its saddles, serve to distinguish it from Aeg. Birchii.

Locality and Stratigraplical Position.-The finest specimens of this shell are found near Charmouth and Lyme Regis, in the zone of Arietites obtusus, associated with Arietites Brookii on the same slab, and with the large Saurians, Ichthyosaurus platyodon and Ichthyosaurus intermedius. It is rare in Gloucestershire, although I have several specimens which were collected from the railway-cutting near Bredon; one of these specimens showed the arrangement of the septa figured at Pl. XXXII, fig. 7.

Aegoceras biferum, Quenstedt. Pl. XXVI, figs. 1-4.

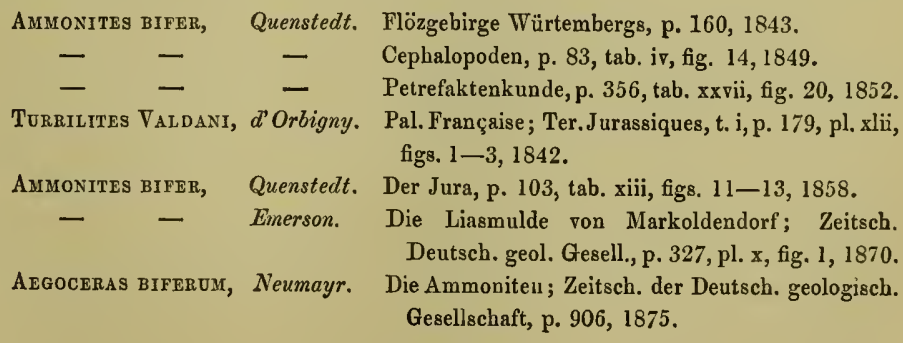

Diagnosis.-In youth shell smooth; at about the fourth whorl short, straight, blunt ribs are developed with spines and processes; when it attains a diameter of 18 millimètres the ribs project, become thin, and winged, and the thin expansion terminates in two 


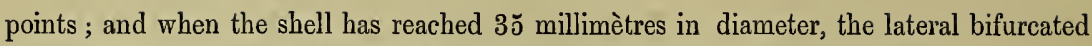
expansions of the ribs impart marked features to the lateral figure of the shell.

Dimensions.-Transverse diameter 24 millimètres; width of umbilicus 12 millimètres ; height of aperture 5 millimètres; transverse width 5 millimètres.

Description.-Professor Quenstedt first recognised this very interesting Ammonite in the Lower Lias of Balingen and Ofterdingen, Würtemberg. It presents an assemblage of characters at different stages of growth which renders it a most interesting morphological study. In the first four whorls, and when the diameter of the tube does not exceed that of a crow's quill, the shell is smooth and without ribs; and in this phase of growth it has a circular mouth-opening, and only fine striæ, scarcely visible without a lens, are seen in the siphonal area covering the smooth shell and bent towards the aperture. In the next stage of growth it develops fifteen short, stout, lateral ribs, which disappear from the siphonal area; and after another whorl or so of growth the ribs extend outwards in thin, sharp folds, which shoot forth two spinous processes. The shell has now attained the size of a florin, and in this phase of growth the sides are ornamented with eighteen thin, sharp, compressed ribs, each terminating in a spinous process (Pl. XXVI, fig, 4), of which the outer spine is the largest; in this stage of growth the aperture is much wider in its lateral than in its vertical diameter. The shell is nearly evolute, and in consequence the winding of the spire it is sometimes excentral, and then assumes the obliquity of a Turrilite; from Captain Valdan finding some specimens in this condition in the Lower Lias of Augy-sur-Aubois, near St. Amand (Cher), with a spiral dextral shell, d'Orbigny regarded them as Turrilites, and figured them as such in the 'Paléontologie Exançaise ' (pl. 42, figs. 1-3), an error which is repeated in another evolute shell, the Aegoceras Coynarti. Both species were collected from the marls of the Lower Lias with Gryphce a arcuata. A similar error has been committed in mistaking the evolute Arietites raricostatus for a Turrilite, and figuring it as Turrilites Boblayi. The lobe-line is simple and is very well seen in one of my young specimens; the siphonal lobe is the longest and terminates in projecting processes (fig. 2); the siphonal saddle is wide, with rounded denticles; the lateral lobes are both about the same size and figure, and the lateral saddles are larger than the lobes; the auxiliary lobes and corresponding saddles are too much concealed to admit of accurate description, the type, however, of the entire lobe-line is that of the character of a Capricorn Aegoceras in all its essential details.

Affinities and Differences.-Aegoceras biferum in early youth resembles the young of Arietites semicostatus, being like it smooth and destitute of ribs. In its second or ribbed phase it resembles a young form of Aeg. Capricornus with lateral ribs and a smooth siphonal area; in its third stage, when it has acquired its winged ribs with compressed bi-spinous terminations, it presents a form unique amongst the group to which it belongs.

Locality and Stratigraphical Position.-This is a very rare Ammonite. I have never seen any other examples in England except the few specimens I collected from the Great-Western Railway cutting in the Lower Lias Beds of Lansdown Road, 
near Cheltenham, in a ferruginous marl, belonging to the Amaltheus oxynotus-zone, and from beds of the same horizon at Gloucester, obtained during the excavations made for the new docks. It certainly is not found at Lyme Regis, and is unknown in Yorkshire. Professor Quenstedt's original specimens were collected from the upper region of Lias $\beta$ at Balingen, Ofterdingen, Betzingen, Würtemberg. There this Ammonite is associated with Belemnites acutus, Mill; Leda Romani, Opp.; Mytilus minimus, Sow.; Plicatula ventricosa, Goldf.; Gryphca obliqua, Sow.; Rhynchonella oxynota, Quenst.; according to Dr. Oppel ('Juraformation,' p. 54).

Aggoceras Planicosta, Sowerby. Pl. XXIV, figs. 1-S; Pl. XXV, figs. 1-3.

AMMONITES PLANicosta,

- LAXICOSTATA,

- PLANicosta,

Planites planicostatus,

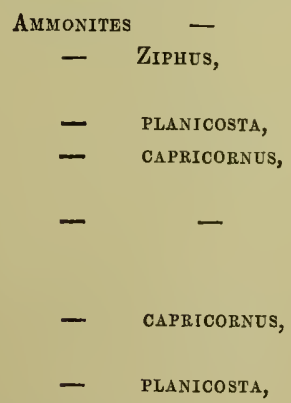

Torrilites Coynarti,

AMMONITES CAPRICORNUS,

- DedRESSIERI,

- CAPRICORNUS nUdUs, Quenstedt.
Sowerby. Mineral Conchology, vol. i, p. 167, tab. 73, figs. $1-5,1814$.

Lamarck. Anim. sans Vertèbres, t. vii, p. 638, 1822.

Young and Bird. Yorkshire Coast, p. 248, pl. 13, fig. 6,1822 .

De Haan. Monogr. Ammonit. et Goniatit., p. 92, No. 26, 1825.

Young and Bird. Yorkshire Coast, p. 259, 1828.

Zieten. Versteinerungen Württembergs, p. 6, tab. 5, fig. 2, 1830.

Voltz. Jahrbuch f. Min. Geol., p. 272, 1830.

Zieten. Versteinerungen Württembergs, p. 6, tab. 4, fig. 8, 1830.

Von Buch. Ueber Ammoniten; Abh. Berlin Acad. d. Wissensch., pl. iv, fig. 4 (1830), 1832.

Roemer. Versteiner. Nord-Deutsch. OolithenGebirges, p. 192, 1836.

Bronn. Lethæa Geognostica, p. 440, pl. xxiii, fig. 1, 1837.

d'Orbigny. Paléontol. Française; Ter. Jurassiques, p. 181 , pl. 42 , figs. $4-7,1842$.

Quenstedt. Flözgebirge Würtembergs, p. 158, 1843.

d Orbigny. Pal. Française ; Terr. Jurassiques, p. 325, pl. 103, 1844.

Cephalopoden, p. 81, tab. iii, figs. $6 a, b$, 1849.

Der Jura, p. 96, tab. 12, fig. 3, 1858.

Aegoceras planicosta, eitschrift der Deutsch, geol. Gesellschaft, p. 906,1875 . 
Description. -This is one of the Ammonites about which much confusion exists, arising from the fact that in youth it very much resembles the young form of another Ammonite, so that when of about the same age specimens of both species are frequently mistaken for each other, whilst the morphological changes in form and structure with advancing life show how widely dissimilar the two forms are before they reach their mature condition. The one form, Aegoceras planicosta, Sow., appertains to the Lower Lias, and the other form, Aegoceras capricornus, Schloth., belongs to the Middle Lias.

The true position of Aegoceras planicosta was well defined by the slab containing this species, which Sowerby figured in 1812. Here we see it associated with Arietites obtusus in a mass of Marston stone found at Marston Magna, near Ilchester. Near Yeovil, in Somerset, also, large slabs of a similar rock full of this Ammonite are raised with their nacreous shells well preserved in clusters, some of the slabs are big enough to form the tops of small-sized sideboards and other pieces of furniture. The beauty of the marble depends upon the number of the Ammonites clustered together; the white pearly layer of their shells is most admirably preserved, whilst the chambers are filled in with fine brown crystallised carbonate of iron or carbonate of lime, which adds much to the colour and richness of the dark grey ground of the Lias Marble.

In the "Yorkshire Coast" the Rev. George Young early noted the specific character of this Ammonite, in alluding to Bird's very bad figure (pl. xiii, fig. 6); he says, p. 259 (2nd edit., 1828), "It is from the lowest shale at Robin Hood's Bay [zone of Arietites obtusus]; it is a small and handsome Ammonite, similar to Ammonites maculatus, having ribs that are sharp on the sides but flattened on the back. But the flat part in this Ammonite bears a much greater proportion to the rest of the rib, and it is therefore named $A$. planicostatus, Sowerby, Tab. 73 and 406 . It is generally found in a pyritous state. In the older specimens a slight knob is sometimes found at each end of the flat part of the back."

Professor Quenstedt also noted that the variety with the broad ribs on the back was found only associated with Ammonites Turneri (=obtusus), from whence also the specimen figured in Zieten's "Württemberg" came and not from Gammelshausen as stated, where hardly any Lias is found. The figures given in the "Cephalopoden," Tab. iv, fig. $6 a, b$, are representations of one form of this Ammonite which I collected from the Stellaris-bed at Lyme Regis, and which are drawn in Pl. XXIV, figs. 1 and 2, of this work, clearly proving the identity of the English and Würtemberg shells.

The Ammonites ziphus, Hehl, figured in Zieten, and which was determined by Mr. Hehl, is distinguished principally by its elevated blunt spines placed at some distance apart. This fragment was regarded by its author as a distinct species; it was found in the Lias Sandstone near Boll. When we compare Zieten's figures with the forms I have figured from Lyme Regis, which are there associated with younger and older forms of the same species, one cannot doubt their identity (Pl. XXIV, figs. 4-7).

The next change in this species is characterised by the shortening of the ribs, which terminate in small tubercles developed near the lateral boundary of the siphonal area, 
and by the rounding of the abdominal surface of this region of the shell. A comparison of d'Orbigny's $\mathrm{Pl}$. 103, figs. 1 and 2, with our Pl. XXIV, fig. 5, will convince the student of the identity of the French and English forms.

In describing this species it will contribute to a more correct knowledge of its forms if we trace them through the four stages over which they pass, and which I shall call-lst, the planicostal, 2nd, the ziphus, 3rd, the Dudressieri, and 4th, the adult condition. The planicostal stage extends to five whorls; the two first whorls are smooth and slowly acquire ribs which, in the other three, are slender and prominent, and as they bend over the siphonal area they become much flattened and are separated by concave spaces as wide as the flat portion of the ribs. All the whorls are fully exposed, and the umbilicus is widely open through the slight involution of the encircling whorls.

The ziplus stage commences witl the sixth whorl, fig. 1. The ribs are now more prominent, and before they bend over the siptional area a sharp prominent tubercle is developed on the termination of the rib, which gives a considerable extension to the area, and leaves the prominence of the large transverse elevations in the direction of the ribs, on the surface of which are ornate lines of delicate sculpture (see Pl: XXIV, figs. 4, 6, 7).

In the Dudressieri stage (fig: 5) the shell is discoidal; thick, and compressed, with a wide open umbilicus and very evolute spire exposing the entire whorls to view. Here we count seven volutions which, when carefully examined, show the different characters already pointed out in the description of the morphology of this species, and which are very well shown in figs. 1 and 5 of $\mathrm{Pl}$. XXIV.

The adult state is not often seen; most of the large shells of this species I have examined had come to grief, partly in consequence of the slender involution of the spire. Fortunately, however, I found a nearly perfect example in the Jermyn Street Museum (School of Mines), obtained from Lyme Regis, which afforded a rare opportunity for studying the adult condition of Aeg.planicosta. No person could be expected to believe the specimen was this species unless he had followed the changes of shape through which this fine Ammonite passed. The fossil afforded not only a good example of a generalised form of a remarkable species, but at the same time showed how persistent and well-defined the different morphological changes were, which allied species of Ammonites endured amongst the various transition forms through which they were destined to pass between youth, adolescence, and old age. Here we discover no confusion with allied species, each holds its own predestined course during the varied evolutionary stages through which it has to pass, so that amongst Ammonites we fail to detect any transmutation of specific forms one into another: on the contrary, each obeys its own law of successive change between the ovum and maturity. PI. XXV shows Aegoceras planicosta, Sow., of its natural size and in its adult condition, and represents a large Ammonites Dudressieri, d'Orbigny. The sides are ornamented with forty ribs, which are straight, regular, and prominent, with equal sulcations between; the penultimate has the terminal tubercles on the ribs as in Dudressieri, but in the last whorl we observe the disappearance of the tubercles, and the appearance of a number of trans- 
verse lines of sculpture. In fig. 2 is represented a portion of the outer lamina of the shell showing lines and perforations highly magnified; in fig. 3 parallel lines formed by a finely-punctated surface are shown.

The siphonal area is large, convex, and wrinkled transversely in the adult; the spire is composed of whorls, which are about as wide as they are high, slightly flattened on the sides and only slightly involute. The aperture is nearly quadrate, mucronated on each side at the siphonal area, and gently grooved by the return of the spire. The septa, according to d'Orbigny-I have not seen the lobe-line-are divided into three lobes, of which the two external are formed of pairs of parts. The siphonal lobe is as long and wide as the principal lateral, and ornamented laterally with three branches, of which the inferior is bifurcated. The siphonal saddle, as large as the principal lateral lobe, is divided into three folioles of which the median has three festoons. The principal lateral lobe is divided into two large, nearly equal terminal branches, and four lateral digitations. The lateral saddle is formed of two parts almost equally bi-lobed; the inferior lateral lobe is oblique, and terminates in two unequal branches, of which the internal is the largest. The accessory lobe is provided with two small unequal points, a radial central line in parting from the extremity of the siphonal lobe touches the points of the principal lateral and passes well above the others.

Affinities and Differences.-In early age this species resembles Aeg.capricornus, whilst in its middle-age and adult conditions it is entirely different; this fact will be demonstrated when the shell-structure and morphology of that species is under discussion.

Locality and Stratigraplical Position.-This species is found in the Arietites oltusus-zone at Lyme Regis, in the same horizon near Yeovil, at Marston Magna near Ilchester, in Robin Hood's Bay, Yorkshire, and the Midland Railway cutting, at Breden, and in other exposures of the same zone in other parts of the Vale of Glo'ster.

Aegoceras subnuticum, Oppel. PI. XXVII, figs. 1 and 2.

Ammonites natrix oblongus, Quenstedt. Cephalopoden, p. 85, pl. 4, figs. $16 a-d$, 1849.

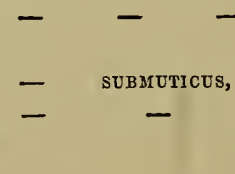

- submuticum,
Oppel. Mittlere Lias Schwabens, Jahreshefte Württemberg, p. 73, pl. 1, fig. 5, 1853.

Oppel. Die Juraformation, p. 158, 1856.

Dumortier. Dépôts Jurassiques du Bassin du Rhône, tom. iii, p. 63, pl. xii, figs. 1, 2; pl. xliv, figs. 2-4, 1869 .

Neumayr. Systematik der Ammonitiden. Zeitschrift der Deutsch. geol. Gesellschaft, p. 906, 1875. 
Diagnosis.-Shell large, flattened on the sides, and slightly involute, umbilicus widely open; spire formed of eight whorls which have a convex margin and are slightly compressed on the sides, the last whorl has thirty-eight slender principal ribs, which are only slight elevations, and terminate in sharp prominent tubercles near the outer border of the siphonal area; the ribs are very feebly marked on the inner volutions; on the last whorl they first bend backwards, then incline forwards, and again bend back and terminate in tubercles. The siphonal area is broad and slightly convex; from the lateral tubercles transverse folds extend across the area, with several smaller elevations between; aperture subquadrate, wide and convex above, flattened on the sides, contracted and grooved below by the turn of the spire; shell extremely thin and well preserved in several parts.

Dimensions.-Transverse diameter 140 millimètres; width of the umbilicus 60 millimètres; height of the aperture 50 millimètres; greatest width above 50 millimètres; below, over the spire, 35 millimètres.

Description.-This is a rare form, and closely resembles the Am. natrix oblongus, Quenst., of the 'Cephalopoden,' and is one of the most elegant species of the Armati group.

The shell attains a considerable size, is gently compressed on the sides, and has a very wide umbilicus; it is, therefore, extremely evolute and fully exposes all the inner turns of the spire, which is formed of eight volutions that are round and slightly compressed and covered with delicate ribs; the last whorl has thirty-eight principal ribs, which are slightly elevated and directed forwards, and they all terminate in small tubercles near the outer border of the siphonal area. The ribs on the inner whorls are very slight elevations, whilst on the outer whorl they describe with sigmoidal curves, smaller intermediate secondary folds lying between them. The siphonal area is wide, convex, and without a trace of keel; large transverse folds pass across the area from one tubercle to another, with one or two smaller intermediate bands between the larger folds. The shell of this Ammonite is extremely thin, and very well preserved on some parts of the figured specimen, and shows that the tubercles were hollow cones filled in with the matrix in which the mollusc was embedded (fig. 1). These form prominences on the mould, which are all embraced and covered over by the turns of the spire. The aperture has a subquadrate figure, much higher than wide, and expanded at the outer side, where it acquires an increased extension by the hollow spines. Fig. 2 shows the size and form of the aperture, the squareness of the same, and the numerous ridges that cross the area between the larger folds.

Dumortier has figured a large fragment of this species, which exhibits its specific characters extremely well, including the structure of the tubercles as here described from my specimen.

The lobe-line is not visible either on the French or English specimens.

Affinities and Differences.-This species resembles Aegoceras armatum, Sow., in its general figure, but differs from that form in having larger whorls; more numerous and smaller tubercles; and a more quadrate aperture. 
Locality and Stratigraphical Position.-The figured specimen was collected at Lyme Regis; it is embedded in a grey Lias Limestone which occurs about the base of the Middle Lias. I had no other specimen from the same bed to check my diagnosis, but it is apparently the base of the Aegoceras Jamesoni-zone. I have not seen another specimen in any of the collections I have consulted.

Aegoceras armatum, Sowerby. Pl. XXVIII, figs. 1-6; Pl. XXIX.

Ammonites armatus, Sowerby. Mineral Conchology, vol. i, tab. 95, p. 215, 1815.

- - - Young and Bird. Yorks. Coast., p. 249, pl. xiii, fig. 9, 1822.

- Hastatus, Foung and Bird. Ibid., pl. xiv, fig. 2, 1822.

Planites fibulatus, Haan. Amm, et Goniat., p. 84, No. 8, 1825.

Ammonites armatus, d'Orbigny. Paléontol. Française; Tér. Jurass., p. 270, pl. 78, 1842.

- $\quad$ - Quenstedt. Flözgebirge Würtembergs, p. 157, 1843.

- - Simpson. Monograph on York. Lias Ammon., p. 26, 1843.

- $\quad$ - Quenstedt. Cephalopoden, p. 82, 1849.

- - Oppel. Juraformation, p. 155, 1856.

- - Simpson. Fossils of York. Lias, p. 64, 1855.

- MILes, Simpson. Ibid., p. 65, 1855.

- aRMatus, Schlönbach. Mittleren Lias, Zeitschrift Deutsch. geol. Gesellschaft, p. 511, Jahr 1863.

- - Dumortier. Dépôts Jurass. du Bassin du Rhône, vol, iii, p. 59 , pl. viii, figs. $1,2,1869$.

- - Emerson. Die Liasmulde von Markoldendorf, Zeitschrift Deutsch. geol. Gesell, p. 330, pl. x, fig. 4, 1870.

Aggoceras armatum, Tate and Blake. Yorkshire Lias, p. 27\%, 1876.

Diagnosis.-Shell large, compressed; whorls slightly involute, umbilicus wide, and inner whorls all exposed; spire formed of from six to eight volutions; the outer whorl, according to age, with from eighteen to twenty ribs, which arise from small striæ at the umbilical suture, and enlarge as they advance towards the margin of the siphonal area, where they terminate in long, stony, tubular spines; between the principal ribs, and on the spines themselves, are other smaller transverse striæ; siphonal area wide, flattened, slightly convex, and ornamented transversely with a continuation of the same striæ that adorn the sides; spire composed of rounded or subquadrate whorls somewhat depressed and inclined towards the umbilicus; aperture subquadrate, the transverse exceeding the vertical in diameter.

Dimensions.-Transverse diameter 115 millimètres; width of umbilicus 55 millimètres ; height of the aperture 30 millimètres; width 36 millimètres.

Description.-Much confusion appears to have existed among the local palæontologists of Yorkshire, where this Ammonite was first discovered, regarding the figure and 
description by Sowerby, who states" that "numerous varieties of this species are found in the great Alum-clay formations at Whitby, where this large-sized specimen was gathered by Mr. Strangewayes. We have here also the advantage of many specimens, the middle being a small plain one, which, indeed, might have been considered a different species; the next circle might, by the same rule, form a second species with larger radii; and, again, the third with the flat disks and fewer striæ than the outer circles. It is worthy of remark that the spines bave the appearance of having been stuck on, probably owing to their being attached to part of the outer shell which is worn away at their bases, the spines sometimes being gone also." In the Rev. George Young's " Geological Survey of the Yorkshire Coast,' this author says " We have met with no shell corresponding exactly with Mr. Sowerby's A. armatus, which he states to exist in our Alum-shale in numerous varieties. We have several distinct species of knobbed Ammonites, but have seen none with striated knobs stuck on like Barnacles or small Patellæ, as in the outer whorl of Mr. Sowerby's shell. We must therefore suppose that the latter is so rare, that it could not be found among all the thousands of specimens which we have examined; or that Mr. Sowerby has beeu misinformed as to its locality; or, which seems most likely that he has made out his figure by combining two specimens together, of which the outer one has not belonged to our Alum-shale, and the imner one has had some of its knobs altered to connect it with the other." It appears from this passage that Mr. Young had not seen a true $A$. armatus when he penned it, inasmuch as he figures in his pl. xiii, fig. 9, one of the varieties of $A$. fibulatus, described as "the inside of Sowerby's $A$. armatus with a little variation in the knobs, which are not striated but plain and rather sharp. The specimen appears to be nearly entire, and we have no reason to think that it has had another whorl like that in Sowerby's figure. Yet in tracing the spire in its several volutions, we see, as in his shell, a succession of different markings. Towards the mouth the ribs are alternately knobbed and plain, and the knobbed rib parts into three at the back, immediately beyond the knob, while the plain rib goes round the back single.",3 This confusion appears to have arisen from an error in Mr. Strangewayes' statement to Sowerby that his specimen was gathered from the Alum-clay formation or Upper Lias, whereas it was doubtless obtained from the lowest beds of the Middle Lias near the village in Robin Hood's Bay, strata, by-the-by, which appear to have been very little known when Young wrote his work, and so, failing to find $A$. armatus in the Alumshale, which he knew so well, he selected and figured as $A$. armatus a good spinous variety of $A$. fibulatus, a very characteristic Ammonite of the Alum-shale. This form he supposed must have been the one Sowerby had before him when he very accurately figured but imperfectly described an Ammonite which Young had not met with in the Alum-shale, because it does not exist in that formation. Young does not appear to have

\footnotetext{
1 'Mineral Conchology,' vol. i, tab. 95, p. 215, 1812.

2 'Geological Survey of the Yorkshire Coast,' Ist edit., p. 248, 1822.

3 Ibid., p. 249.
} 
known that it was to be found in older beds in Robin Hood's Bay. Mr. Simpson ${ }^{1}$ says " I have now got a fair specimen of Sowerby's $A$. armatus which has caused so much trouble to naturalists, the very central whorls are imperfect, but there is sufficient to show that they are plain or nearly so ; the succeeding whorls have the characters exhibited in Sowerby's figure. Where the spines have been knocked off there remain the oval disks. It would seem that when Mr. Strangewayes visited Whitby this species was plentiful; but the specimen I have now described is the only one I have seen, and the one I formerly took to be $A$. armatus, Sow., I believe to be a different species, which I have named $A$. miles."

Like other species of the Armati section of the genus Aegoceras, Aeg. armatum exhibits different forms characteristic of the morphological phases of its growth. In early life the shell is smooth, and about the second whorl ribs commence to show themselves as transverse elevations, and on the fourth whorl small tubercles begin to make their appearance on their sides, and on the sixth whorl they have grown into large, thick, stout spines (Pl. XXVIII, fig. 3). The magnificent specimens figured in Pl. XXVIII, figs. 1, 2, 3, 4, and 5, represent the form this beautiful Ammonite assumes in middle age, when its ornamentation appears to have attained its most perfect state. Now we find the whorls are very slightly involute, a little rounded, and provided with thick ribs, which terminate on the outer side of the siphonal area in twenty strong prominent spines; these, when broken near their base, leave large disc-like marks on the mould; between the ribs are several (four or five) transverse striæ which pass between the ribs, extend across the area (figs. 2, 4, 5), and ornament this region; other smaller striæ creep over the spines themselves (fig. 3), so that the whorls in well-preserved specimens are finely sculptured with graceful lines. Through increasing age the spines are developed wider apart, the body-chamber grows very wide, and enormous recurved spines project from the sides of the siphonal area. I have figured a very fine example of one of these aged specimens of the natural size (Pl. XXIX), showing giant spines on the body-chamber and the comparative smallness of those on the inner whorls. This specimen was collected at Lyme Regis many years ago, and long adorned the cabinet of a local collector. It was purchased for the Museum of the Royal School of Mines and now forms part of their fine collection; it is figured for the first time.

Professor Quenstedt collected this Ammonite in Swabia, where the species is much smaller than our English specimens, but is well defined by the delicate folded striæ or fine concentric ribs which extend along the sides and across the area, among which, near the margin, large thick spines project on both sides, fewer, however, in number than in our specimens.

There are several varieties of this species which have received separate specific names from different anthors. One of these, A. miles, Simpson, deserves more than a passing notice; the spire in this shell consists of six highly evolute whorls, which are round, sleuder, and all exposed in the umbilicus ; the ribs, about sixteen in the last whorl, are wider apart, and each rib terminates near the siphonal margin in a long pointed spine; the lateral 1 'Fossils of the Yorkshire Lias,' p. 64, 1855. 
striæ are fine, numerous, undulating, and annular; and the aperture has a roundish form. This is a much more smooth and elegant form than the typical Aeg. armatum, still it may be specifically identical with it. The smaller diameter of the whorls, and the greater distance the ribs are apart from each other, greatly diminish the number of the lateral spines, which are longer and more slender than in the typical specimens of Aeg.armatum; the lobeline is likewise less complicated, and the septa are also more distant from each other than in fig. 6 ; the inner whorls are striated without ribs or spines. This is a most interesting form of the group Armati; and probably the discovery of other specimens may disclose some features in its form that may justify the distinction Simpson assigned to it.

In Aegoceras armatum (the typical form figured in Pl. XXVIII, figs. 1 and 3), in the middle period of life, the septal chambers are shallow and the lobe-line extremely convoluted, so that it is very difficult to follow its contouring. Professor d'Orbigny sketched a generalised diagram of this line from the specimen he possessed, whilst I have had the lobe-line traced on one of my specimens, and an enlarged drawing made therefrom (fig. 6), which shows that the true ramification of the lobe-line is much more complicated than d'Orbigny's figure led us to suppose. The siphonal lobe is as wide and almost as long as the principal lateral, and has on each side four lateral branches. The siphonal saddle is much wider and longer than the principal lateral lobe, and is divided into two unequal portions, the external of which is the largest and terminates in many folioles; and the internal portion has a similar termination. The principal lateral lobe is highly ornate, and from the wide base two large branches proceed from each side of the stem, which terminate in a long terminal foliated portion. The lateral saddle is small and narrow, and terminates in three folioles. The inferior lateral lobe is small and narrow, about one fourth the size of the principal, it develops three lateral and one long terminal branch; the accessory lobes are oblique and much ramified, and the whole lobe-line forms a most highly complicated contouring of foliations.

Affinities and Differences.-I have separated the Armatum- from the Jamesoni-zone because it constitutes an excellent Ammonite horizon, with an interesting series of elegant forms which range themselves around the original Sowerbyan type as a centre, and which commenced and terminated their existence with the dawn of the Middle Lias; they had, therefore, it would appear, a very limited life in time.

A great family likeness runs throughout the group, which requires accurate observation and a critical judgment to discover and define; all the species have the whorls more or less armed with spines, and with ribs and striæ extending across the siphonal area; in most of the species only one row of spines is developed along the margin of this nrea, whilst in others there are two distinct series of spines, as in Aeg. densinodum, Quenst., and Aeg. brevispinum, Sowerby ; the septal chambers in all are very shallow, and the lobe-line is likewise highly convoluted.

Locality and Stratigraphical Position.-The fine specimens figured in Pls. XXVIII and XXIX were obtained from the Aegoceras armatum-zone at Lyme Regis, and very 
fine specimens have likewise been collected from similar beds at Robin Hood's Bay, Yorkshire, where Sowerby's type was found. I have found fragments of this species in the same zone in some exposures of the Aeg. Jamesoni-beds near Cheltenham.

\section{Aegoceras Milideri, Wright, nov. sp. Pl. XXXVII, figs. 10, 11.}

Diagnosis.-Ammonite large, depressed, flattened on the sides, and slightly involute; shell very thin, not thicker than fine cardboard; whorls broad, much flattened across the siphonal area, vertical height two thirds that of the transverse diameter, sides with slight undulations, terminating in short tubular blunt knobs on the margin; the siphonal area and sides of the tubercles sculptured with a series of longitudinal elevations and depressions, which impart an ornate character to this region of the shell, and form a good specific feature for the distinction of the species.

The size of this Ammonite is unknown, seeing that fragments only have been found, the whorls being so slightly involute that no disc will hold together.

This species resembles Aeg. muticum in the position, form, and size of the tubercles, and likewise in the small amount of its involution; it differs from Aeg. muticum, however, in the absence of longitudinal striæ on the siphonal area (see fig. 10). The lateral view of the whorl (fig. 11) shows the arrangement of the tubercles on the margin of the area.

Locality and Stratigraplical Position.-This fragment was collected by Professor Archibald Geikie, F.R.S., in Pabba, along with other fossils from the zone of Aegoceras Jamesoni sent by my friend to me to determine. Prof. Geikie at the same time requested that, should I meet with any new forms in the collection he had made, I should associate the name of Hugh Miller, of the Old Red Sandstone, with the Pabba beds as a memento of the valuable work he carried out by his researches among the Hebridean Lias beds in his cruise in the 'Betsey'; in compliance with my friend's request, and with very great pleasure in doing so, I dedicate this singular Ammonite to the memory of Hugh Miller.

\section{Aegoceras Leckenby, Wright, nov. sp. Pl. XXX, figs. 1-7.}

Diagnosis. - Shell discoidal, with rounded whorls, one third involute, and a wide open umbilicus; sides of the whorls ornamented with primary and secondary ribs; the primaries vary from twelve to twenty-four in number, they are larger in size, and each rib develops a blunt elongated tubercle near the siphonal area and sends several smaller branches therefrom across the area; and the secondaries consist of numerous smaller sigmoidal annular radii interposed between the primaries, encircling this region which 
is consequently ornamented with numerous close-set transverse folds, nearly uniform in thickness throughout. The lobe-line is extremely convoluted.

Dimensions.-Transverse diameter, 85 millimètres; diameter of umbilicus 35 millimètres; height of last whorl 30 millimètres; transverse diameter 30 millimètres; amount of involution one third the height of the whorl.

Description.-The rounded whorls with small ribs and blunt elongated tubercles, having the siphonal area crossed by numerous transverse folds, and corresponding valleys of about the same proportionate development throughout, form a group of characters which distinguish this species from its congeners. The number of primary lateral ribs varies in the two specimens here figured from fourteen to twenty-four; they arise near the spiral suture by a thickened fold, and, describing a sigmoidal flexure, develop near the margin of the siphonal area a blunt elongated tubercle, from which two or three smaller folds proceed across the area; the tubercles are neither large nor prominent (figs. 1, 2, $4,6)$, and do not terminate in spines, at least in the specimens I have seen. The secondaries are smaller annular folds, which arise from the spiral suture, describe a sigmoidal flexure, and extend directly across the siphonal area, blending with their fellows from the opposite side, and covering the area with a series of elevations and depressions, which impart an ornate aspect to this region of the shell (figs. 2, 3, 6). The whorls are quite one-third concealed in the umbilicus by the involution of the spire (figs. 1, 4).

The lobe-line, as in all the other Armati group, is extremely convoluted (fig. 7); the siphonal lobe is long, and has one large lateral and three smaller terminal branches. The siphonal saddle presents three deeply ramified folioles; the principal lateral lobe is as large as the siphonal, and divides into two branches, which are both much digitated. The lateral saddle is small, narrow, and foliated, and the accessary lobes have a central stem with lateral digitations. The whole forms an oblique and most complicated line of suture, very difficult to trace through all its ramifications.

Affinities and Differences - This species very much resembles Aeg. armatum, but differs from it in the following details of its anatomy. The whorls are rounder and more involute; the spines are shorter, elongate, and non-aculeate; the lobe-line is much less convoluted, and the transverse folds across the siphonal area are smaller and more numerous.

Locality and Stratigraphical Position.-This Ammonite was obtained in the Armatumzone of the Middle Lias at Lyme Regis, associated with Aeg. armatum and Aeg. miles, and the other fossils of this bed. It must be a rare form as I have not seen any other specimens except those here figured, nor observed it in any of the collections examined for the purpose of acquiring all the different species of Armati for my work. This species is dedicated "in memoriam" to my old and much esteemed friend, the late Mr. John Leckenby, F.G.S., of Scarborough, who was always a ready and willing helper by the loan of his most beautifnl specimens for figuring in my works on the Fossil Echinodermata and AmмоnıтіDx, published by the Palæontographical Society. 
Aegoceras Davei, Sowerby. Pl. XXXI, figs. 1, 2.

Ammonites Davex, Sowerby. Min. Conch., vol. iv, p. 71, pl. 350, 1822.

Planites - de Haan. Ammonit. et Goniatit., p. 82, No. 3, 1825.

Ammonites - Zieten. Versteiner. Württembergs, p. 19, tab. xiv, fig. 2, 1830

- - Roemer. Norddeutschen Oolitbgebirg., p. 199, 1836.

- Davoer, Bronn. Lethæa geognost., p. 447, tab. xxiii, fig. 4, 1837.

- - Collegno. Bulletin Soc. géolog. de France, x, p. 247, 1839.

- - Quenstedt. Flözgebirge Würtembergs, 171, 1843.

- Daver, d'Orbigny. Pal. Franę. Juras., tom. i, p. 276, pl. 81, 1842.

- - Quenstedt. Cephalopoden, p. 91, tab. 5, figs. 6, 1849.

- - Savi and Meneghini. Consid. Geologia Toscana, p. 115, 1851.

- - - Studer. Geologie der Schweiz, t. ii, p. 31-35, 1853.

- - Meneghini. Nuovi Fossili Toscani, pp. 10, 31, 1853.

- DavöI, Oppel. Mittlere Lias Schwabens, Jahreshefte Württemberg, p. 80, 1853.

- - Quenstedt. Der Jura, p. 132, 1858.

- - Von Hauer. Die Cephalopoden aus dem Lias der Nord-Ost.

Alpen, p. 54, pl. xvii, figs. 11, 12, 1856.

- - Chapuis. Terr. Sec. de Luxemb., p. 25, t. iv, fig. 5, t. $\nabla$, fig. 1, 1858.

- - Dumortier. Dépôts Jurassiques du Bassin du Rhône, tom. iii, p. 94, pl. xi, figs. 4-6, 1869.

Aegoceras Davoei, Neumayr. Zeitschrift der Deutsch. geol. Gesellschaft, p. 906, 1875.

Diagnosis.-Shell discoidal, depressed; umbilicus wide; whorls round, slightly involute, covered on the sides and area with numerous simple, narrow, oblique ribs; on

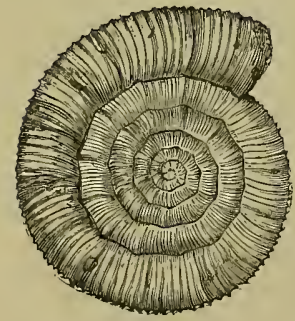

Fig. 188.-Aegoceras Davai, Sow. each revolution of the spire there are eight to ten round, obtuse tubercles developed near the middle of the whorl, and occupying the width of three ribs; siphonal area rounded, slightly depressed, and covered with numerous transverse close-set costæ; spire formed of eight whorls, which are round and slightly depressed on the outer margin; aperture roundish.

Dimensions. - The large figured specimen; transverse dia. meter 112 millimètres; width of umbilicus under aperture 65 millimètres ; vertical height of whorl 26 millimètres ; transverse diameter 30 millimètres. The specimens found in general are much smaller, two before me measure transverse diameter 90 millimètres; width of umbilicus under aperture 55 millimètres; vertical height of last whorl 22 millimètres; transverse diameters 23 millimètres.

Description.-This beautiful Ammonite is a very rare British fossil. The specimen 
here figured formerly belonged to my late friend, Mr. John Leckenby, F.G.S., who obtained it from Charmonth; it is one of the finest examples known, and is now in the Woodwardian Museum, Cambridge; the shell is discoidal and compressed, consisting of rounded whorls, which are only slightly involute, and closely clasp the penultimate volution; they are covered on the sides and area with a series of ribs and sulcations about equal in width thronghout; on the sides the ribs are directed obliquely forwards, whilst across the siphonal area they are transverse and extremely regular. In typical shells each whorl develops from eight to twelve round blunt tubercles about the middle of the whorl, which occupy the space of two ribs and two sulcations; sometimes these tubercles have a thick envelope, and then they form spines; many specimens, however, are wanting in the tubercles, though in the figured specimen the projections are large and regular, and impart a very distinctive character to this Ammonite. The lobe-line is very complicated; the siphonal lobe, as long and wide as the principal lateral, is formed of three branches, two of which bifurcate. The siphonal saddle, as large as the principal lateral, is very irregularly divided into three folioles at the external side, and one at the internal. The principal lateral lobe divides into two large branches, the terminal one is very much ramified, and the external, nearly as large, is equally ramified. The lateral saddle is smaller than the principal lateral lobe, and terminates in four folioles. The lower lateral lobe is small, with five digitations, and the auxiliary lobe, still smaller, possesses three. The lobe-line has been extremely well figured by Quenstedt and d'Orbigny; none of the specimens which have passed through my hands show this structure so well, as they have all retained their shell (or portions thereof) which conceals the true septal suture.

Prof. d'Orbigny had the opportunity for studying the evolution of this Ammonite; he observes : ' - "This species, more or less compressed, varies much according to age. Up to a dianeter of 25 millimètres the whorls are much depressed, and ornamented with from thirteen to fifteen long, sharp-pointed spines; this depression of the whorls is often remarked up to a diameter of 50 millimètres; beyond this diameter there are in general from eight to twelve tubercles; the whorls become more or less thick and compressed. At the largest diameter known (120 millimètres) the ribs become more prominent, and more irregular, and the tubercles are less regularly placed. The spines appertaining to the shell leave a truncated tubercle on the mould."

Affinities and Differences.-This species resembles Aeg. Leckenbyi in its ribs and spines, but is distinguished from that form by its tubercles being set much wider apart, by its regular oblique narrow ribs and valleys on the sides, and by the finer sculpture across the area; the structure of the lobe-line likewise presents an important difference between the two species.

Locality and Stratigraplical Position.-This is a capital leading fossil for a certain horizon of the Middle Lias; the chicf locality in England is the Green Ammonite-beds 
near Charmouth, Dorset (see p. 89), where I have collected it associated with Aeg. Bechei, Belemnites clavatus, and Monotis incequivalvis, all in the same slab. It is found in marls of the same horizon in Somersetshire and Gloucestershire.

Dumortier says :- "Of all the Ammonites of the Middle Lias Am. Davoei is the most important and most characteristic form; its ornamentation and size are more constant; and it presents itself always in the same horizon, that is to say, above the lowest beds of the Middle Lias, and in company with Am. capricornus and Am. fimbriatus. I do not know a bed at this level in which $\mathrm{I}$ have not found $A m$. Davai." It has been collected in many Departments of France, as at Mulhausen and Uhrwiler, Bas-Rhin; near Nancy, Meurthe; Amaye-sur-Orne, and Vieux-Pont, near Bayeux, Calvados ; Saint-Rambert, Ain ; near Lyon, Rhône; Pouilly-en-Auxois, Semur, Venarey, Côte-d'Or; Metz, Moselle.

In Germany, near Boll; at Bargau, near Gmünd and Aalen; at Füzen between Donaueschingen and Schaffhausen.

In Italy, in the Appenines; in Red Limestone at Monte Calvi; in Grey Limestone Monti di Cetona, near Lake Como.

In Switzerland, in the Bernese Alps; and at Coulat and Fondement, near Bex.

Aegoceras Taylor1, Sowerby. Pl. XXXI, figs. 5-7.

Ammonites TaYLORI,

- PROBOSCIDENS,

- Taylori,

- hamellosus,

- TAYLORI,

- $\quad$ - costatus, Quenstedt.

Sowerby. Mineral Conchology, vol. vi, p. 23, pl. 514, fig. I, 1826.

Zieten. Versteinerungen Würtembergs, p. 9, pl. x, fig. 1, 1830.

Quenstedt. Flözgehirge Würtembergs, p. 176, 1843.

d'Orbigny. Pal. Franç. ; Terr. Jurass., pl. 84, 1812.

d'Orbigny. Ibid., p. 323, pl. 102, figs. 3-5, 1844.
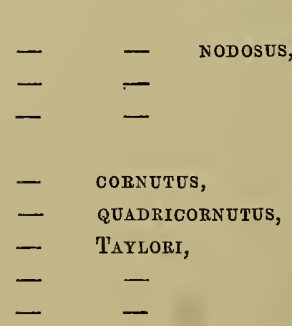

Quenstedt. Ibid., 136, tab. ix, fig. 21, 1849.

Giebel. Fauna der Vorwelt, t. iii, p. 697, 1852.

Oppel. Mittl. Lias Schwabens, Jahresh. Württ., p. 92, 1853.

Simpson. Fossils of the Yorkshire Lias, p. 71, 1855.

Simpson. Ibid.

Oppel. Die Juraformation, p. 165, 1856.

Quenstedt. Der Jura, p. 135, pl. 16, fig. 8, 1858.

Schlönbach. Die Eisenstein d. Mittler Lias; Zeitschr. d.

Deutsch. geolog. Gesellschaft, p. 527, 1863.

Tate and Blake. Yorkshire Lias, p. 279, 1876.

Neumayr. Zeitschrift der Deutsch. geol. Gesellschaft, p. 906 , Jahr 1875 . 
Diagnosis.-Shell discoidal; whorls rounded and externally compressed; sides with fourteen straight, elevated, upright ribs, with two large, blunt, lateral tubercles, one on the side and one on the siphonal area; the ribs separated by wide concave spaces. Siphonal area concave and bi-tuberculate; aperture rotund, two fifths the diameter of the shell.

Dimensions.-Transverse diameter 50 millimètres; width of umbilicus 20 millimètres; height of aperture 18 millimètres; transverse diameter 20 millimètres.

Description.-This beautiful Ammonite is a very rare British fossil, and was very well figured by Sowerby; it appears to be more common in Germany where it has been collected from its true horizon by Professor Quenstedt, who has given good figures of the two varieties of this species found by him. Aeg. Taylori nodosus is the typical form, and is the one I have collected at Lyme Regis, and figured in Pl. XXXI, fig. 5. This variety has four series of blunt, well-marked, prominent tubercles around the whorls; those on the sides appear like a thickened extension of the ribs (fig. 5), which contract above and unite themselves with the prominent nodules (figs. 6 and 7), developed around the lateral region of the siphonal area (fig. 6). When these tubercles were covered with shell they constituted very prominent processes and formed the Am. lamellosus of d'Orbigny (Ter. Jurass., Pl. 84). The specimen figured in Pl. XXXI, fig. 5, is simply a mould and conveys no idea of what this highly ornamented Aınmonite was when it possessed its shell entire.

The second variety, Aeg. Taylori costatus, had in early life very sharp prominent ribs, on which the side tubercles were scarcely developed; those on the margin of the area appear as the termination of the ribs, rising high up on each side of the concave furrow, which the siphoul area forms between the two series of tubercles. This rare variety is very often mistaken for other forms. The ribs are separated by wide concave spaces covered with striæ, which describe the natural curve of the ribs; as they wind over the margin, and pass across the siphonal area, they become more and more developed (figs. 6 and 7 ).

The aperture is rotund, slightly grooved on the outer margin by the turn of the spire, and rather longer longitudinally than transversely, as is well shown in fig. 7.

The lobe-line is complicated; the siphoulal lobe is formed of two branches of equal parts, composed of several lateral digitations with two terminal bific digits. The siphonal saddle is large with several folioles at its termination; the principal lateral lobe as long as the siphonal, is narrow and elongated, with four bifid lateral digitations on each side, and a long terminal digit. The lateral saddle is also wide, terminating in two bifid and one trifid foliole; the lateral lobe is a small representative of the principal. The accessary lobes appear to be well developed, still their details are concealed in the turn of the spire.

Affinities and Differences.-This species resembles the young condition of Aeg. striatum, yet the central furrow along the siphonal area and the row of tubercles on the sides thereof form good diagnostic characters, by which it may be easily distinguished 
from that species. When it attains twenty millimètres in diameter it assumes its own typical distinctive shell characters.

Locality and Stratigraphical Position.-My figured specimen was collected in the zone of Aeg. armatum, near Charmouth; the same form is found at Robin Hood's Bay in beds of the same age; the two varieties mentioned by Quenstedt are likewise found there, and have been catalogued by Simpson as (a) cornutus = costatus, Quenst.; and (b) quadricornutus $=$ nodosus, Quenst. These two forms certainly belong to one species.

The type specimen which Sowerby figured was found by Mr. Taylor, of Norwich, in a water-worn mass of indurated clay approaching ironstone and containing blende in Happisbury Cliff, Norfolk, where it was probably alluvial; it has likewise been found in the Middle Lias of Northamptonshire. A solitary specimen is catalogued by Professor Buckman, F.G.S., from Brickfields, Coltham-field, Hewletts Road, and Leckhampton, near Cheltenham, Gloucestershire. I have never seen a specimen from these beds.

In Germany, Professor Quenstedt collected it in the Middle Lias at Ofterdingen, Reutlingen, Jebenhausen near Goppingen; and Professor Oppel in the same horizon near Boll, Metzingen, and Hechingen, where it was common; in France it was collected by M. Engelhardt at Mublhausen, Bas-Rhin, in a ferruginous matrix.

Aegoceras Densinodum, Quenstedt. Pl. XXXVIII, figs. 5, 6; Pl. XXXIX, figs. 6-10. Pl. L, fig. 11, 12 .

Ammonites armatus Densinodus, Quenstedt. Cephalopoden, tab. iv, fig. 18, p. 82, 1849.

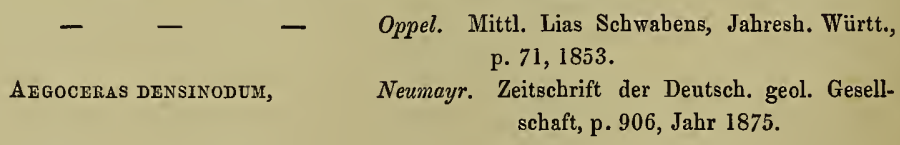

Diagnosis.-Shell much depressed and flattened, whorls very slightly involute; umbilicus wide, with inner whorls all exposed; spire formed of from six to eight volutions outer whorl with twenty-four to thirty slender, oblique ribs directed backwards; each rib supports one small tubercle near its middle, and a large prominent knob at its termination near the margin; siphonal area very narrow and depressed, and ornamented with transverse striæ ; body-chamber long, mouth enlarged with an oblong, trumpet-shaped aperture.

Dimensions-Large specimen.-Plate XXXVIII, figs. 5 and 6 : transverse diameter 110 millimètres; diameter of umbilicus 60 millimètres; height of trumpet-shaped aperture, 40 millimètres; transverse width 27 millimètres.

Small specimen.-Plate XXXIX, figs. 6 and 7 : transverse diameter 73 millimètres; diameter of umbilicus 40 millimètres; height of aperture 20 millimètres; transverse width 17 millimètres. 
Description.-Ammonites armatus, according to Professor Quenstedt, presents two well-marked varieties: A, Armatus sparsinodus, and B, Armatus densinodus. After a careful study of the latter shell, which I have collected in different localities and in considerable numbers, I have erected it into a distinct species, as it exhibits characters which I have found to be specific and permanent.

The shell is discoidal, compressed and slightly involute, with a wide umbilicus, all the whorls being fully exposed in the medium-sized specimen (Pl. XXXIX, figs. 6 and 7). The flat sides are ornamented with twenty-five to thirty oblique ribs, which become visible above the spiral suture. Near the middle of their length they develop a small tubercle (fig. 8); beyond this the rib enlarges, and terminates at the margin of siphonal area in a round, blunt, prominent tubercle. In most of the specimens which lave passed through my hands the ribs are inclined obliquely backwards, on which the double row of tubercles are very well developed (fig. S). In other specimens, however, the marginal tubercles alone are developed, and the position of the inner series on the middle of the rib is indicated by a simple thickening of the lateral fold. The siphonal area is narrow, flat (figs. 7-9), and crossed by numerous transverse striæ; some of these pass from one large tubercle on one side of the area to those of the opposite side; in the intertubercular space three small striæ pass across, so that the area has a highly ornate appearance in well-preserved specimens, as in figs. 8 and 9.

In the large specimen, Pl. XXXVIII, figs. 5 and 6 , and in a smaller individual of the same type, Pl. XXXIX, fig. 6, and Pl. L, figs. 11, 12, the medium row of tubercles is absent, and the ribs have the oblique backward inclined curve so characteristic of this species in the large specimen, which is exceptionally fine ; and the termination of the bodychamber is greatly enlarged and forms a trumpet-mouthed expansion, which is likewise characteristic (Pl. XXXVIII, fig. 5) ; the body-chamber has a quadrate shape, the area is flat, and the whorl ornamented with thirty-eight ribs, the whole structure of the spire being exposed in the widely open umbilicus. The lobe-line is very complicated ( $\mathrm{Pl}$. XXXIX, fig. 10). The siphonal lobe is large and symmetrical, with three digitations on each side and two long terminal branches having serrated sides. The siphonal saddle is wide, and divided into three compartments, the internal and external being deep and terminating in folioles, and the central one narrow from the size of the partition. The principal lateral lobe is long, narrow, and branched; it has an irregular figure, the terminal portion ending in a long point. The lateral saddle is deep, terminating in two folioles like two oak leaves, with a narrow stem between them. The lateral lobe is long, narrow, and oblique, with a freely digitated margin. The auxiliary saddle is small and oblique, and ends in one foliole, and the auxiliary lobe is likewise small and oblique with lateral digitations.

The morphology of this species is very interesting. The facts I have noted were obtained from the study of a large assemblage of the brood of this species, collected from a thin bed in which they were entombed. In the first three volutions the young shell is quite smooth; in the fourth sharp ribs make their appearance with concave spaces 
between; at about the sixth volution of the spire the ribs begin to exhibit tubercles at their termination by the margin of the area, and in the seventh volution the second series of tubercles show themselves. In old age the volutions become less ornamented by first losing the inner row of tubercles, and, secondly, by the outer row becoming smaller and more rudimentary. In all these morphological changes, however, I note several points of difference between the evolution of this species and that of Aeg. armatum.

Afinities and Differences.- This species is undoubtedly closely related to Aeg. armatum, but it has altogether a more slender compressed shell, with a second row of tubercles on the ribs, and is more quadrate in the ensemble; it has likewise a narrower siphonal area, and a much less complicated lobe-line. Compare Pl. XXVIII, fig. 6, with Pl. XXXIX, fig. 10, and Pl. XXVIII, figs. 1, 2, with Pl. L, figs. 11, 12.

Locality and Stratigraphical Position.-I collected this species in the Armatus-bed at the base of the Aeg. Jamesoni-zone in St. Paul's district, Cheltenham, in the Middle Lias, whilst brick-earth was being dug for our town sewers. I have many beautiful examples from near Charmouth, Dorset, embedded in a hard ferruginous clay-ironstone, in fact, all the Armati from the Dorsetshire coast about this horizon are highly charged with ferric oxide. This Ammonite was found in the Jamesoni-beds of the Island of Pabba near Skye, and several specimens were collected for me from the lower beds of the Middie Lias at Ballintoy, Ireland. The specimens obtained from all these widely separated localities closely agree in their specific structure and petrological condition. Those from Ballintoy were embedded in a hard calcareous shale.

Aegoceras Jamesoni, Sowerby. Pl. XI, figs. 4-6; Pl. LI, figs. 1-6.

Ammonites Jamesoni,

- BroNNII,

$\begin{array}{ll}- & \text { JMMESONI, } \\ - & \text { REGNARDI, }\end{array}$

-

- JaMesoni ANGUStus, Quenstedt.

- $\quad-\quad$ uatus,

$-$

- J JMESONI,
Sowerby. Min. Conch., vol. vi, p. 105, pl. 555, fig. l, 1827.

Römer. Nord-deutschen Oolithen-Gebirge, p. 181, 1836.

Quenstedt. Flözgebirge Würtembergs, p. 31, 1843.

d'Orbigny. Paléontologie Française; Terr. Jurass., pl. 72, tom. i, p. 257, 1842.

Quenstedt. Cephalopoden, tab. iv, fig. 8, 1849.

Quenstedt. Ibid., tab. iv, fig. 1, 1849.

Oppel. Mittlere Lias Sehwabens, Jạ.. Württ., p. 76, 1853.

Oppel. Jura-Formation, p. 159, 1856.

Von Hauer. Die Cephalopoden des Lias der Nordostlichen Alpen, pl. xix, figs. $1-3,1856$.

- - ustus, Quenstedt. Der Jura, tab. xv, fig. 15, p. 125, 1858 . 
Ammoxites Jajesoni, Wright. Quart. Journ. Geol. Soc., vol. xiv, p. 27, 195S.

$\begin{array}{ccc}- & \text { Chapuis. Terr. Sécond. Luxembourg, p. 32, tab. vi, fig. l, } \\ 1858 .\end{array}$

Diagnosis. - Shell discoidal, more or less compressed; whorls one third involute, slightly depressed, and convex, ornamented with fifty-six slender, equal, simple ribs, with sigmoidal curve, often developing a tubercle near the margin, and forming an arch across the siphonal area and joining the ribs of the opposite side. Siphonal area narrow, convex, and depressed; aperture oblong; compressed, and elongated.

Dimensions.-Large figured specimen (Pl. LI, fig. 1) 160 millimètres; width of umbilicus 75 millimètres; height of aperture 50 millimètres; width 37 millimètres. Small Pabba fossil (P1. LI, fig. 4)-transverse diameter 76 millimètres; width of umbilicus 37 millimètres.

Seldom found in a satisfactory condition in middle age.

Description.-This Ammonite, very rare in England and Scotland, is much more abundant in Würtemberg, whence my best specimens have been obtained (Pl. XI, fig. 4). Two very distinct varieties have there been described and figured by Professor Quenstedt ; the first named-A, Am. Jamesoni latus, with thick ribs and a broad siphonal area, the normal form of Sowerby; the second-B, Am. Jamesoni angustatus, with more numerous and slender ribs, a narrow, convex, siphonal area, and the aperture compressed and elongated.

A good type shell of Aeg. Jamesoni latum is figured in Pl. LI, figs. 1 and 2, and a good type of Jamesoni angustatum in Pl. LI, fig. 4.

'These figures show that there is a very considerable variation in the form and ribbing of this elegant Ammonite. Sowerby's type was a mere fragment obtained from the Lias of the Island of Mull; two of the specimens I possess were collected from the Middle Lias of the Island of Pabba near the Island of Skye, and one of these is figured in Pl. LI, fig. 4. In the Hebridean fossils we have the true Sowerbyan type; the shell is compressed in early and middle age, the sides are ornamented witl simple equal-sized ribs, gradually increasing in length and thickness with the growtl of the shell; they arise at a short distance from the spiral suture, and describe a slight sigmoidal flexure, the curve being inclined towards the aperture; near the margin the rib becomes thicker and forms an arch across the siphonal area, which in old large shells is thick, wide, and depressed, whilst in middle age it becomes convex, narrow, and prominent. In some specimens the thickened marginal portion of the rib develops a blunt fubercle, and a feeble carina 
extends along the middle of the siphonal area. The large specimen (PI. LI, figs. 1, 2) from Mungar shows a very remarkable development of the ribs on the sides as well as on the siphonal area ; these aged forms may, therefore, represent Jamesoni latum, Quenst. In the middle period the fossils figured in Pl. XI, figs. $4-6$, and in Pl. LI, fig: 3, 4, may be taken as representing Aeg. Jamesoni angustatum, Quenst.; the sides of the whorls are convex aud compressed, and the ribs slender and very numerous; in one specimen there are more than seventy ribs on the last whorl. Sometimes the ribs are fewer in number and stronger, as in the fig. 3 , in which the forty-two ribs are sharp and prominent with wider intermediate valleys, presenting a strong contrast to fig. 4 on the same Pl. LI.

The Middle Lias in Robin Hood's Bay, Yorkshire, yields another variety of Aeg. Jumesoni, which has been described and figured as a new species by Professor Blake nuder the name of Aeg. sagittarium. I have long known this variety, which has roundish whorls nearly ont-third involnte, and large, sharp, sigmoidal ribs, about twenty-four in a whorl, with deep concave valleys between the ribs, which arch forward across the siphonal area. I have figured the young shell of this variety in Pl. LII, figs. 4, 5, and the large adult shell collected by the Rev. Mr. Cross, F.G.S., from the Jamesoni-Lias in Robin Hood's Bay. For further details consult the article on Aegoceras sagittarium.

The lobe-line is very well seen in several of my specimens. The siphonal lobe is shorter and wider than the principal lateral, and ornamented on each side with three ramified branches. The siphonal saddle, much wider than the principal lateral lobe, divides into two nearly equal-sized foliations. The principal lateral lobe is long and much complicated, and divides into three ramified branches. The lateral saddle divides into two unequal parts, of which the internal is the most developed. The lateral lobe is slender and narrow, and consists of a single stem with lateral digitations; and the auxiliary saddle is narrow with a few irregular folioles.

The morphology of Aeg. Jamesoni is extremely interesting. Although only fragments of large whorls have been collected, I have found many very perfect specimens of the brood of this species in the Middle Lias of Leckhampton. A good example is figured, PI. LI, figs. 5,6; in this stage it is Ammonites Bronni, Römer. The shell is ribbed on the sides in the second turn of the spire; and in the fourth turn the sharp ribs acquire small tubercles by the side of the area, fig. 5 ; and as they arch across that space a well marked carina is observed on the mesial line, fig. 6 . With the growth of the shell the tubercles decrease in size, and finally disappear in middle age ; the area, becoming narrow and convex, gradually assumes the form delineated in Pl. LI, figs. 3 and 4, as the typical forms of middle life.

Affities and Differences.-I have long collected the young of this Ammonite in the Middle-Lias brick-yards near Cheltenham; in this state it is Am. Bronni, Römer; another form is Am. Regnardi, d'Orb., and another variety Am. venustulus, Dumortier. It is a very variable fossil, and has been a fertile field for species-mongers. I have specimens from Robin Hood's Bay identical with the Pabba examples; but the large, ribbed, figured specimen, with its undulated sides and waved area, is a very rare variety of this shell; 
the finest examples known have been obtained from the Middle Lias at Heclingen, IVürtemberg; these examples are identical with the Pabba types, one of which is figured on Pl. XI, figs. 4-6, and a second on Pl. LI, fig. 3. I have found only two fragments of a large shell in the Cheltenham beds, and both specimens belonged to the true Pabba type.

Locality and Stratigraphical Position.-Aegoceras Jamesoni is a leading fossil of the zone which it so well characterizes. It is found near Cheltenham, Gloucestershire ; FennyCompton, Warwickshire; Munger, Somerset; Charmouth, Dorset; Robin Hood's Bay, Yorkshire; and in the islands of Mull and Pabba in the Hebrides.

Foreign Distribution.-In France it has been collected at Coutards and Bois-deTrousse, near St. Amand, Cher; Sachi, Ardennes, Evrecy, Calvados; St. Rambert, Ain ; near Lyons, Rhône.

In North-west Germany it has been formd near Rottorf, Roklum, Hedeper, Harzburg, Liebenburg, Bodenstein, Kahlefeld, Willershausen, Oldershansen, Markoldendorf, Falkenbagen, and other localities. In South Germany it is found in Swabia in many localities, as at Pliensbach, near Boll, Soldelfingen, Hechingen, Balingen, \&c. ; in all the localities it occupies the same horizon, namely, at the base of the Middle Lias.

Aegoceras sagittarium, Blake. Pl. LII, figs. 1-5; Pl. LIIa, figs. 1-6.

Ammontes J Juesont, Simpson. Foss. York. Lias, p. 48, 1855.

Aegoceras sagittarium, Tate and Blake. Yorkshire Lias, p. 276, pl. vii, fig. 2, 1876.

Diagnosis.-_hell discoidal, compressed; volutions five, uniformly rounded, and onefourth involute; outer whorl one third the diameter in height with twenty-two to twentysix slightly bent ribs moderately elevated, rounded, and disappearing near the margin of the siphonal area, which is in general smooth and convex, but sometimes has an elevated ridge which occupies the mesial line, and passes longitudinally ronnd the shell; aperture oblong, narrower in the outer half.

Dimensions-Small specimens.-Pl. LII, fig. 4. Transverse diameter 56 millimètres; width of umbilicus 25 millimètres; height of last whorl 19 millimètres; height of aperture $1 \mathrm{~S}$ millimètres; width 17 millimètres.

Large specimen.-Pl. LII, figs. 1, 2. Transverse diameter 240 millimètres; width of umbilicus 95 millimètres; height of last whorl 90 millimètres; width 50 millimètres.

Description.-This shell has been long known to me as a Yorkshire variety of Aegoceras Jamesoni, which I had separated from my Pabba types under a distinct diagnosis; now that Professor Blake has figured this form in his Yorkshire Lias under a specific name, priority of publication entitles him to precedence. I $\mathrm{nm}$ indebted to the 
Rev. J. E. Cross, F.G.S., for the loan of some large specimens of this Ammonite, one of these I have figured in $\mathrm{Pl}$. LII, two-thirds the natural size, and I have another of much larger dimensions in my custody ; it therefore attained a gigantic size, varying very little from the type figured.

The volutions are uniformly rounded, and about one-third or one-fourth of the width of a whorl is involute; the outer whorl in height is one-third the diameter of the shell, its sides are convex, and ornamented with twenty-five narrow, slightly bent ribs, which disappear in some shells near the margin of the area (Pl. LII, figs. 1-2), and in others extend across the space (Pl. $\mathrm{LII}_{A}$, fig. 2). In such shells an elevated ridge is developed on the mesial line and runs longitudinally round the whorl, connecting the ribs with one another, as shown in Pl. LII, fig. 5, and Pl. LII A, figs. 2, 4, and 6; and the ribs are separated by concave spaces three times the width of the ribs.

In most of the young shells which have passed through my hands, measuring from 50 to 60 millimètres in diameter, the ribs terminate in a thickened portion at the margin of the area, whilst the intervening space is smooth, as in Pl. LII, fig. 4 and fig. 5; in other specimens a central rudimentary carina distinctly shows itself, as in $\mathrm{Pl}$. LIIA, fig. 2, and figs. 4 and 6 . This is a true Aeg. Jamesoni character of early life. See Pl. LI, figs. 5 and 6 , in which specimen it is very well seen. The shell is partially preserved in some of my smaller examples, which enables me to state that it is extremely thin.

The umbilicus is very open, and exposes all the inner whorls (Pl. LII, figs 1, 2, 4; Pl. LII A, figs. 3, 5).

The aperture is oblong (PI LII, fig. 2), it is widest at the inner side near the return of the spire, and tapers away at the outer side towards the siphonal area.

The lobe-line resembles the type of that of Aeg. Jamesoni (Pl. LII, fig. 3). The siphonal lobe is shorter and wider than the principal lateral. The siphonal saddle forms a regular arch, festooned with simple folioles on the sides, and at the termination. The principal lateral lobe is long and narrow; it has four lateral digits on each side, and one long terminal bifid process. The lateral saddle, much wider than siphonal, is festooned all round with bilobed leaves, the one side being almost the copy of the opposite. 'The lateral lobe is smaller than the principal, which it very much resembles in shape and digitations. The auxiliary saddle is nearly as large as the siphonal, which it much resembles in the style of its folioles; the accessory lobes are small oblique processes.

I consider the specimen figured in Pl. LII, figs. 1 and 2, as the best type of this form, as it differs very little from the specimens met with as Am. Jamesoni in most collections of Yorkshire Lias Ammonites. My old friend Mr. Leckenby, F.G.S., often pointed out from a type specimen he had, the points wherein he considered the Yorkshire shell to be diff'erent from the true Am. Jamesoni, Sow., of the Mineral Conchology.

'the specincn figured in Pl. III A, figs. 1 and 2, was collected in Robin Hood's Bay, from the samc rock whence the large specimen was obtained; in this example the 
whorls are not so high, the ribs are narrower, sharper, and more bent, and the intercostal valleys are much wider and more concave, the siphonal area is likewise much changed by the presence of a central carina which passes longitudinally between the ribs and connects them with each other. The inner whorls are absent; this body-chamber forms a striking contrast to the figure given in Pl. LII, figs. 1 and 2 ; the small specimens figured in both plates very much resemble each other in the thickness and roundness of the whorls and the sharpness of the ribs as shown in the mould.

Locality and Stratigraplical Position.-Professor Blake says that this Ammonite comes from a different horizon to that in which Aeg. Jamesoni lies, and assigns the base of the zone of Amaltheus oxynotus in Robin Hood's Bay as its true geological position. It was likewise from the same locality and horizon that the Rev. J. E. Cross obtained the large specimens he has so kindly communicated for this work.

Aegoceras ValdDani, d'Orbigny. Pl. XXXVIlI, figs. 1, 2, 3, 4; Pl. LXIX, figs. 2, 3 and 4.

Amonites bipuxctatus, Römer. Versteiner. des Nord-Deutsch. Oolithen-Gebirges, p. $193,1836$.

- Brкснr, Quenstedt. Flözgebirge Würtembergs, p. 173, 1843.

- Valdani, d'Orbigny. Paléontol. Française; Terr. Jurassique, tome i, p. $255, \mathrm{pl} .7 \mathrm{I}, 1844$.

- $\quad-\quad$ Quenstedt. Cephalopoden, p. 90, tab. v, fig. 3, 1849.

- $\quad$ - $\quad$ Giebel. Fauna der Vorwelt, vol. iii, p. 683, 1852.

- - Chapuis et Dewalque. Terr. Sécond. Luxembourg, Mem. Conr. Acad. Belgique, t. xxv, p. 47, pl. vi, fig. 3, 185 3.

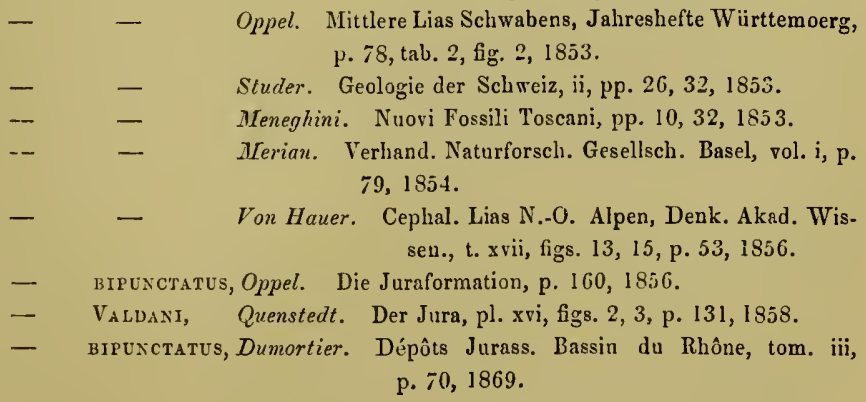

Diagnosis.-Shell discoidal, compressed, carinated; whorls flattened on the sides, with simple, straight ribs, which terminate in two rows of tubercles, one row situated at the 
margin of the siphonal area, the other at some distance from the spiral suture; siphonal area narrow, convex, carinated; aperture narrow, elongated, and flattened laterally.

Dimensions.-Transverse diameter 84 millimètres; width of the umbilicus 45 millinètres; height of aperture 20 millimètres ; transverse width 15 millimètres.

Description.-This Ammonite is supposed to be the bipunctatus of Schlotheim-be. that as it may, it certainly is the bipunctatus of Römer, who has very accurately described it in his 'Versteinerungen, \&c.' The shell is discoidal, compressed, and flattened on the sides of the whorls, which support two rows of small blunt tubercles, the one row bound the margin of the siplional area, the second row is developed at some distance from the spiral suture; and between the two tubercles a short, straight rib extends. The whorls are for nearly one-third their height involute, and the turn of the spire just covers and encloses the outer row of tubercles, whilst the inner row is visible on the whorls up to the earliest turns of the spire. The shell slopes very obliquely, at an angle of $30^{\circ}$ from the inner row of tubercles to the foregoing whorl, so that the umbilicus has a stair-like aspect from the flat step or side of the whorl, and the inclined riser which leads to it. I know of no other Ammonite that has this feature so well shown, and which has been very well represented in fig. 1 . The siphonal area is narrow and angular in consequence of the development of the carina. From the outer tubercles a continuation of the ribs extends obliquely forward towards the aperture, with other intermediate striæ having a like direction; so that good specimens with the shell preserved have the area ornate with fine oblique lines stretching forward from the marginal tubercles towards the central carina. The aperture is quadrate and elongated (PI. XXXVIII, fig. 2), one third less in the transverse than the vertical diameter.

The lobe-line is extremely convoluted (fig. 4). The siphonal lobe is wider and shorter than the principal lateral, and ornamented on each side with three branches, of which the lowest is large and pyramidal. The siphonal saddle is wider than the principal lateral lobe, and formed of two very wide, much ramified, unequal parts, the largest being the innermost. The principal lateral lobe is formed on each side of three short single branches inferiorly, and the two lateral formed of two branches. The lateral saddle is narrower and deeper than the siphonal, and festooned into folioles which are unequally divided by a projecting process, the innernost being the larger of the two groups. The lateral lobe has three unequal branches, the terminal being sharply pointed. The auxiliary saddle is oblique, and formed of two unequal parts, the external being the larger.

I have found the Aptychus of this species in the body-chamber of a moderate-sized fragment (fig. 3); it has a central ridge, from which oblique lines contour the Aptychus, which was a thin structure with fine striations ruming in an opposite direction to the contouring lines of the lobe.

This Ammonite attains a considerable magnitude. I have collected many fragments, which indicated a shell at least 200 millimètres in diameter. The very small amount of 
the involution of this species accounts for the fragmentary condition in which it is found, seeing that the volutions have a very feeble support from the turns of the spine.

Affinities and Differences.--This species very much resembles Aeg. Maugenesti, found with it in the same bed. It is distinguished from that species by its more compressed shell and its carina, by its ribs limited to the middle of the whorl, and by the two tubercles between which the ribs are limited. These two Ammonites are certainly very nearly allied, although they are distinct.

Locality and Stratigraplical Position.-I have collected this species from the Middle Lias of Leckhampton, near Cheltenham, associated with Aeg. Mangenesti, Aeg. Ibex, and Aeg. Loscombi; and it is found in the same lorizon in Somersetshire.

Foreign Distribution.-In the Middle Lias of France at Saint Amand, Cher; at Atys and at Maltol, near Caen, Calvados; Venarey, near Semur, Côte-d'Or; near Avallon, Yonne; Saint Fortunat, La Pointe d'Orchex, Rhône; Somme-Thonne, Luxembourg.

Germany, Middle Lias, Kahlefeld; in Swabia it is associated with Aeg. Ibex and Aeg. Maugenesti, as near Cheltenham. A beautifnl specimen (Pl. LXIX, figs. 2, 3, 4) from the Middle Lias of Würtemberg is here figured.

Aegoceras Maugenesti, d'Orbigny. Pl. XXXVII, figs. 1, 2.

Ammonites Mavaexesti, d' Orbigny. Pal. Franç.; Terr. Jurrass., t. i, p. 254, pl. 70, 1842.

- Mravgesestir, Quenstedt. Cephalopod., p. 99, tab. v, fig. 1, 1849.

- Mavgexestr, Oppel. Mittl. Lias Schwabens, p. 77, tab. 2, fig. 3, 1853.

- - Oppel. Jura-Formation, p. 160, 1856.

- $\quad$ - Von IIauer. Cephalopod. Lias N.-O. Alpen, Denk. Akad. Wissen., p. 53, tab. xvi, figs. 7-9, 1856.

- Mavgenestir, Quenstedt. Der Jura, p. 132, tab. xvi, fig. 5̄, 1858.

- Maugexestr, Dumortier. Dépôts Jurass. du Rhône, vol. iii, p. 69, 1869.

- $\quad$ - Seebach. Hannov. Jura, p. 82, 1864.

- - Emerson. Lias von Markoldendorf, Zeit. Deut. geol., p. $311,1870$.

Diagnosis.-Shell discoidal, depressed, sub-carinate; whorls slightly involute, compressed, and flattened on the sides, which are ormamented with from twenty to twentyfour distant equal-sized ribs, straight, erect, and terminating in a row of tubercles at the outer margin of the siphonal area, which is wide, obtuse, and angulated.

Dimensions.-Transverse diameter $5 \mathrm{~s}$ millimètres; width of umbilicus 28 millimètres; height of the aperture 20 millimètres; width of ditto 15 millimètres.

Description.-The shell of the species very much resembles that of Aeg. Valdani; 
the whorls between are broader and not so high ; like it, however, it is clepressed, discoidal, and slightly carinated, without a distinct keel; the sides of the whorls are flattened, and transversely ornamented with from twenty to twenty-four ribs, according to the age of the shell. They commence at a short distance from the spiral suture, and ascend radially straight to the margin of the siphonal area, where they terminate in small prominent tubercles (fig. 1). The area is ridged in the middle, and declines on each side at a low angle. The row of tubercles from the termination of the ribs bounds this region, which is a clear, angulated, and well-defined area (fig. 2). The spire is composed of compressed whorls, flattened on the sides and angular externally, with a sloping riser internally. The aperture is quadrate, compressed on the sides, and arched in the line of the area; the height is greater than the breadth, and it is wider near the spiral suture than toward the onter margin.

The lobe-line is extremely complicated. The siphonal lobe is about the same size as the principal lateral, and ormamented on each side with simple digitations, and two branches, of which the last is the most highly ramified. The siphonal saddle, much wider than the principal lateral lobe, is formed of two unequal branches; the internal is the larger, and is formed of three foliations. The principal lateral lobe divides into five branches, which are bifurcate or trifurcate, and unequally disposed. The lateral saddle is smaller than the siphonal, and divided into two unequal foliations; the internal is the larger and formed of three foliations. The lateral lobe is oblique, and furnished with four unequal branches. The auxiliary saddle is small, and formed of three leaves, and there are two or three small additional oblique auxiliary lobes.

Affinities and Differences.-'I'his species very much resembles Aeg. Valdani; it is, however, a thicker shell, and the whorls are wider and not so high as in that species. It has only one row of tubercles on the sides, and the ribs are straighter, more erect, and prominent, and arise much nearer the spiral suture than in Aeg. Valdani. The lobeline differs, likewise, in its style of ramification; the aperture is wider, more angular, and narrower near the spiral suture than at the onter margin, the opposite to the form and dimensions that prevail in Aeg. Valdani. It much resembles some of the young shells of Arietites Sauzeanus from the Arict. Bucklandi-beds of the Lower Lias; the absence of a keel and the ribbing on the siphonal area clearly distinguish the two shells from each other. It resembles Aeg. brevispina in some respects; still the absence of a carina in that species affords a diagnostic character between them.

Locality and Stratigraplical Position.-I have collected this Ammonite from the zone of Aegoceras Ibex in the brick-pits of the Middle Lias at Leckhamptom, near Cheltenham, associated with Aeg. Valdani, Aeg. Loscombi, and Aeg. Ibex. It has been found in the same horizon at Munger, near Radstock, by Mr. Tawney, F.G.S.; in the Aeg. Jamesoniand Ibex-beds at Fenny Compton by Mr. Beesley, F.G.S.; in beds of the same age near Ilminster, Somersetshire, by Mr. Chas. Moore, F.G.S.; and between Lyme Regis and Charmouth, Dorset, associated with Aeg. Loscombi, by several collectors. 
In France it is found at Coutards, near St. Amand, Cher; at Evrecy and at Curcy, Calvados; and near Semur, Côte d'Or. In the Middle Lias at Ofterdingen, Germany.

Aegoceras brevispina, Sowerly. Pl. XXXII, figs. 2, 3, 4; Pl. L, figs. 13, 14.

\begin{tabular}{|c|c|c|}
\hline \multicolumn{2}{|c|}{ AMMONITES BREVISPINA, } & $\begin{array}{l}\text { Sowerby. Min. Conchology, vol. vi, p. 106, tab. 556, } \\
\text { fig. } 1,1827 \text {. }\end{array}$ \\
\hline - & NATRIX, & $\begin{array}{l}\text { Zieten. Versteinerung Württembergs, p. } 5 \text {, tab. iv, } \\
\text { fig. } 4,1830 \text {. }\end{array}$ \\
\hline - & ROTUNDUS, & Quenstedt. Cephalopoden, p. 85, t. iv, fig. $17,1849$. \\
\hline 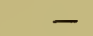 & LATÆCOSTA, & Quenstedt. Ibid., t. iv, fig. $15,1849$. \\
\hline- & BREVISPINA, & $\begin{array}{l}\text { d'Orbigny. Pal. Franç. Terr.; Jurass., t. i, p. } 272, \\
\text { pl. } 79,1842 .\end{array}$ \\
\hline - & - & Simpson. Fossils, Yorkshire Lias, p. 69, $185 \overline{5}$ \\
\hline- & - & $\begin{array}{l}\text { Wright. Quart. Journ. Geol. Soc., vol. xiv, p. 28, } \\
1858 .\end{array}$ \\
\hline - & - & $\begin{array}{l}\text { Schlönbach. Eisenstein d. Mittl. Lias; Zeitschr. } \\
\text { Deutsch. geolog. Gesellsch., p. } 517 \text {, } \\
\text { Jalır } 1863 .\end{array}$ \\
\hline - & - & $\begin{array}{l}\text { Dumortier. Dépôts Jurass. du Bassin du Rlône, } \\
\text { vol. iii, p. } 97,1869 .\end{array}$ \\
\hline
\end{tabular}

Aegoceras brevispincm, Tate and Blake. Yorkshire Lias, p. 280, 1876.

Diagnosis.-Shell discoidal, depressed; whorls slightly involnte, flattened on the sides, and ornamented with blnnt, narrow, oblique ribs, on which two small tubercles are developed, one near the spiral suture, and one near the margin of the area, with wide, concave spaces between the ribs; siphonal area narrow, convex, aud crossed by a transverse extension of the ribs between the marginal tubercles; lobe-line extremely complicated; aperture oblong, with vertical sides and convex outer surface.

Dimensions.-Transverse diameter 93 millimètres; width of the umbilicus 50 millimètres.

Description.-This is a very rare Ammonite in the English Lias, and the typographical error in the lettering of Sowerby's plate has created much confusion anent the identification of the shell he called $A$. Urevispina, for the text and the numbering of Pl. 556 do not agree. Fig. 1 in Sowerby's plate 556 represents Am. Jrevispina, Sow., and fig. 2 in same plate, Am. latcecosta, Sow. The numerals have been reversed in error.

I have had Sowerby's original type specimens redrawn in PI. XXXII of this work in order that the doubt and confusion may be removed. On comparing the type fragments of Aeg. Orevispina with Am. natrix, Zieten, from the Middle Lias of Balingen, Swabia, I find them to be identical; the spines on the ribs nearest the spiral suture are nearly obsolete, and those at the margin are short and well-developed processes, characterised by the 
specific name brevispina. The type specimen was collected by the late Sir Roderick Murchison from the Middle-Lias Shales at Pabba; and I have had another specimen sent me by Professor Geikie, F.R.S., for determination, collected by him from the Middle Lias Pabba.

The specimen figured in Plate L, figs. 13 and 14, was collected by the Rev. J. E. Cross, F.G.S., from the Aeg. Jamesoni-beds of Robin Hood's Bay. In this specimen the sides of the whorls are much flattened, and each small, oblique, forward-directed rib carries two small tubercles; the spire is so slightly involute that both tubercles are visible on the sides in all the six turns of the spire. The siphonal area of this specimen, shown in fig. 14, exhibits a convex surface crossed at intervals by the ribs which stretch transversely from one tubercle to the other. The intermediate concave valleys are smooth and without ornament. The lobe-line is very complicated (Pl. XXXII, fig. 4). The siphonal lobe is shorter and wider than the principal lateral, and ornamented on each side with four branches, each many-digitate. The siphonal saddle is as large as the principal lateral lobe and divided into two equal foliations by a projecting process. The principal lateral lobe has a very irregular figure provided with three large ramified terminal branches and several small upper ones. The lateral saddle smaller than the siphonal is divided into two unequal foliations, of which the internal is the larger. The lateral lobe and the auxiliary lobes are small and very oblique, the whole forming a highly complicated structure.

Affinities and Differences.-This species resembles Aegoceras Valdani and Aeg. Birchii in having two rows of spines upon the lateral ribs of its shell. It differs, however, from Aeg. Valdani in possessing a round siphonal area, crossed by folds and depressions, and a more simple lobe-line; and from Aeg. Birchii in having flatter ribs, smaller tubercles, a narrower siphonal area and wider folds thereon, and in possessing a much less complicated style of lobe-line.

Locality and Stratigraplical Position.-It occurs in the Middle Lias of Pabba in the Jamesoni-zone, likewise in the same horizon at Robin Hood's Bay, Huntcliff, and Normanby, Yorkshire. The specimens figured Pl. L, figs. 13, 14, came from Robin Hood's Bay.

Foreign Distribution.-In France it is found at Saint-Christophe, Saône-et-Loire; Saint-Amand, Cher. In North Germany it is the associate of Aegoceras Jamesoni in all the localities that I have noted for that Ammonite. In South Germany it occurs at Gammelshausen, Hechingen, and Balingen. 


\section{Fourth Section.-InvouU'I.}

Aegoceras pettos, Quenstedt. Pl. XXXVII, figs. 5-7, Pl. LXIX, figs. 5-6.

\begin{tabular}{|c|c|c|}
\hline MMONITES & CRENATUS, & $\begin{array}{c}\text { Zieten. Versteinerung. Württembergs, p. } \\
1830 .\end{array}$ \\
\hline - & PETTOS, & Quenstedt. Flözgebirge Würtembergs, p. 178, 1843. \\
\hline - & Grenotillouxi, & $\begin{array}{l}\text { Française; Terr. Jurassique, tome i, } \\
\text { pl. } 96,1842 \text {. }\end{array}$ \\
\hline - & PETTOS, & Quenstedt. Die Cephalopod., p. 179, tab. 14, fig. 8, 1849. \\
\hline- & - & Oppel. Mittlere Lias Sclıwab., Jahr. Wurtt., p. 93, 1853. \\
\hline - & - & Oppel. Die Juraformation, p. 165,1856 \\
\hline - & - & $\begin{array}{l}\text { Schlünbach. Eisenstein d. Mittl. Lias, Zeitsch. Deutscb. } \\
\text { geol. Gesell., p. 527, } 1863 .\end{array}$ \\
\hline - & -- & $\begin{array}{c}\text { Beesley. Lias of Fenny Compton, Proceedings Warwick. } \\
\text { Nat. Field Club, p. } 16,1877 .\end{array}$ \\
\hline EGOCERA & - & $\begin{array}{l}\text { Neumayr. Zeitschrift der Deutsch. geol. Gesellsch., } \\
\text { p. } 906,1875 .\end{array}$ \\
\hline & & Tate and Blake. Yorkshire Lias, p. 280, 1876. \\
\hline
\end{tabular}

Diagnosis.-Shell discoidal, depressed; umbilicus narrow, deep; whorls half involute, sides ornamented with twenty-five short, oblique, mucronated ribs; from each tubercle three transverse striæ proceed across the siphonal area, which is wide, depressed, slightly convex, and without a carina; aperture depressed, narrow in the vertical, wider in the transverse diameter.

Dimensions.-Transverse diameter 33 millimètres; width of umbilicus 15 millimètres ; height of aperture 8 millimètres ; transverse diameter 15 millimètres; amount of involution one half the height of the whorl.

Description.- This is a very rare fossil in the Middle Lias of England, although a very common Ammonite in the Numismalismergel of Germany, and of the Lias moyen of France. The shell is discoidal, compressed, and with a very deep umbilicus; from the spiral suture a series of short, oblique, regular ribs proceed, which end about the middle of the whorl in a rounded tubercle on the mould, and a thorny spine when the test is preserved, from each tubercle a fasciculus of two or three striæ passes across the area and join those from the opposite side; the siphonal area is convex and depressed, and well defined by the oblique tubercles developed on the unargin, from whence the fasciculi of transverse striæ proceed to unite with their fellows from the opposite side along the middle line of the area. The whorl is widest along the row of the mucronated ribs, whence it slopes sharply inwards towards the spiral suture, for this reason, the umbilicus is deeply concave; the line of the spiral suture lies outside the tubercles, and the umbilicus thus acquires an ornate appearance. The aperture is transverse, depressed, arched, and angular on the sides; the septa are symmetrical, and the lobe- 
line describes three lobes and three saddles. The siphonal lobe is wider, and as long as the principal lateral ; it is ornamented on each side witl four branches, of which the two superior form single points; the third has two, and the fourth four. The siphonal saddle is a little wider than the principal lateral lobe, its space is divided laterally into wide leaves, and terminates in one bi-lobed and two tri-lobed folioles. The principal lateral lobe is outwardly formed of three digitations, and internally of six unequal processes, and terminates in one long digit. The lateral saddle, one third wider than the principal lateral lobe, divides into two nearly equal-sized leaves, each formed of three folioles. The small lower lateral lobe has an irregular figure, one long lateral digit is directed inwards, and there are two small laterals on each side and a long terminal process. The auxiliary saddle, half the size of the lateral, is divided into two portions; the small auxiliary lobe is oblique, and formed of a single digitation.

Afinities and Differences.-This shell very much resembles Steplanoceras Blagdeni, Sow., figs. 157, 158, p. 251, from the Inferior Oolite. In the breadth of the whorls it is a very variable species; the marginal tubercles are also always more or less approximated, and the transverse striæ across the siphonal area are not by any means constant as regards number and elevation. It cannot be mistaken for any other shell in the Middle Lias, as its specific characters are so prominent and well developed.

Locality and Stratigraphical Position.-It has been collected from the Jamesoni beds at Fenny Compton, Warwickshire; Munger and Paulton, Somerset; and Robin Hood's Bay, Yorkshire.

In France it is rare at Coutards près St. Amand-Montrond, Cher; Avallon, Yonne.

In Germany it is found in the Jamesoni-bed at Ofterdingen and Gammelshausen.

I have several specimens from the Numismalismergel at Riederich near Metzingen and One of these is figured Pl. LXIX, figs. 5, 6.

Aegoceras gagateum, Young and Bird. Pl. XXXVII, fig. 8, 9.

AMMONITRS gagateUs,

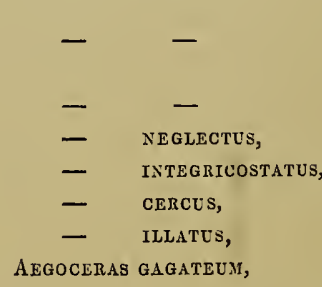

Young and Bird. Yorkshire Coast, 2nd ed., p. 255, pl. xii, fig. 7, 1828.

Simpson. Monograph on the Ammonites of the Yorkshire lias, p. 13, 1843.

Fossils of the Yorkshire Lias, p. 45, 1855.

- Fossils of the Yor $\quad$ Ibid., p. 45,1855 .

Ibid., p. 46,1855 .

Ibid., p. 47,1855 .

Ibid., p. 39,1855 .

Tate and Blake. Yorkshire Lias, p. 275, 1876.

Diagnosis.-Shell discoidal, depressed ; umbilicus wide, whorls round, inner margin 
rather prominent ; ribs sharp, annular, elevated, inclined backwards, separated by wide deep, concave spaces; siphonal area convex, each rib as it passes across the area has a slight elevation at the middle with an elevated line on the concave surface; aperture roundish, depressed, widest in the transverse diameter.

Dimensions. - Transverse diameter 37 millimètres; width of the umbilicus 20 millimètres; height of the aperture 10 millimètres; transverse diameter 11 millimètres.

Description.-This rare and beantiful little shell has sharp, elevated, and very prominent ribs, as each of these passes over the siphonal area it is slightly thickened and raised in the centre; the ribs are separated by concave spaces, the whorls being narrower on the sides than on the area; they diminish very gradually and regularly, "the smaller whorls showing their prominent ribs like rows of jet beads ;" hence Young called it gagateus; the ribs on the sides first incline backwards and afterwards arch forward before they cross the siphonal area.

This Ammonite resembles Aegoceras planicosta and Aeg. capricornus, but is very distinct from both, and has a life in time intermediate between these two well-known forms. The ribs are very prominent and the inner edge of the whorls much elevated, sometimes overhanging the line of the spiral suture; the whorls being only slightly involute; the spire is occasionally one-sided and a little distorted, when it very much resembles Turrilites Coynarti, d'Orbigny.

Afinities and Differences.-This species occupies an intermediate position in structure between Aegoceras planicosta and capricornus. It wants the flattening of the ribs seen in Aeg. planicosta, where they cross the siphonal area, and the spines which are developed on their sides. The sharpness, narrowness, and elevation of the ribs distinguish it from Aeg. capriconnus, which it otherwise very much resembles.

Locality and Stratigraplical Position.-Young's type specimens were collected from the hard bands in the Alum-shale of the Hawsker shore. Tate and Blake state that they obtained it from the zone of Ammonites oxynotus, of which it is highly characteristic, at Robin Hood's Bay, Warter, and Market-Weighton. It appears to be absent from the Lower Lias beds of the Midland Counties.

Aegoceras latæzos'ta, Sowerby. Pl. XXXII, fig. 1.

Ammonites latecosta, Sowerby. Min. Conch., vol. vi, p. 106, pl. 556, fig. 2, 1827.1 - Brevrspina, d'Orbigny. Pal. Franç. Terr.; Jurass., vol. i, p. 272, 1842.

Diagnosis.-Shell discoidal, compressed, radiated; whorls five, exposed ; radii large, sharp, slightly waved, much flattened and widened as they pass over the rounded front; aperture oblong.

1 In Sowerby's description of his plate 556 for fig. 1 read fig. 2. 
Description.-The above diagnosis and the following description are in Sowerby's own words :- "The flattened sides of this Ammonite distinguish it from the young state of A. planicosta independently of its much larger size. When young neither has any appearance of spines; when old the last whorl of the latacosta has only slight indications of tubercles, which consist of two small knots upon each ray on each side. 'The planicosta has one large spine in place of two, and that only upon some of the rays. A Lias fossil. All the specimens $I$ have seen except one are from the alluvium; that one is from Lyme; it is about three inches and a half in diameter, and was liberally presented by Mrs. Murchison. One specimen, nearly four inches in diameter, shows the little knots upon the rays ; it is in the collection of W. Peete, Esq., of Dartford. Several small ones have been found by Miss Baker, of Braunston, in what is called a gravel-pit."

Having examined the original Sowerbyan type of latcesta, and compared it with other Ammonites from the same Green Ammonite-bed, I am prepared to state that latcocosta, Sow., is the middle-age condition of Aegoceras Henleyi, which I shall describe in the following article. As this statement may excite doubts in the minds of some persons, I have taken the precaution to have Sowerby's type shell, now in the British Museum, drawn, Pl. XXXII, fig. 1; and I have quoted in extenso Sowerby's own words, viz. those he had written on the subject; for nothing is so difficult to eradicate as our early notions, whether true or false, of the specific forms of organic bodies.

Aegoceras Henleyi, Sowerby. Pl. XXXIII, figs. 1, 2, and 3.

Ammonites Henleyi, Sowerby. Mineral Conchology, vol. ii, p. 161, tab. 172, 1817.

- Henley, Reynès. Géol. et Paléontol. Aveyronnaises, p. 88, pl. i, fig. 2, 1868.

Aegoceras - Tate and Blake (pars). Yorkshire Lias, p. 281, 1876.

Diagnosis.-Shell with external whorl inflated, internal whorls discoidal and compressed; composed of six volutions, all exposed; inner whorls with simple, obtuse, annular ribs, separated by concave valleys, the ribs flattened as they pass over the siphonal area; part of the outer whorl much expanded, and ornamented with numerous fine, narrow ribs on the sides, which split up beyond the outer tubercles into two or three branches, before they pass across the area; all the ribs have two tubercles more or less developed, and very prominent on those of the last whorl; aperture large, oblong, without processes.

Dimensions.-Transverse diameter 135 millimètres; width of the umbilicus 55 millimètres; height of the aperture 55 millimètres; transverse diameter 50 millimètres.

Description.-Much confusion has long existed regarding the natural history of this Ammonite, so much so that nearly all the authors have mistaken Aegoceras striatum 
Reinecke, for Aeg. Henleyi, Sowerby, although the two fossils are sufficiently distinct from each other, Aeg. striatum having large, highly involute whorls, a narrow umbilicus, with a constant uniform growth and ornamentation, whilst Aeg. Henleyi has a slightly involute shell with a wide umbilicus, and changes its outward whorl in a remarkably sudden manner at about its sixth volution. In this stage of its growth it much resembles Aeg. striatum; and, as the inner whorls are seldom preserved with the outer whorl in consequence of the evolute character of the shell, the two species have been usually grouped together and known in most works as Aeg. Henleyi, whilst Reinecke's capital species has been entirely lost sight of.

In early age this Ammonite has a compressed discoidal shell, with slightly involute whorls, flattened on the margin, and ornamented with simple, obtuse ribs on the sides, each having two small tubercles; the inner row very small, the outer row larger, and both can be detected with the finger when they are seen with difficulty. From the outer tubercles the rib forms a prominent arch over the siphonal area with deep valleys between. In this condition it is figured and described as Aeg. latacosta. In the adult state the shell is entirely transformed by the sudden enlargement of the body-chamber (fig. 2), the ribs of which become much smaller and more numerous, and the two rows of tubercles are enlarged and form conspicuous objects in the ornamentation of the shell; those of the inner row remain small, and those of the outer row grow more elongate; and from each the rib splits into two or more branches before it crosses the wide siphonal area, which region is thus highly sculptured by the numerous fine lines that traverse it from side to side (fig. 3). A change of form in the morphology of the shell is observed in most Ammonites at different periods of their lives, as we have seen in Aeg. planicosta, Aeg. biferum, and others; but in none is the transformation scene so rapid and complete as in Aeg. Henleyi, and in a nearly allied form, Aeg. heterogenum. When examining my specimens many naturalists have remarked that they looked as if two different Ammonites had been joined together by mistake.

When Sowerby figured the specimen collected by Mr. Henley, it was only the bodychamber that was known, which forms the arc of a much larger circle than a corresponding fragment of Aeg. striatum; this important fact in relation to a specific character was overlooked, and its general likeness led to the belief in their identity; nor was it until the figured specimen was discovered that the difference became evident which exists between striatum and Henleyi.

The lobe-line is very imperfectly shown; the siphonal lobe is as long as the principal lateral, and divides into several small side digitations (fig. 1). The siphonal saddle is not shown. The principal lateral lobe has several small side and two long terminal branches. The lateral saddle is small, and so likewise are the lateral lobe and the auxiliaries.

The aperture is very large, in consequence of the rapid expansion of the bodychamber (fig. 2); it is arched above and flattened at the sides, and is apparently destitute of any lateral appendages. 
Affinities and Differences.-In the young shell, Aeg. latacosta resembles Aeg. capricornus, although the style of ribbing in the two shells is different; Aeg.capricornus has rounder whorls with simple obtuse ribs without spines. Compare Pl. XXXII, fig. 1, with Pl. XXXIV, fig. 1. ${ }^{1}$ In both species it is the sixth whorl which becomes suddenly enlarged, Aeg. latacosta becoming Aeg. Henleyi, and Aeg. capricornus evolving Aeg. leterogenum. No description can do justice to the remarkable morphological change effected in the sixth whorl of their shells, and so I have given good figures of the best examples I know, for it is very difficult to obtain a specimen of Aeg. lieterogenum now on the Yorkshire coast, and it is equally rare to find one of Henleyi at Charmouth; in fact, the example I have figured in Plate XXXIII is the only one I know that shows the inner and outer whorls in sitû, as it lived in the Middle-Lias Sea.

Locality and Stratigraplical Position.-I have obtained all my specimens of Aeg. Henleyi from the Green Ammonite-bed, near Charmouth, where it is associated with Aeg. Davai, Aeg. Bechei, Lytoceras fimbriatum, and Plylloceras Loscombi; for details of the petrology of this remarkable bed the reader is referred to p. 89. A portion of the shell is preserved on one of the whorls, where it is seen to be very thin, and many of the fine striæ which cross the area are only feebly impressed on the mould. In one large specimen with six whorls the latacosta condition continues up to a diameter of 130 millimètres, whilst in a dwarfed shell with six whorls it continues to 70 millimètres, from which I infer that it is not the size of the shell, but the number of the whorls which indicates the age of the Ammonite, and determines the excessive development of the bodychamber of this remarkable Ammonite. Aeg. Henleyi appears to be a rare species in France. The late Dr. Reynès, who made the study of Lias Ammonites a speciality, knew only two specimens in the Aveyron, both of which had been collected from limestones of the Middle Lias at St. Jean-d'Alcapies in company with Lytoceras fimbriatum, Sow., Aeg. Beclei, Sow., and Gryplica cymbium, the same associates with which it lies in the Green Ammonite-bed of the Dorsetshire coast.

Aegoceras Capricornus, ${ }^{1}$ Schlotheim. Pl. XXXIV, figs. 1 -S.

Ammonites Capriconnus, Schlotheim. Petrefaktenkunde, p. 7I, 1820.

- Maculatus, Young and Bird. Geol. Survey, p. 248, pl. xiv, fig. 12, 1822.

$\begin{array}{lll}- & - & \text { Phillips. Geol. of Yorkshire, pl. xiii, fig. 11, } 1829 . \\ - & - & \text { Quenstedt. Cephalopoden, p. 85, tab. iv, fig. 7, } 1849 . \\ \text { - } & - & \text { Simpson. York. Lias Fossils, p. 48, 1855. }\end{array}$

As to the synonymy of this Ammonite, I nay observe that Dr. K. Schlönbach made a very careful study of the Schlotheim Collection in the Mineralien-Kabinet of Berlin,

1 In the explanation of PI. XXXIV this species is termed in error Aegoceras maculatum. 
and states that the name Ammonites capricornus was given by Schlotheim to a species, examples of which are there displayed from Whitby (England), and from Amberg and Heinberge near Göttingen (Germany). All the specimens which he saw with the ticket Ammonites capricornus undoubtedly belonged to the species which Professor Quenstedt in his works calls Ammonites maculatus.

Diagnosis.-Shell flattened and discoidal, whorls round and slightly involute ; ribs annular, sharp, and bent towards aperture, with wide concave spaces between; siphonal area round, rib-arch prominent, with nunerous striæ between; aperture circular; umbilicus wide.

Dimensions.-Transverse diameter 80 millimètres; width of the umbilicus 45 millimètres; height of aperture 25 millimètres; transverse diameter 22 millimètres.

Description.-This is a variable Ammonite as regards the form and size of the ribs, which are quite annular, thickened,

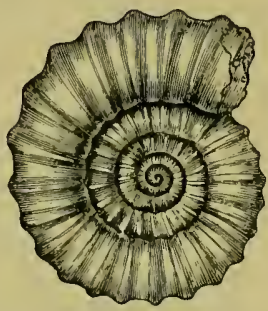
and flattened where they pass across the siphonal area. After selecting from a number of specimens I consider the shell figured Pl. XXXIV, figs. 1, 2, 3, a good typical example, and in figs. 4, 5, 6 of the same, I have had a larger specimen delineated. Here we observe the outer whorl becomes greatly enlarged, and two rows of tubercles make their appearance with the commencement of the sixth whorl, whilst the annular ribs of its former condition have assumed a new livery. This is very well seen in the side view where the tubercles first appear, and the great enlargement of the last whorl is well expressed in fig. 6, where the ribs proceeding from the tubercles are seen to split, and the intermediate spaces are covered with transverse strix.

The figures in this plate are arranged to show that Aeg. capricornus or maculatum as we usually meet with it, is the young form of a shell resembling Am. hybrida of d'Orbigny, figs. 4, 5, 6, and which in better developed specimens we shall find to be the true Am. heterogenes of Young.

Affities and Differences.-The young form of this Ammonite resembles the specimen figured by d'Orbigny as $A m$. planicosta, which certainly is not the planicosta of Sowerby. I have already shown by the figures and description of Aeg. capricornus that it resembles, however, $A m$. latacosta, Sow., whilst the round whorls, straight annular ribs witlout tubercles and circular month aperture, indicate close affinities with a nearly allied species.

Stratigraphical Position.-This is a very characteristic Ammonite of the zone in which it is found at the base of the Amaltheus margaritatus beds at Huntcliff, Robin Hood's Bay, Staithes, Coatham Scars, and Guisborough, Yorkshire Coast. 


\section{Aegoceras heterogenum, Young and Bird. Pl. XXXV, figs. 4-6; Pl. XXXVI, figs. $1-4$. \\ Ammonites heterogenes, Young and Bird. Geol. Surv., p. 264, pl. xiv, fig. 7, 1828. \\ - hybrida, d'Orbigny. Paléontol. Franç. Terr. Jurass., t. i, p. 285, pl. 85, 1842. \\ Oppel. Mittlere Lias Schwabens, Jahr. Würt., p. 53, pl. iii, fig. 3, 1853. \\ - Heterogenes, Simpson. Fossils York. Lias, p. 69, 1855.}

Diagnosis.-Shell irregular in form; whorls six, all exposed; inner whorls small, round, and slightly involute, with annular obtuse ribs; body-chamber greatly enlarged, forming the outer whorl; ribs more closely approximated, and having two rows of tubercles developed on each; from the outer narginal tubercle the ribs split up into two or three divisions, and cover the convex siphonal area with fine transverse striæ; aperture wide, oblong; lobe-line highly complicated.

Dimensions.-Transverse diameter 125 millimètres; width of the umbilicus 50 millimètres; height of the body-chamber 50 millimètres; height of penultimate whorl 20 millimètres; height of aperture 52 millimètres; width 50 millimètres.

Description.-This is another very remarkable Ammonite closely related to Aeg. Henleyi, like it the body-chamber in the sixth whorl becomes much expanded, and assumes a form and livery widely different from that exhibited in early life. It was well remarked of this species by the Rev. George Young, when he proposed the species, "that it is one of the most singular of all our Ammonites, the outer whorl of which has also two rows of knobs. The interior part of the shell is comparatively flat, with ribs rather prominent and flattened on the back, very much like those of Am. maculatus; near the outer whorl the ribs begin to have two slight knobs on the sides, and on that whorl the ribs grow depressed and the knobs elevated, making two prominent rows, as is sometimes the case in the outer whorls of the Am. perarmatus in the Oolite formerly noticed. But the most remarkable circumstance to be stated is, that the last part of the outer whorl suddenly swells to a great thickness, as if it had belonged to another shell; the difference being the more striking, as the ribs in this part, instead of being flattened on the back, are split into three at the outer row of the knobs. The mouth, as in the last species, is sub-heptangular. We may name this singular shell Am. heterogenes."

Pl. XXXV, fig. 4, shows the side view of a small specimen. Here the two rows of tubercles are very prominent, the inner row being at some distance from the spiral suture, and the outer row near the margin of the area; the intervening ribs, fig. 5 , show the front view of the tubercles : we observe also how the obtuse annular ribs are set widely apart on a whorl of moderate width with tubercles developed on the margin of the round area. In fig. 6 we note the sudden expansion of the body-chamber, the width of the siphonal 
area, the increasing prominence of the tubercles, and the ribs proceeding from them becoming split up into two or three divisions, thus covering the area with lines of transverse sculpture. In Pl. XXXVI, fig. 1, we have another specimen of still larger size collected in Robin Hood's Bay; here we observe a closer approximation of the ribs as they approach the aperture, and their comparative smallness when contrasted with those on the penultimate whorl. In fig 2 the thick obtuse ribs seen on the front view of this fossil, form a remarkable contrast to the narrow transverse ribs which regularly cover the wide convex siphonal area so well delineated in fig. 3 of the same plate.

The lobe-line is extremely complicated (fig. 4). The siphonal lobe is as long and wide as the principal lateral, and ornamented on each side with extended branches, of which two are transverse. The siphonal saddle as wide as the principal lateral lobe terminates in three foliations, of these the central is the largest, with a trifid foliole; the principal lateral lobe is highly ornate, with two large external and two small internal branches, and a long terminal ramified branch. The lateral saddle ends in two unequal foliations. The lateral lobe is small and divides into three digitations, and the auxiliary lobes are much smaller and end in single digits.

Affinities and Differences.-Aegoceras heterogenum very unch resembles Aegoceras Henleyi in having a youthful form of shell entirely different from its adult condition, both having passed through a remarkable transformation in the figure and capacity of the body-chamber about the sixth volution of their growth. I have compared the two forms very closely with each other, and my specimens lead me to the conclusion that Aeg. latecosta, the young form of Aeg. Henleyi, is distinct from Aeg. capricornus, the young condition of Aeg. heterogenum, and that the adult states of both species are evidently distinct from each other.

Locality and Stratigraphical Position.-This Anımonite is very rare on the Yorkshire coast; it is occasionally found at Huntcliff, and in Robin Hood's Bay in beds referred to the zone of Aegoceras capricornus. I have one example from a ferruginous shaly band, and another, figured in Pl. XXXVI, which I collected from the Marlstone of Yorkshire.

Aegoceras acericostatom, Wright, nov. sp. Pl. XXXV, figs. $1-3,7$.

Diagnosis.-Shell discoidal, depressed; whorls rounded and slightly involute; sides ornamented with twenty-four sharp waved ribs, which pass round the margin and disappear from the middle of the siphonal area; umbilicus wide; inner whorls all exposed; aperture oblong.

Dimensions.-Transverse diameter 85 millimètres ; width of umbilicus 33 millimètres ; height of aperture 30 millimètres ; transverse diameter 25 millimètres.

Description.-This is a very distinct form, which belonged to the cabinet of my late friend, Mr. J. Leckenby, F.G.S., and was collected from the Aegoceras Jamesoni beds of 
Robin Hood's Bay ; it very much resembles one of the forms of Aeg. Jamesoni, var. sagittarium, in the cabinet of the Rev. J. E. Cross, F.G.S., and may indeed prove to be such, but in the absence of more specimens for comparison I shall retain the name I gave it long ago.

It is a regular, well-formed Ammonite, with rounded whorls, which are only slightly involute. The ribs, which are sharp and narrow with a sigmoidal flexure, arise from a thickened root. At the spiral suture they wind up the side and over the margin (fig. 1), and vanish in the middle of the siphonal area (fig. 3), which is convex and smooth; near the turn of the penultimate whorl (fig. 2) the ribs are sometimes enlarged before they terminate, leaving only a narrow swooth space in the middle of the area. The umbilicus is wide, and the inner whorls are all fully exposed. The aperture is oblong and a little flattened at the sides.

The lobe-line (fig. 7) is apparently simple; the siphonal lobe is longer and wider than the principal lateral, and has a few digitations with two terminal points. The siphonal saddle is small and terminates in three small leaves. The principal lateral lobe is narrow and oblique with four digitations on each. The lateral saddle is wide and much larger than the siphonal, it terminates in three chief foliations and several smaller ones. The lateral lobe is larger than the principal lateral, with three lateral on each side and two terminal digitations. The auxiliary saddle has a foliated termination, and the auxiliary lobes are small with oblique digitations.

Affinities and Differences.-This Ammonite resembles some of the transition phases in the evolution of Aeg. sagittarium. I know of no other form with which to compare this Cephalopod, which remained long unnamed in my old friend's collection, and is now figured and described for the first time.

Aggoceras Portlockil, Wright, nov. sp. Pl. XLVIII, figs. 4, ј.

Diagnosis.-Shell discoidal, compressed, and carinated; whorls compressed, slightly involute, thicker at the spiral suture, and tapering towards the keel; sides ornamented with stout regular ribs, having a well-defined sigmoidal figure, and being well rounded throughout; carina stout, into which the ribs appear to blend, the space between the ribs concave aud smooth.

Dimensions.-I have only the fragment of a whorl.

Description.-This fragment was collected by the Irish Geological Survey, and represents a form which I have from the Aeg. Jamesoni beds of Robin Hood's Bay. The whorls are wide and slightly involute; they are covered with strong, regular rounded ribs, having a sigmoidal flexure, and all obliquely placed at regular intervals apart, and concave intermediate spaces between them. The carina is thick and prominent, and the ribs, slightly enlarged before they terminate, appear to blend into the keel. The specimen 
is only a fragment of a whorl, and belongs to the Museum of the Irish Survey, Dublin. It was collected by the officers of the Irish Geological Survey, and was obtained from the Aeg. Jamesoni-bed of the Middle Lias at Carncastle.

This Ammonite is noted in General Portlock's 'Report on Londonderry,' p. 133, under the name Ammonites radians, Reinecke, and was found in a highly calcareous bed, approaching to impure grey limestone, at Carncastle, Ballygalley Head, County Antrim.

Aegoceras Carusense, d'Orbigny. Pl. L, figs. 9, 10.

Ammonites Carusensis, d'Orbigny. Paléont. Franç. Terr. Jurass., t. i, p. 284, pl. 84, figs, 3-6, 1842.

Diagnosis.-Shell compressed, discoidal ; whorls narrow, numerons, and slightly involute; sides depressed, and encircled by sharp, straight annular ribs; siphonal area convex, and crossed by transverse ribs; umbilicus widely open; aperture round.

Dimensions.-35 millimètres; width of the umbilicus 20 millimètres; height of aperture 4 millimètres; width 4 millimètres.

Description.-This elegant little Anmonite was collected in great numbers many years ago from the Aeg. Jamesoni beds near Cheltenham, associated with the young shells of Aeg. densinodum. I was long under the impression that it might be the young form of a larger Ammonite, still as I have never met with one larger than the figured specimen, which possesses its body-chamber, I have come to the conclusion that it is the complete Ammonite.

The shell is suborbicular and compressed; the whorls are very slightly involute, and often distorted, so that this Ammonite has been mistaken for a Turrilite. The whorls are rounded on the sides, and encircled by twenty-nine sharp, straight, annular ribs, which bend gently backwards where they cross the area; sometimes they are interrupted in their transit, but oftener they pass entire. This shell appears to undergo no change in the different phases of its life. The spire is formed of seven narrow, depressed whorls, uniformly ornamented with regular, straight, sharp ribs, and narrow, concave spaces between. The aperture is round and slightly compressed at the sides.

'The lobe-line is very simple. The siphonal lobe is longer and wider than the principal lateral, with simple digitations on its margin. The siphonal saddle is twice the size of the principal lateral lobe, with four simple leaves at its termination. The principal lateral lobe is very small, with a few digits on its sides. The lateral saddle is large, ending in three irregular foliations. The lateral lobe is very short, and ends in three digits, and the auxiliary lobe has only a single point.

Affinities and Differences.-It resembles the young forms of Aeg. densinodum, which 
witl age develops spines; this Aeg. Carusense never does. It is altogether a unique Ammonite from the basement bed of the Middle Lias.

Locality and Stratigraplical Position.-I have found this species in the Aeg. Jamesoni beds, Swindon Road, near Cheltenham.

Algoceras Slatteri, Wright, nov. sp. Pl. L, figs. 1-8.

Diagnosis.-Shell discoidal, depressed; whorls high, two thirds involute; sides ornamented with thick, obtuse, curved ribs, which alternate with concavities of the opposite side; siphonal area convex and smooth, the knobs of the ribs alternating on the margin ; aperture oblong, narrow.

Dimeensions.-Transverse diameter 55 millimètres; width of the umbilicus 15 millimètres; height of aperture 23 millimètres; transverse diameter 13 millimètres.

Description.-This singular Anmonite was collected by my friend Mr. 'T. J. Slatter, F.G.S., of Evesham, from the Lias of Broughton, near Pershore. 'The specimens are all fragmentary, and therefore I describe it with some hesitation; the shell is discoidal and much compressed; the whorls high and quite one half involute (fig. 1); the sides ornamented with bent, obtuse, recurved ribs, which thicken out into knobs at the margin of the siphonal area; the ribs on the right side of the shell correspond to concavities on the left, so that the costæ on the right and left sides alternate with each other, which becomes very obvions when we examine the specimens (figs. 2, 4, 5). In early life the shell appears to have resembled an Amaltheus, and had a small carina in the centre of the area (figs. 6,7 ), which carina appears to be covered over by the future whorl as in fig. 3, and to be indicated in fig. 4. The thin shell is only partially retained on a portion of some of the fragments. In the larger segments the siphonal area is rounded and marked by transverse lines, and the terminal knobs of the ribs form conspicuous objects in the specimen delineated in fig. 5 .

The lobe-line (fig. 8) is very simple. The siphonal lobe is about the size of the principal lateral with three lateral digitations on each side, and a single terminal point. The siphonal saddle is wide and deep and terminates in three principal foliations. The principal lateral lobe is nearly as long and a little wider than the siphonal, and has three lateral digitations on each side, with a bifid termination. The lateral saddle in size and structure very much resembles the siphonal, and has four terminal folioles around its termination. The lateral lobe is smaller than the principal lateral, the onter margin is serrated, and its terminal portion bushy. The auxiliary lobe is very small and simple.

Affinities and Differences. - The style of the ribs in this species has no parallel among the Lias Ammonites; at first I thought it might be an accidental monstrosity or an acquired alternate character of ribbing from descent, as all the specimens hitherto found possess the 
alternation of the rihs on the two sides of the shell. Until more specimens are found I inust treat it as a distinct species, and dedicate it to my friend whose industry disinterred it and brought it under my notice.

Stratigraplical Position.-Mr. Slatter found it in the Lias beds at Drake's Broughton, near Pershore, Worcestershire, where it was associated with the following list of fossils which he has kindly contributed.

List of Fossils from the Lower and Middie Lias, Broughton, near Pershore. Cephalopoda.

Aegoceras Slatteri, Wright.

- sagittarium, Blake. Amaltheus oxynotus, Quenst. - Simpsoni, Bean. Phylloceras Loscombi, Sow.
Phylloceras Salisburgensis, Von Haner.

\section{- Nodotianus, d'Orb.}

Belemnites brevis secundus, Quenst.

- acutus, Mill.

Nautilus striatus, Sow.

Gasteropodu.

Cerithium rotundatum, Terq.

- Collenoti, Terq. et Piette.

Chemnitzia crassissima, Tate.

Dentalium minimum, Strickland.

- elongatum, Münst.

Pleurotmaria foveolata, Deslong.

Trochus Thetis, Münst.
Actaonina secale, Terq.

- fragilis, Dünk.

- striata, Terq. and Piette.

- triticum, Terq.

Turbo admirandus, Tate.

- solarium, 'l'erq. and P.

Lammellibranchiata.

Macrodon numismalis, Tate.

- intermedius, Simp.

Astarte amalthei, Quenst.

$$
\text { - cingulata, Terq. }
$$

Avicula cuneata, Terq. and Piette.

- incequivalvis, Sow.

Cardinia liybrida, Stutch.

- crassissima, Stutch.

Cardita multicostata, Phillips.

Hippopodium ponderosum, Sow.

Leda acuminata, Goldt.

Nucula inflexa, Quenst.

- Galathaa, d'Orb.
Nucula variabilis, Sow.

- navis, Piette.

- cordata, Goldf.

Leda Renevierei, Oppel.

Mytilus numismalis, Oppel.

Protocardium oxynoti, Quenst.

$$
\text { - truncatum, Sow. }
$$

Ostrcea arcuata, Lamark.

Plicatula, sp.

Limcea acuticosta, Goldf.

Lima gigantea, var. minzma, Sow.

Pecten calvus, Goldf. 
Bracliopoda.

Rhynchonella variabilis, Schloth.
Annelida.

Ditrypa quinquesulcata, Münster.

\section{Crinoidea.}

Pentacrinitis scalaris, Goldf.

Aegoceras Polymorphum, Quenstedt. Pl. XL, figs. 1-3.

AMMONITES POLYMORPHUS,

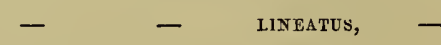

Quenstedt. Cephalopoden, p. 86, tab. iv, fig. 13, 1849.

Der Jura, p. 128, tab. xv, fig. 14, 1858.

Diagnosis.-Shell discoidal, compressed, with numerous-about seven-whorls, which are slightly involute, and have their sides covered with innumerable fine hair-like striations, which arise above the spiral suture and ascend obliquely forwards towards the siphonal area, over which they pass and join the striæ from the opposite side. Shell extremely thin, leaving all the markings on the mould; body-chamber occupies nearly an entire whorl.

Dimensions.-Transverse diameter 45 millimètres; width of the umbilicus 22 millimètres; height of the aperture 15 millimètres; transverse diameter 9 millimètres.

Description.-This is a very difficult fossil to determine, as the specimen is badly preserved, and is the only one that has been found. I have, however, put it well together, and enlarged the drawing two diameters; the shell is in part existing, and is extremely thin. The whorls are only slightly involute, and have their sides ornamented with numberless fine striations, which arise above the spiral suture and are directed obliquely forwards towards the aperture; they all pass over the siphonal area, forming a series of little ridges there; the body-chamber occupies nearly an entire whorl, jndging from the portion that remains and what is lost.

The aperture is oblong, arched above, and flattened at the sides; there does not appear to have been any lateral processes; the mouth aperture corresponding with the oblique sweep of the hair-like ribs.

'The lobe-line is not complicated, and resembles the style of Aeg. Jamesoni. The siphonal lobe (fig. 3) is narrow, and as long as the principal lateral lobe. The siplonal saddle is wide, and ends in four foliations. The principal lateral lobe is long, and has several lateral and two terminal branches, both of which have trifid processes. The lateral saddle is smaller than the siphonal, and ends in one large internal and two smaller external foliations. The lateral lobe is very small and ends in three points.

Affinities and Differences.- This Ammonite so closely resembles Am. polymorphius lineatus, Quenstedt, that after much consideration I have determined to treat it as such, although I confess my disinclination to decide species upon such insufficient evidence as 
this specimen affords; should other examples in better preservation be found the name niay either be retained or another specific appellation given. The Polymorphi, according to Quenstedt, exhibit many varieties, as shown in $P$. lineatus, $P$. costatus, $P$. interruptus, $P$. mixtus, and $P$.quadratus, and so for the present, I have considered this species as one of the group.

Locality and Stratigraplical Position.-Found in the Middle Lias of North Lincolnshire by the Rev. J. E. Cross, F.G.S., to whose cabinet it belongs.

Aegoceras curvicorne, Schlönbach. Pl. XXXI, figs. 3 and 4.

AMMONites CURVICORNis,

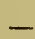

$-$
(1)

MaCULATUS ANGULATUS

CURVICORNIS,
Schlönbach. Eisenstein des Mittl. Lias, Zeitsch. Deutsch. geol. Ges., Bd. $x \nabla$, p. 522 , pl. xii, fig. 4, 1863.

Wagener. Liasschichten Thalmulde Rheinl. Westphal. Verhandl., p. $166,1860$.

Schlönbach. Beiträge zur Palæontologie der JuraForm. Palæontographica, p. 163, 1865 .

Diagnosis. - Shell discoidal, compressed, with six round, bold-ribbed, slightly involute whorls; sides ornamented with fifteen thick prominent ribs, which support two thorn-like spines, the ribs and costæ separated by wide concave valleys covered with striæ; siphonal area wide and convex; thick ribs arched forwards, passing across from the marginal tubercles; concavities deeply sculptured with fine bent striæ; aperture round.

Dimensions.-Transverse diameter 80 nillimètres; width of the unbilicus 4.0 millimètres.

Description. - I have long known this Ammonite from the Green Ammonite bed of Charmouth, and at one time inclined to the opinion that it was a distinct species, until an example showing the transition to an enlarged body chamber at the same age as in Aeg. Hcnleyi was found; this led to a restudy of the series, and the conclusion that Aeg. curvicorne is an extreme form of Aeg. latcocosta, having round, depressed whorls, with extremely sharp ribs and prominent thom-like spines, and that on attaining the sixth volution of its spire it commences the expansion and enlargement of the body chamber.

Among the group of specimens of Aeg. capricorne in the Berlin Museum, V. Schlotheim has distinguished by distinct names the following varieties:- $a$. Am. capricornis angulatus ; b, Am. spathosis ; $c, A m$. capricornis dorsuosus.; it is to the first of these varieties that Dr. Wagener has referred the fossil now under consideration, in this opinion I am inclined to concur, and regard Aeg. curvicorne as a marked variety of the early stages of Aeg. Henleyi, with depressed whorls, prominent ribs, and constricted spire; having the same expancled body clamber in the sixth volution of development as in the type form. 
Affinities and Differences.-This fossil closely resembles some forms of Aeg.capricornus or maculatum, and may be only a variety with more pronounced characters of that species. Locality and Stratigraphical Position.-This specimen was collected from the MiddleLias Limestone at Charmouth, where it appears to be rare.

Aegoceras striatum, Reinecke. Pl. XLII, figs. $1-5$.

Nautilus striatus,

Reinecke. Naut. et Arg., No. 32, p. 85, pl. viii, figs. 65 , $66,1818$.

Ammonites heptangulanis, Young and Bird. Yorkshire Coast, 2 ed., p. 263, pl. xiv, fig. 1, 1828.

$\begin{array}{ll}- & \text { striatus, } \\ - & \text { cheltiensis, } \\ - & \text { striatus, } \\ - & - \\ - & - \\ - & - \\ - & \text { Henteit, } \\ - & - \\ - & \text { strdatus, }\end{array}$

Aegoceras striatum,
Zieten. Versteinerung. Württemburgs, p. 7, tab. v, fig. 6,1830 .

Murchison. Geol. of Cheltenham, 1st Edit., p. 19, 1834.

Römer. Nord-deutsch. Oolith-gebirg, p. 199, 1836.

Bronn. Leth. geog., p. 449, tab, xxiii, fig. $7,1837$.

Quenstedt. Flözgebirge, Würtembergs, p. 177, 1843.

- Cephalopoden, p. 135, tab. ix, fig. 24, 1849.

d'Orbigny. Paléontol. Française Terr. Jurass., p. 280, pl. lxxxiii, 1842.

Simpson. Fossils of the Yorkshire Lias, p. 70, $18 \tilde{5} 5$.

Quenstedt. Der Jura, p. 134, tab. xvi, figs. 9, 10, 1858.

Dumortier. Depôts Jurass. du Bassin du Rhone, III, p. 76, pl. xviii, fig. 1, 1869 .

Tate and Blake. Yorkshire Lias, p. 281, 1876.

Diagnosis.-Shell inflated, whorls depressed, one half involute, sculptured with numerous delicate, longitudinal striations; outer whorl very thick; sides flattened and provided with two rows of tubercles; ribs arise near the siphonal suture, and unite in the inner row of tubercles; from thence sometimes one, sometimes two, short, straight, slender ribs proceed and unite in the second series of tubercles which bound the margin of the siphonal area; from each marginal tubercle nearly always two strong ribs proceed, which pass transversely across the area; umbilicus small, deep, and narrow; inner row of tubercles alone visible in the spiral volutions; aperture roundish or of a heptangular form.

Dimensions. - Transverse diameter 130 millimètres; width of the umbilicus 34 millimètres; height of the aperture 65 millimètres; transverse diameter 75 millimètres. The smaller specimen has the same relative proportions and dimensions.

Description.-I have already pointed out the error palæontologists have committed in confounding this shell with the true Aeg. Henleyi, Sow., although it had long ago been accurately described by the Rev, George Young in his 'Yorkshire Coast,' who says : 
- "This is a rare and singular shell from the Hawsker shore, armed with a double row of spines placed on angular ridges on the sides. Between the two rows are irregular ribs, rmning from the inner knobs to the outer, and each generally splits into two elevated ribs on the back, partly fimbriated, wherens on the inner part of the whorl, within the interior row of knobs, the ribs are replaced by numerous slender striæ. The space between the rows is also slightly striated; the whorls are few, the outer being very large, and the central part forming a deep cavity or umbilicus; interior whorls are much concenled; the back is rounded, but seems to acquire an angle behind, near the aperture, which therefore approaches the heptangular. On account of this we may name this species Am. heptangularis." It is very evident from this description that Young had clearly discerned the specific distinction between this shell and $A$. Henleyi, a difference which has been entirely overlooked by many subsequent anthors. Sir Roderick Murchison, in his 'Geology of Cheltenham,' figured this fossil as Am. Cheltienensis, and subsequently d'Orbigny, in his 'Paléontologie Française,' gave a very finc figure of it under the name $A m$. Henleyi, whilst he correctly quoted Reinecke's figure and species, and erroneously confused it with Sowerby's Henleyi in his synonymy of the species.

The shell is largely inflated and ornamented longitudinally with innunierable small fine striations; the sides of the shell have throughout two rows of large tubercles, the inner row connected with the spiral suture by numerous fine strix, and the outer with the inner row by short, straight, split ribs. The outer row of tubercles is developed on the margin of the siphonal area, and from cach tubercle proceeds the strong band which passes across the area, and joins its fellow, on the mesial line from the opposite side. The siphonal area is convex, depressed, and boldly sculptured with transverse bands and intermediate concave depressions. The outer whorl is very large, and nearly conceals the penultimate whorl, which is more than one half involute. The whorls in this Ammonite increase very rapidly in every dimension, and they consequently leave a narrow, deep umbilicus, in which less than half of the inner whorls are visible, the internal row of tubercles decorating the margin of the spire.

'The lobe-line is very complicated. The siphonal lobe (fig. 5) is a little shorter and narrower than the principal lateral lobe, and ornamented with three branches. The siphonal saddle as wide as the principal lateral lobe, terminates in three foliations of oakleaf forms. The principal lateral lobe terminates in three large branches, with lateral ranifications. The lateral saddle terminates in two unequal foliations. The lateral lobe is oblique, smaller than the principal, but has a similar figure. The auxiliary saddle has three contracted foliations, and the auxiliary lobe ends in several digitations.

The aperture is large, wide, and expanded, and has a rounded or a heptangular form. This species assumes in early life the specific form and ornamentation I bave described, and does not pass through any apparent metamorphoses so peculiarly characteristic of Aeg. Henleyi and Aeg. heterogenum. The longitudinal striations so distinctive of the species are found only in the structure of the shell, and are not observed on the 
monld, whilst the ribs and tubercles on the sides and siphonal area are distinctly visible throughout.

Affinities and Differences.-The outer whorl of Aeg. striatum resembles the body chamber of Aeg. Henleyi, but the inner whorls are quite distinct in form and structure in the two shells. The umbilicus is deep and narrow in Aeg. striatum and wide and open in Aeg. Henleyi, and the arc of the circle described by Aeg. striatum is that of a much smaller circle than the one which is represented by Aeg. Henleyi. The one Ammonite (Aeg. Henleyi) undergoes an important change of form about the sixth whorl of its age the other (Aeg. striatum) appears to retain its form and characters without much change through life.

Locality and Stratigraplical Position.-This appears to be a very abundant and leading Ammonite of the Middle Lias, with an extensive distribution in time and space. It is found in the Henleyi zone at lenny Compton, Warwickshire; Radstock, Somersetshire ; Lyme Regis, Dorsetshire; and Robin Hood's Bay, Yorkshire. In Gloucestershire it is found in the Aeg. Henleyi zone of the Cotteswolds Hills at Hewletts, near Cheltenham, Whitcombe, near Gloucester, and in other exposures of these beds.

Foreign Distribution.-In France the late Professor d'Orbigny noted this species at Saint Amand, Cher ; Fontaine-Etoupe-Four, Croisilles, Curcy, Landes, Calvados ; Breux, Meuse; Mulhausen, Bas Rhin; Pouilly, Semur, Venarey, Côte-d’Or; Avallon, Yonne; the late Mons. Dumortier cites Saint-Fortunat, Saint-Cyr, Saint-Diedier, Rhône; he collected a magnificent example, 190 millimètres in diameter, in a region where Jurassique fossils are little known, in the middle of France, at the foot of the Pyrenees, at Albas, Aude. In Germany the typical example figured by Reinecke was discovered in Coburg. In Swabia it is found pyritic, associated with Amaltheus ibex in the middle region of Amaltheus margaritatus, but it is not obtained from either higher or lower zones.

Aegoceras Bechei, Sowerby. Pl. XLI, figs. 1-5.

AMmonites Bechei, Sowerby. Mineral Conchology, vol. iii, p. 143, pl. 280, 1821.

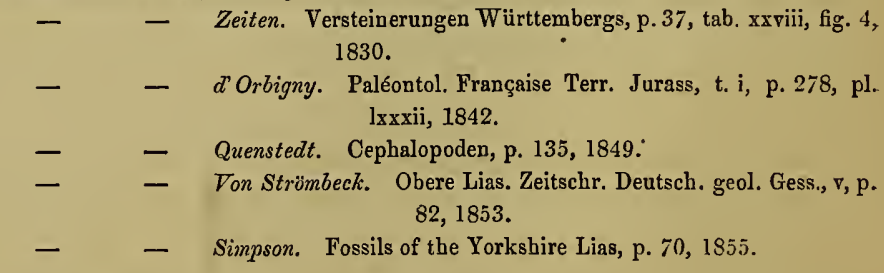

Diagnosis.-Shell globose, last whorl much inflated, highly involute, and entirely covered with fine longitudinal striations; sides ornamented with two rows of small 
tubercles united by short bifurcated ribs; from the outer row of tubercles bifurcate and trifurcate ribs proceed across the siphonal area. Passing over the sides and across the area many single ribs ascend between the tubercles. Siphonal area rotund and highly convex, beautifully sculptured with longitudinal striæ and transverse ribs; aperture widely expanded, a little flattened on the sides, and very convex externally.

Dimensions.-Transverse diameter, 120 millimètres; width of umbilicus, 10 millimètres; height of aperture, 70 millimètres; width of aperture, 70 millimètres; the smaller specimen has the same relative proportions.

Description.-This fine Ainmonite has a very globose shell and greatly enlarged outer whorl; the sides between the two rows of tubercles are slightly flattened; the small ribs below are nearly straight, about two to cach tubercle, with one between the tubercles; the umbilicus is deep and narrow, so that the spire is nearly entirely concealed. The longitudinal striæ are sharply defined and limited to the structure of the shell, being absent from the mould.

The siphonal area is rotund and very convex, from each tubercle of the marginal row, a bifurcate, and then a trifurcate, rib proceeds transversely across the area, with one or two single ribs between the bifurcations, these form a very regular series of transverse ribs with corresponding concavities between, the whole being intersected by numerous close-set, longitudinal striæ, which are extremely well defined in this species, and produce a highly ornate surface on the extremely convex siphonal area of its beautiful shell.

The aperture is as wide as it is high, and occupics more than half the diameter of the shell; it has a rounded figure, slightly flattened on the sides, corresponding with the depressed space between the lateral rows of tubercles. The lobe-line is extremely complicated and much resembles the lobe-line of Aeg. striatum. The siphonal lobe (fig. 5) is much shorter and narrower than the principal lateral, and ornamented on each side with three branches, of which the terminal one is bifurcate. The siphonal saddle is smaller than the principal lateral lobe, and terminates externally in three ramified foliations, and internally in one. The principal lateral lobe is large, formed of two branches on each side, and a long ceutral branch with a bifurcate terminal digitation. The lateral saddle terminates in three foliations on each side. The lateral lobe has two external branches and one terminal digitation. The auxiliary saddle has three foliations. The auxiliary lobes, four in number, are all small and oblique, and gradually decrease in size from without inwards.

Affinities and Differences.-This species undoubtedly resembles Aeg. striatum, and by many continental authors is considered to be identical with it. Still I am satisfied the following differences are sufficiently permanent to justify their separation. In Aeg. Bechei the whorls are much more involute, and the umbilicus narrower and deeper than in Aeg. striatum. The tubercles, likewise, are smaller, the ribs much more slender, and the longitudinal striæ sharper and better defined than in the latter species. Herr 
Köclılin Sclilumberger ${ }^{\mathrm{I}}$ has, through a series of strict investigation of a quantity of material from Mende, Lozère, and Venarey, Côte d'Or, arrived at the conclasion that Am. Henleyi and Am. Bechei, as figured by d'Orbigny, do not belong to two different species, but constitute only varieties which, through transition forms, are completely united into one species. The two forms are bracketed together in the works of Quenstedt, Oppel, Dumortier, and by Professors Tate and Blake in their Yorkshire Lias. Still, notwithstanding these authorities, the fact remains that the two species lie close together in the same bed on the Dorsetshire Coast, without any transition forms uniting them.

Locality and Stratigraplical Position.-This Ammonite is found in the Upper Marls without mica, near Charmouth, Dorset, in which many specimens are found associated with Lytoceras fimbriatum, Aegoceras striatum, Plylloceras Loscombi, Nautilus semistriatus, \&c. I have found a specimen in the Green Ammonite Bed of the same section above the marls in company with Aeg. Davœi and Monotis incquivalvis. It likewise has been collected from the Middle Lias at Fenny Compton, Warwickshire, and in Northamptonshire, as well as in Robin Hood's Bay, Yorkshire, from the zone of Aeg. capricornus $=$ Aeg. Henleyi.

Foreign Distribution.-In France it has been collected in the Middle Lias below the beds with Gryplica cymbium at Saint-Rambert, Ain; at Courtards, near Saint-Amand, Cher; at Fresnay-le-Puceux, at Curcy, at Vieux-Pont, Calvados; at Semur and Venarey, Côte-d'Or; and Avallon, Yonne, by several distinguished palæontologists. Professor Quenstedt says Sowerby makes two species, Am. Bechei and Am. Henleyi, out of Am. striatus, observing " Am. Bechei, with its rounded back, finer ribs, smaller tubercles, and more rapid increase in thickness, is very often found in Würtemburg. Whilst $\mathrm{Am}$. Henleyi, with its hexagonal mouth-opening, larger ribs, stronger tubercles, slower increase in thickness, and indistinct longitudinal striæ, lies deeper, and in Würtemberg is more rare." 'Cephalopoden,' p. 135.

\section{Family._ARCESTID $\approx,{ }^{2}$ Mojsisovics, 1875.}

This interesting family, containing the genera Arcestes, Didymites, Lobites, Ptyclites, Pinacoceras, Sageceras, Amaltheus and Schloenbaclia, and comprising for the most part the first Ammonites that appeared in the Trias seas, has the ancient genus Arcestes, Suess, as its type. The shell is usually more or less globose, or has largely inflated sides, occasionally it is compressed and carinated; it is either smooth, or possesses an ornate surface, formed of transverse folds, costæ, or fine longitudinal striations. The lobe-line in Arcestes is very complicated and formed of many divisions, each having a central stem with short, transverse, and oblique digitations, the whole constituting most intricate folia-

\footnotetext{
1 'Bullet. Soc. Géol. de France,' Juin, 1854, p. 628.

2 See page 238 of this Monograph.
} 
tions on the mould. The body-chamber is long in the older forms, thus in Arcestes it is a whorl and a half, and in Amaltheus two thirds of a whorl in length. The mantle-impression in Arcestes has left deep constrictions around the aperture of the body-chamber, which are absent from the polythalamous portion of the shell.

Arcestes, Didymites, Lobites, Ptychites, Pinacoceras and Sageceras, are obtained only from the Trias; Amaltheus from the Trias, Lias, and Jurassic rocks, and Schloenbachia is limited to the Cretaceous formation.

Genus III.-Analtheus. Montfort, 1S0S.

Genus-Amaltireus, IIontfort. Conchyliologie Systematique, t. i, p. 91, 1808.

Family-AxaltueI, ron Buch. Ueber Ammoniten, Abb. Akad. Berlin, pp. 143, tab. 3, fig. 3, 1832.

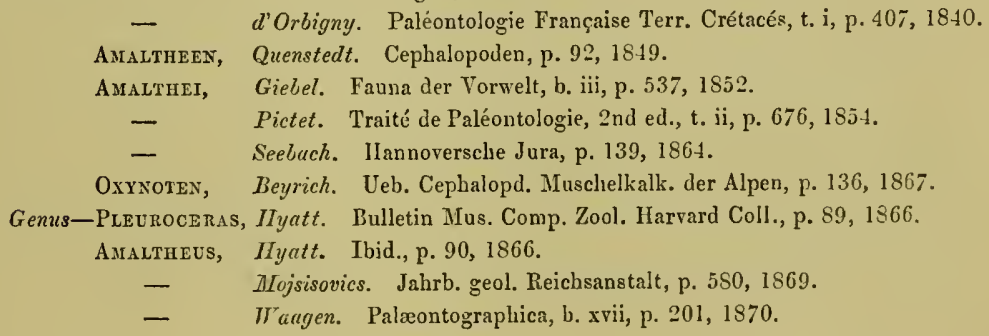

This genus is characterised by having a compressed discoidal shell; the siphonal area narrow, sharp, and keeled; the ribs when present are all flexed forward and end in a keel or plaited ridge (fig. 190). The external shelly lamina in some species develops fine longitudinal spiral lines. The body-chamber is short, about one half to two thirds of a whorl. The mouth-border of the shell is simple, the ventral portion ending in a long projecting process. The lobe-line is extremely complicated and very difficult to trace. The siphonal lobe is shorter than the principal lateral, which is mostly broad and wedge shaped.

This genus presents three distinct types of shell form which appeared together about the same period of time, they are therefore not derived from each other, but descendants of different groups; the first of these has Amaltheus Greenoughi and Amal. Guibalianus, the second Analtheus oxynotus, and the third Amaltheus margaritatus as their representatives.

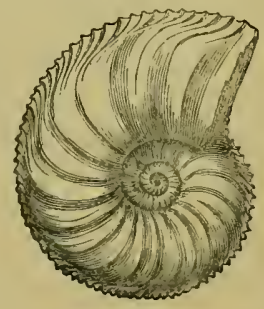

Fro. 190.-Amallheuscos. dalus, Sow.

Dr. Waagen states that a horny divided Anaptychus has been fornd in some species.

This genus has an extensive range in time. In the Trias is found Amal. megalodiscus, 
Beyrich, Amal. Sansovinii, Mojsisovics. In the Lias Amaltheus Greenougli, Sow., Amal. Guibalianus, d'Orbigny, Amal. oxynotus, Quenst., Amal. Lymensis, Wright, Amal. margaritatus, Montfort, Amal. spinatus, Brug. In the inferior Oolite, Amal. discus, Sow., Amal. Truelli, d'Orbig. In the Oxfordian, Amal. Chamusseti, d'Orb., Amal. cordatus, Sow.

\title{
Amaltheus Greenoughi, Sowerby. Pl. XLIV.
}

\author{
Ammonites Greenotghi, Sowerby. Mineral Conchology, vol.ii, p. 71, tab. 132, 1816.

$\begin{array}{lll}\text { - } & - & \text { De Haan. Ammonit. et Goniatit., p. 131, 1825. } \\ \text { - } & - & \text { Lonsdale. Trans. Geol. Soc., 2nd series, iii, p. 272, } 1832 . \\ \text { - } & \text { Guidoni. Boué Journal de Geologie, iii, p. 276, 1831. } \\ \text { - } & - & \text { MIorris. Catalogue of British Fossils, p. 173, } 1843 . \\ \text { - } & - & \text { Giebel. Fauna der Vorwelt, iii, p. 554, 1852. } \\ \text { - } & - & \text { Studer. Geologie der Schweiz, ii, p. 36, 1853. }\end{array}$ \\ Nordöst. Alpen, p. 46, taf. xii, 1856.
}

Diagnosis.-Shell large, discoidal, compressed; whorls two-thirds involute, outer whorl slightly convex, obscurely undulated by sixteen to eighteen straight, nearly obsolete ribs; inner whorls with prominent costæ; mouth-aperture elliptical and deeply indented by the penultimate volution.

Dimensions.-Plate one half the natural size. Transverse diameter of the specimen 440 millimètres; width of the umbilicus 150 millimètres; height of the last whorl 180 millimètres.

Description.-I searched the Sowerbyan Collection of Ammonites in the British Museum with green labels attached, Sowerby's mark of the figured species, for the original Am. Greenhoughi. The type was in such a state of decomposition from the iron pyrites it contained that it could not be disturbed unless at the risk of its falling to pieces. On searching among the Ammonites stored upon the top of the glass cases in the duplicate room, I found a magnificent specimen of this Ammonite which forms the subject of Plate XLIV, the figure being one half the natural size; unfortunately it had no label attached indicating its locality, but from the petrological character of the matrix in which it was embedded, it probably came from the Lias at Lyme Regis.

Sowerby says " this rather singular Ammonite is often formed of pyrites of rich golden and iridescent tints, and crystallised in the greatest variety of forms, from octaëdron to the icosaedron, following the undulations of the chambers and the most attennated ramifications of the spreading folliculæ, sometimes forming in the plaee of shells, \&c. \&c., occasionally fiiled with a great variety of crystals of carbonate of lime an inch or more in length." Specimens vary in size from twelve to eighteen inches or even more. The outer whorl has 
generally few or no undulations, while they are more distinct in the centre, which, if even separated, might be mistaken for another species."

The younger shells of this species, according to von Hauer, differ much from the old form figured Pl. XLIV. In a shell of from four to five inches in diameter, a distinct, extremely thick keel, was found upon the middle line of the siphonal area, which in larger specimens, about eight and a half inches in diameter, had disappeared. Youngcr shells have the sides of the whorls covered with numerous straight ribs, which bend forward towards the aperture as they approach the margin of the area. The ribbing of the inner whorls is very well seen in the umbilicus of our figure. The outer whorl is very large and capacious; the sides are convex and ornamented witl obscure undulations representing ribs, which, now becoming broad folds, disappear in old age.

Von Hauer has given two very good figures showing the lobe-line of this Ammonite. The siphonal lobe of a large specimen has two expanded branches, each having several lateral digitations. The siphonal saddle is wide and terminates in six folioles arranged almost in pairs; the principal lateral lobe is longer and narrower than the siphonal ; it has three branches on each side and a projecting terminal one; the lateral saddle is wide and deep, and terminates in a bifid and trifid and several lateral folioles; the lateral lobe is smaller than the principal; it has two lateral branches on each side, and a pointed terminal one; the auxiliary lobes and saddles become much smaller between the inner lateral lobe and the spiral suture.

Affinities and Differences.-Specimens from six to eight inches in diameter resemble Amalthens Guibalianus in the general form of their shells and in the presence of a keel. In larger shells the resemblance between these species diminishes and the adult conditions of hoth are widely distinct from each other.

Locality and Stratigraplical Position.-The figured specimen has no locality attached to it, but the rock appears to resemble the Lias of Lyme. I have seen two fine large specimens of this Ammonite at Charmouth. Both of these came from the Lower Lias. As the collector in whose possession they were had not brought any other shells from the bed I was unable to determine the horizon. Two large Ammonites referred to this species were obtained from the Amal. oxynotus-beds of Robin Hood's Bay, and are recorded with doubt by Professor Blake as representing Amal. Greenhoughi. Monsieur Dnmortier recognised some fragments of this Ammonite at Saint Fortunat, Rhône ; Nolay, Côte-d'Or, in beds belonging to the zone of Amaltheus oxynotus.

\section{Amajtheus Guibalianes d’Orbigny. Pl. XLV, figs. 1-7.}

Ammonites Guibalianus, d'Orbigny. Paléontol. Française Terr. Jurass., i, p. 259, pl. $73,1842$.

$\begin{array}{llll}- & - & \text { Quenstedt. } & \text { Leonard aud Bronn, Jahrbucb, p. 89, } 1845 . \\ - & - & - & \text { Cephalopoden, i, 351, } 1849 .\end{array}$


Ammonites Guibalianus, Bronn. Gesch. d. Natur., iii, pt. i, p. 44.

Oppel. Die Juraformation, p. 86, 1856.

Dumortier. Depôts Jurass. du Bassin du Rhône, ịi, p. 140, 1867.

Diagnosis.-Shell compressed, carinated; whorls compressed, and extrenely involute ; sides convex, numerous sigmoidal ribs extend from the spiral suture to the carina, with short supplementary ribs on the upper half of the wider valleys; siphonal area narrow, with sloping sides, a central carina, and oblique transverse ribs, aperture ellipticolanceolate, much indented by the penultimate whorl; lobe-line extremely complicated.

Dimensions.-Transverse diameter of figs. 6 and 7, 133 millimètres; width of umbiiicus 20 millimètres; height of aperture 75 millimètres; width 35 millimètres. Figs. 3, 4, transverse diameter 70 millimètres; width of umbilicus 16 millimètres; height of aperture 40 millimètres, width 22 millimètres. Figs. 1, 2, transverse diameter 50 millimètres; width of umbilicus 12 millimètres; height of aperture 27 millimètres ; width?

Description.-I have figured three specimens of this Ammonite and given their respective dimensions to show that very little change takes place in the growth of this species, which attains dimensions very much greater than the shell figured in 6 and 7 selected for the type figure of this fossil, because in early life its ribs are more defined and in old age they become obsolete. M. Dumortier states " that his largest specimen came from Lournand; it is 245 millimètres in diameter; the width of the last whorl $46 / 100$; the thickness $26 / 100$; the size of umbilicus $18 / 100$. The last whorl has thirty-six ribs or folds slightly marked, and which appear less flexed than the ribs of the inner whorls. This specimen is furnished with lobes up to its extremity, consequently its transverse diameter when provided with its body-chamber must have exceeded 360 millimètres." My largest specimen measures 245 millimètres in diameter, the width is 70 millimètres, the height 120 millimètres, and the width of the umbilicus is 35 millimètres.

The shell is compressed and sharply carinated, and ornamented with from thirty-six to forty ribs; the number, however, differs in different specimens. Most of the ribs pass from the spiral suture to the carina undivided, many of them, however, bifurcate, and a number of short secondary ribs make their appearance between the primaries in the wider valleys (fig. 7). In some young shells the ribbing is very regular (figs. 1 and 2), whilst in others it becomes irregular as in fig. 4, in which the primary ribs are few in number and the secondaries numerous. The ribs describe a sigmoidal flexure and bend forward towards the carina, their increase in number depends either upon the bifurcation of the primary rib or on the introduction of short small secondaries in the upper part of the whorl.

The spire is composed of six whorls which are extremely involute, and the umbilicus is consequently deep and narrow, the inner whorls being mostly concealed by the matrix.

The siphonal area is narrow, and slopes down to the sides; the keel varies, sometimes it is obtuse, sometimes acute, and in general it is marked with fine lines of shell growth, which impart a serrated structure to the carina when the shell happens to be preserved. 
The aperture has an elliptico-lanceolate figure, and is deeply occupied by the penultimate whorl.

The lobe-line is very complicated, and drawn with difficulty. Fig. 5 is from a tracing made upon a mould, which shows the lines most distinctly; it differs somewhat from the figure given by d'Orbigny. 'The siphonal lobe, longer and much larger than the principal lateral lobe, is formed of a large terminal branch and three other branches on cach side. The siphonal saddle, much wider than the principal lateral lobe, terminates in five-lobed folioles. The principal lateral lobe has a central stem with two lateral divisions on each side and two terminal branches. The lateral saddle is one third wider than the principal lateral lobe, and terminates in five- or six-lobed folioles. The lateral lobe, much smaller than the principal, has an oblique stem with small lateral branches on each side, and a terminal twig with trifid digits.

The auxiliary saddles, three in number, diminish in size from without inwards, and the three auxiliary lobes are short with many points on their margins.

The septa are closely approximated in the shell, and when the lobe-lines are seen in situt on the sides, they exhibit a most complicated labyrintli of lines very difficult to trace out on the mould.

Afinities and Differences.-This Anmonite occupies, as d'Orbigny remarked, an intermediate position between Amal. margaritatus and Amal. cordatus (fig. 190). It is distimguished from both by its more prominent and better defined carina, and the absence of the cordlike structure of the one sliell and the serrated structure of the other. Its whorls likewise are much more involute, and its lobe-line very different from both.

Locality and Stratigraplical Position.-I have found this Ammonite near Cheltenham, and possess a good series of well-preserved examples from the Amal. oxynotus-bed of the Lower Lias. I know no Ammonite which maintains, so constantly and with so little change, its specific form through all its morphological history as does this species.

Amaltheus oxynotus, Quenstedt. PI. XLVI, figs. 4-6.

Amonites maeandrus?, Zieten. Die Versteinerung. Württemberg8, p. 12, tab. ix, fig. 6,1830 .

- oxynotos, Quenstedt. Flözgebirge Wiirtembergs, p. 161, 1843.

- Polyophyllus, Simpson. Monograph of the Ammonites of Yorkshire Lias, p. 39, 1843.

- Robinsoni, - Ibid., p. 42, 1843.

- Buckir, - Ibid., p. 42, 1843.

- oxynotus, Quenstedt. V. Leonhard and Bronn's Jahrbuch, p. 87, 1845.

- cultellus, Buckman. Geology of Cheltenham, p. 103, tab. xii, figs. 4, 5, 1845 .

- oxyotus, Quenstedt. Petrefactenkunde Cephalopod., pp. 98, 262, tab. $v$, fig. 11, 1849. 
Ammonites oxynotus, von Hauer. Jahrbuch der k. k. geol. Reichsanstalt, iv, p. 754, 1853.

- POLyophylues, Simpson. Fossils of the Yorkshire Lias, p. 81, 1855.

- Robinsoni, - Ibid., p. 83, 1855.

- BucKII, - Ibid., p. 84, 1855.

- Dejectus, - Ibid., p. 85, 1855.

- oxynotus, von Hauer, Cephalopod. der Nordöst. Alpen, Deukschr.Akad.

Wissensch., p. 48, Taf. xiii, figs. 4-10, 1856.

Oppel. Die Juraformation, s. 85, 1856.

Wright. Quart. Jour. Geol. Soc., vol. xvi, p. 407, figs. 1, 。 $2,1860$.

Dumortier. Dépôts Jurass. du Bassin du Rhône, ii, p. 143, tab. xxxiii, figs. $1-5,1867$.

Amaltheus - Tate and Blake. The Yorkshire Lias, p. 291, 1876.

Diagnosis.-Shell discoidal, very much compressed; whorls five, extremely involute, inner volutions scarcely exposed; outer whorl very high, half the diameter of the shell; inner margin rounded, sides convex, outer margin thin, sharp, and cutting; sides slightly convex, with thirty to forty irregular folds limited to the middle, and which at two thirds of the whorl bifurcate, the branches bending forward at an acute angle towards the aperture; umbilicus very narrow, aperture lanceolate.

Dimensions. - This species varies much in size, and in old age attained a considerable diameter. I have collected specimens from one inch and a half, or 40 millimètres, up to one foot, equal 300 millimètres, in diameter, with the body-chamber, all of which are in my collection. I consider the shell figured (Pl. XLVI, figs. 4, 5, 6) as a good type form of this species in middle age, and which gives the following measurements :-Transverse diameter 90 millimètres; width of umbilicus 18 millimètres; height of aperture 51 millimètres; greatest width 18 millimètres.

The late Monsieur Dumortier collected a number of specimens of different sizes from Lournand, Jambles, St. Helene, St. Fortunat, and in his excellent work has given the measurements of six of these for comparison. ${ }^{1}$

\begin{tabular}{|c|c|c|c|}
\hline Diameter. & Height of last whorl. & Thickness of last whorl. & Size of umbilicus. \\
\hline 20 mill. & $45 / 100$ & $25 / 100$ & $28 / 100$ \\
$71, "$ & $45 / 100$ & $17 / 100$ & $18 / 100$ \\
86, & $46 / 100$ & $17 / 100$ & $19 / 100$ \\
$185, "$ & $47 / 100$ & $20 / 100$ & $23 / 100$ \\
220, & $45 / 000$ & $12 / 100$ & $20 / 100$ \\
330, & $44 / 000$ & $23 / 100$ & $21 / 100$ \\
\hline
\end{tabular}

l 'Dépôts Jurassiques du Bassin du Rhône,' ii, p. 143. 
Description.-In the above measurements we observe that the relative proportion varies chiefly as regards the thickness of the shell and the width of the umbilicus; in other respects, the specific characters are very well maintained.

The shell is discoidal, and very much compressed; the whorls are ligh and extremely involute; the outer whorl being half the diameter of the shell. The sides are convex, the inner margin gently rounded, and the outer third bevelled away into a thin, sharp

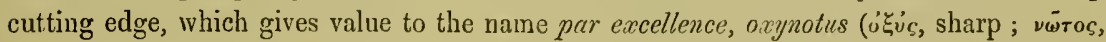
back), as it is the sharpest Ammonite extant. The ribs are slight obliqne folds, thirty to forty in number, which ascend from the spiral suture two thirds up the side; bere the shell begins to bevel off, and the ribs at this point make a sharp angular bend towards the carina (fig. 192), and dividing into two or three costæ as they incline forward to the aperture (fig. 191).

The umbilicus is more or less open in different spccimens, being very narrow in young, and becoming wider with increasing age, the amount of involution varying from one fourth to one sixth of a whorl.

The aperture is acutely lanceolate (fig. 192), the sides of the last whorl deeply embracing the penultimate one as slown in fig. 5 .

The lobe-line (Pl. XLVI, fig. 6) is very complicated from the close approximation of the septa. The siphonal lobe is wide with two divergent branches, each having three lateral digits on each side, and a ramose terminal tuft. The siphonal saddle is also wide

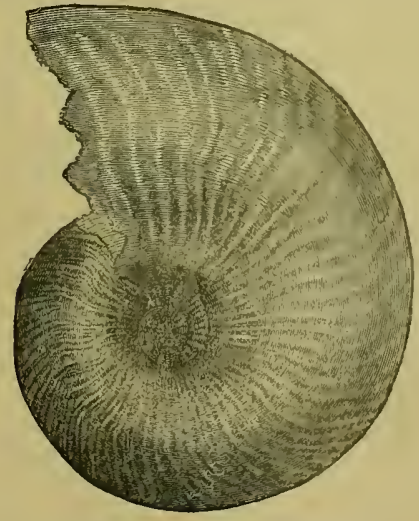

Fra. 191.-Amaltheus oxynotus, Qurnst.

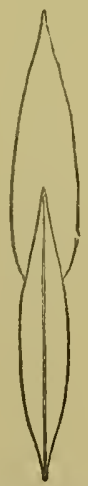

Fre. 192.-Front view.

and shallow, and ends in five deep lobe-like folioles. The principal lateral lobe is much smaller than the siphonal, and consists of a central stem with short lateral branches, and a trifid terminal one. The lateral saddle is narrow and deep, and ends in five folioles.

The lateral lobe is short and oblique with five digitations around its margin. The auxiliary saddles are wide and shallow, and the auxiliary lobes mere short digitations. 
The morphology of this Ammonite has been closely studied; when examined at 7 millimètres in diameter, the sides of the whorls are slightly more convex in proportion than in older shells, and ten or twelve wide folds are noticed around the umbilicus, the first indications of the lateral ribs; at 20 millimètres, the shell remains still proportionally thicker, the carina very little elevated forms a small round keel separated from the ribs, and the shell in this condition resembles Am. maeandrus, Reinecke; at 50 millimètres, the shell assumes its typical form, which it retains to 130 millimètres; it now, however, begins to lose its ribbed foldings on the body whorl; and at 160 millimètres, the cutting edge becomes thickened and the shell less compressed; but from first to last the specific characters scheduled in the diagnosis are well preserved throughout its life history.

The study of some large specimens of this Ammonite with their shell well preserved, enabled the late M. Dumortier ${ }^{1}$ to complete an observation he had already made on other Ammonites, on the structure of the shell in a good state of preservation. He found the test to consist of two very distinct laminæ ; an internal layer very thick near the umbilicus, diminishing progressively in proportion as it approaches the margin, where it is as thin as a sheet of stout paper; and an external layer, very thin on the contrary, near the umbilicus, and thickening progressively as it approaches the margin, where it acquires a thickness of 3 millimètres. By this arrangement a process of compensation is established by which the general thickness of the shell is maintained throughout.

Affinities and Differences.-Amaltheus oxynotus resembles three other species associated with it in the same zone, these are Amal. Lymensis, Amal. Simpsoni, and Amal. Wiltslivei. It differs from Am. Lymensis in having an open umbilicus, a lesser convexity of the sides, and a different style of the ribs; from Amal. Simpsoni in having a more compressed shell, much flatter around the umbilicus, and a different texture of shell structure; from Amal. Wiltshirei, with its closed umbilicus, in possessing an open umbilicus ; ribs entirely different, and a distinct shell structure.

Locality and Stratigraplical Position.-This Amnionite is the leading fossil in beds which separate the zone of Arietites obtusus from the zone of Arietites raricostatus, and which are so well shown in Gloucestershire, Dorsetshire, and Yorkshire (see p. 52). This bed is very rich in many species of Ammonites.

Foreign Distribution.-It is found in Swabia and Würtemberg. In France it was collected in abundance, according to Dumortier, at St. Fortunat, St. Cyr, Lournand, St. Helewe, and Jambles; and, according to Oppel, he found very large specimens in the Blue Limestone of Nancy.

It is singular that d'Orbigny has not figured a true Amal. oxynotus in his Paléontologie Française, although it certainly occurs in abundance in the basin of the Rhône.

Ammonites lyna, d'Orb., Ammonites Coynarti, d'Orb., and Ammonites Collenoti, d'Orb., 
which some authors consider to be synonyms of Amal. oxynotus, are certainly very different specics according to our reading of their outlines, markings, and lobe-lines.

Amaltheos Lymensis, Wright, nov. sp. PI. XLVI, figs. 1-3.

Diagnosis.-Shell discoidal, much compressed; whorls extremely involute, umbilicus occluded by the volutions; outer whorl very high, nearly two thirds the dianeter of the shell; sides regularly convex, covered with delicate sigmoidal folds, which make one sweep without interruption from the inner to the outer margin; siphonal area thin, sharp, and cutting, aperture lanceolate, nearly half its height occupied by the turn of the penultimate whorl.

Dimensions.-Transverse diameter 105 millimètres; height of the last whorl 65 millimètres; width 21 millimètres.

Description.-This beautiful Ammonite is the southern representative of Amal. oxynotus of the midland and northern counties. It is found in a thin bed of dark pyritic marl near Black Venn, between Charmouth and Lyme. This species is highly charged along the septa with sulphide of iron, whilst the chambers are filled with crystallised carbonate of lime ; these specimens are, therefore, well adapted for cutting and polishing from the beautiful contrast afforded by the ferruginous and calcareous elements of which this fossil is composed.

The sides are regularly convex, and ornamented with from fifty to sixty sigmoidal folds, which proceed in regular order from the inner to the outer border, the upper curve of the rib being inclined towards the aperture (fig. 1) without any change in the angle of the curve or bifurcation in the rib itself, as seen in Amal. oxynotus (fig. 4); the outer whorl embraces the entire shell, and the umbilicus is entirely occluded thereby.

A section of one of the shells, 45 millimètres in diameter, discloses some points in the anatomy of the shell which cannot otherwise be observed in the outer whorl of this specimen. There are twenty-five chambers, each being surrounded by a thin line of sulphide of iron, the septa between the iron lines being composed of carbonate of lime. The whorls in this specimen are six in number and they are all filled in with crystallised carbonate of lime. The shell is extremely thin, consisting of two lamina, on the outer of which fine hair-like lines of growth impart a delicate and ornate sculpture to it.

The lobe-line is very complicated. I have had a good example carefully figured from an accurate tracing on the mould (fig. 3). The siphonal lobe is wide, and has two small lateral and one large terminal branch on each side, the two sides forming pairs. The siphonal saddle is as large as the lobe, and terminates in two large, bi-lobed folioles, and three smaller, two on the outer and one on the inner side of the saddle. The prin- 
cipal lateral lobe is as long but not so wide as the siphonal; its sides have two small lateral digitations and a terminal one divided into two branches. The lateral saddle is deeper and narrower than the siphonal, and terminates in one short foliole on the outer and a longer and more complicated foliole on the inner side. The lateral lobe is much smaller than the principal lateral, and has three lateral digitations and a longer trifid terminal one. The auxiliary lobe terminates in two folioles, and the other auxiliary lobes and saddles are small, insignificant processes. A comparison between the lobeline of this shell and that of Amal. oxynotus figured on the same plate (fig. 5) will enable the student to realise the difference between the two lobe-lines of these two representative species, which have been hitherto confused together as one and the same species.

Affinities and Differences.-The more regular convex form of the shell, the regularity of the line of flexure of the folds, the difference in the arrangement of the lobe-line, the occlusion of the umbilicus, and extreme involution of the spire, form a group of diagnostic characters by which this Ammonite may be easily distinguished from "A. oxynotus.

Locality and Stratigraplical Position.-I only know this species from the pyritic Marl Bed near Black Venn, between Lyme and Charmonth, in the zone of Amal.oxynotus. On some of the fossils I have observed young shells of Aegoceras densinodum adhering to their surface. For the other forms in the Amal. oxynotus Bed I must refer to pp. 52-55 of this work.

Amaltheus Simpsoni, Bean. Pl. XLVII, figs. 4-7.

Ammonimes Simpsoni, Bean, MS. Simpson's Monograph on Ammonites of the Yorkshire Lias, p. 37, 1843.

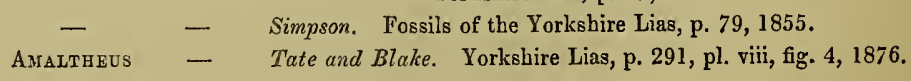

Diagnosis.-Shell discoidal, very much compressed; whorls four or five, extremely involute, the inner seven eighths concealed; outer volution one half the diameter of the shell, and inflated and rounded near the spiral suture; ribs nearly obsolete; sides with twenty undulating folds limited to the inner two thirds, outer third with numerous fine striæ bent forward toward the aperture; the keel thin, sharp, and cutting; aperture acutely lanceolate.

Dimensions.-Transverse diameter 100 millimètres; height of the outer whorl at aperture 50 millimètres; transverse diameter of the small shell (fig. 6) 40 millimètres ; height of the aperture 20 millimètres.

Description.-The only example of this shell I have seen is the one figured, which now belongs to the Woodwardian Museum, and was formerly the property of my old friend Mr. John Leckenby, F.G.S., in whose collection I studied it. This shell is distinguished from Amal. oxynotus by the inflation of the inner third of the whorls, the lesser 
convexity of the middle third, and the thinness and roncavity of the outer third, whilst the keel is sharp and cutting. The shell is thin, often preserved, and covered with fine striæ.

The lobe-line (fig. 5) is much more simple than the lobe-line of Amal. oxynotus. The siphonal lobe has a few short digitations. The siphonal saddle is oblique, with four or five simple folioles. The principal lateral lobe is short and narrow, with a few lateral digitations; the lateral saddle resembles the siphonal in its simple folioles; the lateral lobe is short and stunted, with a few digitations, and the whole structure appears to be like a dwarfed imitation of the lobe-line of Amal. oxynotus.

'The morphology of this species is not well known. I have figured two small examples from the same collection, which very much resemble young forms of Amal. oxynotus of about a like diameter. It certainly very much resembles that Ammonite, and may prove to be only a variety of that fine shell. The materials at my command, however, are so limited that I cannot venture upon a decided opinion on the subject.

Affinities and Differences.-The affinities all connect this shell with Amal. oxynotus, but it differs from that Ammonite in having the inner third of the whorls inflated, the sides without ribs, and a much simpler lobe-line. These characters, although slight, are said to be constant, and are considered to afford proofs of its being really distinct.

Locality and Stratigraphical Position.- The type specimen was collected from the Amal. oxynotus-zone, Robin Hood's Bay. It does not appear to have been found, aecording to Professor Blake, out of Yorkshire.

Amaltheus Wiltshirei, Wright, nov. sp. Pl. XLVIII, fig. 3.

Diagnosis.-Shell discoidal, very much compressed, outer volution very large, enveloping all the inner whorls; sides high, convex, and covered with slight sigmoidal folds, best seen on the mould. Shell structure ormamented with very delicate lines, which describe the curve seen on the mould; umbilicus occluded by the outer whorl; siphonal area thin and narrow; keel blunt.

Dimensions.-Transverse diameter 125 millimètres; height of the outer whorl 70 millimètres; width of aperture 24 millimètres.

Description.-This Ammonite was collected several years ago from the Green Ammonite Bed near Charmoutl, and since that discovery a second specimen has come into my possession, with some of the associated species embedded in the block. I have examined all the collections of Lias fossils to which $I$ have had access with a view to identify the species, but invariably without success, and conclude the form is new and rare. I have, therefore, very great pleasure in dedicating it to my old friend, our worthy Secretary, the Rev. Professor Wiltshire, F.G.S., as a humble but sincere acknowledgment of the great assistance he has given me in prosecuting this work. 
The extreme involution of the shell and the size and height of the outer whorl are the distinguishing features of this Ammonite. The sides are regularly convex, and ornamented with numerous slightly-elevated folds, best seen on the surface of the mould; in the lower two thirds they have a gentle inclination forward, in the upper third they bend more towards the aperture, a style of curvature which appears to be common to the entire group of the Oxynoti. The shell is only partially preserved. It is thin on the sides and thicker near the umbilicus; the surface appears to have had fine lines on the surface, which followed the bend of the folds. Both my specimens have suffered in cleaning, and the delicate shell sculpture is indistinguishable. The keel is blunt, from a thickening of the shell around this region, and I bave failed to observe the position of the siphuncle. The aperture is extremely lanceolate, and deeply encroached upon by the turn of the spire and the penultimate whorl.

The lobe-line is a very elegant and complicated foliation (fig. 3). The siphonal lobe has two long terminal diverging branches on each side, and several lateral ones with many digitations. The siphonal saddle is very complicated, and divided into two portions by a long central branch; the folioles are numerous, narrow, and deep. The principal lateral lobe is a large complicated structure, it has two large lateral branches internaliy, and three small digitations externally, and two branched terminal twigs. The lateral saddle is nearly as large as the principal lobe, and ends in four or five long, narrowbranched folioles. The lateral lobe is much smaller than the priucipal lateral, and has two lateral branches on each side, and a terminal one with three divisions. The lateral saddle is smaller but more regularly formed than the principal saddle, and terminates in many foliations. The auxiliary lobes, four or five in number, are elegantly branched, and the auxiliary saddles diminish in the size and number of their parts as they approach the umbilicus, the great height of the whorl necessitates a greater number and extension of the auxiliary lobes and saddles.

Affinities and Differences.-This Ammonite very much resembles Amal. Lymensis. It is altogether a more rotund shell, with more convex sides, and has a different style of lobe-line, which is apparent when we compare Pl. XLVII, fig. 3, with Pl. XLVIII, fig. 3.

Locality and Stratigraphical Position.-This Ammonite was obtained from the Green Ammonite Bed, near Charmouth, containing Belemnites longissimus, Miller, and Belemnites elongatus, Miller, and others that are indeterminable. I have found no other shells associated with it. 
Amaltheus Ibex, Quenstedt. Pl. XXXIX, figs. 4, 5.

Ammonites iвex, Quenstedt. Flözgebirge Würtembergs, p. 179, 1843.

- Boblayei, d’Orbigny. Paléont. Française Terr. Jurass., p. 25I, tab. 69, 1842.

- $\quad$ - Buckman. Murchison's Geology of Cheltenham, pl. xii, fig. 1, p. 89,1845 .

- IBEx, Quenstedt. Cephalopoden, p. 101, tab. 6, fig. 6, 1849.

- - Oppel. Mittlere Lias, Jahr. Würt., p. 87, t. 2, fig. 7, 1853.

- Boblatei, Morris. Catalogue of British Fossils, p. 290, 1854.

- IBEX, Quenstedt. Der Jura, p. 119, tab. xiv, fig. 5, 1858.

Diagnosis.-Shell discoidal, compressed; whorls two thirds involute, flattened on the sides, and ornamented with twenty-five to thirty short, wavy folds, which vanish at about two thirds the height of the whorl; siphonal area narrow, with twenty-five thick transverse nodules, the apparent termination of the bi-flexed lateral folds; aperture oblong, truncated anteriorly.

Dimensions.-Transverse diameter 80 millimètres; width of umbilicus 15 millimètres; height of aperture 40 millimètres; width 17 millimètres.

Description.-This very beautiful Ammonite is seldom well preserved, it is in general found in nodules of the Middle Lias, sometimes with its shell in a semi-fossil condition, and oftener in the form of moulds with a well defined sculpture thereon. The shell is discoidal and compressed; the volutions, five or six in number, are extremely involute, and the last whorl forms the conspicuous part of the disc; its sides are flattened, slightly convex, and ornamented with a number of bi-flexed folds or ribs, which are more pronounced in middle-aged shells like fig. 5, which shows a specimen in my collection magnified; here the ribs consist of two sets, the inner series occupy two thirds of the whorl, they are all flexed obliquely forward, and terminate abruptly in a thickened portion; the second series commence near the outer third, and pass very obliquely toward the margin where they form thick knobs which extend transversely across the siphonal area; between the series are found free indistinct ribbon-like impressions. In older shells, as in the specimen (fig. 4), the ribs on the middle of the volution are not so prominent, and gradually diminish on the body-chamber. The siphonal area is very narrow, and the obtuse knobs, developed at intervals in this region, resulting from the outer series of ribs impart a striking feature to the shell of this species, and liken it to the horn of an 1bex. The aperture is oblong and flattened on the sides; and the volutions of the inner whorls, from the narrowness of the umbilicus, can only be seen in young specimens. The lobe-line is peculiar, and has been well described and figured by d'Orbigny. As none of my specimens show this structure I quote his description.

"The siphonal lobe is as wide and much shorter than the principal lateral lobe, and 
ornamented with three points, of which the inferior one is bifurcated. The siphonal saddle is as wide as the principal lateral lobe, and terminates in five rounded leaves resembling palettes. The principal lateral lobe is formed of five branches, of which the large terminal one is trilobed. The lateral saddle, as wide as the principal lateral lobe, is composed of six leaves rounded like those in the siphonal saddle. The lower lateral lobe, one third smaller than the principal lateral, is ornamented also with five unequal branches. The other lobes gradually diminish in length and ornawentation as they approach the umbilicus."

Professor d'Orbigny appears to have had more than 100 specimens of this Ammonite before him for comparison, and from lis study of these varied forms at different ages has made the following observations." "This species is without contradiction one of the most singular in its varieties of age. Up to a diameter of 7 millimètres it is smooth, with a round inflated margin; its whorls are narrow, and frequently marked with deep furrows, which pass over the siphonal area; these furrows suddenly cease at this period of growth, the whorls become flattened and enlarged, and almost carinated on the siphonal area; they remain thus more or less for some time according to the individuals, and then commence to assume some lateral undulations. The nodosities on the back, and all the external ornaments, only usually show themselves when the shell attains about 20 millimètres in diameter, then the nodosities increase in size with the growth, whilst the radiating ribs of the sides appear, on the contrary, to become attenuated up to the greatest diameter of which we have knowledge. Among the large number of specimens that I have had the opportunity of comparing, I have found one remarkable variety having closer lateral ribs, with the knobs on the back at least three times as numerous as in the other specimens."

Affinities and Differences.-This Ammonite has few affinities in structure with its congeners, the large nodosities formed in the siphonal area by the rib-like structure that develop these, liken it to Amaltheus margaritatus; it is readily distinguished from that species by the greater width of the area, by its being more obtuse, and provided with much larger and fewer tubercles than are found in Amal. margaritatus. In early age the shell is without lateral spines, and the lobe-line much less complicated than in Amal. margaritatus.

Locality and Stratigraplical Position.-I have collected this Ammonite in nodules of ochreous Middle Lias from brick pits at Hewletts Hill, Southam, and Leckhampton, Gloucestershire; and Mr. Beesley records it from the Jamesoni Beds at Fenny Compton, Warwickshire. In France it has been collected from the Middle Lias at Contards, Vallèe de Saint-Pierre, près de Saint-Amand, Cher, Fresnay-le-Puceux, Calvados.

In Germany this shell is found in Swabia associated with Aeg. Maugenesti, Aeg. bipunctatum, Aeg. centaurus, and Aeg. Valdani.

1 'Paléontologie Française Terr. Jurassique,' tom. i, pp. 252 and 253. 
Amaltheus margaritatus, Montfort. Pls. LIII, LIV, figs. 1-3, and LVI, figs. 6$16,19,20$.
Ammonis cornu striatum striss rarioribus, langius. Hist. Lapid. Figuratorum Hel- vetiæ, p. 96, tab. xxv, fig. 2, 1708.
Connd Ammonis,
AMMONite,
Amaltheus margaritates,
Amonites acutes,
Nattilds rotula,
AmMonites STOKesi,
- AMALTHEUS,
- - Gibbosus
- Rotula,
- acuTus,
- amaltheos,
- Clevelandicus,
- amaltheus,

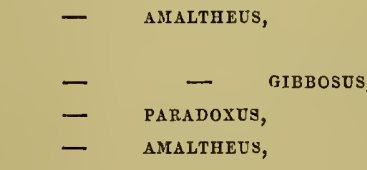
Aifaltheus margaritatus,
Seba. Thes, vol. iv, tab. 107, figs. 6, 10, 13, 1734.
Knorr et Walch. Tome II, p. 42, pl. A ii, fig. 3, 1768.
Montfort. Conchyliologie Systématique, t. i, p. 90, fig. xxiii, 1508 .
Sowerby. Mineral Conchology, vol. i, p. 51, pl. 17, fig. $1,1813$.
Reinecke. Nautili et Argonautæ, No. 5, p. 59, tab. i, figs. 9, 10, 1818.
Suwerby. Mineral Conchology, vol. ii, p. 205, tab. 191, 1818.
Schlotheim. Die Petrefactenkunde, p. 66, No 9, 1820 .
Ibid., No. 10, p. 66.
Young and Bird. Geol. Surv. Yorksh. Coast, p. 253, pl. 13, fig. 11, 1822.
Haan. Ammon. et Goniat, p. 106, 1825.
- Ibid., p. 108, 1825.
- Ibid., p. 105, 1825.
Phillips. Geology of Yorkshire, pl. xiv, fig. 6, 1829.
Zieten. Versteinerungen Württembergs, p. 4, pl. 4, fig. I, 1830.
Ibid., pl. 4, fig. 2.
p. 15 , pl. xi, fig. 6 .
Roemer. Norddeutsch. Oolithen-Gebirg., p. 188, 1836.
Bronn. Lethæa geog., p. 434, pl. xxii, fig. 13, 1837. Tate and Blake. Yorkshire Lias, p. 293, 1876.

Diagnosis.-Shell discoidal, much compressed; whorls one half involute, outer whorl flattened on the sides, slightly convex and transversely costated; costæ in form of doubly bent convex folds, the outer curve inclined forwards towards the aperture; siphonal area narrow and carinated; keel formed of short supplemental ribs, which grasp the margin of the whorl and have their angles directed forward, forming a rope-like structure extended along the outer margin; the external half of the whorls covered with close-set longitudinal lines; aperture narrow, compressed; and sagittate; lobe-line highly complicated. 
Dimensions._Large shell, Pl. LIII.-Transverse diameter, 200 millimètres; width of umbilicus, 52 millimètres; height of aperture, 92 millimetres. Small shell, Pl. LVI, fig. 15.-Diameter, 67 millimètres; width of umbilicus, 15 millimètres; height of aperture, 33 millimètres.

Description.-This has been a long well-known shell of the Middle Lias. De Montfort, who established the genus, says "the Amaltheus is still more flat than Planulites and Ellipsolitis. Many of the petrified shells of the genus have still preserved their nacre and lustre, others are ochreous and ferruginous. We find some that are more than five inches in diameter. The back of the Amaltheus, instead of being rounded, is carinated and armed with a crest, which renders the mouth triangular lanceolate. The specimen I figure is still nacreous, and came from the environs of Anvers. This genus is very numerous in fossil species; we find them in all the cabinets, but we do not yet know their living analogues, and for this reason we are obliged to place Amaltheus among sea shells, which perhaps happily hazard may bring to light some other day."

The shell is very much compressed and carinated; the sides of the whorls are ornamented with slightly elevated transverse ribs, which arise straight from the sides of the spiral suture, they first bend backwards and then incline forward towards the margin, where they vanish ; the siphonal area is narrow, and has on its outer border a rope-like prominent keel formed by a number of small short ribs which become imbricated, and incline forward in a ridge-like form (PI. LIV, figs. 1, 2, 3).

The spire is composed of six whorls (Pl. LIII), which are nearly two thirds involute; the outer whorl very large and embracing, leaves, however, all the inner turns of the spire visible. The whorls are very much compressed, they are thickest around the umbilicus and taper gently away towards the outer border. In well-preserved specimens more than two thirds of the width of the whorl is covered with fine, close-set, punctated lines, which follow the turn of the spire, and apparently proceed from the outer lamina of the shell; they are very well represented in Pl. LIII and Pl. LVI, figs. 10 and 15. The aperture is very narrow and compressed (PI. LIV, fig. 1), and forms an acute angle with slightly convex sides. The lobe-line is very complicated (Pl. LIII, fig. 1). The siphonal lobe is as wide but shorter than the principal lateral lobe, and ornamented on each side with two large lateral, each subdivided into several secondary, branches. The siphonal saddle is nuch wider than the principal lateral lobe, and terminates in five long leaves separated by prominent branches. The principal lateral lobe is highly developed, consisting of a central stem and several branches, two smaller internal and one larger lateral branch, with a long terminal branch having several lateral digitation's. The lateral is much smaller than the siphonal saddle, and terminates in four folioles much divided around their edges. The inner lateral lobe is much smaller than the principal lateral, and has a central stem with four lateral branches, all the sides of which are much incised. The auxiliary saddle is small with two terminal foliations, and the auxiliary lobes are small with sharp 
points for digitations. A radial line extended from the umbilicus to the siphonal lobe would pass through the middle of the principal lateral and touch the points of all the others.

The evolution of this Ammonite is extremely interesting. Several years ago I obtained a series of young shells from the Amal. margaritatus-bed near Reutlingen, Würtemberg, which show the morphological phases through which the shell passes. When it has attained the diameter of 10 millimètres, the sides of the whorls are round, and the straight ribs develop small tubercles about the middle, each rib then curves forward towards the keel (Pl. LVI, figs. 13 and 14); in the next stage (figs. 11, 12) the ribs are better clefined, and the tubercles more prominent; the siphonal area is proportionally much wider and forms a ridge with two angles as is shown in the aperture (fig. 12). Another variety, about the same age, is delineated in figs. 8,9 , the whorls are wider, and the ribs and tubercles more pronounced in figs. 19, 20. When the diameter of 17 millimètres is attained the whorls are still round, the ribs distinct, and develop a tubercle near the middle of their height, the ribs then bend sharply forward towards the aperture; the keel is now prominent with ridge-like, short, supplementary ribs set obliquely forward between the primaries. Fig. 10 , with a diameter of 22 millimètres, has the ribs well-marked, the tubercles blunted, and the outer half of the whorl encircled by fine longitudinal lines; the keel well marked and carinated, is notched by the angular ridge-like pieces. Figs. 6, 8, representing a form of 20 millimètres in diameter, has all the parts of the shell already described more fully developed, and the siphonal area exhibits its sharp prominent ridge and angular sides, bounded by a prominent tubercle on each side. A specimen before me, 31 millimètres in diameter, is a perfect example of the form figured by Quenstedt as Amaltheus coronatus, which has round whorls, short thick ribs, prominent tubercles, and two branches from each inclined towards the aperture; the keel prominent and nodulated, is altogether a very pronounced variety of the usual type. When the shell has attained 40 millimètres in diameter it then becomes Amal. depressus, Quenst. The ribs are biflexed and fiat; the keel rope-like and carinated, and the shell ornate with longitudinal punctated lines which encircle the outer whorl; the spines begin now to disappear, though they are seen all round the turns of the inner whorls when we examine the umbilicus. When the tubercles cease to be developed the shell assumes the form of its adult condition. In another specimen, of 70 millimètres diameter, the shell has attained all the characters so well displayed in the large adult shell, beautifully delineated in Pl. LIII.

Affinities and Differences. - The remarkable form which the keel assumes in this species resembles Amaltheus ibex, but is distinguished by its narrower area, acute ropelike carina, more triangular whorls, and more complicated lobe-line; some of its varieties assume shapes that resemble Amal. spinatus, but the ribs and spines of that species, with the thickness of its whorls, and the breadth of the siphonal area, form distinguishing characters by which the two species may be readily diagnosed from each other.

Locality and Stratigraplical Position.-I have collected fine specimens of this 
Ammonite from the Marlstone Rock Bed at Gretton, near Winchcombe, and at Dumbleton and Alderton, Gloucestershire ; South Petherton, Somerset; near Charmouth, Dorset; associated with Lytoceras finbriatus, where I have found them in the same block of rock. Professor Judd has collected numerous specimens of large size and great beauty in the Middle Lias Clays of Ouston, Billesdon, Roscart, Rutlandshire. In Yorkshire it is collected at Hawsker, Staithes, Rockcliff, Hummersea, Huntcliff, and Saltburn, from coast sections of the Marlstone Beds.

In France it has been collected from the Upper Beds of the Middle Lias in all the departments in which strata belonging to the Amal. margaritatus zone occur.

In Germany, in Alsace, near Uhrweiler, it is found in all its varieties in blue clay, beautifully preserved with its calcareous shell; at Metz, near the banks of the Moselle, imbedded in blue clay in great numbers. It is found in Swabia in many localities, and is widely distributed through the Middle Lias of Würtemberg; it is found at Wasseralfingen, Kirchheim, Metzingen, Sondelfingen, Breitenbach, Hinterweiffer, Hechingen, Frommern, Aselfingen, and at Wutach, according to Oppel, and in numerous localities throughout North Germany according to Brauns.

Amalthecs Engelhardti, $d$ Orbigny. Pl. LXX.

Ammonites Evgethardti, d’Orbigny. Paléontol. Française; Terr. Jurass., i, pl. 66, p. $245,1842$.

Diagnosis.-Shell discoidal, compressed; whorls compressed; sides flat and longitudinally costated; costæ consist of elevated ridges of shell closely approximated with longitudinal narrow valleys between the ridges; external costæ more closely approximated; siphonal area narrow, sharp, and cutting; aperture oblongo-lanceolate.

Dimensions: English specimen.-Transverse diameter 205 millimètres; width of unıilicus 30 millimètres; height of aperture 110 millimètres.

Frencl type specimen.-Transverse diameter 250 millimètres, in relation to the diameter width of the last whorl $\frac{40}{100}$; amount of involution $\frac{12}{100}$; thickness of the last whorl $\frac{16}{100}$; width of umbilicus $\frac{20}{100}$.

Description.-The shell of this interesting Ammonite is much compressed, subcarinated, and ornamented on the sides with small longitudinal costæ, not much elevated, and more closely approximated on the outer half of the shell. When the shell, which is extremely thin, is preserved the longitudinal costæ are crossed by very fine transverse striæ resulting from the growth of the shell, and giving a highly ornate appearance to the sides of the whorl. The extreme tenuity of the shell renders the opportunity rare for inspecting. 


\section{PALAONTOGRAPHICAL SOCIETY.}

INSTITUTEI) MI)CCCXLVII.

VOLUME FOR 1883.

L O N D O N :

MDccelxxxII. 



\title{
M ONOG RA PH
}

ON THE

\section{I A S}

\section{AMMONITES}

OF

\section{THE BRITISH ISLANDS.}

BY

\section{THOMAS WRIGHT, M.D., F.R.S., F.G.S.,}

VICE-PRESIDENT OF THE PALÆONTOGRAPHICAL SOCIETY; CORRESPONDING MEMBER OF THE ROYAL SOCIETY OF SCIENCES OF LIÈGE; THE SOCIETY OF NATURAL SCIENCES OF NEUCHÂTEL; VICE-PRESIDENT OF THE COTTESWOLD NATURALISTS' FIELD CLUB; CONSULTING SURGEON TO THE CHELTENHAM HOSPITAL; AND MEDICAL OFFICER OF HEALTH TO THE URBAN SANITARY DISTRICTS OF CHELTENHAM, CHARLTON KINGS, AND LECKHAMPTON.

\section{PAR'T SIX'IH-DESCRIP'TION OH' SPECIES.}

Pages 401-440; Plates LXX-LXXVII.

\author{
LON DON .
}

PRINTED FOK THE PALEONTOGRAPHICAL SOCIETY. 
PRINTED BY

3. F. ADLARD, BARTHOLOMEW CLOEK. 
this character, which, however, is fairly shown in portions of the fine specimen figured in Pl. LXX. The shell is extremely involute, and has a much smaller umbilicus than its associated species, Amal. margaritatus, with which in other respects Amal. Engelhardli stands in very close relationship. The siphonal area is very narrow forming a sharp keel, the margin of which is in general smootlly rounded and sometimes obscurely crenated; the spire is composed of very compressed whorls, which become thinly flattened away towards the siphonal area, and thickened near the nmbilicus, around which they present an obliquely truncated wall; the aperture is high, oblongo-lanceolate, narrow, and compressed, its sides form an acute angle, rounded internally, where it embraces three fourths of the penultimate whorl. The suture-line is extremely complicated, forming a number of extremely minutely divided lobes, and in this respect differing from the suture-line of Amal.margaritatus (Pl. LIII). By taking an impression of one of these my artist has been enabled to give a very accurate delineation of the sutural ontline, which he has placed in situi on the figure, and which is now drawn for the first time. Of this structure d'Orbigny said, "Je n'ai pu les apercevoir assez pour les dessiner et les dècrire." The siphonal lobe is large and composed of several long lateral branches. 'The siphonal saddle is wide and terminates in small narrow folioles. The principal lobe is very large, it has a long, terminal, ramified stem in the centre, and three lateral ramified stems on each side, all of which are highly digitated. The lateral saddle is much smaller than the siphonal saddle, and terminates in six narrow folioles. The internal lateral lobe is much smaller than the principal lateral, and consists of a central stem terminating in a trifurcation, with two divided branches on each side of the central stem. The auxiliary lobes are small, with delicate pointed ramifications, and the auxiliary saddles terminate in minute rounded folioles; the sutural-lines are so closely approximated on the sides of the mould in consequence of the narrowness of the chambers that they present an inextricable labyrinth to the student, and require a most careful study in order to follow them out through all their windings.

I have not seen a young shell of this species, nor had d'Orbigny, but he felt assured that it presented the same characters throughout at all ages, and that it was not an adult variety of Amal. margaritatus. Young and Bird ${ }^{2}$ described an Ammonite under the name $A$. lenticularis, which appears to be identical with Amal. Engelliardti. They say "the exterior of the whorl runs to a thin edge, plain, or very faintly crenated; the sides are smooth or marked with very faint undulating lines; the central part is an umbilicus, with upright sides, the inner whorls being scarcely visible and the aperture forms a triangle, of which the outer angle is extremely acute, owing to the thinness of the edge." Mr. Simpson ${ }^{2}$ has described. A.reticularis, which agrees so well with Amal. Engelhardti that, in the absence of figure, or specimen, his diagnosis may be considered identical. "Volutions five, inner ones more than three fourths concealed; outer whorl one half the diameter, most convex on the outer half. Transverse striæ numerous, fine, waving, crossing ; numerous fine, longitudinal striæ; keel

1 'Geological Survey of the Yorkshire Coast,' 2nd ed., p. 269, 1828.

2 'Fossils of the Yorkshire Lias,' p. 78, 1855. 
rounded and slightly crenated by striæ; aperture triangular or slightly ovate. Found in the ironstone bands of the Middle Lias along with A. Hawskerensis."

Affinities and Differences.-This species very much resembles Amal. margaritatus, of which it may be only a variety of that well-defined form. Those naturalists who insist upon the distinctness of the two species point to the longitudinal ribbing of the shell, the larger amount of the involution of the whorls, and smallness of the umbilicus in Amal. Engelhardti, the more complicated convolutions of the suture-line and the minute subdivisons of the lobes and saddles, and likewise the fact that the same characters are persistent throughout its life-history which approximate to, but are distinct from, some of the more lenticular varieties of Amal. margaritatus.

Locality and Stratigraphical Position.-This Ammonite has been collected from the upper portion of the Marlstone beds of the Middle Lias at Grettan Hill, near Winchcombe, and at Stinchcombe Hill by Dursley, localities which have yielded all the fine specimens I have obtained in Gloucestershire. It is found in the same bed at Yeovil, South Petherton, and Ilminster, Somersetshire, along with Amal. spinatus. In Yorkshire it is collected from the Amal. spinatus-zone, in the rich ironstone beds at Eston, Upleatham, Hawsker, \&c., so that its true horizon is the uppermost strata of the Middle Lias.

Amaltheus spinatus, Bruguière. Pl. LV, figs. 1 and 2 ; Pl. LVI, figs. 1-5.

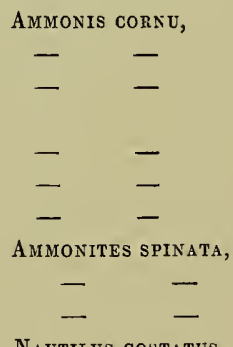

NaUtilus costatus,

Ammonites angulatus,

- costatus,

- spinatus,

- HatSKERENSTS,

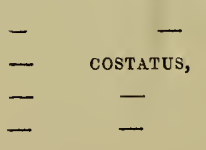

Lachmund. Oryctogr. Hildesheim, p. 49, 1669.

Lister. Hist. Animal. Angliæ, p. 207, tab. vi, fig. 3, 1678. Synops. Conchyl., Edit. alt., tab. 1041, fig. 21, 1770.

Baier. Oryctographia norica, p. 64, tab. 3, figs. 4, 5, 1708. Leibnitz. Protogæa, p. 41, tab. 5, 1749.

Knorr and Walch. Petrif., tom. ii, t. A II, fig. 1, 1755.

Bruguière. Encycl. Méthod., t. i, p. 40, No. 14, 1792.

Bosc. Buffon de Déterville, t. $\nabla, \mathrm{p} .176,1801$.

Roissy. Hist. des Mollusques, t. $\nabla$, p. 25, 1805.

Reinecke. Naut. et Argon., p. 87, tab. ix, figs. 68, 69, 1818.

Schlotheim. Die Petrefaktenkunde, p. 70, No. 16, 1820. Ibid., p. 68 , No. 12,1820 .

Haan. Mon. Amm. et Goniatites, p. 102, No. 1, 1825.

Young and Bird. Geol. Survey, p. 258, pl. xiv, fig. 6, 1828.

Phillips. Geol. of Yorkshire, pl. xiii, fig. 8, 1829.

Zieten. Versteiner. Würtemb., p. 5, pl. iv, fig. 7, 1830.

Roemer. Norddeut. Oolithengebirg., p. 188, No. 16, 1836.

Bronn. Leth. geognostica, Bd. i,p. 436, t. xxii, fig. 12, 1837 


\section{Aumonites Hawskerensis, Simpson. Foss. York. Lias, p. 90, 1855.
- spinatus, d'Orbigny. Pal, Française, Ter. Jurass, t. 52, p. 209, 1842.
- costatus, Quenstedt. Die Cephalopoden, pl. v, figs. $10 a, b, 1849$.
- spinatus,
Giebel. Fauna der Vorwelt, Bd. iii, p. 537, 1852.
Chapuis et Dewalque. Fossiles terr. secondaires, Mém. cour. l'Acad. Roy., tom. $\mathbf{x x y}$, p. 49 , pl. vi, fig. 4,1854 .

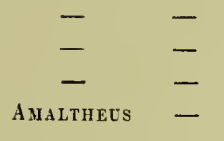 \\ Mrorris. Catal. British Fossils, p. 295, 1854. \\ Dumortier. Dépôts Jurassiques, partie iii, p. 213, 1869. \\ Brauns. Untere Jura, p. 240, 187 !. \\ Neumayr. Zeitschr. Deutsch. geol. Gesellsch., Bd. xxrii, p. 886,1875 . \\ Tate and Blake. Yorkshire Lias, p. 295, 1876.}

Diagnosis.-Shell discoidal, compressed, slightly involute; umbilicus widely open ; ribs prominent, sharp, bituberculated, separated by wide valleys, straight on the sides, and bent suddenly towards the aperture at an acute angle; siphonal area wide and concave; keel prominent, crenated, with small clevroned ribs, convex anteriorly ; aperture quadrangular, outer border with two sinuses separated by the median carina, inner border slightly grooved by the turn of the spire.

Dimensions-large shell.-PI. LV. Transverse diameter 180 millimètres; width of umbilicus 75 millimètres; height of aperture 60 millimètres, width 70 millimètres.

Sinaller shell.-Pl. LVI, fig. 5. Diameter 100 millimètres; width of umbilicus 43 millimètres; height of aperture 34 millimètres, width 30 millimètres.

Sinallest shell.-Pl. LVI, fig. 1. With test preserved showing the sharpness of the spines, ribs, and carina. Diameter 53 millimètres; width of umbilicus 22 millimètres; height of aperture 17 millimètres, width 18 millimètres.

The measurements of the French specimen, given by Professor A. d'Orbigny, were made on a shell, 135 millimètres in diameter, and the proportions in relation to the diameter were-width or height of the last whorl $\frac{31}{100}$, involution of the whorls $\frac{7}{10} \overline{0}$, thickness of the last whorl $\frac{31}{100}$, width of umbilicus $\frac{40}{100}$.

Description.-This is one of the most characteristic Ammonite-forms from the upper beds of the Middle Lias, always presenting its typical features and appearing as a leading fossil in the horizon to which it is limited. The shell is discoidal, compressed, with a wide siphonal area, having an elevated keel in the middle with concave depressions on each side ; the keel is formed of short chevroned ribs, which produce a carinated structure with small arches, the convexities of which are directed forwards; the ribs, twenty-two to twenty-four in number, are sharp and straight on the sides, and bent forward towards the aperture at the angle; they each carry two tubercles, one blunt near the umbilical space, and another sharp, prominent, and thorn-like, near the siphonal angle; these spines are very distinct when the shell is preserved, as in Pl. LVI, fig. 1, but are not so demonstrable on the mould ; the angle formed by the bending of the rib develops another considerable prominence of 
shell, which bas been mistaken for a third tubercle; the sides have wide concave valleys which separate the ribs from each other and clearly define their structure and character.

The whorls are slightly involute, and the umbilicus is therefore widely open, exposing the straight sides of all the ribs with their bituberculated eminences on each, and hence the umbilicus of this Ammonite has a highly ornate interior, which, together with the breadth of the siphonal area, and its bold, oblique ribbings and carinated keel, cause this species to be one of the liandsoniest shells in the Lias formation, as may be seen in this figure on Pl. LV. The aperture is nearly quadrangular, it presents two sinuses on its. external border, which are separated by the median carina, and the inner border is slightly indented by the return of the spire (Pl. LV, figs. 1 and 2, and Pl. LVI, figs 3 and 5).

The sutural-line is rather complicated, and forms three lobes and as many saddles. The siphonal lobe is as long but not so wide as the principal lateral (Pl. LVI, fig. 4), it is ornamented on each side with four lateral branches and a terminal tuft of digitations. The siphonal saddle, wider than the principal lateral, is rounded above and divided into three accessory lobules, their size augmenting in length and width from without inwards. The principal lateral lobe is wide below, and ornamented with five branches, two lateral and one large terminal, each having several simple digitations. The lateral saddle is much smaller than the principal lateral lobe, and terminates in one round terminal and two lateral, unequal folioles on each side; of the two accessory lobes the external is the longest, and consists of a stem witl several simple digitations, the internal is short and. terminates in a point. The auxiliary saddles are very snall, and terminate in two folioles.

The morphology of this species, when traced by a series of specimens, is very interesting. Up to a size of $2-3$ millimètres the shell is entirely smooth with a round siphonal area, and its sides are covered with short, straight ribs; the siphonal area. remains round until it attains 7 millimètres in diameter. The median line now becomes. slightly prominent, and when a diameter of 12 millimètres is attained a keel makes its appearance. When the shell has grown to 34 millimètres in diameter, it has acquired all its ornamentation, and at 54 millimètres the row of external tubercles is very large and prominent. At abont 180 millimètres (Pl. LV) it has attained its full measure of development; as old age draws on the ribs are not so numerous, and the tubercles are less prominent. There are some differences in the form of the shells which may probably depend upon sexual characters, such as a greater or lesser flattening of the shell in certain individuals, but as this is a problematical subject, I merely touch upon it here, as we have no facts on which to found any decided opinion.

Affinities and Differences.-In early life this species very much resembles Amalliens: margaritatus, but as growth proceeds its specific characters gradually evolve themselves, and finally new lines of development separate each form into its own special type, the uarrorv siphonal area of Amal. margaritatus with its deeply carinated keel, the longitudinal lines of punctations and lateral undulatory folds on the sides, produce a form widely different from the typical Amaltheus spinatus figured in Pl. LV. 
Locality and Stratigraphical Position.-This Ammonite is found in the uppermost strata of the Marlstone Rock bed of the Midland Counties, where I have collected it in the Marlstone quarries at Grettan, Alderton, Churchdown, and Stinchcombe Hills. In Somersetshire it is found at South Petherton and Yeovil. In Dorsetshire the bed with Amal. spinatus forms the uppermost portion of the micaceous marls of De-la-Beche, consisting of brownish sands and sandstones with this species as the leading fossil. Associated with this Cephalopod are many Gastropods and other fossils with their shells intact, and in a fine state of preservation. From the extreme hardness of the rock they are extracted witl extreme difficulty. I liave collected herc Amaltheus spinatus, Brug.; Belemites breviformis, Voltz; Pleurotomaria precatoria, Deslong. ; $P$. bitorquata, Deslong. ; P. rustica, Deslong. ; $P$. mirabilis, Deslong. ; $P$. procera, d'Orbigny; Cryptania expansa, Sow.; Straparollus sinister, d'Orb. Resting on this remarkable conglomeration of well-preserved shells are beds of Upper Lias Limestone with Harpoceras serpentinum, Reinecke. Professor Judd, 'Geology of Rutland,' found this species in the Marlstone Rock bed, along the sides of the Oakham and Melton-Mowbray Canal, and in a stone-pit nortl-west of the village, where it appears to be rare. In Yorkshire the Amal. spinatus-beds are well seen at Hawskers bottoms. Another section of these beds is found at Kettleness, where they form the base of the cliff, and have been long known as the "Kettleness beds" of Young and Bird. The Ironstone series of Old Nab, near Staithes, is chiefly formed of the Amal. spinatus-beds (see section of this coast, p. 105); and the reader is referred to an exhanstive acconnt of the equivalent deposit in Tate and Blake's 'Yorkshire Lias,' p. 11S. Professor Tate found the Amal. spinatus-bed at the south side of Portree Harbour, Isle of Skye. For a list of fossils in this bed, see p. 107.

Foreign Distribution.-In France the Amal. spinatus-beds are found at FontaineEtoupe-Four, Curcy, Croisille, Evreux, Vieux-Pont, Calvados ; Avesnes, Doubs ; HauteSaone ; Salins, Jura ; Saint-Antand, Cher ; Saint-Fortunat, Rhône; Department of Aveyron. In Luxemburg at d'Aubange, near Athus. In Italy this zone is likewise found in Lombardy ; and Province of Brescia (Reynès).

In Germany the Amal. spinatus-beds are found in Tönnisberg, Hanover; Winzenburg, Westerberg; Helmstadt, Goslar, Huttenberg; Quedlinburg, Kley ; Falkenhagen, Lauter, Bayreuth, and several other localities. In Sonth Germany this zone is found in Swabia; one of the best exposures is in the vicinity of Altdorf in Bavaria, where it is found well displayed in relative position to the Amal. margaritatus-bed below, and the Posidonomyan or Upper-Lias schists above. 


\section{Family.-LYTOCERA'TID止, Neumayr, 1875.}

This family includes several genera which differ very much in external form, but closely resemble each other in internal structure. The shells are elongated cones rolled into cornute whorls, more or less involute, in the spire. They have a short body-chamber about two thirds the length of last turn ; the mouth-aperture is circular and slightly produced on the columellar side. So far they have characters in common, but in the form of the shell, and in the morphological changes at different periods of life, the divergence from a common type is extreme. This becomes evident when we compare Lytoceras and Phylloceras with each other and these again with Hamites, Turritites, and Baculites, all of which are grouped together in the natural family Lytoceratidæ.

\section{Genus IV.-Lytoceras, Suess, 1865.}

Shell discoidal, more or less flattened; umbilicus wide and open, exposing all the inner turns of the spire; the whorls round and loosely embracing each other. Body-chamber two thirds the length of the last whorl ; mouth-border simple in the lateral and ventral sides, with a lappet-like production resting on the preceding whorl at the columellar side.

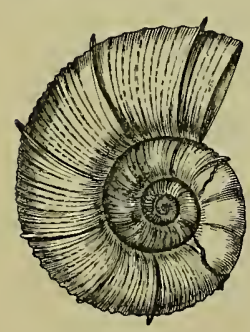

Fig 193.-Lytoceras fimbriatum, Sow.

The shell is highly ornate by the presence of transverse parallel lines of growth which encircle the whorl, crossed at right angles by longitudinal ridges, these together form a remarkable reticulatc structure in Lytoceras cornucopia, Young (Pl. LXXIII). The shell of several species is ornamented with wing-like elevations forming prominent fringed ribs as in Lyt. fimbriatum, (Pls. LXXI and LXXII), or deep intermittent depressions formed from previous contractions of the aperture as in Lyt. hircinum, (Pl. LXXV, fig. 4), or rounded ribs as Lyt. torulosum (Pl. LXXVI, fig. 4).

The suture-line is very complicated and very well shown in $L y t$. cornucopia (Pl. LXXIII, fig. 3). The lobes are few in number but much branched; the lateral lobes and saddles are much divided into small, uniform, symmetrical digitations; there are only two lateral, one very large principal, and a small lateral, with a large columellar lobe covered by the preceding whorl, see (Pl. LXXIII, fig. 3). The siphonal lobe is small and narrow, and almost concealed by the wide-spreading branches of the principal lateral.

The genus Lytoceras is found first in the Trias, where it is represented by Lyt. Morloti, Hauer; Lyt. spharoplyllum, Hauer ; Lyt. patens, Mojs.; and Lyt. engyrum, Mojs. 
In the Lias it appears in the Marlstone (Middle Lias) as Lyt. fimbriatum, and Lyt. lineatum, in the Upper Lias in the zone of Harpoceras bifrons as Lyt. cornucopia, and in the zone of Lyt. Jurense as Lyt. Jurense, Lyt. hircinum, and Lyt. torulosum.

Lytoceras fimbriatum, Sowerby. Pls. LXXI, fig. 1 ; LXXII, figs. 1-4.

Ammonites fimbriatus, Sowerby. Min. Conchology, vol. ii, p. 145, pl. 164, 1817.

- - Hann. Amm. et Goniat., p. 135, No. 79, 1825.

- $\quad$ - Keferstein. Naturgesch., ii, 401, 1834.

- - von Buch. Pétrif, remarq., tab. viij, fig. 2, 1831.

- $\quad$ - Roemer. Norddeutschen Oolitligeb., p. 194, 1836.

- _ Zieten. Versteinr. Würtemb., p. 16, tab. xii, fig. 1, 1830.

- - - d'Orbigny. Pal. Fr., Terr. Jurass., t. i, p. 313, pl. 98, 1842.

- Lineatus var. Fimbriatus, Quenstedt. Flözgebirge Würtemb., p. 171, 1843

- - - - Cephalopoden, p. 103, 1849.

- Lineatus, Oppel. Mittlere Lias Schwabens, p. 50, 1853.

- fimbriatus, Morris. Catal. British Fossils, p. 292, 1854.

- $\quad$ - Simpson. Yorkshire Lias, p. 40, 1855.

- - von Hauer. Cephalopod, N. E., Alp., p. 62, pl. xxii, figs. $1-4,1856$.

- Lineatus, Quenstedt. Der Jura, p. 134, tab. xvi, fig. 13, 1858.

- Fimbriatus, Dumortier. Dépôts Jurassiques, partie iji, p. 92, 1869.

- $\quad$ - Brauns. Untere Jura, p. 234, 1871.

Lytoceras fimbriatum, Neumayr. Zeitschr. Deutsch. geol. Gesellsch., Bd. xxvii, p. 893,1875 .

- $\quad$ - Tate and Blake. Yorkshire Lias, p. 297, 1876.

Description.-This Ammonite was first figured and described by Mr. James Sowerby from a specimen collected at Lyme Regis by the late Dr. Buckland. The fragment that formed the subject of the Plate was very imperfect and has long been much misunderstood. Sowerby ${ }^{1}$ says " that the mouth in a full-grown shell is furnished with an undulated reflected lip or ruffle, and the more or less perfect formation of this at various periods produces either undulating lines of growth, some of which are obtuse and others acute, or thin, annular fimbriæ surrounding the volutions at certain intervals. The obtuse lines of growth are indented at their backs, but straight towards the mouth and indicate that the undulation of the lip is strongest at the back of it. The whorls do not appear to have been very numerous ; the shell is thin, and the margins of the septa have rounded lobes."

The very beautiful specimens figured in Pls. LXXI and LXXII obtained from the Marlstone beds at Lyme Regis, exhibit in a satisfactory manner the anatomy of the shell of this splendid Ammonite. The shell is discoidal and formed of a round, elongated cone, a little compressed on the sides and rolled up into a disk, the volutions of which

1 'Mineral Conchology,' vol. ii, p. 145, tab. clxiv. 
are only slightly involute. The shell is thin and ornamented transversely with from eighty to one hundred elevated striæ, the free margins of which in perfect specimens are fimbriated as shown in Pl. LXXI, and between these striæ, as they cross the siphonal area, a number of smaller intermediate striæ are introduced. Besides these regular fimbriated annular striæ the outer whorl exhibits from eight to twelve prominent plates, which stand boldly outwards and embrace the entire circumference of the volutions. These remarkable processes are finely preserved and carefully cleaned out in the splendid specimens figured in Pls. LXXI and LXXII.

The siphonal area is well rounded (Pl. LXXII, fig. 3), and partitioned off by the wing-like foliations ; the body-aperture (Pl. LXXII, fig. 2) is oblong, only slightly grooved by the last turn of the spire; the sides are a little compressed, and the lip is thickened by an oral band shown to be a product of the mantle, which periodically put on increased formative activity and developed annular bands of shell-growth eight or ten times during the evolution of the last whorl.

The sutural line is very complicated, and the siphonal lobe (Pl. IXXII, fig. 4) is much smaller than the principal lateral. Each stem has four lateral branches, of which the two posterior are the longest and most digitate. The siphonal saddle is small and divided into two portions by the multidigitate cliaracter of the lobes.

The principal lateral lobe is very large and springs from a thick stem which divides into two large branches, each of which subdivides into a number of digitations producing an arborescent character in this well-developed lobe, as shown in Pl. LXXII, fig. 4 .

The principal lateral saddle is much smaller than the lobe and formed of two unequal parts by a central secondary lobe, the external portion is the largest and most ramified.

The internal lateral lobe is about half the size of the principal, and like it has a central stem bifurcating into two branches which subdivide into several smaller branchlets.

The accessory lobe is formed of small oblique digitations, and the corresponding saddle is proportionately wider than the others, where it rests upon the involution of the spire.

The evolution of this species is only imperfectly known. D'Orbigny stated that when a young shell had attained a diameter of 12 millimètres and retained its test, he had noticed transverse striæ and indications of laminæ. In older shells these characters became more developed; in one shell, 30 millimètres in diameter, the specific characters were well shown, and the lateral striæ were very small; the vertical laminæ on the sides were inclined obliquely forward, and were vertical across the area.

The mould when entirely denuded of its shell is smoolh; at those parts where laminx have existed, depressions instead of prominences, may be observed; these mark the former successive terminal apertures of the body-chamber.

Affinities and Differences.-This species has been often confused with Lytoceras cornucopia. In Lyt. fimbriatum the whorls are narrower and compressed on the sides, 
whilst they are more convex and laterally inflated in Lyt. cornucopia. D'Orbigny has further observed that in Lyt. fimbriatum there are only two lateral lobes, whilst in Lyt. cornucopia there are three lateral lobes. To these differential characters it may be added that the shell is deeply ornate, and has a series of longitudinal strix which intersect at right angles the transverse strix, but produce a less regular square-celled structure than in the shell of Lyt. cornucopia. The wing-like elevations are more numerous and less elevated in cornucopia than they are in fimbriatum.

Locality and Stratigraphical Position.-Lytoceras fimbriatum had a considerable range of distribution in time during the deposition of the Middle Lias. I have collected this Ammonite in the Aeg. Jamesoni, Aeg. Henleyi, and Amal. margaritatus beds in the Counties of Gloncester, Somerset, and Dorset. The finest specimens were those collected near Charmouth, from a sandy stratum, associated with Amaltheus margaritatus.

Lytoceras lineatum, Schlotheim; Pl. LXIX, fig. 1.

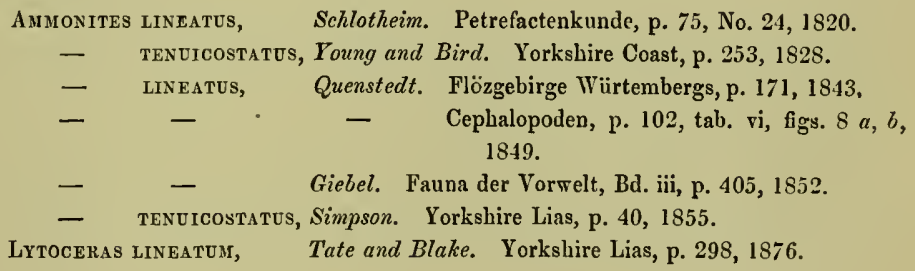

Diagnosis.-Shell discoidal, volutions five, all exposed, rapidly diminishing in size; outer whorl two fifths the diameter of the shell; numerous fine, hair-like ribs, commencing at the suture, inclining gently towards the aperture, passing across the broad, round, siphonal area, and uniting with the ribs from the opposite side; the fine ribs are feebly fimbriated, and there are two wing-like elevations on the last whorl.

Dimensions.—Transverse diameter 168 millimètres; width of umbilicus 62 millimètres ; height of aperture 70 millimètres.

Description.-This Ammonite possesses a leading feature, which is well expressed in the list of synonyms given above, but whether the numerous, slender, annular ribs with fimbriated margins encircling the whorls constitute a character of sufficient importance to differentiate a species distinct from Lyt. fimbriatum, with which it has so many points of structure in common, may well be doubted, I would prefer considering Lyyt. lineatuns as a small-ribbed variety of the typical Lyt. fimbriatum I have described in detail, and of which $I$ have figured several very beantiful examples. If Sowerby's type figure ('Mineral Conchology, vol. ii, pl. 164) be compared with Pl. LXIX, fig. 1, it becomes evident 
that both represent a similar object. This affords an illustration of the confusion and misunderstanding arising from authors publishing imperfect specimens as types of species, and imparts a lesson to all palæontologists to excrcise the greatest care in the selection of well-preserved examples for figures of new species. If this be not done endless trouble is entailed on those who in after years have to consult plates in original works; in fact it may be truthfully said that many of the figures of our predecessors are utterly useless and misleading when critically compared with better examples of the objects themselves that have been subsequently discovered.

This specimen from my collection has much of the thin shell well preserved; and the delicate fimbriæ on the free side of the numerous annular ribs are all directed obliquely forward, indicating the ornate character of this beautiful Cephalopod when it floated in the Jurassic sea. The whorls are extremely evolute, hence the fragmentary condition in which it is so often found. The penultimate whorl when perfect exhibits four winglike projections at about equal recurrent intervals in the length of the whorl, the last whorl, which appears to have been the body-chamber of the Ceplalopod, has only one of these processes, although they appear to have been developed in the inner whorls.

Affinities and Differences.-I consider this form to be only a fine-ribbed variety of Lytoceras fimbriatum, and I assume that the shells figured in Pl. LXXI and Pl. LXXII are the most perfect types of the species.

Locality and Stratigraphical Position.-I collected this specimen at Lyme Regis from a dark, shaly stratum of the Middle Lias, which readily wasted away when washed in water, but which has since dried up hard and has well preserved my formerly fragile specimen.

Lytoceras corndcopia, Young and Bird. Pl. LXXIII, figs. 1-3.

Ammonites corndcopia, Young and Bird. Geol. Surv. York.,p. 252, pl. xii, fig. 6, 1822.

$\begin{array}{llrl}- & \text { nitidus, } & \text { Ibid., p. 256, pl. xii, fig. 8, } 1828 . \\ \text { - } & \text { BnLtentus, } & \text { Phillips. } & \text { Geol. York., pl. xii, fig. 17, 1829. }\end{array}$

- fimbriatus, Simpson. Monogr. Amm., p. 16, 1843.

- - Z Zieten. Versteiner. Würtemb., p. 16, pl. xii, fig. 4, 1830.

- $\quad$ - Bronn. Leth. geognostica, Bd. I, p. 441, Tf. xxiii, fig. 2, 1837.

- cornucopis, d’Orbigny. Paléontol. Française, Ter. Jurass., tom. i, p. 316, pl. 99, 1842.

- CORnucopiæ, Dumortier. Depôts Jurassiques du Rhône, partie iv, p. iii, pl. $x x i x, 1874$. 

Ammonites fimbriatus, Quenstellt. Flözgebirge, p. 260, 1843.
- cornucopix, Giebel. Fauna der Vorwelt, Bd. iii, p. 396, 1852.
- - - Chapuis et Dewalque. Terr. Second., Mém. Cour. Acad. Roy.,
- Conndcopia, Simpson. Fossils of York. Lias, p. 40, 1855.
- Fasciatus, - Ibid., p. 41, 1855.
- Fimbriatus, Brauns. Der untere Jura, p. 235, 1871.

Lytoceras cornucopie, Neumayr. Zeitschrift Deutsch. geol. Gesell., Bd. xxvii, p. $893,1875$.

- Connucopia, Tate and Blake. Yorkshire Lias, p. 298, 1876.

Diagnosis.-Shell discoidal; whorls round and slightly depressed, encircled with from eighteen to twenty prominent, annular, undulating fimbriæ, with erect lamellæ; surface of the shell covered with transverse and longitudinal striæ, which cross each other and produce a successive series of small quadrate cellular depressions in the shell texture; whorls nearly evolute; siphonal area convex; aperture flattened at the sides.

Dimensions.-The figure is half the natural size. Transverse diameter 320 millimètres; width of umbilicus 126 millimètres; height of aperture 120 millimètres; transverse diameter of aperture 110 millimètres.

Description.-This is a very hanàsome Ammonite, which sometimes attains considerable dimensions. The finest specimen I have seen is in the Geneva Museum, for which it was purchased from a celebrated French collection of Upper-Lias fossils from Verpillière, Isère. By the kind permission and aid of my friend, Monsieur P. de Loriol, I had a very accurate delineation of this specimen, of the natural size, drawn by Monsieur Lunel, of Geneva, and have reduced his figure one half natural size to come into the plate. Having failed to discover in any of our museums an English specimen good enough for delineation in this work, I have had the French specimen drawn as a magnificent example of the typical characters which this species exhibits and especially in the ormamentation of its beautiful sculptured surface.

The shell is discoidal and slightly compressed on the sides. The whorls are round and nearly evolute, so that the whole of the inner whorls are fully exposed. The outer whorl is encircled by eighteen annular undulating fimbriæ, with erect, pointed lamellæ directed backward, the whole of the rest of the surface being covered with transverse and longitudinal strix, which cross each other at right angles and evolve a consecutive series of small quadrate or polygonal cellular depressions, with raised walls, in the texture of the shell. The whorls are almost evolute, and the whole of the six volutions are exposed in the fine specimen herein figured. The siphonal area is romd, and on it the elegant sculpturing of the shell is well displayed. The aperture is nearly round and only slightly flattened on the sides. In the opening lies embedded in the matrix a specimen of Harpoceras bifrons, one of the leading shells of the Upper Lias, and indicating the zone to which Lyt. cornucopia belongs. 
The sutural line is "extremely tortuous and followed with much difficulty; it forms three lobes and three saddles and some accessory parts. The siphonal saddle is smaller than the principal lateral lobe, and divides into two branches, each of which terminates in trifid folioles. The siphonal lobe is much smaller than the principal lateral, and formed of two nearly equal parts deeply divided in the middle. The principal lateral lobe forms two large, highly-ramified branches (Pl. LXXIII, fig. 3), which arise from a multibranched stem. The outer lateral saddle is much smaller than the superior lateral lobe, its central stem divides into two trifid folioles, with a central stem dividing them (fig. 3). The inner lateral lobe is not half the size of the principal lateral, and its stem, with lateral twigs, divides into two nearly equal-sized trifid terminal branches. The auxiliary saddle terminates in three folioles, and the auxiliary lobe is very short and divides into two long branches.

The late Professor A.'d'Orbigny had an opportunity of studying some young forms of the shell, and his observation amounts to this that Lyt. cornucopia is very variable in form according to the different states of conservation in which it is found, and the precise age when it is examined; a shell of the diameter of 25 to 30 millimètres is ornamented with striæ united into fasciculi, and each is separated from the other by a furrow. Like Lyt. fmbriatum it has, according to the age of the individual, prominent undulating fimbriated ribs. When the external layer of the shell exists there are small ribs with very prominent festoons; when this layer is wanting the inner layer still retains feeble impressions, the mould, however, only shows a surface altogether smooth.

Affinities and Differences.-This species is closely related to Lyt. fimbriatum, it has the rounded whorls, prominent ribs, and fimbriated margin of that species, but the whorls are larger and more evolute, and the lobes and saddles are somewhat different.

Locality and Stratigraphical Position.-This Ammonite is collected from the Upper Lias with Harpoceras serpentinum at Whitby and Runswick, and with Stephanoceras annulatum, according to Prof. Blake, at Millington, Yorkshire. I have not met with it in the Midland Counties, nor in any collection of Upper-Lias fossils derived from this region, so conclude it is a rare form in the Midland district.

Foreign Distribution.-Professor d'Orbigny enumerates Ligny, near Lyon; Muhlhausen, Gundershofen, Bas-Rhin; Mende, Lozère; Fressac, Gard; Belvédère près de St. Amand, Cher ; Clapier, Aveyron; Charolles, Saône-et-Loire.

Monsieur Dumortier ${ }^{1}$ says A. cornucopia " is one of the most persistent and most important fossils of the zone; it is accompanied throughout by $A$. bifrons, and is recognised of all sizes. The mines of Verpillière have yielded a great number of very beautiful specimens (Pl. LXXIII an example), some of these were 400 millimetres in diameter. The test is well preserved, and does not appear to lave suffered the least alteration in its form."

1 'Etudes Paléont. sur les Dépôts Jurassiques du Bassin du Rhône,' tom. iv, p. 113, 1874. 
Lytoceras Jurense, Zieten. Pl. LXXIV, figs. 3-5 ; Pl. LXXIX.

Amonites Jurensis, Zieten. Versteiner. Würtemb., p. 90, tab. lxviii, fig. 1, 1830.

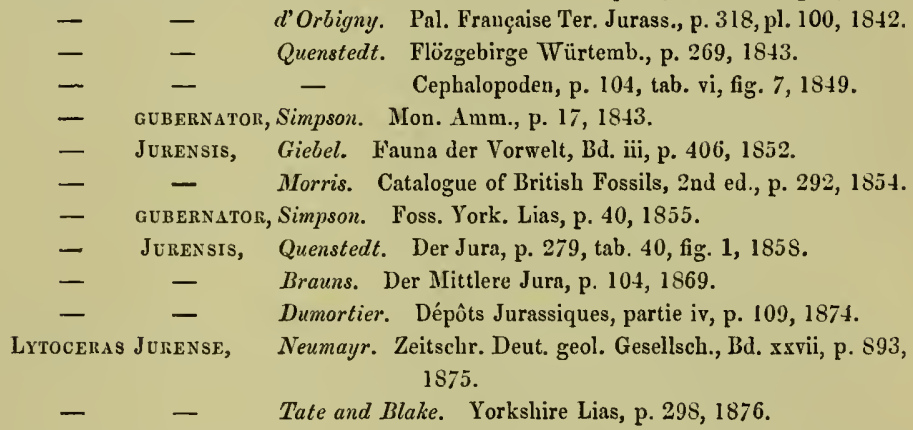

Diagnosis.-Shell discoidal, compressed; whorls half involute; sides flattened, and bevelled away towards the umbilical suture; siphonal area convex; shell ornamented with very fine lines of growth; mould smooth without a trace of shell-lineation ; suture-line very complicated.

Dimensions. - Some German examples attain a diameter of two feet. One example in my collection from the Lias at Wasseralfingen, and only the imner portion of a large shell, is 155 millimètres in diameter; the inner whorls are convcx and flat, and the outer whorl expands largely and abruptly with a deep concave slope towards the umbilicus. The small specimen, Pl. LXXIV, figs. 3-5, is 105 millimètres in diameter; the height of the aperture is 50 millimètres, and its width 32 millimètres.

Description.--Thirty years ago I collected this Ammonite from the Liassic sands of Frocester Hill, where a few individuals at that time were found. My original specimens were mislaid and lost soon after they were discovered, and the species was not again met with until 1880, when three or four rough examples were re-discovered in the same locality, and these have served to prove that the Jurense-zone exists in the Cotteswold Hills.

The shell is discoidal and compressed; the whorls, which rapidly increase in height, are one half involute; they are flattened or slightly convex on the sides, and bevelled away towards the umbilical suture, a character which serves to distinguish this species from Lytoceras oolitlicum, d'Orb., an inferior oolite species with which it has many affinities. The siphonal area is extremely convex. The shell is extremely thin, and seldom preseryed. When found it is seen to be ornamented with numerous very fine lines of growth that leave no mark on the mould, which is quite smooth. The sutural line (fig. 3) is very complicated. The siphonal lobe is one third shorter and as wide as the principal lateral, 
it has four lateral branches on each side, which augment in size from without inwards, the terminal branch is the largest and bifurcated. The siphonal saddle is as large as the principal lateral lobe, and terminates in eight folioles, four on each side, which are nearly the copies of each other. The principal lateral lobe is almost symmetrical in structure, there are two short branches on each side of the stem near the base, and two large terminal branches, which bifurcate and trifurcate in their terminations, and are deeply divided by a small accessory saddle. The lateral saddle nearly resembles the siphonal in magnitude, structure, and symmetry. The inner lateral lobe is about half the size of the principal; the stem has two short lateral processes on each side, and the summit divides irregularly into three branches. The inner lateral saddle is much smaller than the outer lateral saddle, and terminates in three folioles. The auxiliary lobes, three in number, are small and unimportant.

Affinities and Differences.-This Ammonite appears to vary very little at different periods of growth, preserving nearly always the same form. Some specimens, however, are more convex and compressed than others; a few have the thickest portion of the shell near the umbilicus, from whence the shell is bevelled away towards the siphonal area, and the body-chamber then assumes a somewhat triangular form. I have large specimens of this from the Lias of Wasseralfingen, which strongly resemble the large forms obtained from Frocester Hill; in other varieties, as in the type fossil, a very fine monld, figured by Zieten, Verstein. Würtemb., tab. lxviii, the whorls are more curved and inflated than is the case in the beautiful specimen I have figured in Pl. LXXIV, figs. 3-5, in which the bevelling away of the shell between the side wall and the umbilical suture is very well shown, as well as the suture-line ou its sides.

Locality and Stratigraplical Position.-I have collected this Ammonite from the hard argillaceous shales at the base of the yellow sand above the Alum Shale at Blea Wyke, near Robin Hood's Bay, Yorkshire, associated with Harpoceras variabile, $H$. insigne, and $H$. striatulum, and other fossils of the Jurense-zone. In Gloucestershire I know it only from the Ammonite bed of the Liassic sands at Frocester Hill.

Foreign Distribution.-Prof. Quenstedt has shown the importance of this zone of the Upper Lias in Würtemberg and Swabia; Prof. Leonhard in Baden; Profs. Strombeck, Ewald, and Credner in North Germany in many localities. Prof. R. Lepsius las described the Jurensis-Mergel in Lower Elsace; M. 'Terquem near Metz, Moselle ; M. H. Harté near Bayeux. In addition Thouars, Deux-Sèvres; Verpillière and St. Quentin, Isère; Charolles, Saône-et-Loire; Mont d'Or, near Lyons, Saint-Romain, St. Fortunat, Poleymieux, Rhône; Semur, Côte d'Or; Saint-Julien, Charlieu; and Uhrweiler-Selzbrunnen, Bas-Rhin, may be cited as localities where this shell has been collected, and where the zone of Lytoceras Jurense is developed. I have given the geographical distribution of this zone of life in Europe somewhat in detail as it has been much misunderstood by English geologists, and has not received the consideration to which it is entitled from students of Jurassic geology. 
Lytoceras hircinum, Schlotheim. Pl. LXXV, figs. 4-7; Pl. LXXVI, fig. 6.

AMmonites

AMMONITES IIRCINUS,

- interruptus,

- obliquè in

- hircinus,

- $\quad-$

$--\quad-$

- LeCKENBY,

- Hircinus,

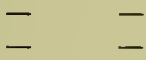

LYTOCERAS HIRCINUM,

- Germanit,
Knorr. Sammlung von Merkwürdigkeiten, pt. ii, pl. i, figs. I, 2 ; pl. A, fig. 12, 1750.

Schlothcim. Petrefaktenkunde, No. 19, p. 72, 1820.

De Haan. Ammonit, et Goniatit., p. 130, 1825.

Zieten. Verstein. Würtemb., tab. xv, fig. 3, 1830.

Schübler in Zieten. Ibid., tab. xv, fig. $4,1830$.

d'Orbigny. Pal. Franç., Ter. Jurass., p. 320, pl. 101, 1842.

Quenstedt. Flözgebirge Würtemb., p. 273, 1843. Cephalopoden, p. 103, tab. vi, figs. $10 a, b, c, 1849$.

Giebel. Fauna der Vorwelt, Bd.iii, p. 402, 1852.

Oppel. Jura Formation, p. 254, 1856.

Lycett. Cotteswold Hills Handbook, p. 123, pl. ii, fig. 7, 1857.

Quenstedt. Der Jura, p. 280, tab. 40, figs. 3-8, 1858.

Brauns. Der Mittlere Jura, p. 103, 1869.

Dumortier. Dépôts Jurassiques, tom. iv, p. 117, 187.

Neumayr. Zeitschr. Deutsch. geol. Gesellsch., Bd. xxvii, $p 893,1875$.

Tate and Blake. Yorkshire Lias, p. 298, 1876.

Diagnosis.-Shell discoidal, compressed, not carinated; whorls one-third involute, flattened on the sides, narrowing and rounded at the siphonal area; shell with small, annular, oblique ribs, intcrruptedly sulcated with twelve to fourteen marked constrictions, which are deepest on the siphonal area; umbilicus widely open; aperture oval.

Dimensions.-Transverse diameter 60 millimètres; width of umbilicus 18 millimètres; height of aperture 25 millimètres.

Description.-This Ammonite is nearly always found in England as a monld (PI. LXXV, figs. 4-7) and seldom has any shell preserved. The mould is discoidal, compressed, the sides convex and flattened, the siphonal area narrow and extremely convex, but not carinated. When the shell, which is extremely thin, is preserved (PI. LXXVI, fig. 6) it is ormamented with numerous delicate oblique striations or fine costæ; and on the last whorl there are about twelve to fourteen oblique sulcations, which were occupied by prominent ribs that extended beyond the intermediate costæ. The sulci are deeper and more marked on the siphonal area; and, as they approach the aperture, the constrictions are very deep in the two outer whorls; but are absent in the inner ones, and they likewise disappear in the old shells. The spire is formed of six very narrow cylindrical 
whorls, which are about one-third involute. The aperture is oval or oblong, convex at the sides, tapering towards the area, and slightly grooved by the return of the spire. The sutural line is simple, and forms very symmetrical lobes and saddles. The siphonal lobe, almost as long and wide as the principal lateral, is furnished on each side with three points, and one branch with four. The siphonal saddle terminates in two unequal folioles, of which the external consists of three festoons and the internal of two. The principal lateral lobe divides into two terminal branches, of which the external is the larger. The lateral saddle terminates in one large external and two smaller internal festoons; the three other small auxiliary lobes decrease in size from without inwards.

Affinities and Differences.-The number of the large ribs which occupy the sulcations varies from twelve to fourteen, they resemble the annular fimbrix seen on Lyt. fimbriatum. The intermediate oblique annular ribs in French specimens, according to d'Orbigny's figure, are in general extremely small, whilst in German forms, according to Zieten, they are larger (Pl. LXXVI fig. 6). When the shell was complete this Ammonite must have had a very elegant form. When the shell is absent, as is almost always the case in English specimens, the mould is smooth, with deep, wide, smooth constrictions on the outer and first inner whorls.

When the shell attains the diameter of seventy millimc̀tres, according to d'Orbigny, it loses its ribs and sulci entirely, and becomes altogether smooth; the whorls then are very large and always much inflated, and very unlike the inner whorls of the shell.

This Ammonite, by its periodical interrupted constrictions in middle life, manifests affinities with Lyt. fimbriatum and Lyt. cornucopia; it differs from both, however, in having deep permanent sulcations on the mould, which are absent in these species; the suture-line likewise is much less complicated, and the whorls are compressed and never cylindrical. A perfect specimen of this fossil would display one of the most beautiful Ammonite structures with which I am acquainted, but the extreme thinness of its delicate shell, with the small amount of involubility in the whorls, renders it one of the Ammonite gems of the Lias formation. It resembles Lyt. torulosum (Pl. LXXVI, fig. 5) in general form, but differs from that species by its recurrent constrictions.

Locality and Stratigraplical Position.-I have collected several fragments from the Jurense-hed at Frocester Hill; and Prof. Blake reports a single fragment from Blea Wyke, Yorkshire Coast, associated with Harpoceras striatutum. The specimen figured Pl. LXXVI, fig. 6, is from Germany.

Foreign Distribution.-Schlotheim collected his numerous examples from the JurensisSchicht at Aschach, north-east of Amberg, in the Oberpfalz; Zieten's examples came from Gross-Eislingen and Wasseralfingen; it has been collected likewise from the same zone at Altdorf, Heiningen, Uhrweiler, and Muhlhausen. 1'Orbigny states that this Ammonite was collected from the uppermost beds of the Upper Lias of the Charolles, Saône-et-Loire; in the cnvirons of Salins, Jura; at Villenotte, near Semur, Côte-d'Or ; and at Verpillic̀re, Isère. 
Lytoceras torulosum, Sclü̈bler. Pl. LXXVI, figs. 4, 5.

Ammonites tonulosus, Schübler, in Zieten. Versteiner. Würtemb., p. 19, tab. xir, fig. 1, 1830.

- Tornulosus Keferstein. Naturgesch., ii, 414, 1834.

- Tordlosus, d' Orbigny. Terr. Jurass., i, p. 322, pl. 102, figs. 1, 2, 6, 1842.

- _ Q Quenstedt. Flözgeb. Würtemb., p. 287, 1843.

- - $\quad$ Quenstedt. Cephalopoden, i, p. 104, tab. vi, p. 99, 1849.

- - Morris. Catalogue of Brit. Fossils, p. 295, 1854.

- - Quenstedt. Der Jura, p. 306, tab. 42, fig. 7, 1858.

Lytoceras torolosum, Neumayr. Zeitschrift Deutsch. geol. Gesells., Bd. xxvii, p. $89.3,1875$.

Diagnosis.-Shell discoidal, one third involute; whorls round, and transversely ribbed; costæ nearly straight, broad, round, and separated by wide valleys; siphonal area round with very large ribs; shell thin, ornate, with numerous transverse striæ; umbilicus wide, ribs becoming attenuated near the spiral suture.

Dinensions.-Transverse diameter, 80 millimètres; height of aperture, 35 millimètres; width of whorl, 30 millimètres.

Description.-This fine Cephalopod has a discoidal shell slightly compressed and about one third involute. The sides and siphonal area are covered with nearly straight, round, prominent ribs, about from thirty to forty in number, according to age; on the last whorl they are separated by deep concave valleys, which impart a distinctive character to the ribbing of this shell. On the area the ribs attain their greatest thickness and the valleys their greatest depth, whilst near the umbilicus and around the spiral suture they are much attenuated and closely approximated. The shell is extremely thin and seldom preserved; when it exists, the outer lamina is found to possess a series of long, delicate striæ, which run along the ribs, and these are very well delineated on the area (Pl. LXXVI, fig. 5).

The siphonal area is wide, round, and very convex; the ribs are larger and the valleys deeper in this region than on the sides (figs. 4 and 5). The spire is composed of five or six roundish or ovate whorls, which are nearly one third involute. The aperture is oval and grooved below by the return of the spire.

The shell is extremely thin, about the thickness of drawing paper, and its outer lamina is covered with narrow, sharp striations, two or three of these adorn and follow the line of the ribs, and a portion of this structure is preserved on the siphonal costæ of the fragment delineated in fig. 5 of Pl. LXXVI. Most of the examples I have examined appear to have broken off at the line of junction of the body-chamber with the last septum. One specimen, a compressed fossil from Mossingen, in a browuish shaly clay, has much of the shell preserved, showing upon the convex sides of the ribs from two to four sharp, well-defined striæ, but in none of the examples has the sutural line been observed.

Afinities and Differences.-Lytoceras torulosum in many respects resembles Lytoceras 
fimbriatum, but it is distinguished from that and other congeneric forms by its large convex ribs and deep valleys, and by the well-defined striations which adorn the convex surface of the ribs, whilst it wants the longitudinal striæ that are seen on the shells of Lyt. fintriatum and Lyt. cornucopia; it is evidently a well-marked species of the group to which it belongs.

Locality and Stratigraplical Position.-I have only seen fragments of a mould referred to this species in connection with the Harp. opalinum-bed at Frocester Hill, Chideock Hill, and Burton-Bradstock, near Bridport, Dorsetshire, associated with Harpoceras opalinum, Turbo capitaneus, Gervillia lata, Rlynchonella cynocephala. This bed forms a thin stratum, rich in many well-preserved specimens of these mollusks.

Foreign Distribution.-The Torulosum-zone is very well exposed in many parts of Germany; the type specimen of Lyt. torulosum was found at Stufenberg. Professor Quenstedt collected it at Gomaringen, Aselfingen, and Wutzch. In the vicinity of Kloster Banz a considerable number of the leading fossils of this zone have been collected, and many of them were figured in Goldfuss. It has been carefully described by Professor Lepsius in his ' Unter Elsass.' This zone is found in many of the Departments of France, as Jura and Doubs; Milhau, Aveyron; Lozère ; at St. Quentin and Verpillière, Isère; and in the Sarthe and Calvados.

\section{Family.-LYTOCERATID无-continued.}

\section{Genus V-Phylloceras, Suess., 1865.}

Shell discoidal, highly involute, with delicate sculpture sometimes supporting contractions or elevations, or having the shell covered with fine striæ, which describe graceful curves inclined towards the aperture. Body-chamber short; aperture simple, with lateral or aural processes, directed forwards ; suture-line highly tortuous, forming eight or

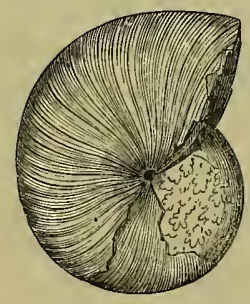

FIG. 194.-Phylloceras hetero. phyllum, Sow. nine lobes on each side of the mesial line; saddles bladdershaped, with well-rounded terminations; body-chamber widely expanded and fan-shaped, with undulating radii, as seen in Phylloceras heterophyllum, Sow. (fig. 194).

Professor Neumayr distinguishes in the Dogger and Malm four subgroups, of which the following are the types:-1. Phyll. heteropliyllum, Sow.; 2. Phyll. tatricum, Pusch; 3. Phyll. capitanei, Catullo; 4. Phyll. ultramontanum, Zieten.

This genus first appears in the Trias, wherc we find Plyyll. debile, Hauer, Phyll. despectum, Mojs., Plyyll. Neojurense, Quenst., Phyll. occultum, Mojs., Pliyll. pumilum, Mojs., Phyll. invalidum, Mojs.

In the Middle Lias appear Phyll. Loscombi, Sow., Phyll. Buvignieri, d'Orb., Phyll. Zetes, d'Orbig. 
In the Upper Lias Phyll. heteroplyyllum, Sow., Phyll. subcarinatum, Young.

In the Oxfordian we find Phyll. tatricum, Pusch; Phyll. viator, d'Orb.; Phyll. Hommairei, d'Orbig.; Pliyll. Zignodianum, d’Orbig.

In the Cretaceous rocks we find Plyll. subalpinum, d'Orbig., Phyll. Vellida, d'Orbig.: and Professor Waagen has figured and described ${ }^{2}$ several interesting species closely allied to European forms from the Upper-Jurassic rocks of Kutch, Western India.

Phylloceras Loscombi, Sowerby. Pl. XL, figs. 4, 5.

\begin{tabular}{|c|c|c|}
\hline $\begin{array}{l}\text { AMMONITES I } \\
\text { GLobItes }\end{array}$ & Loscomis, & $\begin{array}{l}\text { Sow. Mineral Concb., vol. ii, pl. } 183,1817 . \\
\text { Haan. Ammon. et Goniatit., p. } 147,1825 \text {. }\end{array}$ \\
\hline AMMONITES & - & d'Orbigny. Pal. Franç., Ter. Jurass., p. 262, pl. 75, 1842. \\
\hline-1 & Loscombir, & Morris. Catalogue of British Fossils, p. 173, 1843. \\
\hline - & HETEROPHYLLUS & NUMISMaLIS, Quenst. Cephal., p. 100, tab. vi, fig. 5, 1849. \\
\hline - & - & $\begin{array}{l}\text { - Oppel. Mittl. Lias, p. } 48, \text { tab. ii, fig. 9, } \\
1856 .\end{array}$ \\
\hline- & LoscoMri, & Oppel. Juraformation, p. 162,1856 \\
\hline - & - & $\begin{array}{l}\text { Dumortier. Dépôts Jurassiques Bassin du Rhône, t. iii, } \\
\text { p. } 78,1869 .\end{array}$ \\
\hline Phylloceras & - & $\begin{array}{l}\text { Neumayr. Zeitschr. Deutsch. geol. Gesell., Bd. xxvii, } \\
\text { p. } 903,1875 .\end{array}$ \\
\hline- & - & Tate and Blake. Yorkshire Lias, p. 296, 1876. \\
\hline
\end{tabular}

Diagnosis. - Shell very thin, discoidal, compressed; whorls wide, four fifths involute; sides flattened and slightly convex, covered with delicate, transverse, biflexed striæ which, on passing over the narrow, round siphonal area, develop prominent folds; aperture oblong, widest near the spiral suture ; umbilicus narrow, exposing the inner whorls.

Dimensions.-Transverse diameter 140 millimètres; width of umbilicus 20 millimètres; depth of the last whorl 75 millimètres; height of aperture 70 millimètres; transverse diameter 33 millimètres.

Description.-This beautiful shell is a very characteristic fossil of the "Green Ammo. nite-bed," Middle Lias, near Charmouth. It is here nearly always found firmly embedded in the matrix, so that a correct outline of the shell is seldom obtained. The specimen I have figured is one of the finest $I$ have seen. The shell is extremely thin and lustrous, of a discoidal figure, and covered with delicate striæ on the body-chamber, and with small, biflexed ribs on the inner whorls. The shell is thickest around the spiral suture near the umbilicus, and some specimens have likewise an elevated ridge or longitudinal carina rising about the middle of the height of the whorl; from this elevation proceed a number of oblique striæ which extend backwards towards the area. In the two best specimens I possess the longitudinal carina and the oblique backward-directed striæ,

1. 'Palæontologia Indica,' Ser. ix. 2. (Jurassic fauna of Kutch) p. 25, pls. $\nabla$-vii, ix, 1875. 
are very plainly visible. None of the shells I have examined have the suture-line preserved; and, as Prof. d'Orbigny had examples showing this character, I give the chief points of his description. "The septa are symmetrical, divided on each side into six lobes and saddles formed of unequal parts. The siphonal lobe is much shorter than the principal lateral lobe, formed of three branches, of which the terminal one ends in three twigs. The siphonal saddle is as large as the principal lateral lobe, and terminates in five oval, spatuliform leaves. The principal lateral lobe is long and ornate; it has three branches without and two within, all very unequal. The second lateral has much the same figure as the principal lateral, but does not attain to one half its size. The three auxiliary lobes have irregular branches, and the three auxiliary saddles terminate in oval leaflets."

D'Orbigny likewise observed that " $A$. Loscombi is a very variable species. The mould is in general smooth, nevertheless some specimens are found, considered to be the young of this species, with slightly marked transverse constrictions very closely approximated. It is, perhaps, one of the forms which exhibits the most marked variation at different ages. Up to the diameter of 5 millimètres its whorls are only one half involute, the umbilicus is very wide, and the shell ornamented transversely by a spiral revolution of six, deep, transverse, oblique constrictions. These constrictions and this form continue for a longer or shorter time in different individuals; sometimes the constrictions disappear and the whorls enlarge up to the diameter of 8 millimètres, although in others this state continues up to the diameter of 20 millimètres : this is the extreme limit observed in which the shell preserves the ornamentation of youth." Terr. Jurass., tom. i, p. 265.

M. Dumortier found a fragment of this species 190 millimètres in diameter at Mazaugues, Var; which carried its lobes up to the last extremity, proving that it had attained to much larger dimensions. The shell was in part preserved, and permitted him to see the small lines radiating very equally and regularly and forming an elegant ornamentation; these lines, slightly flexed, are strongly inclined forward, and afterwards describe a round sinus on the area where they preserve all their value" ("Dépôts Jurassiques,' tom. iii, p. 78).

Affinities and Differences.-This species, both in its form and the structure of the suture-line, closely resembles the Phylloceras heterophyllum; it is readily distinguished from that species by its open umbilicus, the structure of the lobes, and by the siphonal lobe being formed of single elements, whilst in Phyll. heterophyllum they are in pairs.

Locality and Stratigraphical Position.-This Ammonite is a leading Mollusk of the Green Ammonite-bed, the zone of Aeg. Davœi in the Middle Lias. I have it in the same zone from Thackwell's brickfields, Leckhampton, and Professor Blake reports it from the same horizon in Robin Hood's Bay and Huntcliff, Yorkshire, where it is rare.

In France it has been collected in the Middle Lias which it characterises at Coutards and near Saint Amand, Cher.; Mulhausen, Bas-Rhin ; Vieux-Pont and Bayeux, Calvados ; Venavey, near Semur, Côte-d'Or ; Saint Hélène, Saone-et-Loire; Mazaugues, Var. 


\section{Philloceras Buvignieri, d'Orbigny. Pl. LXXVI, figs $1-3$.}

Anmosites Buvignieri, d' Orbigny. Paléont. Franç., Terr. Jurass., pl. 74, p. 61, 1842. - $\quad$ - Ralph Tate. Proc. Belfast Nat. Field Club, Appendix I. Irish Liassic Fossils, p. 6, 1870.

Diagnosis. -Shell diseoidal, compressed; whorls extremely involute, umbilicus nearly occluded ; sides smooth, convex, covered with delicate biflexed lines of growth, which become more developed near the border; siphonal area compressed, subcarinate, marked by angular strix; aperture compressed, subangulated; suture-line very complicated, developing eiglt lobes.

Dimensions.-Transverse diameter 145 millimètres; height of the aperture 80 milli. mètres; greatest width of shell across umbilicus 47 millimètres; width of umbilicus 5 millimètres.

Description.-This appears to be a very rare Cephalopod, as I have not seen the shell in any of our museums, and find it noticed only in Tate's 'Catalogue of Irish Liassic Fossils.' The specimen figured came into my hands with a collection of Irish Liassic Ammonites obtained in the North of Ireland, and belonging to the Belfast Museum, sent to me purposely for the determination of the species.

The fossil is much injured, still it retains all the specific characters by which this beautiful Ammonite is distinguished. The shell is very much compressed and not carinated; the sides are smooth and delicately marked with very fine lines of growth, which become more developed and angular on the siphonal area. The whorls are compressed, convex, and extremely involute; the last whorl is very deep ; it embraces almost entirely the inner whorls, and nearly occludes the umbilicus, leaving only a small aperture indicating its position (PI. LXXVI, fig. 1). The siphonal area is compressed and bevelled on each side, and rounded in the middle (Pl. LXXVI, fig. 2); it is marked with wellmarked angular strix all directed forward toward the mouth (Pl. LXXVI, fig. 1).

The aperture is lanceolate and much compressed, forming a blunt angle before with two points behind.

The suture-line is very complex. The septa are symmetrical and divided on each side into eight lobes and into many saddles, formed of unequal parts. The siphonal lobe (fig. 3) is as long as and wider than the principal lateral lobe; it is much ramified and provided on each side with five branches, two of which are much larger than the others. The siphonal saddle is narrow and very irregularly divided into folioles, of which the central one is trilobed. The principal lateral lobe is formed of many irregular branches, four on the inner and five on the outer side of the lobe. The right lateral saddle, much higher than the siphonal, is much foliated, and terminates in three unequal leaves. The inner lateral lobe has a similar form, but is much smaller and shorter than the principal lateral lobe. The first auxiliary saddle divides into two, the others are very 
irregular, both as regards the size and number of their folioles. The auxiliary lobes are placed at irregular distances apart and decrease in magnitude towards the innermost lobe, which is quite rudimentary.

Affinities and Differences.-Phyll. Buvignieri very much resembles Amm. lynx, d'Orb., in its compressed, extremely involute shell, with its almost occluded umbilicus, and in the style and structure of the suture-line ; but though it wants the festooned carina, and has a narrower umbilicus than Amm. lynx, the affinities are very close indeed.

Locality and Stratigraplical Position.-This species is marked on the ticket, Belemnites-acutus zone, Ballintoy. I have a small specimen of this species, 5 millimètres in diameter, which exhibits all the characters of the large and middle specimens. So it appears to retain its specific form through life, the only difference I detect is that the young shell is proportionately thicker and its siphonal area rounder than in the large figured example with its subcarinated area. The figured specimen belongs to the Belfast. Museum.

Phylloceras Zetes, d’ Orbigny, Pl. LXXVII, fig. 1-3.

Ammonites Heterophyllus amalthet, Quenstedt. Cephalopoden, p. 100, pl. 6, fig. $1,1846$.

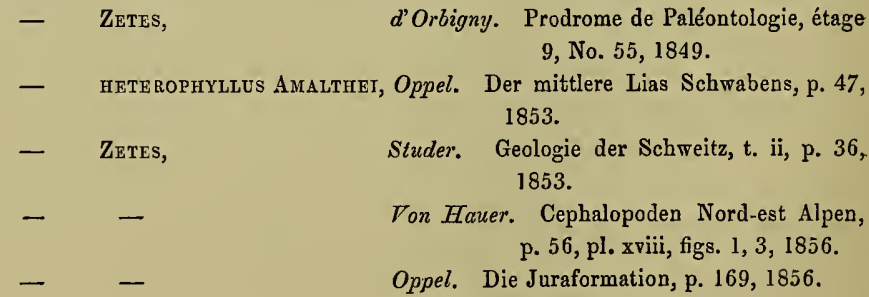

Diagnosis.-Shell compressed, discoidal, highly involute; umbilicus small, narrow, open, exposing the inner whorls. Shell very thin, marked with delicate hair-like lines, all inflected forward; sides flattened, smooth; siphonal area round; lobe-line very tortuous, developing from nine to eleven lobes.

Dimensions.-The figured specimen : transverse diameter 180 millimètres; height of the last whorl at aperture 100 millimètres; greatest width near the spine 45 millimètres; width of umbilicus 20 millimètres. A larger specimen in my collection measures as follows : transverse diameter 294 millimètres; height of last whorl at aperture 170 millimètres; greatest near spire 90 millimètres; width of umbilicus 30 millimètres.

Description.-The Heterophyllida form a remarkable natural group closely related to each other by form and structure, differentiated, however, by fairly-marked specific 
characters. Professor Quensted described these Ammonites as one species, and named what he considered their varieties by the zones in which they were found, hence we have Plyyll. heteropliyllus memismalis $=$ Pliyll. Loscombi, Sow., Plyyll. heteroplyyllus amalthei $=$ Pliyll. Zetes, d'Orbig., Phyll. heteropliyllus Posidonia = Phyll. Leterophyllus, Sow.

Pliylloceras Zetes has a discoidal shell, much compressed and extremely involute, the last whorl enveloping nearly the entire disc. The sides are flat, and gently bevelled toward the siphonal area, which is narrow and round; the greatest width of the disc being around the umbilical elevation. The shell is extremely thin, and sculptured with very fine lines of growth, which are straight on the inner and gracefnlly bi-flexed on the walls of the body-chamber. The siphonal area is narrow and smoothly rounded, and the small syphon lies immediately beneath the shell (fig. 2), where the longitudinal line indicates its position. The umbilicus is narrow from the extreme involution of the spiral, which envelopes four fifths of the lateral surface of the whorls (see fig. 1). The suture-line is extremely complicated, but very beautiful in its tracery, forming nine lobes in its varied convolutions. The siphonal lobe is short and wide, having four lateral branches on each side, the innermost is small, the second and third have several branches, and the fourth or terminal one ends in two lanceolate twigs. The siphonal saddle is wider than the siphonal lobe, and ends in numerous folioles, which are larger on the inner than on the outer side of the saddle, from the root of which supplementary lobules arise (see fig. 3). The principal lateral lobe is very large, being much longer and wider than the siphonal, it has an arborescent appearance, having a thick stem with two lateral branches on each side, after which it bifurcates, and gives off two longer branches, the external branch bends over towards the siphon and sends out six branches, three long, extending into the siphonal saddle, and three smaller, bending towards the inner side. The inner terminal branch divides into two branchlets, which send out lanceolate terminations. The outer lateral saddle is long and narrow, and terminates in from six to eight long, narrow folioles. The inner lateral lobe is about the same length, but much narrower than the principal lateral, and composed of a central stem with five lateral branches on each side and a long terminal branch, each dividing into lanceolate points, having a style of incision much resembling the principal. The inner lateral saddle is much shorter and narrower than the outer lateral saddle, and terminates in three branched folioles; there are six anxiliary lobes, which much resemble each other in structure in laving a solid stem with a number of sharp lanceolate lateral and terminal branches. The lobes diminish in length and width from without inwards, and the six auxiliary saddles lave their sides foliated nearly after the same fashion.

The extremely complicated suture-line of this species produces one of the most beantiful foliated structures that I am acquainted with in Ammonites; a portion is delineated in fig. 3, and is beautifully drawn in Quenstedt's 'Cephalopoden,' tabl. vi, fig. 1 .

Afinities and Differences.-This species very much resembles Plylloceras hetero- 
plyyllum, Sow., found in the Upper Lias of Whitby; the following differences I have long observed after a careful comparison of many good examples with each other :

1st. The shell is much more compressed in Pliyll. Zetes than in Pliyll. leterophyllum. The sides are much flatter, and the siphonal area narrower.

2nd. The umbilicus is wider in Phyll. Zetes, and permits all the inner whorls to be seen, whilst in Plyyll. heteroplyyllum the umbilicus is almost occluded.

3rd. The suture-line consists of a much more angular tracery, a finer subdivision of the parts of the lobes, and much smaller folioles in the saddles than what we observe in Phyll. lieteropliyllum. Any one in the habit of studying these shells has no difficulty in deciding on the species from an examination of the suture-line alone. In figs. 3 and 4 I have given accurate drawings of the suture-line in the two species for comparison.

4th. The lines of growth on the shell are more marked in Phyll. heterophyllum, and the wonderful fan-like folded expansion of undulating ribs, which I have for the first time delineated in Pl. LXXVIII, fig. 1, and which characterise the body-chamber of Phyll. lieteropliyllum have not yet been observed in any of the fine examples of Plyll. Zetes hitherto collected.

Locality and Stratigraplical Position.-My specimens of Phyll. Zetes were obtained from the Amal. spinatus-bed at South Petherton, Somersetshire, and from the same horizon at Grettan, Gloucestershire. In Swabia, according to Dr. Oppel it is found at Breitenbach, with Am. amaltheus gigas, and in a rich pyritic bed at Bachs, and near Sondelfingen in the Baling region. Von Hauer obtained his fine example from the dark red limestone of Enzesfield, North-eastern Alps. Studer reports many localities in the Bernese Alps of Switzerland, where he has found this species; and Meneghini collected a specimen in the Upper Lias of Sibilla and a broken fragment at Spezzia.

Dr. Oppel collected one specimen from the Middle Lias of Normandy. Its lobes are so different from those of the true Pliyll. leteroplyzllum, Sow., that he was convinced a separation from that species was necessary, and this he carried out in his 'Juraformation,' p. 169.

Philloceras heterophyllum, Sowerby.

Ammonis conne,

- NaUtilites,
Ammonites heterophyllus,
NaUtilus Whitbiensis,

Globites heterophylues, AMMONITES

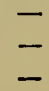

Pl. LXXVII, fig. 4; Pl. LXXVIII, figs. 1, 2.

Martin Lister. Synops conchyliorum, (Edit. alt.) tab. 1049, fig. 24. 1770.

J. Baier. Oryctogr. noric., p. 60, tab. ii, fig. $1,1708$. Sowerby. Mineral Conchology, pl. 266, 1820.

Young and Bird. Geol. Yorkshire Coost, Pl. xiii, fig. 1, 1822.

Haan. Ammon, et Goniat., 148, 1825.

Phillips. Geology of Yorkshire, pl. xiii, fig. 2, 1829.

Hartmann. Versteiner. Würtemb., p. 21, 1830.

Buckland. Bridgewater Treatise, pls. 38, 39, 1836. 
AMmonites Terveril,

- Heterophylles,
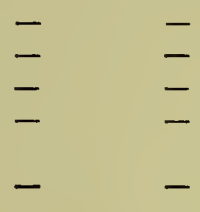

- $\quad-$
d'Orbigny. Paléont. Franç., Terr. Crét., t. i, p. 179, pl. 54, figs. 7-9, 1840.

Paléontol. Française, Terr. Jurassique, tom. i, p. 339, pl. 109, 1842 .

Simpson. Ammonites Monogr., p. 7, 1843.

Quenstedt. Flözgeb. Würtemb., p. 259, 1843.

Morris. Catalogue British Fossils, p. 173, 1843.

Quenstedt. Cephalopoden, p. 99, pl. vi, figs. 1-5, 1849.

Oppel. Die Juraformation, p. 251, 1856.

Quenstedt. Der Jura, p. 252, pl. 36, fig. 4, 1858.

Dumortier. Dépôts Jurassiques, t. iv, p. 104, 1874.

Phylloceras heterophyllum, Neumayr. Zeitschr. Deutsch. Geol. Gessellschaft, Bd. xxvii, p. 903, 1875 .

Tate and Blake. Yorkshire Lias, p. 297, 1876.

Dimensions.-The figured specimen. Transverse diameter 410 millimètres.

Description.-The magnificent specimen figured in Pl. LXXVIII, fig. 1, is, as far as I know, a unicum, which I discovered in the collection of the late Mr. Marshall, of Whitby, jet-dealer, many years ago. It was so different to any other Ammonite I had ever seen that I at once secured it for my cabinet. My old friend, Dr. S. P. Woodward, was with me when I made the purchase, so that, when we had realised the rarity and value of the fossil I had bought, he pleaded hard with me to part with it to the National Collection, which I accordingly did. Up to that time the true anatomy of the shell of Am. heterophyllus, Sow., was unknown, as the specimens contained in public collections, and which had formed the subject of published figures of the species, were inner whorls, mostly destitute of the shell, so that when the body-chamber was seen in situi in the grand specimen we had found, its value became enhanced accordingly. My figure is drawn just half the natural size, and displays the body-clamber of the shell in all its beauty, with the test finely preserved and ornamented with striæ,- - that important portion which had been unknown before. The inner whorls had been figured by Sowerby, Buckland, and d'Orbigny, but the fan-like body-chamber was absent in their specimens. M. Dumortier figured two fragments of the shell of the fan of this species as "corps de nature inconnue," and observed that the bodies, of which a drawing was given (Dép. Jurass., partie iv, p. 228, pl, xlviii) of the natural size, were found in Thiollière's collection; with the two specimens was a note in the handwriting of V. Thiollière :- ' Minerai du Lias Supérieur de la Verpillière; fouilles près de Serres; donnés par M. Drian, Octobre, 1854.' "'The principal fragment has the appearance of a leaf with very large undulations, the surface is covered with ribs, or regular flutings, up to the number of twenty or so on each undulation. On these ribs we notice the indications of smaller nodosities irregularly disposed; nevertheless, we think we recognise the tendency to a concentric serial disposition. The ribs and the large undulations have a fan-like disposition, as if they took their origin from a single point, which is absent from the 
specimen under notice. The two fragments which I have examined appear to indicate a much larger total development. The reason which prevents us from attributing this fossil to the vegetable kingdom is the thickness of the body, which is from two to three millimètres, and which seems to diminish on leaving the base of the fan. Onght we to regard it as a fragment of the test of an unknown Ammonite of very large size?" This extract from the work of so good an observer proves the importance of having found the bodychamber in sitû, thus settling the question of its true nature. During a visit I paid some time ago to the Woodwardian Museum, Cambridge, I found a portion of a very large fan of this shell, which was then unknown to the museum authorities. This I identified and described, and it has now passed out of the unknown into the region of known fossils.

The shell is somewhat compressed, and uncarinated, with a narrow umbilicus nearly hidden. The spire is composed of very involute whorls, which almost entirely embrace the preceding ones ; and the whorls, which are always oval, rounded, and compressed, have their greatest width at the inner third near the spire, and they are especially wider here than at the entire half of the shell. The sides of the shell and area are covered with fine radiating lines which curve gently forward towards the aperture (Pl. LXXVIII, fig. 1). The size of the lines varies with the age of the shell; in youth they are extremely narrow, but in the middle-aged shells they become more and more developed. As old age advances. the body-chamber of this grand shell (Pl. LXXVIII, fig. 1) assumes a fan-like structure, in consequence of the lines being grouped into bundles of fasciculi, which radiate outwards in gentle flexures from the umbilicus to the siphonal area, in elegant waved undulations, as shown in our plate of this fine specimen, now in the British Museum, reduced one half the natural size. It will be noted that the mould behind the suture-line is entirely smooth, whilst in front of that line it develops the undulating folds which produce the fanshaped structure seen in the body-chamber of this magnificent specimen, and which I believe up to this hour is quite unique. The radiating undulations appear to exist on the body-chamber only inasmuch as on the moulds of the chambered portions of this fossil we fail to observe those radiating depressions which constitute so important a character in the body-chamber of this remarkable Cephalopod.

The suture-line forming the lobes is extremely complicated, and formed of single parts (Pl. LXXVIII, fig. 2). The siphonal lobe is shorter, but as wide as the principal lateral, and ornamented on each side with two branches, the inner being small, the outer much ramified. The siphonal saddle is wide, and terminates in five large, oval, unequal leaves.

The principal lateral lobe is very large, and provided on each side with three ramified branches, and a long terminal branch divided into three wide foliations; the lateral saddle, longer than the siphonal, terminates in six unequal leaves, the three internal leaves being smaller, whilst the three outer ones have large oval folioles which make conspicuous figures on the mould; the inner lateral lobe resembles the principal lateral in structure, but is not more than two thirds the size of the principal; the first and second auxiliary saddles are formed of five folioles, the others of only three. The 
auxiliary lobes all preserve the same form, but become less and less complicated as we trace them from without inwards. When we describe a radial line from the digital points of the siphonal lobe to the digital points of the auxiliaries, it touches the points of all the others, and cuts the terminal branches of the principal lateral. The near approximation of the chambers, and the great development of the suture-line, produces on the surface of the mould of this Ammonite a number of figures which are as difficult to trace out as they are beautiful to behold.

Professor d'Orbigny had an opportunity of examining several young forms of this species, and stated that a shell ten millimètres in diameter had absolutely the same form and the same lobes as the adult, and was entirely smooth, and that it did not acquire striæ until it had attained a diameter of from twenty to thirty millimètres.

The mould is always entirely smooth. When the inner lamina of the shell was preserved he remarked that striæ were only slightly visible, but when the external layer of the shell existed the striæ were well shown. ${ }^{1}$

The late Mons. Dumortier ${ }^{2}$ observed of this Ammonite " that the veritable $A$. heteroplyyllus, Sow., is very different to the $A$. Zetes of the Middle Lias. The specimens of large size from Verpillièrc, Isére, are remarkably beautiful, both as regards their wellpreserved forms as well by the perfection of the details of their ornaments ;" and again, " upon some examples of moderate size we remark from six to seven radiated depressions, very slight upon the last whorl, but which terminate upon the siphonal contour by a round prominence and form a sinus in front. As all the other characters remain unaltered this peculiarity is to be considered as an accidental variety of $A$. lieterophyllus." This was doubtless a mould of the fan-like portions of the body-chamber which had lost its shell, whilst the fragments which Dumortier figured as "corps de nature inconnue" were in fact the shell of the fan without the monld on which it rested.

Affinities and Differences.-In the Jurassic rocks we find five species of Ammonites, which may all be referred to the group Heteropluyllide. 1st. Plyyll. Loscombi of the Middle.Lias, with a large umbilicus, without ribs in early life, and the suture forming six lobes. 2nd. Pliyll. Zetes, d'Orbigny, from the Middle Lias (the Amal. spinatus-zone) distinguished from Plyyll. Leteroplyyllum by more compressed whorls, a wider umbilicus, and a different suture-line. 3rd. Pliyll. leterophyllum, the type of the group, which has just been described in detail. 4th. Phyll. Calypso, from the Upper Lias, distinguished by the five flexed contractions observed on the last whorl of the spire. 5th. The Phyll.tatricum, Pasch, from the Lower Oxfordian, with six to eight bent constrictions of the outer whorl, which is very involute and covered with a thick shell finely sculptured, with minute striæ. All these Jurassic Heteroplyllida are very distinct from other members of the same natural family which are found in the Cretaceous formations.

Locality and Stratigraplical Position,-Plylloceras leteropleyllum, Sow., is found in

1 'Paléontologie Française, Terr. Jurassiques,' tom. i, p. 340, 1842.

2 'Dépôts Jurassiques du Bassin du Rhône,' tom. iv, p. 105, 1874. 
the Upper Lias at Whitby and Boulby, in Yorkshire; Lyme Regis, Dorsetshire; Dumbleton and Alderton, Gloucestershire. The Whitby specimens are by far the most beautiful and best preserved.

Foreign Distribution.-In France it has been collected at Fontaine-Etoupe-Four, Croiselle, Calvados ; Charolles, Saône-et-Loire ; Thouars, Deux-Sèvres ; Cheville, Sarthe ; Avallon, Yonne ; Semur, Côte-d'Or ; Mende, Lozère ; Verpillière, Isére ; Saint-Rambert, Ain ; Gundershoffen, Haut-Rhin.

Luxembourg.-In the Marnes de Grande Cour.

In Germany.-In the Posidonomyen-schiefer of Altdorf, Bavaria, Boll, and Württemberg.

Phylloceras subcarinatum, Young and Bird. Pl. LXXXI, figs. 1, 2, 3.

Nadtulus subCarinates,

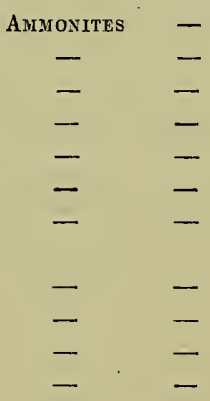

Young and Bird. Geol. York. Coast, p. 255, pl. xii, fig. 7,1822 .

Phillips. Geol. of Yorkshire, p.167, pl. xiii, fig. 3, 1835. Simpson. Monogr. on Ammonites, p. 8, 1843.

Morris. Catalogue of British Fossils, p. 145, 1843.

Catullo. Ammonit. delle Alps. Venete, pl. 13, fig. 3, 1846.

Bronn. Index Palæontologicus, p. 60, 1848.

Giebel. Fauna Vorwelt, Bd. iii, p. 747, 1852.

Morris. Catalogue of British Fossils, 2nd ed., p. 295, $18 \overline{5} 4$.

Oppel. Die Juraformation, p. 251, 1855.

Simpson. Fossils of York. Lias, p. 37, 1855.

Guembel. Beschr. d. Bayr. Alpen, p. 474, 1861.

Oppel. Paläontol. Mittheilungen, p. 140, pl. 44, figs. $1,2,1862$.

Phylloceras subcarinatum, Tate and Blake. Yorkshire Lias, p. 297, 1876.

Diagnosis.-Shell discoidal, extremely involute, inner volutions nearly concealed, outer whorl one-half the diameter of disk; sides convex, inflated, covered with straight or slightly flexed obtuse irregular radii, obsolete near aperture ; striæ very numerous, fine, annular, irregular, diverging ; siphonal area wide, with central ridge, and two fiattened bands on each side; umbilicus narrow and deep. Aperture ovate, widest at the spiral border and bevelled away towards the area.

Dimensions.-Transverse diameter 100 millimètres; breadth of area 18 millimètres; height of aperture 50 millimètres; width of whorl at the aperture 40 millimètres; width of umbilicus 15 millimètres.

Description.-Phylloceras subcarinatum has been long known to the Yorkshire naturalists, and is remarkable for its dissimilarity from other congeneric forms ; still this- 
species has not been included in the classical works on Liassic Cephalopoda by Quenstedt, d'Orbigny, and Von Hauer, nor has it been noticed as a doubtful species, or one that had fallen under their observation in any way; - an omission which may perhaps be explained by the fact that it was very badly drawn in the two Yorkshire monographs in which it was first figured. Dr. Oppel correctly described this species and pointed out its affinities in his Juraformation, as he had obtained the fossil himself at Whitby from the dealers and showed me the purchased specimens. One of these he has figured most beautifully in his 'Paläontologische Mittheilungen,' pl. 44.

The shell is extremely thin and ornamented with numerous fine annular striæ, which pass over the area and encircle the whorl. The siphonal area is wide and has an obtuse ridge in the centre and two flat bands extended on each side of the carina, but without any groove or sulcus, such as exists on each side of the keel in the genus Arietites. The umbilicus is narrow and the inner whorls are much concealed (Pl. LXXXI, fig. 1). The aperture is ovate (Pl. LXXXI, fig. 2), widest across the inner or spiral side, and gradually tapering from thence towards the siphonal area (Pl. LXXXI, fig. 2). 'This area is extremely characteristic, having an obtuse ridge running round the middle line of the shell, with two lateral flat bands on each side (Pl. LXXXI, figs. 2 and 3), forming a structure by which this species is readily distinguished from all its congeners.

The suture-line is not exposed in a satisfactory manner in any of my specimens, the thin shell being so often retained in the matrix that the suture-lines cannot be traced.

Affinities and Differences.-The Ammonite which most nearly resembles Phyll. subcarinatum is the Phyll. cycloides, d'Orbigny, from the Inferior Oolite of Moutiers. The young forms of this species have a keel, lateral ribs, and a narrow umbilicus, but in later life the shell becomes smooth, the keel is less prominent, and the lateral bands are smoother, the ribs disappearing; with all its affinities Phyll. cycloides is, nevertheless, a very different form to Phyll. subcarinatum.

Locality and Stratigraphical Position.-It is obtained from the Alum-shale, near Whitby, in company with Harpoceras bifrons, Harp. Lythense, and Stephanoceras commune. This species is rare when compared with the other forms with which it is associated.

Dr. Oppel states that in the Munich Musenm there is a specimen, named by Münster, from Altdorf, in Franconia, ont of the Monotis-limestone; and in the Berlin Museum there is a specimen from the Iron-earth of Verpillière, near Lyons; so Pliyll. subcarinatum is a leading fossil for the Upper Lias in France and Germany, as well as in the British Isles. 


\section{Family.-AEGOCERATID E-continued.}

Genus VI-Harpoceras, Waagen, 1869.

\begin{abstract}
Family-FalcifenI, Von Buch, 1832. d'Orbigny, 1841. FalctFeren, Quenstedt, 1849.
\end{abstract}

$\begin{array}{cc}\text { Family-Disci sive CLYPeIFoRMes, Giebel, } 1852 . \\ \text { FaLCIFERI, } \\ - & \text { Giebel, } 1852 . \\ & \text { Seebach, } 1864 .\end{array}$

The Falciferi of Von Buch have long been recognised as a remarkable group of Ammonites, which have undergone several changes of nomenclature, still all authors agree on the special characters on which they were originally described and fignred for the first time in the 'Ueber Ammoniten.' The external outline of their shells is of various forms, the

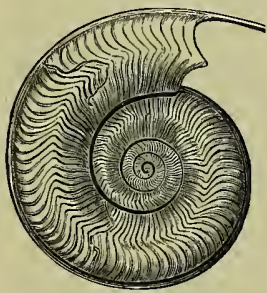

FIG. 194.-Harpoceras serpentinum, Reinecke ventral area is always keeled with a round or angular border; the sides of the whorls are ornamented with elegant falciform ribs of various degrees of thickness. The aperture of the shell is in general sickle-shaped, with lateral auricles and a long, pointed ventral process, as seen in one of the typical forms, Harpoceras serpentinum, Reinecke (fig. 194). The body-chamber is from one half to two thirds the length of the whorl. The suture-line is moderately ramified. The siphonal lobe is in general short and bifurcate, with divergent branches, and always shorter than the principal lateral lobe, which is usually largely ramified; the inner lateral lobe is much smaller than the principal, and succeeded by several still smaller auxiliaries. The Aptychus is thin calcareous and bivalved, with a shelly coating and several longitudinal folds, as seen in Harpoceras Levisoni (Pl. LXI, fig. 4).

When the shell is preserved the radii on the sides of the whorls in many species are in the highest degree fine and delicate, as in Harpoceras opalinum. It is the external lamina of the shell which fills in all the unevenness between the thickness and divisions of the folds of the inner lamina. All these folds have a falciform figure; they first bend forward, then incline backward, and near the siphonal area again turn forward towards the aperture, so that a well-formed, strongly-bent sickle is described thereby. The siphonal area in general forms a sharp ridge, which sometimes contains the siphuncle and gives a marked character to the shell. The umbilicus is usually well open, although in a few species it is contracted. The Falciferi are very rich in species, which well characterise the horizons in which they are found.

The oldest forms are found in the Middle Lias. They are very numerous in the Upper Lias, which is the metropolis of the species; they are found in the Lower and Middle Jurassic rocks, finally disappearing in the Kimmeridge Clay with Harpoceras Zio, Oppel. 
Harpoceras antiquem, Wright, nov. sp. Pl. LVII, figs. 1-4.

Diagnosis.-Shell discoidal, compressed, and carinated, volutions one-half involute, sides convex and flattened; ribs formed of many biflexed striæ, sometimes prominent, and always well bent forward towards the aperture; keel thick, prominent, and in parts crenated.

Dimensions.-Transverse diameter 180 millimètres; height of aperture 70 millimètres; thickness 40 millimètres; width of umbilicus 60 millimètres.

Description.-This shell very much resembles Am. Normanianus, d'Orb., in its style of ribbing; but, as the specimens that have come under my observation are all fragmentary and belong to a much larger and older specimen than d'Orbigny's figure, which was drawn natural size, the difference between my fragments and d'Orbigny's shell may be only those of increased age rather than of specific distinction. Am. Normanianus is much less involute, and has a wider umbilicus than Harpoceras antiquum. The discovery of younger and better specimens of this shell will enable future observers to solve the problem; as I have no trace of a suture-line on any of the fragments, one of our best guides is absent.

The shell is much compressed, carinated, and provided with a strong keel; the whorls are nearly one-half involute, and are thickest at the spiral suture; thence they diminish towards the siphonal area, which is narrow and lanceolate and terminates in a thick keel. The sides are traversed transversely by a number of unequal, highly flexed falciform ribs, made up apparently of a number of striæ, which unite in fasciculi, and form unequal, obtuse costæ on the sides. The keel is thick, cord-like, and prominent, and makes an important element in the structure of the shell. The test is very well preserved in some of the fragments, the transverse fracture of these exposes the crystalline structure of the thin shell, which does not exceed one millimètre in thickness. The structure and falciform flexures on the sides of the whorls are well seen in two fragments, delineated in Pl. LVII, figs. 3 and 4. Both of these specimens have the shell preserved, so that we have here the true character of the ribs, with their shelly covering transformed into ferrous disulphide ( $\mathrm{FeS} 2$ ), by which the microscope markings on the test are preserved. As the shell increases in size (Pl. LVII, fig. 1) the ribs lose their prominence, the siphonal area becomes thicker and rounder, and the keel is more defined.

Affinities and Differences.-This Ammonite is nearly allied to Am. Normanianus, $\mathrm{d}^{\prime} \mathrm{Orb}$. It is, however, more regularly ribbed, the ribs remain single and do not bifurcate ; the volutions are more involute, and the umbilicus wider than in that species. There is, however, a very near affinity between the forms, which can only be satisfactorily settled by a careful comparison of more specimens.

Locaity and Stratigraphical Position.-This Ammonite was collected by the Rev. J. 
E. Cross, F.G.S., and Peter Cullen, from a shaly ferruginous pyritic bed of clay in the north corner of Robin Hood's Bay, Yorkshire Coast, referred by them to the Aeg. Jamesoni-zone of the Middle Lias, and containing other fossils of this zone.

Harpoceras nitescens, Young and Bird. Pl. XLIX, figs. 2-7.

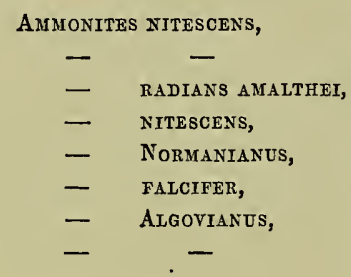

Harpoceras Algovianum,

Young and Bird. Geol. Surv. York. Coast, p. 257, 1828.

Simpson. - Monogr. Ammon., York. Lias, p. 45, 1843.

Oppel. Mittl. Lias Schwabens, p. 5 1, tab. 3, fig. 1, 1853.

Simpson. Fossils of Yorksh. Lias, p. 87, 1855.

Oppel. Juraformation, p. 168 (non d'Orb.), 1856.

Quenstedt. Der Jura, p. 173, tab. 22, fig. 28, 1856.

Oppel. Palaeontol. Mittheilung, p. 137, 1862.

Regnès. Géol, et Paléontol. Aveyron., pl. ii, fig. 1, 1868.

Tate and Blake. Yorkshire Lias, p. 302, pl. viii, fig. 1,1876 .

Diagnosis.-Shell discoidal, compressed, carinated, and slightly involute; volutions six, inner very little concealed; sides of whorls flat, with from twenty-five to thirty straight, sharp ribs, developing a series of blunt tubercles near the siphonal area, and then bending forward to the keel, which is thick and prominent without lateral sulci; aperture oblong, with straight sides; suture-line very complicated.

Dimensions.-A prolonged search in the Whitby Museum during the summer of 1S81, with Mr. Simpson, among some of the unfigured species of Lias Ammonites recorded in his list, afforded me an important insight into the characters of several of his species, and I had the pleasure of finding in the type specimen of Am. nitescens an unmistakable example of the Am. Algovianus, Oppel. I was anxious to have figured Young's type shell, but Mr. Simpson will not allow any specimen to leave the building; afterwards I had the good fortune to find a specimen of this shell in my friend $\mathrm{Mr}$. Slatter's cabinet, collected from the Amal. margaritatus-bed in the Midland Counties, and figured in Pl. XLIX, figs. 2, 6, and 7. Much better examples of this species are found in the Marlstone near Chipping-Norton, where it occurs in a brown sandy bed, which has well preserved the shell-texture. I am indebted to Mr. James Windus of that town for the small specimen I have figured $(3,4$, and 5$)$, and which I have magnified two diameters, as the fossil was too small to exhibit its characters without enlargement.

The shell is compressed and carinated. 'l'he sides of the whorls are flat, and ornamented with straight, simple, angular, well spaced-out ribs, which develop a series of obtuse tubercles at the side of the area before they bend suddenly forward towards the aperture. In the centre of the siphonal area is a high, prominent, sharp keel, which conceals and overlaps the siphuncle that lies beneath, and this structure is very well shown in 
Pl. XLIX, figs. 4 and 5, in which the shell is preserved and in the other specimen (figs. 6 and 7). Where the shell is absent all the sharp specific characters derived from the straight sharp ribs and high prominent keel are much modified.

The suture-line is well shown in both specimens; the siphonal lobe is short and narrow, with three digitations on its inner border; the siphonal saddle, large and wide, is divided into two segments by a short accessory lobe which issues from the bottom of the saddle; the outer foliole lias three lobes, and the inner is larger and terminates in four; the principal lateral lobe is large, and has a stout thick stem, with three lateral digitations on each side, and one long terminal branch; the lateral saddle is rather smaller than the siphonal, and terminates in fonr folioles; the inner lateral lobe is about one third the size of the principal, with short side digitations; the inner saddle is larger than the lobe, and terminates in three small folioles; the auxiliary lobes and saddles are very small (fig. 3).

Affinities and Differences.-This species very much resembles Harp. striatulum, Sow., its ribs, however, are more straight and sharp, and they possess obtuse tubercles near the area, which are wanting in Harp. striatulum, the whorls are also more flattened and square, and the suture-line is more acute and intricate than in Harp. striatulum. 'This species differs from Harp. Nomanianum, with which it was formerly confused, in having simple, straight, sharp, tuberculated ribs, all of which are undivided, and it has the keel much higher, sharper, and more prominent.

Loculity and Stratigraplical Position.-Harpoceras nitescens is found in the Marlstone beds at Hawsker, Staithes, Saltburn, and Rockcliff, Yorkshire, where it is rare. In Chipping Norton it occupies the same horizon, associated with several species of Mollusca that are found in the Amal. margaritatus-zone as Pecten aquivalvis, Monotis cygnipes, Pinna folium, Modiola scalprum, Cardium truncatum, Ploladomya ambigua, Trochus imbricatus, Cryptania expansa, Cryptania complanata, Belemnites Milleri, as reported to me by Mr. Windus.

Harpoceras serpentinum, Reinecke. Pl. LVIII, figs. 1-3.

Argonauta serpentinus, Reinecke. Naut, et Argon,, p. 89, No. 2, pl. xiii, figs, 74, $75,1818$.

- Cестlia, - Ibid., p. 90, No. 3, pl. xiii, figs. 76, 77, 1818. Ammonites serpentinus, Schlotheim. Die Petrefactenkunde, p. 64, No. 6, 1820.

- Capellinus, - ibid., p. 65, No. $7,1820$.

- Strangewaysi, Sowerby. Min. Conchol., vol, iii, p. 99, pl. 254, figs. 13,1821 .

- Falcifer, $\quad-\quad$ Ibid, vol, iii, p. 90, pl. 254, fig. 2, 1821.

- Mulgravids, Young and Bird. Geol. Survey, York. Coast, p. 251, pl. xiii, fig. 8, 1822 . 

Planites serpentinus,
Amonites Cezcilia,
- MULGRAVIUS,
- Falcifer,
- SERPENTINUS,

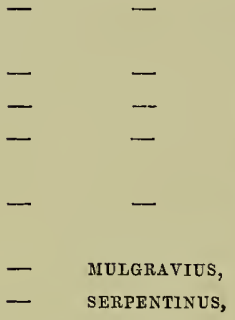
Harpoceras serpentinum, Neumayr. Zeitschr. Deutsch. geol. Gesellsch., Bd. xxriii, p. $909,1875$.
d'Orbigny. Pal. Franç., Terr. Jurass., tom. i, 215, pl. 55, 1842.
Quenstedt. Flözgebirge Würtembergs, p. 258, 1843.
-Quenstedt. Die Cephalopoden, tab. vii, fig. 3, 1849.
Chapuis et Dewalque. Terr. second. Luxemb., p. 68, pls. ix, fig. 4 , and $x$, fig. 1,1854 .
Morris. Catalogue of British Fossils, p. 295, 2nd ed., 1854.
Simpson. Fossils of Yorksh. Lias, p. 73, 1855.
Dumortier. Dépôts Jurassiques du Bassin du Rhône, p. 50,1874 .

\section{- $\quad$ - Tate and Blake. Yorkshire Lias, p. 307, 1876.}

Diagnosis.-Shell discoidal, depressed, and carinated; whorls flat, with lateral sulcus. upper border sloping towards the siphonal area, inuer border abruptly truncated at the umbilical margin; ribs 100, transverse, rugose, and undulated; curved forward in the middle, and abruptly truncated at the umbilical margin; siphonal area rounded, sloping, with a subacute elevated carina in the middle, towards which the lateral ribs bend forward. Suture-line tortuous, forming four lobes. Aperture with laterol processes, and a long projecting abdominal spine.

Dimensions.-Transverse diameter 180 millimètres; height of last whorl 60 millimètres; width of ditto 30 millimètres; width of umbilicus 80 millimètres.

Description. - This beautiful Ammonite is a capital leading fossil for the determination of the horizon in which it is found; the shell has received so many different names that it is well to master the synonymy of the species. In early life and before the ribs have acquired their special form, it is readily mistaken for Harp.radians; when it has attained a diameter of forty millimètres the ribs become flexed and curved in the middle; and they retain this form until old age, when the ribs gradually disappear, and the last whorl bears a smooth shell.

An adult form of this Ammonite was well figured by Reinecke in 1818 as Argonauta serpentinus, and the young form as A. Cacilia. Sowerby, in 1821, figured an adult specimen from the Upper Lias of Ilminster as Am. Strangewaysi, and the young form thereof as Am. falcifer. The following year Young and Bird figured it as Am. MLulgravius.

The shell is compressed, discoidal, strongly carinated, and provided with a prominent carina; the whorls are flattened and slightly convex; their sides covered with numerous 
rugose, highly-flexed ribs (fig. 1), which proceed from the umbilical nıargin, pass forward, and at about two-fifths of their length form a prominent curve backwards; then again turn forwards in a graceful bend towards the siphonal area, sweeping away towards the aperture by the side of the subacute keel (fig. 2). 'The whorls are flattened, and about cne fourth involute, down the middle of the sides is a shallow depression or lateral sulcus, into which the curved portion of the ribs dips; the siphonal area is narrow, and formed by the forward bending of the ribs, and the straight, prominent, elevated keel, which is not distinct from the ribs, but appears to be formed by their union. The spire is composed of five or six whorls, which are all fully exposed in the wide umbilicus, the amount of involution being about one fourth part of their height which leaves all the inner volutions fully exposed. The spiral margin of the whorls is very acute, abrupt, and angular, imparting a remarkable stair-like character to the umbilicus of this species.

The aperture is oblong and compressed; the sides have two lateral lappets as shown in the woodcut (Fig. 194), and the abdominal portion extends outwards in the form of a long projecting spine, intimately associated with the lateral curving forward and retreating backward of the inflected ribs.

The suture-line is very complicated (figs. I and 3); the siphonal lobe is narrow, and much shorter than the superior lateral, it is ormamented on each side with five digitations, and is larger at the base than at the summit of the lobe.

The siphonal saddle is two-fifths wider than the principal lateral lobe, and is divided into two unequal portions, by a long accessory lobe, the internal being the largest, much resembling in size and structure the inner lateral lobe. Each of the compartments of the siphonal saddle terminates in six or seven folioles.

The principal lateral lobe has a large complicated structure, having a thick stem, ornamented on each side with five or six long digitations, the internal branches being the longest, with a large terminal tuft at the summit.

The lateral saddle is much smaller than the principal lateral lobe, and has a very irregular form from the unequal size of its folioles. The internal lateral lobe is much smaller than the principal lateral, being about one third the width and one half the length of that large lobe. It has a very irregular form, with two lateral and one terminal bifid branches.

The first auxiliary saddle, having a similar form, is about one half the size of the lateral saddle. The two auxiliary lobes are small, the largest resembles in miniature the principal, and the smaller is simple and bifid. The chief character to be noted in the suture-line of this species is the excessive development of the principal lateral lobe and the great size of the siphonal saddle, with its long accessory lobule. This structure is very fairly delineated in the suture-line drawn in siti on the side of fig. 1 and in the outline of fig. 3.

Affities and Differences.-This Ammonite resembles Harpoceras radians, Ilarpoceras 
öifrons, and Harpoceras Levisoni ; it is distinguished from Harpoceras radians by having wider and flatter whorls, a less circumscribed keel, with less prominent ribs, a lateral sulcus, and a different suture-line. It is distinguished from Harpoceras bifrons by having wider whorls, smaller and more numerous rugose ribs, with a much smaller and shallower lateral sulcus, the want of the tricarinated and bisulcated siphonal area, and a difference in the structure of the lobes and saddles. It differs from Harpoceras Levisoni in having wider and less involute whorls, of the same form and strncture in youth as in adult age; whilst in Harp. Levisoni the young shell has large obtuse ribs, and a carina with lateral sulci, and style of building resembling the young shells of the genus Arietites.

Locality and Stratigraphical Position.-Harpoceras serpentinum has been collected from the zone of Harpoceras bifrons at Stinchcombe, Frocester, and Stroud, in Gloucestershire; Bloxam, Oxfordshire ; and many localities in Rutland; from the Santon Railwaycutting, in north-west Lincolnshire; and from numerous exposures of the Upper Lias on the Yorkshire coast, and known there under the names A. Mulgravius and falcifer.

Foreign Correlations. - I have devoted several pages of this work to the correlations of the Upper-Lias beds of north and south Germany, and several of the departments of France, and I must refer to pages 129-136 for ample details on the correlation of the Harp.-serpentinum beds in these countries.

Harpoceras bifrons, Bruguière, 1792. Pl. LIX, figs. 1-4.

Cornu Ammonis, Lister. Hist. Animal. Angliæ, tab. vi, fig. 2, 1678.

$\begin{aligned} & - \\ & -\end{aligned}-\quad \begin{aligned} & \text { Baier. Oryctogr. noric., p. 65, tab. iii, fig. 9, } 1708 . \\ & \text { Rumphius. Thesaurus, tab. 60, fig. A.D., 1739. } \\ & \text { - }\end{aligned}$


Ammonites bifrons, Dumortier. Dépôts Jurassiques, partie iv, p. 48, pl. ix, figg. $1,2,1874$.

Harpoceras - Neumayr. Zeitschr. Deutsch. geol. Gesellsch., Bd, xxvii, p. 908,1875 .

Tate and Blake. Yorkshire Lias, p. 307, 1876.

Diagnosis.-Shell discoidal, compressed; siphonal area tricarinated and bisulcated; whorls compressed, slightly biconvex, with a deep longitudinal sulcus occurring at twothirds distance from the siphonal area and intersecting the ribs; ribs strong, obtuse, biflexed, and curved against the line of the sulcus; whorls one-third involute, outer twothirds most strongly ribbed; aperture quadrate, elongate, lateral walls vertical with projecting convex lappets, outer abdominal margin having an elongated process ( $\mathrm{PI}$. LIX, fig. 1).

Dimensions.-Transverse diameter 155 millimètres; height of whorl near aperture 40 millimètres; width of umbilicus $\$ 0$ millimètres; height of aperture 38 millimètres ; transverse diameter of aperture 30 millimètres; thickness of shell across the last septum 28 millimètres; length of the body-chamber three-fonrths the length of the last whorl.

Description.-Although it is now two centuries ago since this common Ammonite was first figured by Lister, no such accurate delineation of this beautiful form has ever before been drawn as that given in Plate LIX, which displays the whole external anatomy of the shell, shows the length of the body-chamber, and the processes of the aperture. I collected this specimen a few years ago at Whitby, but I have never found a second example as perfect as this type.

The shell is discoidal and much compressed; the siphonal area is tricarinated, the median carina most elevated, the two lateral carinæ less so and separated from the median carina by two well-marked grooves; the whorls are compressed and exhibit at their inner third a deep longitudinal sulcus, which divides the side of the whorl into two convex portions, the outer portion is covered with sixty obtuse convex ribs, the concavities of which are directed towards the aperture; the inner portion is narrower and more convex, being limited by the sulcus, and shows feeble traces of very small ribs; it is this portion of the whorl that forms the prominent ornament of the umbilicus (see figures 3 and 4). This style of double ribbing is well developed in the two fragments which, covered with the mother-of-pearl coating of the shell, have preserved their markings in great perfection.

The aperture is quadrate, elongated, and compressed at the sides, and its transverse section (fig. 2) exhibits at the summit two slight simnosities, and at the base a grooving formed by the return of the spire; the walls of the aperture (fig. 1) show short convex lateral lappets on each side, and the outer abdominal portion a long projecting process. On this figure likewise is delineated the true position of the last septum, marked by the suture-line, and showing from its position that the body-chamber occupied three fourtlis of the last whorl.

Professor d'Orbigny made some instructive observations on the morphology of this 
species, he noticed that, as in other carinated Ammonites, the keel did not appear until the shell had attained the size of from two to four millimètres in diameter, and commenced to develop at the same time, the folds on the sides of the whorl indicating the appearance of the ribs. The deep lateral sulcus made its appearance when the shell had attained seven millimètres in diameter. The then shell continued to grow with all its ornaments. The whorls were proportionally larger in the young than in adult specimens. Soon the ribs became less prominent, and the sides less inflated, and when the diameter of 140 millimetres had been reached the ribs entirely disappeared, and the shell appeared almost smooth, and the lateral sulcus was then only feebly marked and less shallow than in early life.

Affinities and Differences.-Harpoceras bifrons makes one of the remarkable group Falciferi, among which there are many characters common to the whole. It resembles very much Harpoceras serpentinum, and is regarded by some as only a variety of that species; there are, however, several organic features which distinguish them: 1 . The three carinæ on the siphonal area and the two lateral sulci on each side of the median keel ; 2. The deep longitudinal sulcus which divides the whorls along their length, the outer two thirds of the side having convex ribs, and other narrow portions being inflated and smooth; 3 . The suture-line is very different also in the two forms. It has many affinities with Harpoceras Levisoni ; these, however, will be pointed out in the following article, which will embrace the history of that species.

Locality and Stratigraplical Position.-This is one of the characteristic fossils of the Upper Lias, and is the type form of the zone it represents; it is found at Crickley, Frocester, and Stinchcombe Hills sections, and at Alderton, Grettan, Dumbleton, Gloucestershire ; at Bloxam, Oxfordshire; several localities in Rutland, Santon, north-west Lincoln; and Whitby, Yorkshire, the metropolis of the species; from the last locality my beautiful figured specimen was obtained.

Foreign Distribution.-I must refer to my 'Correlation of the Harp. bifrons-zone,' pp. 127-136 of this Monograph, for an exhaustive account of the distribution of this horizon of life in north and south Germany, France, and Switzerland.

Harpoceras Levisoni, Simpson. Pl. LX figs. 1 and 2 ; and LXI, figs. 1-6.

Aumonites Levisons, Simpson. Monogr. on Ammonites of Yorksh., p. 99, 1855.

- $\quad$ Borealis, Seebach. Der Hannover. Jura, p. 140, taf. vii, fig. 5, 1864.
- $\quad$ comensis, Reynès. Géol. et. Paléontol. Aveyron, pl. 5, fig. 6, 1868.
Levisoni, Dumortier. Dépôts Jurass., part. iv, p. 49, pl. ix, figs. 3, 4, 1874.
Harpoceras $\quad-\quad$ Tate and Blake. Yorksh. Lias, p. 307, 1876.

Diagnosis.-Shell discoidal, compressed, carinated, with a very wide umbilicus; 
whorls flat on the sides, ribs obtuse, sigmoidal, equal in width to the intervening valleys. Carina thick and slightly elevated, with indistinct furrows on each side; inner whorts strongly ribbed, outer much smoother; aperture quadrate, with lateral lappets and an abdominal projection.

Description.-This form is nearly allied to the preceding species. The shell is compressed, discoidal, and carinated. The whorls are narrow, and about one-third involute. The sides are flat, and ornamented with broad, obtuse, sigmoidal ribs, separated by valleys of a like breadth. The ribs are thicker and more prominent in the inner whorls, but the last whorl of the adult shell has very obtuse distant undulations, which gradually become by degrees a nearly smooth surface. The inner or spiral side of each whorl is well rounded down at right angles to the previous one, so that the wide umbilicus of this species presents a succession of flat terraces of a stair-like form. The siphonal area is round, with a smooth, thick, low carina rising in the middle of two indistinct depressions, one on each side. The evolution of this Ammonite differs from some of its congeneric forms. In early life the suture-line develops on each side three lobes and three saddles composed of single parts. The siphonal lobe, a little narrower and shorter than the principal lateral lobe, is divided by the median line up to one third of its height, and presents only one chief terminal point and several lateral digitations. The dorsal saddle very wide, almost twice the size of the principal lateral lohe, is divided by a small accessory lobe into two portions, each of which terminates in obtuse shallow folioles. The principal lateral lobe is an elongated mass, ornamented on each side with three or four simple digitations, and terminates in several branches, of which the two central are the longest. 'The lateral saddle is long and narrow, about half the width of the siphonal; it lies in the sulcus, and is seen with difficulty; it terminates in a few obtuse shallow folioles. The internal lateral lobe is small, about one fourth the size of the principal, it bends inwards, and has a few lateral digitations, terminating in a longer lanceolate process. The auxiliary saddle is very short and bilobed. The auxiliary lobe is less than the internal lateral, and is armed with lateral digits and a terminal point; it lies well down torvards the spiral suture on the slope of whorl.

A radial line stretched from the extremity of the siphonal lobe cuts the three last digitations of the principal lateral lobe, but does not approach any of the others.

In its morphology this species forms a remarkable contrast to Harp. bifrons; when of the diameter of forty-five millimètres, it possesses thick, prominent ribs, has a low keel, and two sulci on the area, and in this condition it very much resembles an Arietites, as shown in Pl. LXI, figs. 1 and 2. The next volution exhibits the ribs more obtuse and distant from each other; and in the following volution the ribs have a highly sigmoidal curve, are well inclined backwards, and then curved forwards upon the area. This style of ribbing is very well shown in the beautiful shell figured in Pl. LXI, figs. 5 and 6 , from the Upper Lias of Ilminster. The fine large adult shell, which forms the subject of 
Pl. LX has a singular history. One half of this specimen was discovered at Grettan, Gloncestershire, a long time ago, in the turning over of a heap of rubbish, from whence it came into my hands. I found the inner costated whorls of its early condition very well displayed in the fragment, and a portion of its adult state as well. I promised my collector a good fee if he would find the rest of the fossil, which I was certain, from the fractured surface, remained in the heap; after a two days' search a second fragment was. found, which when placed in position still left a gap. Again I renewed my promise, and another long search over the stuff disclosed the third missing fragment. Soaking the mutilated specimen in boiling water I detached all the fragments, and having cleaned their fractured surfaces, cemented them together and produced the fine Harpoceras Levisoni figured in Pl. LX. The shell is converted into crystallised carbonate of lime, which completely conceals the mould and much of the suture-line; this line, however, is shown in the young ribbed shell (PI. LXI, fig. 3).

The siphonal lobe is long, the sides present several digitations, and it terminates in a long divergent branch. The siphonal saddle is twice the width of the lobe, it has an accessory lobule arising in the middle, and dividing the space into two compartments, which terminate in many shallow folioles. The principal lateral lobe is a large mass with four or five lateral digitations, and a round head surmounted by four digitations (Pl. LX, fig. 1, and Pl. LXI, fig. 3). The lateral saddle is smaller than the siphonal, it is unequal in form, inclines towards the principal lobe, and terminates in five or six shallow, obtuse folioles. The inner lateral lobe is much smaller than the principal, it has. several lateral digitations, and a terminal lanceolate one. The auxiliary lobes and saddles were small and imperfectly shown in the specimen examined.

In the outer portion of the body-chamber of one specimen (PI. LXI, fig. 4) is one half of the Aptyclus. This body is covered with oblique ribs, and lies in the longitudinal line of the shell.

The aperture is elongated (Pl. LXI, fig. 6), flattened on the sides, and rounded at. the outer margin; at the lower portion of the side near the spire is a projecting convex lateral lappet (fig. 5), with a concavity, above which it ends in a long projecting abdominal process, well delineated in Pl. LXI, figs. 5 and 6.

Plate LXI, figs. 1 and 2, are accurate delineations of a young shell sent to me for determination more than thirty years ago. The build of this shell with its fifteen robust prominent oblique ribs and deep intervening valleys (fig. 2), and broad siphonal area, having a central keel and lateral furrows, so closely resembled an Arietites that I thought a mistake had been made when it was said to have been collected from the Upper Lias of Ilminster, and I told my friend, the Iate Dr. Lycett, who sent the smallribbed Ammonite to me for determination, that, if there was no mistake about its horizon, it must be the young form of some larger Ammonite, which at that time we did not know. It was not until many years afterwards, when I found a similar Ammonite in the interior whorls of an undoubted Harp. Levisoni that the real truth dawued upon me. 


\section{PALAONTOGRAPHICAL SOCIETY}

INSTITUTED MDCCCXLVII.

VOLUME FOR 1884.

LONDON:

minccelXXXIv. 



\section{MONOGRAPH}

ON THE

\section{LIAS}

\section{AMMONITES}

OF

\section{THE BRITISH ISLANDS.}

BY

THOMAS WRIGHT, M.D., F.R.S., F.G.S.,

VICE-PRESIDENT OP THE PALEONTOGRAPHICAL SOCIETY; CORRESPONDING MEMBER OF THE HOYAL SOCIETY OF SCIENCES

OF LIEेGE; THE SOCIETY OF NATURAL SCIENCES OF NEUCHÂTEL; VICE-PRESIDENT OF THE COTTESWOLD NATURALISTS' FIELD CLUB; CONSULTING SURGEON TO THE CHFLTENHAM HOSPITAL; AND MEDICAL OFFICER OF HEALTH TO THE URBAN SANITARY DISTRICTS OF CHELTENHAM, CHARLTON KINGS, AND LECKHAMPTON.

PART SEVEN'TH-DESCRIPTION OF SPECIES.

Pages 441-480; Plates LXXVIII-LXXXVII.

LON DON :

PRINTED FOR THE PALEONTOGRAPHICAL SOCIETY. 
PRINTED BY J. E. ADLARD, BARTHOLOMEW CLOSE. 
Affinities and Differences.-Harpoceras Levisoni has strong affinities with Harp. bifrons, still the build of the shells presents important points of difference. In Harp. Levisoni the shelly laminæ are thicker, and the style of costation different; the lateral groove which divides the costæ on the sides, and produces an outer costated half and an inner smooth half in Harp. bifrons, is absent in Harp. Levisoni. The form of the siphonal area is likewise different, in Harp. bifrons we have a small keel with grooves on each side, whilst in Harp. Levisoni there is a thicker and more prominent keel, and an absence of the two lateral furrows on each side of the carina.

The morphology of the two species is likewise different. In early life the shell of Harpoceras Levisoni likens it to that of an Arietites; it has thick, straight costæ, knobbed at the angle, and a siphonal area with stout keel, and two lateral grooves, like Ariet. obtusus; all these characters, however, become obsolete as the evolution of the shell proceeds. It is only by breaking up large specimens and finding the nucleus, that the truth is revealed. When all these differences in the structural characters are fairly considered, they are sufficient to justify the separation into two distinct species.

Harpoceras exaratum, Young and Bird. Pl. LXII, figs. 1, 2, 3.

$$
\begin{gathered}
\text { Ammonites exaratus, } \quad \text { Young and Bird. Geological Survey of Yorkshire Coast, } \\
\text { p. 266, 1828. }
\end{gathered}
$$

Diagnosis.-Shell discoidal, depressed, carinated, extremely involute, volntions threefonrths concealed; outer whorl in height about half the diameter of the disc. Costæ numerous, broad, distinct, simple, uniform, twice bent, and separated by neatly-cut sigmoidal grooves; sides of the whorls convex in the middle, inner margin sloping towards the spiral line. Siphonal area narrow; keel sharp, prominent, and entire; aperture elongated, lateral lappets short, slightly convex; abdominal spine prolonged. Umbilicus narrow, with its walls forming a re-entering angle.

Dimensions.-Transverse diameter 95 millimètres; height of the last whorl 45 millimètres; width of the aperture 21 millimètres; width of the umbilicus 18 millimètres.

Description.-Harpoceras exaratum is a well-defined and very abundant form in the Upper-Lias jet rock on the Yorkshire coast, where some large and beautiful shells are 
sometimes found. Confusion has been introduced into the history of this Ammonite in consequence of d'Orbigny having mistaken this shell for Ammonites complanatus, Bruguière, which is a different species and not well defined by its author "Ammonites striis simplicibus undulatis obliquis, sulco utrinque intermedio carina acuta," Bruguière, 'Encycl. Méthod.', tom. i, p. 38. This diagnosis applies equally to two distinct forms; $a$, those in which the keel is not separated from the sides, and forms only the continuation thereof, and $\delta$, those in which the area shows three carinæ with two intermediate sulci. The first form has Harp. exaratum for its type, the second has Am. bicarinatus, Münster (in Zieten), for its type. D'Orbigny's pl. 114, figs. 1, 2 is an admirable delineation of Frarpoceras exaratum and perfectly in accordance with a very good figure given by Chapuis and Dewalque under the name Am. complanatus. In Harp. exaratum the shell is discoidal, depressed, carinated, and extremely involute, the volutions concealing three fourths of the whorls, and the height of the outer whorl about one half the diameter of the disc; the radii are numerous, always bifiexed and simple, appearing as if etched out with a graver, as expressed by the name, and extended upon the keel, which is not separated from the sides, of which it is only a continuation, and upon which they are prolonged in a marked manner. The very numerous radii parting from the spiral junction first incline forward, then bend backward, and again sweep forward in such a manner as to describe a sickle-shaped curvature; and, as they are all simple, it follows that the radii stand wide apart around the siphonal area, and are closely set together in a very regular form near the spiral angle (PI. LXII, fig. 1). The umbilicus is narrow and deep with an angular margin without being trenchant, and the juner edge of each whorl overhangs part of the next whorl ; this form of the spire permits a much larger portion of the inmer volutions to become visible than would have been the case had the margin inclined ontwards instead of inwards. The overhanging of the whorls constitutes a difference between Harp. exaratum and Harp. bicarinatum. In Harp. bicarinatum the inner sides of the whorls are vertical or nearly so.

The evolution of Harp. exaratum is well shown in two or three specimens collected by me in one mass from the jet-rock. One of the shells is only 21 millimètres in diameter, yet the sides are well ribbed with prominent radii, and there is a small carina on the siphonal area; the proportions and ornamentation of the young shell are clearly similar to those of the larger specimen found with it in the same mass of stone.

D'Orbigny united with his Am. complanatus the Am. bicarinatus, Zieten, and stated (p. 355) that the young shells of Am. complanatus show a tricarinate siphonal area, and he figured in his pl. 114, fig. 3, a small Am. bicarinatus in support of his assertion. In this the learned author was mistaken, as the young shell of Harp. exaratum, which is identical with his Am.complanatus, has only a single carina in the area. In fact, Harp. bicarinatum is a distinct form, for from its flattened sides and square area two small lateral carinæ arise on each side of the keel; three specimens before me from Milhaud, Aveyron, support this determination. 
Dumortier has figured and described an Ammonite under the name Am. exaratus, which is very different from Young's typical shell ; this is either a defaced specimen or another form. The plates which I consider to contain good figures of Harp. exaratum are those given by d'Orbiguy, pl. 114; Dumortier pl. $\mathrm{x}$ and $\mathrm{xi}$, figs. 1, 2; and the medium-sized shell drawn in Pl. LXII, figs. $1-3$, in this work. The late Dr. Reynès in his 'Monographie des Ammonites,' Marseille, 1879, pl. iv, "Ammonites du Lias supérieur," figs. 4, 5, 6, gave admirable delineations of this species under the false name $\mathrm{Am}$. elegans, Sow.

Affinities and Differences.-The Falciferi of Von Buch, whilst truly one of the most natural families of the Ammonoida, is at the same time one of the most difficult to differentiate into specific forms. Mere descriptions without carefully drawn and accurate delineations are in a great measure valueless, hence the confusion which exists in testing several of the species of this group. The difliculty an author experiences in detecting mistakes is very great, unless he has a set of good type specimens to refer to for comparison; seeing so much depends on the shape of the whorl, the style and diameter of the ribbing, the amount of involution, the inversion, eversion, or verticality of the spiral angle, the structure of the keel, the contouring of the suture-line, and the form of the appendages of the aperture; and so closely balanced are all these points with each other that without an actnal comparison of typical specimens mistakes of identity are readily made.

Harpoceras exaratum closely resembles Harp. serpentinum in general outline, but differs in the following details :- The sides are more convex, the whorl is higher, the involution greater, the umbilicus narrower, and the sigmoidal valleys between the radii are much more sharply defined; the longitudinal sulcus also so characteristic of Harp. serpentinum is absent.

Harp. exaratum differs from Harp. bicarinatum, Münster; in the latter the sides are flatter, the area squarer, with a low keel and two lateral carinæ on the boundaries of the area; the involution is likewise greater, and the radii broader, less numerous, and very falciform (see Pl. LXXX11, figs. 9, 10, 11).

Harp. exaratum resembles Harp. Lythense; but in the latter the outer whorl is higher, the ribs fewer, larger, and rounder; the umbilicus narrow, the spiral angle very acute, and the sides of the walls vertical, exposing all the inner volutions; the aperture is sagittate, the upper portion sloping away toward the keel.

Locality and Stratigraplical Position.-This fine Ammonite, which sometimes attains 210 millimètres in diameter, is found in the zone of Harp. serpentinum, Upper Lias, at Whitby, Yorkshire. 
Harpoceras Lythense, Young and Bird, Pl. LXII, figs. 4, 5, and 6.

Ammonites Lythensis, Young and Bird. Geol. Surv. Yorksh. Coast, p. 267, 1828.

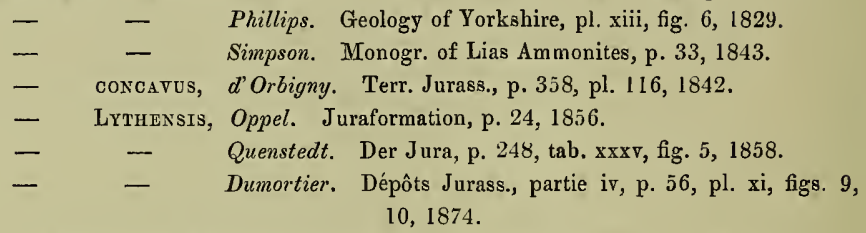

Harpoceras Lythense, Tate and Blake. Yorksh. Lias, p. 304, pl, ii, fig. 4, 1876.

Diagnosis.-Shell stout, discoidal, depressed, and carinated; volutions four or five, nearly concealed; outer whorl in height exceeding the semi-diameter of the disc, thicker near the inner margin (which is acute, with rectangular walls), and sloping towards the outer margin, which terminates in a thick keel; inner half of the whorl longitudinally depressed and almost smooth, outer half sloping from a ridge towards the siphonal area, and covered with strong, obtuse, bent radii, which vanish on the side of the area; umbilicus narrow, with deep sides, rising stair-like from a sunken pit-like depression; aperture high and compressed, acute towards the margin, and deeply grooved by the return of the spire.

Dimensions.-Transverse diameter 95 millimètres; height of last whorl 50 millimètres; height of aperture 50 millimètres; breadth 23 millimètres; width of umbilicus 17 millimètres.

Description.-This is a well-known, and highly-characteristic species of the Upper-lias beds near Whitby, which has been sadly misrepresented by bad figures. It may trúly be said that Mr. Gawan's delineation of Harp. Lythense is the first accurate representation of the Yorkshire type. D'Orbigny, under the false naine Am. concavus, figured a French shell obtained from the Upper Lias, which he identified with Sowerby's Am. concavus; this was a grave mistake, as the $A m$. concavus, Sorverby, is a very different shell, belonging to the Harp.-Sowerbii zone of the Inferior Oolite. I have no doubt therefore that the subject of d'Orbigny's figure is a true Harp. Lythense, which differs little from the typical form which this species assumes in the Yorkshire beds, and of which I have selected a very fine average specimen for the beautiful figure in Pl. LXII, figs. 4-6.

This shell is stout, depressed, discoidal, and carinated; the whorls are deep and extremely involute, the outer whorl exceeding in height the semi-diameter of the disc; on the inner lalf of the whorl there is a slightly depressed, longitudinal space, which near the middle rises into a low ridge, whence to the margin the side slopes away to the area, and forms a good character of the species; the keel is strong, but often absent, as the syphon lies safely buried in the mould of the shell; the keel is formed by a continuation of the sides, and is separated from them by a slight lateral depression. The 
ribs, from fifty to sixty in number, are sigmoidal in form, feebly developed at the inner half of the whorl, and strongly developed on the external half from the low ridge outwards; they are here broad, flattish waves of the shell, with undulations of a similar breadth between. The shell-strncture is very well shown in one of uy speciunens, in which the outer and inner laminæ are freely exposed; the outer lamina has rather a coarse texture, whilst the inner lamina is thin and smooth. The inner margin or spiral angle is very acute, and, as Young so well expressed it, "the interior edge of each whorl being rectangular, the central part appears like a small round pit with perpendicular sides." The aperture is elongated and compressed; and in one of my specimens the mouth is preserved, the sides of the apertnre have two convex lappets, which correspond to the forward curve of the ribs, and there is an abdominal projection produced by the forward flexion of the costæ; in fact, here, as in all the other congeneric forms, the shape of the walls of the aperture is derived from the form and direction of the radii.

The suture-line is very complicated and not satisfactorily shown on any of my Yorkshire specimens. Professor d'Orbigny, who figured this structure, says that the siphonal lobe is narrower and shorter than the principal lateral and consists of one branch; the siphonal saddle is very large and divided unequally into two portions by a long accessory lobe, the external portion is much shorter and sinaller than the other; the principal lateral lobe is large and provided without and within with five branches independent of the terminal branch. The lateral saddle is unch narrower than the principal lateral lobe, and is divided into two equal parts; the other saddles are very irregular, the inner lateral lobe resembles the principal lateral in form, but is not more than one third its size, and the three auxiliary lobes are very small.

Affinities and Differences.-Professor d'Orbigny has given capital figures of this Ammonite, but comnitted a mistake in identifying it with Sowerby's species Am. concavus, which is an Inferior-Oolite shell belonging to the zone of ILarp. Sowerbii, hence the confusion that has followed in the lists of species special to different beds; Ammonites concavus being quoted by some as a leading fossil of the Upper Lias, though it is known to those acquainted with its true form that it is never found out of the zone Harp. Sowerbii of the Inferior Oolite. Harpoceras Lythense is a thicker shell, strongly ribbed on the outer half of the whorl and slightly so on its imner half. Harp. concavun is a much thinner shell, with feehle costæ on the outer side of the whorl and nearly a smooth surface within. In ILarp. Lythense the umbilicus is encircled by an acute angle, and the whorls are cut into vertical walls, whilst in Am. concavus the umbilicus is a concave cavity formed by a sloping away of the angles of the whorls. IIarp. Lytleense has a distinct and prominent keel, $A m$. concavus has no keel, but the siphonal area is bevelled away on each side, like the roof of a house.

Locality and Stratigraphical Position.-Harpoceras Lythense is collected at Whitby from the Upper Lias in beds of a shaly clay belonging to the zone of Harpoceras serpentinum. It was at one time common, but has now become rare. 
Harpoceras ovatum, Young and Bird. Pl. LXIII, figs. 4, 5, 6, 7.

Aмmonites ovatus, Toung and Bird. Geological Survey, p. 251, pl. xiii, fig. 4, 1822.

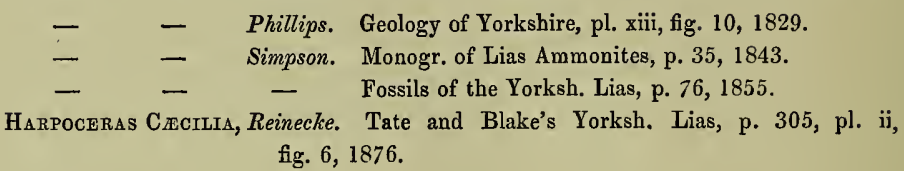

Diagnosis.-Shell discoidal, compressed, and carinated; whorls ovoid, one half involute; radii sigmoidal, bifid, each feebly-developed stem divides into two branches, of which from fifty to sixty are found on the convex side of one volution; the inner margin slopes evenly down to the penultimate whorl without any spiral angle; keel sharp, prominent, and entire, having two narrow shallow grooves on each side thereof. Aperture ovate, sides with convex lateral lappets, and a short projecting abdominal spine.

Dimensions.-Transverse diameter 105 millimètres; height of the last whorl 40 millimètres; width of umbilicus 29 millimètres; height of aperture 28 millimètres; width 23 millimètres.

Description.-This is a well-marked form in the Upper-Lias beds near Whitby; it often occurs as a rough, irregular-formed, discoidal, compressed shell, having ovoid whorls, which are one half involute; the inner third of the whorls slopes gently down to the spire without any angular margin such as is seen so well marked in Harp. exaratum, Harp. Lythense, and Harp. elegans; the sides of the whorls are, in fact, nearly convex in a regular well-formed shell, sometimes, however, the inner third of the whorl protrudes beyond the convex curve; the ribs arise by a number of feeble striæ from the inner margin, which soon coalesce and form stems, and each soon divides into two branches; the ribs are all twice bent, first a little forward, then well bent backward, and, lastly, again well directed forward; the radii are not prominent (Pl. LXIII, fig. 4).

The shell slopes away to the siphonal area, which is the narrowest portion of the volution. The keel is sharp, narrow, entire, and prominent, with two small longitudinal sulci on each side of it, on which the forward directed portion of the ribs finally vanish (Pi. LXIII, fig. 6).

The aperture is oval, and the walls form two lateral convex lappets and a forwarddirected abdominal spine; just before the aperture the walls of the shell become slightly expanded, and show irregular foldings (Pl. LXIII, figs. 4, 5).

The suture line is of the radians type. The siphonal lobe is large, with two widelydiverging branches, and is nearly the size of the siphonal saddle, which is provided with an accessory lobule that divides the space into two unequal folioles, the inner one being the largest. The principal lateral lobe is very large; it has three lateral denticles on each side, and a long terminal branch; the lateral saddle likewise ends in two folioles, 
with several leaf-like cells on the sides. The inner saddle is constricted in the middle, and surrounded by numerous folioles on the sides. There are three thick auxiliary lobes, and three narrow saddles between them, where they disappear under the spiral suture. The suture line is seen in sitî on Pl. LXIIl, fig. 4, and an enlarged drawing of it is carefully drawn in Pl. LXIII, fig. 7.

Affinities and Differences.-Harp. ovatum is distinguished from the other congeneric species by its ovoid whorls without vertical or concave folds at the inner margin, by having a prominent keel with two lateral sulci, and by being provided with only faint sigmoidal radii, every two springing from a common stem. This species more closely resembles Harp. radians than any of the other furms with which it is associated in the Upper Lias of Yorkshire.

Locality and Stratigraphical Position.-This species appears abundant in the jetrock and hard shales of the Upper Lias near Whitby and Runswick; it is rather an abundant fossil, but most of the examples are very rough and deformed; it is rare, therefore, to find so good an example as the one which I have figured as a type of the species.

Harpoceras elegans, Young and Bird, Pl. LXIII, figs. 1-3.

Ammonites eleqans, Young and Bird (non Sowerby). Yorksh. Coast, p. 267, pl. xiii, fig. 11, 1828.

- candidus, d' Orbigny. Terr. Jurass. (no description), pl. 63, 1842.

- $\quad$ elegans, Simpson. Monogr. of the Lias Ammon., p. 31, 1843.

- $\quad$ - $\quad$ Fossils of the Yorksh. Lias, p. 72, 1855.

Diagnosis.-Shell discoidal, compressed, subcarinated; whorls slightly convex, twothirds involute; spiral angle acute, with a concave slope on the penultimate whorl; inner third concave, outer two thirds slightly convex; siphonal area narrow, sloping, with an elevated ridge in the middle; radii simple, sigmoidal, well marked in young shells, and becoming very delicate with age; aperture elongated and sagittate, with two slightly prominent lateral lappets.

Dimensions.-Transverse diameter 100 millimètres; height of the last whorl 38 millimètres; width of umbilicus 24 inillimètres; height of aperture 27 millimètres; width 20 millimètres.

Description.-This is another common Whitby Ammonite which has hitherto been badly drawn, as shown in pl. xiii, fig. 11, of Young and Bird's work. Some authors refer this Ammonite to Ammonites elegans, Sow., but none of the specimens I have examined correspond with Sowerby's figure, which does not appear to be a Lias shell at all; as I have not seen the type specimen I refrain from further criticism. The figure which approaches nearest to this fossil is that given by d'Orbigny in bis pl. lxiii, under the uame 
Ammoniles candidus, d'Orb., 'Lias supérieur,' but oddly enough the author has omitted to give any description of his plate, nor does he make any allusion to it either in the text of his great work 'Paléontologie Française,' or in his 'Prodrome Paléont.;' I believe, however, in the identity of the Am. candidus, d'Orb., with Harp. elegans, Young.

The elegance of this Ammonite and the persistency of its beautiful lines long attracted my attention, and I have collected many examples from the jet-rock and hard shale of the Upper Lias near Whitby, where it was at one time a very common species. The specimen I have figured is a very good type of this form. The shell is thin and very well preserved in the figured specimen, which displays the structure of the radii in the shelly lamine itself, and the impressions they leave upon portions of the mould exposed to view.

The shell is discoidal, compressed, and subcarinated. The keel does not form a distinct prominent elevation, but is a protruding ridge rising from the middle of the siphonal area, and is formed by the union of radii from the two sides joining together along the mesial line; the inner third of the whorl is slightly concave, and the outer two thirds convex and sloping upward into the keel. Some authors describe this species as possessing a sharp, prominent, entire keel, which does not agree with the foregoing description, so it is right to state that my definition applies to specimens which have the shell-structure preserved entire, whilst in other specimens in which the mould only exists the keel is much more distinct. The inner or spiral angle is acute and elevated (PI. LXIII, fig. 1), and slopes inwards in a concave curve towards the penultimate whorl. The umbilicus, although narrow, is nuch exposed by the successive slopes of the inner volutions of the spire.

The shell thin, smooth, and shining, is ornamented on the sides in younger specimens by moderately prominent sigmoidal ribs, which gradually become less defined in older specimens, and finally degenerate into the very fine radii on the body-chamber.

The aperture is narrow, elongated, and sagittate; it has short, convex, lateral lappets, and a prolonged abdominal spine, with a thickening of the shell around the aperture.

The mould of this species, when entirely denuded of its shell, has a very smooth, shining appearance, and the very characteristic concave sloping of the inner margin of the whorls, already noted, is now more conspicuous, so that it is readily distinguished from its congeneric associates by this character alone.

Affinities and Differences.-It differs from Harp. Lythense in having narrower whorls and smaller ribs in youth, and by wanting them in age. The sloping concave character of the inner margin of the spire in Harp. elegans forms a marked contrast to the acute spiral angle and vertical marginal wall of the umbilicus in Harp. Lythense.

It differs from Harp. exaratum by the absence of the well-marked regular sigmoidal ribs and deeply grooved valleys possessed by that species, and by the want of the concave marginal slope of the whorls, which forms so good a diagnostic character; this also distinguishes it from Harp. Lythense, and it is equally good as a diagnostic trait of character between Harp. elegans and Harp. exaratum.

Harp. clegans is nearly related to Harp. ovatum; the latter, however, has convex 
whorls without the spiral angle and concave slope seen in the former. Harp. ovatum has also a distinct prominent keel with a shallow groove on each side.

Locality and Stratigraphical Position.--This species is collected from the jet-rock and hard shales of the Upper Lias near Whitby and Runswick. Some very well-preserved specimens are found in the ironstone nodules abounding in these strata.

Harpoceras radians, Reinecke. Pl. LXIV, figs. 1-7; Pl. LXXIV, figs. 1, 2 ; Pl. LXXXI, figs. $4,5,6$.

\begin{tabular}{|c|c|c|}
\hline $\begin{array}{l}\text { NAUTILUS } \mathbf{R} \\
\text { AMMONITES }\end{array}$ & - & $\begin{array}{l}\text { Reinecke. Nautil. et Argonant., figs. } 39,40, \text { p. 71, } 1818 . \\
\text { Zieten. Versteiner. Würtemh., p. 5, tab. iv, fig. 3, } 1830 \text {, }\end{array}$ \\
\hline- & - & Roemer. Norddeutschen Oolithgebirg, p. 185, 1836. \\
\hline - & - & d'Orbigny. Pal. Franç., Terr. Jurass., t. i, p. 226, pl. 59, 1843. \\
\hline - & - & Flözgebirg. Würtembergs, p. $270,1843$. \\
\hline - & - & Cephalopoden, p. 110 , t. vii, fig. 4,1849 . \\
\hline- & - & $\begin{array}{r}\text { Chapuis et Dewalque. Mém. Cour. Acad. Roy. Belgique Foss. } \\
\text { Luxembourg, p. 72, pl. xi, fig. 1, } 1854 .\end{array}$ \\
\hline- & - & Oppel. Juraformation, p. $247,1856$. \\
\hline - & - & Quenstedt. Der Jura, p. 281, table 40, figs. 13, 14, 1858. \\
\hline
\end{tabular}

Diagnosis.-Shell discoidal, compressed, carinated with a wide umbilicus; spire formed of six volutions, depressed, slightly convex on the sides, of a regular elliptical figure, and covered with from sixty to eighty round ribs, slightly prominent, always flexed, and simple from the umbilicus upwards; siphonal area narrow with a prominent keel, well separated from the ribs, much elevated, and persistent in its form.

Dimensions.-Pl. LXIV, fig. 1. Transverse diameter 115 millimètres; width of umbilicus 42 millimètres; height of aperture 30 millimètres; width of aperture 20 nillimètres.

Description.-The species of Ammonites composing the Radians group are closely related to each other and require to be carefully studied at different periods of growth to ascertain their affinities and differences with other congeneric forms, and also to differentiate the species. The type of the Am. radians, Reinecke, fig. 39, is a well-defined form; the shell discoidal, compressed, and carinated, has a wide umbilicus, the spire is composed of six volutions, which are nearly one half involute; the whorls are gently convex, and a transverse section of the outer whorl gives a fairly elliptical figure. There are from sixty to eighty simple, blunt, biflexed radii on the last whorl, which extend singly from the spiral suture to the area without bifurcation. The keel is prominent, continuous, and entire, it is present in very young as well as in old shells, and is well separated from the flanks by a smooth or costate space, and in some varieties by a considerable width of the area. This shell appears to undergo very little change of form through life, a fact I have ascertained by breaking up several large Ammonites in order 
to arrive at the truth. One small specimen, 5 millimètres in diameter, was costated and carinated like the outer whorl of the same species 40 millimètres in diameter. So that both the form, ornamentation, and figure are retained with very little change through life in this species. My learned friend, Professor Quenstedt, with his usual accurate eye for the discrimination of Ammonite forms, has described the following varieties of $\mathrm{Am}$. radians :

a. Radians depressus, which is identical with Ammonites striatulus, Sowerby.

$\beta$. Radians compressus, resembling Am. Capellinus, Reinecke; its outer whorl is much higher than in Am. radians depressus.

$\gamma$. Radians quadratus, Quenst., of the type of Am. radians depressus; the keel has two lateral grooves on each side as in Harp. bifrons.

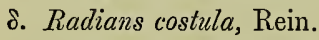

ع. Radians comptus, Rein., an intermediate form between Reinecke's Ammonites radians and Quenstedt's Ammonites ammonius, to which Harpoceras opalinum and Harpoceras Murchisoni appertain.

The septa are well displayed in figures 1 and 4, Pl. LXIV. They are symmetrical and are on each side divided into three lobes and three saddles, formed of single parts. The siphonal lobe is narrower and shorter than the principal lateral, and ornamented on each side with three digitations and two terminal divergent branches. The siphonal saddle is as large as the principal lateral lobe and divided by an accessory lobe into two unequal portions, the internal portion being the largest, and both terminate in many large unequal-sized folioles. The principal lateral lobe is large and ornamented on each side with five short and three elongated terminal branches, with numerous points to each branch. The lateral saddle is one third less than the principal lateral lobe and ends in large leaf-like expansions. The inner lateral lobe is not one half the size of the principal, its sides have several irregular digitations; besides these regular lobes there are two or three auxiliary lobes which are both short and irregular in figure.

The morphology of this species shows that at the diameter of 5 millimètres the keel and ribs were developed, the latter chiefly on the area first, afterwards appearing on the sides. At 24 millimètres diameter there were nearly forty ribs; at 43 millimètres diameter fifty-four ribs; at 70 millimètres diameter there were seventy ribs; and at 128 millimètres diameter the shell had ninety-four ribs, so that the number of the ribs of Harpoceras radians was in a direct ratio with the diameter of the shell. In the large German specimen, belonging to the British Museum Collection (Pl. LXIV, figs. $5,6,7)$, which attains 135 millimètres in diameter, there are ninety-six ribs.

Affinities and Differences.-Harpoceras radians very much resembles Harp. serpentinum both in form and ribbing. Its whorls, however, are not so high, and its ribs are only flexed and not bent in the middle; the sides are likewise convex, more involute, and not truncated at the inner border.

Locality and Stratigraplical Position.-This Ammonite attains a full development in 
the Lyt. Jurense zone at Frocester Hill, from whence the shell drawn on Pl. LXIV, figs. 1-3 was collected; the large specimen, figs. 5, 6, 7, on the same Plate, was obtained from the equivalent horizon in Germany, the locality is unfortunately not recorded. I have a beautiful specimen from the Upper Lias of Somersetshire, depicted on Pl. LXXXI, fig. 4. Most of the examples of Harpoceras radians from Frocester and Nailsworth Upper Lias Sands are small, compressed, thick, stout shells.

Harpoceras striatulum, Soverby. Pl. LXXXIV, figs. 4, 5, 6.

Ammonites striatulus,

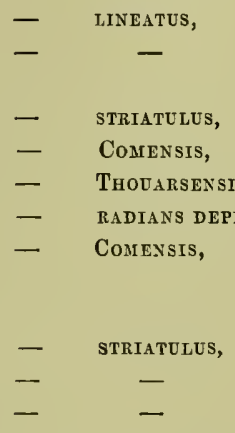

- Thouarsensis,

Harpoceras striatuluas,
Sowerby. Min. Conchol., vol. iv, p. 23, tab. 421, fig. 1, 1823.

Schlotheim. Petrefactenkunde, p. 75, No. 24, 1820.

Zieten. Verstein. Würtembergs, p. 12, pl. ix, fig. 7, 1830

- Ibid., p. 19, pl. xiv, fig. 6, 1830.

Von Buch. Petrif, remark, pl. ii, figs. 1-3, 1831.

d'Orbigny. Terr. Jurass., p. 222, pl. 57, 1842.

ss, Quenstedt. Cephalopoden, tab. vii, figs. 4-6, 1849.

Chapuis and Dewalque. Mlém. Cour. Acad. Roy. Belgique, t. xxv; Fossil Luxembourg, p. 63, pl. ix, fig. 1, 1854.

Simpson. Fossils York. Lias, p. 87, 1855.

Oppel. Die Juraformation, p. 248, 1856.

Dumortier. Dépôts Jurassiques, partie iv, p. 64, pl, xvi, fig. 1,1874 .

Ibid., p. 63, 1874 .

Tate and Blake. Yorkshire Lias, p. 308, 1876.

Diagnosis.--Shell discoidal, depressed, carinated; whorls about one third involute, convex on the sides; radii short; biflexed slender, vanishing from the inner third, thereby producing a smooth open umbilicus; siphonal area narrow, sloping towards the sides; radii terminate near the keel, which is small, trenchant, and bounded by two shallow sulci. Aperture elliptical ; suture-line tortnous; septa wide apart.

Dimensions.-Transverse diameter 60 millimètres; width of the umbilicus 25 millimètres ; height of aperture 18 millimètres; width of aperture 13 millimètres.

Description.-This Ammonite, evidently the Am. radians depressus, Quenst., and Am. Thouarsensis, d'Orbig., is easily distinguished from Am. radians, Reinecke, by the smooth inner portion of its convex whorls, from which the ribbing is absent, a character Sowerby failed to delineate in his otherwise good figure. The other point to which he attached so much importance, and upon which he founded the name striatulus, is seldom present, as the striæ only exist on the onter lamina of the shell which is seldom preserved. The baldness of the inner side of the whorl is a most persistent character, as the several specimens before me from different localities satis- 
factorily prove. The shell is discoidal and compressed; the whorls about one third involnte, are convex on their sides, and the outer two thirds of the height of each are ornamented with from forty to fifty short, slender, biflexed ribs; the inner third of the whorl, where it slopes towards the umbilicus is smooth, and from the summit of the slope the ribs commence; sometimes they are single, and sometimes they bifurcate, each stem dividing into two branches. The ribs first bend forward then backward, and again sweep forward towards the area and terminate at the side of a shallow sulcus, from which rises a thin prominent keel; the umbilicus is wide and the inner whorls are exposed, these have an ornate character as each whorl is smooth internally and ribbed externally. The aperture is either ovate or elliptical according to the amount of compression of the sides; the suture-line is well shown in many of my specimens, the chambers appear to have been large, as the septa are moderately distant from each other, and are composed of three lobes and three saddles with smaller auxiliaries. The siphonal lobe is as wide as but shorter than the principal lateral, and ornamented on each side with three short points and two single terminal branches. The siphonal saddle is one third larger than the principal lateral lobe, and divided into two unequal parts by an accessory lobe which arises from the concave surface, the whole ending in large folioles. The principal lateral lobe is large; it has two or three points on the sides and three longer terminal processes on the summit, and forms a conspicuous object on the side of the mould as it remains well apart from all the others. The lateral saddle is one third narrower than the principal lateral lobe, and terminates in two long folioles. The inner lateral lobe is about half the size of the principal and has an irregular figure with two or three small lateral points. The auxiliary saddle is wide, shallow, and trilobed, and the auxiliary lobes, two or three in number, are small and pointed, and pass into the ventral lobe, which is entirely concealed by the turns of the spire.

Affinities and Differences.-Some authors regard this species as the true type of Harp. radians and synonymous with it, I have, however, endeavoured to show the affinities and differences which exist between the two forms that lived together in the same sea abounding with congeneric species; still Harp. striatulum preserved the characters I have pointed out most persistently throngh life. And the same observation applies to the forms of this species recognised as Am. Thouarsensis, d'Orbig., and Am. Comensis, von Buch, in the respective French and German formations.

Locality and Stratigraphical Position.-I have collected this species from the dark Greyish Marl at Blea Wyke, near Robin Hood's Bay, associated with Harpoceras variabile and Harp. insigne, both characteristic fossils of the Lyt. Jurense zone. I have collected this shell likewise from the Lyt. Jurense Ammonite bed at Frocester Hill, Gloucestershire; these are the only localities I know in England. Sowerby's type specimen came from Blea Wyke, near Peak Hill, Robin Hood's Bay, Yorkshire, where it was collected by Mr. Crawford, of Scarborough, who sent the Ammonite to Sowerby; the specimen I have figured (Pl. LXXXIV, fig. 4) was collected by myself from the same locality. 


\title{
Ifarpoceras insigne, Schübler. Pl. LXV, figs. I-6; Pl. LXVI, figs. $1-3$.
}

\author{
Ammonites insignis, Schübler in Zieten, Verst. Würtemb., p 20, tab. xv, fig. 2, \\ 1830. \\ - $\quad$ - Quenstedt. Flözgebirge Würtemb., p. 272, 1843. \\ - Phillipsir, Simpson. Monog. Ammonites, p. 36, 1843. \\ - Insignis, Quenstedt. Cephalopoden, p. 97, 1849. \\ - - d'Orbigny. Paléont. Française, Terr. Jurass., p. 347, tab. \\ $112,1842$. \\ - Phillipsir, Simpson. Foss. of Yorksh. Lias, p. 78, 1855. \\ - Insignis, Oppel. Die Juraformation, p. 250, 1856. \\ - _ - Quenstedt. Der Jura, p. 280, pl. 40, figs. 4, 5, 1858. \\ - - Dumortier. Dépôts Jurassiques, partie iv, p. 74, pls, xvii, xviii, \\ 1874. \\ Harpoceras insigne, Tate and Blake. Yorkshire Lias, p. $310,1876$.
}

Diagnosis.-Shell discoidal, depressed, and carinated; volntions six, one half involute; whorls convex on the sides, a row of tubercles developed at the angle near the inuer margin, from which round fasciated ribs, slightly bent forward, proceed to terminate by the side of the carina; a short single rib lies in general between each pair of fasciated ribs ; carina large, round, and not prominent ; in youth and middle age the whorls are round; in large specimens the outer whorl becomes triangular, PI. LXVI, fig. 2.

Dimensions.-The specimen figured on Pl. LXV, fig. 1, transverse diameter 133 millimètres; width of the umbilicus 53 millimètres; height of the aperture 40 millimètres; width 35 millimètres. This shell may be considered as a good typical example of the middle period of life of this species. By far the finest example of this species is that contained in the Museum of Geneva. The specimen was collected from the iron stone either of Thouars Deux-Sevres or of La Verpillière, and is figured in Pl. LXVI, figs. 1-3. Its dimensions are transverse diameter 290 millimètres; amount of involution two thirds the height of the whorl ; the width of the umbilicus 100 millimètres ; height of the aperture 114 millimètres; width of aperture near the base 110 millimètres. In this grand specimen the siphonal area forms a trigon, as is very well seen in the transverse section of the aperture.

Description.-I have figured three varieties of this Ammonite. Pl. LXV, fig. 1, I consider a good type form of this species during middle lifc. 'The shell is discoidal, the sides depressed, and the area supports a thick round keel, towards the sides of which the costæ approach and terminate (figs. 2,3 ); the volutions, six in number, are one half iuvolute, the sides are convex, and on the inner margin near the angle there is a row of round prominent tubercles, from each of which a fasciculus of round costæ, slightly inflected forward, pass over the sides toward the siphonal area, increasing in thick- 
ness as they advance, and terminating abruptly by the side of the carina; the size and regularity of the tubercles, the straightness of the ribs, and the manner they end by the side of the thick round keel, distinguish this species from all other congeneric forms. When it attains a diameter of 120 millimètres the tubercles begin to disappear, the costæ fine down into depressed radii, and the keel becomes blunt and disappears, the outer whorl and the body-chamber change their form and become triangular, and the shell assumes a form which I have represented in Pl. LXVI. Just about the point where this metamorphosis takes place we notice on the mould a remarkable constriction, always in that portion of the shell where the septa are present; it is always unique, and never present before or after. At one time I was of opinion that the constriction might have been the result of an accident to the mollusk or to its shell during life; afterwards, however, I observed like constrictions in other specimens at the diameter of 120 millimètres, and hence it occurred to me that the Ammonite changed its lines of growth when it had attained that magnitude, just as we have a similar metamorphosis at a definite age in Aegoceras lieterogenum of the Middle Lias. The two specimens delineated in Pl. LXV, figs. 1 and 4 , show the constriction described, and a large imperfect specimen, 210 millimètres in diameter, from Heiningen, Würtemberg, in my collection, has a little mark on the mould at 120 millimètres diameter. In both the figured specimens referred to, the form of the whorl changes beyond the constriction; the whorls which up to that mark had been of a rounded or elliptical figure, begin henceforth to assume a distinctly triangular outline. In the beautiful and accurate plate of Am. insignis given by d'Orbigny (Pl. 112) this fact is very well represented, although nothing is stated in the text relating to the change of form by that most accurate observer, who appears to have had a large series of specimens illustrative of the morphology of Harp. insigne. On this subject our anthor states that " this species is without contradiction one of the most remarkable in reference to its changes of form according to the age and sex of individuals. An example of the diameter of 4 millimètres is entirely smooth, with a round back without keel. Another of a diameter of 5 millimètres presents some slight prominences around the umbilicus, and preserves them for some time without an indication of a carina. When the diameter has reached 10 millimètres the lateral costæ, the tubercles, and the carina become conspicuous. At the diameter of from 15 to 20 millimètres fourteen tubercles and thirty-two costæ can be counted. There are seventeen tubercles and thirty-eight costæ when the shell is of the diameter of 50 millimètres. A compressed specimen at the diameter of 125 millimètres showed thirty-four tubercles and eighty-four costæ. The period of degeneracy commences sooner or later according to individuals. With a diameter of 180 millimètres in bulky inflated specimens the tubercles sometimes cease; the ribs at 210 millimètres ; the remaining portion being very smooth throughout."

I am able to supplement this account of the morphology of Harpoceras insigne by facts disclosed during the study of an interesting example of this Ammonite collected from the light-coloured marly beds of Upper Lias at Sheepscombe, near Painswick, 
Gloncestershire. The diameter of this specimen is 220 millimètres. The body-chamber is not complete up to the aperture, although it has left indications on the mould showing the limits of its internal extent. 'The body-chamber occupies the whole of the last whorl. The shell of the body-chamber appears to have been quite smooth, the whorl is compressed and triangular, without carina and ribs, and on a portion of the penultimate whorl the ribs have vanished, and the carina has disappeared. The suture-line is so well preserved in the mould that it affords a safe gnide for these observations.

Affinities and Differences.-This Ammonite resembles Harp. variabile, by the series of tubercles and fasciated ribs around the umbilicus. It is, however, a much thicker and less elegant shell, and the whorls are likewise more rotund and not so high, the keel is likewise much thicker and never attains the extreme elevation and remarkable structure seen in Harp. variabile. Its ribs are likewise less flexed and the siphonal area much broader in Harp. insigne than we shall find it to be in Harp. variabile.

Locality and Stratigraplical Position.-This Ammonite forms one of the leading fossils in the Lyt. Jurense zone in England. I have collected it at Frocester Hill, Sheepscombe, near Painswick, and at Ozleworth, all in Gloucestershire.

Foreign Localities. - In France it is a common species in the Upper Lias above the zone with Harp. serpentinum, and Harp. bifrons. According to Dumortier it is found at Saint-Cyr, Poleynieux, Saint-Fortunat, St. Romain, Limas, La Verpillière, Semur, St. Julien, St. Nizier, Charnay, Fressac, Mortiès, Vaux; Fevroux, Ain ; Besançon, Thouars, Mort, Charolles, St. Quentin; and it is to be seen in the Museum at Lyons. In Germany it lies in the uppermost stratum of the Upper Lias, the zone of Lyt. Jurense, near Heiningen, Meiningen, Reichenbach, Hechingen, also near Uhrweiller-les-Vignes, Bas-Rhin.

Harpoceras variabile, d' Orbigny. Pl. LXVII, figs. 1-6; LXVIII.

Ammonites obliquatus, Young and Bird. Yorksh. Coast, p. 265, 1828.

- Beanir, Simpson. Ammonites York. Lias, p. 36, 1843.

- variabilis, d'Orbigny. Paléontol. Française, p. 350, pl. 113, 1842.

- - Chapuis et Dewalque. Mém. Cour. Acad. Roy. Belgique;

Fossiles du Luxembourg, t. $x x v$, p. 61 , pl. ix, fig. 2,1854 .

- $\quad$ Oppel. Die Juraformation, p. 250, 1856.
- $\quad$ Dispanses, Lycett. Trans. of the Cotteswold Club, vol. iii, p. 5, 1865.
- $\quad$ variabilis; Dumortier. Dépôts Jurass., partie iv, p. 77, 1874.

Diagnosis.-Shell discoidal, compressed, carinated; volntions one half involute; sides convex, transversely costated; costæ sigmoidal, inflated towards aperture, and fasciated; fasciculi arise from a tubercle situated near the inner margin, in general a single 
rib between the tubercles; siphonal area narrow, keel very thin and extremely prominent, distinct from the siphuncle; aperture compressed, sagittate, acute; suture-line tortuous, four lobed.

Dimensions.-PI. LXVII, fig. 1. Transverse diameter 140 millimètres; width of umbilicus 45 millimètres; height of aperture 55 millimètres; width of aperture 27 millimètres.

Pl. LXVII, figs .3, 4, var. dispansum. Transverse diameter 85 millimètres; width of umbilicus 25 millimètres; height of aperture 35 millimètres; width of aperture 18 millimètres.

Pl. LXVIII. Transverse diameter 210 millimètres; width of umbilicus 75 millimètres; height of aperture 75 millimètres.

Description.-This beautiful Ammonite is one of the most dominant forms of the Lyt. Jurense-zone in Gloucestershire, from whence all the fine examples so accurately delineated in Pls. LXVII and LXVIII were collected. The shell is discoidal, much compressed and excessively carinated; the volutions, six in number, are one balf involute; the whorls are ornamented with from sixty to seventy transverse sigmoidal costæ, all inflected towards the aperture; most of these are fasciated, and arise in pairs from wellmarked tubercles developed around the inner margin, whilst others are short and single, and lie between the fasciated pairs; there is in general one simple rib between each fasciculus. The siphonal area is narrow (Pl. LXVII, fig. 2), in which the inflected costæ all terminate; from the centre arises a very narrow, extremely prominent keel (figs. $1,2,5,6)$, which is rarely preserved, it stands straight out from the shell, and is situated outside and entirely distinct from the siphuncle (fig. 2), where it is well delineated. Here we observe that an accidental fracture of a portion of the shell has exposed some of the chambers and the siphuncle is shown in sitú beneath the outer lamina of the shell. The prominent calcareous carina has been entirely broken away from the area and was evidently independent of, and detached from, the siphuncle, which really lies embedded within the shell itself. In Pl. LXVII, figs. 3, 4 I bave figured an example of the dispansum variety, from the sands at Frocester Hill. The sides are more convex and run out into a narrower area, with a thinner and sharper keel, the lateral costæ are smaller and more numerous, and the fasciated bundles less pronounced. The Ammonite described as Am. Beanii, Simp., is undoubtedly the same as d'Orbigny's Am. variabilis, and it was the discovery of this species in the Grey Marl, zone of Lyt. Jurense at the Peak, that settled the point as to the age of that bed with me. This species and Harp. striatulum, which I found associated together, proved that the Frocester Sands and the Grey Marls at the Peak were upon the same horizon of life.

The aperture is narrow, and elongated (Pl. LXVII, figs. 2, 6), and sometimes lanceolate, as in PI. LXVII, fig. 4.

The suture-line is extremely tortuous, and in its contour developes four lobes and four saddles. The siphonal lobe is as wide but shorter than the principal lateral, and is 
divided by the median line up to two fifths of its height, and on cach side presents three points and one long terminal branch. The siphonal saddle is very wide, and divided by an accessory lobe at its termination into two unequal parts, the internal being the longest. The principal lateral lobe is large and pyramidal, and on each side has four lateral and two long terminal branclies with many points. The lateral saddle is narrow, is divided by an accessory lobe into two portions, and terminates in from six to eight leaf-like expansions, but on a smaller scale than those found in the siphonal saddle. The inner lateral lobe is about half the size of the principal lateral, and is ornamented on each side with three branches, each terminating in a long slender filament. The auxiliary saddle is oblique and unequally divided, the external portion being the largest; it terminates in two lateral folioles and a terminal trifid foliole. The two auxiliary lobes are very unequal, the external is long, with lateral digitations; the inner much smaller, and develops only a sharp point. The radial line touches the points of the siphonal, inner lateral, and auxiliary lobes, and cuts the long terminal branches of the principal lateral lobe.

This species varies much in form at different periods of life. In youth the shell is thicker and more inflated, and the keel small or absent ; afterwards both carina and lateral costæ are evolved, the marginal tubercles soon make their appearance, and the costæ assume the fasciated style they long maintain, until with advancing years the shell becomes flatter, the whorls more expanded, and the tubercles and costre alike disappear from the surface. It cannot with justice be said, as d'Orbigny's name suggests, that its specific characters vary much : on the contrary, I consider that they are all wcll marked and stationary.

Affinities and Differences.-We discover two distinct varieties of ITarpoceras variabile. The first (Pl. LXVII, figs. 1 and 5) may be considered as the type $a$, or d'Orbignian form, the second, $b$, (Pl. LXVII, fig. 3) I shall describe as the Dispansian form. The d'Orbignian form is found in the lower sands, whereas the Dispansion variety is found in the upper sands. This latter shell (Pl. LXVII, figs. 3 and 4) is much more discoidal, the keel more acute, the marginal tubercles smaller and more irregular, the costæ more delicate, sigmoidal, and fasciated. I have placed together on the same plate (LXVII), and side by side, the two forms into which the species ranges itself, and in Pl. LXVIII have figured one of the finest and largest shells I have ever seen of Harp. variabile, with all its shell preserved; it came from the upper sands. I shall here quote a passage from the paper of my old friend Dr. Lycett "On the Ammonites of the Sands between the Upper Lias and Inferior Oolite :"l

"Ammonites dispansus, Lycett. This was long confounded with $A$. variabilis, and it has only been after a comparison of very numerous specimens of both species, and of all stages of growth, that it has been found necessary to separate them; their geological position is also quite distinct, $A$. dispansus occurs only in the upper 1 'Proceedings of the Cotteswold Naturalists Field Club,' vol. iii, p. 5. 
sands, $A$. variabilis does not pass higher than the lowest fossiliferous beds of the sands; both are very limited in their vertical range, and never occupy the same horizon. Both in the young and adult conditions of growth $A$. dispansus is always more discoidal than the other; the figure of the back more especially differs in its acute keel, the tubercles upon the inner margin of the volutions are much more faintly marked, and unlike those of $A$. variabilis they are irregular ; they give origin to numerous fasciated sigmoidal radii ; in $A$. variabilis the radii constitute rigid, nearly straight, and comparatively prominent ribs; the septa in $\mathcal{A}$. dispansus have the lobes much more simple, less pointed, and less produced; the test is preserved very rarely and only in young specimens, it is delicate, and exhibits the fine hair-like sigmoidal radii much more distinctly than the casts. Specimens and fragments are very abundant at Frocester Hill; at Haresfield Hill they are present, but are badly preserved. The largest specimen in my possession is five inches and a half across, but very few exceed three inches."

Locality and Stratigraplical Position.-The type form I have collected from the sands between the Lias and Inferior Oolite near Bridport. The specimen (Pl. LXVII, figs. 1 and 5) came from that locality. 'The Harp. dispansum type (Pl. LXVII, figs. 3, 4) was collected at Frocester Hill and Pl. LXVIII near Nailsworth, Gloucestershire.

Harpoceras Aalense, Zieten. Pl. LXXV, figs. 8-10; Pl. LXXX, figs. 1-3; Pl. LXXXII, figs. 1-4.

Nautilus comptus? Reinecke. Naut. et Argon., p. 57, tab. 1, figs. 5, 6, 1818.

Ammonites sigmifen? Phillips. Geol. of Yorksh., pl. xïi, fig. 4, 1829.

- Aalensis, Zieten. Versteiner. Würtemberg, p. 37, pl. xxviii, fig. 3, 1830.

- Rugatulus, Simpson. Fossils of Yorksh. Lias, p. 73, 1855.

- Aalensis, Oppel. Die Juraformation, p. 248, 1856.

- Moorer, Lycett. Cotteswold Hills Handbook, p. 122, pl. i, fig. 2, 1857.

Harpoceras Aalense, Tate and Blake. Yorksh. Lias, p. 303, 1876.

Diagnosis.-a. Adult condition.-Shell discoidal, much depressed, carinated; whorls compressed, two fifths involute, inner border untruncated, sides slightly convex, closely covered with fine, simple, irregular striæ bent forward and inclined toward the carina, which is neither elevated nor distinct.

b. Young condition.-Striæ much larger, more unequal, distant, and distinct ; siphonal area thinner and more trenchant; aperture narrow, elliptical.

Dimensions.-Large specimen, Pl. LXXX, figs. 1, 2 (=Ammonites Moorei, Lycett) : transverse diameter 8 jo millimètres; height of whorl 30 millimètres; width of umbilicus 35 millimètres; width of aperture 15 millimètres.

Small specimen (Pl. LXXXII, figs. 1, 2, Ammonites Aalensis, Zieten) transverse 
diameter 39 millimètres; height of whorl 16 millinètres; width of umbilicus 14 millimètres; widtlı of aperture 9 millimètres.

Description.-This Ammonite has long been a puzzle to naturalists, seeing that the young shells agreed very well with Zieten's pl. xxviii, fig. 3, whilst the adult shells approached Harpoceras opalinum. I therefore, by the kindness of Professor Fraas, of Stuttgart, obtained some type specimens of Am. Aalensis collected from the Grey Marl of the Lias beds of Wasserelfingen near Aalen, from whence Zieten's type was derived, and on comparing these German specimens with a series obtained from the Ammonite bed of Frocester Hill, I found them to be identical with shells of the same size, and that the large shell which my late friend Dr. Lycett figured in his liandbook as a new species under the name Am. Moorei, was in fact the adult condition of Harpoceras Aalense, Zieten (Pl. LXXV, fig. 9). In order to understand the history of this species we must study Harp. Aalense in its young and adult conditions (Pl. LXXXII, fig. 1, Pl. LXXX, fig. 1). In youth the radii are larger and wider apart, of unequal size, and always simple, the carina is acute and distinct, and the striæ are sometimes grouped in bundles together near the inner edge (PI. LXXXII, fig. 1). When the shell reaches 30 millimètres in diameter an important change takes place; the striæ become smaller and more closely approximated, they cover the sides and pass over the carina in close apposition ; the change from the large costæ of the young shell to the fine strix of the outer whorl of the larger forms is very sudden, and affords a strong contrast, when seen within the umbilicus.

In the adult, so well figured in Pl. LXXX, figs. 1-3, and in Pl. LXXV, figs. 9, 10, the beauty and regularity of this species are well delineated. The shell is discoidal, much depressed, and carinated; the whorls are two fifths involute; the sides covered with very numerous, small, single, biflexed striæ, which become hair-like and more closely set together in larger shells; so numerous are they, in fact, in the specimen I have figured, that they are counted with difficulty on the body-chamber. The whorls slope towards the previous volution, and are equally rounded towards the carina, which is not elevated or distinct from the area, and forms only its acute summit. The suture-line (Pl. LXXX, fig. 3) resembles that of Harp. radians (Pl. LXIV, fig. 4). The siphonal lobe is short and wide, it has several lateral digitations and two divergent terminal points. The siphonal saddle is wide, and divided by a small accessory lobe into two nearly equal spaces, which terminate in three folioles on each side. The principal lateral lobe is large ; with three lateral digits on each side and two terminal points at its summit. The lateral saddle is small, and the inner lateral lobe, about one third the size of the principal, has a few digits on its circumference. The accessory saddle is a shallow space leading to two small auxiliary points.

The test of Harp. Aalense is very thin, and in general well preserved. The mould exhibits the form and direction of the radii in great perfection, better, in fact, than in those specimens which have retained their test.

Afinities and Differences.-Harp. Aalense, Ziet., resembles Harp. radians, Rein.; it 
is, however, more compressed, the siphonal area more acute, without a distinct keel, and its fine, lair-like striæ pass over the ridge; the radii, likewise, are more unequal in size, and differ much during their evolution; the difference observed in the character of the radii in young and old shells forms another point of comparison which ought not to be omitted in treating of the affinities of this beautiful Ammonite, which is still more closely related to Harpoceras opalinum. A critical comparison of Harp. Aalense with Harp. opalinum will, however, be more in place in the article devoted to the description of that most interesting and beautiful form (p. 463).

The young forms of Harp. Aalense present a wide range of variability in the ornamentation of the shell, and it is only after the acquisition of a number of examples of genuine types, and a critical comparison of these with one another, that we realise the fact that we have first to learn the morphology of the species before we can study the varieties. In Pl. LXXXII, figs. 1-4, I have given accurate delineations of two examples of Harp. Aalense from the Lias beds of Wasserelfingen near Aalen, a deposit and locality from whence Zieten's type specimens were collected. These shells lead up, by a series of changes, from the young form (Pl. LXXXII, fig. 3) through a largely costated variety to a smaller costated form and up to a still finer ribbed variety which makes a transition link to the adult form presented by some of the smaller forms of Harp. Moorei (Pl. LXXX, fig. 1). Now, all these varieties I have in years past collected from the upper sands of Frocester Hill, and a few from a like bed at Nailsworth, Gloucestershire, and from Burton, Bradstock, and Chideock Hill, Dorsetshire. The English and the German varieties match each other so closely that we are bound to admit the forms mentioned are the necessary changes the organism has passed through in the evolution of the species.

Reinecke appears to have figured the young form with fine costæ under the name of Nautilus comptus, and Lycett a variety under that of Am. Moorei, whilst Zieten has figured the most typical shell (Pl. LXXV, fig. 8) as Am. Aalensis. In truth, all these forms are readily united by the intermediate links which one finds in a tray full of examples obtained from the Upper Lias Sands.

The variety "Harp. comptum" of Reinecke is in the young state distinguished by having fine, closely arranged, sigmoidal radii, which are fasciated at irregular intervals by folds of growth; subsequently the fasciated character disappears in older forms.

Locality and Stratigraphical Position.-Harpoceras Aalense is limited to the Opalinum zone of Frocester Hill and Nailsworth, and is found in the same horizon at Burton Bradstock and Chideock Hill, Dorsetshire. This Ammonite is a leading fossil in the upper part of the Lyt. Jurense-marl at Wasserelfingen near Aalen, and this same stratum has a wide distribution through Germany, as at Gundershoffen, and Uhrviller, Bas-Rhin; in France at Saint-Quintin, Isère, and the environs of Saint-Rambert, Ain ; Saint-Romain, Rhône; and Verpillière, Isère, where magnificent specimens are obtained from the ironstone bands. 
Harpoceras costula, Reinecke. Pl. LXXXII, figs. 5 and 6.

\begin{tabular}{|c|c|c|}
\hline Navtilus & STULA, & Reinecke. Naut. et Argonaut, p. 68, tab. iii, figs. 33 \\
\hline & costatulus, & Petrefactenkunde, No. 33 , p. $78,1820$. \\
\hline - & & Zieten. Versteiner, Würtemb., pl. $7,1830$. \\
\hline - & NS Costula, & Quenst. Cephalopoden, p. 113, t. vii, fig. 11, 1849. \\
\hline - & Costula, & Oppel. Die Juraformation, p. 247,1856 \\
\hline
\end{tabular}

Diagnosis._Shell small, discoidal, compressed, carinated; whorls two thirds involute ; sides covered with fifteen to twenty straight, prominent ribs, which occupy the inner two thirds of the whorl with wide, deep valleys between; area smooth with distinct, elevated, prominent keel; inner margin not truncated; aperture oblong.

Dimensions.-(Fig. 6) Transverse diameter 26 millimètres; width of umbilicus 8 millimètres; height of the last whorl 10 millimètres; (fig. 5) transverse diameter 33 millimètres; width of umbilicus 8 millimètres; height of last whorl 11 millimètres.

Description.--This small shell belongs to the same horizon as the preceding species; it is always diminutive in size, seldom attaining more than one inch in diameter and exhibiting then a portion of the body-chamber. The shell is compressed; the whorls are more than two thirds involute, and the sides ornamented with from fifteen to twenty straight, prominent ribs, which occupy only two thirds of the inner side of the whorl, and leave the upper portion of the side and area smooth with a strong prominent keel standing in the centre of the area. The umbilicus is narrow, and the inner whorls smooth and without costæ. The aperture is oblong and much invaded by the return of the spire.

Affinities and Differences.-This Ammonite resembles some of the ribbed youthful forms of Harp. Aalense; still, the prominent ribs at wide intervals apart, with the keel entire and prominent, are characters that are wanting in the usual forms in Harp. Aalense.

Locality and Stratigraphical Position.-The specimen I have figured (Pl. LXXXII, fig. 5) was collected from the fine grey marl in the Kocher Thal, by Wasserelfingen, Würtemberg, associated with Harp. Aalense and Harp.radians, all forms that characterise the Lyt. Jurense-zone in Germany. The same form with less coarse ribs (fig. 6) occurs in the Lyt. Jurense-zone at Frocester Hill, where it has long been considered to be the inner portion of Harp. Aalense, with which it is found associated. 
Harpoceras bicarinatum, Münster. Pl. LXXXII, figs. 9, 10, 10a, 11 .

\author{
Ammonites bicarinatus, Münster. In Zieten's Versteiner Würtemberg, p. 21, pl. xv, \\ fig. 9, 1830.
- Elegans, Sowerby. Mineral Conchology, vol. i, p. 213, pl. 94, 1815.
- - $\quad$ Phillips. Geol. York., pl. xiii, fig. 12, 1829.
- complanatus, d'Orbigny. Paléontol. Française, Terr. Jur., p. 353, pl. 114, figs. $1-4,1842$.
- BICARINatus, Quenstedt. Der Jura, p. 578, 1858.
- - Dumortier. Dépôt Jurassique, partie iv, p. 55, pl. xi, figs. $3-7,1874$.

Diagnosis.-Shell compressed; whorls broad, sides flattened and ornamented with simple, narrow, nearly equal, biflexed costæ, separated by well-marked sulcations; siphonal area obtuse, with a small, central, vertical carina raised on a flat, and two lateral ridges which bound the flanks and form therewith an acute angle; umbilicns narrow, with vertical walls; aperture compressed, elongated, subquadrate.

Dimensions.-Transverse diameter 49 millimètres; width of umbilicus 6 millimètres; height of last whorl 25 millimètres; width of aperture 12 millimètres.

Description.-This beautiful little Ammonite has occasioned much confusion in the description of the "falcifers" of the Upper Lias beds, in consequence of d'Orbigny having figured in his plate 114, fig. 3, a shell of Am. bicarinatus as the young shell of his $A m$. complanatus.

Harp. exaratum (complanatum, d'Orb.) has a round siphonal area and prominent keel (Pl. LXII, figs. 1-3), whilst Harp. bicarinatum has a flat area, small central keel, and two lateral ridges separating the area from the flanks. I have a series of four fine specimens from Milhaud, Aveyron, before me, which show this character very well. The specimen I have figured (Pl. LXXXII, figs. 9, 10) is the only English example I know. There is a neatness and angularity about the entire outline of this Ammonite which serve to distinguish it. Dumortier put this question to a crucial test, he broke up several large specimens of Am. complanatus, d'Orb., for the purpose of procuring their small interior whorls in order to compare them with true forms of Am. bicarinatus. The result of this comparative study convinced him that there was nothing to justify the union of the two shells, and that $A m$. bicarinatus was a good species, well separated by the form of its carina and whorls, which never varied, and that none of the examples of Am. complanatus, d'Orb., which he had obtained had shown a structure of the siphonal area similar to the one so accurately delineated in figs. 9 and 10, Pl. LXXXII.

The whorls are oval and the spire extremely involute, so that the last whorl occupies one half the diameter of the disc; the costæ arise by simple, hair-like stems around 
the umbilicus, and widen as they pass singly over the sides, describing a double flexure thereon and terminating in the lateral ridge which bounds the area. The umbilicus is very narrow with vertical walls and shows all the inner whorls.

'The suture-line is complicated (Pl. LXXXII, fig. $10 a$ ); the siphonal lobe is short and narrow; the siphonal saddle very large, with a long oblique accessory lobe which divides the area into two spaces; the external is the smallest and its walls are incised by six or eight folioles; the internal is nearly as large as the principal lateral, and here are twelve folioles in the walls. The principal lateral lobe is very large and surrounded with ten long denticles; the lateral saddle is likewise large and the walls have many folioles; the external lateral lobe is much smaller than the principal, it has two side branched denticles, and a terminal tuft; the auxiliary lobes and saddles, four in number, diminish in magnitude from without inwards, and present nothing of interest before reaching the umbilicus.

This species exhibits abroad many varieties in its young state; some have the sides flattened and the area angulated, others have sides and area gracefully cnrved, some have the costæ delicate, regular, and closely arranged, others unequal and deep, with distant sulci between; hence these various forms have been mistaken for other species. In the adult condition, however, this Ammonite preserves a very uniform figure and ornamentation, and is a very characteristic fossil of the zone of Lyt. Jurense.

Locality and Stratigraplical Position.-The specimen figured (PI. LXXXII, figs. $9,10)$ belonged to the late Dr. Lycett who collected it from the Lower Sands near Nailsworth, it is now the property of the Museum, Geological Survey, Jermyn Street. Fig. 11, Pl. LXXXII, is copied from d'Orb., Pal. Franç. 'Terrains Jurassiques,' tom. i, pl. 114, fig. 3 .

Harpoceras opalinum, Reinecke. PI. LXXX, figs. 4, 5, 6, 7, 8 .

Nautilus opalinus, Reinecke. Nautil. and Argonaut, p. 55, figs. 1, 2, pl. i, 1818.

- MeAndrus, _ - lbid., p. 56, tab. 1, figs. 3, 4, 1818.

Ammonites Primordialis, Schlotheim. Die Petrefactenkunde, No. 8, p. 65, 1820.

- carinatus, Maan. Ammon. et Goniat., p. 139, 1825.

- Primordialis, Zieten. Versteiner Würtemb., p. 5, tab. iv, fig. 4, 1830.

- opalinus, Quenstedt. Flözgebirge, p. 285, 1813.

- - - - Cephalopoden, p. 115, tab. 7 , fig. 10, 1849.

- Primordialis, d'Orbigny. Paléont. Franç., Terr. Jurassiques, p. 235, tab. 62, 1842.

- opalinus, Quenstedt. Der Jura, p. 307, tab. 42, fig. 8, 1858.

- - Lycett. Proc. Cotteswold Nat. Club, vol. iii, p. 5, 1865.

Diagnosis. - Shell discoidal, compressed, and subcarinated; volutions six, two thirds involute; sides slightly convex or flattened, inner margin concave, outer margin 
sloped into a trenchant, slightly prominent carina without a keel, over which fine striæ pass; test moderately thick, striated with many fine, falciform depressions, sometimes fasciated; siphuncle lies immediately beneath the carina, which envelopes it; aperture elongate, sagittate, with projecting lateral lappets, and a long abdominal spine; suture-line tortuous.

Dimensions.-Transverse diameter 115 millimètres; width of umbilicus 25 millimètres; height of aperture 50 millimètres; width of ditto, 24 millimètres.

Description.-This beautiful Ammonite characterises the uppermost stratum of the Liassic sands in Gloucestershire and Dorsetshire, where I have collected it in sitú. In Germany this same stratum with Lyloceras torulosum is classified with the Brown Jura or Lower Oolite, but the English sections have induced me to place it with the Ammonites of the sands. I have taken a specimen at Haresfield in a block of rock with its impression on the Lower Oolite which rested immediately upon it, so high does it range.

The shell is compressed, discoidal, and strongly carinated, but withont a distinct keel; the volutions, six in number, are about two thirds involute, raised a little in the middle, convex on the outer half, and slightly depressed on the inner. The whorls are likewise concave at the inner margin, where they embrace the umbilicus, and curve towards the siphonal area, where they form a trenchant carina without a distinct keel, producing an acute bevelled edge over which striæ pass from the right to the left side of the shell, as shown in Pl. LXXX, figs. 7 and 8.

The surface of the shell is ornamented with innumerable fine striations, rather unequal in size, biflexed in figure, and extending uninterruptedly from the umbilicus to the area. The striæ are sometimes fasciated at the inner margin from the clustering together of so many striæ into a limited space. In many shells this is wanting, but may be noted in the two fine examples (PI. LXXX, figs. 4,6). The aperture is compressed, elongated, and sagittate. The sides have, when perfect, long, narrow, lateral lappets and a projecting abdominal spine, all of which leave their impression on the mould of the body-chamber.

The suture-line is tortuous, and forms six lobes on each side. The siphonal lobe is shorter and as wide as the principal lateral, and ornamented on each side with two branches, of which the terminal one is bifid. The siphonal saddle is wide and divided into two portions by a long accessory lobe ; the innermost is the widest and terminates in two complex and one simple foliole, the outer portion is long and narrow and develops several lateral folioles. The principal lateral lobe has a long, stout, straight stem, with three digitations on each side and three terminal branches. The lateral saddle is very symmetrical, and as large as the principal lateral lobe; it is divided into two parts by a short accessory lobe at the base, and the sides and bottum terminate in a numher of rounded leaves. The inner lateral lobe is narrower and shorter than the principal lateral, and its sides and terminal portion develops many pointed digitations. The outer auxiliary saddle is rather large, developing a number of folioles; the first auxiliary lobe is a little smaller than the 
inner lateral, and the other two auxiliaries are much smaller, with saddles of corresponding sizes (see Pl. LXXX, fig. 5).

Affinities and Differences.-This shell resembles IIarp. radians (PI. LXXXI, figs. 4, 5) in possessing biflexed striæ and a sharply carinated siphonal area, but is distinguished from that species by the absence of a distinct keel, and in having smaller and less prominent striæ on the sides, a much narrower umbilicus, and more numerous side-lobes in the septa. It still more closely resembles Harp. Aulense (PI. LXXX, figs. 1, 2), from which it differs only in a very few particulars and these are as follows. The whorls are higher, they have always an angular and concave inner margin (Pl. LXXX, figs. 4, 6); the umbilicus is narrower; the inner whorls are almost entirely concealed, the striæ are more marked and flexed, and the side-lobes more numerous. Harp. opalinum and Harp. Aalense are doubtless very nearly allied forms, and which apart might be mistaken for each other, but when carefully compared the distinctions pointed out appear to be persistent. The carefully drawn delineations of Harp. Aalense, which I have given, and which I have placed on the same plate for comparison with those of Harp. opalinum, will aid the student in his diagnosis of Harp. opalinum and Harp. Aalense much better than words.

In reference to this species I annex the following remarks sent to me by the late Dr. J. Lycett :

"In my paper entitled 'Notes on the Ammonites of the Sands intermediate to the Upper Lias and the Inferior Oolite "I have followed the example of all preceding palæontologists and arranged Ammonites opalinus as distinct from Am. Aalensis, Ziet. All examination of numerous Gündershöfen specimens of Am. opalinus has recently convinced me that the two supposed species are identical, and that both are referable to varieties of Ammonites Aalensis described in the paper above referred to.

"In the course of the twenty years which comprise my experience of collecting at Frocester Hill, it has often been a matter of surprise to me that no specimen of $A m$. opalinus should have rewarded my endeavours, and that only some two or three examples should have been obtained by other collectors at that locality; it now appears that some examples of the variety of Am. Aalensis termed by me Moorei differ from Gündershöfen specimens in no feature of any importance, and that the greater envelopment of the volutions exhibited by the majority of the foreign specimens is by no means persistent even in them, the Cotteswold specimens exhibiting much variability in this respect, some few of the more depressed forms having the volutions much enveloped, and acquiring some degree of angularity upon the inner slopes of the volutions, as is more commonly seen in the Gündershöfen shells; nor are instances wanting in the latter wherein the radii become large, distant, irregular, and unequal in size, thus constituting the variety 'Aalensis ;' upon the whole, however, the Gündershöfen specimens of all sizes do not exhibit so considerable a variability in the figure and omamentation as is 1 'Proceedings of the Cotteswold Nat. Club,' vol. iii, p. 1, 1865. 
seen in the Frocester Hill shells, and we miss the two varieties with obtuse backs and distant radii which constitute the varieties 'costula' and 'regularis ;' perhaps, however, these deficiencies might also disappear upon examining good Swabian collections. The septa are identical both in Swabian and Cotteswold shells, the observer should, however, be careful to examine both sides of the Gündershöfen specimens, as in one now before me the septa of the right side exhibit a singular abnormal change from the true design, which, however, is perfect upon the left side, and the general figure of the shell has nothing peculiar; this variability does not occur in Frocester Hill shells.

"Quitting the examination of specimens I will now advert to the literature of the species; the first figure and description is that of the 'Nautilus' opalinus of Reinecke. Quenstedt, in his several works, has figured forms of the variety 'Moorei' with the volutions much enveloped as Am. opalinus, and has also given examples of Aalensis and of costula as distinct species. D'Orbigny, in his 'Paléontologie Française,' has figured an aged shell resembling the variety 'Moorei,' but unusually inflated, as Am. candidus, afterwards changed to Am. primordialis upon an erroneous idea that it was the species figured under that name by Schlotheim. Upon another plate he has figured both young and aged examples of the allied species Am. Aalensis, which are very truthful in all the details of their ornamentation; a comparison of the septa figured by him of the two supposed species which are taken from some of the last-formed chambers of aged shells will show that in both the pattern and the design are the same, and that the differences are of the most trifling description, if these, indeed, are not attributable to the artist; the descriptions of Am. primordialis and Am. Aatensis are also substantially alike, if in both we may use the word costa and striæ. The author in question makes no reference to the Am. opalinus, Reineck."

Locality and Stratigraphical Position.-This Ammonite is entirely limited to the uppermost bed of the Harp.-opalinum zone. I have collected it only in these localities : Frocester, Haresfield, Gloucestershire; and at Burton Bradstock and Chideock Hills, Dorsetshire. 
Harpoceras discoides, Zieten. Pl. LXXXII, figs. 12, $12 a, 13$.

\author{
Ammonites discoides, Zieten. Verst. Würts., p. 21, pl, xvi, fig. 1, 1830. \\ - - d'Orbigny. Paléontol. Française, Ter. Jurass., p. 356, pl. 115, \\ 1842. \\ - - Oppel. Die Juraformation, p. 245, 1856. \\ - - - Quenstedt. Der Jura, p. 283, pl. 40, fig. 7, 1858.
}

Diagnosis.-Shell compressed, carinated; whorls broad, nearly entirely involute; sides compressed, slightly convex, and covered with biflexed sulcated undulations; umbilicus nearly occluded; siphonal area narrow, lanceolate, and slightly serrated; aperture very deep, broad at the base, and narrowly lanceolate at the outer border.

Dimensions.-Transverse diameter 70 millimètres; height of the last whorl at aperture 38 millimètres; transverse width at thickest part 15 millimètres; height of aperture 35 millimètres; width of umbilicus 5 millimètres.

Description.-This is a very rare Ammonite in the Cephalopoda-bed of Frocester, and the specimen I have figured is the largest I have collected; it agrees so well with Zieten and d'Orbigny's figures that there is no doubt about the identity of the species.

The shell is much compressed, strongly carinated, and provided with a very small keel. The whorls are broad and the last exceeds in depth more than half the diameter of the disk, so that the shell is extremely involute with a very small umbilicus. The sides are ornamented transversely with simple, equal, biflexed costæ, which spring separately from the circumference of the umbilicus, and gently and gracefully bend forward, then incline backwards, and afterward shoot forward towards the outer border, the costæ are separated by shallow sulci which have a similar curve to the costæ (Pl. LXXXII, fig. 12).

The siphonal area is narrowly lanceolate, and provided with a short and slightly prominent keel. The spire is composed of compressed whorls which are angular towards the umbilicus and trenchant at the border, the umbilicus is very narrow with declining walls. The aperture forms an acute angle, rounded at the base (fig. 13). The sutureline is very complicated, and as none of my specimens show the beautiful lines of this structure, I have copied d'Orbigny's capital figure of the same. The chambers are symmetrical and divided on each side into nine lobes and nine saddles formed of single parts.

The siphonal lobe nearly as long and much wider than the principal lateral lobe, is provided with four branches; of these the inferior branch is very large and oblique. The siphonal saddle, twice as large as the principal lateral, is divided into two large unequal-sized branches, of which the internal is the widest, with a very large 
accessory lobe. The principal lateral lobe, large and oblong, is adorned on each side with five ramified branches, not including the terminal branch. The lateral saddle, nearly as large as the principal lateral lobe, is surrounded by nine folioles. The auxiliary lobes are seven in number, the first is large and the inner six rapidly diminish in size as they approach the umbilicus and are separated by as many small saddles with foliated walls. A radial line extended between the siphonal lobe and the umbilicus would pass beneath all the other lobes.

Prof. d'Orbigny ${ }^{1}$ had the opportunity of examining a young form of Harp. discoides, he says at the diameter of 5 millimètres it has a smooth, round, siphonal area, which soon becomes angular but remains smooth up to a diameter of 10 or 11 millimètres. The simple transverse costæ and sulci afterwards begin to appear, and are nearly as equally spaced out as they are in the adult. Each additional whorl contains a greater number than the penultimate whorl, and thus the number of the costæa and furrows increases with the growth of the shell.

Affinities and Differences.-This species very much resembles Harp. exaratum in the width of the whorl, and in the flexures of the costæ, which in both are simple and distinct throughout, both have a small umbilicus with a similar involution of the whorls. In the siphonal area lies the difference, Harp. discoides has a sharp trenchant area, whereas in Harp. exaratum there is a central keel with two lateral furrows, and two outer carinæ bounding the area.

Locality and Stratigraplical Position.-I have collected three or four specimens of this shell from the Upper Sands at Frocester Hill in the zone of Harp. opalinum. The largest example I possess is the one now figured. In France it has been obtained from many localities where the Harp.-opalinum zone crops out as at Milhaud, Aveyron; near Fontenay, Vendèe; Sant-Rambert, Ain; Uhrviller, Bas Rhin ; near Lyons, near Salins, Jura ; la Verpillière, Isère ; Privas, Ardèche ; Fressac, Gard ; la Cride, Var ; St. Fortunat, Rhône; St. Romain, Rhône; whenever this beautiful little Ammonite is found it may be considered to be a leading fossil of the Harp.-opalinum zone.

1 'Paléontologie Française, Terrains Jurassiques,' tom. i, p. 357. 
Harpoceras actidu, Tate. Pl. LXXXII, figs. 7 and 8.

Ammonites "falciferen," Quenstedt. Jura, p. 174, tab. xxii, fig. 31, 1858.

Amontes serpentrnus, Beesley. Geol. of Banbury, p. 10, 2ud ed., 1873.

- Acutus, Tate. Geological Magazine, decade ii, vol. ii, p. 204, 1875.

Diagnosis.-Shell discoidal, carinated, and compressed; whorls one half involute, sides convex, covered with numerous small, single, close-set, biflexed radii, which impart a neatness and compactness to the whorls; siphonal area convex, with a thick, prominent keel, imner side sloping gently to the spiral suture; aperture oval.

Dimensions. - Transverse diameter 31 millimètres; height of last whorl 13 millimètres; width of umbilicus 9 millimètres; height of aperture 12 millimètres; width of aperture 8 millimètres.

Description.--This neat little Ammonite was collected by my friend Professor Quenstedt near Dürnau, associated with Am. globosus in a bed of Lias equivalent to the zone of Am. spinatus. It was subsequently discovered in England by Mr. Beesley, F.G.S., and catalogued' as Am. serpentinus in his 'Sketch of the Geology of Banbury.' Its difference from the young forms of that species was, however, noticed by Professor Ralph Tate, who entered this Ammonite in his "Notes on some New Liassic Fossils," under the name Ammonites acutus. Our author writes :- "This species has some resemblance to, but is obviously distinct from, $A$. serpentinus. No specific name has yet been applied to the species represented by Quenstedt's figure, though one or two authors have songht to include it under certain new species described by them. A. pseudo-radians, Reynès makes a near approach to it, but the whorls are more embracing in the present species, which I call $A$. acutus on account of its sharp, elevated keel. As Sowerby's $A$. acutus is now recognised as belonging to $A$. margaritaius, the specific name is free to be re-applied."

This is certainly a very elegant little Ammonite belonging to the radians group, is remarkable for its small, thin, lustrous shell, and convex sides closely covered with simple, hair-like, bi-flexed striæ, which commence at the umbilicus, ascend over the sides, and pass over the thick, prominent keel, certainly large in proportion to so small a shell. The radii are very delicate in young shells, and become more prominent in those of larger growth, such as the specimen I have figured and enlarged two diameters. The umbilicus is narrow, and all the inner whorls are exposed. 'The aperture is ovate, and cut out below by the return of the spire.

Afinities and Differences.-Harpoceras acutum certainly belongs to the radians

1 'Sketch of the Geology of the Neighbourhood of Banbury,' 2nd ed., 1873.

2 'Geological Magazine,' decade ii, vol, ii, p. 204, 1875 
group, and resembles an elegant form of that species observed in the passage-beds between the Amaltheus-spinatus and Stephanoceras-commune zones in Dorsetshire.

Locality and Stratigraphical Position.-Mr. Beesley collected his specimen at Adderbury. Mr. Edwin A. Walford collected those he kindly sent me for inspection from Chipping Warden, Northamptonshire, where it is associated with Stephanoceras commune and forms approaching Stephanoceras crassum.

Harpoceras Normaniandm, d'Orbigny. Pl. LXXXIII, figs. 1, 2.

Ammonites Normanranus, d'Orbigny. Paléontol. Française, Terr. Jurassiques, p. 291, pl. $88,1842$.

Diagnosis.-Shell compressed, carinated, bisulcate, and slightly involute; whorls compressed, convex in the middle, and flattened at the marginal and spiral sides, regularly costated transversely, with upwards of seventy simple biflexed radii with nearly equal sulci between. Siphonal area narrow; carina prominent, having a narrow groove on each side; aperture quadrate, compressed on the sides, and roundly angulated.

Dimensions.-Transverse diameter 85 millimètres ; width of umbilicus 40 millimètres ; height of aperture 25 millimètres; width 17 millimètres.

Description.-The Ammonite figured on Plate LXXXIII, figs. 1, 2, resembles Am. Normanianus, d'Orb., more closely than any other that has passed through my hands. It has the same number of simple costæ equally biflexed, a like amount of involution, but in addition it has two small lateral grooves on each side of the carina which are absent in d'Orbigny's type shell ; how far this may be a variable or persistent character is unknown.

Locality.-I found this specimen in one of the cases of the British Musenm with the MS. name I have retained; the shell was numbered, but the locality from whence it had been collected was not mentioned. Judging from the petrology of the matrix it appears to be Middle Lias.

The existence of the small, bell-shaped Aptychus in the body-chamber induced me to have the specimen figured. 


\section{Family.-AEGOCERATIDÆ-continued.}

Genus VII.-Stephanoceras. IVaagen, 1869.

Family-CoronariI,

Coronaten,

Planulati,

Coronati,

Genus-Peronoceras (pars)

Deroceras (pars),
Dactrlioceras (pars), - $\quad$ Ib., p. 84.
Ib., p. 95.

Stephanoceras, Waagen. Formenreihe, Benecke's Beitr., ii, 247, 1869.

IV. Neumayr. Zeit. Deutsch. Geol. Gesellschaft, Bd. Ixxvii, p. $915,1875$.

The general form of the shell in the genus Stephanoceras is very variable; the siphonal area is in general large and round without keel, border, or channels, and the sculpture is often highly ornamental. From the umbilical suture rises a short stout rib which often ends in a tubercle at the middle or upper part, from which spines project as in Steple. Deslongchampsii (fig. 202); from the tubercle two or three smaller costæ pass over the area and unite with their fellows from the opposite side. Sometimes the tubercles are absent, and a number of fine encircling costæ complete the sculpture, as seen in Steplanoceras commune and

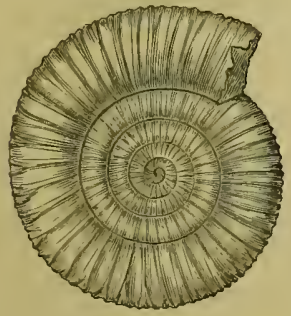

Fio. 196.-Stephanoceras commune.

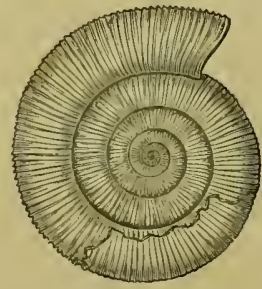

F16. 197.-Stephanoceras annulatum. FIG. 198.-Stephanoceras Braikenridgii.

in Stephanoceras annulatum in which the style of costation just described is very well shown. 
The border of the aperture is encircled either by a broad band as in Steplt. commune, or lateral lappets are produced and inflected as in Steph. Braikenridgii, in which they are often conspicuous and well preserved (figs. 198 and 199). In Steph. Blagdeni, Steph. Humphriesianum, and Steph. Deslongchampsii the mouth is encircled with a broad band. The body-chamber varies from one half to one and a quarter whorls in length. The suture-line is much ramified. The siphonal and principal lateral lobes are nearly of equal length; the inner lateral is much smaller and there are several auxiliary branches.

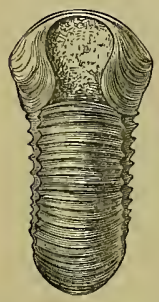

FIG. 199.-Stephanoceras Braikenridgï.

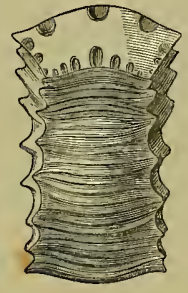

FIa. 200.-Stephanoceras Blagdeni.

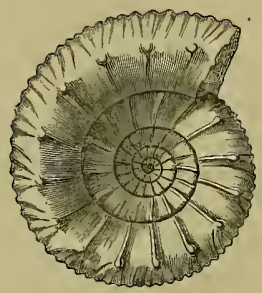

Fra. 201.-Stephanoceras Blagdeni.

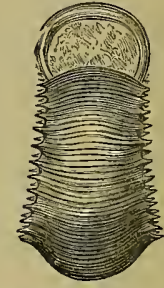

FIG. 202.-Stephanoceras Deslongchampsii.

Many characteristic species appear for the first time in the Upper Lias, as Stepl. commune, Steph. annulatum, Steph. crassum, Steph. fibulatum, and Steph. subarmatum. The zone of Steph. Humphriesianum in the Inferior Oolite is a great depository of the species of this genus both in England and in France. In this horizon we find-

Stephanoceras Braikenridgii, Sow.

$\begin{array}{ll}- & \text { Brocchii, Sow. } \\ \text { - } & \text { Brongniarti, Sow. } \\ \text { - } & \text { coronatum, Brüg. } \\ \text { Blagdeni, Sow. }\end{array}$

Stephanoceras Deslongchampsii.

$$
\begin{array}{ll}
\text { - } & \text { Gervillii, Sow. } \\
\text { - Humphriesianum, Sow. } & \text { Sauzei, d'Orb. } \\
\text { - } & \text { linguiferum, d'Orb. }
\end{array}
$$

The Aptychus is bivalved, calcareous, and very thin, and has upon its external surface numerous small granules.

The genus Stephanoceras appears to have certain near relations with the genus Aegoceras through the species Aeg. pettos of the Middle Lias (see p. 363).

The group represented by other Jurassic forms, as Stephanoceras modiolare, Luid., and Stephanoceras macrocephalum, Schloth., stands well apart from the more compressed forms of Harpoceras in the Upper Lias. All the varieties of the Macrocephali are globose from the extreme involution of the spire and the narrowness of the umbilicus; they also possess a remarkably complicated suture-line. This genus has very few forms in the European Jurassic rocks and occupies a limited horizon in them, commencing with Stephanoceras macrocephalum in the Cornbrash of England and 
the equivalent horizon in Germany. Species of Stephanoceras are found also in the Kelloways rock and in the clay bed interposed between it and the dark clays at the base of the Oxfordian.

Stephanoceras commune, Sowerby. Pl. LXXXIII, figs. 3-4; Pl. LXXXIV, figs. $1-3$; Pl. LXXXVII, figs. 9, 10.

\begin{tabular}{|c|c|c|}
\hline & & ster. $\mathrm{Hi}$ \\
\hline Al & & Sowerby. Min. Conch., vol. ii, p. 10, pl. 107, fig. 3, 1815. \\
\hline - & & - $\quad$ Ibid., vol. ii, p. 9, pl. 107, fig. 1, 1815. \\
\hline UTILUS & & Nautil. et Argon., pl. vi, figs. 56, 57, 1818. \\
\hline & & Keferstein. Catal., 1819. \\
\hline - & ANNULATUS, & Schlotheim. Petref., p. 61, No. 2, 1820. \\
\hline - & JARIS, & Ibid., p. 78, No. $32,1820$. \\
\hline - & $\cos 3$ & $\begin{array}{c}\text { Young and Bird. Yorksh. Coast, p. 246, pl. xii, fig. 3, } \\
1822 .\end{array}$ \\
\hline ANITE & & Maan. Amm. et Goniat., p. 86, No. 13, 1825. \\
\hline & & Phillips. Yorksh., p. 16 \\
\hline - & - & $\begin{array}{l}\text { Zieten. Versteiner. Würtemberg., p. 9, pl. vii, fig. } \\
1830 .\end{array}$ \\
\hline - & NULARIS, & - $\quad$ Ibid., p. 14, pl. x, fig. 10, 1830. \\
\hline- & COMNUNIS, & Simpson. Monogr. on Ammon., p. 18, 1843. \\
\hline - & -- & $\begin{array}{l}\text { d'Orbigny. Pal. Fr., Terr. Jurass., p. } 336 \text {, pl. } 108 \text {, } \\
1842 .\end{array}$ \\
\hline - & - & Die Cephalopod., p. 172, pl. xiii, fig. 8, 1846 . \\
\hline - & - & - \\
\hline & & Nermayr. Zeitsch. Deut geol. Gesell. \\
\hline- & - & Tate and Blake. Yorksh. Lias, p. 299, \\
\hline
\end{tabular}

Diagnosis. - Shell discoidal, slightly compressed; whorls round and well costated on the area and sides; lateral costæ 50, straight and directed obliquely forward, at the side of the area they divide into two branches which arch forward over the area and unite with those from the opposite side. Aperture orbicular and slightly grooved, embracing the whorl.

Dimensions.-Transverse diameter 83 millimètres; height of last whorl 20 millimètres; width of last whorl 20 millimètres; width of umbilicus 48 millimètres.

Description.-Shell discoidal and slightly compressed; whorls feebly involute, round, and gently flattened on the sides; the latter covered with from forty-five to fifty sharp, narrow costæ, commencing at the spiral suture and ascending obliquely forward two thirds of their length, when they regularly bifurcate without a trace of tubercle, and pass over the siphonal area; one of the two loops passes entire, whilst the second is often not complete at the point of bifurcation. The whole of the costæ of the area describe arches, 
the convexity of which are directed towards the aperture. The spire is composed of round whorls, a little higher than they are wide; in some varieties the whorls incline towards a quadrate section and embrace the penultimate whorl feebly so that this species is extremely involute. 'The aperture exhibits nearly a round or sub-orbicular section being hollowed out below to receive the return of the spire. In Pl. LXXXIII, figs. 3, 4, I have figured a specimen of Stephanoceras commune from the British Museum Collection which has the mouth aperture well preserved. There is first a circular constriction, and then a round, prominent band surrounding the aperture; there are no side lappets ; and it is wortlyy of note that the mantle of the animal, when producing this termination, formed the simple rib on the side and bifurcate ribs which extend across the area. This specimen shows also that the dwelling chamber of Stephanoceras commune was very short and occupied little more than half the length of the last whorl of the shell. The suture-line (Pl. LXXXIV, fig. 3) forms three lobes and three saddles on each side. The siphonal lobe is long but wider than the principal lateral, and develops on each side four digitations terminating in two pointed processes. The siphonal saddle is much larger than the principal lateral lobe, and terminates in three unequal, trilobed folioles. The principal lateral lobe has an irregular figure, having three digits on each side and a terminal obtuse one. The lateral saddle is small and oblique, terminating in four unequal folioles. The inner lateral lobe is small and oblique, and terminates in two points, the auxiliaries are quite rudimentary.

Locality and Stratigraphical Position.-This Ammonite, as its name implies, is one of the most common fossils in the Upper Lias, and was at one time found in- great numbers near Whitby, some parts of the beach at one time were literally paved with nodules containing them; in those days a cart load might have been had in a short time ; the fossils were usually inclosed in nodules and it was for these the search was made, as the nodules were largely used in the manufacture of Roman cement; the demand having exceeded the supply, they are now no longer abundant.

Although this species is so common in England, Prof. d'Orbigny stated that he did not know it in France; however, since that time, Dumortier has figured a very good example from the Ironstone Sands at la Verpillière, Isère; where it is associated with Steplianoceras annulatum.

It is very commonly met with as a leading fossil in the Upper Lias strata of Northampton, Warwick, Gloucester, Somerset, and Dorset, and has a wide distribution in these counties. 
Stephanoceras annulatum, Sowerby. Pl. LXXXIV, figs. 7, 8, 9.

Nattilus anguines, Ammonites annulatus,

Planites anguinus, AMmonites annulatus,

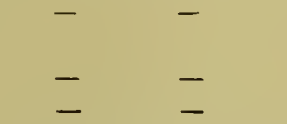

Reinecke. Nautil. et Argonant., fig. 73, 1818.

Sowerby. Min. Conchol., vol. ii, p. 41, pl. 222, fig. 5, 1819.

Haan. Amm, et Goniat., p. 89, 1825.

Young and Bird. Yorksh. Coast, p. 253, pl. xii, fig. 11, 1828.

d'Orbigny. Paléont. Franç., Terr. Jurass., p. 265, pl. 76, figs. 1, 2, 1842 .

Simpson. Monogr. on Ammonites, p. 21, 1843.

Quenstedt. Cephalopoden, p. 173, tab. xiii, fig. I1, 1849.

Stephanoceras annulatum, Tate and Blake. Yorkshire Lias, p. 299, 1876.

Diagnosis.-Shell discoidal, compressed; whorls round, narrow, a little depressed on the sides, and slightly involute; costæ small, slender, flattened, annular, and very numerous, some simple, others bifurcate, and both alternate; siphonal area round, and truncated beneath for the return of the spire.

Dimensions.-Transverse diameter 80 millimètres; width of umbilicus 45 millimètres; height of aperture 20 millimètres; width of aperture 20 millimètres.

Description.-The shell of Stephanoceras annulatum presents a marked difference to the other forms of the Steph. commune group, like them it is discoidal and a little compressed on the sides; the whorls are narrow, round, and each revolution of the spire is ornamented with one hundred and thirty slender costæ, flat on the edge, and cut out as neatly and sharply from the shell as if they had been chiselled with a tool ( $\mathrm{Pl}$. LXXXIV, fig. 7); the costæ are all of the same size and directed obliquely forward, some are simple and annular passing over the area undivided like rings, whilst other bifurcate at the margin, so that the two forms alternate singly or doubly with one another. Considerable irregularity in this arrangement, however, is sometimes visible, and in those cases two or three simple costæ alternate with one bifurcate rib. In early life and up to a diameter of fifty millimètres, there was alteruately one simple rib and a bifurcate rib encircling the area, with increased dimensions; when the shell had attained to eighty millimètres in diameter, the number of bifurcated ribs began to increase and the simple annular costæ to diminish. The umbilicus is widely open and exposes all the inner whorls of the spire, which consists of seven whorls a little higher than they are wide; all are slightly involute. The aperture is oval and only feebly grooved by the return of the spire.

Affinities and Differences.-Stephanoceras annulatum resembles Slephanoceras commune (Pl. LXXXIV, fig. 1), but is distinguished by its more numerous, slender ribs less 
regularly bifurcated, more closely placed together and neatly cut as with a tool, and in addition by its annular, straight ribs which are not bent forward at the point of inflection.

Locality and Stratigraphical Position.-This species is found in ironstone nodules in the Upper Lias of Whitby in the zone of Steplianoceras commune.

Stephanoceras fibulatum, Sowerby. Pl. LXXXV, figs. $\check{-}-11$.

Ammonites fibulatus, Sowerby. Min. Conchol., vol. iv, p. 147, pl. 407, fig. 2, 1823.

Young and Bird. Geol. Surv. York. Coast, p. 262, pl. xiii, fig. $9,1828$.

- $\quad$ - $\quad$ Simpson. Monogr. on Ammonites, p. 22, 1843.

- ANDREA $\quad-\quad$ Yorkshire Lias, p. 59, 1855.

Stephanoceras fibulatum, Tate and Blake. Yorkshire Lias, p. 301, 1876.

Diagnosis.-Shell discoidal, compressed; whorls round on the area, flattened on the sides, and slightly involute; spire entirely exposed; costæ numerous, united in pairs by a small, smooth tubercle near the outer margin, then split again into two or three arched costæ on the area where they join their fellows. Section of aperture subquadrate.

Dimensions.-Transverse diameter 85 millimètres; breadth of area 20 millimètres; height of aperture 22 millimètres ; width of umbilicus 46 millimètres.

Description.-One of the most obvious characters in this very beautiful Ammonite is the uniting of the radii by knobs, like a button and loop; in some specimens this style is very uniform, in others modifications are observed; for example, in one shell two of the radii unite on the knob, and then a single rib passes up between them, bifurcates and extends over the area; in other examples three ribs are seen to be united. The whorls are flattened on the sides and ornamented with upwards of fifty sharp, oblique costæ (Pl. LXXXV, figs. 6 and 7) which commence at the spiral suture, ascend obliquely upwards and forwards to the border of the siphonal area, where a spiny tubercle is developed, from this point two small costre arise and cross the area in an arched form, the convexity being directed towards the aperture. The siphonal area is round and highly ornamented by the ribs which cross it with great regularity. T'he costæ on the inner whorls are usually small, so that within the umbilicus the shell is in general fine-ribbed, presenting a marked contrast in this respect to the highly ornamented sides of the last whorl. Mr. Young, who had a large series of this species in his possession, says in his 'Survey of the Yorkshire Coast," "Some of the inner whorls are marked with double ribs meeting in the knobs, and then parting into three on the back; and on the outer whorl or whorls, we find strong, single ribs, knobbed, each splitting into three beyond the knobbed towards the back. In some specimens, the ribs on the outer whorl are alternately knobbed and plain; in each case the 
plain rib passes over the back undivided, while the knobbed rib parts into three. The double rib and knob resemble a button and loop, whence the name fbulatus, and sometimes the whole disk, from the margin of the back to the centre, is found marked in this style."

I have figured for comparison specimens showing the variation in the style of this species, a variety in which the side knobs are small (Pl. LXXXV, fig. 5), another (PI. LXXXV, fig. 7) in which they are large and spinous, and another (Pl. LXXXV, fig. 8), which has received the name of Andrea ; in fact, this Ammonite presents many modificatious of its style of ribling, but all the examples return into the loop and knob style so well described by Mr. Young. Pl. LXXXV, figs. 10, 11, is the var. Steplian. Bollensis of Quenstedt.

Affinities and Differences.-I have encleavoured to describe as accurately as possible the peculiar character of the ribbing in Stephanoceras fibulatum, seeing that it is in this character we discover the difference between it and Stephanoceras commune, and likewise the distinction between Stephanoceras fibulatum and Stepleanoceras subarmatum with which it is very often confounded, as several specimens before me prove.

Locality and Stratigraplical Position.-This species is found in the Upper Lias at Whitby and Lofthouse, Yorkshire, in the zone of Stephanoceras commune.

Stephanoceras subarmatum, Young. Pl. LXXXV, figs. 1-4.

Ammonites surarmatus, Young and Bird. Geol. Surv. of Yorks., p. 250, pl. 13, fig. 3,1822 .

$\begin{array}{lll}- & - & \text { Sowerby. Min. Conchol., vol. iv, p. 146, pl. 407, fig. 1, } 1823 . \\ \text { Planites } & - & \text { Haan. Ammon. et Goniat., p. 84, 1825. } \\ \text { Ammonites } & - & \text { Young and Bird. Geol. Surv., p. 263, pl, xiv, fig. 8, } 1828 . \\ - & - & \text { Simpson. Monogr. on Ammonites, p. 23, 1843. } \\ - & - & \text { d'Orbigny. Paléont. Fr., Terr. Jurass., p. 268, pl. 77, } 1842 .\end{array}$

Diagnosis.-Shell discoidal, thick, whorls subquadrate, involute; their width exceeds the height; transversely costated; costæ simple or fasciated; inner whorls develop spiny tubercles near the line of the spiral suture which are mostly absent in the last whorl; at the tubercle the costæ split and divide into two or three finer costæ which pass across the margin ; area convex, flat, closely costated; aperture less in height than in width; section subquadrate.

Dimensions.-Transverse diameter 65 millimètres; height of aperture 20 millimètres; thickness 25 millimètres; width of umbilicus 30 millimètres.

Description.-The shell of this species is thick, discoidal and compressed; the 
whorls are subquadrate, wider than high, and slightly involnte, they are transversely ornamented with 36 to 42 small costæ which commence at the spiral suture and cover the sides, some remain single, whilst others unite in pairs and form a tubercle which develops a long outward directed spine; the tubercles and spines occupy the margin of the inner whorls and form a deep spiny nmbilicus. On the outer whorl the tubercles begin to disappear, and the costation then consists of a simple bifurcate rib which sends its branches across the area. The siphonal area which is broad and flat, is closely adorned with small costæ derived from the fasciated tubercles, as well as from the intermediate simple ribs that pass freely and singly up the sides and over the area. The spire is formed of subquadrate whorls compressed in contact with each other and marked by the elongated spines that proceed from the tubercles along the line of the spiral suture. The apertnre in section is subquadrate, and when the termination is preserved it is found to consist of a circular contraction and a round thickened band similar to the appendage I have figured as appertaining to Steph. commune in Pl. LXXXIII, fig. 3. The septa are symmetrical on each side, the principal lateral lobe is large and terminates in three large branches; the lateral saddle is narrower than the principal lobe and terminates in two large folioles of which the internal is the largest. The inner lateral lobe has an irregular figure terminating in two horn-like points.

Affinities and Differences.-I have figured two types of this Ammonite, the large tumid specimen (Pl. LXXXV, figs. 2, 3) from the Upper Lias of Chipping Warden, Northamptonshire. The specimen (Pl. LXXXV, fig. 1) with large knobs and fasciated costæ resembles a variety of Stephanoceras fibulatum from the Upper Lias at Whitby. This last specimen is not a satisfactory example, still it is the best I could obtain of the species at Whitby.

Stephanoceras Raquinianum, d'Orbigny. Pl. LXXXVI, figs. 5, 6, 7. Pl. LXXXVII, figs. $1,2,3,4,7,8$.

Anmonites Requinianus, d'Orbigny. Palecnt. Fr., Terr. Jurass., p. 332, pl. 106, 1842.

Chapuis et Dewalque. Mem. Cour. Acad. Roy. Belgique, t. xxv, Foss. du Luxembourg, pl. vii, fig. 1, 1854. Quenstedt. Der Jura, p. 251, 1858.

Diagnosis.-Shell discoidal; whorls tumid, one half involute, transversely costated; sides inflated, covered with short, straight ribs, twenty to thirty, commencing at the umbilicus, and half way up the side becoming tuberculated, fasciated, and 
split up into two or three smaller costæ, which pass across the outer margin and join those of the opposite side. Siphonal aren large and convex; aperture depressed, subquadrate.

Dimensions.-Transverse diameter 45 millimètres; height of last whorl 15 millimètres; width of umbilicus 15 millimètres; height of aperture 18 millimètres; width of aperture 19 millimètres.

Description.- 'l'be shell of this species is very thick; the whorls are one half involute and depressed, much wider than deep; the sides are inflated and costated, with from twenty-two to thirty-two short, straight ribs, which commence at the umbilicus and terminate at the lateral border of the siphoual area, either it a small blunt tubercle or a fasciation of the ribs; from these points two or three minute costæ pass across the area and unite with their fellows from the other side of the shell; besides the small costre proceeding from the tubercles or fasciated group there are other simple costæ which pass between the ribs from the umbilicus and the area, and others between the costro on the area and contribute to the increased costation which adorns the broad siphonal area of this beautiful form.

The siphonal area is very broad, depressed, and convex, and closely covered with fine transverse costæ. The spire, composed of depressed whorls, is wider than high, and embraces half of the preceding whorl. The aperture is semilunar and depressed, convex above and concave below, where it receives the return of the spire.

The septa are symmetrical, and form on each side two lobes of single elements and two large saddles. The siphonal lobe is as long and much wider than the priucipal lateral, and ornamented on each side with three branches, of which the lower one has five points. The siphonal saddle terminates in three unequally festooned folioles. The principal lateral lobe terminates in three branches, which are slightly digitate. The lateral saddle is neither so deep nor wide as the siphonal, and ends in four shallow folioles, divided by an accessory lobule; the auxiliary lobes are rudimentary.

Prof. d'Orbigny ${ }^{1}$ investigated the morphology of this species, and found that at the diameter of 20 millimètres it possessed nineteen costæ; at the diameter of 35 millimètres it possessed twenty-seven, but at the maximum height it had forty-eight. The Professor stated also that in youth it had always an intermediate rib between the fasciated pair, whilst the bifurcated ribs alone prevailed in adult forms. He noticed that when the test was preserved the costæ were prominent, but they stood ont very feebly on the mould, and sometimes disappeared altogether from the area; further, that when the aperture possessed the termination of the oral appendage the mouth of the shell had a much smaller diameter than the rest of the whorl.

Affinities and Differences.-This shell differs from Stephanoceras Braunianum (Pl. LXXXVI, fig. 4) in having inflated sides and a convex area; in the ribs on the sides being shorter, and in the general costation being neater.

1 'Paléontologie Française, Terr. Jurassiques,' tom. i, pp. 333. 
Locality and Stratigraplical Position.-I collected three specimens of this shell many years ago from the Upper Lias clay at Stinchcombe Hill. I also obtained one small tolerably perfect specimen from the Upper Lias sands at Nailsworth. The species appears to be rare in Gloncestershire, seeing that $I$ have never met with it in other collections.

Stephanoceras Braunianum, d'Orbigny.

Ammonites Braunianus,

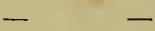

Pl. LXXXVI, figs. 3, 4; Pl. LXXXVII, figs. 5,6 .

d'Orbigny. Paléont. Fr., Terr. Jurass., t. 104, fig. 3,1842 .

Chapuis et Dewalque. Mem. Cour. Acad. Roy. Belgique, t. $\mathrm{xxv}$ (Foss. du Luxembourg) pls: vi and vii, fig. $2,1854$.

Stephayoceras Braunianum, Tate and Blake. Yorkshire Lias, p. 300, 1876.

Diagnosis. - Shell discoidal, compressed; area round, flat; whorls quadrate, slightly involute, transversely costated ; costæ thirty-six to forty, straight, simple, approximate, externally mucronated near the margin, and bifurcated over the area:

Dimensions.-Transverse diameter 35 millimètres; height of last whorl 12 millimètres; width of umbilicus 18 millimètres; height of aperture 10 millimètres; width of aperture 12 millimètres.

Description.-The shell of this species has a neat quadrate form, the outer whorl, is slightly involute, flat on the sides, which are covered with thirty-six straight, simple, acute ribs, which terminate in a point sitnated at the angle of the siphonal area; here the rib bifurcates, the two smaller costæ pass over the flat area and both form a curvature the convexity of which is directed forward. The siphonal area is flat and convex, provided with twice as many costæ as are seen on the sides. The spire is composed of depressed subquadrate whorls, which are only slightly involute. The section of the aperture is subquadrate, and slightly grooved by the return of the spire.

Neither of my specimens exhibit the suture-line. In Pl. LXXXVI, figs. 3, 4, I have figured a very perfect small example of this species (magnified $2 \frac{1}{2}$ diameters) which displays the structure of the test very well.

Afinities and Differences. - In its general form it somewhat resembles Steplianoceras commune, but it differs from that species in possessing sharp prominent tubercles at the angle of the area, in the whorls being less in number, and in the costæ being coarser.

Locality and Stratigraplical Position.-My two specimens were both collected from lower sands at Nailsworth belonging to the npper portion of the Lytoceras Jurense bed, which is well developed there. 
Stephanoceras crassum, Young and Bird. Pl. LXXXVI, figs. 1, 2, 8-10.

Ammonites crassus, Young and Bird. Geol. Survey Yorkshire Coast, p. 253, 1822.

$\begin{array}{lccc}- & - & \text { Phillips. } & \text { Geology of Yorkshire, pl. xii, fig. 15, } 1829 . \\ - & - & \text { Simpson. } & \text { Monogr. on Ammonites, p. 20, 1843. } \\ - & - & \text { Quenstedt. } & \text { Cephalopoden, p. 174, tab. xiii, fig. 10, } 1846 . \\ - & - & - & \text { Der Jura, p. 251, tab. xxxri, fig. 1, 1858. }\end{array}$

Diagnosis.-Shell discoidal, whorls subquadrate, depressed, and slightly involute; shell thick, with a circle of spiny tubercles on the margin of the siphonal area, sides ornamented with thirty-four costre, which commence near the umbilicus and extend to the tubercle, where each bifurcates and sends two branches across the area to unite with their fellows on the opposite side; aperture subquadrate, slightly grooved below to receive the return of the spire.

Dimensions.-Transverse diameter 75 millimètres; height of last whorl 20 millimètres; width of umbilicus 42 millimètres; height of aperture 20 millimètres; width of aperture 22 nillimètres.

Description.-This shell exhibits similar characters to Stephanoceras commune, but is a much thicker and more robust cephalopod with a deeper umbilicus. The costæ between the umbilicus and the tubercles are rather irregular, some are bent, others straight, and the circle of spiny tubercles around the margin of the siphonal area gives this variety a crown-like form. I have figured (Pl. LXXXVI, figs. 1, 2) a variety which closely resembles one of the varieties of Steph. fibulatum, and is usually collected from the same shaly beds of the Upper Lias.

\section{ADDENDA.}

\section{Lytoceras Jurense, ${ }^{1}$ Zieten. Pl. LXXIX.}

The very fine fossil so beautifully delineated two thirds the natural size in this Plate, was presented several years ago to the Museum of the Royal School of Mines by the Earl of Emniskillen, F.R.S. The locality is not recorded, but I have no doubt after an examination of the matrix that it was obtained from the Lyt.-Jurense-zone of Dorsetshire. The shell is preserved, and shows all the delicate sigmoidal curves it formed during growth. This specimen I met with accidentally in one of the wall cases of the top gallery of the 
museum, when searching for another Ammonite. The fossil is one of the finest examples of this grand species extant, and shows the remarkable flattening-in of the spiral margin of the whorl where it encircles the umbilicus; the same specific character is displayed even nore perfectly in the beautiful little mould of this species figured in Pl. LXXIV, figs. 3-5. The Earl of Enniskillen's specimen was not known to me when Pl. LXXIV was drawn, and the German mould being at that time the best example I could figure, it was given as a type. My description of the species had been written for a considerable time before this giant Lytoceras Jurense was found, so that I was unable to do more than give the reference to PI. LXXIV on p. 413.

Amaltheus lenticularis, Young and Bird. Pl. LXXXII, figs. 14 and 15.

Ammonites Lenticula Ris, Young and Bird. Geol. Surv. Yorkshire, p. 269, 1828.

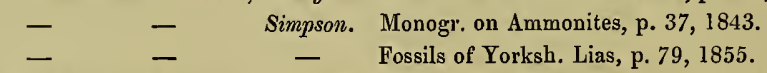

Amaltheus Engelhardti, Tate and Blake. Yorkshire Lias, p. 294, 1876.

Diagnosis.-Shell much compressed; inner whorls nearly concealed, outer whorl one half the diameter of the disc; sides slightly convex; siphonal area very thin, forming a sharp, feebly crenulated edge at the border; umbilicus narrow, with upright walls; sides covered with fine transverse striæ, slightly bent; beneath the transverse radii four or five longitudinal obsolete lines; aperture narrow and acutely triangular.

Dimensions.-Transverse diameter 73 millimètres; height of aperture 40 millimètres ; transverse diameter at base 12 millimètres; width of umbilicus 13 millimètres.

Description.-The rare example of Amaltheus lenticularis, Young, now for the first time figured, shows very clearly the flat, involute, obsoletely-radiated, longitudinallystriated, sharp-pointed character of the species, which is a rare form in the Yorkshire Lias and of which Mr. Young says :- "The last shell of this family which we shall name is more lenticular than any that we have scen. The exterior part of the whorl runs to a thin edge, plain or very faintly crenated; the sides are smooth, or marked with very faint undulating lines; the central part is an umbilicus, with upright sides, the inner whorls being scarcely visible, and the aperture forms a triangle, of which the outer angle is extremely acute, owing to the thinness of the edge. This rare species, found in the Lias bands, may fitly be termed Ammonites lenticularis." The anthors of the 'Yorkshire Lias ' regard this Ammonite as a form of Amaltheus Engelhardti, but with this view I cannot agrec.

The beautiful specimen I have figured was presented by my old friend, the late Mr.

1 'Geological Survey of the Yorkshire Coast,' 2nd ed., pp. 268, 269, 1828. 
John Leckenby, F.G.S., of Scarborough, to the Royal School of Mines Museum, London, as a very good type of a rare Yorkshire species.

Locality and Stratigraphical Position.-Amaltheus lenticularis is found in the zone of Amaltheus spinatus in the rich Ironstone beds at Eston, and Upleatham, near Saltburn, also at Hawsker. I am indebted to my friend Mr. E. T. Newton, F.G.S., Palæontologist to the Geological Survey, for calling my attention to this specimen now figured for the first time.

In the preceding portions of the Monograph ${ }^{1}$ I have referred to the remarkable curved plates, sometimes calcareous and sometimes horny, occasionally found in position within the shell of the Ammonite, and I have drawn attention to the fact that the distinctive cliaracter of the structure of the plates is associated with modifications of the septa and of the general ornamentation of the shell, as well as with geological position. Since these remarks were in type, I have had drawn on Plate LXXXVIII four specimens derived from the Oolitic and Liassic beds, which may be taken as representatives of the calcareons and divided forms (Aptychi) and of the lorny and undiviảed ones (Anaptychi).

Figure 1 of Plate LXXXVIII represents an almost perfect Aptychus from the upper beds of the Inferior Oolite of Leckbampton Hill. It consists of thin shelly laminæ, exhibiting lines of growth, and is in length 140 millimètres and in breadth 95 . I imagine it must have belonged to Cosmoceras Parkinsoni. In my cabinet is an example of this species from the upper beds of the Inferior Oolite at Halfway House, near Yeovil. The specimen is 500 millimètres in diameter, and has its last chamber transversely fractured, the curve and size of which agrees very nearly with that of the Aptychus.

Figure 2 is a drawing of an Anaptychus, which I dislodged from the outer chamber of a large Arietites stellaris, taken out of the Lower Lias strata of Charmouth. This body is bell-shaped, corneous, lighly undulated on the surface and displays the lines of growth. It is difficult to understand low bodies so irregular, as are many of the Anaptychi, conld have fitted the internal surface of the final chamber.

Figure 3, from the British Museum, but without locality, is another of the bellshaped Anaptychi. It has a thickened central column and lateral biflexed undulations passing off on each side. The upper part of the body runs out into a pear-shaped process.

Figure 4 is also from the British Museum, but has no label of locality. The fossil appears to have been in its original condition a symmetrical structure, and resembled in

${ }_{1}$ Pp. 182-185, general statement; p. 269, account of forms belonging to Arietites; p. 307, to Aegoceras; p. 383 , to Amaltheus ; p. 430 , to Harpoceras; p. 472 , to Stephanoceras. 
some degree a horse's hoof. Around its convex border, and within each half of the body as well as towards the two projecting terminations, there are traces of a muscular attachment. This Anaptychus is another of the bell-shaped type. Its figure reminds me of a very fine Anaptychus contained in the body chamber of a large Arietites Bucklandi, which had been used in building a part of the Bath Station, and which I saw protruding from the stone the last time I visited that city.

The lists of British fossils given in my account of the Zones of the Lias Formation (pp. 14-149), and derived from the Memoirs of various authors, contain references to a few species of Ammonites not figured by me. The omission has arisen from the fact that these forms have not come before my notice in any of the English museums or private cabinets I have investigated. In all probability the identification of the Ammonites in question with foreign species was not perfectly accurate. 


\section{INDEX TO THE GENERA ${ }^{1}$ AND SPECIES OF THE LIASSIC AMMONITES DESCRIBED IN THIS MONOGRAPH.}

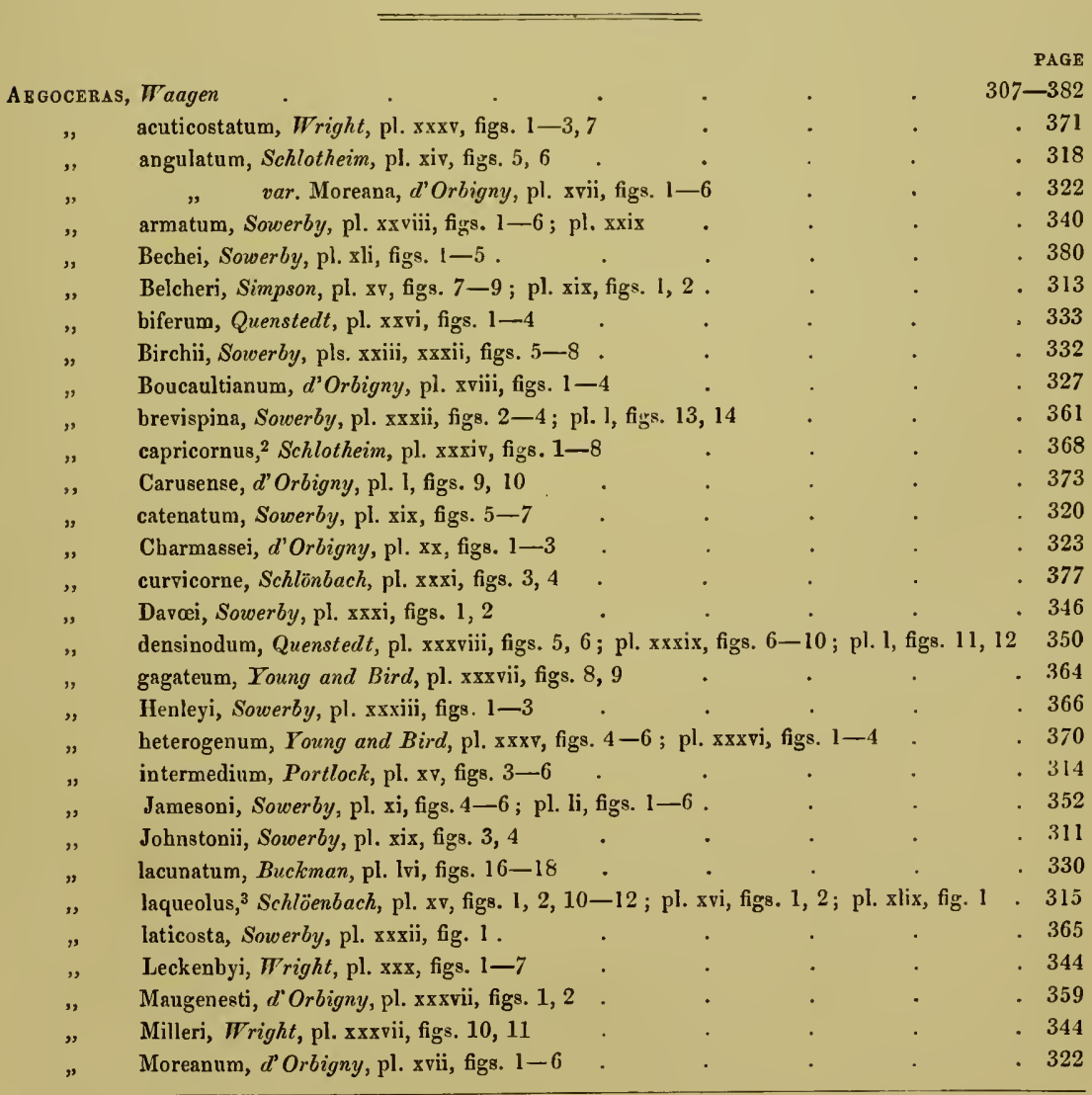

1 The synonyms are printed in italics.

2 Named on the plate Aegoceras maculatum in error.

3 Termed Aegoceras Liassicum on pls. xv, figs. 1, 2, and xvi, and Aegoceras tortile on pl. xv, figs. $10-12$. 
Aegoceras pettos, Quenstedt, pl. xxxvii, figs. $5-7$; pl. lxix, figs. 5,6

A⿰cocenas pettos, Quenstedt, pl. xxxni, figs. 5-7; pl. lix, figs. 5,6 sagittarium, Blake, pl. lii, figs. $1-5$; pl. lii $\Lambda$, figs. $1-6$

acutus, Sowerby ; see Amaltheus margaritatus angulatus, Quenstedt; see Aegoceras Charmassei 
AMmonites bifrons, Bruguière; see Harpoceras bifrons

bisulcatus, Bruguière ; see Arietites Bucklandi

Bodleyi, Buckman; see Arietites semicostatus

Bonnardii, d'Orbigny; see Arietites Bonuardii

Boucaultianum, d'Orhigny; see Aegoceras Boucaultianum

brevispina, d'Orbigny; see Aegoceras latæcosta

Sowerby ; see Aegoceras brevispina

Bronnii, Römer ; see Aegoceras Jamesoni

Brooki, Sowerby; see Arietites Brooki

Buckii, Simpson; see Amalthens oxynotus

Buvignieri, d'Orbigny; see Phylloceras Buvignieri

candidus, d'Orbigny; see Harpoceras elegans

capellinus, Schlotheim; see Harpoceras serpentinum

capricornus, Scblotheim; see Aegoceras capricornus

" Zieten; see Aegoceras planicosta

, nudus, d'Orbigny ; see A egoceras planicosta

earinatus, Haan; see Harpoceras opalinum .

Carusensis, d'Orbigny ; see Aegoceras Carusense

catenatus, Sowerby ; see Aegoceras caternatum

cereus, Simpson; see Aegoceras gagateum

Charmassei, d'Orbigny ; see Aegoceras Charmassei

Charpentieri, Quenstedt; see Arietites nodotianus

Cheltiensis, Murchison; see Aegoceras striatum

Clevelandicus, Young and Bird; see Amaltheus margaritatus

Collenotii, d'Orbigny ; see Arietites Collenotii

colubratus, Zieten; see Aegoceras angulatum.

comensis, von Buch ; see Harpoceras striatulum

" Reynès; see Harpoceras Levisoni. .

communis, Sowerby ; see Stepbanoceras commune

complanatus, d'Orbiguy ; see Harpoceras exaratum

d'Orbigny ; see Harpoceras bicarinatum
cavus, d'Orbigny ; see Harpoceras Lythensis

concavus, d'Orbigny; see Harpoceras Lythensis
cornucopia, Young and Bird; see Lytoceras cornucopia

cornutus, Simpson; see Aegoceras Taylori

costatulus, Schlotheim; see Harpoceras costula

costatus, Schlotheim; see Amaltheus spiuatus

crassus, Young and Bird; see Stephanoceras crassum

crenatus, Zieten ; see Aegoceras pettos

cultellus, Buckman; see Amaltheus oxynotus .

curvicornis, Schlönbach ; see Aegoceras curvicorne

Davœi, Sowerby ; see Aegoceras Davœi

327

365

. 361

- 352

. 280

- 387

. 421

447

433

- 368

- 335

- 335

- 463

- 373

- 320 
Ammonites dejectus, Simpson; see Amaltheus oxynotus . denotatus, Simpson; see Arietites Collenotii . discoides, Zieten; see Harpoceras discoides.. dispansus, Lycett; see Harpoceras variabile .

Dudressieri, d'Orbigny; see Aegoceras planicosta

elegans, Sowerby; see Harpoceras bicarinatum

"Young and Bird; see Harpoceras elegans Engelhardti, d'Orbigny; see Amaltheus Engelhardti erugatus, Phillips; see Aegoceras planorbis. exaratus, Young and Bird; see Harpoceras exaratum exortus, Simpson; see Arietites raricostatus . falcaries, Quenstedt; see Arietites semicostatus falcifer, Quenstedt ; see Harpoceras nitescens " Sowerby; see Harpoceras serpentinum fasciatus, Simpson; see Lytoceras cornucopia fibulatus, Sowerby; see Stephanoceras fibulatum fimbriatus, Sowerby ; see Lytoceras fimbriatum

" Simpson; see Lytoceras cornucopia

Fowleri, Buckman; see Arietites impendens . geometricus, Oppel ; see Arietites semicostatus numismalis, Quenstedt; see Phylloceras Loscombi

Hildensis, Young and Bird; see Harpoceras bifrons 
Ammonites, Jamesoni, Sowerby; see Aegoceras Jamesoni .

Johnstonii, Sowerby ; see Aegoceras Johnstonii

lacunatus, Buckman ; see Aegoceras lacunatum

lamellosus, d'Orbigny ; see Aegoceras Taylori .

laticosta, Quenstedt ; see Aegoceras brevispina

Sowerby; see Aegoceras laticosta.

laxicosta, Lamarck; see Aegoceras planicosta

Leckenbyi, Lycett ; see Lytoceras hircinum .

Levisoni, Simpson; see Harpoceras Levisoni .

liassicus, d'Orbigny ; see Aegoceras laqueolus

lineotus, Oppel ; see Lytoceras fimbriatum

, Schlotheim; see Harpoceras striatulum

451

" Schlotbeim; see Lytoceras lineatum

409

" var. fimbriatus, Quenstedt; see Lytoceras fimbriatum

polymorphus lineatus, Quenstedt ; see Aegoceras polymorphum

Loscombi, Sowerby; see Phylloceras Loscombi

376

Lythensis, Young and Bird; see Harpoceras Lythense .

Macdonellii, Portlock; see Arietites nodotianus

maculatus, Young and Bird; see Aegoceras capricornus

angulatus, Wagener; see Aegoceras curvicorne

maeandrus? Zieten; see Amaltheus oxynotus

Maugenesti, d'Orbigny; see Aegoceras Maugenesti

miles, Simpson; see Aegoceras armatum

multicostatus, Sowerby ; see Arietites bisnlcatus

Moorei, Lycett; see Harpoceras Aalense

Moreanum, d'Orbigny; see Aegoceras Moreanum

Mulgravius, Young and Bird; see Harpoceras serpentınum

natrix, Roemer; see Arietites semicostatus .

419

444

300

368

377

387

359

340

275

458

322

433

284

272

361

338

361

424

364

432

410 


\section{Ammonites oblique-costatus, Haver.; see Arietites rotiformis}

" interruptus, Schübler; see Lytoceras hercinum . obtusus, Sowerby ; see Arietites obtusus opalinus, Quenstedt; see Harpoceras opalinum oxynotus, Quenstedt; see Amalthens oxynotus ovatus, Young and Bird; see Harpoceras ovatum paradoxus, Zieten; see Amaltbeus margaritatus personatus, Simpson; see Arietites Scipionianus pettos, Quenstedt; see Aegoceras pettos Phillipsii, Simpson; see Harpoceras insigne . planicosta, Sowerby; see Aegoceras planicosta planorbis, Sowerby ; see Aegoceras planorbis . polymorphus, Quenstedt; see Aegoceras polymorphum . polyophyllus, Simpson; see Amaltheus oxynotus primordialis, Schlotheim; see Harpoceras opalinum proboscidens, Zieten; see Aegoceras Taylori . psilonotus, Quenstedt ; see Aegoceras planorbis quadricornutus, Simpson; see Aegoceras Taylori Quenstedti, Schafhäult; see Arietites nodotianus radians, Zieten; see Harpoceras radians amalthei, Oppel ; see Harpoceras nitescens costula, Quenstedt; see Harpoceras costula depressus, Quenstedt ; see Harpoceras striatulum adiatus, Simpson; see Arietites impendens Raquinianus, d'Orbigny; see Stephanoceras Raquinianum raricostatus, Zieten; see Arietites raricostatus Redcarensis, Young and Bird; see Aegoceras angulatum Regnardi, d'Orbigny; see Aegaceras Jamesoni resupinatus, Simpson; see Arietites Sauzeanus Robinsoni, Simpson; see Amalthens oxynotus rotiformis, Sowerby ; see Arietites rotiformis . rotula, Haan; see Amaltheus margaritatus rugatulus, Simpson; see Harpoceras Aalense Sampsoni, Portlock; see Aegoceras planorbis . Sauzeanus, d'Orbigny; see Arietites Sauzeanus Scipionianus, d'Orbigni; see Arietites Scipionianus semicostatus, Young and Bird; see Arietites semicostatus serpentinus, Schlotheim; see Harpoceras serpentinum . sigmifer, Phillips ; see Harpoceras Aalense Simpsoni, Bean; see Amaltheus Simpsoni Smithi, Sowerby, see Arietites obtusus spinaries, Quenstedt; see Arietites Sauzeanus .

Wagener; see Arietites semicostatus spinatus, Bruguière; see Amaltheus spinatus stellaris, Sowerby; see Arietites stellaris Stolesi, Sowerby; see Amaltheus margaritatus Strangewaysi, Sowerby ; see Harpoceras serpentinum 
Aмmonites striatulus, Sowerby; see Harpoceras striatnlum

PAGE

, striatus, Zieten; see Aegoceras striatum . .

451

"subarmatus, Young and Bird; see Stephanoceras subarmatum

378

subcarinatus, Phillips; see Phylloceras subcarinatum

submuticus, Oppel ; see Aegoceras submuticum

subnodosus, Young and Bird; see Arietites subnodosus .

subplanatus, Dumortier ; see Harpoceras exaratum

sulcatus, Simpson; see Aegoceras Charmassei

Taylori, Sowerby; see Aegoceras 'I'aylori

, costatus, Quenstedt ; see Aegoceras Taylori

"nodosus, Quenstedt; see Aegoceras Taylori

tenellus, Simpson; see Arietites Collenotii

tenuicostatus, Young and Bird; see Lytoceras lineatum .

Terverii, d'Orbigny; see Phylloceras heterophyllum

Thouarsensis, d'Orbigny ; see Harpoceras striatulum

tortilis, d'Orbigny; see Aegoceras laqueolus.

torulosus, Schübler; see Lytoceras hircinum .

torus, d'Orbigny; see Aegoceras Johnstonii .

transformatus, Simpson; see Arietites Sauzeanus

trapezoidalis, Sowerby ; see Aegoceras catenatum

Turneri, Sowerby ; see Arietites Turneri

Valdani, d'Orbigny; see Aegoceras Valdani .

variabilis, d'Orbigny; see Harpoceras variabile

Walcot $t$, Sowerby ; see Harpoceras bifrons .

Zetes, Studer; see Phylloceras Zetes

Ziphus, Zieten; see Aegoceras planicosta

",

Argorauta Cacilia, Reinecke; see Harpoceras serpentinum

serpentinus, Reinecke; see Harpoceras serpentinum

A RIETITES, Waagen

bisulcatus, Bruguière, pls, iii and iv .

Bonnardii, d' Orbigny, pl. xi, figs. $1-3$

Brooki, Sowerby, pl. vi, figs. 4, 5 .

Bucklandi, Sowerby, pl. i, figs. 1-3

Collenotii, d'Orbigny, pl. vi, fig. $1 ;^{1}$ pl. xxii $A$, figs. $6-9$; pl. xxiiß, figs. $1-3$

Conybeari, Sawerby. pl. ii, figs. 1-3

Crossii, Wright, pl. x, figs. 1,2

impendens, Young and Bird, pl. xxiiA, figs. 1-5

nodotianus, d'Orbigny, pl. xxxvii, figs. 3,4

abesulus, Tate and Blake, see Arietites subnodosus

obtusus, Sawerby, pl. xxi, figs. $1-5$.

raricostatus, Zieten, pl. vii, figs. $2-6$; pl. $x \times v i$, figs. 5-14

rotiformis, Sowerby, pl. v, figs. 1-4; pl. vii, fig. 1; pl. ix, figs. 1-3

Sauzeanus, d'Orbigny, pl. viii, figs. $1-6$

,

Scipionianus, d'Orbigny, pl. xiii, figs. $1-3$; pl. xix, figs. $8-10$

1 Named Arietites denatatus on explanation of pl, vi. 
Anienites semicostatus, Young and Bird, pl. i, figs. 4-8 .

$\mathrm{H}_{A \mathrm{RPOCERAS}}$ Waagen

Aalense, Zieten, pl. lxxv, figs. $8-10$; pl. 1xxx, figs. 1-3; pl. lxxxii, figs. 1-4 . 458

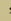
acutum, Tate, pl. lxxxii, figs. 7,8 . antiquum, Wright, pl. lvii, figs. 1-4

bicarinatum, Münster, pl. lxxxii, figs. 9-11.

bifrons, Bruguière, pl. lix, figs. $1-4$

Normanianum, d'Orbigny, pl. lxxxïi, figs. 1, 2

, fimbriatum, Sowerby, pl. lxxi, fig. 1; pl, lxxii, figs. 1-4 bircinum, Schlotheim, pl. lxxv, figs. 4-5; pl. lxxvi, fig. 6 Jurense, Zieten, pl. lxxiv, figs. 3-5; pl. lxxix

NAUTILUs anguinus, Reinecke; see Stephanoceras annulatum comptus, Reinecke; see Harpoceras Aalense costatus, Reinecke; see Amaltheus spinatus costula, Reinecke ; see Harpoceras costula

" mceandrus, Reinecke; see Harpoceras opalinum 


\section{INDEX TO GENERA AND SPECIES.}

NA UTıLUs opalinus, Reinecke; see Harpoceras opalinum .

" radians, Reinecke; see Harpoceras radians

463

" rotula, Reinecke; see Amaltheus margaritatus ,

Plantes anguinus, Haan; see Stephanoceras annulatum .

" Birchi, Haan; see Aegocerns Birchii .

" bisulcatus, Haan; see Arietites Bucklandi

Puylloceras, Suess

Stephanoceras, Waagen .

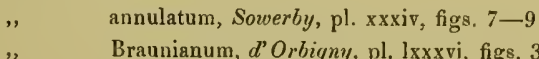
crassum, Young, pl. Ixxxvi, figs. 1, 2,8-10 . . . . . 481 fibulatum, Sowerby, pl. lxxxv, figs. 5-11

Turrulites Boblayei, d'Orbigny; see Arietites raricostatus. 



\section{GENERAL INDEX.}

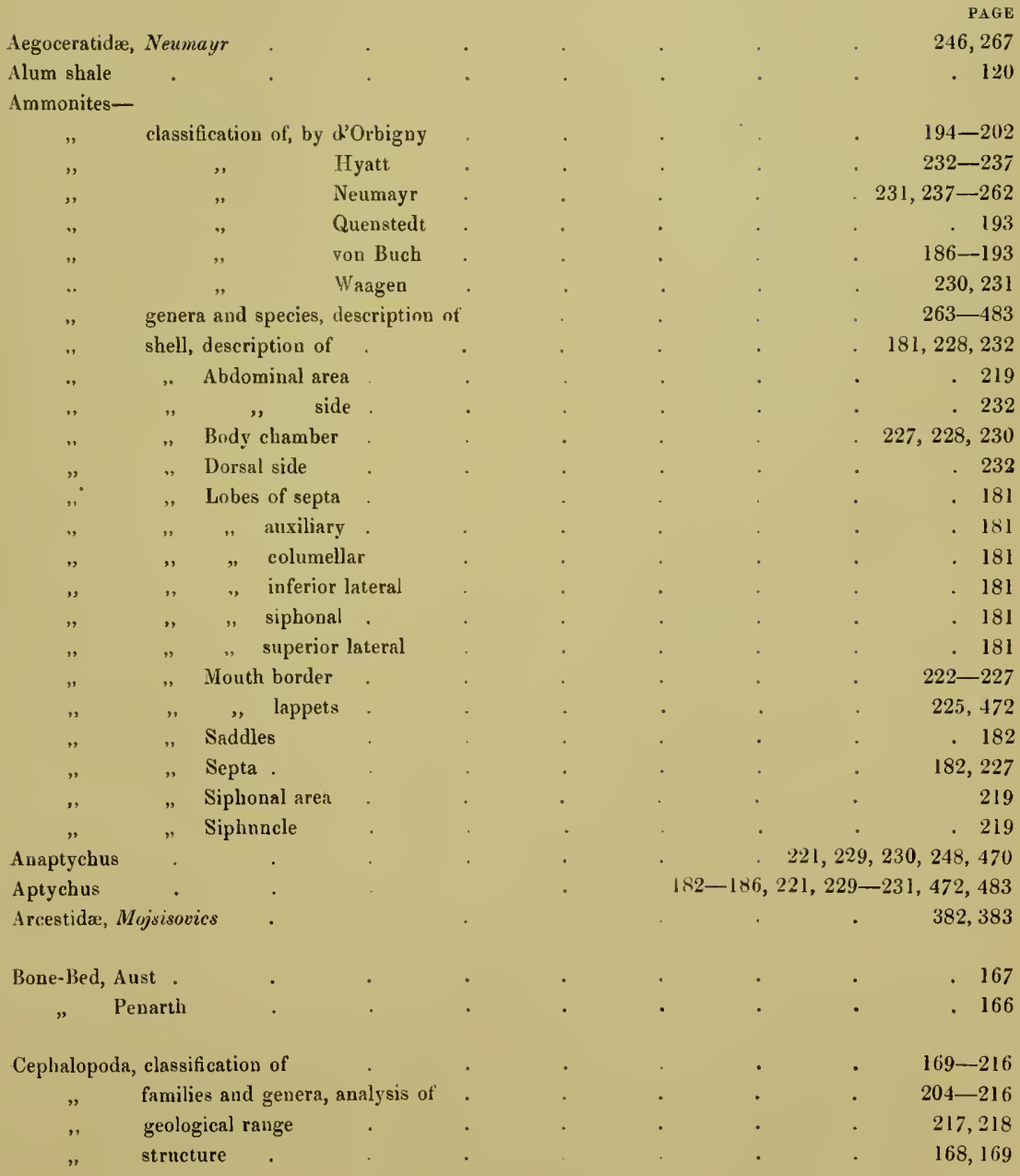


Classification of the Ammonitidæ, modern

Cotham marble-bed

Correlation of the Lias Beds of England, France, and Germany

Descriptions of zones-

Aegoceras angulatum-zone

$$
27-35
$$

$87-93$

$69-80$

$14-26$

$81-86$

Amaltheus Ibex-zone

, Jamesoni-zone

", planorbis-zone

" margaritatus-zone

" oxynotus-zone .

", spinatus-zone

Arietites Bucklandi-zone

, obtusus-zone

" raricostatus-zone

"Turneri-zone

A vicula contorta-zone

Harpoceras bifrons-zone

$93-103$

$52-54$

103-112

$35-47$

$49-52$

$55-60$

47,48

$4-14$

$127-137$

$148-\mathrm{I} 50$

$116-127$

$137-148$

Lytoceras Jurense-zone

Dibranchiata, description of

$170-173$

Fishes of Lias from Lyme Regis

Fossil Fauna of Aegoceras angulatum-zone

$61-64$

$28-30,32-34$

$87-93,100$

$69-78$

$16,17,20,23-26$

Jamesoni-zone

planorbis-zone

Amaltheus ibex-zone .

" oxynotus-zone

spinatus-zone

Arietites Bucklandi-zone

" obtusus-zone

" raricostatus-zone

" Turneri-zone

Avicula enntorta-zone

Harpoceras bifrons-zone

" serpentinum-zone

Lytoceras Jurense-zone

82,85

$53-55$

$104-109$

$36-39,42-47$

$50,5 \mathrm{I}$

56,57

48

13

$128-133,135-137$

$117-127$

$140-142,144-147$

Genera of Cephalopoda, characters of-

Acanthoceras, Neumayr

. 257

Actinoceras, Stoles

. 210

Aegoceras, Waagen

Amaltheus, Montfort

Ancyloceras, d'Orbigny

$223,228,230,246-248,307-382$

$223,228,230,235,240,383-405$

215,253 
Genera of Cephalopoda, characters of (continued)--

PAFE

Androgynoceras, Hyatt

234

Anisoceras, Pictet

216

Aphragmites, Barrande

211

Arcestes, Suess

- 239

Arietites, $W$ aagen

$222,230,248,268-306$

Arnioceras, Agassiz

- 233

Ascoceras, Barrande

- 211

Aspidoceras, Zittel

. 260

Asteroceras, Hyatt

Aturia, Bronn

Aulacoceras, Hauer

- 212

Bactrites, Sandberger

. 210

Baculina, d'Orbigny

. 213

Baculites, Lamarck

- 254

Batbmoceras, Barrande

215,244

Belemnitella, d'Orbigny

- 212

Belemnites, Lister

Belemnosis, Edwards

Belemnoteuthis, Pearce

Beloptera, Lamarck

. 207

Beloteuthis, Münster

206

- 205

Cameroceras, Conrad

Ceratites, Haen

Choristoceras, Hauer

- 210

- 214

Clymenia, Münster

. 242

- 213

Cochloceras, Haeur

Coloceras, Hyatt

- 242

- 235

Coroniceras, Hyatt

Cosmoceras, $\boldsymbol{W}$ aagen

Crioceras, d'Orbigny

- 233

Cycloceras, Hyatt

Cyrtoceras, Goldfuss

Cyrtocerina, Billings

Dactylioceras, Hyatt

Deroceras, Hyatt .

Didymites, Mojsisorics

Discoceras, Ayassiz

Endoceras, Hall .

Enoploteuthis, d'Orbigny

Geoteuthis, Münster

Glossoceras, Barrande

Goniatites, Haan .

Grammoceras, Hyatt

Hamites, Parkinson

Hammatoceras, Hyatt

Hamulina, d'Orbigry 
Genera of Cephalopoda, characters of (continued)-

Haploceras, Zittel

250

Harpoceras, $W_{\text {aagen }}$

$224,228,229,249,430-470$

Helicerus, Dana .

. 206

Helicoceras, d'Orbigny

Hercoceras, Barrande

Heteroceras, d'Orbigny

Hildoceras, Hyatt

Hoplites, Neumayr

Huronia, Stokes .

Leioceras, Hyatt .

Leptoteuthis, von Meyer

Liparoceras, Hyatt

Lituites, Breynius .

Lituunculus, Barrande

Lobites, Mojsisovics

Loligo, Lamarck .

Lytoceras, Suess .

Microceras, Hyatt

Nautilus, Belon .

Nothoceras, Burrande

Olcostephanus, Neumayr

Ommastrephes, d'Orbigny

Oncoceras, Hall .

Ophidioceras, Barrande

Ophioceras, Hyatt

Oppelia, Waagen .

Ormoceras, Stokes

Orthoceras, Breynius

Peltoceras, Waagen

Perisphinctes, Waagen

Peronoceras, Hyatt

Phragmoceras, Broderip

Phylloceras, Suess

Phylloteuthis, MLeek

Phymatoceras, Hyatt

Piloceras, Salter .

Pinacoceras, Mojsisovics

Platypleuroceras, Hyatt

Plesioteuthis, Wagner

Pleuroceras, Hyatt

Psiloceras, Hyatt .

Ptychites, Mojsisovics

Ptychoceras, d'Orbigny

Rhabdoceras, Suess

Rhacoceras, Agassiz

Sageceras, Mojsisovics

. 216

- 211

. 259

- 237

225,256

. 210

. 237

205

. 234

209

. 209

. 239

. 205

$225,228,229,243,406-418,481$ 
Genera of Cephalopoda, characters of (continued) -

Scaphites, Parkinson

215,255

Schloenbachia, Neumayr

. 241

Sepia, Iinné

Simoceras, Zittel

Spirulirostra, d'Orbigny

- 205

Stephanoceras, $\boldsymbol{T}$ aagen

- 262

Stoliczkaia, Neumayr

. 206

Streptoceras, Billings

T'eudopsis, Deslongchamps

Thysanoceras, Hyatt

Toxoceras, d'Orbigny

Trachyceras, Laube

Tretoceras, Salter

Trochoceras, Barrande

Tropidoceras, Hyatt

Tropites, Mojsisovics

Turrilites, Lamarck

llorizons of Lower Lias in the European area

" Middle "

- 112

- 164

Inferior Oolite Ammonite zones

Lias-Lower beds, description of

Liassic zones, foreign correlations ofAegoceras angulatum-zone-

In France .

"North Germany

Aegoceras Henleyi-zone-

In Brunswick

, North Germany

In France. 
Liassic zones, foreign correlations of (continued) -

Aegoceras planorbis-zone-

In Baden

25

, France .

"North Germany

"Swabia.

Amaltheus ibex-zone-

In France .

85,86

, South-west Germany

"Swabia

Amaltheus margaritatus-zone-

In France .

102, 103

, North Germany

Amaltheus spinatus-zone-

In France

"North Germany

"Swabia .

Arietites Bucklandi-zone-

In Belgium .

„Eastern Alps

"France.

"South Germany

"Swabia.

Arietites obtusus-zone-

In France .

, North Germany

"South Germany

Arietites raricostatus-zone-

In France

$57-60$

Harpoceras bifrons-zone-

In Belgium .

. 132

„France

,South-west Germany

"Swabia.

Harpoceras opalinum-zone-

In France .

150

"North Germany

"Swabia.

. 149

. 149

Lytoceras Jureuse-zone-

In France .

. 148

, North Germany

. 147 40,4 I

Lincolnshire (north-west) Lias beds of, generalised

Lists of Lias fossils from-

Ballintoy, Ireland

- 56

Binton, Warwickshire

19-21

Bloxam, Oxfordshire

Blue Wick, Yorkshire

128,129

$144-146$ 
Lists of Lias fossils from (continued) -

Boll, Germany

PAGE

Bridport, Dorsetshire

$130-132$

67,68

Broughton, near Pershore, Worcestershire

- 375

Charmouth, Dorsetshire

50,89

Cheltenham, Gloucestershire

Churcbdown, Gloucestershire

$57,69,82$

Clapier, France.

. 118

102,103

Côte d'Or, France

$33,34,45-47$

Curcy, Normandy

Fenny Compton, Warwickshire

- 136

$72-75$

Garden Cliff, Gloucestershire

Halberstadt, Germany

Iiminster, Somerset

Liehenberg, Germany

Lincolnshire (north-west) .

- 6

. 24

. 119

- 110

40,41

Lumachelle de l'Auxois, France

25,26

Lyme Regis

Oldenrode, Germany

Pabba, Scalpa, and Skye, Scotland

Raasay, Scotland

Radstock, Somerset

Redcar, Yorkshire

Rhone Basin, France

Robin Hood's Bay

Salford, Gloucesterslire

Saltwick, Yorkshire

Skye, Scotland .

South Petherton, Somerset .

Staithes, Yorkshire

Street, Somersetshire

Swabia, Germany

Uphill, Somerset .

Witcombe, Gloucestershire

$38,39,48,51,61-64$

83,84

77,78

- 101

76,77

$28-30,42,43$

- $58,59,80,81$

$53-56,70-72,90,91$

36,37

122,123

100,107

95,96

97,105

16,17

85,109

. 11

88,89

Lithology of Aegoceras angulatum-zone

\begin{tabular}{|c|c|c|}
\hline " & ", & Henlyi-zone . \\
\hline & $"$ & Jamesoni-zone \\
\hline & ", & planorbis-zone \\
\hline & Amaltheus & is ibex-zone . \\
\hline & $"$ & margaritatus-zone \\
\hline & , & oxynotus-zone \\
\hline & ", & spinatus-zone \\
\hline & Arietites I & Bucklandi-zone \\
\hline & $"$ & obtusus-zone \\
\hline & , $\mathbf{r}$ & raricostatus-zone \\
\hline & Harpocera & as bifrons-zone \\
\hline & " & opalinum-zone \\
\hline
\end{tabular}

. 28

$87,89-91$

$70-72$

- 21

- 81

94, 96-99

53,54

$104-106$

$36-39$

49,50

55

$127,130,132,133,135,137$

148,149 
Lithology of Harpoceras serpentinum-zone

$117-125$ , Lytoceras jurense-zone .

$138,139,144$

Lytoceratidæ, Neumayr

Marlstone

94-99

Mollusca, morphology of .

$264-267$

Pea Grit of Leckampton Hill

$151,152,161$

Range of Genera of Fossil Cephalopoda in Geological Time

217,218

Rhone Basin, Table of Middle Lias Beds

80,81

Sections at-

Aust Cliff

Brockeridge and Defford Commons

Binton, Warwickshire

Broad Ledge, Cbarmouth

Churchdown Hill

Cleeve Hill

Curcy, Calvados .

Down Cliffs, Bridport Harbour

Dundry Hill

Fenny Compton, Warwickshire

Forester Hill

Garden Cliff

Harbury Cutting, Great Western Railway

Honeybourne Railway Cutting

Leckhampton Hill

Lyme Regis

Market Harborough

Marle Hill, Cheltenham

Oldershausen

Penarth Cliffs

Puriton Railway Cutting

Redear .

Rockcliff, Whitby

Saltford Cutting, near Bath, Great Western Railway

Saltwick Nab, Whitby

Shepton Mallet Railway cutting

St. Audrey's Slip, near Watchet

Staithes Harbour.

Strawberry Bank, llminster.

Street, Crees Quarry

, Seymour's Quarry

"Talbot's Quarry

" Underwood's Quarry

Symonds Hall Hill

- 8,9

. 18

. 19

. 50

- 118

$154-162$

. 136

. 67

$141-143$

. 72

$115,116,138$

$5,6,7$

- 27

. 56

$150-152$

$38,39,48$

- 125

. 55

. 83

10,165

. 12

- 28

124

$12,36,37$

121-123

. 12

- 119

. 15

. 15

. 15

. 15

. 94 
Sections at (continued) -

Thouars

Wells.

Weston, near Bath

Whitchurch

Wotton-under-Edge

Uphill Railway cutting, Bristol and Exeter line .

Up Lyme (Fowler's Quarry)

, (Webb's Quarry).

Species of Ammonites (British) described-

Aegoceras, Waagen; (section), Angulati, Neumayr

$247,308,318-331$

.,

Armati "

,

"

Involuti "

Amaltheus, Montfort

Psilonoti ",

Arietites, Waagen

Harpoceras, Waagen

Lytoceras, Suess .

Phylloceras, Suess

Steplanoceras, Waagen

Springs of the Upper Lias .

$247,308,332-362$

$248,308,363-382$

$247,307,308-317$

$383-405$

$269-306$

$430-470$

$407-418$

$419-429$

$473-481$

117,141

Stratigraphical Distribution of British Ammonites-

In Lower Lias
"Middle Lias
"Upper Lias

Tetrabranchiata, description of

. 66

. 113

. 163

Tropitidæ, Mojsisovics

$173-177$

. 241 


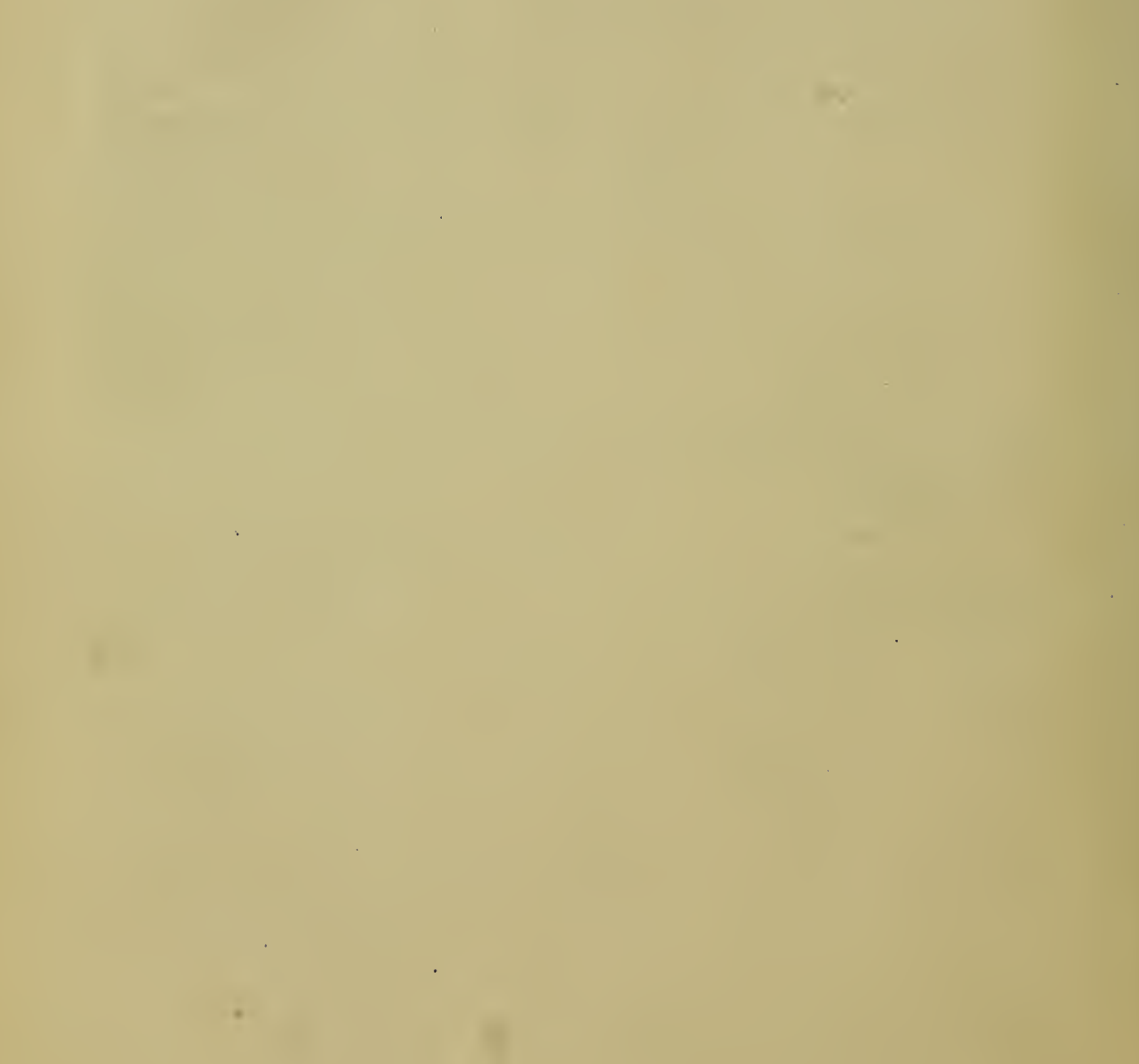







2522 D)

m.

ख)

33

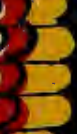

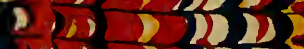

${ }_{2} \rightarrow 2$

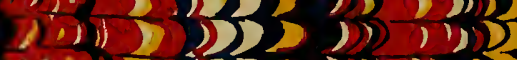

(1)

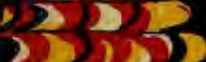

I.) 2 - 2

$12 \cdot 7,5=2$

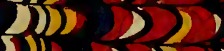

D)

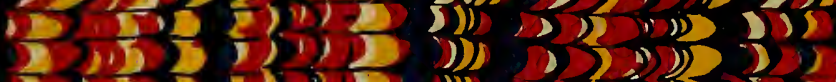

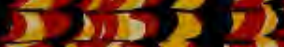

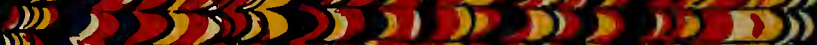

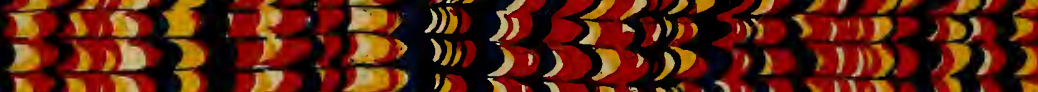

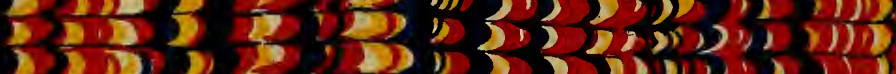

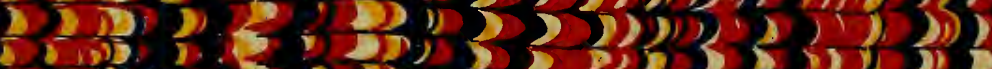

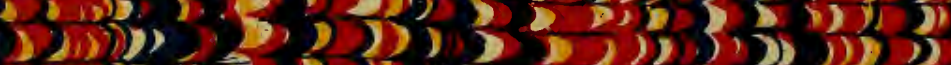

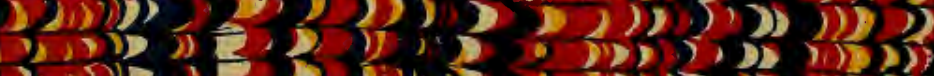

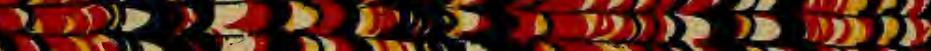

(1)

1.

(1), $2 D$

(1) $120 D$

is 250

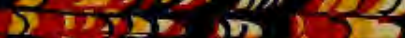

3. 2502

i) $17 D$

D) 259

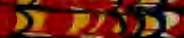

D.

ID 1

F, DD D?

, 2)

D)

1) 3,2

(2) D1 1

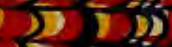

in $2, y=$

$\because 121$

b)) (2)) या

)) (1)

is

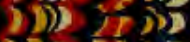

2

2) 2111

1)!

ID DN 121

(1) $(1.0)$ (N)

5

D) $21 \pi$

i) $), 1 D 3$

2i) 213

(5) 510

2)

(3) 21013

(2) D) ?

(j)

,

ขอ

- D DDE

i)

3 i) a

है

1. TV

))

2

)

28 


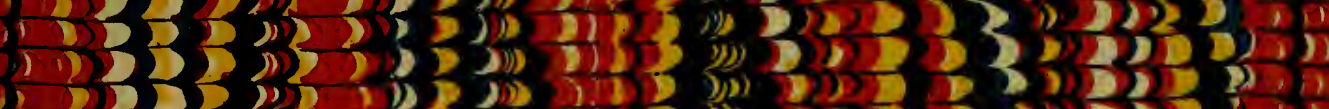

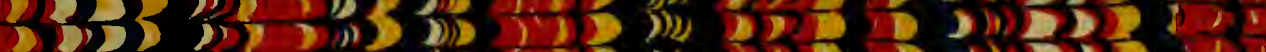

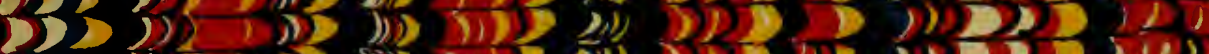

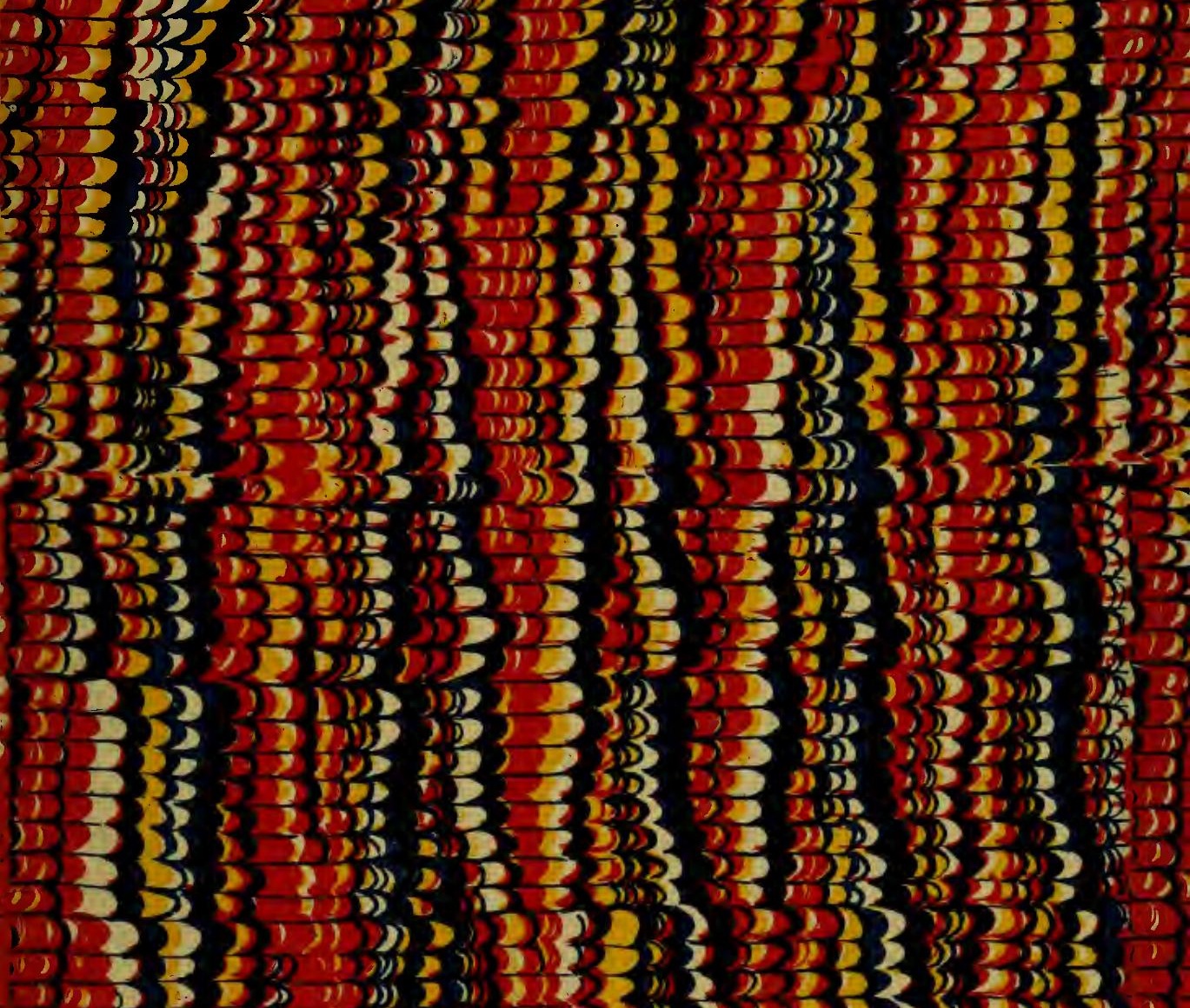

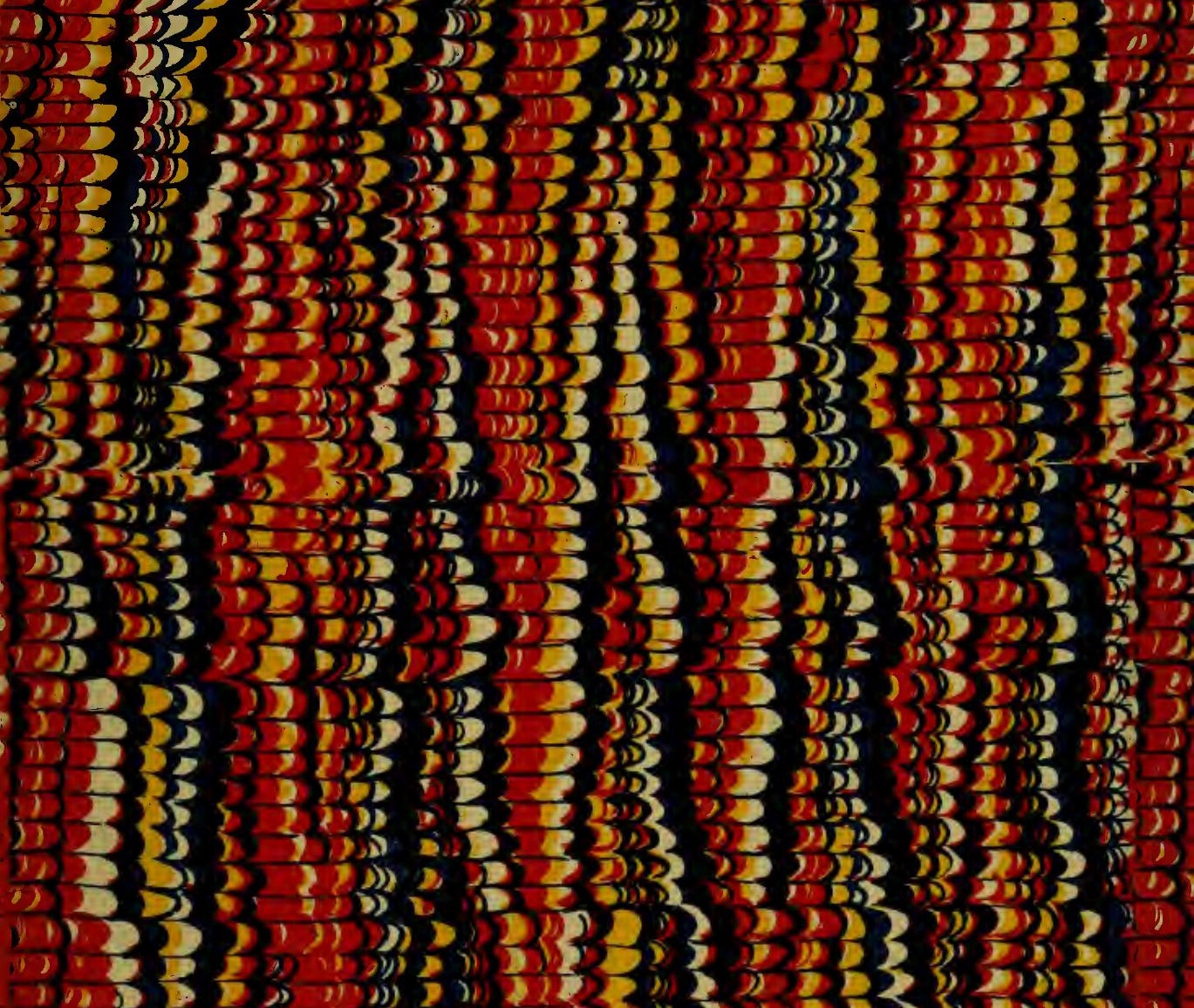

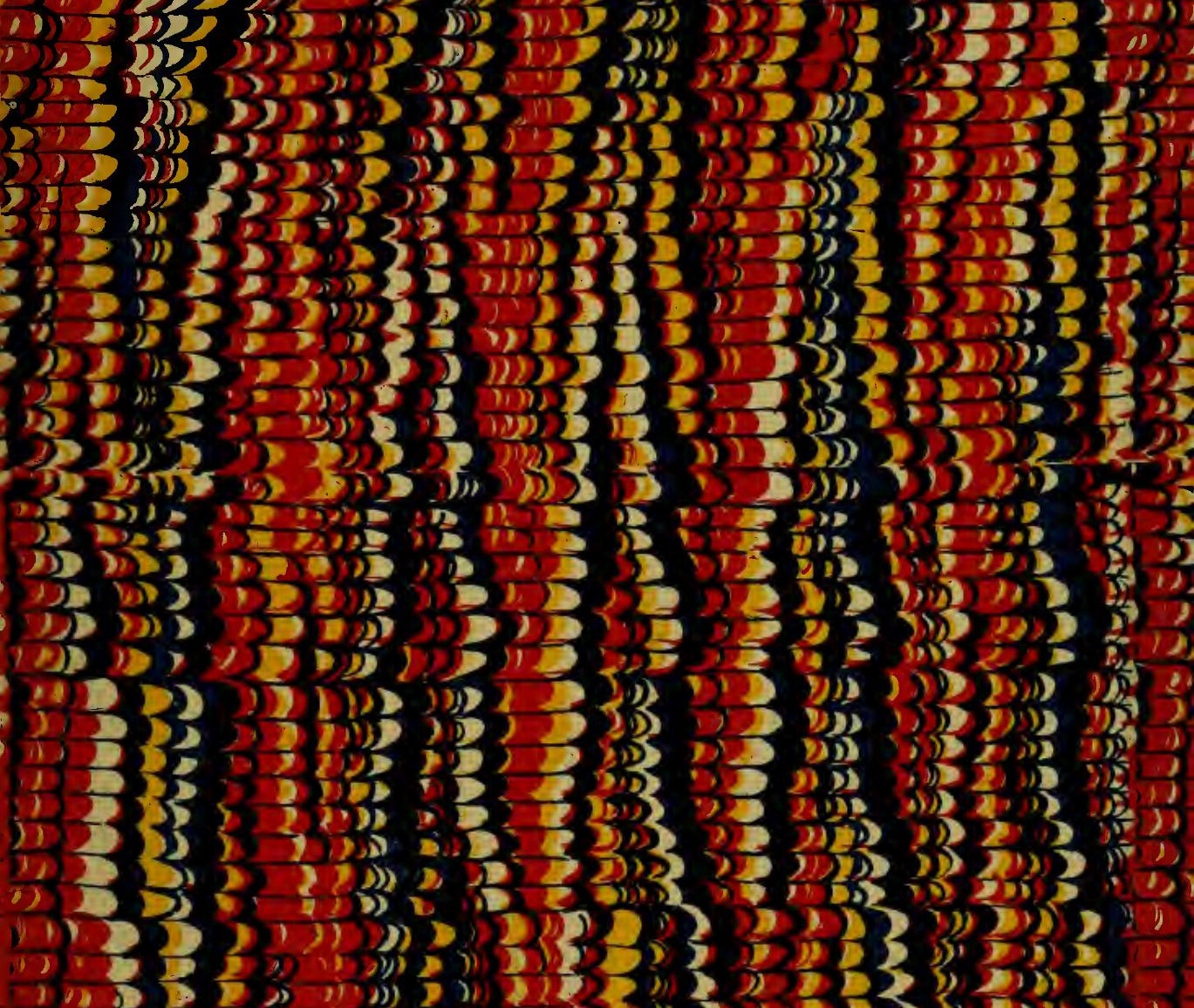

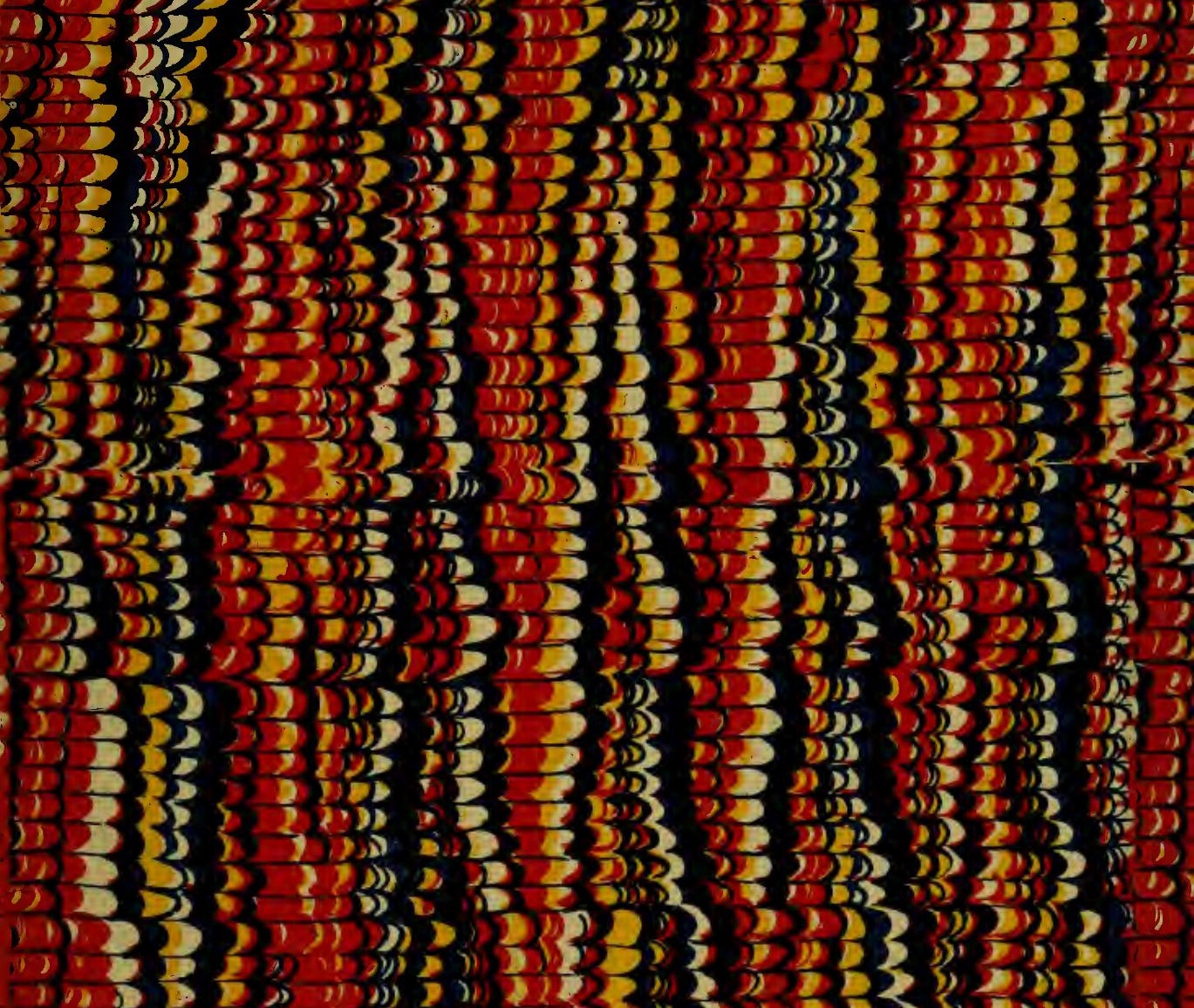

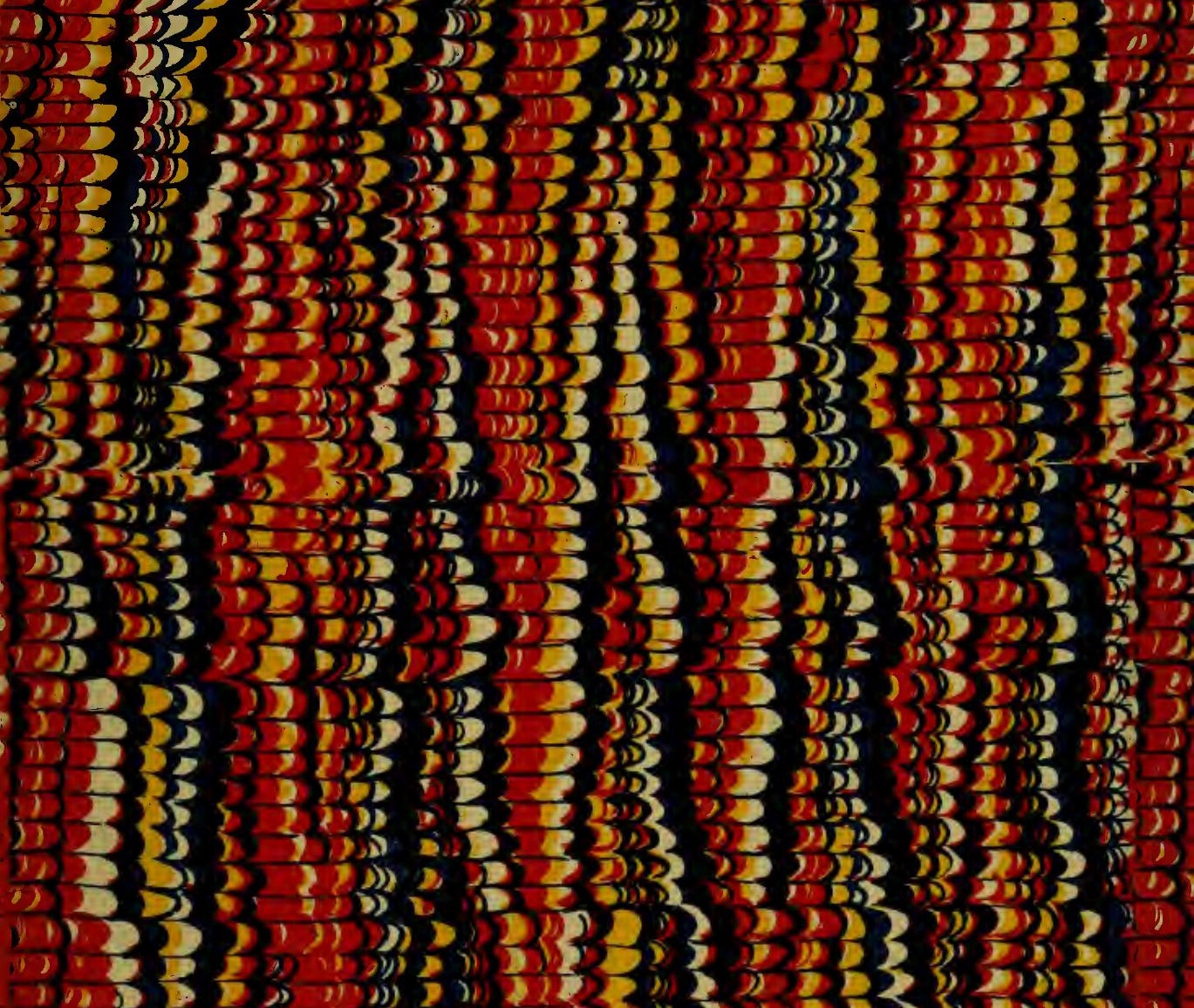

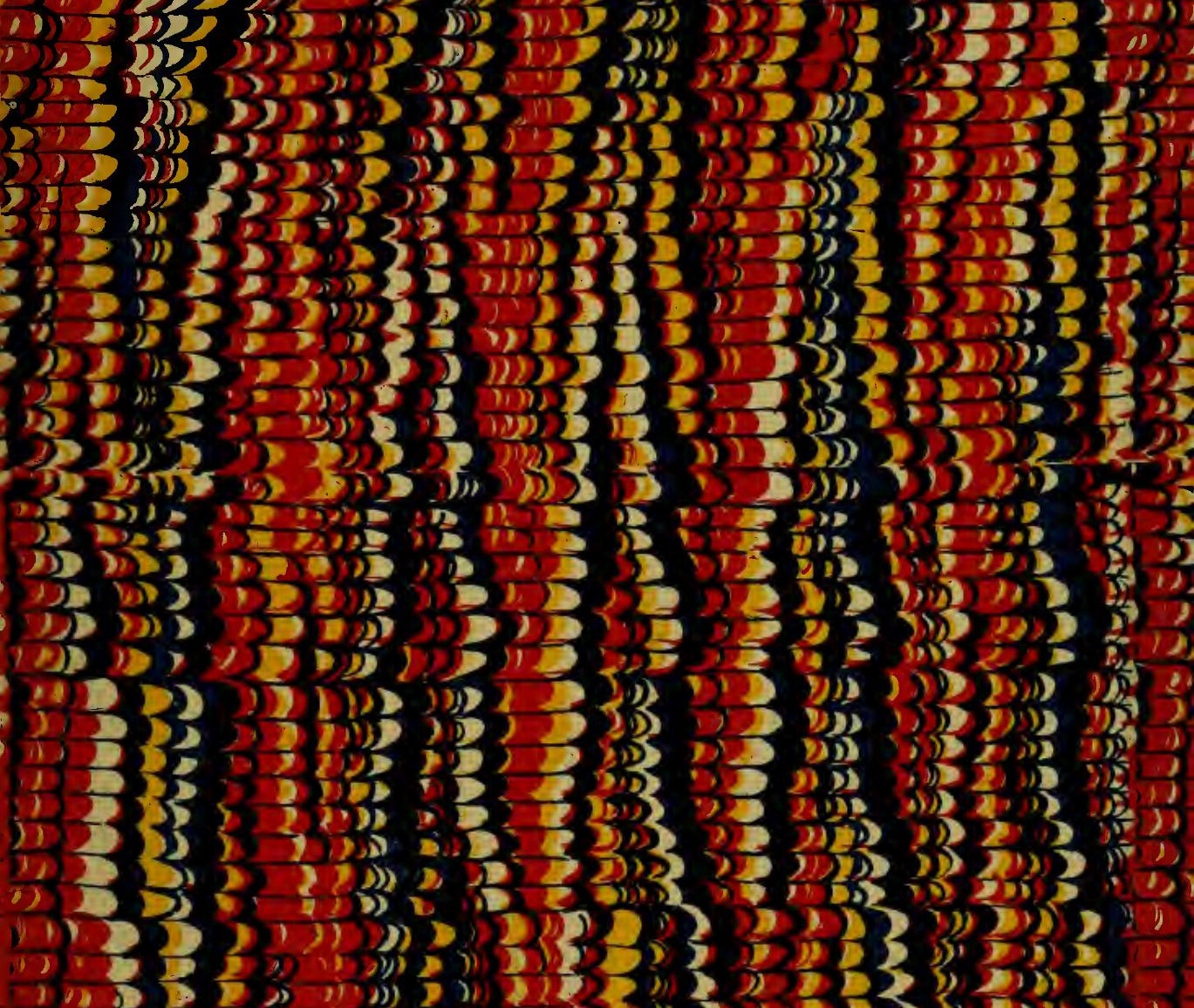

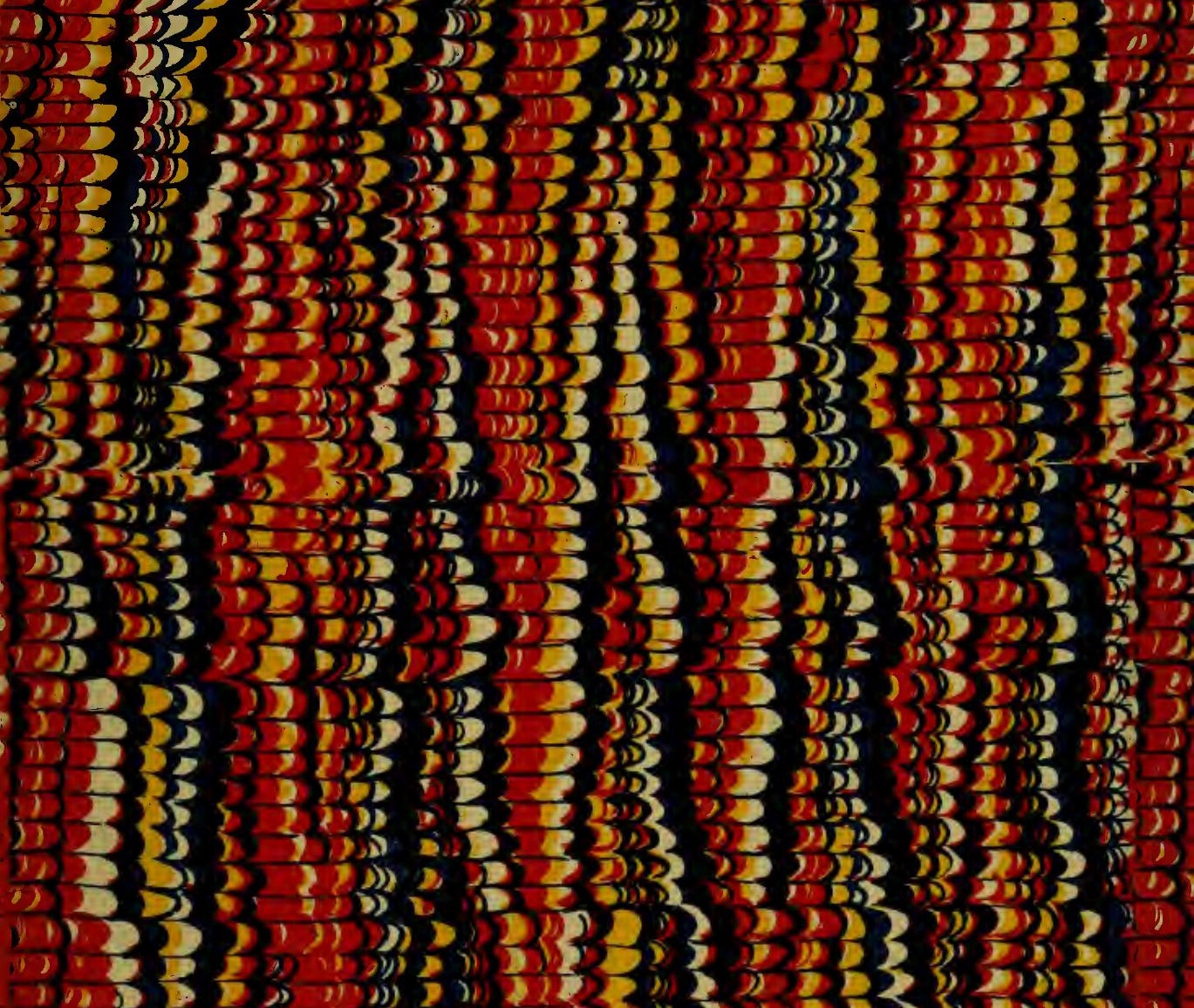

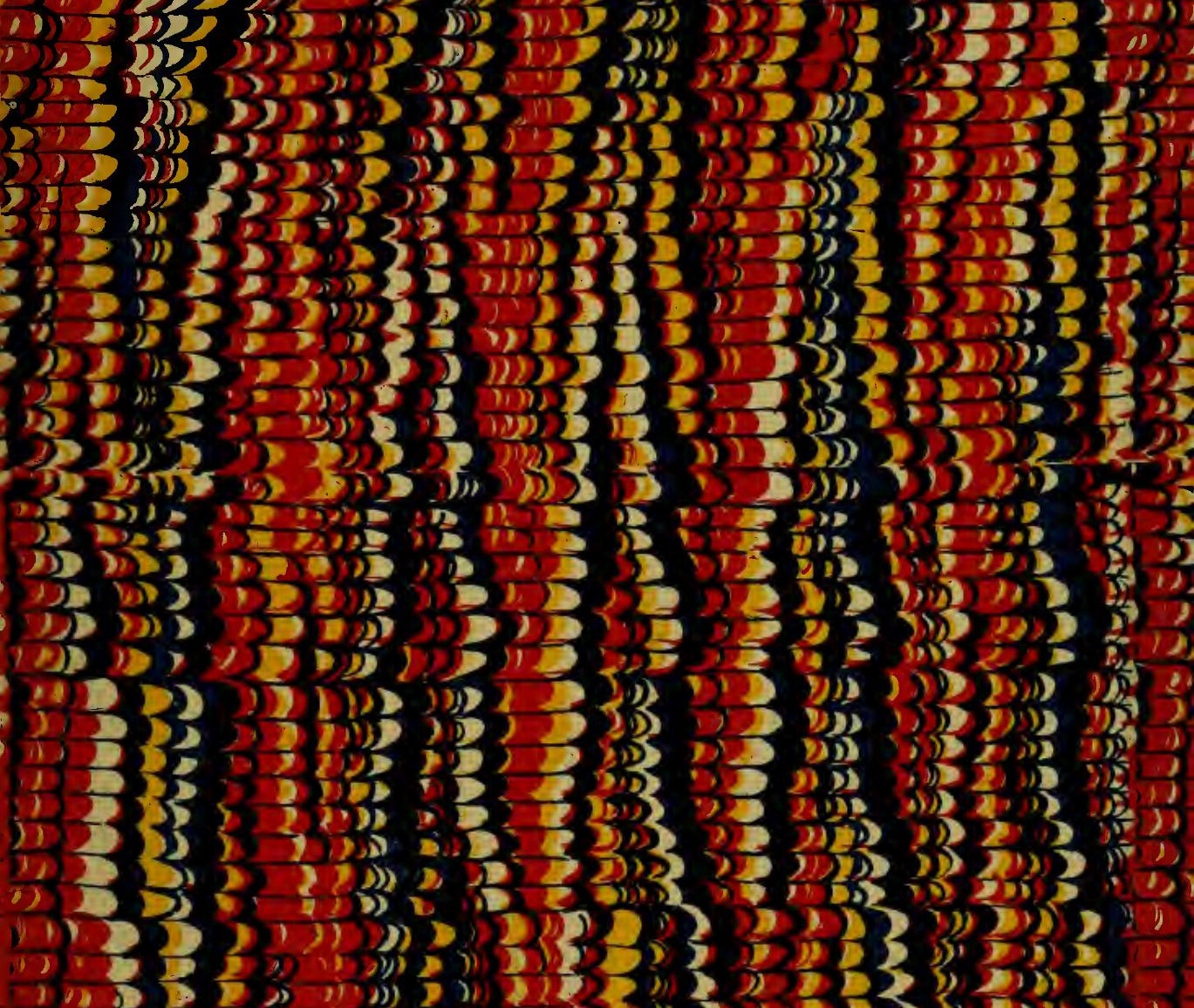

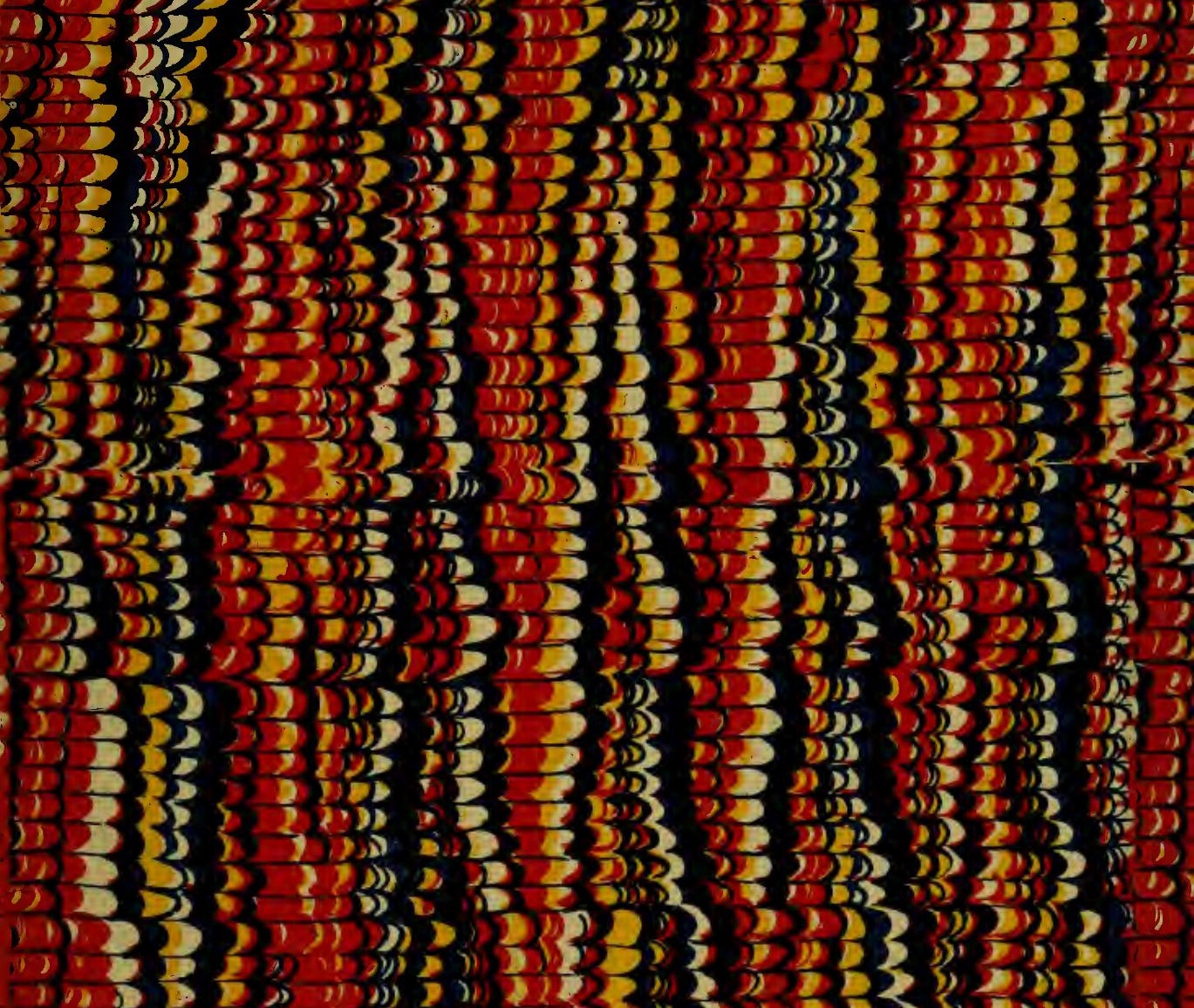

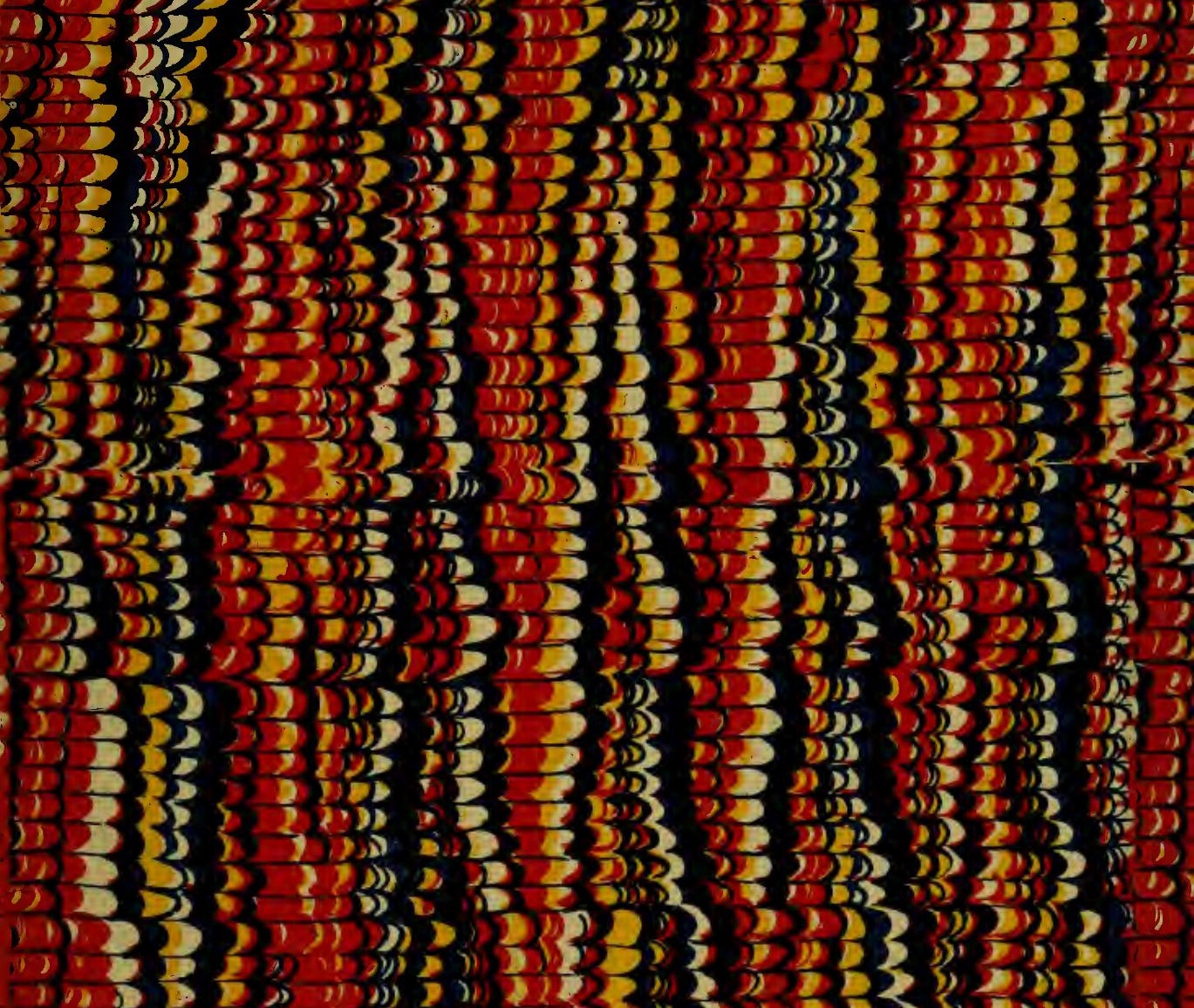

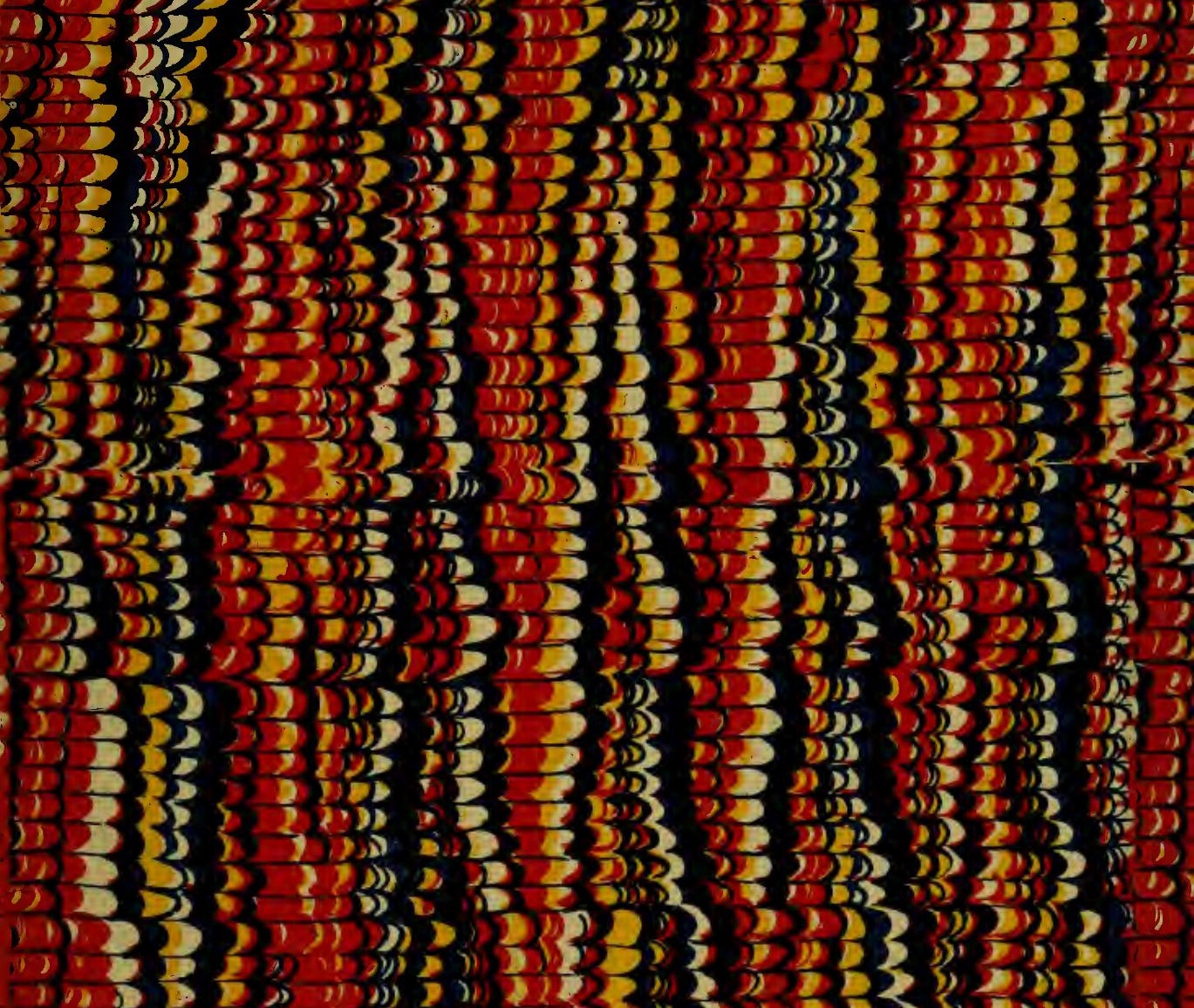

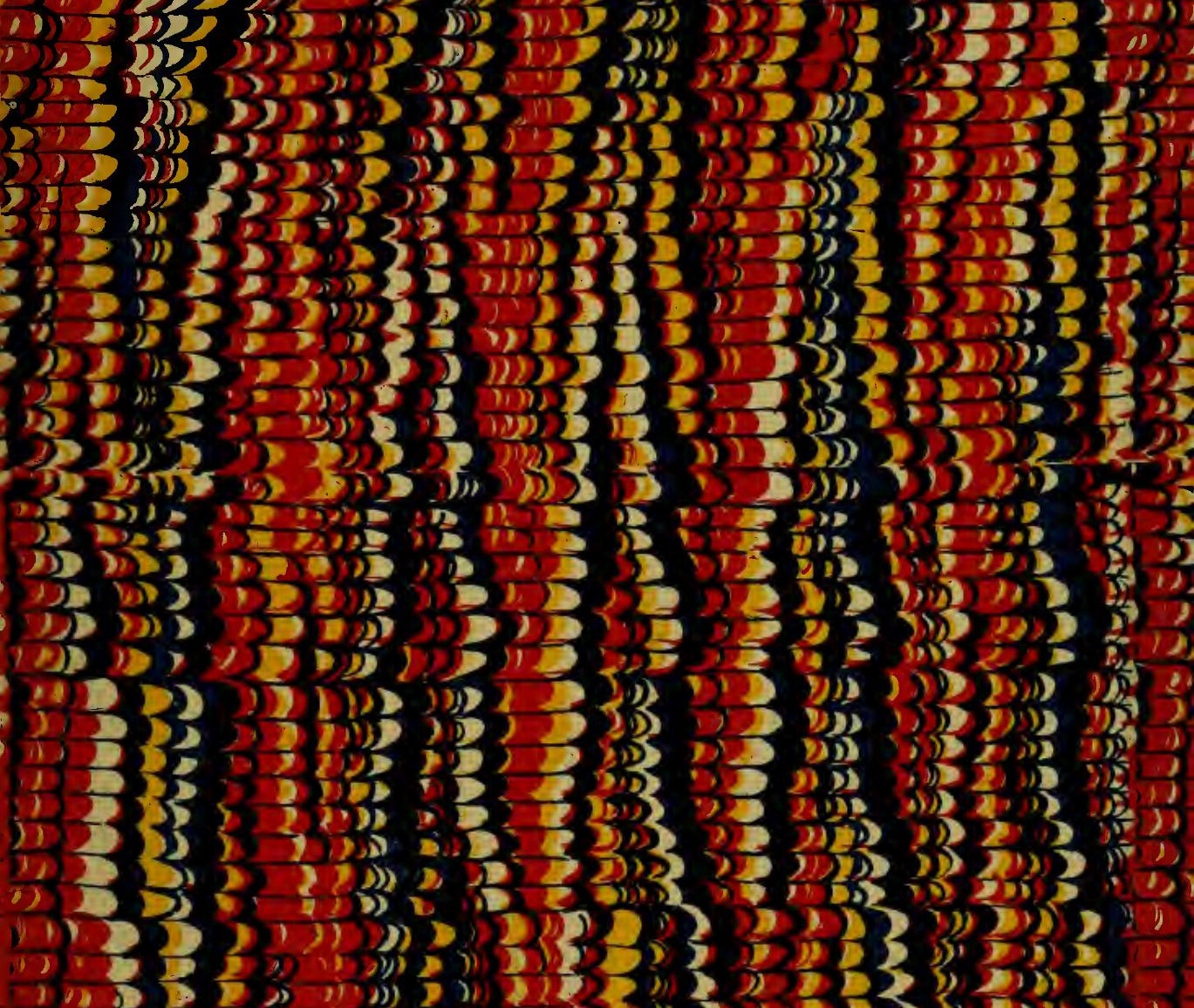

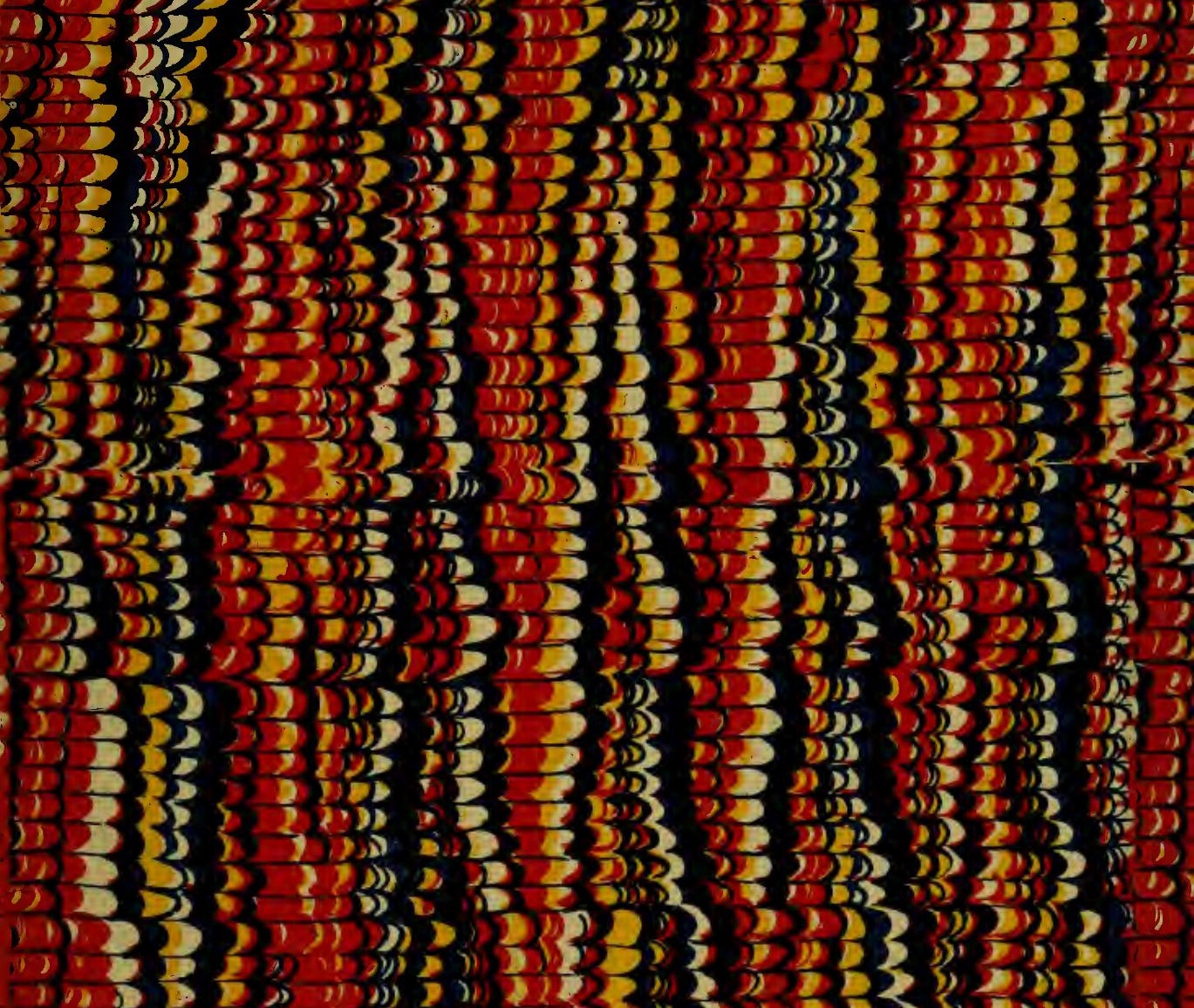

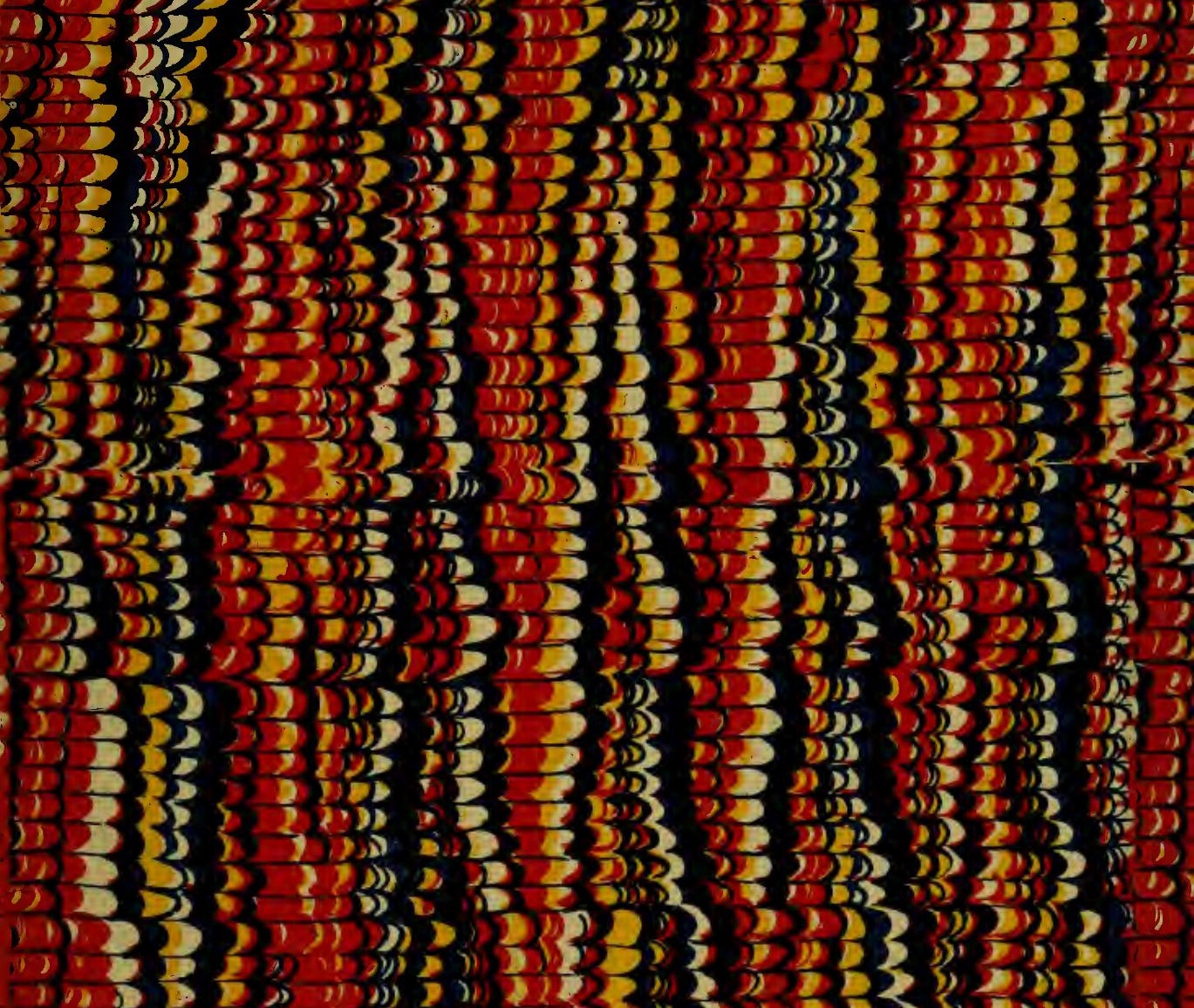

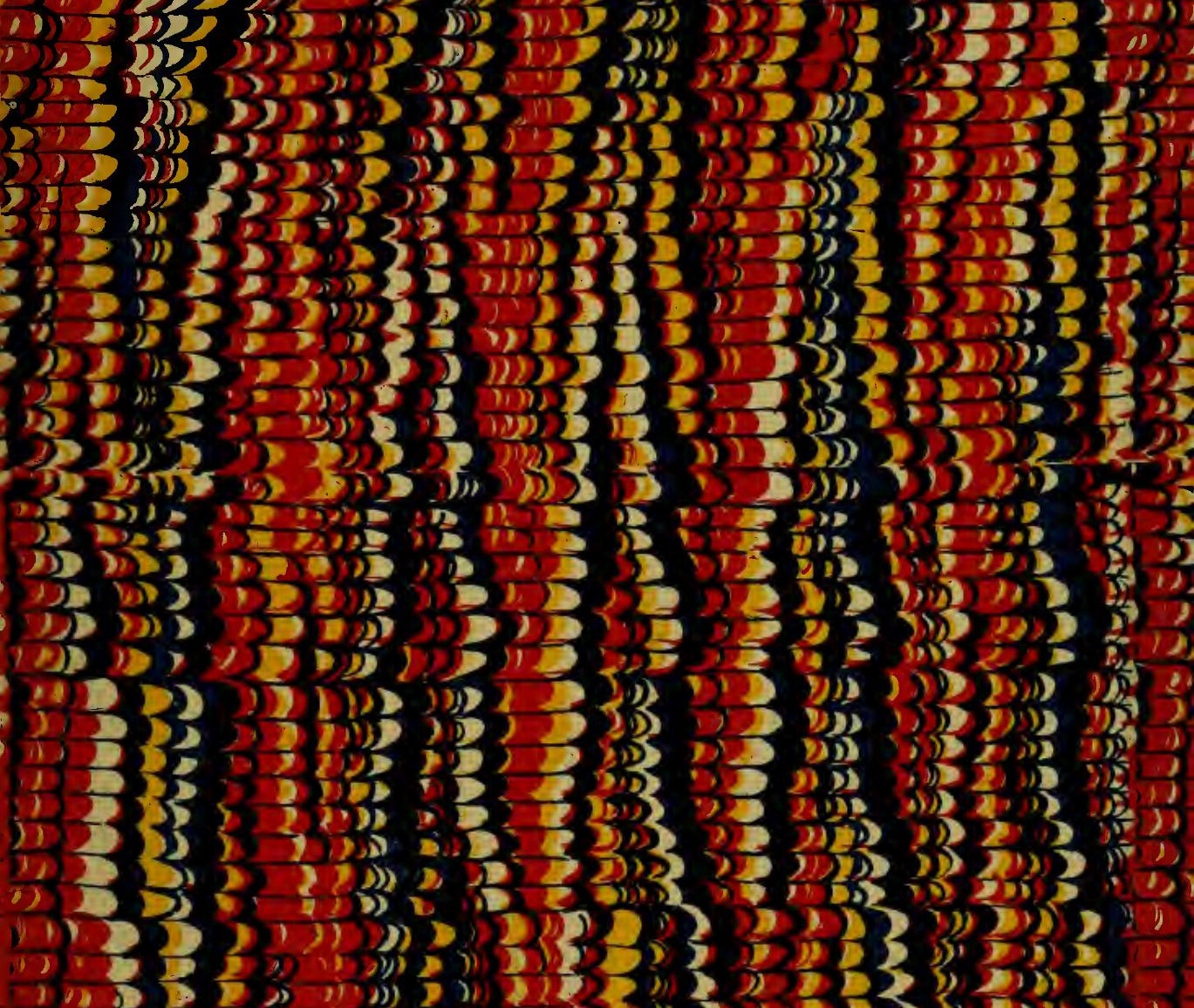

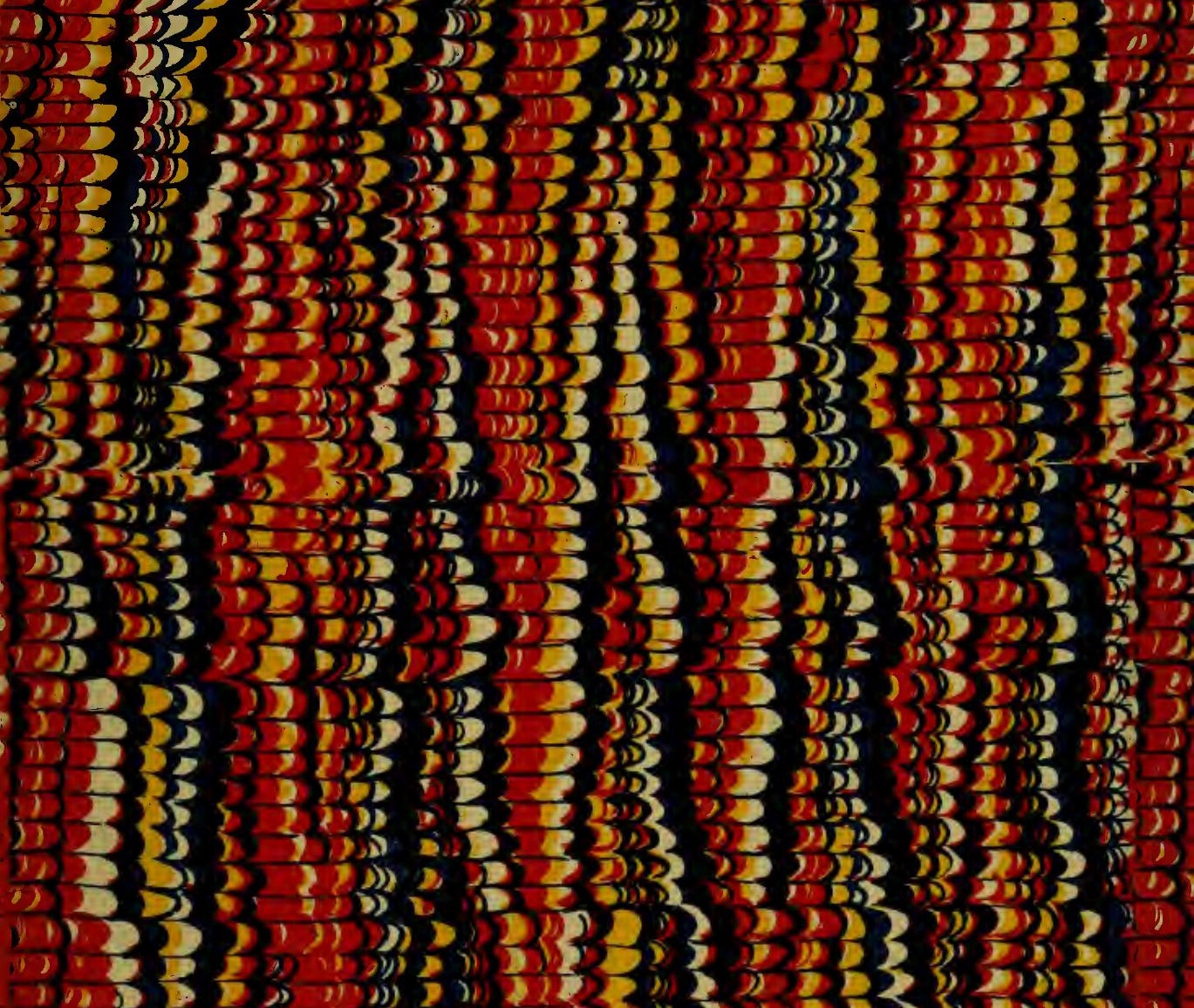

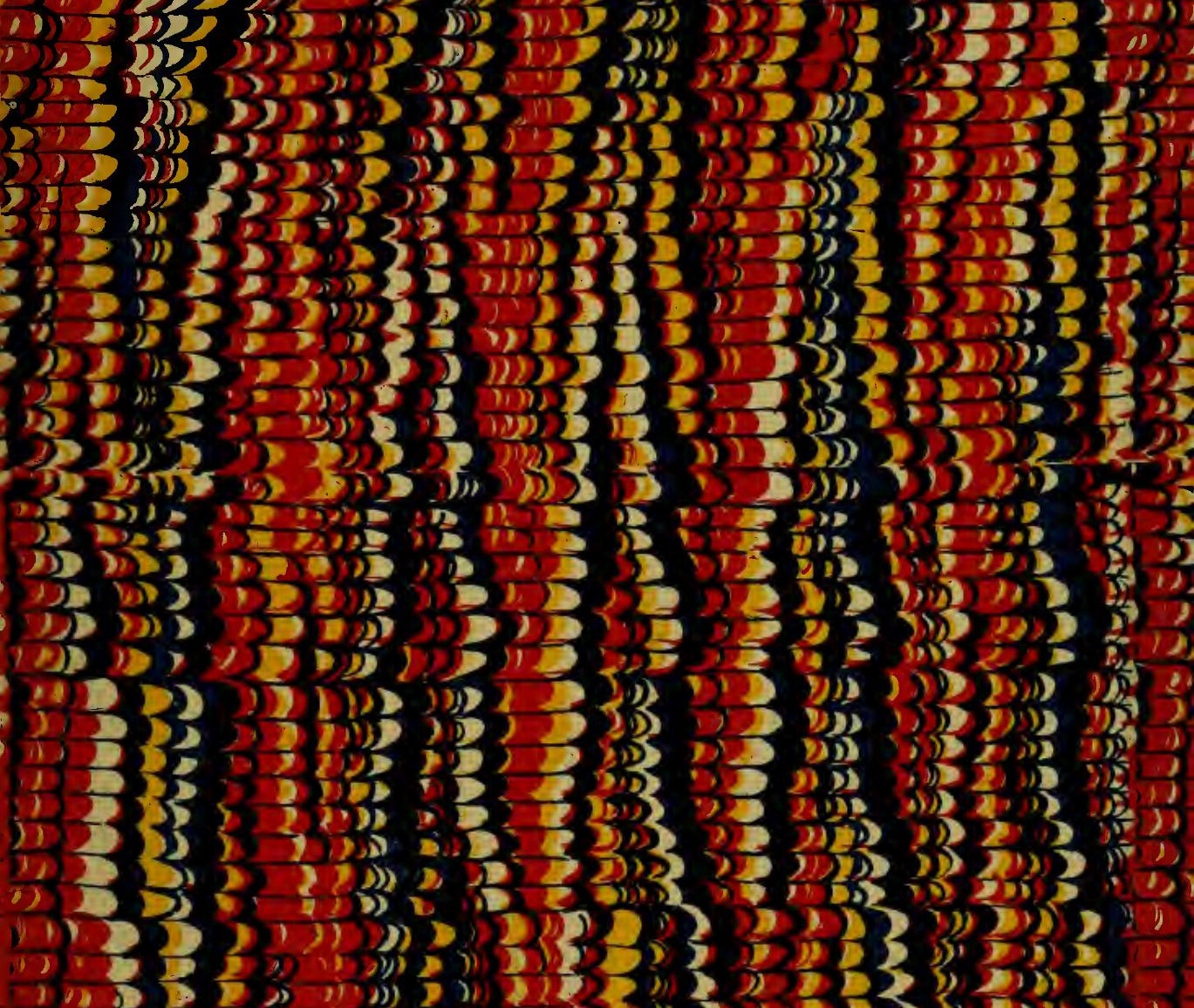

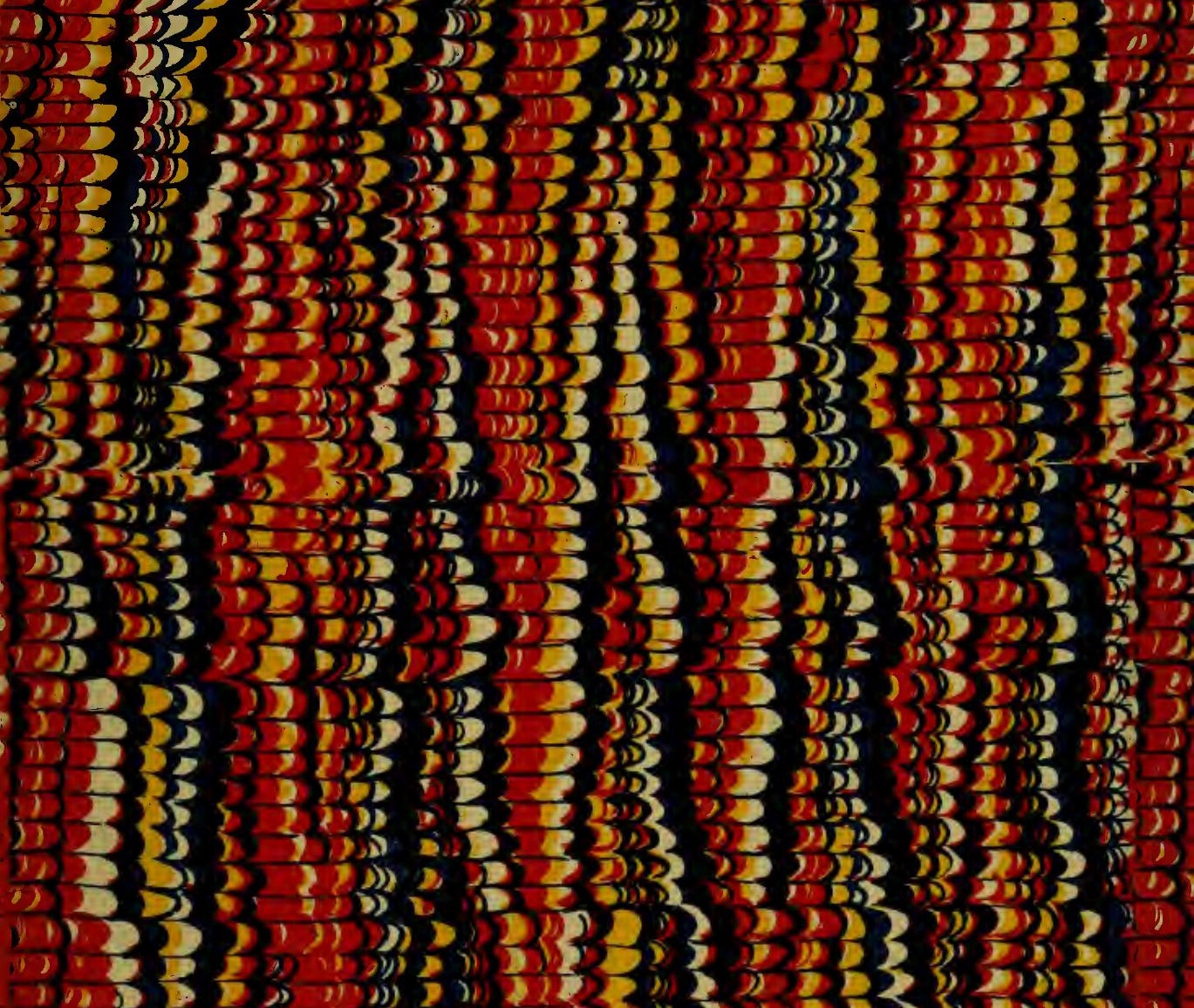

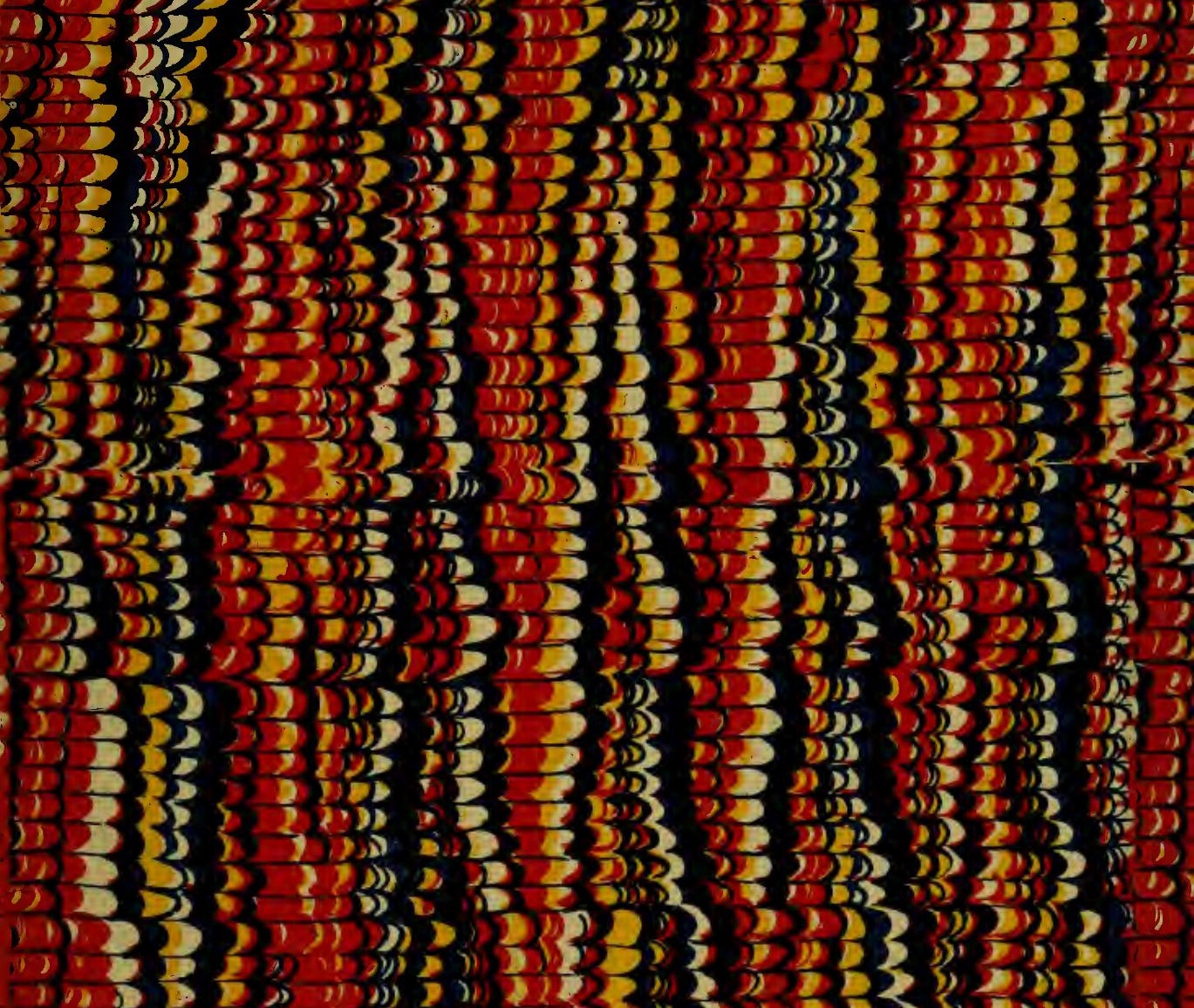

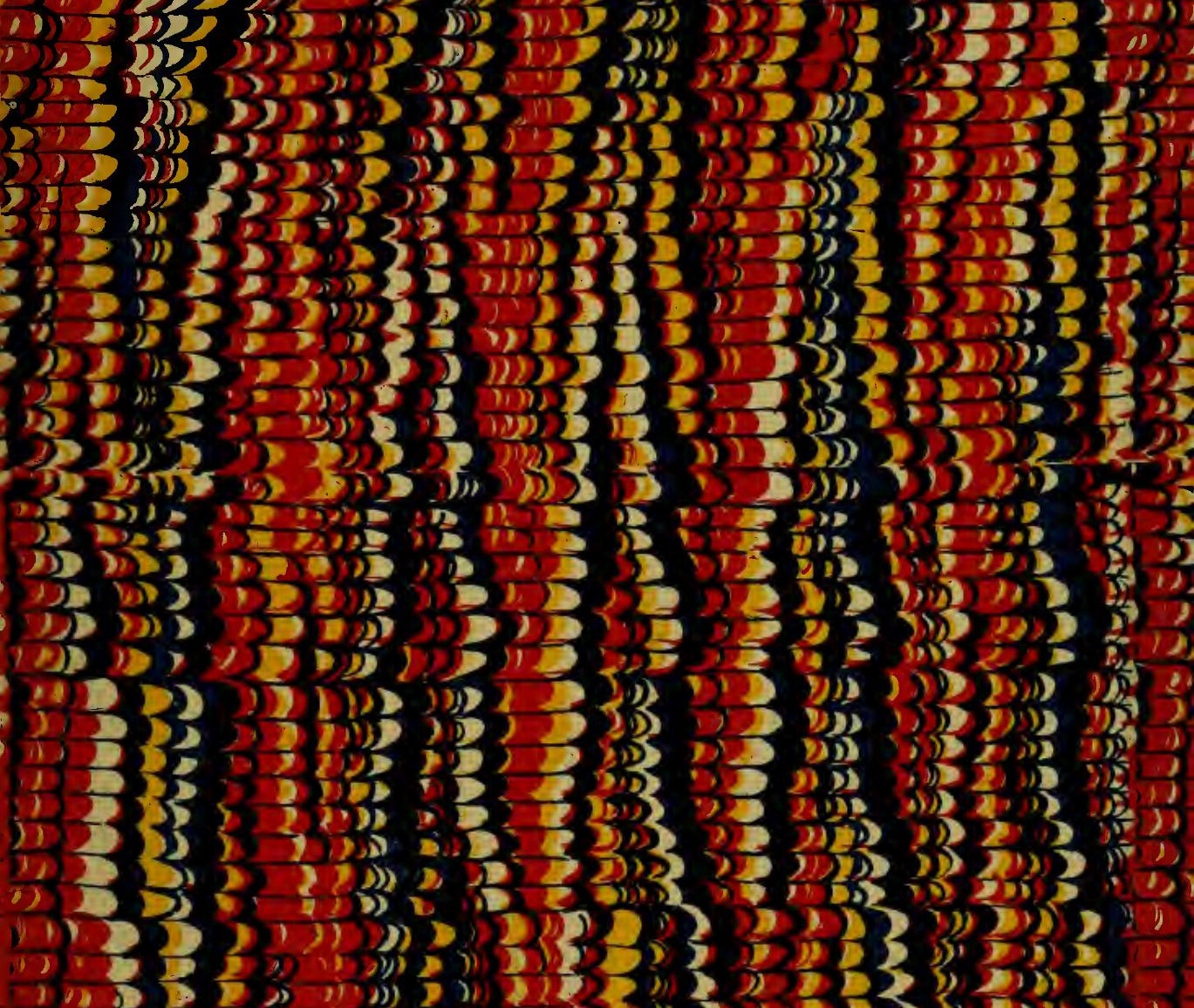

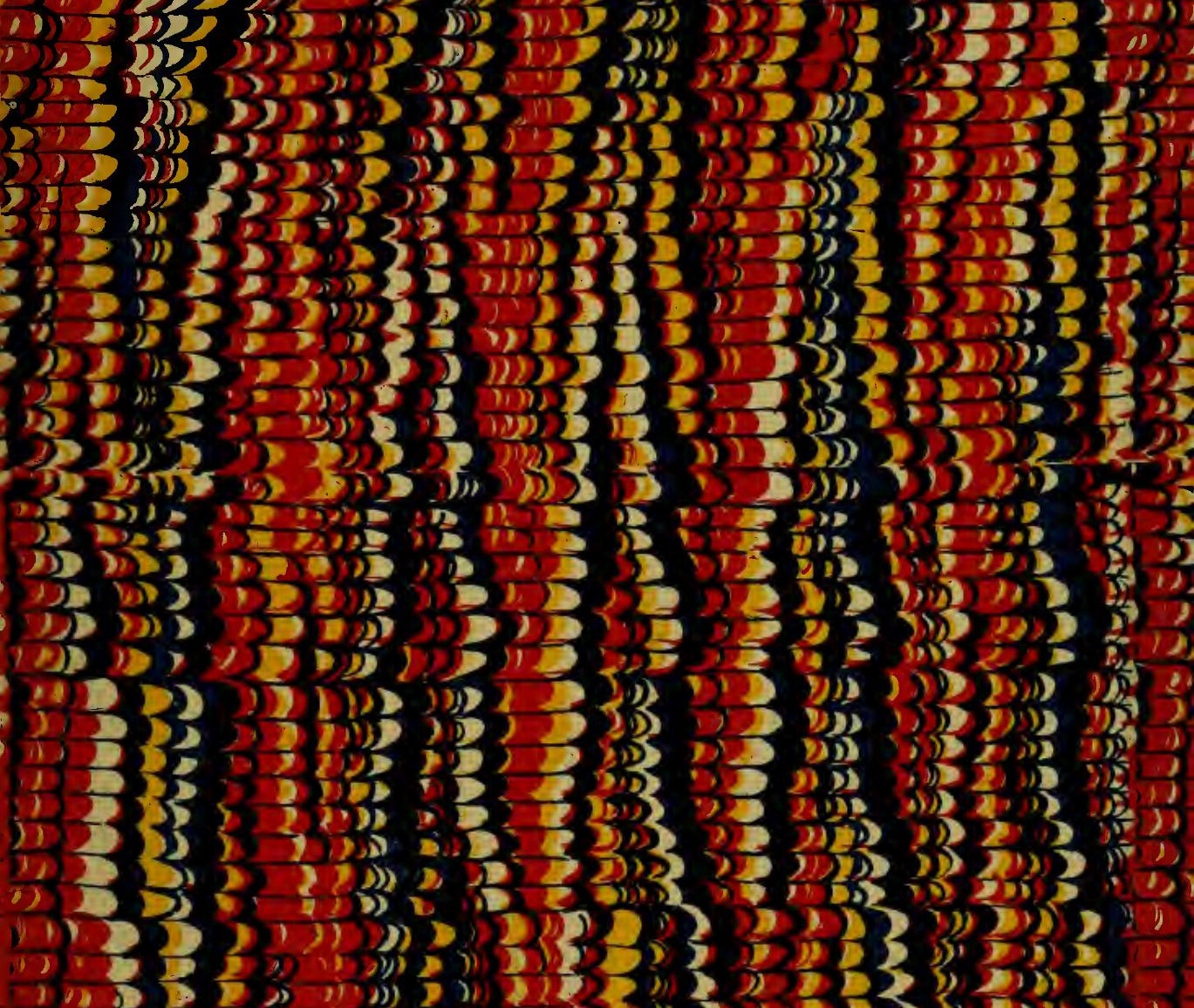

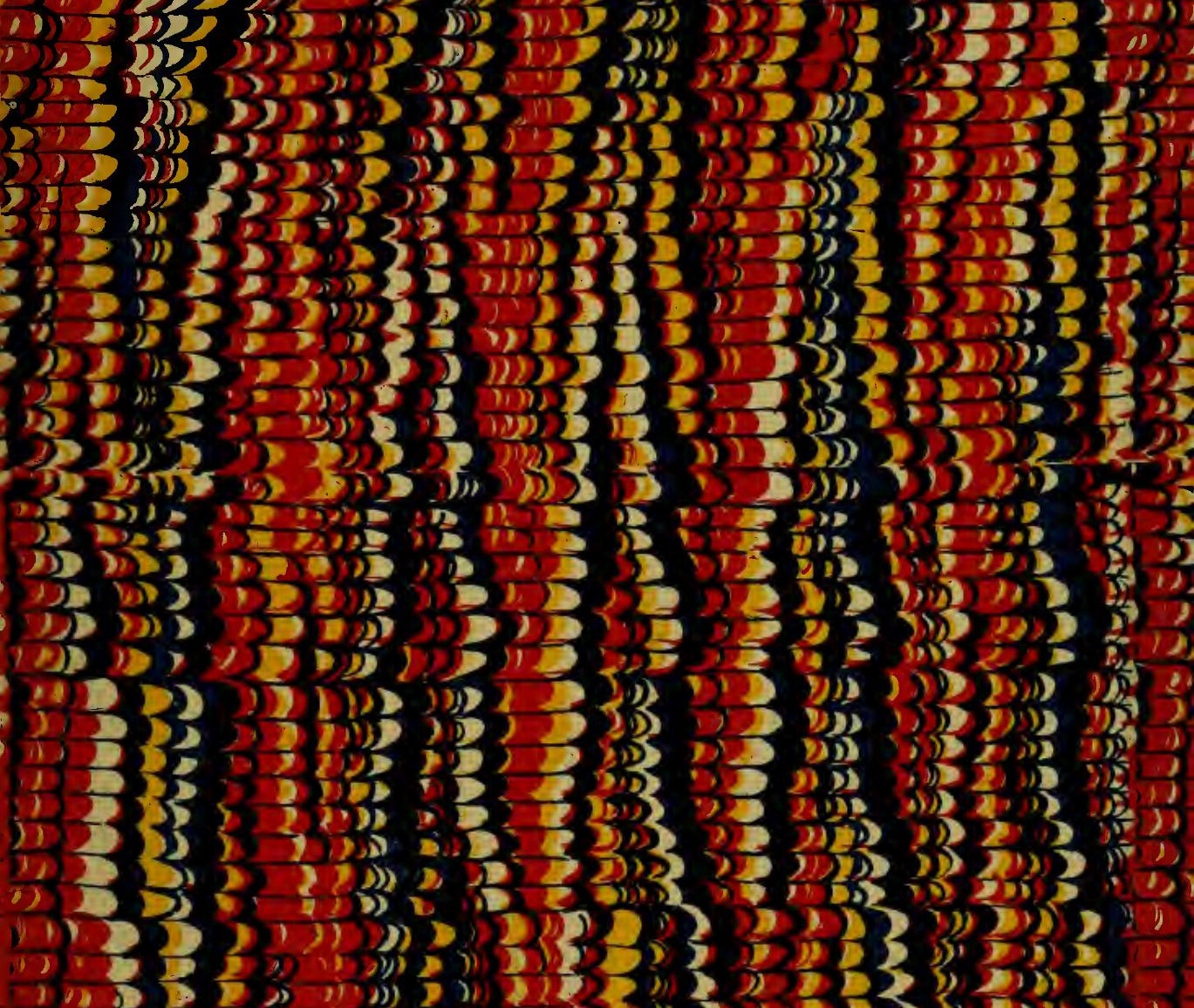

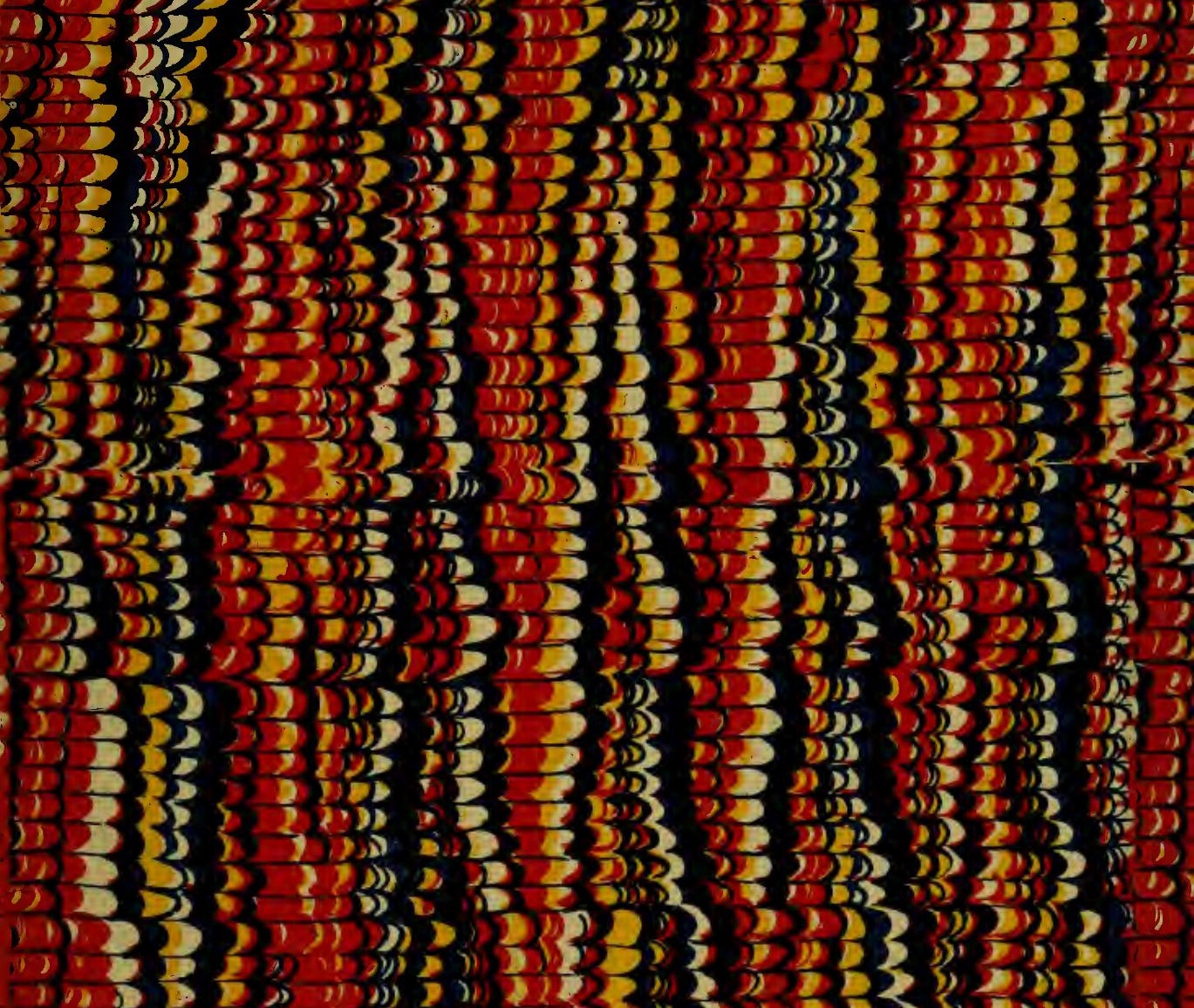

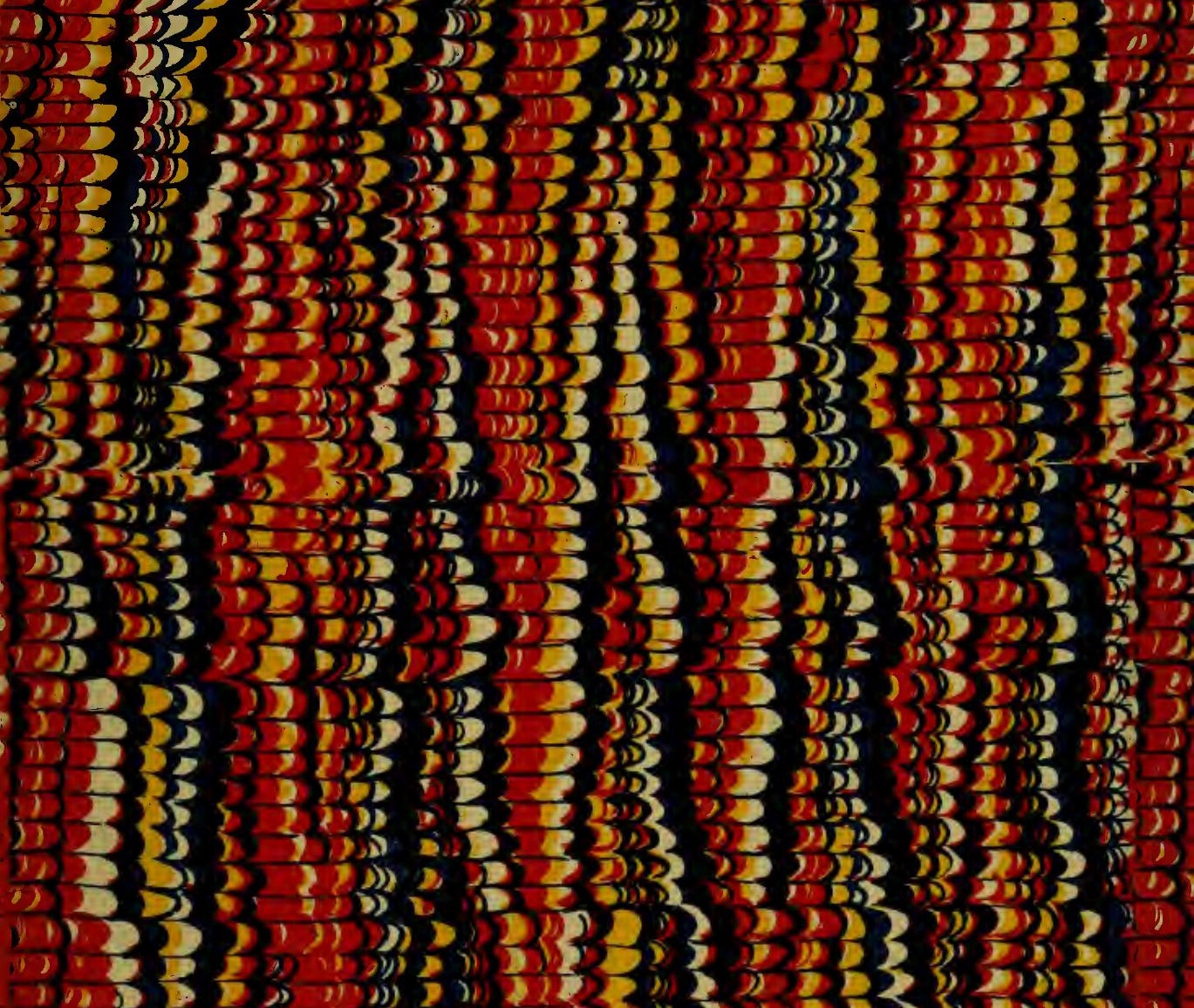

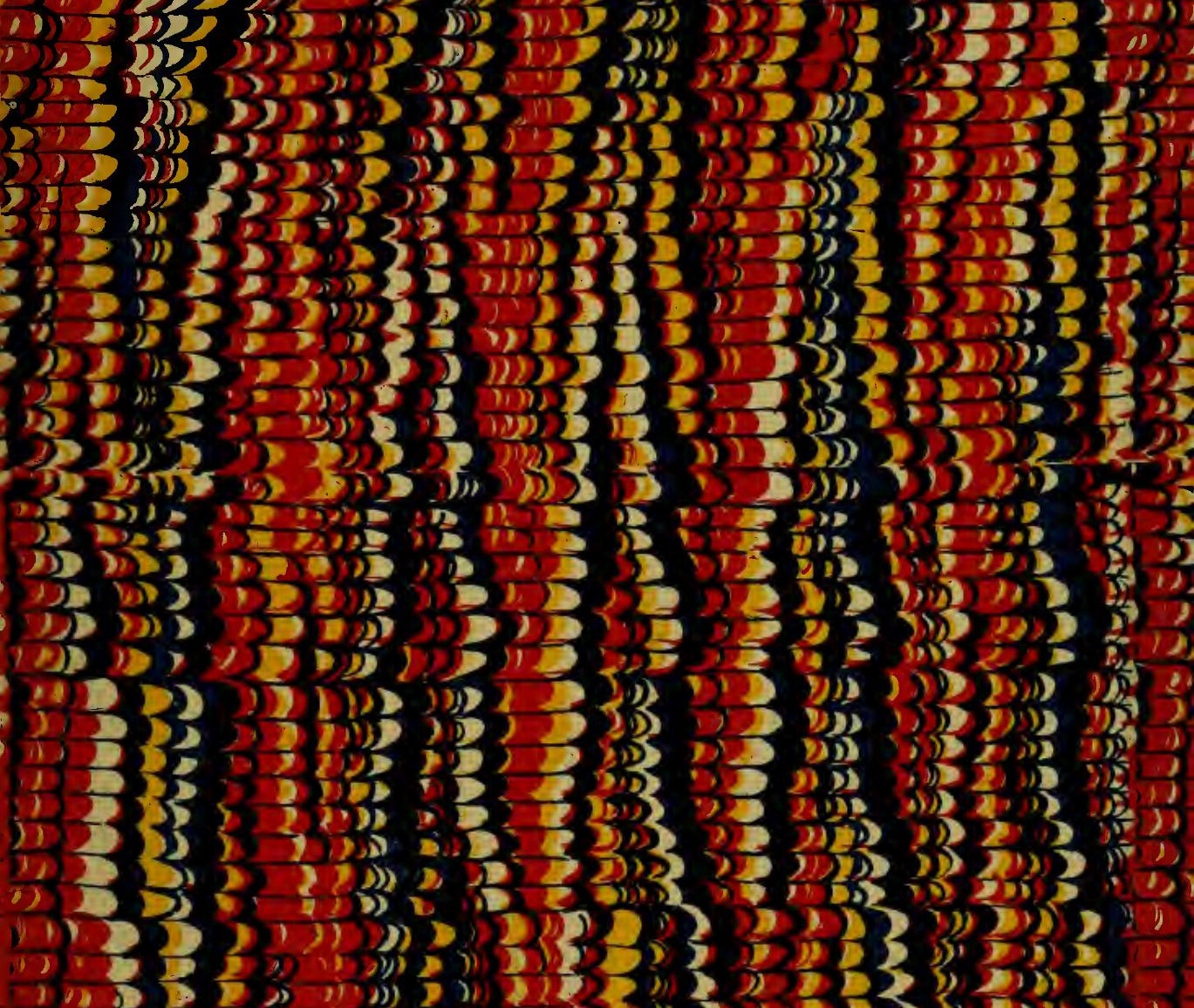

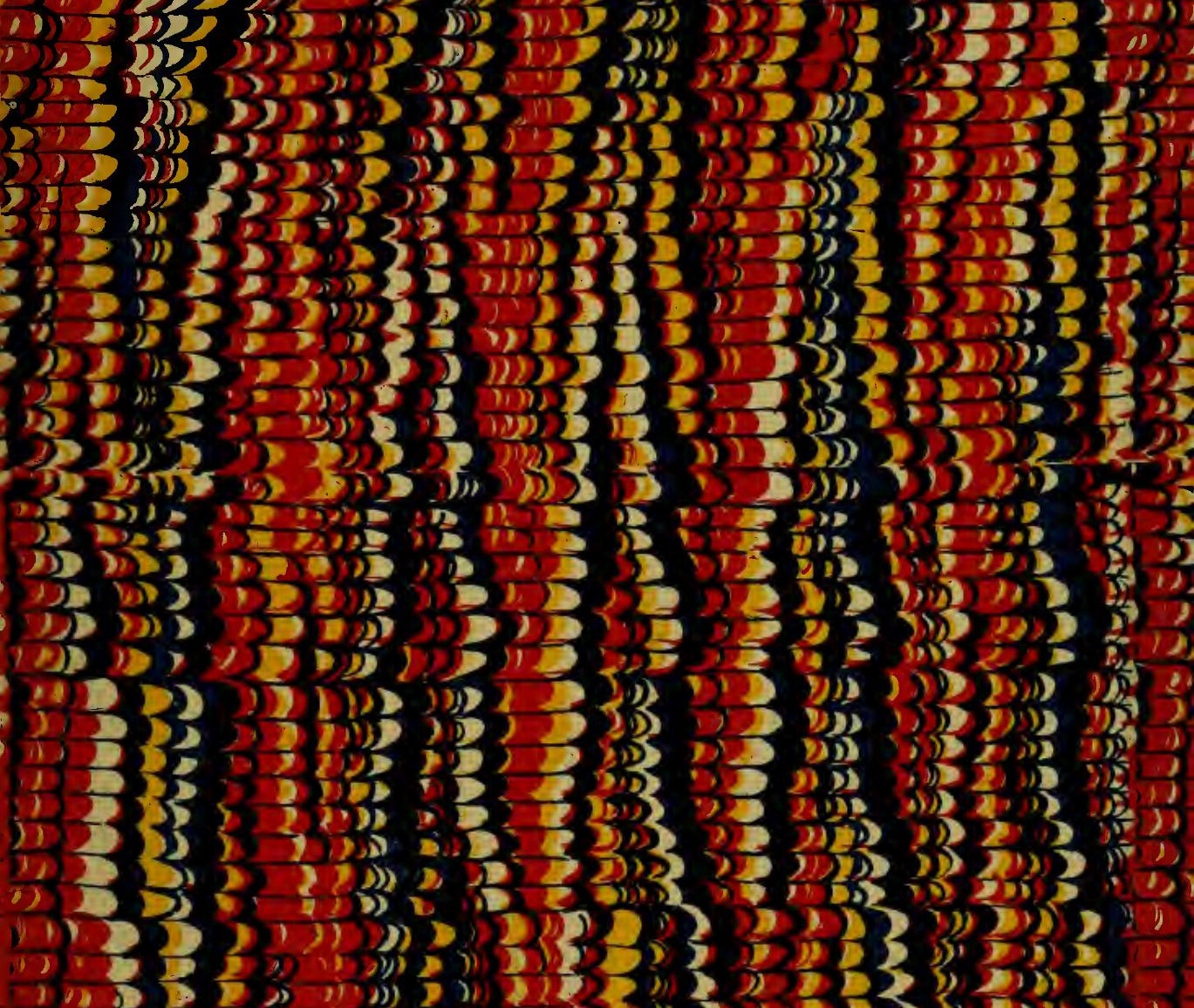

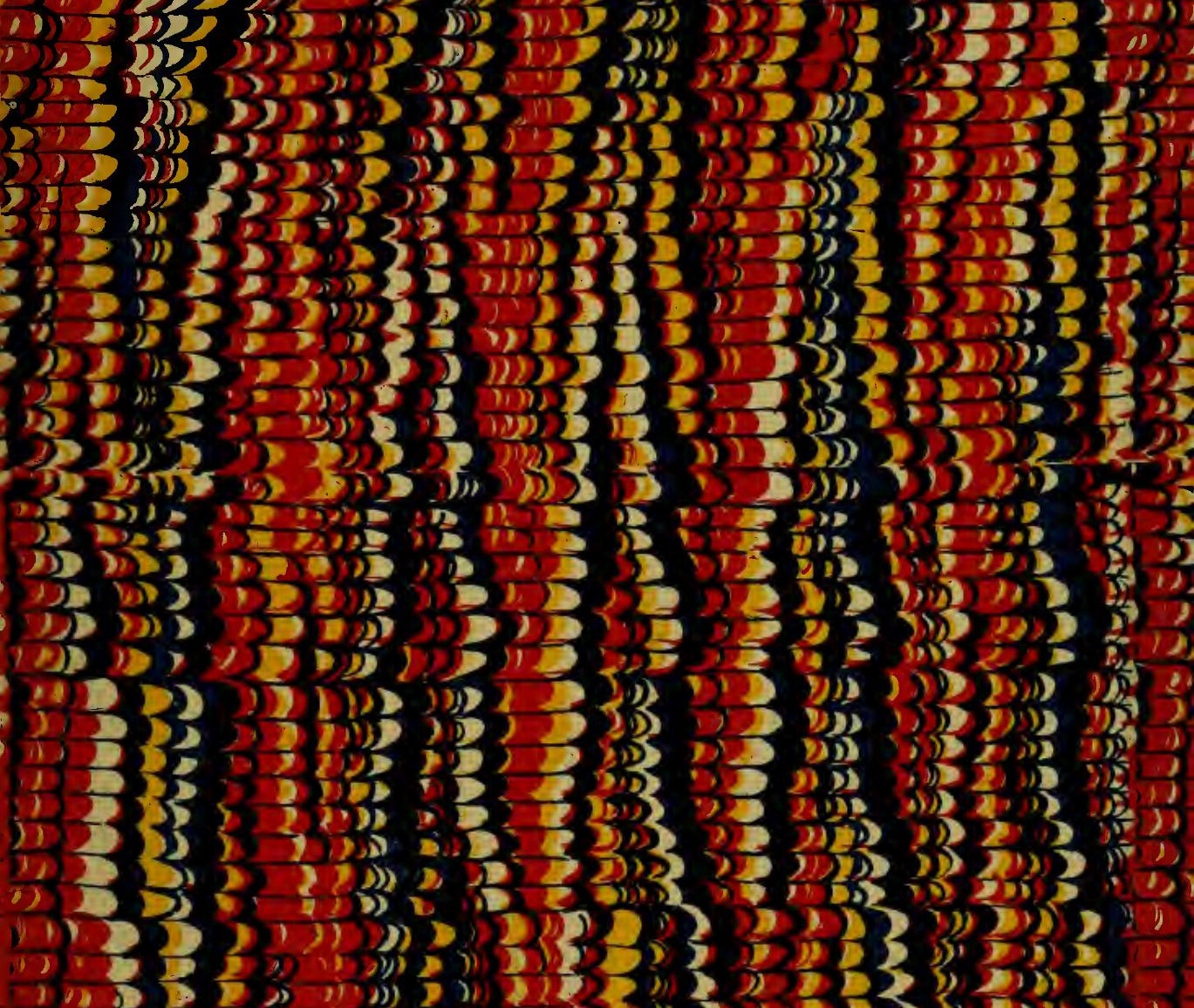

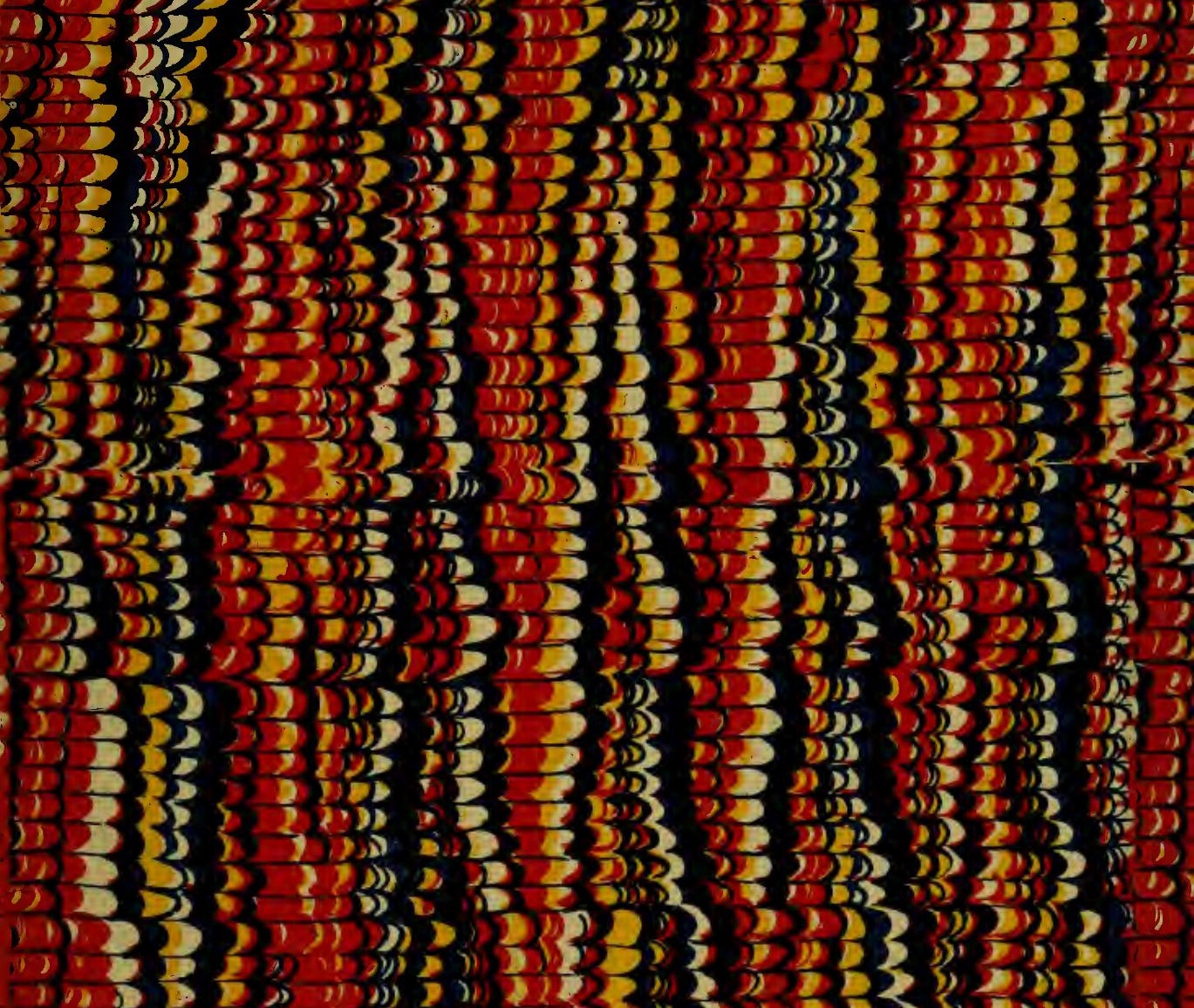

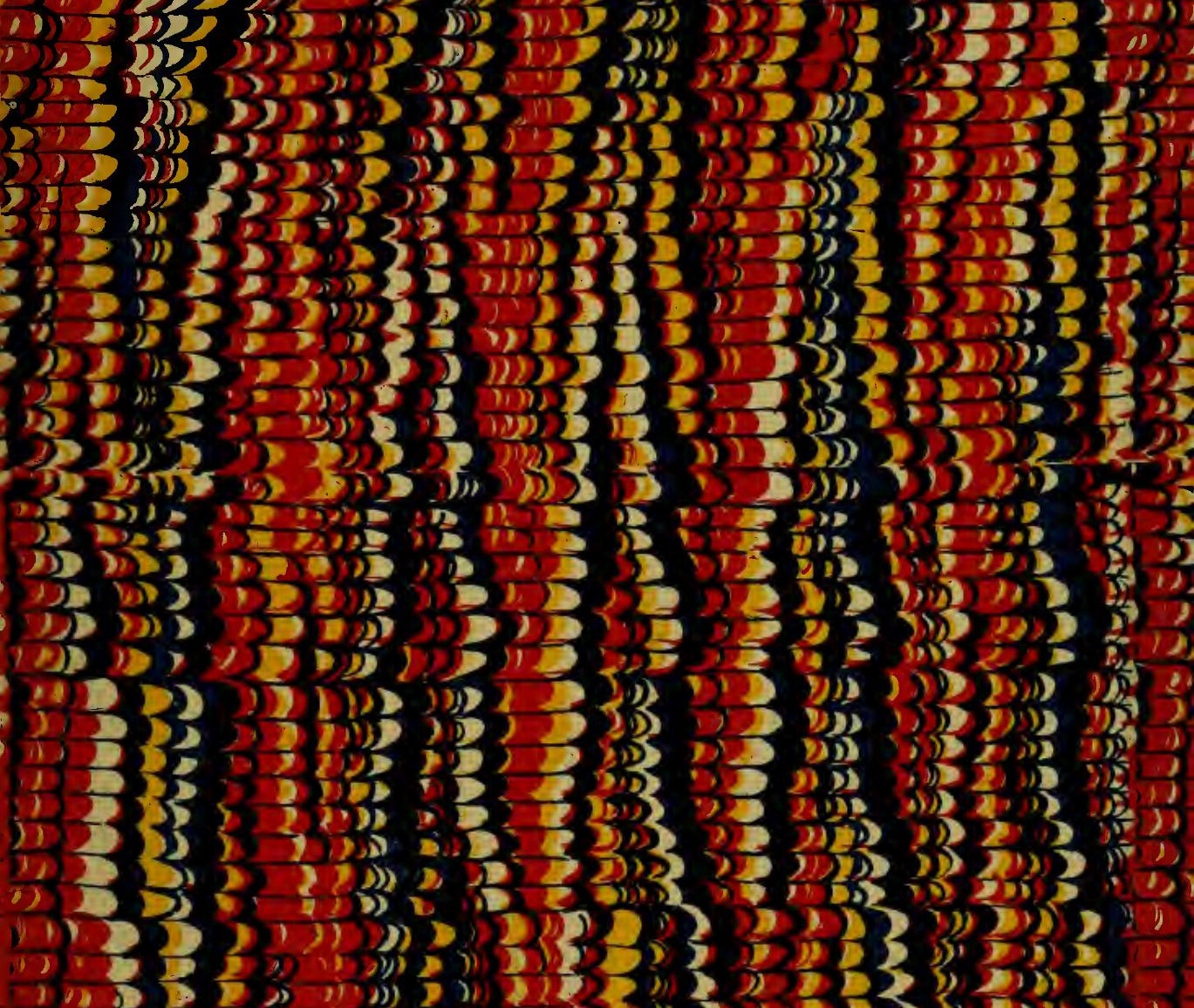

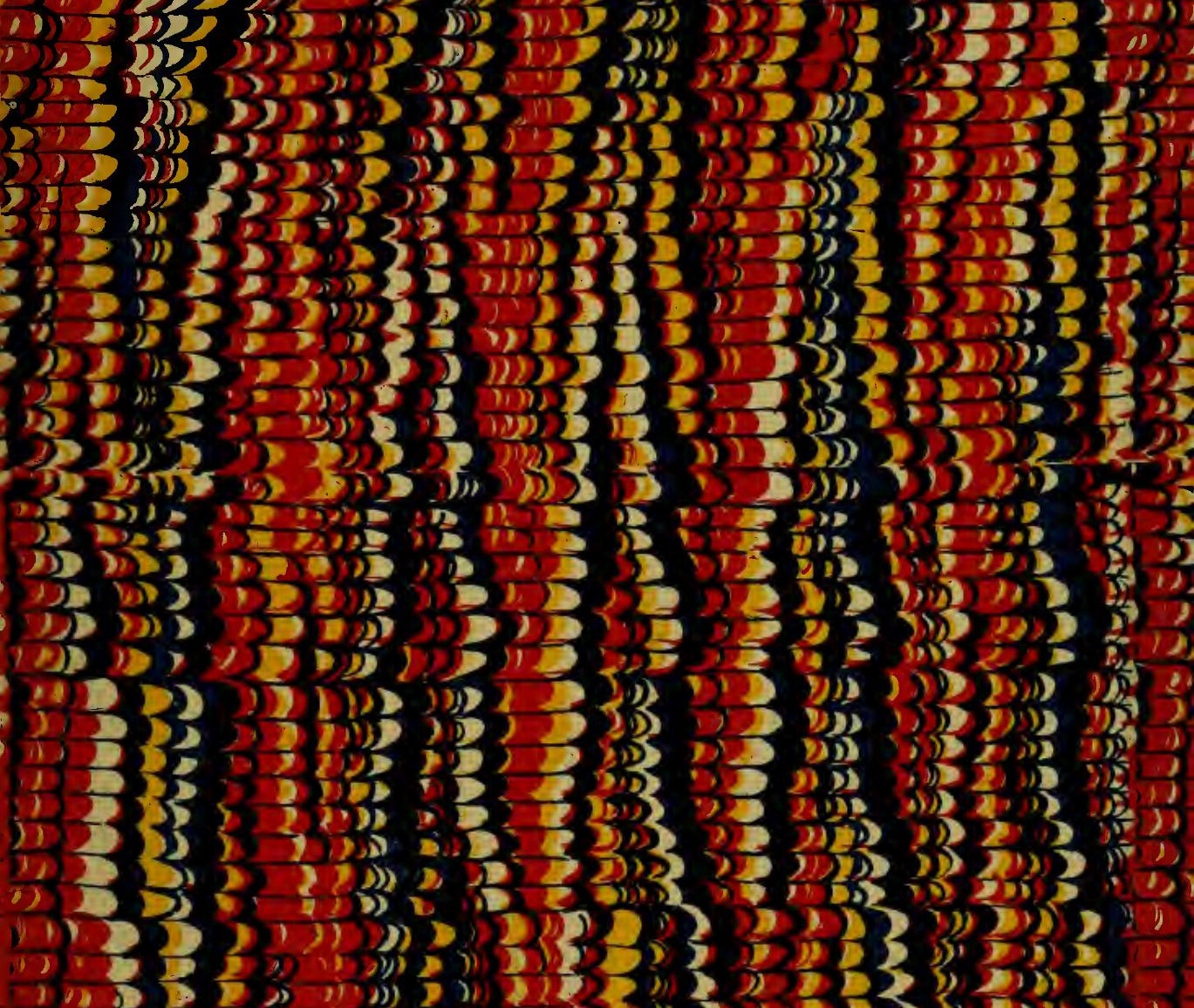

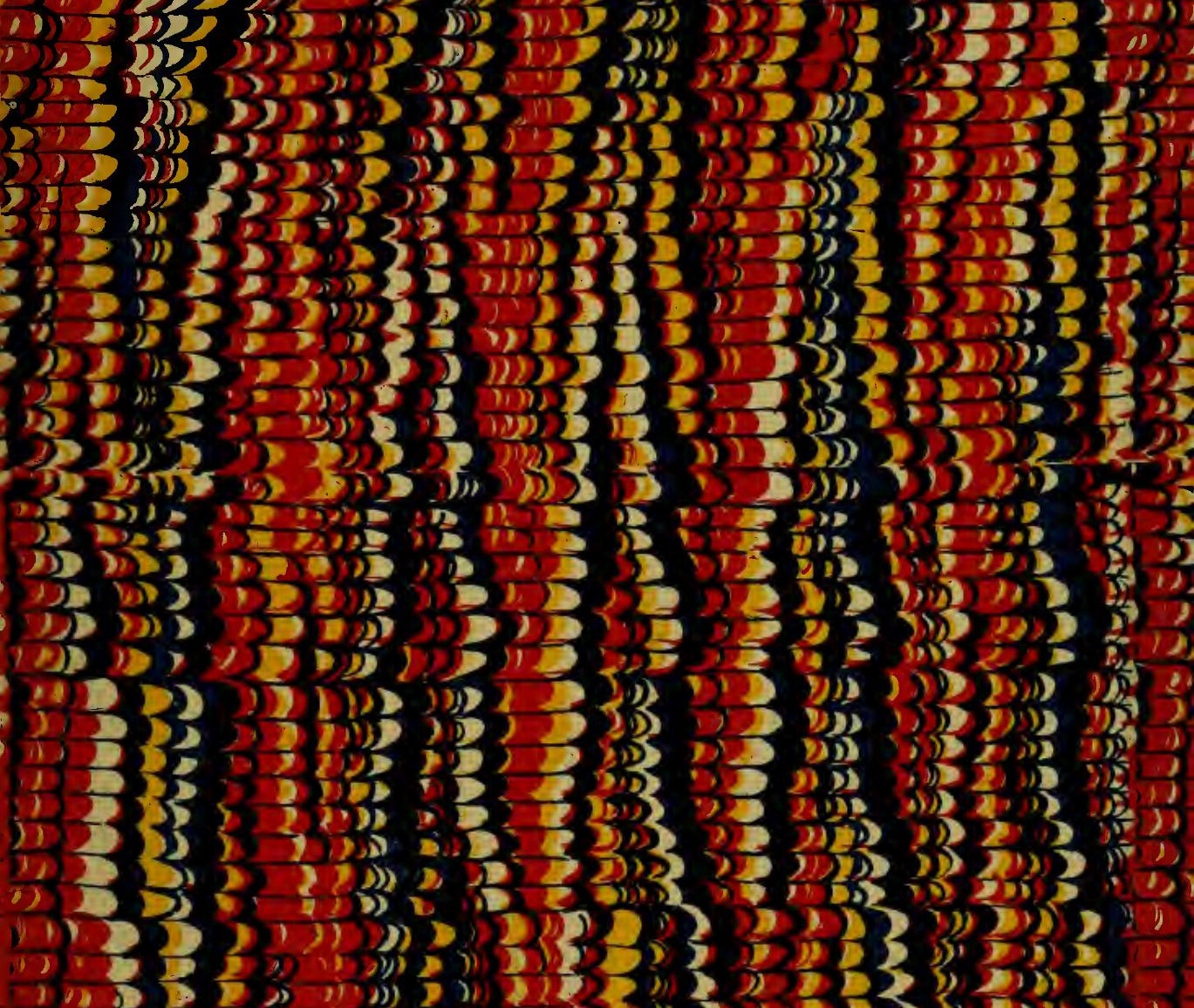

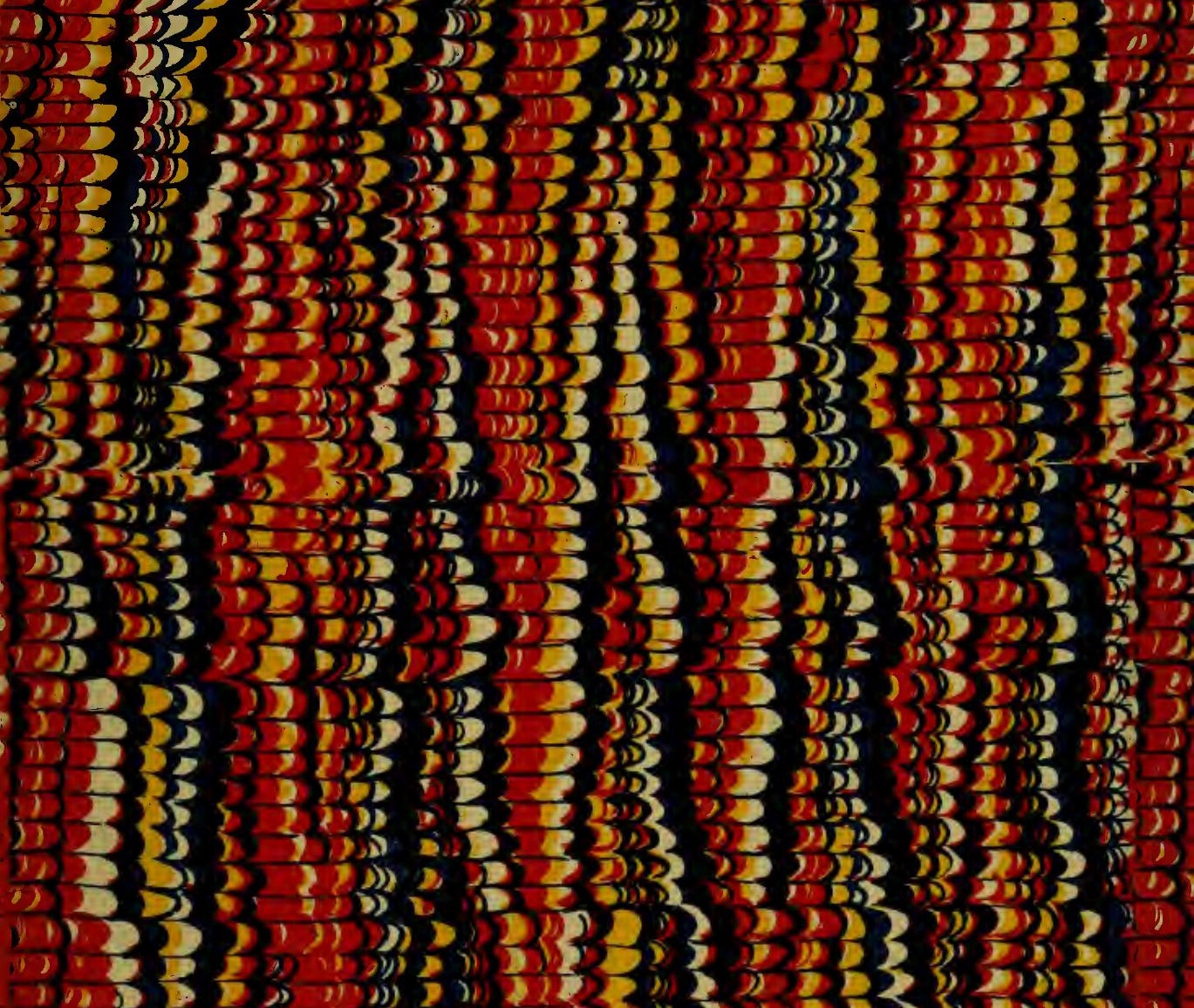

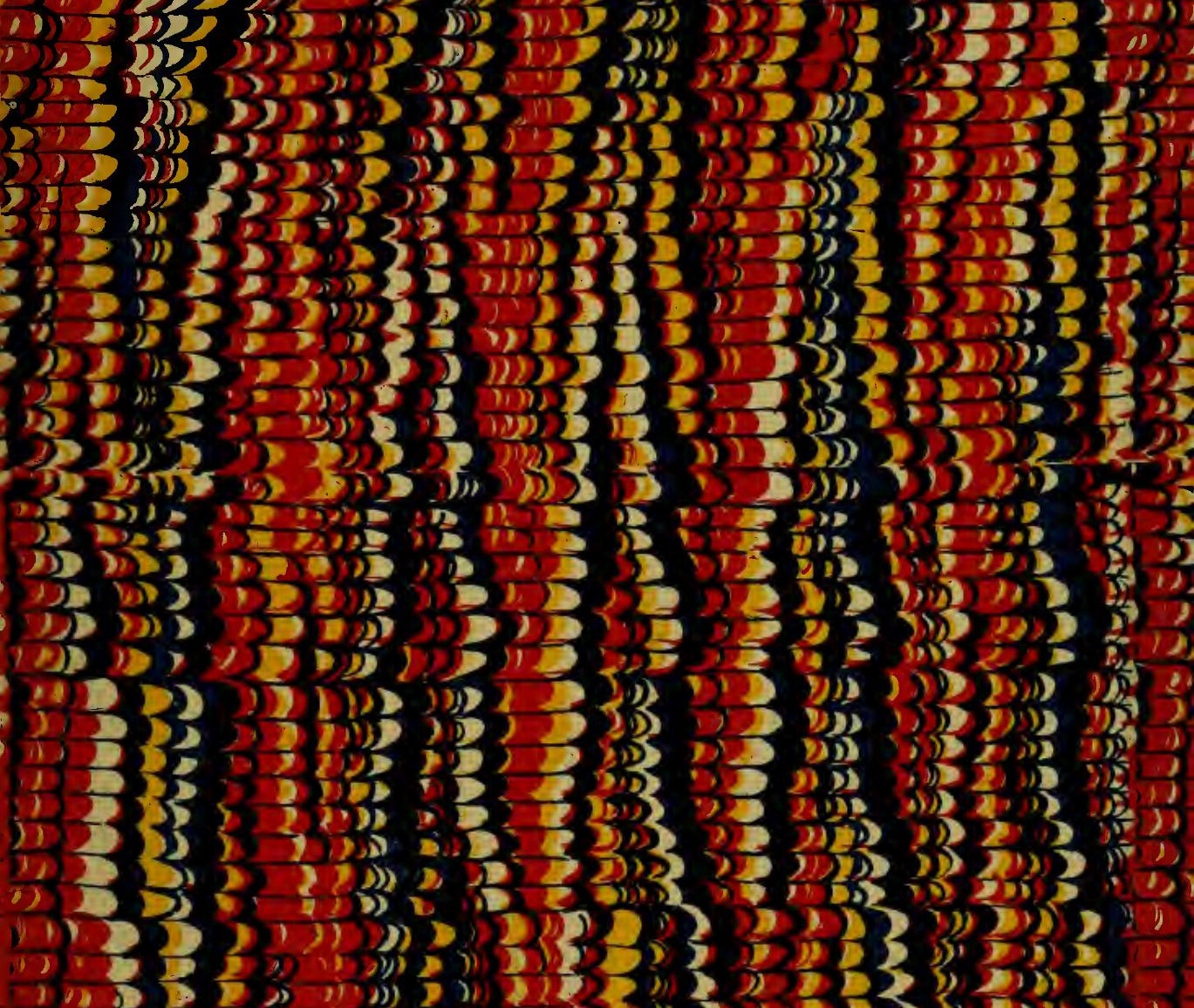

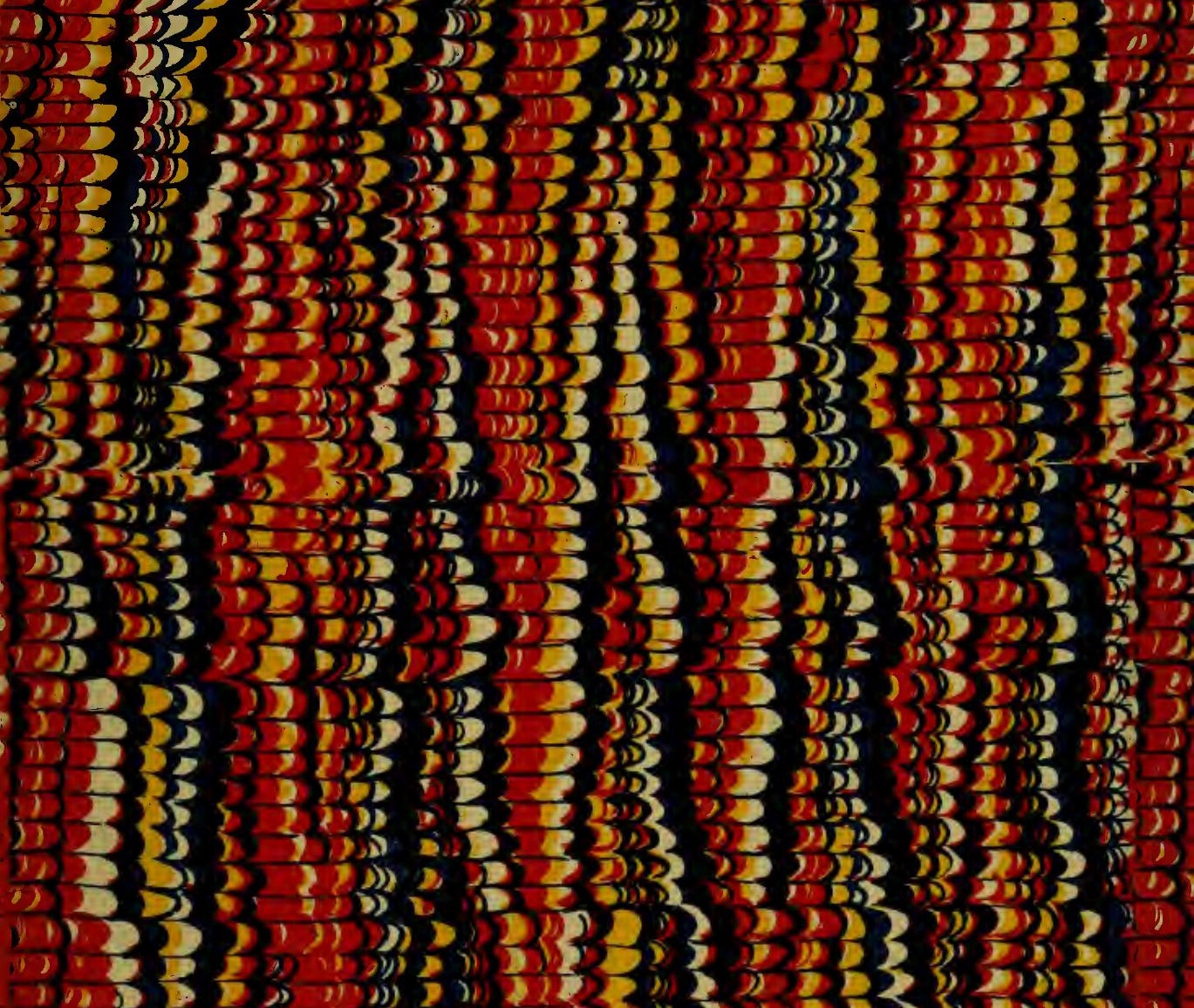

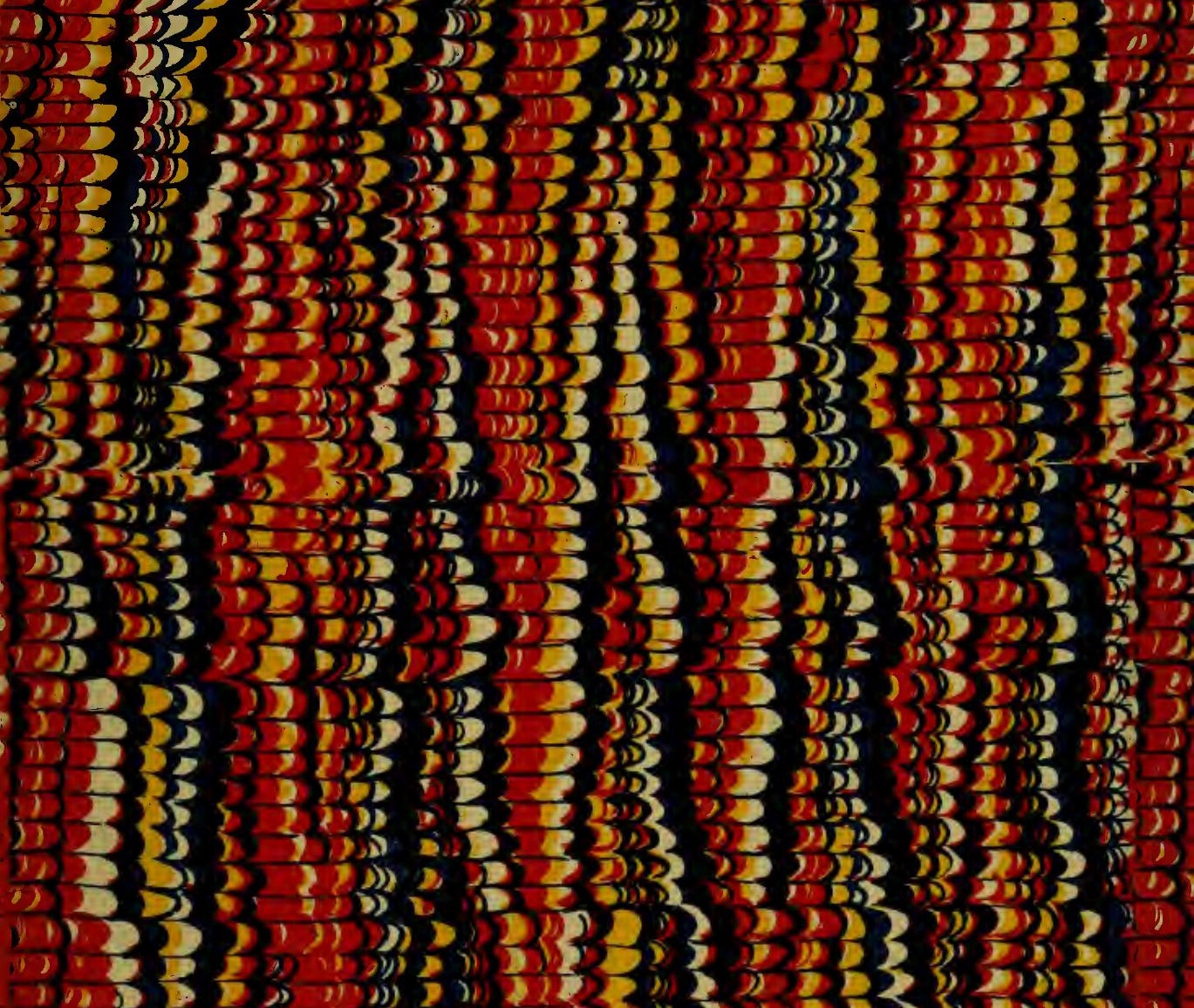

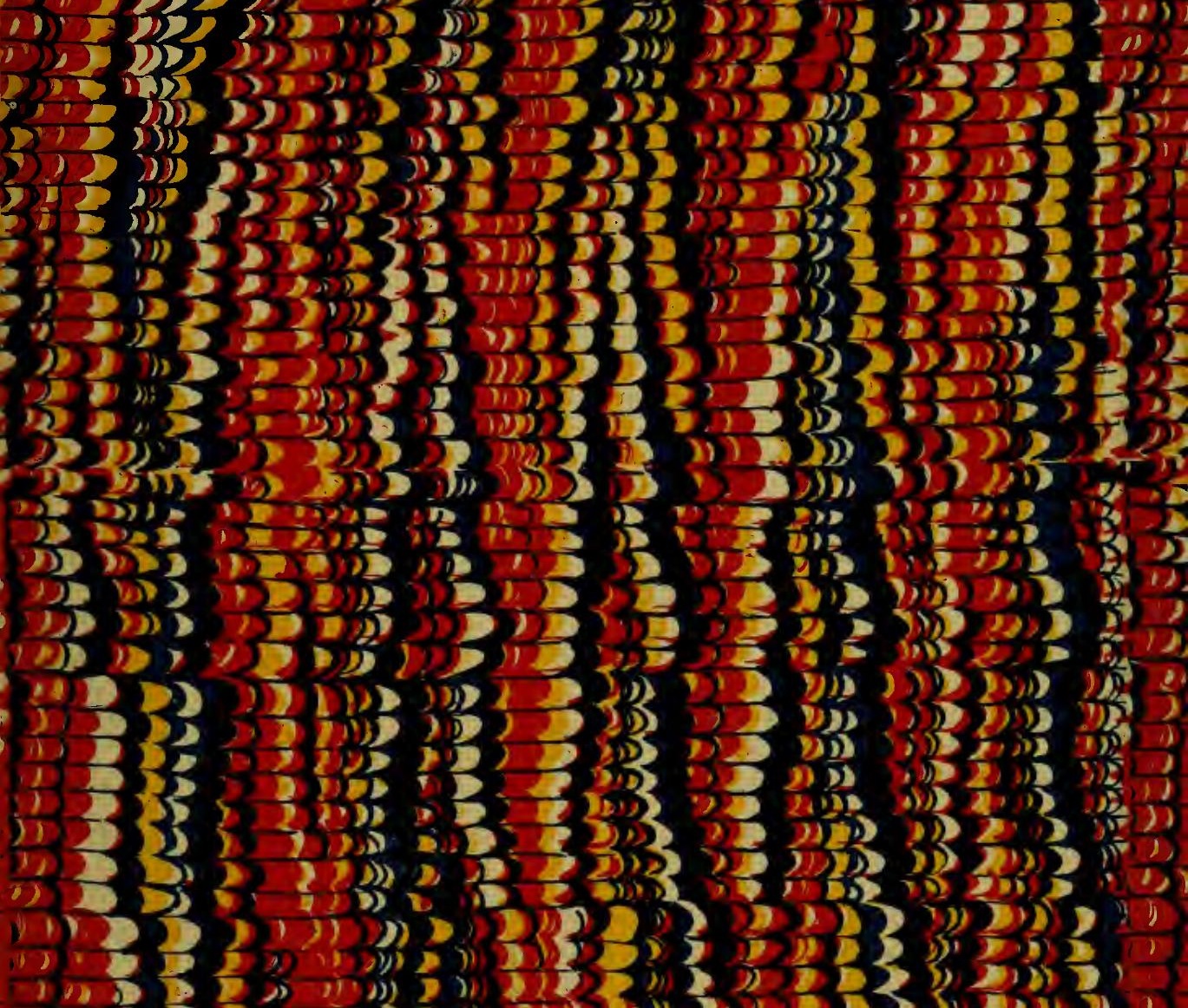

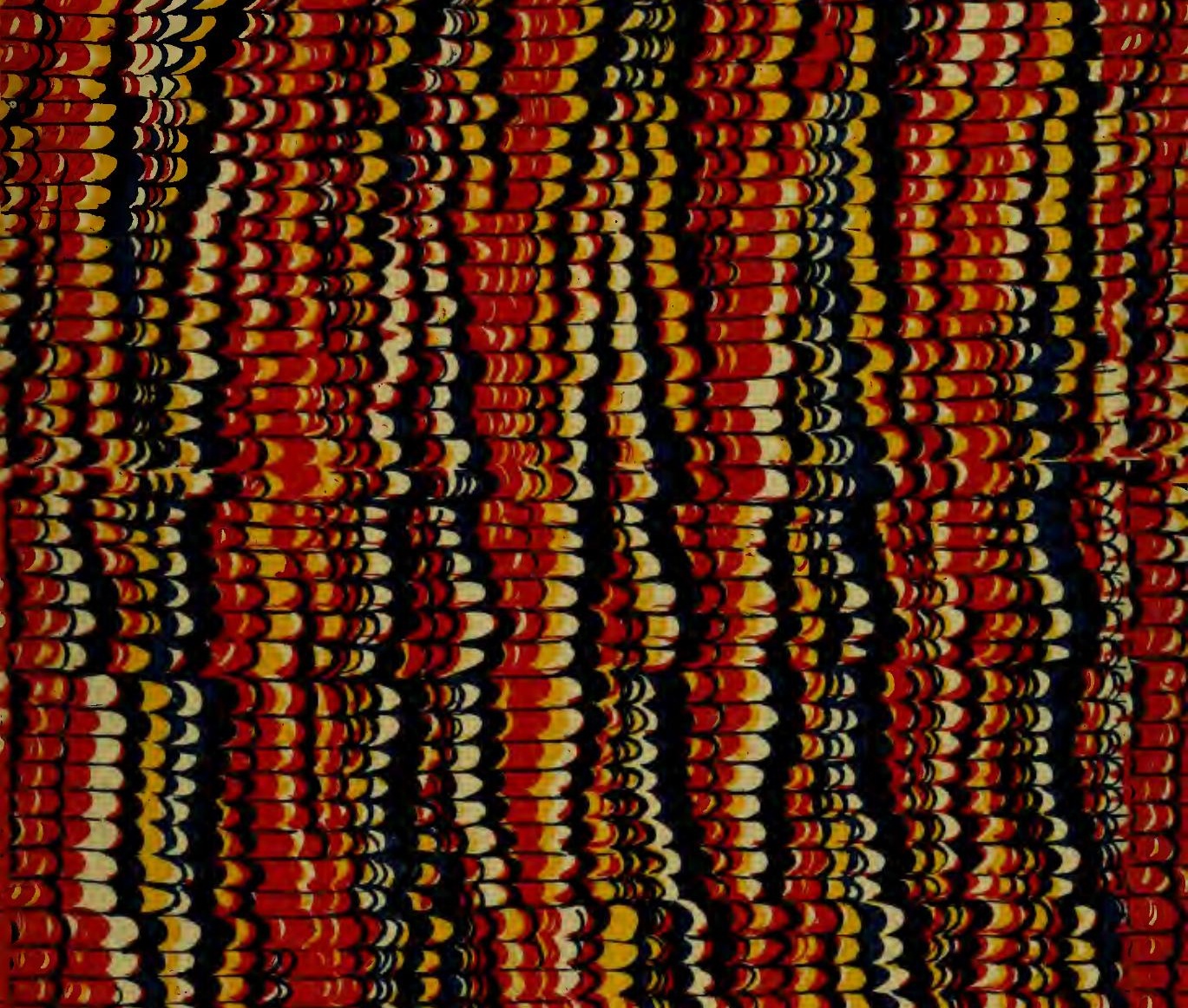

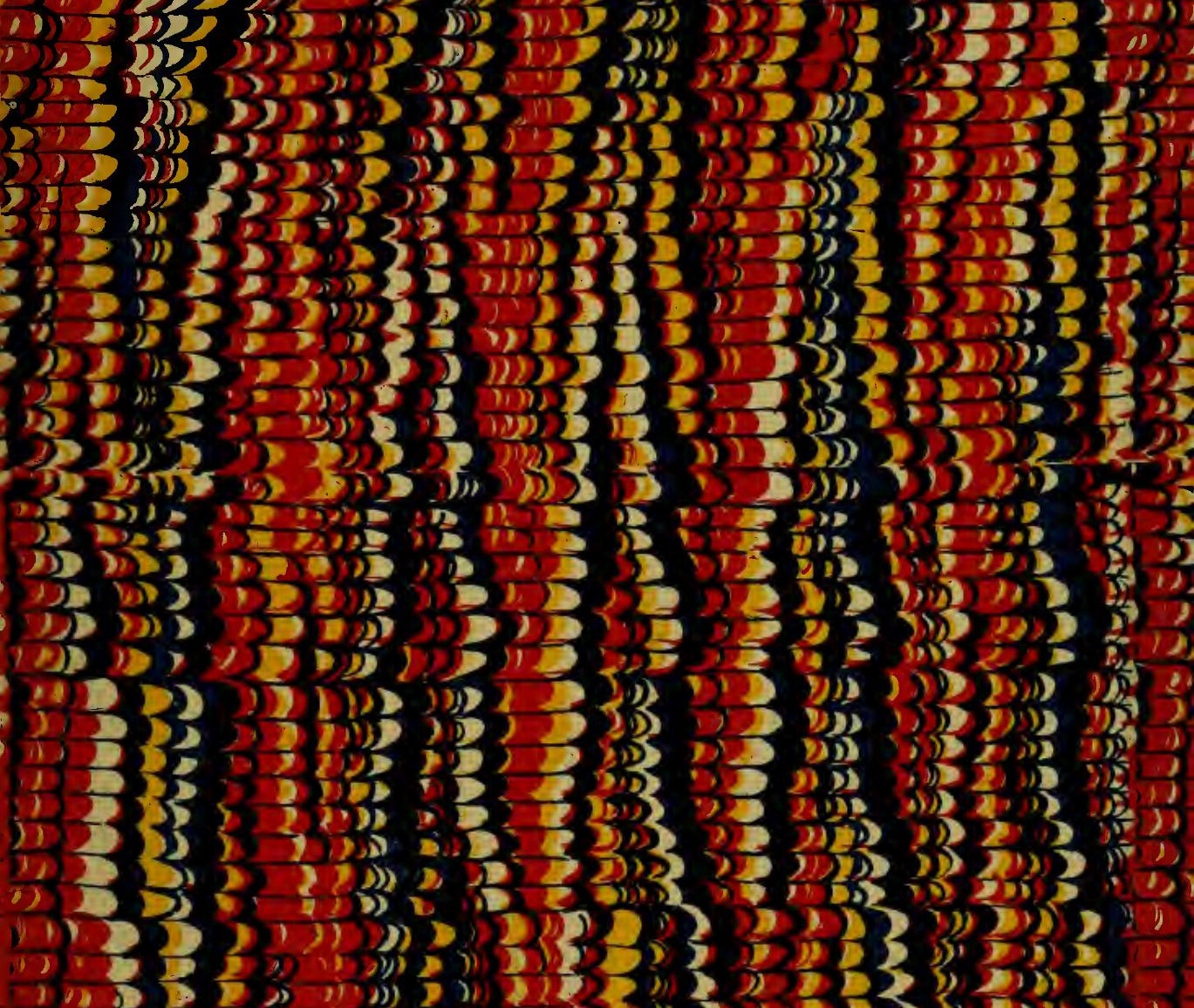
D) 2 ग

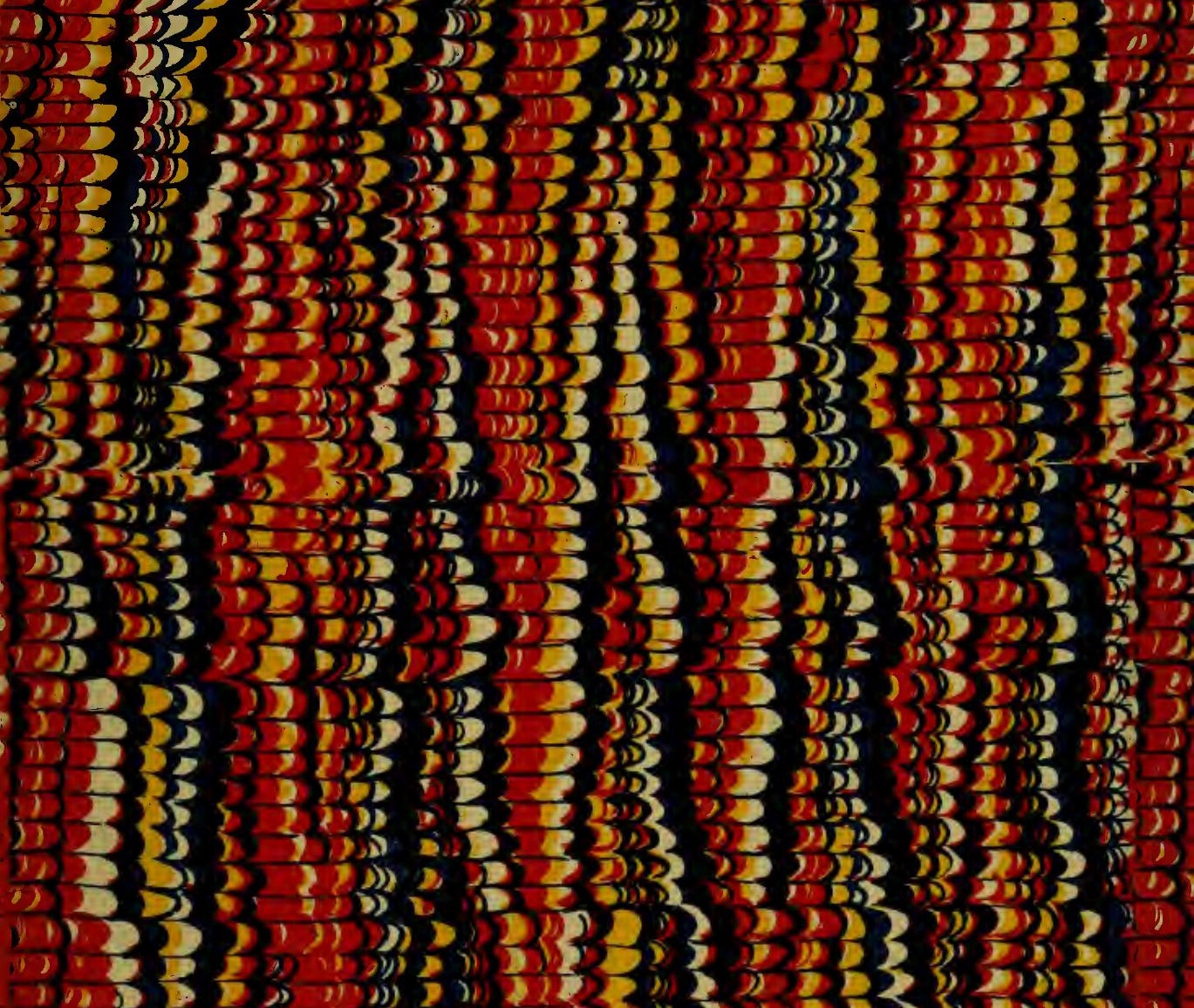

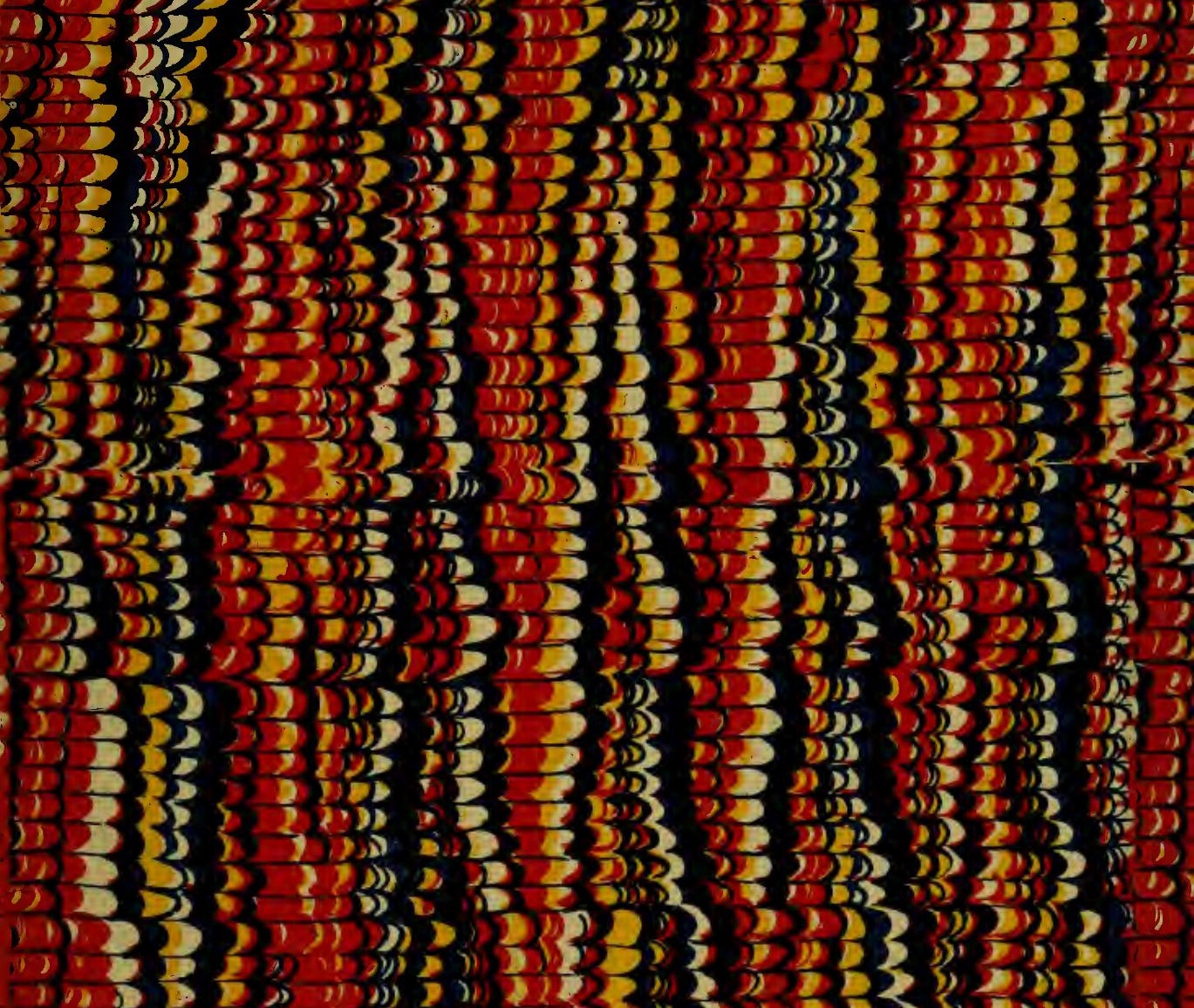

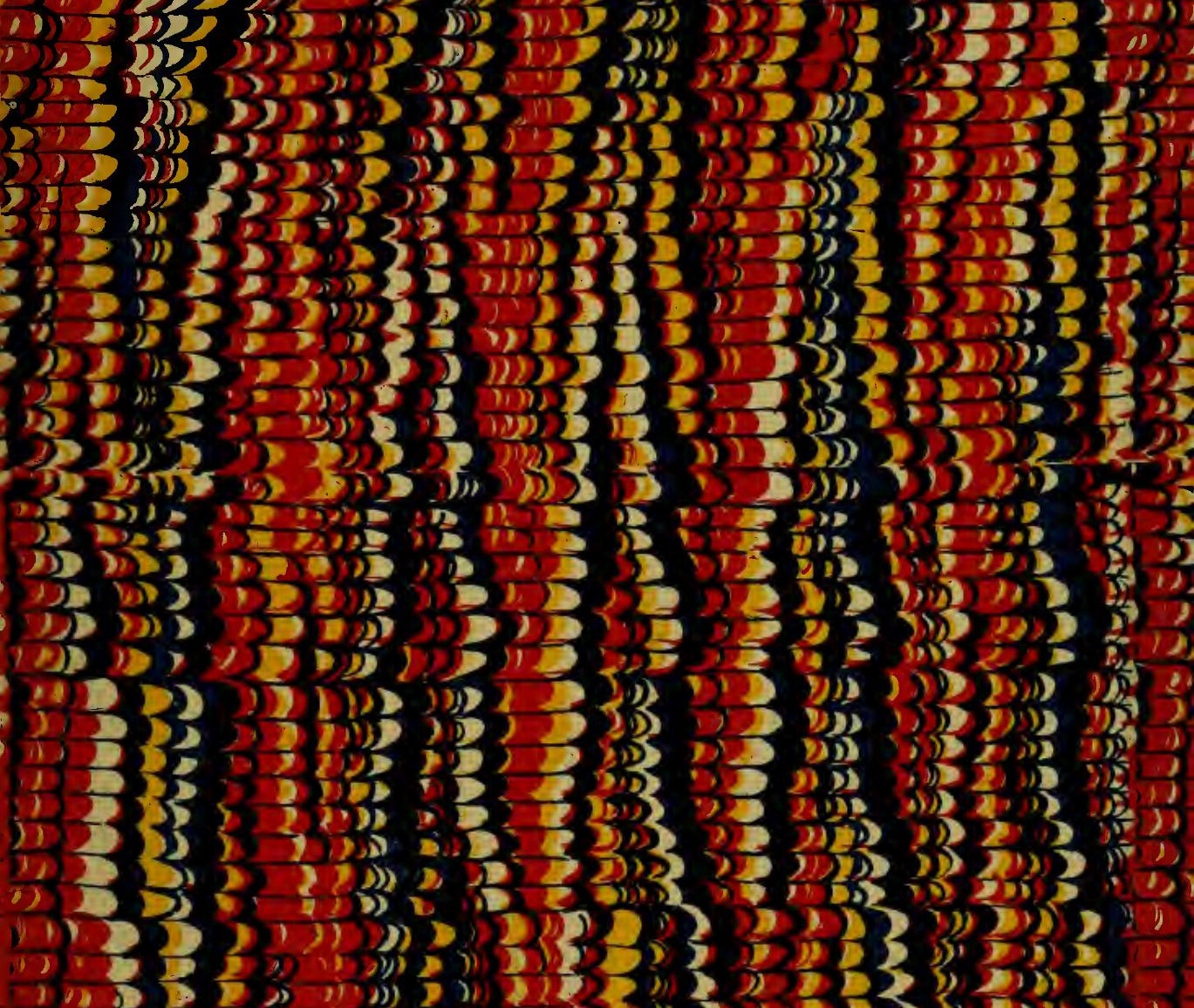

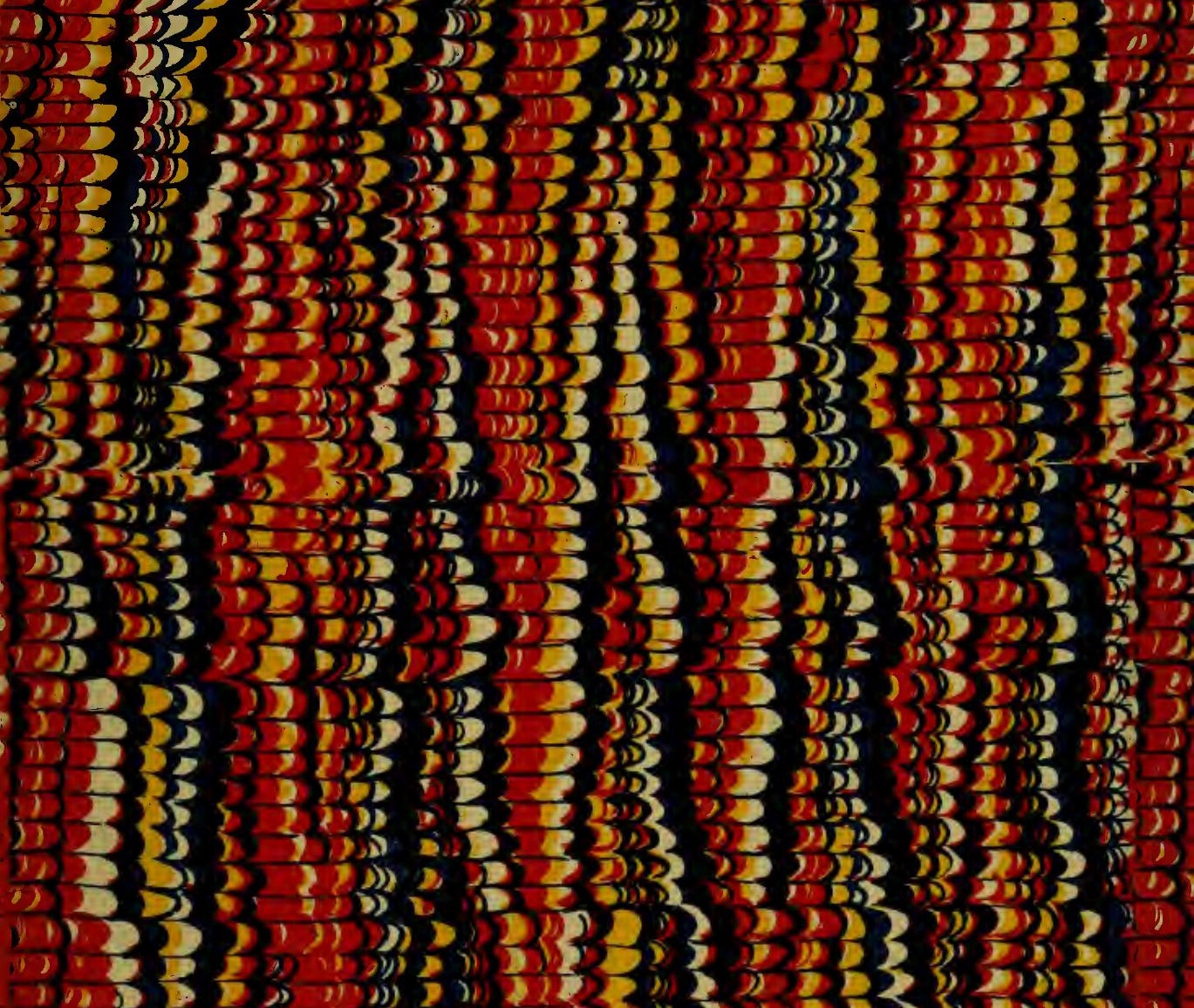
1
1
1

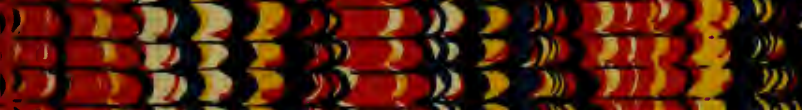

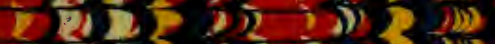

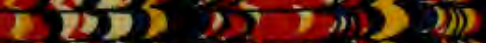

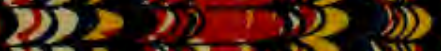

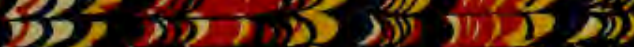

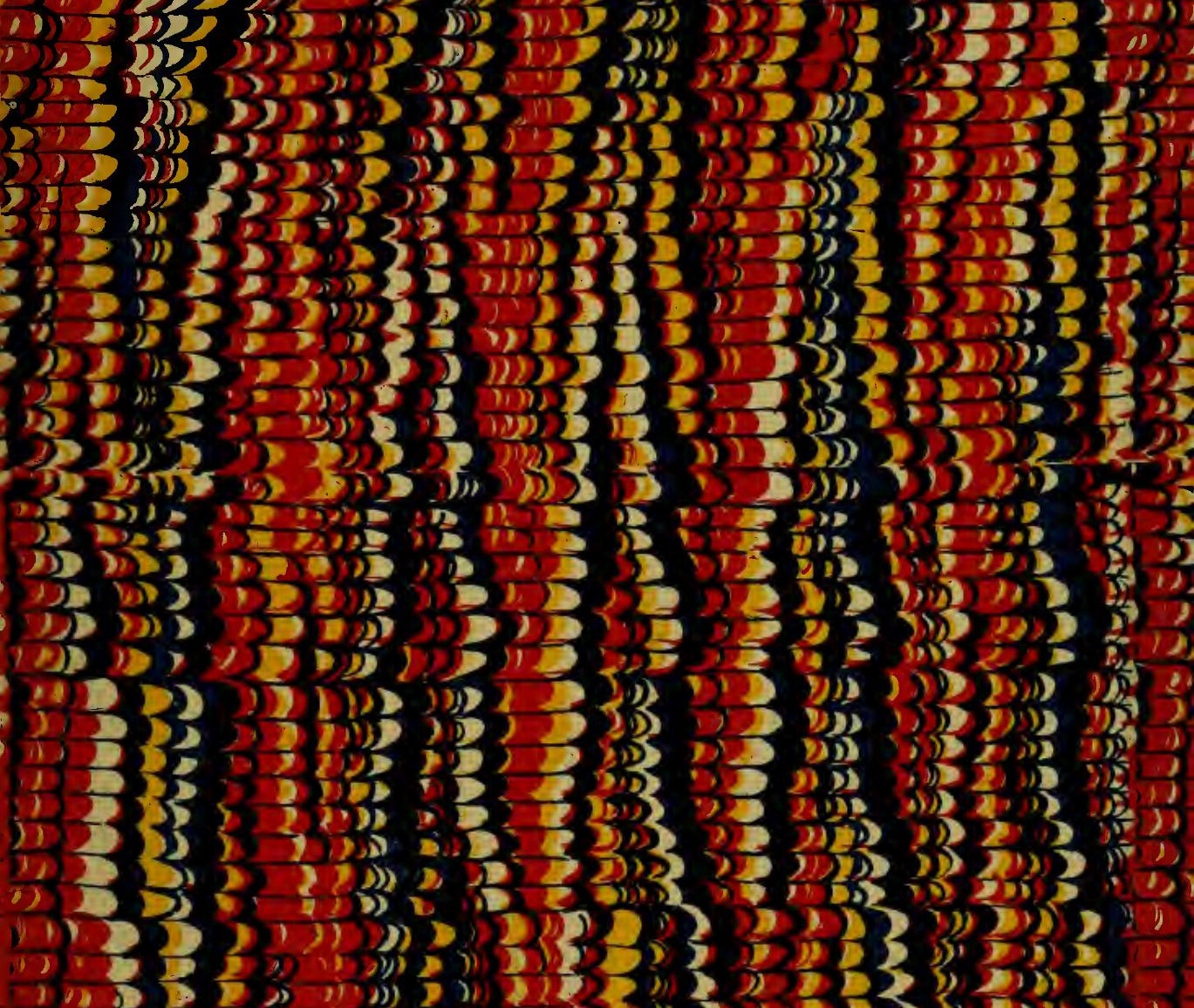

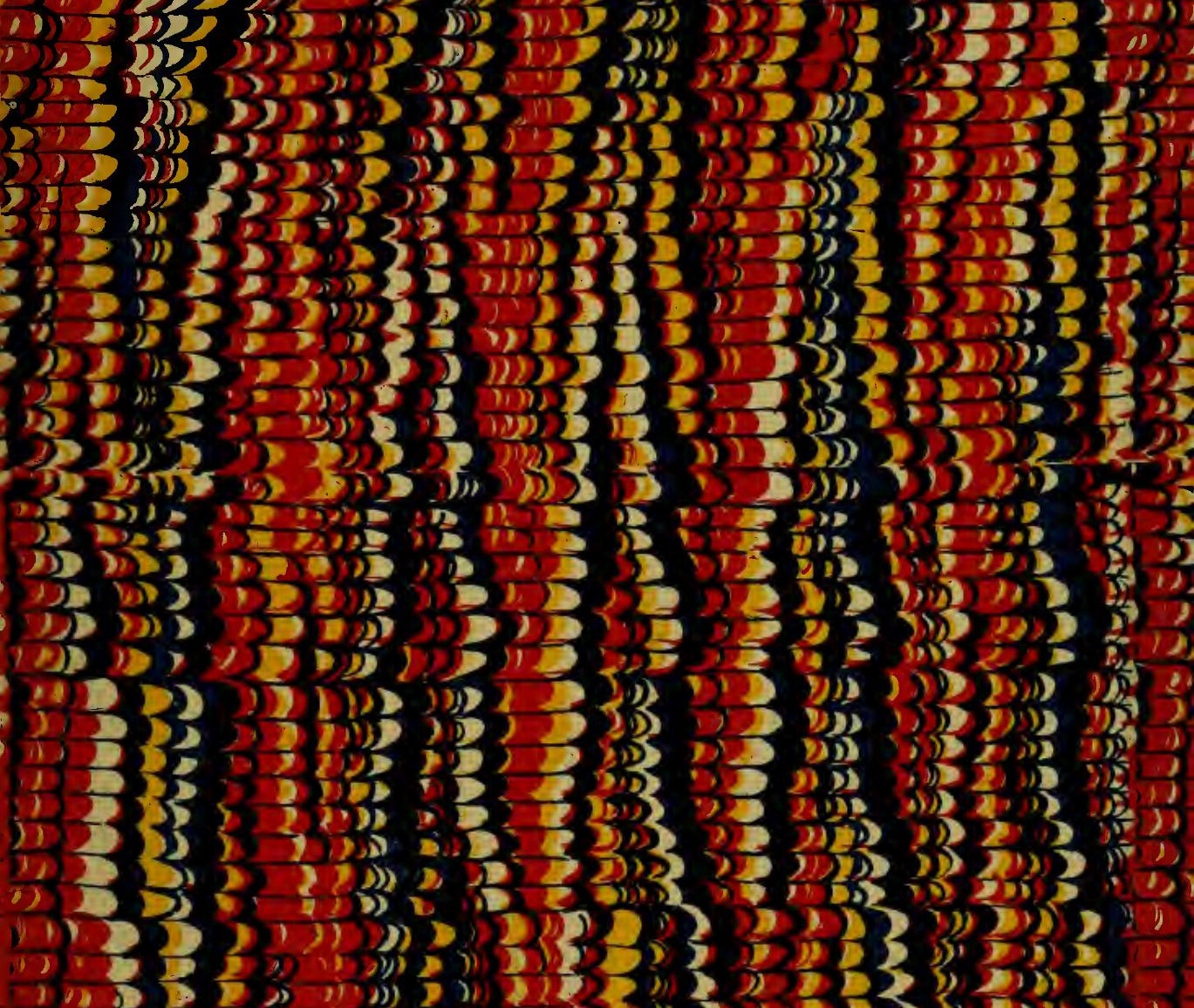

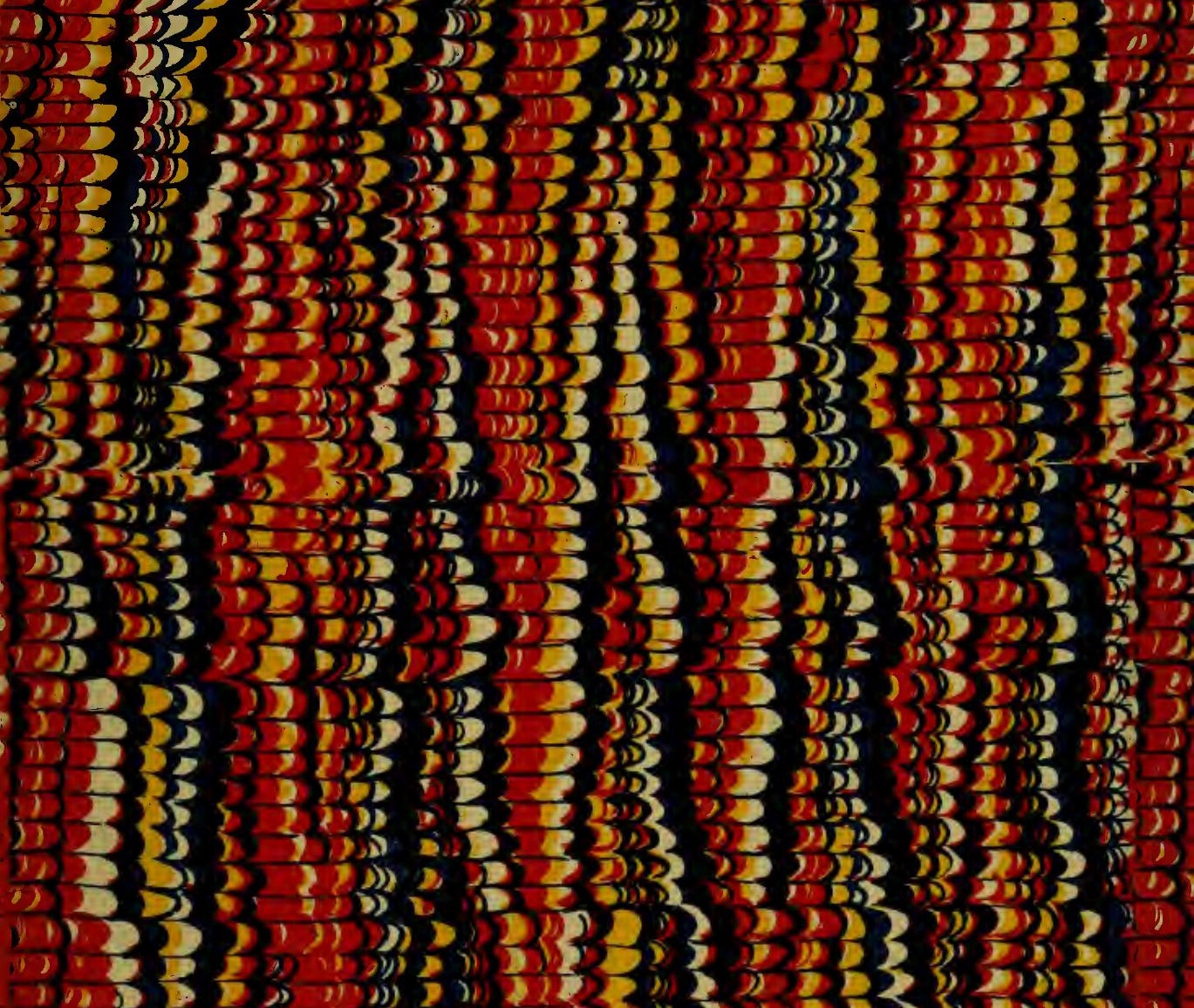

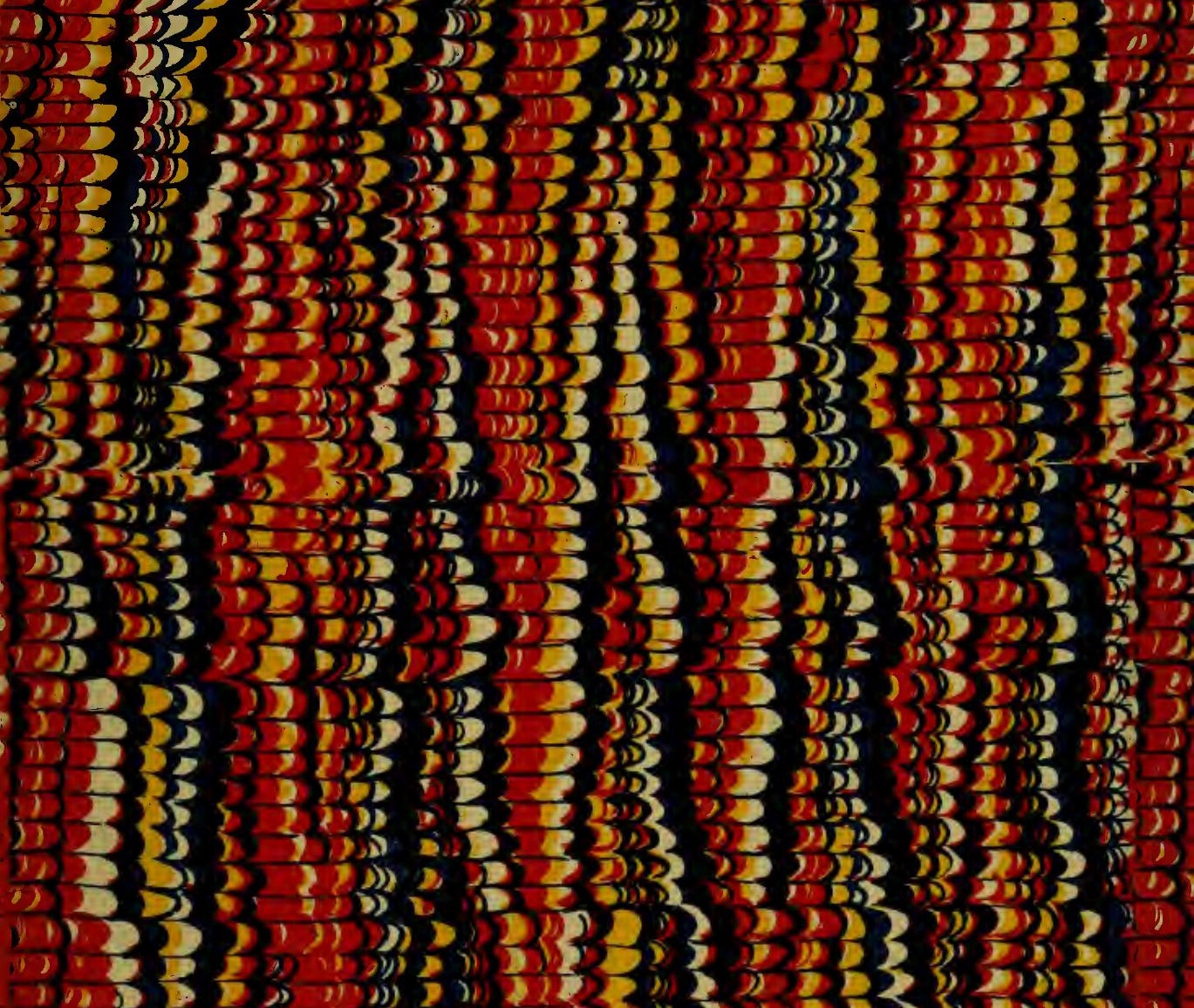

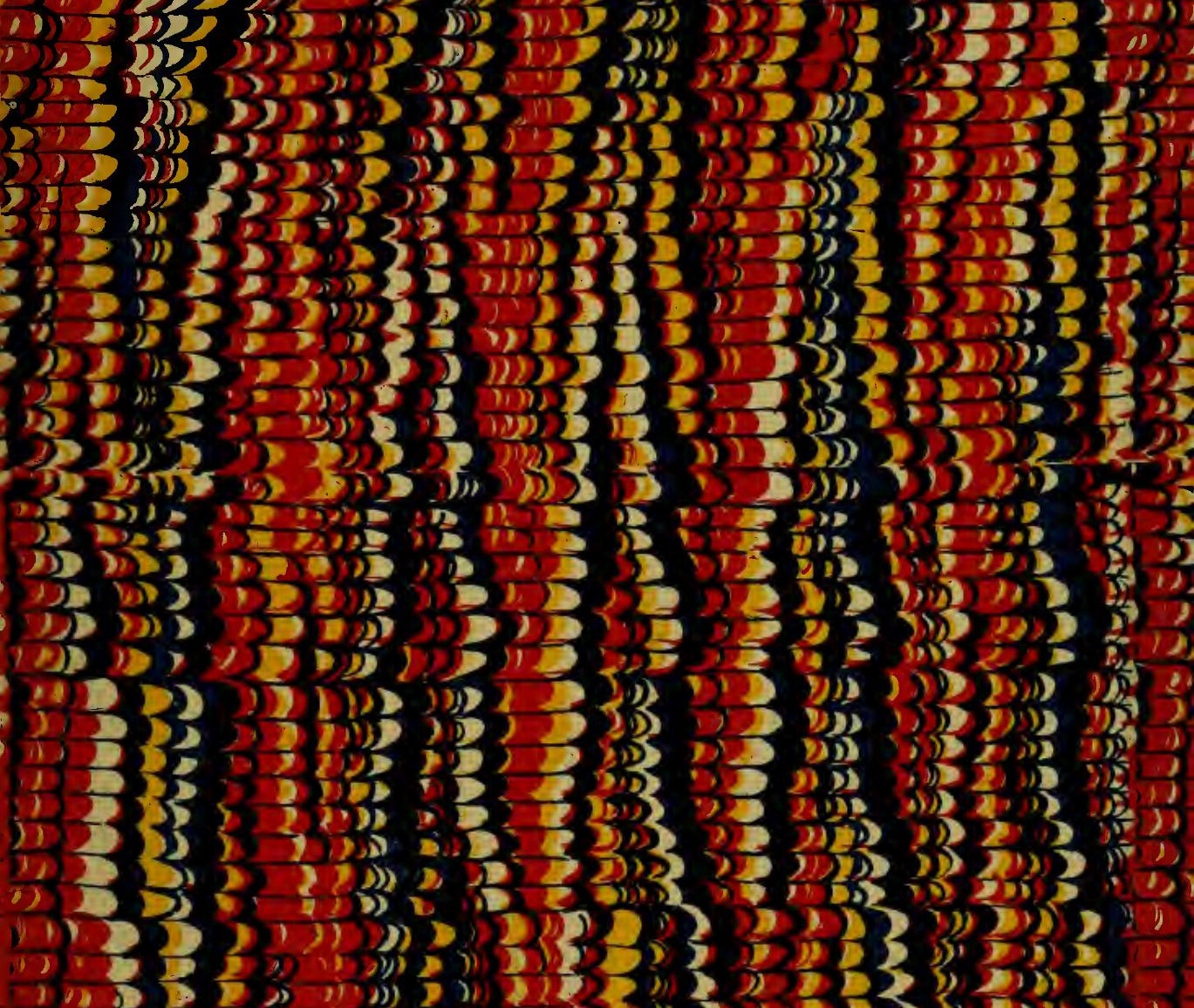

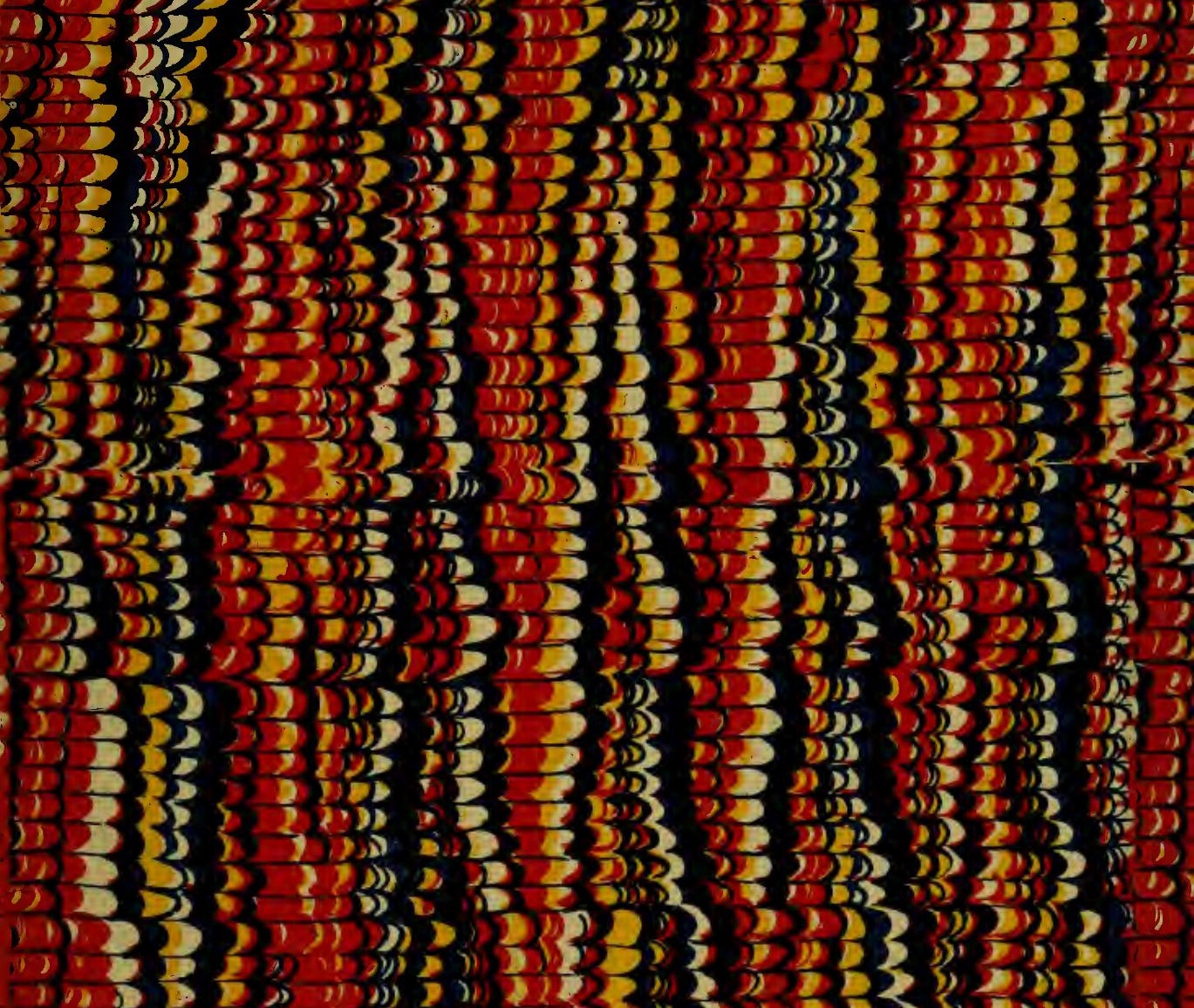
in 2 2

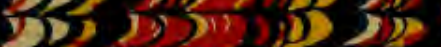
(1) 325 ) 225$)$ 2

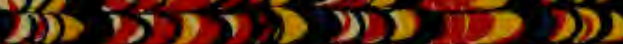
$\prod_{i \rightarrow 3}$ 
SMITHSONIAN INSTITUTION LIBRARIES 